UC-NRLF

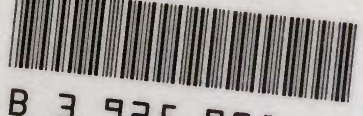
B 3925908 


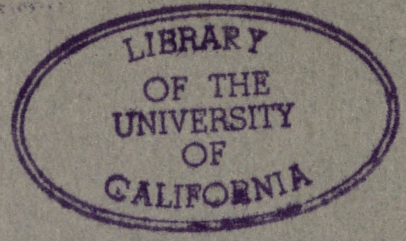

PALEONTOLOEY LIBRARY 


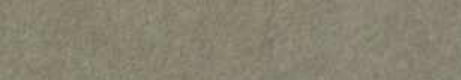

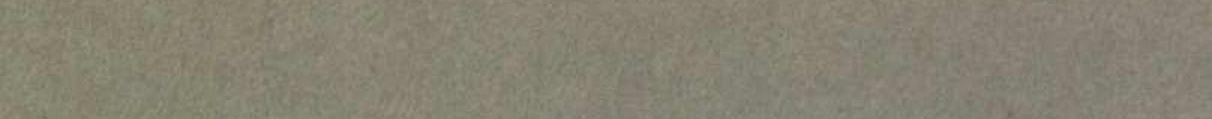
(1)

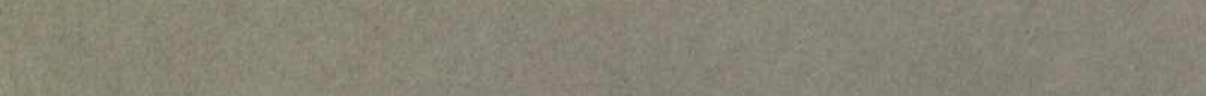

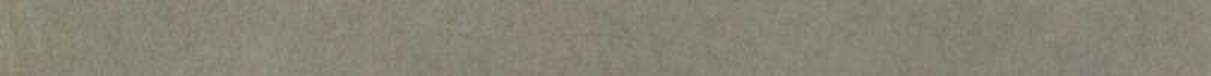

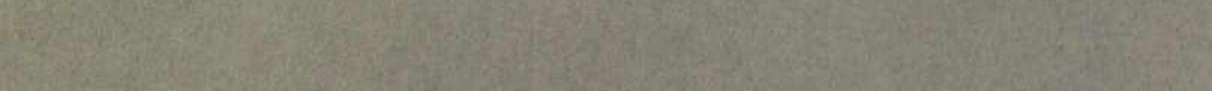

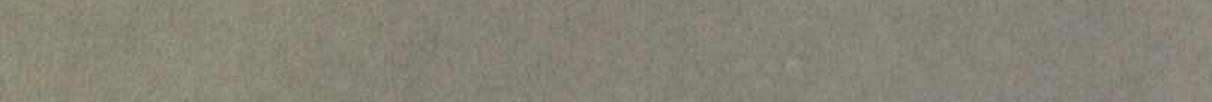

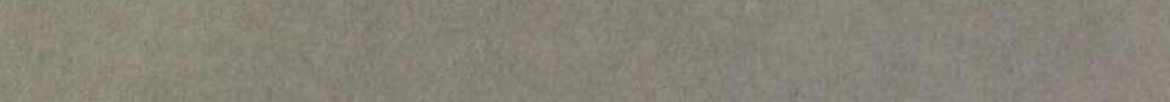

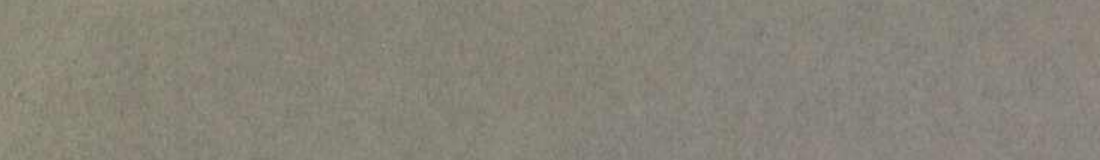
1.

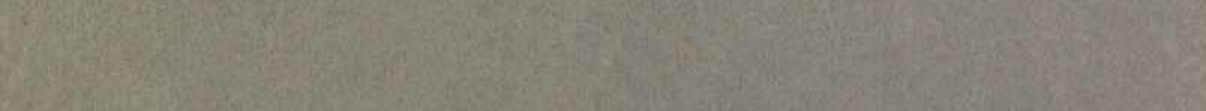
(5) .

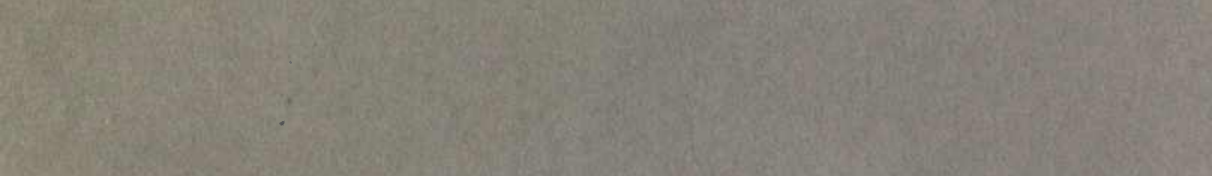

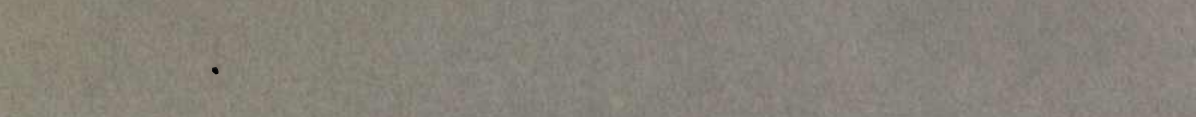

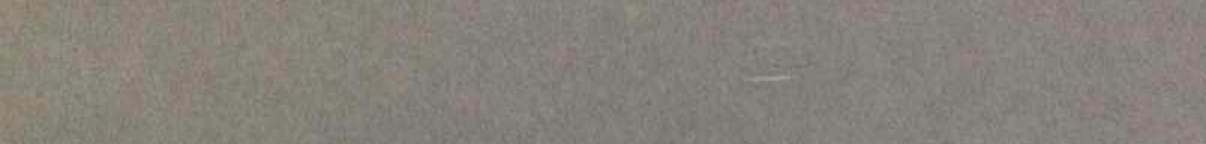

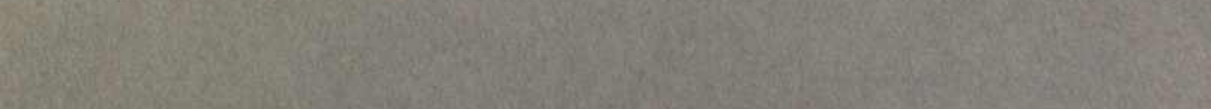

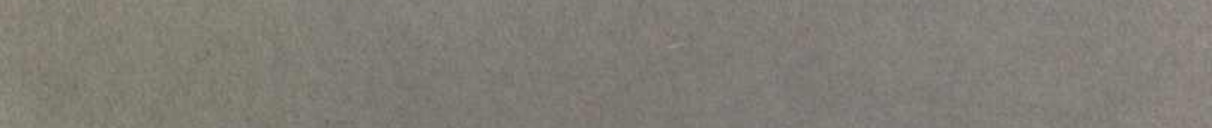

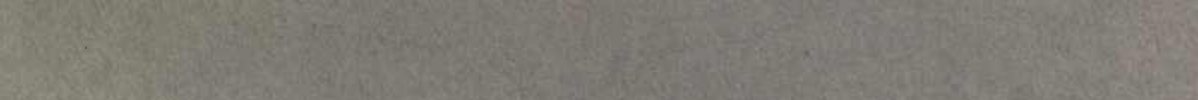

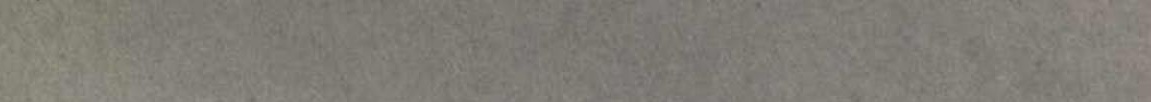

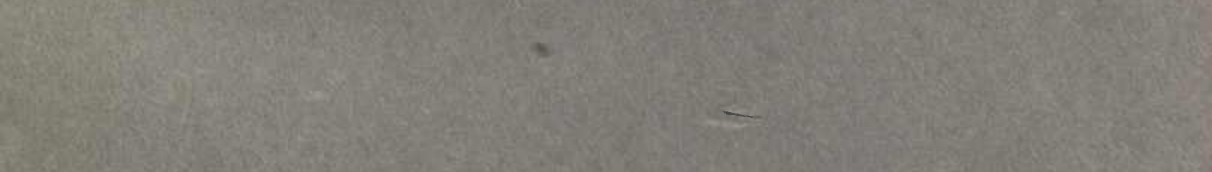

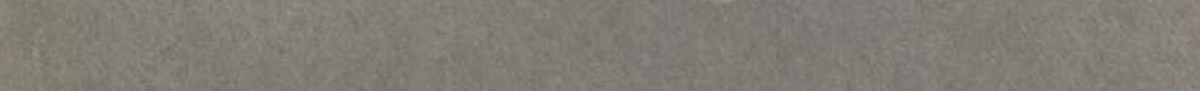

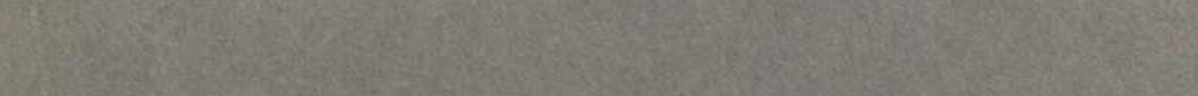

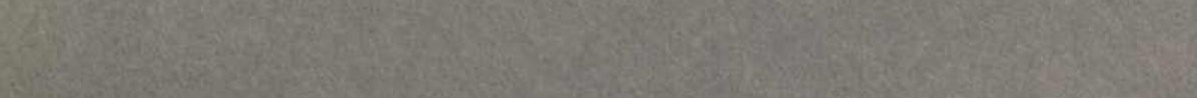
S. His.

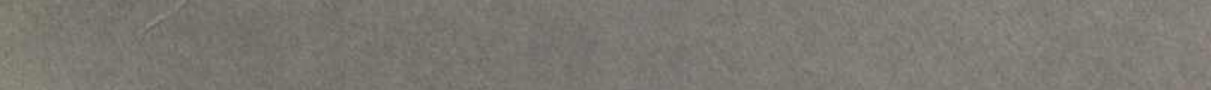

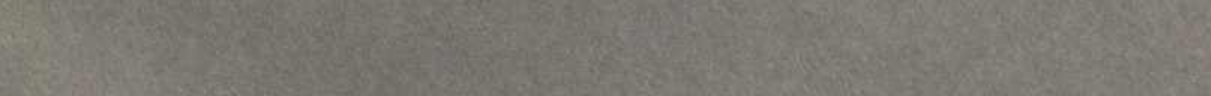
W 5 a W. W.

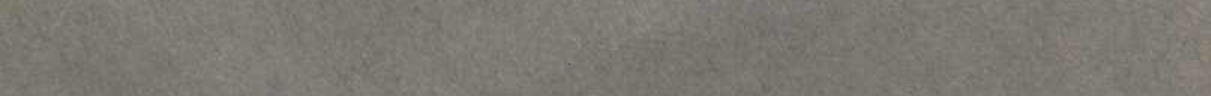

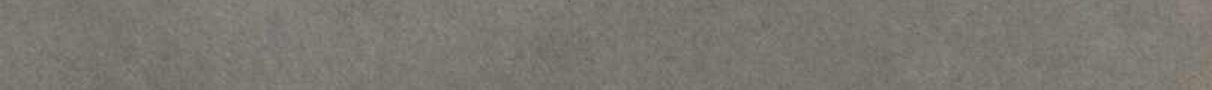

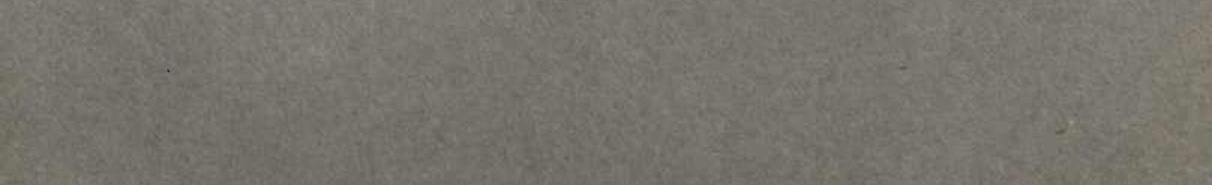


17-

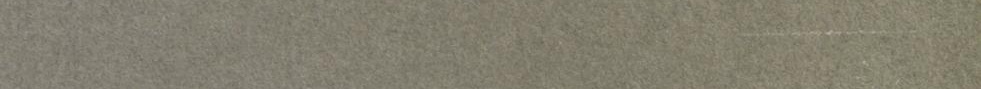

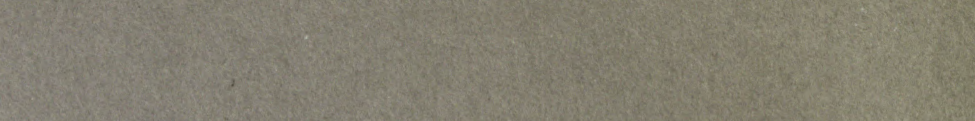

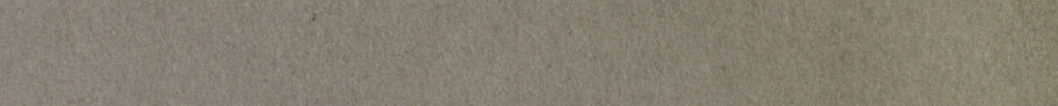

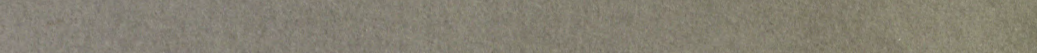

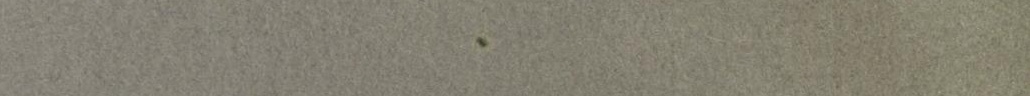

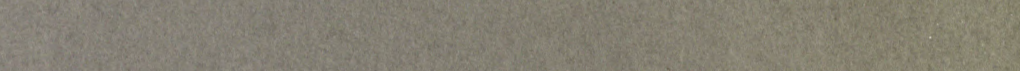

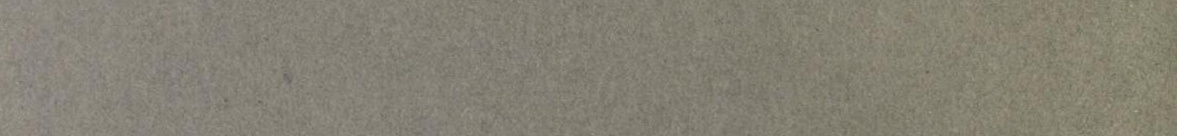

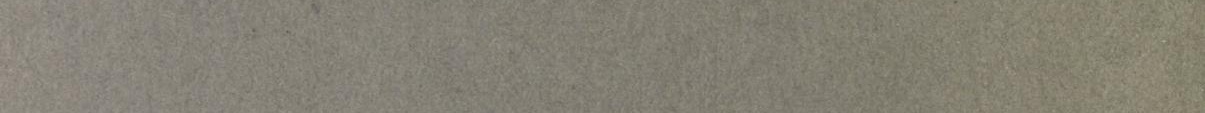

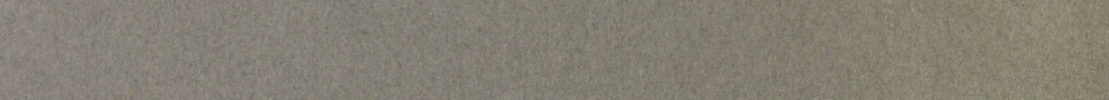

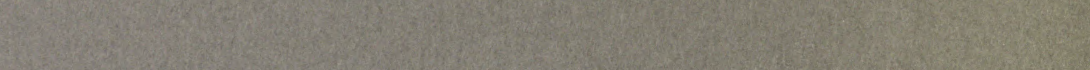
2.

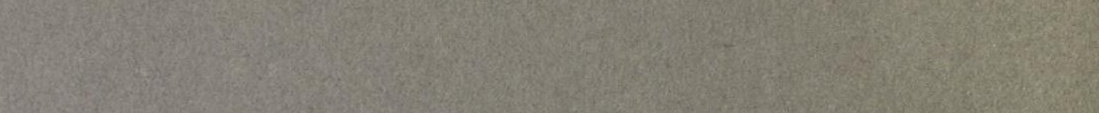

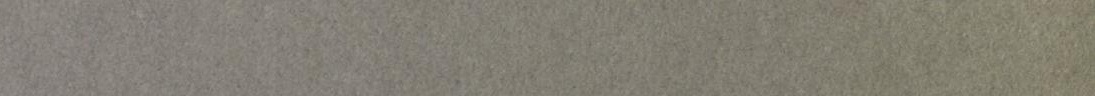
(5) (1)

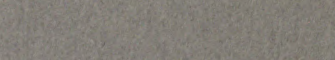

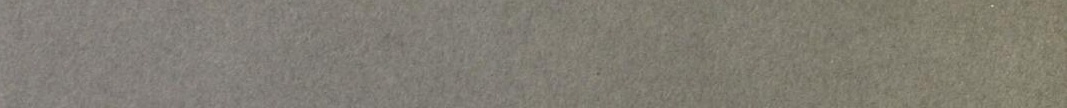

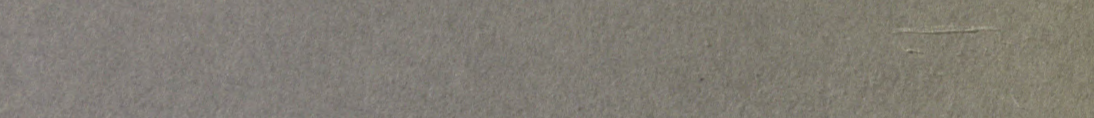

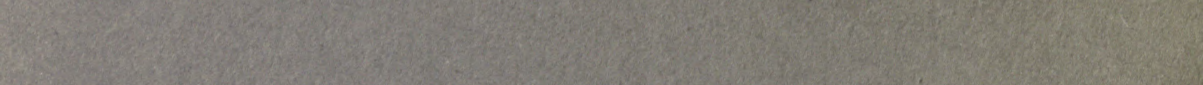

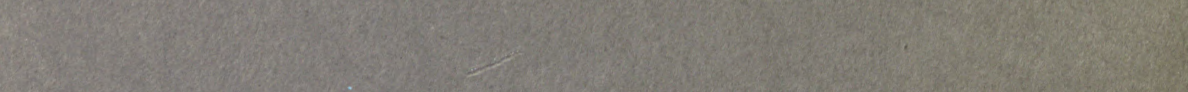

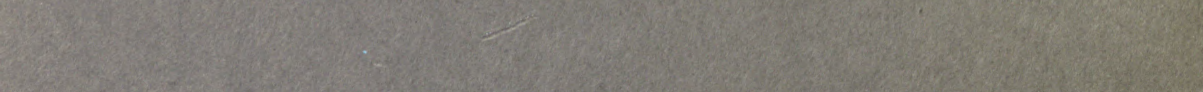

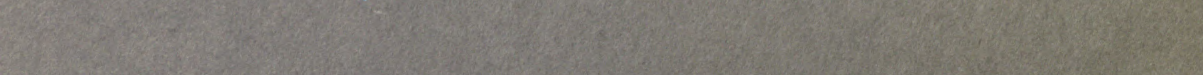

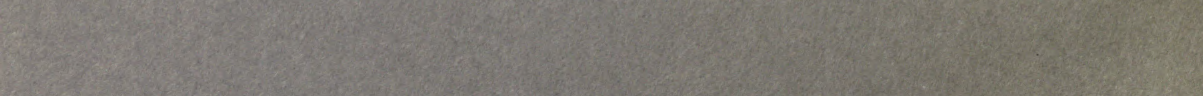
Q

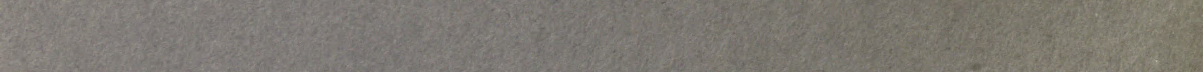

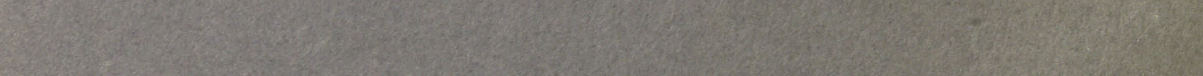

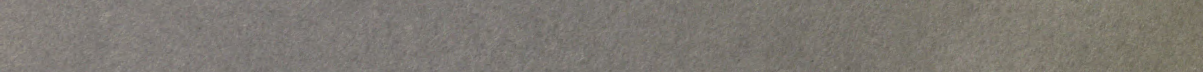
2.

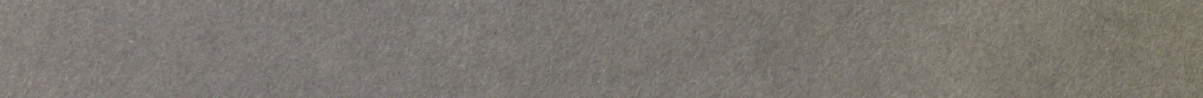

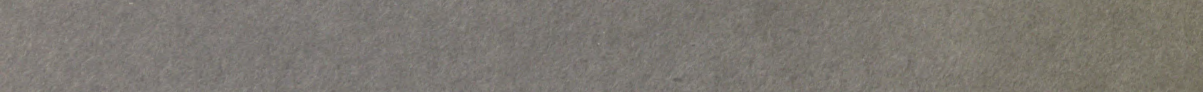

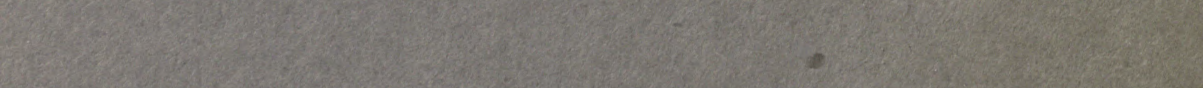

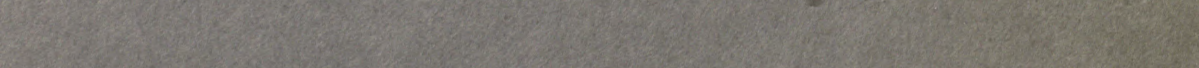
7. W.

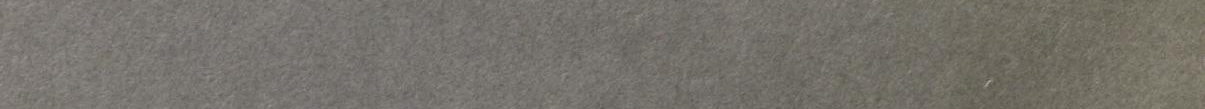

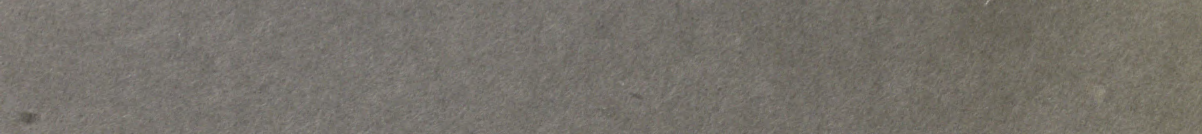

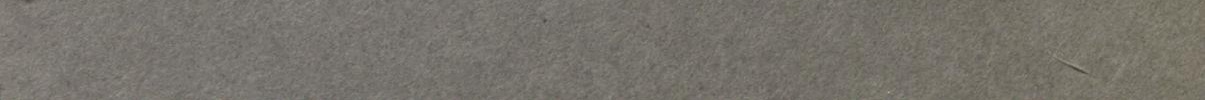


SMITHSONIAN INSTITUTION

UNITED STATES NATIONAL MUSEUM

Bulletin 88

REVISION OF PALEOZOIC STELLEROIDEA WITH SPECIAL REFERENCE TO NORTH AMERICAN ASTEROIDEA

\author{
BY \\ CHARLES SCHUCHERT \\ Professor of Paleontology, Yale Unizersity \\ New Haven
}

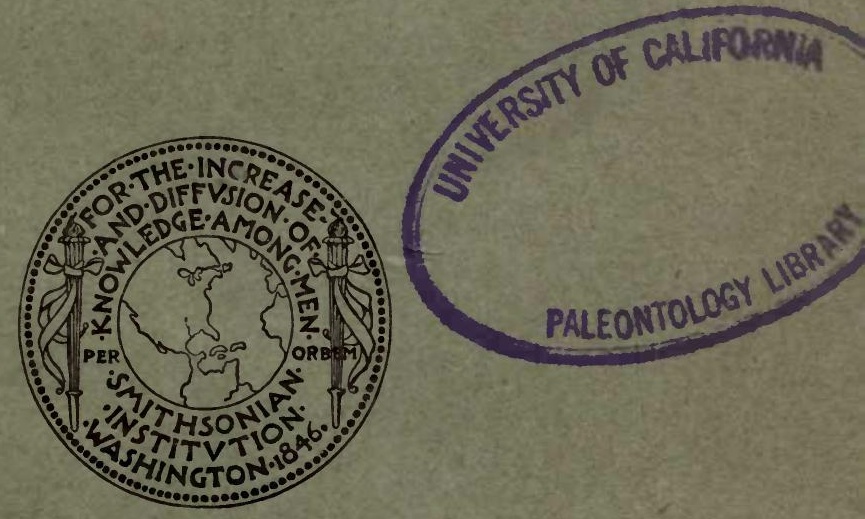

WASHINGTON

GOVERNMENT PRINTING OFFICE 



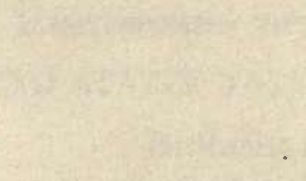





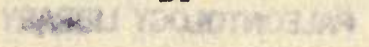 \\ CHARLES SCHUCHERT \\ Professor of Paleontology, Yale University \\ New Haven
}

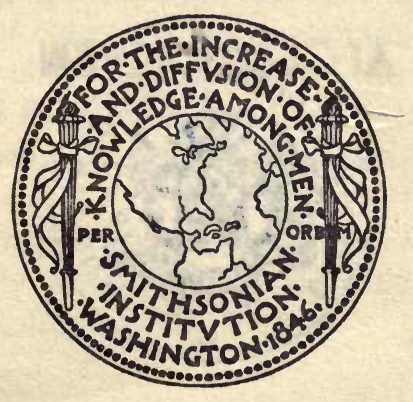

WASHINGTON

GOVERNMENT PRINTING OFFICE 


\section{PALEONTOLOGY LIBRYYY}

BULLETIN OF THE UNITED STATES NATIONAL MUSEUM.

Issued MARCH 20, 1915.
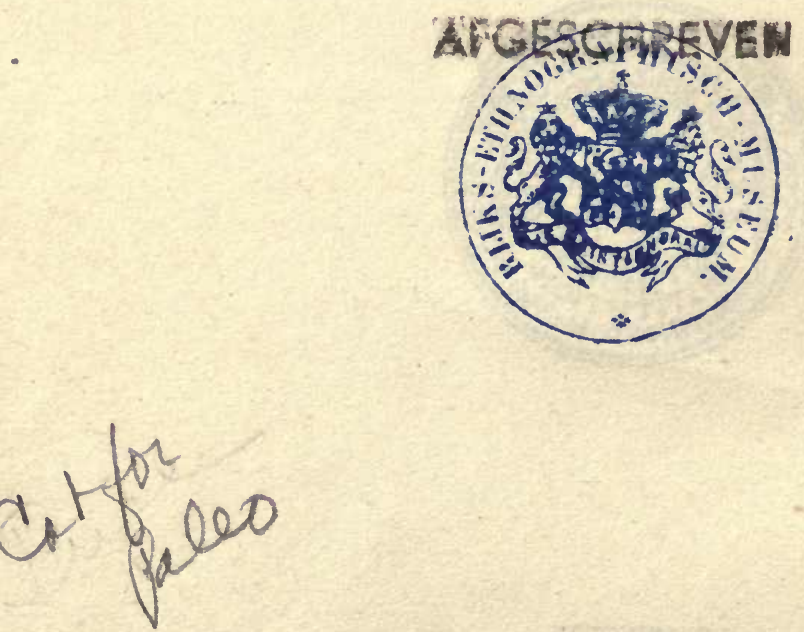


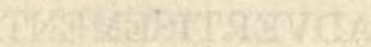

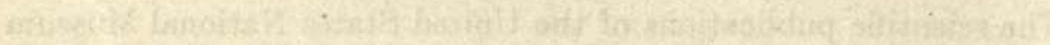

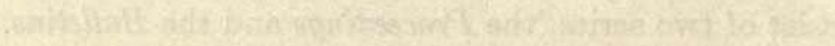

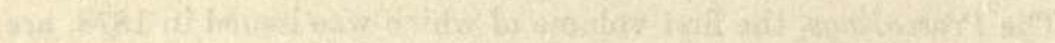

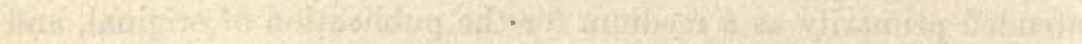

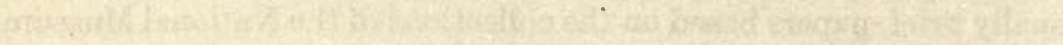

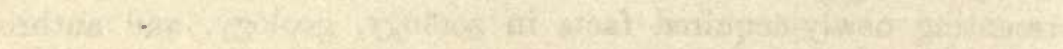

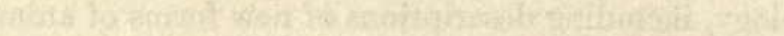

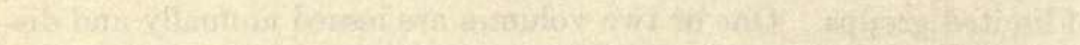

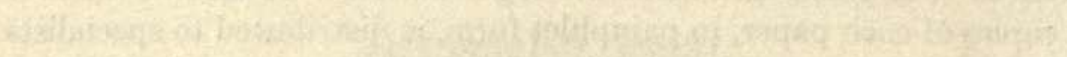

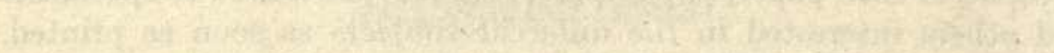

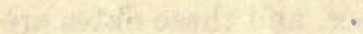

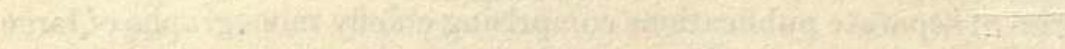

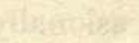

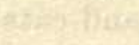

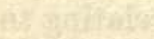

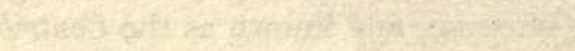




\section{TABLE OF CONTENTS.}

Preface

Page.

Terminology as applied to the skeleton of Paleozoic Asteroidea.............

Finding list of Paleozoic Stelleroidea..............................

Remarks on the development of Paleozoic Stelleroidea...................

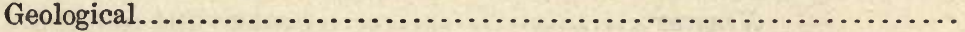

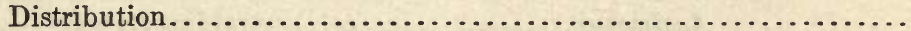

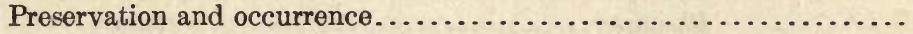

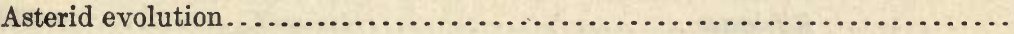

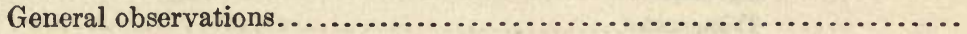

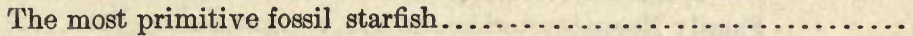

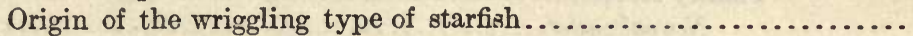

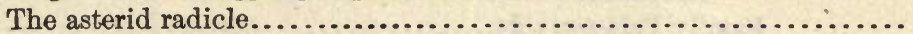

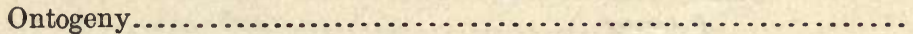

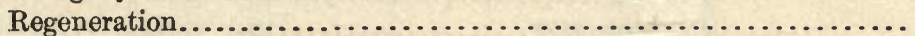

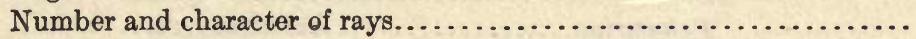

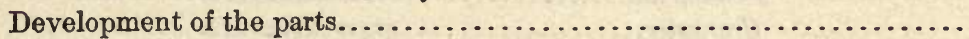

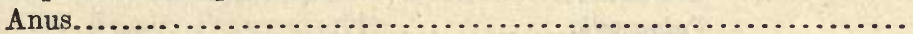

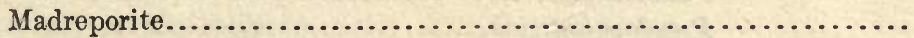

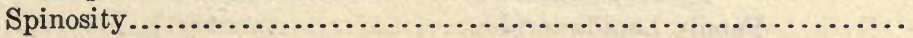

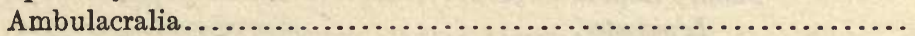

Adambulacralia..........................................

Inframarginalia . . . . . . . . . . . .

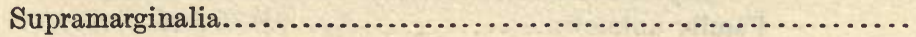

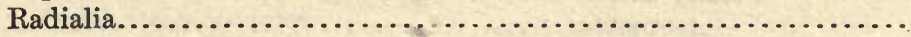

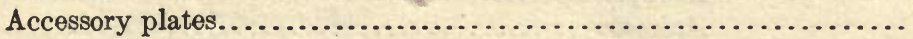

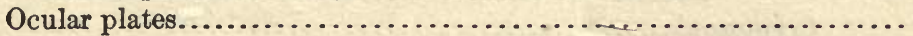

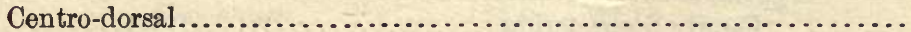

Primary disk-plates.......................................

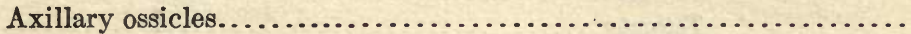

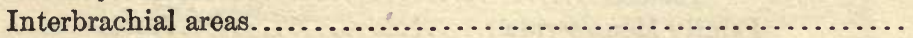

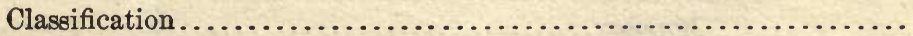

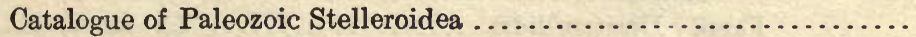

Description of genera and species..................................

Class Stelleroidea.

Subclass Asteroidea.

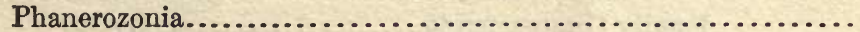

Family Hudsonasteridæ...........................

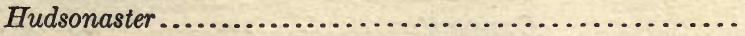

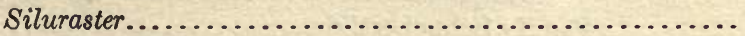

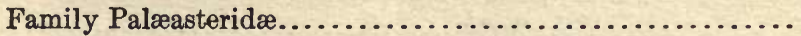

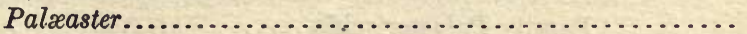

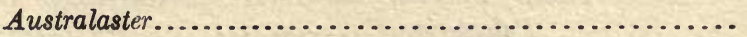


Description of genera and species-Continued.

Class Stelleroidea-Continued.

Subclass Asteroidea-Continued.

Phanerozonia-Continued.

Page.

Family Promopalæasteridæ...................... 73

Subfamily Mesopalæasterinæ.................... 74

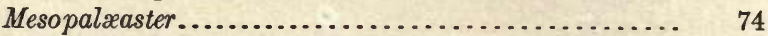

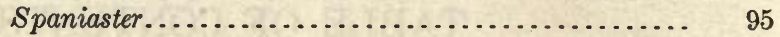

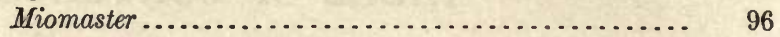

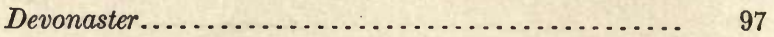

Subfamily Promopalæasterinæ................... 102

Promopalæaster............................ 102

Subfamily Anorthasterinæ...................... 125

Anorthaster............................... 125

Family Xenasteridæ............................. 128

Xenaster.................................. 129

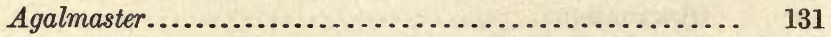

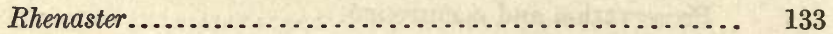

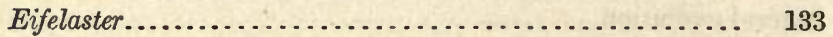

Trimeraster................................... 134

Family Neopalæasteridæ.......................... 134

Neopalæaster............................... 134

Family Palasterinidæ.......................... 138

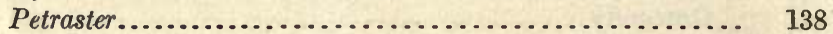

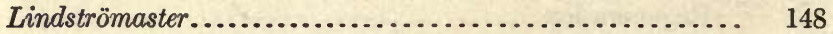

Palasterina................................. 150

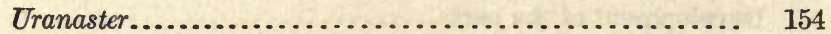

Palæostella................................ 155

Pseudopalasterina............................ 156

Family Lepidasteridæ........................... 157

Lepidaster.................................. 158

Helianthaster............................... 159

Lepidasterella............................... 160

Family unknown............................... 161

Astropecten............................... 161

Ataxaster................................. 161

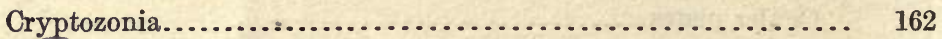

Family Stenasteridæ............................ 163

Stenaster................................. 163

Tetraster.................................... 167

Family Monasteridæ............................ 170

Monaster................................. 170

Family Urasterellidæ............................ 172

Urasterella.............................. 173

Family Calliasterellidæ.......................... 190

Calliasterella.................................. 190

Family Compsasteridæ........................... 191

Jaekelaster................................. 192

Compsaster................................ 192

Family Schuchertiidæ........................... 194

Schuchertia................................ 195

Family Palasteriscidæ............................ 199

Palasteriscus............................. 200

Echinasterella............................. 200 
Description of genera and species-Continued.

Class Stelleroidea-Continued.

Subclass Asteroidæ-Continued.

Cryptozonia-Continued.

Family Palasteriscidæ-Continued.

Page.

Loriolaster.................................. 201

Cheiropteraster.............................. 202

Family Schœnasteridæ.......................... 202

Schœnaster................................ 202

Family Palæosolasteridæ......................... 207

Palæosolaster................................. 209

Echinasterias.............................. 211

Echinodiscaster ............................. 211

Echinostella.............................. 212

Medusaster................................. 212

Subclass Auluroidea.................................. 213

Order Lysophiuræ.................................... 215

Family Protasteridæ............................. 215

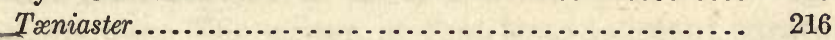

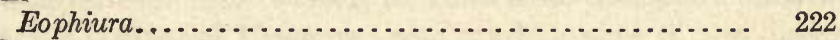

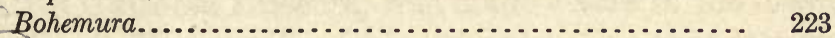

Palæura................................... 223

Protaster.................................... 224

Alepidaster.................................... 228

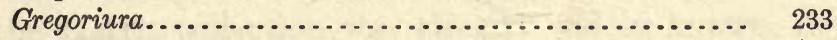

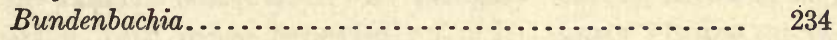

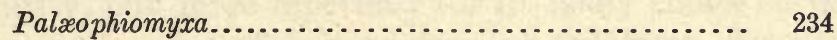

Family Palæophiuridæ.......................... 235

Palæophiura............................... 235

Stürtzura............................... 236

Eugasterella............................... 237

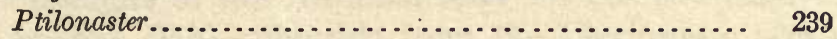

Family Encrinasteridæ........................... 241

Encrinaster................................. 241

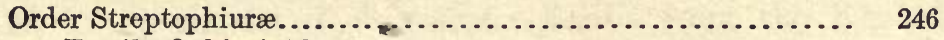

Family 0 phiurinidæ.......................... 246

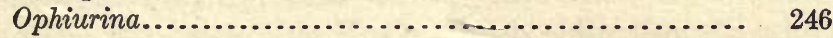

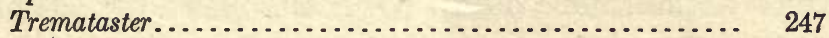

Family Lapworthuridæ............................. 248

Squamaster................................... 249

Lapworthura................................ 250

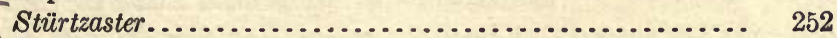

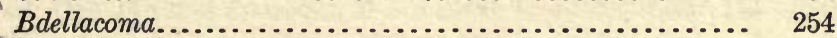

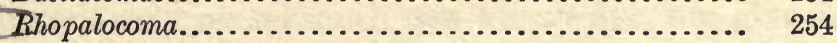

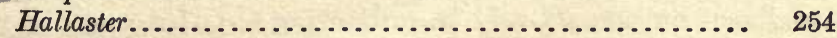

Sympterura............................... 256

Furcaster................................ 261

Palastropecten............................... 261

Family Eoluidiidæ............................. 262

Eoluidia.................................. 262

Eospondylus.............................. 263

Miospondylus................................ 263

Family Aganasteridæ........................... 263

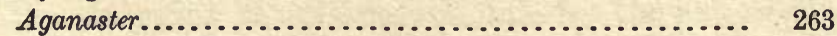

Family Cholasteridæ............................ 265

Cholaster.................................. 265 
Description of genera and species-Continued.

Class Stelleroidea-Continued.

Subclass Ophiuroidea................................. 267

Family Onychasteridæ....................... 268

Onychaster.............................. 268

Forms whose relationships are unknown ...................... 274

Cribellites carbonarius................................. 274

Order Ophiocistia....................................... 275

Family Eucladiidæ.................................... 276

Eucladia........................................... 276

Euthemon.......................................... 279

Bibliography............................................ 281

Explanation of plates..................................... 289

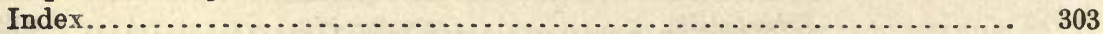




\title{
REVISION OF PALEOZOIC STELLEROIDEA WITH SPECIAL REFERENCE TO NORTH AMERICAN ASTEROIDEA
}

\author{
By Charles Schuchert \\ Professor of Paleontology, Yale University, New Haven.
}

\section{PREFACE}

This memoir had its inception in 1896, and came about through the force of circumstances. The writer, at that time assistant curator in the United States National Museum, was made aware of the desire of Mr. I. H. Harris, of Waynesville, Ohio, to present to that institution his extensive collection of Ordovicic fossils. He had long known Mr. Harris, having met him as a young man, about the year 1876, at which time the Harris collection was already widely known, not only for its quantity, but more especially for its many choice specimens of the rarer species of starfishes, crinids, and trilobites. Twenty years later came Mr. Harris's desire to present to the National Museum the collection upon which he had been at work for fifty years. This gift brought to the National Museum not less than 40 asterids, 35 (31 on one slab) ophiurids from the Cincinnatic strata (the great majority from the Waynesville formation), besides an asterid and 12 specimens of Onychaster flexilis from the Keokuk formation at Crawfordsville, Indiana. Some years later the National Museum acquired the very valuable E. O. Ulrich collection, in which there were also many good starfishes. Accordingly, it is safe to state that in no other museum are there so many Ordovicic asterids, in so great a variety and in such excellent preservation.

The material of the Harris collection seemed to show that its complete study would not only reveal much new knowledge, but give an insight as well into the probable evolution of the Paleozoic starfishes. When these facts were made known to the then director of the National Museum, Dr. G. Brown Goode, he asked the writer to invite Mr. Harris to join him in a work on the Ordovicic starfishes. This was done and Mr. Harris was greatly pleased to undertake the joint authorship. He did all he could to further the work, but it went very slowly, because the present writer was so much occupied with curatorial work as well as the arranging of museum exhibits for the expositions in which the United States Government participated and which came 
nearly every year. Unfortunately, Mr. Harris died on October 17, 1897, when the work was still in the first stages.

At odd times during subsequent years the writer kept up his studies and in the spring of 1904 the work on the Asteroidea was practically completed. Then came his appointment to the chair of paleontology at Yale University. Here new duties and new lines of thought kept him away from the study of the Paleozoic ophiurids which had been planned, but the hope was strong that somehow the time would be found to complete the work. However, this hope has not materialized, others have gone to work on the starfishes, and one genus and generalization after another has slipped away. Therefore it was thought best to revise what had been done, bringing the asterids up to date. In regard to the ophiurids, it was found impossible to restudy the specimens, but as the writer had kept abreast of the literature, this was put into order and is here presented, in the hope that subsequent workers will find it useful in enabling them to find the references on any species and the taxonomic status of any form.

A study of the specimens in the Harris collection made it plain that no satisfactory taxonomic and systematic results would follow unless the undertaking also embraced many other Paleozoic forms, of Europe as well as of America. Species and genera had been proposed in a very loose manner; in fact, most of the Paleozoic literature on asterids and ophiurids up to the time this work began had no other value than to force the reviser under the rules of nomenclature to recognize the names proposed. The International Rules of Zoological Nomenclature have here been strictly followed. Under these circumstances, all of the typè-specimens had to be seen, and most of them have been accessible. In this way the work finally came to be extended to all Paleozoic Stelleroidea. To make it plain how little the American Paleozoic starfishes were known in 1889, it will suffice to give one example: Miller in his North American Geology and Palaeontology lists 23 species under Palæaster; in the present work there is but a single form of this genus, the genotype, $P$. niagarensis, the remainder having been distributed among seven genera, all new and proposed in the past few years or at this time. As a result, every paleontologist will be obliged to disregard what he has learned regarding American Paleozoic starfishes and start anew. To facilitate this, a list has been prepared and is here presented of all the names so far given to Paleozoic asterids and ophiurids, with cross references to the names adopted in this work.

Now that this study is finished, at least for the present, it is plain to the author that his species and genera are also in some cases too comprehensive. The future student will restudy the specimens along with the new material and go more deeply into the detailed structure of the parts. He who attempts this, along with painstaking recon- 
struction of the skeleton as it was in life, will learn where to separate and what to reject.

During the past 10 years, Schöndorf has revised most of the German asterids and has studied deeply into the structure of the ophiurids. His work is very detailed and the best extant on the Paleozoic forms. Every student of Stelleroidea intending to do thorough work will have to examine his results. In classification he has laid the foundation, and has shown that some asterids are not Asteroidea at all, but that they and the bulk of the so-called ophiurids of the Paleozoic must, because of their peculiar structure, ambulacral and otherwise, be referred to another class, the Auluroidea.

In regard to the evolution of the Asteroidea, the writer hoped to find the time to present his views concerning it in detail in this memoir, but that also is not possible. However, the main lines and often the generic directions of organic change are stated and will be found either in the introductory pages or scattered throughout the work, generally in the remarks under the generic discussions. These results in connection with the work of Schöndorf, it is thought, ought soon to place the Paleozoic Stelleroidea in such order that a final classification, based on ontogeny, chronogenesis, and phylogeny, and embracing not only the Paleozoic forms but those of Mesozoic, Cenozoic, and Recent time as well, can be made.

Many museums and individual paleontologists have loaned the writer the specimens in their collections or in their keeping, and he wishes here to thank them, one and all, for these loans. The greatest bulk of the material studied is of course in the United States National Museum in the Harris and UTrich collections; a number of Trenton specimens and some from the English Siluric have also been given to the National Museum by Mr. Walter R. Billings, of Ottawa. Since the writer has been in New Haven, Dr. R. S. Bassler, of the National Museum, has often kindly helped him to further his studies, and during the past year has made a large number of photographs of the specimens under his charge. The many Mississippic specimens in the Frank Springer collection have not been studied.

The author is greatly indebted to Dr. F.A. Bather, of the British Museum (Natural History), for a large number of gutta-percha and wax squeezes made by him of certain species in that great museum. These casts, which are all in the United States National Museum, have enabled the writer to understand several genera that otherwise he could not have worked out. He is also indebted to him for many bibliographic corrections and suggestions.

The second largest American collection is at Harvard University, in the Museum of Comparative Zoölogy. Most of the material is in the Charles D. Walcott, Charles B. Dyer, and Charles Wachsmuth collections. In the first-named collection there is excellent material from the Middle Ordovicic; the second has many fine specimens 
from the Cincinnatic formations; while the Wachsmuth material has species from the Mississippic. To all of this material the author has had access through the kindness of Director Samuel Henshaw and Profs. R. T. Jackson and P. E. Raymond.

At the University of Chicago there is a great deal of excellent material in the W. F. E. Gurley, Charles Faber, and U. P. James collections, to which Weller has added other specimens. All of this material has been studied through the courtesy of Prof. Stuart Weller. Most of it is from the Cincinnatic formations.

All of the specimens described by E. Billings and now in the Victoria Memorial Museum in Ottawa, Canada, have been seen at one time or another. In this matter the writer was much aided by the late Dr. J. F. Whiteaves and more recently by Drs. P. E. Raymond and E. M. Kindle, to the latter of whom thanks are also due for several photographs reproduced in this memoir. Most of the specimens are from the Ordovicic.

In the University of Toronto there is much material from the Ordovicic and Siluric in the Sir Edmund Walker collection, and there may be studied a great many specimens of Stenaster salteri. All of this has been seen through the great liberality of Prof. William A. Parks.

The genotype of Palxaster, from the museum of Cornell University, was loaned to the author at different times by Prof. H. S. Williams. It is one of the best preserved of Paleozoic specimens and has become very valuable because of the continual discussion that centers around the species, $P$. niagarensis.

To all the specimens in the Peabody Museum of Yale University access was had through the kindness of the late Prof. Charles E. Beecher. Among them is the unique branching form, Eucladia beecheri.

Photographs have been made for this memoir by Dr. John M. Clarke of specimens in the New York State Museum, and by Prof. George H. Hudson, of Plattsburg, New York, of other material. Prof. Arthur M. Miller loaned two specimens that he collected and deposited in the State University, Lexington, Kentucky. Prof. George W. Harper, of Cincinnati, loaned a specimen of Palxaster clarkana (= Hudsonaster incomptus).

Nearly all the original drawings were traced from the specimens by aid of the camera lucida. These outlines were then inked and shaded by the late Dr. J. C. McConnell, a draftsman and artist of the first rank.

To Miss Clara Mae LeVene the writer is especially thankful for the great interest she has taken in getting the manuscript into order for the printer, keeping the bibliography up to date and correctly citing it, and for the careful reading of the proof. 


\section{TERMINOLOGY AS APPLIED TO THE SKELETON OF PALEOZOIC} ASTEROIDEA. ${ }^{1}$

Abactinal.

See Body-wall. The integumentary skeleton opposite to that having the ambulacral grooves, or that of the upper or dorsal side of the animal. Also known as the aboral surface. See Actinal.

Aboral.

See Abactinal.

Accessory plates.

This term refers to the abactinal longitudinal columns, or transverse rows, of small plates between the radials and supramarginals (=radial accessory plates or dorsolaterals), or between the inframarginals and supramarginals (=ambital plates or intermarginals), or where there are no radials, to all the ossicles between the two supramarginal columns. There may also be accessory actinal plates which are termed accessory interbrachials, accessory actinals, or interactinals. The accessory plates form the secondary skeleton and are inserted between the columns of the primary skeleton. It is in the secondary skeleton that much of the specific and generic evolution takes place. See Interbrachial. Actinal.

See Body-wall. The integumentary skeleton with the ambulacral grooves, or that of the under or ventral side of the animal. Also known as the oral surface. Adambulacrals.

The single columns of prominent plates adjoining the ambulacrals. There are never more than two of these columns in a ray, one on each outer side of the depressed ambulacrals. They are generally large and thick and bear the larger, or adambulacral, spines. These spines may be inwardly directed and serve as a protection for the tube-feet. The oral armature in Paleozoic species usually consists of five pairs of modified adambulacrals, each pair being the oral projection of two united columns of adjoining rays. They are also called Adambulacralia. Also see Interbrachial.

Ambital.

The abactinal space between the infra- and supramarginal columns, occupied by accessory plates. These are best developed in the axillary disk areas (disk ambitals), while those of the rays are referred to as ray ambitals. They are also known as intermarginals.

Ambulacral.

Ambulacral grooves (five or more), plates, or ossicles are situated actinally and perradially along the center of the rays and disk. They are also called ambulacralia. The ambulacral columns are in pairs, the interlocking movable plates of adjoining columns may be alternate or opposite (always so in recent forms), and the plates of a column may be superposed like the tiles on a roof. The podial openings through which the fleshy tube-feet protrude are situated between the sutures of adjoining plates. In early forms there are but two columns of podial openings in each ray, one on each side of the axial line, but in later forms there may be as many as eight columns. The ambulacral grooves may be tapering or petaloid.

Anal opening.

The only Paleozoic form in which an anal opening may exist visually is Hudsonaster. Here it is on the disk between the central plate and the madreporite. The anal pore is nearly always obscured in fossil starfishes, and is absent in some recent species.

${ }^{1}$ Also in the main applicable to the Auluroidea and somewhat to the Ophiuroidea. 
Arcs.

Axil.

See Axil.

The angle formed by the junction of the rays. Also known as arcs. In primitive forms each axil is occupied by a single plate, the axillary inframarginal. In others this plate is crowded orally and its place occupied by two prominent proximal inframarginals. In forms with large disks having well-developed marginals these are termed disk marginals. Also see Ambital and Interbrachial. Bivium.

The two rays of a starfish that inclose between them the madreporite. When oriented toward the student, the ray on the left is numbered 1 and the other on the right is numbered 5. A line drawn through the madreporite and the center of the upward directed ray (ray 3) divides the animal into symmetrical halves (=left and right sides). The upper left-hand ray is numbered 2 and the one opposite is 4 . Rays 2, 3, and 4 form the trivium.

Body-wall.

The outer surface of both disk and rays, made up of movable calcareous plates which are either closely adjoining or form a more or less loose network of ossicles. These are held together in the living animal by connective tissue and muscular fibers, which after death soon decompose, freeing the plates. It is for this reason that fossil starfishes are so rarely found entire. Imbedded in the body-wall everywhere are blunt, short, calcareous spines, arranged in a more or less definite order, and often movable upon the underlying plates.

Covering the whole surface of the body, including the spines and pedicellariæ, is a delicate membrane or skin, clothed externally with closely placed vibratile cilia, which keep the integument clean. The calcareous skeleton of starfishes is therefore integumentary.

Cracal pores.

The openings between reticular plates for the protrusion of the respiratory cæcal processes. These pores are either restricted to the abactinal area or may be distributed over the entire body. The processes are also known as papulæ.

Central disk.

See Disk.

Central disk plate.

A prominent plate, most conspicuous in primitive forms, which often appears in the center of the disk. It holds the same position as the centro-dorsal plate in embryonic crinids of the genus Antedon. Also called the abactinal-central plate or simply central plate.

Centro-dorsal plate. Disk.

See Central disk plate.

The central portion of a starfish. In this work, the term generally applies only to the abactinal central area formed either by the union of the rays, or by the rays plus the axillary areas. The mouth is in the center of the disk on the under or actinal side. Disk plates are the small plates over this area on the abactinal side. Central disk plate refers to a larger primary plate in the center of the disk. There may be other large primary plates, but these are more properly referred to the rays. See Radial, Interradial, Marginal, and Ambital.

\section{Inframarginal.}

See Marginal plates.

\section{Interbrachial.}

The actinal and marginal areas between the rays. These spaces have plates derived from various regions. In primitive forms, but a single plate is present, the axillary interbrachial, derived by crowding orally the axillary inframarginal. In other genera, inframarginals are crowded in pairs orally and form interbrachial 
areas, the interbrachial marginals. Or the adambulacrals may enter into the construction of these areas, forming interbrachial adambulacrals. When the adambulacrals and inframarginals are separated by small plates, the latter are called accessory interbrachials; they may extend almost to the distal ends of the rays. Interradial.

A point half-way between the perradii. The interambulacral areas are interradial in position. See Perradial.

Interradial plates.

These abactinal plates are rarely retained in living mature starfishes. In many Paleozoic genera they are large, interradial in position, five in number, and lie inside the basal or proximal supramarginals and between the primary radials. They may be homologous with the basals of crinids. They are also known as genitals.

Madreporite or-madreporic plate.

A sieve-like or spongy plate, with many irregular openings for the circulation of sea water into the so-called "stone canal," or better, into the water-vascular system. It is commonly granular or striated, and in Asteroidea is abactinal on the disk, basally situated between two rays, but in the Auluroidea is probably always actinal in position. In recent multiradiate forms there are species with more than one madreporite.

Marginal plates.

In general the plates which make up the marginal columns bounding the rays, or disk, or the entire animal. They are parts of the primary skeleton. In the early Paleozoic genera the inframarginal and supramarginal columns are usually not directly superposed, making one column of superposed halves as in Mesozoic and Recent starfishes, but the former column lies outside or laterally of the latter. The inframarginals are then the true marginals, and form a part of both the abactinal and actinal sides. In the primitive arrangement the inframarginals adjoin the adambulacrals, but in derived forms with large pentagonal disks they are separated from the latter by accessory interbrachial plates. The situation of the marginals is, however, not always at the margin of the disk and rays, but they may retain their primitive position beside the adambulacrals; this is more especially true in forms having a well-developed pentagonal disk. These plates are also referred to as marginalia, supramarginalia, and inframarginalia.

In some forms the supramarginals are not recognizable as such, while the inframarginals are well-developed; and in others none of the marginals are distinctly discernible. Sometimes the plates of the inframarginal columns adjoin one another, while those of the supramarginal series are separated by small accessory supramarginal pieces. Then the inframarginals may be separated from the supramarginals by ambital ossicles (see Ambital). A proximal supramarginal is the proximal plate of a column and may not be homologous with the primary supramarginal in primitive forms. Proximal inframarginal is used in a similar way and refers to the proximal axillary plate, two of which of adjoining columns occupy an axil or lie on either side of the axillary marginal. The latter in primitive forms alone occupies the angle between the rays. The marginals in large disks without angles may be termed disk infra- and supramarginals. The large disk of some species is formed by the oral crowding of pairs of proximal inframarginals, the interbrachial marginals.

Measurements.

The size of starfishes is usually given in millimeters along the greater and lesser radii, that is, from the center of the mouth or disk to the tips of the rays. The symbol for this line is $R$. The smaller radius is from the center of the animal to the center of the interradii; the symbol is $r$.

$50601^{\circ}-$ Bull. $88-15-2$ 
Mouth angle plate.

See Oral armature.

Ocular plate.

A single large, grooved eye-plate occupying the distal ends of rays and supporting a sensory tentacle at the base of which occurs the eye-spot. They appear in the larval stage as the primary radials and with growth pass outward, remaining at the tip of the rays as the oculars. They are also known as terminals. These large plates are not present as such in early Paleozoic genera, and are unknown before the Carboniferous.

Oral.

See Actinal.

Oral angles.

The interradial actinal areas around the mouth.

Oral armature.

The pairs of plates, usually five in number, composing the apices around the central actinal opening or mouth. In most Paleozoic forms the armature consists of the proximal modified adambulacral plates. These pieces are also known as Mouth angle plates.

In some Paleozoic forms (Hudsonaster) there lies in front of each pair of mouth angle plates a single plate; this is known as the Torus.

Gregory (1900, p. 241) writes that "the Oral Skeleton (or actinostomial ring) consists of a solid calcareous ring around the mouth. It is composed of thirty plates in a quinqueradiate starfish, there being always six times as many plates as there are rays. Each segment of the oral skeleton consists of two pairs of ambulacral, and of one pair of adambulacral ossicles. In Asterias [a cryptozonian] the ambulacral plates are more prominent than the adambulacrals, and project into the oral cavity."

When the ambulacral elements are the more prominent, the oral skeleton is said to be of the ambulacral type. This is only present in cryptozonians. When the adambulacral ossicles are the most prominent, the oral skeleton is of the adambulacral type. This latter construction is the more primitive and occurs in all the Phanerozonia, but is also present in some of the cryptozonians.

Ossicles.

See Plates.

Papulæ.

In living Asterias, a cryptozonian, from between the spicular plates there rise from all parts of the external surface short and small integumentary protuberances that are used for respiration. In the more heavily plated Phanerozonia they are limited to the abactinal surface enclosed between the supramarginal plates. It is probable that papulæ were present in all Paleozoic forms having rounded or spicular ossicles, issuing in the open spaces between the plates. They probably were absent in the earliest closely plated starfishes, such as Hudsonaster. See Crcal pores.

Paxillæ.

Minute calcareous processes arranged around large spines. None are known in Paleozoic genera.

"Another type of spines occurs as part of the structures known as 'paxillæ.' Each paxilla consists of a thick plate supporting a number of short, calcareous pillars, the summit of each of which is covered by a group of small spines. In some Phanerozonia * * * the paxillæ occupy almost the whole abactinal surface of the Asteroid" (Gregory 1900, p. 247).

Pedicellarix.

Pincer or scissors-like calcareous appendages, attached to the spines, the plates, or the skin, which keep the body-wall clean of parasites. None have as yet 
been detected with certainty in Paleozoic genera. In the primitive Recent forms they are also absent, the integument being protected by an abundance of closely set spines.

"The Pedicellariæ of Asteroids are of four main types. The simplest form consists of a row of pairs of small, sessile, opposable spines; these are the 'pseudopedicellariæ.' The members of the second set are 'sessile.' The next advance is the development of a stalk; of these pedunculate pedicellariæ there are two varieties: (1) the 'forficiform,' in which the two hooks are attached to the nearest end of the basal plate nearest to them; (2) the 'forcipiform,' in which the two hooks cross one another and are attached to the end of the basal plate farPerradial. thest from them" (Gregory 1900, p. 247; also see Verrill 1914, pp. 25-34).

The area along the center of the rays. The ambulacra are perradial in position. See Interradial.

Plates.

Some writers restrict the term plates to the five primary radials, five interradials, and the central disk piece, and refer to all the other calcareous parts as ossicles. The word plates is here used in the widest sense, and as interchangeable with ossicles. For the sake of brevity the plates will be often referred to as marginalia, radialia, etc.

Podial openings.

The rounded openings between the ambulacral plates for the protrusion of the locomotor organs, the podia or water-tube-feet. See also Ambulacral.

Primary radial.

See Radial.

Primary skeleton.

The skeleton of a starfish is made up of primary and secondary ossicles. The primary skeleton consists of the longest inherited and the first appearing plates in the young, as the ambulacral, adambulacral, marginal and radial columns, plus the primary pieces of the disk. All the other ossicles inserted between Radial. these are of the secondary skeleton.

Refers only to the prominent abactinal primary plates holding a radial position. Where present, they form columns of continuous reticular or separated radialia, situated along the radial center of the rays. Proximal radials are those on or near the disk and should not be confounded with the primary radials, the probable homologues of the radials in crinids. These plates are also known as Rays. median dorsals, dorsals or carinals; also as radialia.

The radial "arms" of starfishes. These are hollow and contain the digestive, reproductive, and water-vascular systems and other organs. The rays merge gradually and without sharp demarcation into the central disk.

Respiratory pores.

See Cæcal pores.

Secondary skeleton. Spines.

See Primary skeleton and Accessory plates.

See Paxillæ and Pedicellarix.

Supramarginal.

See Marginal plates.

Terminals.

See Ocular plate. 
Torus.

See Oral armature.

Trivium.

See Bivium.

Vertebral ossicles.

In the Ophiuroidea each pair of adjoining ambulacralia is united into a single plate, the vertebra of the arms. As the arms are very flexible, these ossicles articulate upon one another as do the bones in the vertebral column of vertebrates.

\section{FINDING LIST OF PALEOZOIC STELLEROIDEA.}

Acroura (Ophiura) schlotheimii Münster. Known to the writer only from the list in Woodward, Geol. Mag., dec. 2, vol. 1, 1874, p. 7. Siluric.

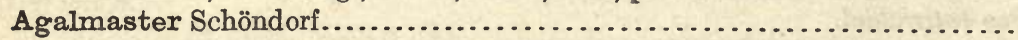

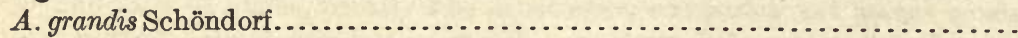

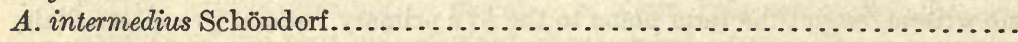

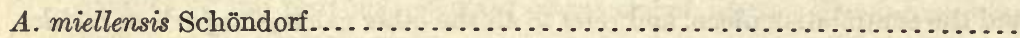

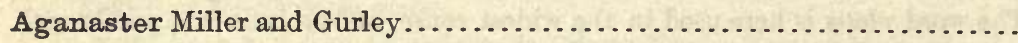

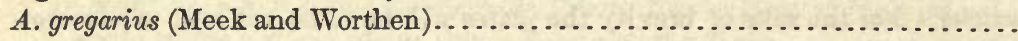

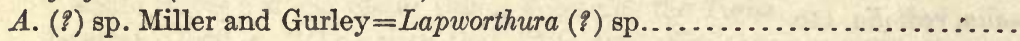

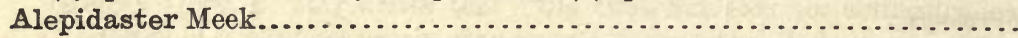

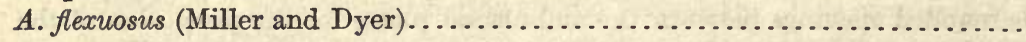

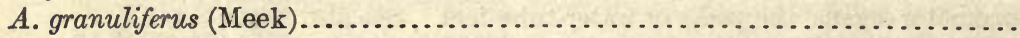

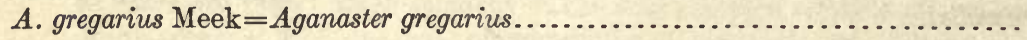

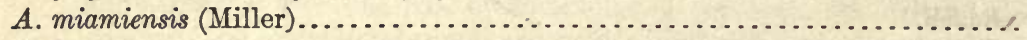

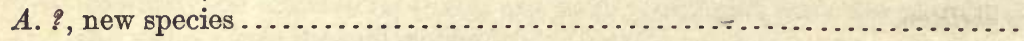

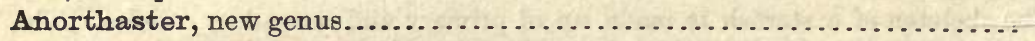

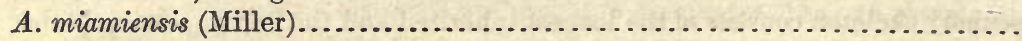

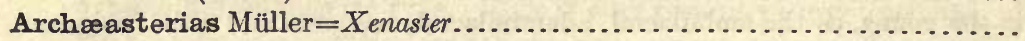

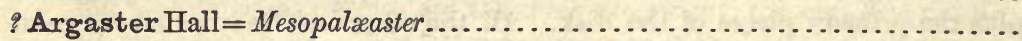

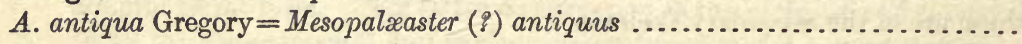

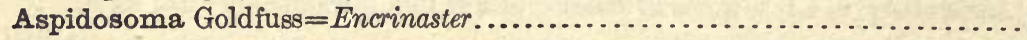

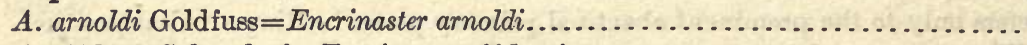

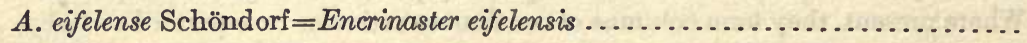

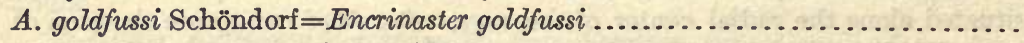

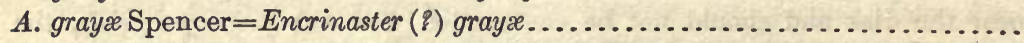

A. petaloides Simonovitsch $=$ Encrinaster petaloides........................

A. petaloides goslariensis Halfar =Encrinaster petaloides goslariensis.............

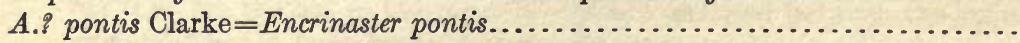

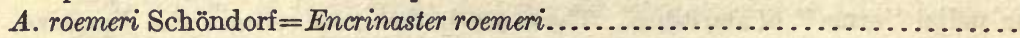

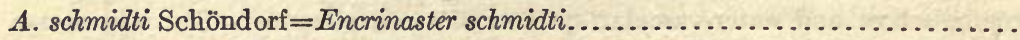

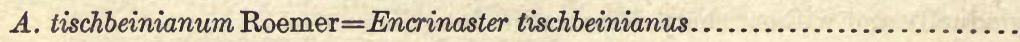

Asterias Graham, Anthony, and James $=$ Petraster ( $($ ) americanus.............

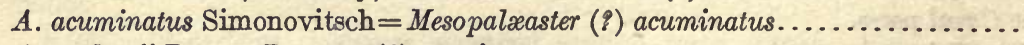

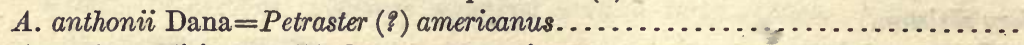

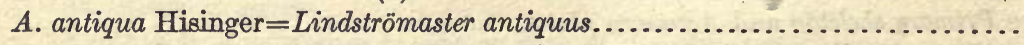

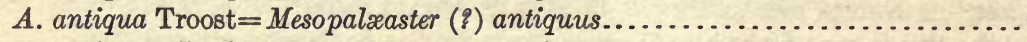

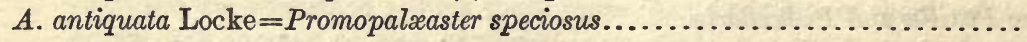

A. asperula Roemer $=$ Urasterella asperula............................

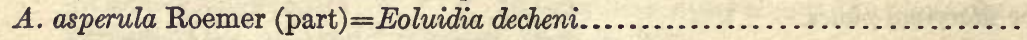

A. constellata Thorent $=$ Urasterella $($ ? $)$ constellata..................... 187

A. matutina Hall $=$ Hudsonaster matutinus........................ 57

A. montanus $S$ tschurowsky $=$ Urasterella montana................... 189

A. primæva Salter and Sowerby $=$ Stenaster $($ (q) obtusus................ 167 
Asterias primordialis Anon $=$ Promopalæaster, sp. undet............... 108

A. (Archæasterias) rhenana Müller $=$ Xenaster (?) rhenanus................ 131

A. spinosissima Roemer. An unsolved starfish from the Lower Devonic of

Bundenbach, Germany. See Roemer, Palæontographica, vol. 9, 1863, p. 147, pl. 29, fig. 4; and Schöndorf, Jahrb. nassauisch. Ver. Naturk., Wiesbaden, vol. 62,1909, p. 33 .

A. sp. undet. Hall $1847=$ Cœlaster tenuiradiatus.

Asteriscus antiquus Pictet $=$ Lindströmaster antiquus. ..................

Astropecten Link.

A. (?) schlüteri Stürtz......................................

Ataxaster Jaekel.........................................

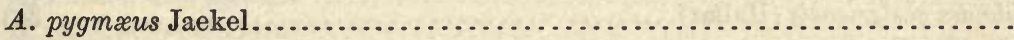

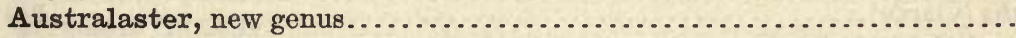

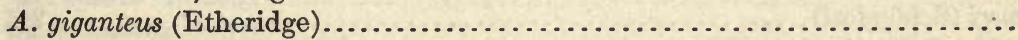

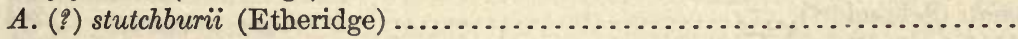

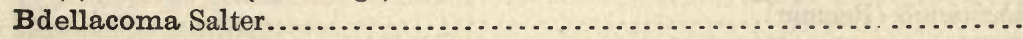

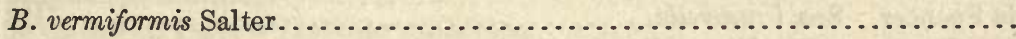

Bohemura Jaekel......................................

B. jahni Jaekel............................................

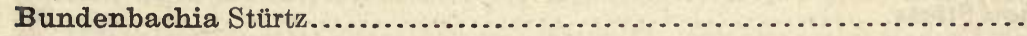

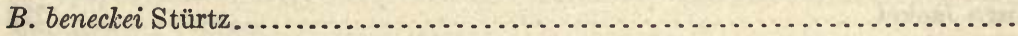

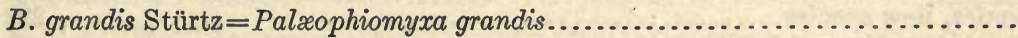

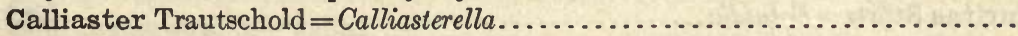

C. mirus Trautschold $=$ Calliasterella mira ..........................

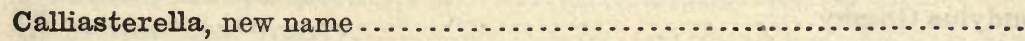

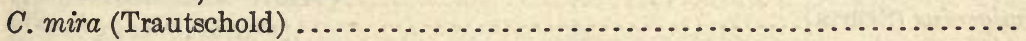

Cheiropteraster Stürtz . ...................................

C. giganteus Stürtz........................................

Cholaster Worthen and Miller.................................

C. peculiaris Worthen and Miller.................................

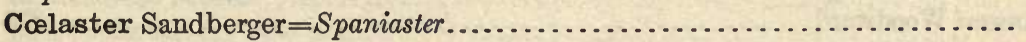

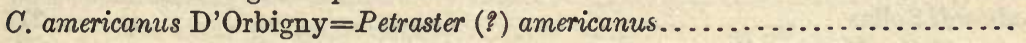

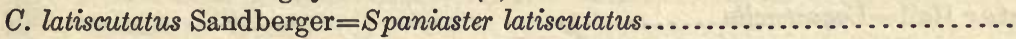

C. tenuiradiatus D'Orbigny, Prodr. de Paleont., vol. 1, 1849, p. 22. Based on an isolated madreporite described as Asterias, sp. undet., Hall, Pal. New York, vol. 1, 1847, p. 18, pl. 4, figs. $11 a, 11 b$.

Compsaster Worthen and Miller.

C. formosus Worthen and Miller.

$C .$, new species.

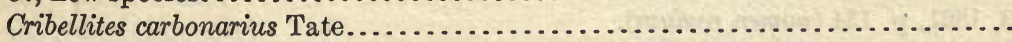

Devonaster, new genus....................................... 97

D. chemungensis, new species................................ 101

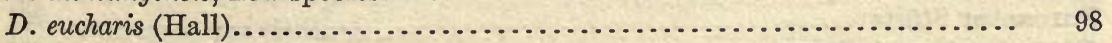

Echinasterella Stürtz...................................... 200

E. ? darwini Clarke......................................... 200

E. sladeni Stürtz............................................ 200

Echinasterias Stürtz....................................... 211

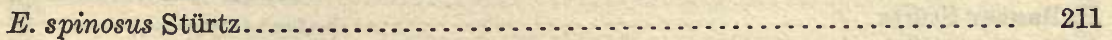

Echinodiscaster Delage and Hérouard.......................... 211

E. multidactylus (Stürtz)..................................... 211

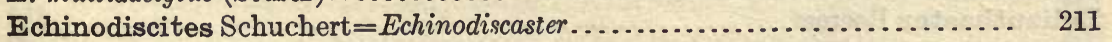

Echinodiscus Stürtz $=$ Echinodiscaster ............................. 211

E. multidactylus $\mathrm{Stürtz}=$ Echinodiscaster multidactylus................... 211 
Echinostella Stürtz.

E. traquairi Stürtz.

Eifelaster Schöndorf.

E. follmanni Schöndorf.

Encrinaster Haeckel.

Encrinaster Haeckel (part) = Protaster

$E$. arnoldi (Goldfuss)

E. eifelensis (Schöndorf)

$E$. goldfussi (Schöndorf).

E. grayæ (Spencer)

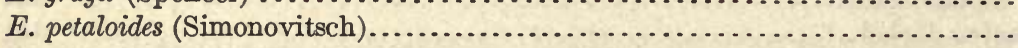

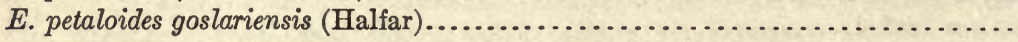

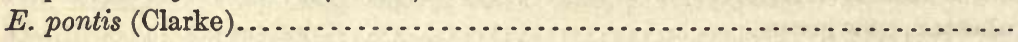

E. roemeri (Schöndorf).

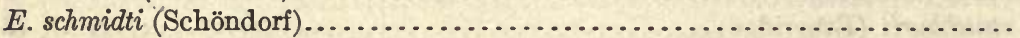

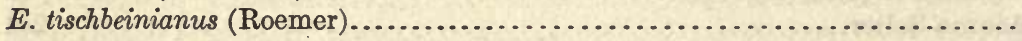

Eoactis Spencer. See Urasterella................................ 173

E. simplex Spencer. See Urasterella girvanensis ..................... 186

Eoluidia Stürtz......................................... ${ }^{262}$

$E$. decheni Stürtz........................................ 262

Eophiura Jaekel....................................... 222

$E$. bohemica, new species.................................... 222

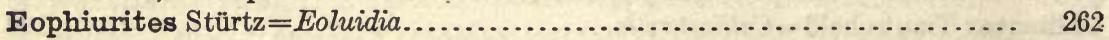

E. decheni $($ Stürtz $)=$ Eoluidia decheni............................ 262

Eospondylus Gregory..................................... 263

$E$. primigenius (Stürtz)........................................ 263

Etheridgaster Gregory $=$ Monaster $\ldots \ldots \ldots \ldots \ldots \ldots \ldots \ldots \ldots \ldots \ldots \ldots \ldots . \quad 170$

E. clarkei Gregory=Monaster clarkei......................... 172

Eucladia Woodward...................................... 276

$E$. (q) beecheri, new species................................. 278

E. johnsoni Woodward.................................... 276

E. woodwardi Sollas.......................................... 277

Eugaster Hall $=$ Eugasterella................................ 237

E. concinnus Ringueberg $=$ Eugasterella $($ ?) concinna................. 239

E. logani Hall=Eugasterella logani........................... 238

Eugasterella, new name................................ 237

$E .($ q) concinna (Ringueberg)................................... 239

E. logani (Hall) ............................................ 238

Euryale annulatum DeKay. Apparently a lysophiurid. See Hall, Pal. N. Y., vol. 3,1861 , p. 134 (nomen nudum).

Euthemon Sollas.

E. igerna Sollas............................................. 279

Furcaster Stürtz........................................... 261

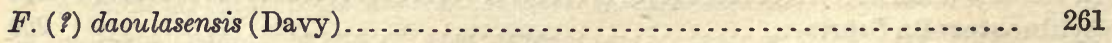

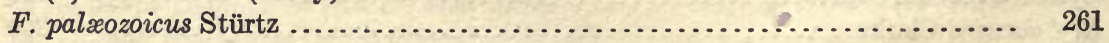

Gregoriura Chapman................................... 233

G. spryi Chapman......................................... 234

Hallaster Stürtz........................................... 254

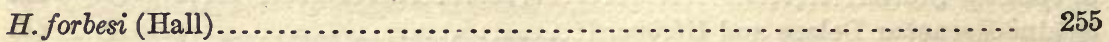

Helianthaster Clarke (part) $=$ Palæosolaster ...................... 209

Helianthaster Roemer.................................... 159

$H$. filiciformis Woodward .................................... 160

H. gyalum Clarke $=$ Palæosolaster $($ ? $)$ gyalum $\ldots \ldots \ldots \ldots \ldots \ldots \ldots \ldots \ldots \ldots .210$ 
Page.

Helianthaster gyalum Clarke (part) $=$ Lepidasterella babcocki.............. 160

H., new species Clarke $=$ Lepidasterella babcocki....................... 160

H. rhenanus Roemer ..................................... 159

H. roemeri Clarke $=$ Palæosolaster roemeri. ........................ 211

Hisingeraster $\mathrm{Stürtz}=$ Lindströmaster ............................. 148

H. antiqua Stürtz $=$ Lindströmaster antiquus.......................... 149

Hudsonaster Stürtz..................................... 53

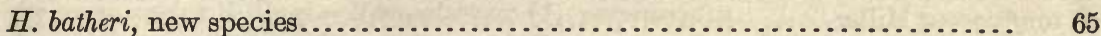

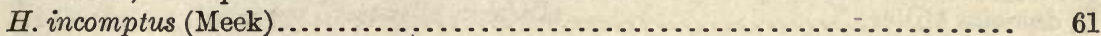

H. matutinus (Hall) .................................... 57

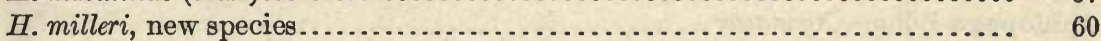

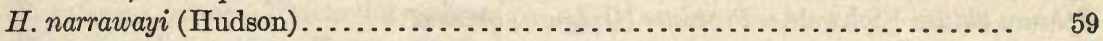

H. rugosus (Billings).................................... 64

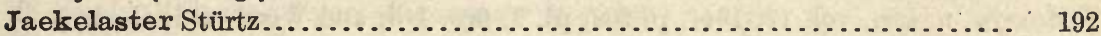

$J$. petaliformis Stürtz....................................... 192

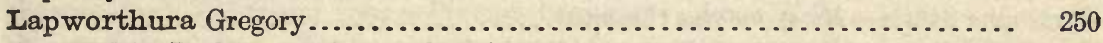

L. cylindrica Parks $=$ Tæniaster cylindricus.......................... 220

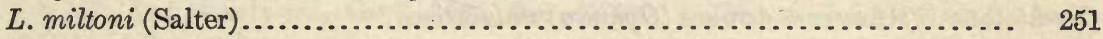

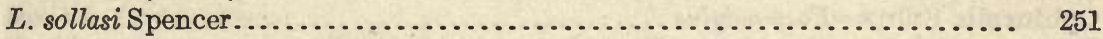

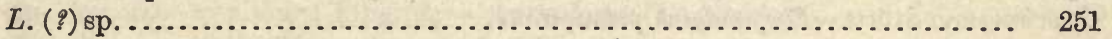

Lepidaster Forbes................................................ 158

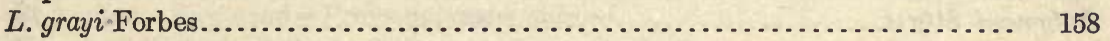

Lepidasterella, new genus.................................. 160

L. babcocki, new species......................................... 160

Iindströmaster Gregory........................................ 148

L. antiquus (Hisinger) ......................................... 149

Loriolaster Stürtz ............................................ 201

L. mirabilis Stürtz............................................ 201

Medusaster Stürtz............................................ 212

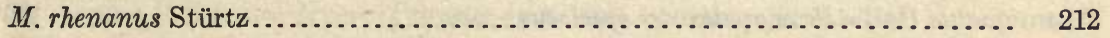

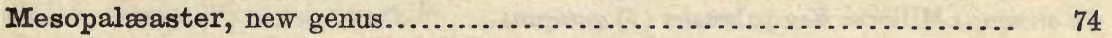

$M$. (?) acuminatus (Simonovitsch) ................................. 93

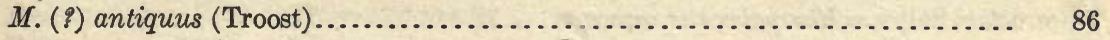

M. bellulus (Billings).......................................... 91

M. caractaci (Gregory)........................................ 92

$M .($ ?) cataractensis, new species.................................. 89

M. (?) clarki (Clarke and Swartz)................................. 94

M. (?) dubius (Miller and Dyer)................................... 85

M. finei (Ulrich) .......................................... 81

M. granti (Spencer) ......................................... 89

M. intermedius, new species.................................. 79

M. (?) lanceolatus, new species................................. 82

$M$. (?) parviusculus (Billings)..................................... 87

M. proavitus, new species................................. 83

M. shafferi (Hall) ............................................ 77

$M$. (?) wilberanus (Meek and Worthen)............................. 84

Miomaster Schöndorf........................................ 96

M. drevermanni Schöndorf.................................... 96

Miospondylus Gregory ...................................... 263

$M$. rhenanus (Stürtz) .......................................... 263

Monaster Etheridge........................................... 170

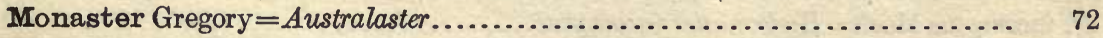

M. $\operatorname{clarkei}($ De Koninck)...................................... 172 
Monaster giganteus Etheridge=Australaster giganteus .................. 73

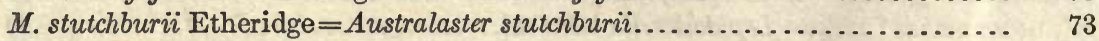

Neopalæaster, new genus....................................... 134

$N$. crawfordsvillensis (Miller).................................... 136

Onychaster Meek and Worthen................................ 268

O. asper Miller................................................. 272

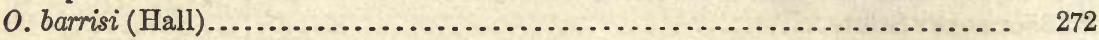

0. confragosus Miller............................................ 273

0. demissus Miller........................................... 274

0. flexilis Meek and Worthen...................................... 270

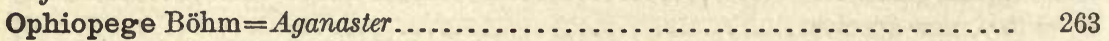

Ophiura obtusa Eichwald=Protaster (Ophiura) obtusus.

O. (?) ramosa Fahrenkohle. Unknown to writer. See Bull. Soc. Imp. Nat. Moscow, n. ser., vol. 17, 1844, p. 208, pl. 3, figs. 1-3; and Woodward, Geol. Mag., dec. 2, vol. 1, 1874, p. 7 (listed only). Coal Measures.

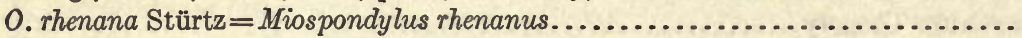

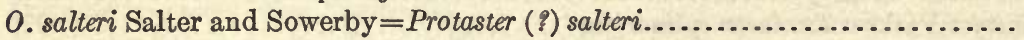

O. schlotheimii Münster=Acroura (Ophiura) schlotheimii.

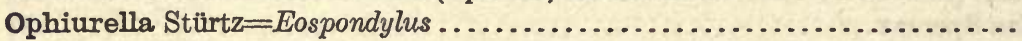

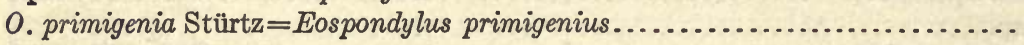

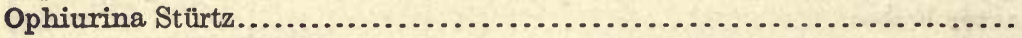

0. lymani Stürtz.......................................................

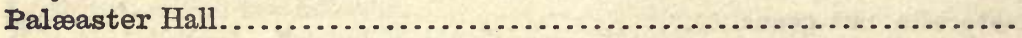

Palæaster of authors=Hudsonaster, Mesopalæaster, Devonaster, Promopalæaster, Anorthaster, Neopalæaster, Petraster, Palasterina, Monaster, Urasterella.

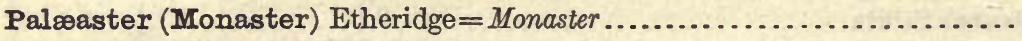

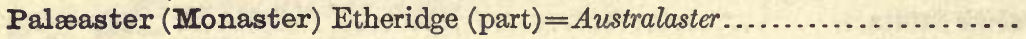

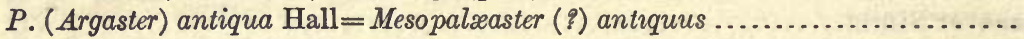

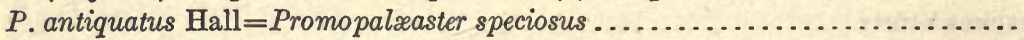

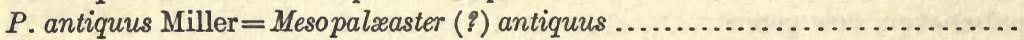

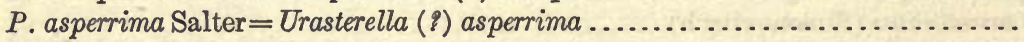

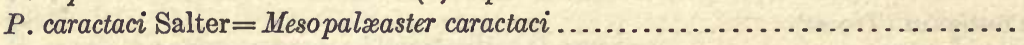

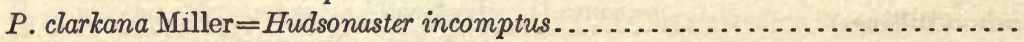

$P$. clarkei De Koninck = Monaster clarkei.............................

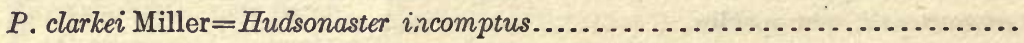

P. clarki Clarke and Swartz $=$ Mesopalæaster $($ ? $)$ clarki.....................

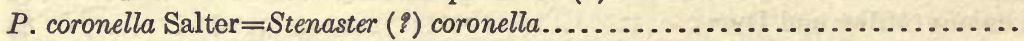

$P$. crawfordsvillensis Miller $=$ Neopalæaster crawfordsvillensis.................

$P$. dubius Miller and Dyer $=$ Mesopalæaster (?) dubius .......................

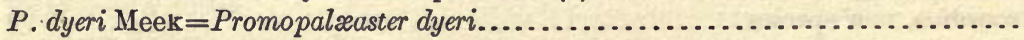

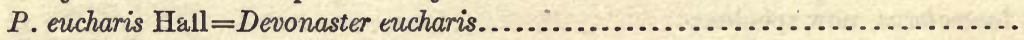

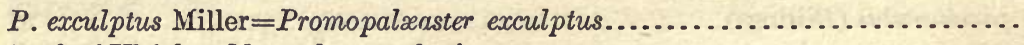

$P$. finei Ulrich $=$ Mesopalæaster finei..................................

P. (Monaster) grganteus Etheridge $=$ Australaster giganteus....................

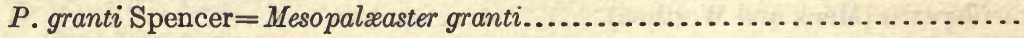

$P$. granulosus $\mathrm{Hall}=$ Promopalæaster granulosus........................

P. granulosus Meek = Promopalæaster speciosus.........................

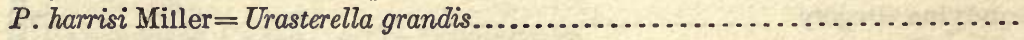

$P$. hirudo Salter $=$ Urasterella hirudo...............................

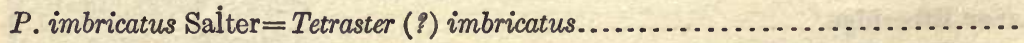

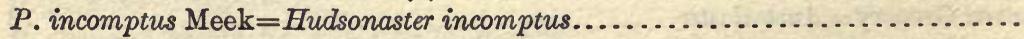

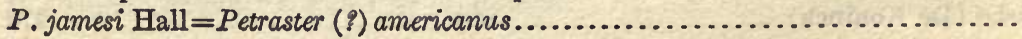


Palæaster longibrachiatus Miller=Promopalæaster spinulosus ..................

P. magnificus Miller = Promopalæaster magnificus........................

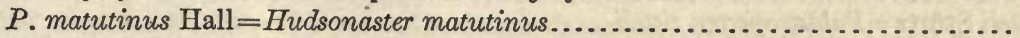

$P$. miamiensis Miller $=$ Anorthaster miamiensis.

$P$. montanus Trautschold = Urasterella montana

P. niagarensis Hall.

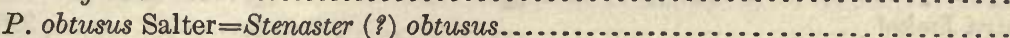

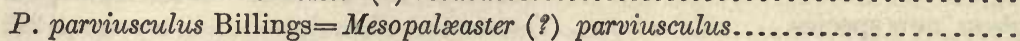

$P$. pulchellus Billings $=$ Urasterella pulchella..........................

$P$. pygmæa Eichwald. Not known to writer. Middle Ordovicic, Pulkowa, Russia.

P. ruthveni Salter $=$ Urasterella ruthveni.

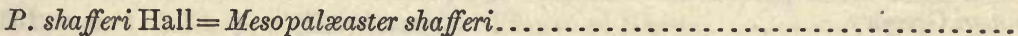

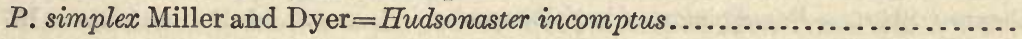

P. speciosus Meek=Promopalæaster speciosus. ..........................

$P$. spinulosus Miller and Dyer $=$ Promopalæaster spinulosus...................

P. squamatus Salter. Not known to writer. See Cat. Woodwardian Mus., 1873,

p. 47; and Woodward, Geol. Mag., dec. 2, vol. 1, 1874, p. 7 (listed only). Bala of England.

$P$. (Monaster) stutchburii Etheridge =Australaster $($ ( ) $)$ stutchburii...............

$P$. wilberanus Hall = Mesopalæaster (?) wilberanus........................

P. ? wilsoni Raymond = Promopalæaster wilsoni .........................

$P$. wykoffi Miller and Gurley $=$ Promopalæaster wykoffi.....................

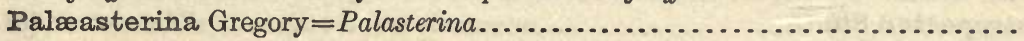

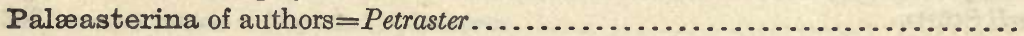

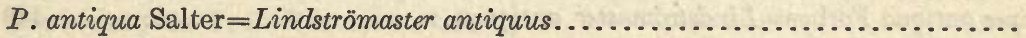

$P$. approximata Miller and Dyer $=$ Petraster speciosus......................

$P$. fimbriata Meek and Worthen $=$ Schonaster fimbriatus...................

$P$. rugosa Billings $=$ Hudsonaster rugosus.............................

P. speciosa Miller and Dyer $=$ Petraster speciosus...........................

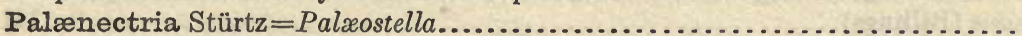

$P$. devonica Stürtz $=$ Palæostella solida................................

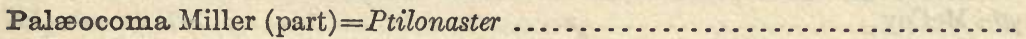

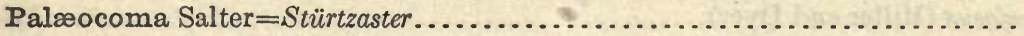

Palæocoma (Bdellacoma) Salter $=$ Bdellacoma .......................

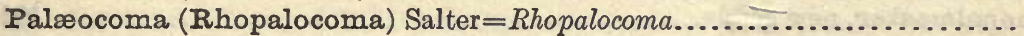

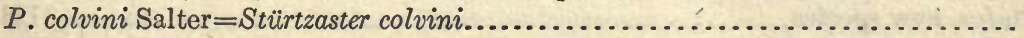

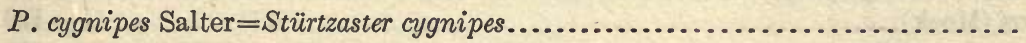

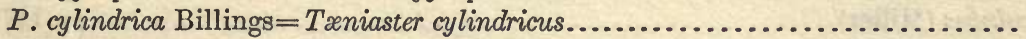

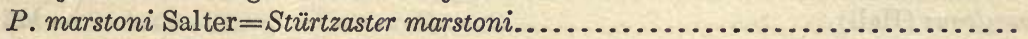

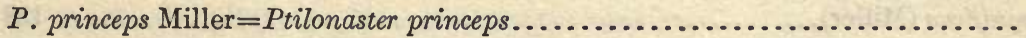

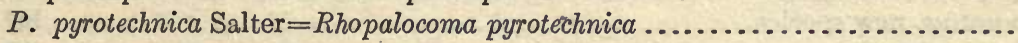

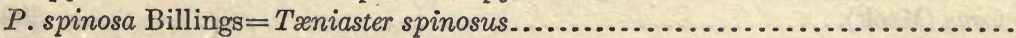

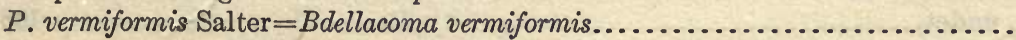

Palxodiscus ferox Salter =an echinid. See Jackson, Mem. Boston Soc. Nat.

Hist., vol. 7, 1912, p. 250.

Palæophiomyxa Stürtz.

$P$. grandis (Stürtz).

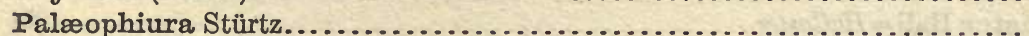

$P . \operatorname{simplex}$ Stürtz..............................................

Palæosolaster Stürtz.............................................

$P$. gregoryi Stürtz..............................................

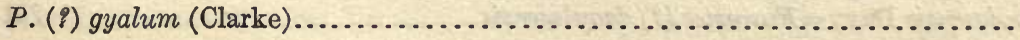


Page.

Palæosolaster roemeri (Clarke)................................. 211

Palæospondylus Stürtz $=$ Palastropecten $\ldots \ldots \ldots \ldots \ldots \ldots \ldots \ldots \ldots \ldots \ldots \ldots .261$

P. zitteli Stürtz $=$ Palastropecten zitteli.......................... 262

Palæostella Stürtz.................................... 155

P. solida Stürtz.......................................... 156

Palæspondylus Stürtz $=$ Palastropecten $\ldots \ldots \ldots \ldots \ldots \ldots \ldots \ldots \ldots \ldots \ldots \ldots . \ldots \ldots 1$

Palæura Jaekel......................................... 223

P. neglecta, new species...................................... 223

Palasteracanthion Stürtz $=$ Urasterella $\ldots \ldots \ldots \ldots \ldots \ldots \ldots \ldots \ldots \ldots \ldots . \quad 173$

Palasterina Billings (part) $=$ Schuchertia ....................... 195

Palasterina McCoy ........................................ 150

$P$. antiqua Salter $=$ Lindströmaster antiquus ..................... 149

$P$. bonneyi Gregory......................................... 153

$P$. follmanni Stürtz $=$ Pseudopalasterina follmanni .................. 157

$P$. (q) jamesi Dana $=$ Petraster $(\xi)$ americanus ...................... 146

$P$. kinahani Baily $=$ Uranaster kinahani......................... 155

$P$. primæva (Forbes)....................................... 153

$P .($ ) ramseyensis Hicks................................... 154

$P$. rigidus Billings $=$ Petraster rigidus.......................... 141

$P$. rugosa Billings $=$ Hudsonaster rugosus.......................... 64

$P$. stellata Billings $=S$ chuchertia stellata....................... $\quad 196$

Palasteriscus Stürtz.................................... 200

$P$. devonicus Stürtz........................................ 200

Palastropecten Stürtz.................................. 261

$P$. zitteli Stürtz ............................................... 262

Palmipes antiqua Forbes $=$ Lindströmaster antiquus.................. 149

Petraster Billings........................................ 138

$P .($ () americanus (D’Orbigny) ................................... 146

$P$. (?) antiqua Shumard = Mesopalæaster $($ ?) antiquus.................. 86

$P$. bellulus Billings= Mesopalæaster bellulus.......................... 91

$P$. rigidus (Billings)....................................... 141

$P$. rigidus $($ Billings) $($ part $)=$ Hudsonaster matutinus ................... 57

P. smythi McCoy....................................... 147

$P$. speciosus (Miller and Dyer)............................... 142

$P$. wilberianus Meek and Worthen=Mesopalæaster (q) wilberanus............. 84

Promopalæaster, new genus................................ 102

$P$. bellulus, new species...................................... 113

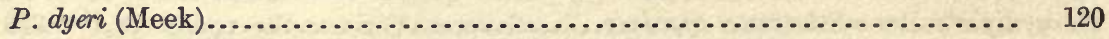

P. exculptus (Miller)...................................... 117

P. granulosus (Hall)..................................... 112

$P$. magnificus (Miller)...................................... 122

$P$. prenuntius, new species................................. 107

P. speciosus (Meek).......................................... 109

$P .$, sp. undet............................................. 108

$P$. spinulosus (Miller and Dyer)............................. 115

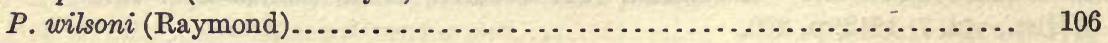

P. wykoffi (Miller and Gurley)................................ 119

Protaster Forbes............................................. 224

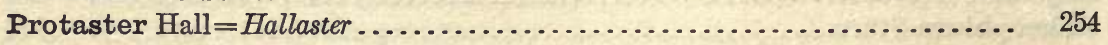

P. ? barrisi Hall $=$ Onychaster barrisi............................ 272

P. biforis Gregory.......................................... ${ }^{2} 26$

P. brisingoides Gregory=Stürtzura brisingoides................... 236

$P$. daoulasensis Davy $=$ Furcaster $($ ? $)$ daoulasensis................... 261 
Protaster decheni Dewalque $=$ Tremataster $($ ( ) decheni.................. 248

$P$. elegans Parks $=$ Tæniaster elegans.......................... 221

$P$. flexuosus Miller and Dyer $=$ Alepidaster flexuosus...................... 231

$P$. forbesi $\mathrm{Hall}=$ Hallaster forbesi................................ 255

$P$. (?) granuliferus Meek =Alepidaster granuliferus..................... 230

$P$. (?) gregarius Meek and Worthen=Aganaster gregarius................. 264

$P$. groomi Sollas and Sollas.................................... 227

P. leptosoma Salter $=$ Stürtzura leptosoma........................ 237

$P$. miamiensis Miller $=$ Alepidaster miamiensis........................ 233

$P$. miltoni Salter $=$ Lapworthura miltoni.......................... 251

$P$. (Ophiura) obtusus Eichwald. Unknown to the writer. See Schichtensystem Esthland, p. 193; Lethæa Rossica, p. 661; and Woodward, Geol. Mag., dec. 2 , vol. 1, 1874, p. 7 (listed only). Siluric of Russia.

$P$. petri Salter. Unknown to the writer. See Salter, Cat. Mus. Pract. Geol., p. 30; and Woodward, Geol. Mag., dec. 2, vol. 1, 1874, p. 7 (listed only). Probably Bala, Church Stretton, England.

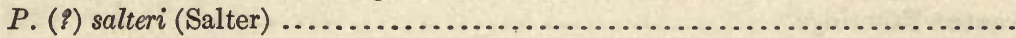

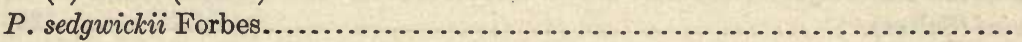

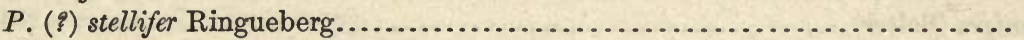

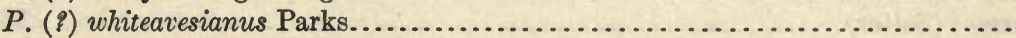

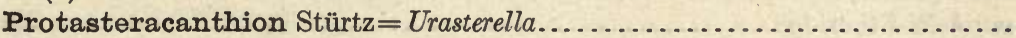

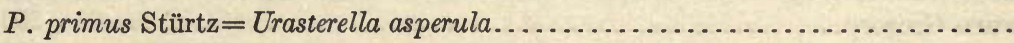

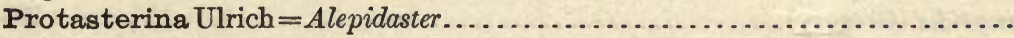

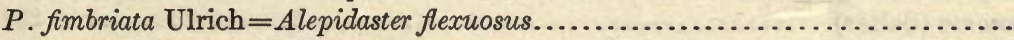

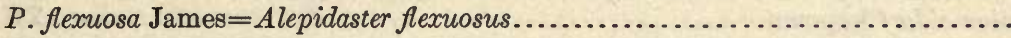

Protoeuryale C. F. Roemer =a crinid.

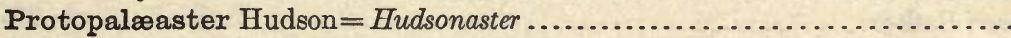

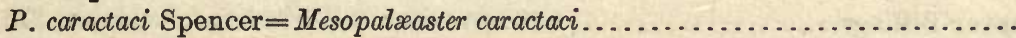

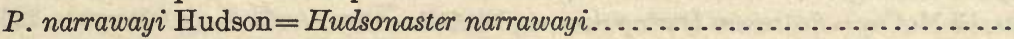

Pseudopalasterina Stürtz....................................

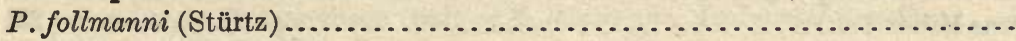

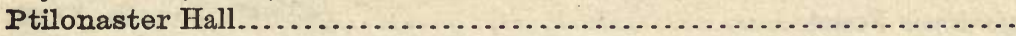

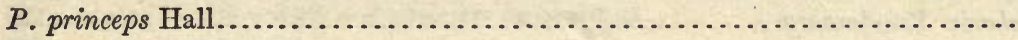

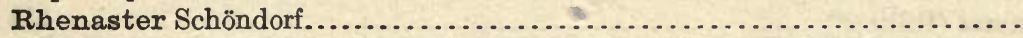

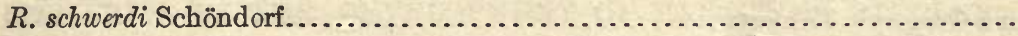

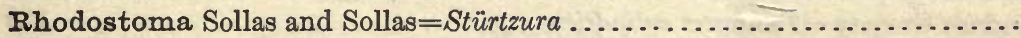

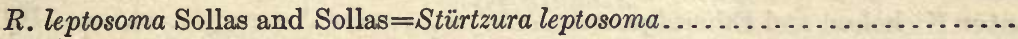

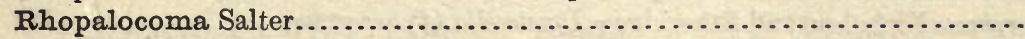

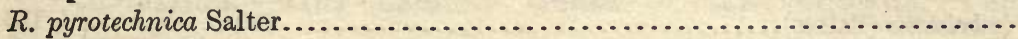

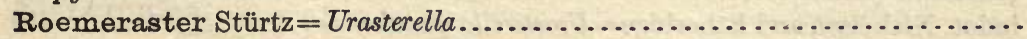

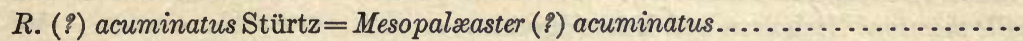

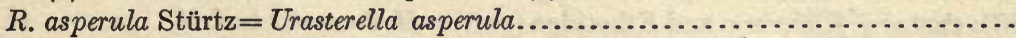

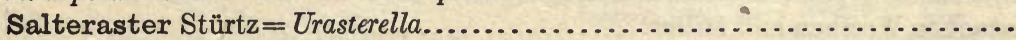

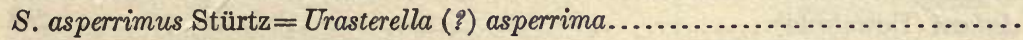

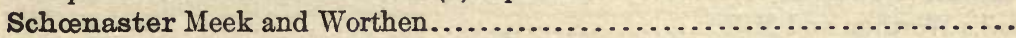

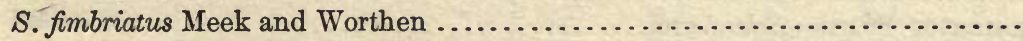

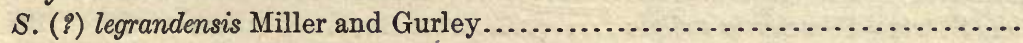

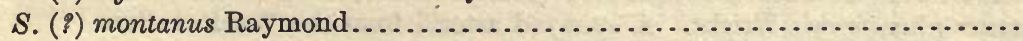

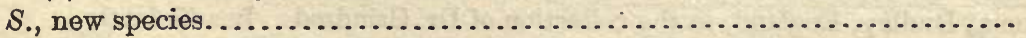

S. (?) wachsmuthi Meek and Worthen............................. 205

Schuchertia Gregory.......................................... 195

S. laxata, new species......................................... 198

S. ordinaria, new species..................................... 199 
Schuchertia stellata (Billings)............................... Page.

Siluraster Jaekel.......................................... $\quad 65$

S. perfectus Jaekel............................................ 66

Spaniaster Schöndorf........................................ 95

S. latiscutatus (Sandberger)................................... $\quad 96$

Squamaster Ringueberg..................................... 249

S. echinatus Ringueberg........................................ 249

Stenaster Billings.......................................... 163

Stenaster Billings (part) $=$ Urasterella............................. 173

S. (?) confluens Trautschold..................................... 167

S. (?) coronella (Salter)...................................... 167

S. grandis Meek=Urasterella grandis............................... 180

S. huxleyi Billings = Urasterella huxleyi........................... 182

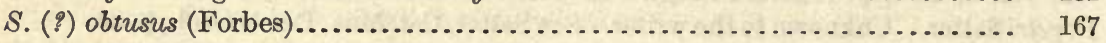

S. pulchellus Billings=Urasterella pulchella........................ 178

S. salteri Billings....................................... 165

Stürtzaster Etheridge................................... 252

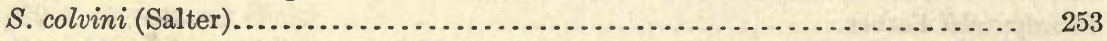

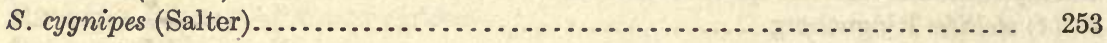

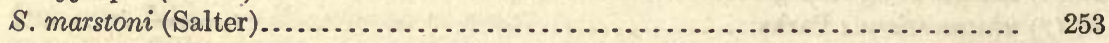

$S .($ (q) mitchelli Etheridge....................................... 254

Stïrtzura Gregory.......................................... 236

S. brisingoides (Gregory).................................... 236

S. leptosoma (Salter) ...................................... 237

S. leptosomoides Chapman.................................... 237

Sympterura Bather.................................. $\quad 256$

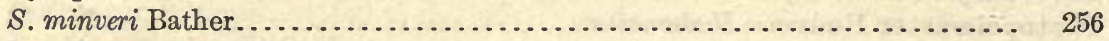

Tæniaster Billings........................................ 216

T. australis $\mathrm{McCoy}=$ Stürtzura brisingoides........................ 236

T. cylindricus (Billings).................................... 220

T. elegans Miller......................................... 221

T. meafordensis Foerste.................................... 221

T. schohariæ Ruedemann.................................... 220

T. spinosus (Billings)....................................... 219

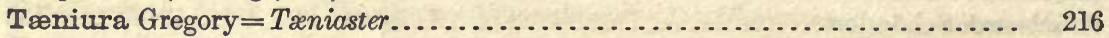

T. cylindrica Gregory=Tæniaster cylindricus $\ldots \ldots \ldots \ldots \ldots \ldots \ldots \ldots \ldots \ldots \ldots . . \ldots 220$

Tetraster Nicholson and Etheridge............................ 167

T. asperrimus Nicholson and Etheridge = Urasterella (?) asperrima ........... 187

T. (?) imbricatus (Salter)........................................ 169

$T$. sp. indet. Nicholson and Etheridge $=$ Urasterella girvanensis............ 186

T. wyville-thomsoni Nicholson and Etheridge....................... 168

T. wyville-thomsoni Nicholson and Etheridge (part)=Hudsonaster batheri...... 65

Tremataster Worthen and Miller............................ 247

T. (?) decheni (Dewalque)................................... 248

T. difficilis Worthen and Miller.................................. 247

Trentonaster Stürtz $=$ Schuchertia............................ 195

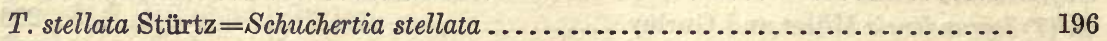

Trichotaster plumiformis Wright. A 10-rayed asterid from the Wenlock limestone at Dudley, England, in the collection of Dr. Grindrod. Insufficiently described to be regarded as defined. See Quart. Journ. Geol. Soc., vol. 29, 1873, p. 421; also Woodward, Geol. Mag., dec. 2, vol. 1, 1874, p. 7 (listed as Trochitaster plumiformis).

Trimeraster Schöndorf. 
Trimeraster parvulus Schöndorf.

Trochitaster plumiformis Wright=Trichotaster plumiformis.

Uranaster Gregory..................................... 154

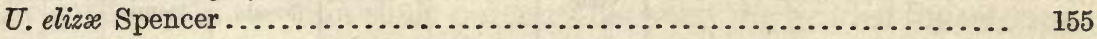

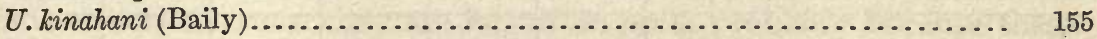

Uraster hirudo Forbes $=$ Urasterella hirudo......................... 188

U. obtusus Forbes $=$ Stenaster $(q)$ obtusus....................... 167

U. primævus Forbes $=$ Palasterina primæva....................... 153

U. ruthveni Forbes $=$ Urasterella ruthveni......................... 187

Urasterella McCoy........................................ 173

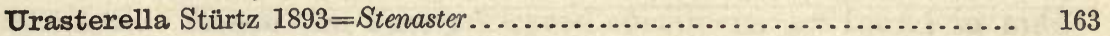

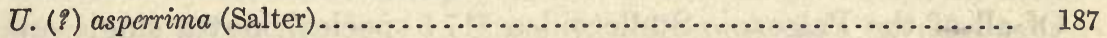

U. asperula (Roemer)....................................... 188

U. (q) constellata (Thorent)................................. 187

U. girvanensis, new species.................................... 186

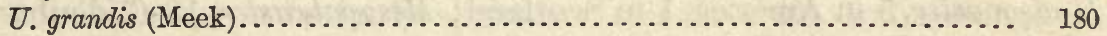

U. hirudo (Forbes).......................................... 188

U. huxleyi (Billings)....................................... 182

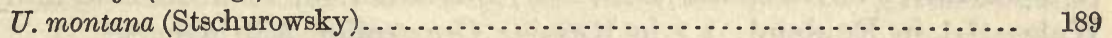

U., new species .......................................... 189

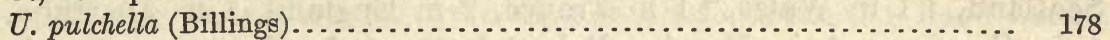

U. ruthveni (Forbes)......................................... 187

U. selwyni McCoy............................................ 188

U. ulrichi, new species.................................... 183

Xenaster Simonovitsch.................................. 129

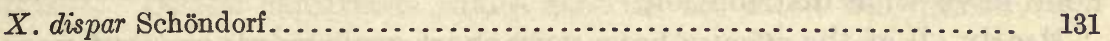

$X$. elegans Schöndorf...................................... 131

$X$. eucharis Schöndorf $=$ Devonaster eucharis ...................... 98

$X$. margaritatus Follmann $=X$. elegans ........................ 131

$X$. margaritatus Simonovitsch.............................. 131

$X$. margaritatus Simonovitsch (part) $=X$. dispar and Agalmaster grandis.... 131, 132

$X .($ (q) rhenanus (Müller).................................... 131

$X$. simplex Simonovitsch $=S$ paniaster latiscutatus.................... $\quad 96$

REMARKS ON THE DEVELOPMENT OF PALEOZOIC STELLEROIDEA. Geological.

Distribution.-This memoir treats of the following Paleozoic Stelleroidea:

\begin{tabular}{|c|c|c|c|c|c|}
\hline & Genera. & Species. & $\begin{array}{c}\text { North } \\
\text { Ameri- } \\
\text { can } \\
\text { species. }\end{array}$ & $\begin{array}{c}\text { Euro- } \\
\text { pean } \\
\text { species. }\end{array}$ & $\begin{array}{l}\text { Southern } \\
\text { Hemis- } \\
\text { phere } \\
\text { species. }\end{array}$ \\
\hline Asteroldea............. & 45 & 110 & 51 & 53 & 6 \\
\hline 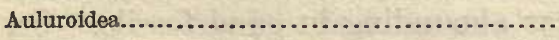 & 30 & 59 & 18 & 36 & 5 \\
\hline 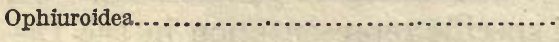 & 1 & 5 & 5 & 0 & 0 \\
\hline Total..... & 76 & 174 & 74 & 89 & 11 \\
\hline
\end{tabular}


Arranged geologically the distribution is as follows:

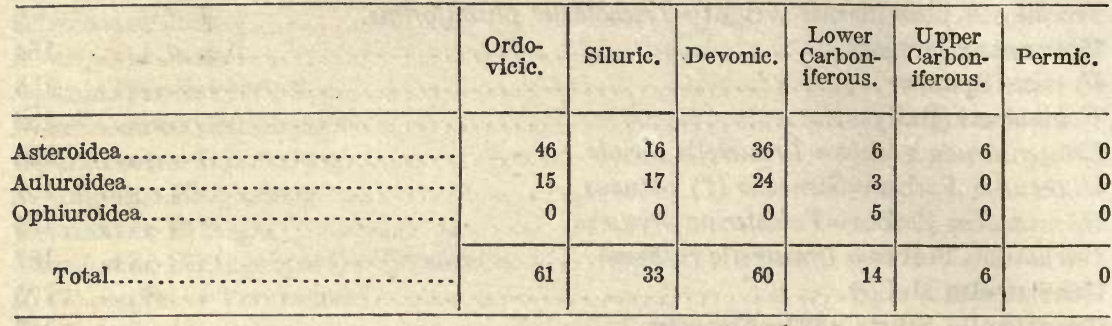

Of all of the Paleozoic Stelleroidea (174 species), not a single one is common to North America and Europe. Of genera having specific representation in more than one continent there are the following: Hudsonaster, 5 in America, 1 in Scotland; Mesopalxaster, 13 (7 doubtful) in America, 1 in England, ? 1 in Germany; Petraster, 3 in America (1 doubtful), 1 in Australia; Stenaster, 1 in America, ? 1 in Ireland and Wales, ? 1 in England, ? 1 in Russia; Urasterella, 5 in America, 1 in Scotland, ? 1 in Wales, ? 1 in France, 2 in England, 1 in Australia, 1 in Germany, 1 in Russia; Palxosolaster, 1 in Germany, ? 1 in America; Protaster, ? 2 in America, 1 in England, 2 (1 doubtful) in Wales; Tremataster, 1 in America, ? 1 in Belgium. Of Ophiuroidea, none have wide distribution.

Nearly all of the species have very short geologic ranges, but very few occurring in more than a single formation. Mesopalxaster intermedius ranges from the ? Utica to the Maysvillian, M. stuafferi from the Maysvillian to the Richmondian, Alepidaster flexuosus from the basal Edenian to the upper Maysvillian, Hudsonaster incomptus from the Edenian into the Richmondian, Promopalxaster magnificus and Petraster speciosus from the Maysvillian to the Richmondian.

These tables also show that the Ophiuroidea do not begin earlier than the Lower Carboniferous (Burlington) and that the Auluroidea cease to exist after the same period, for none are as yet known in the Upper Carboniferous or Permic. The latter attained their maximum of development in the Siluric and Devonic, with very rapid decline in the Lower Carboniferous.

The great development of Asteroidea in the Ordovicic is due to the marked specific evolution of the genera Mesopalxaster and Promopalzaster in North America. This knowledge is the result of careful work by local collectors in areas abounding in good fossils. On the other hand the marked rise in specific representation in the Devonic is due to the protracted collecting in the earlier beds of this period, the roofing slates of Bundenbach, Germany.

Preservation and occurrence.-Starfishes are most often preserved in sandstones and mudstones and least often in limestones. The 
reason why they occur less frequently in limestones is partially accounted for by the fact that during the weathering process they are almost always ruined. Those found in such deposits nearly always occur in the thin shale partings between the bedded limestones. In coarse sandstones they are less often seen, probably because these sediments are so much moved by the storm waves-action that destroys the skeleton by separating the plates. Unless a starfish is quickly covered by sediment it is sure to be broken up and jumbled into a mass of unrelated ossicles, because the skeletal parts are rarely coossified. Hence the best preserved specimens are found in mudstones and especially in the fine-grained, somewhat muddy sandstones. Here they usually occur as fine molds, since all of the calcium carbonate has been dissolved out by the atmospheric waters. Such material is apt to be fairly abundant in individuals, and although a little difficult to study is often well preserved. Its interpretation is dependent on artificial casts or squeezes in wax or gutta-percha. When found in black slates, as at Bundenbach, the skeleton is preserved in iron pyrite, and even though these sediments have been subjected to mountain making, the specimens can be cleaned mechanically of the adhering slate. The process is, however, a laborious one and has been successfully used only by Stürtz and his two preparators. In the calcareous shales asterids are often well preserved, with the original skeleton more or less permineralized and the ossicles cemented together so that parts of the individuals weather out as free fossils. This is particularly the case in the Richmondian deposits of Ohio and Indiana.

As a rule, starfishes are obtained in single specimens and as accidental finds, and for this reason they are among the rarest of known Paleozoic animals; they are the "fancy fossils" of the local collectors and the "choice specimens" of the museums. All of this is, however, due to the accident of preservation plus their great destruction through weathering. That starfishes and ophiurids were common, though probably not so abundant as aulurids, is proven when they are located in their entombing sediment and then quarried for. This is best seen in the well-known Lower Devonic slates of Bundenbach, where the quarrying for roofing material has produced as many starfisheg as all other localities put together. A great variety has also been secured here, so that it is the only locality and time of which we can say that we know the starfish fauna. The most remarkable starfish find, however, is that made near Saugerties, New York, where over 400 examples of the Middle Devonic Devonaster eucharis were found in a fine-grained, somewhat muddy sandstone, extending over an area of 200 square feet. They occur as natural molds, and as the animals are found closely associated with Grammysia, it is thought that while feeding on these bivalves 
they were suddenly entrapped by the engulfing sand. In the crinid bed of the Keokuk formation at Crawfordsville, Indiana, the ophiurid Onychaster flexitis is also often met with.

Aulurids, although as a rule not well preserved, are probably more often seen than starfishes, and certainly are far more abundant than ophiurids. The latter condition is, however, probably explained by the fact that no ophiurid is known older than the Carboniferous. Of the aulurid Tæniaster elegans 31 individuals occur on one small slab. It is probable that if aulurids and asterids were systematically dug for, a far greater harvest would result than that now at hand. Whenever such specimens are found in place, such prospects should be followed up by digging or by prolonged search on the part of the local workers.

It is very seldom that a Paleozoic asterid is so well preserved that all of its parts can be made out, and this is especially true as regards the dorsal side. During the decay of the animals it is probably true that in most cases the individual lies with its ventral side down, and as the soft parts vanish the dorsal skeleton sinks in irregularly over the actinal skeleton. It is the central region of the disk that suffers dismemberment most. Then, as the two sides of the skeleton finally come to be fully compressed, the rays take on an unnaturally great width, so that in many of the fossils preserved in shales the ambulacral furrow is considerably wider than in nature. For these reasons it is often impossible to say whether the ambulacralia are of the opposite or the alternate arrangement, and what was the original structure of the disk and the interambulacral areas.

\section{ASTERID EVOLUTION.}

\section{Generat Observations.}

The majority of the starfishes studied by the writer are from the Ordovicic strata of North America. Collectively these show considerable evolution, for at this early time in the history of the earth Phanerozonia, Cryptozonia, and primitive ophiurids (=Auluroidea) are present. Even near the base of the Middle Ordovicic the two former groups appear to be equally common, while the aulurids are as a rule rare and small, though there are occasional large ones. Here the primitive phanerozonian asterids are also small, hardly ever exceeding $15 \mathrm{~mm}$. in diameter, while the derived and far more complex Cryptozonia are large, some of them having rays exceeding $50 \mathrm{~mm}$. In the Lower Ordovicic of America no starfishes are known, while the few that have been reported from Great Britain appear to the writer to be from the Middle Ordovicic.

These facts show that in spite of their absence in Lower Ordovicic rocks there must have lived at that time various kinds of starfishes. 
Not only this, but we may confidently add that the varied organization of those of the Middle Ordovicic proves that there is a long previous history of which paleontology knows nothing. The origin of the Asteroidea goes back in all probability to the Proterozoic, as may be inferred from the complex metamorphosis of the starfish larva. In all of the Cambric, however, not a single starfish has been found, and this is the more surprising when one considers the abundance of life unearthed from these sediments in so many places throughout the world. This may mean that a preservable starfish skeleton was not evolved until Lower Ordovicic time, where they will surely be found.

The most primitive fossil starfish.-Of the Ordovicic starfishes, the genus Hudsonaster is the most primitive, but with the full quota of parts in the primary skeleton that an unmodified or unspecialized starfish must have. Among living starfishes this primitive skeleton is rarely seen, but occurs in Heterasterias volsellata, "and in a few other species, especially when young" (Verrill 1914:27). There are other genera with a simpler skeleton (Stenaster and Tetraster), but these are clearly cryptozonian forms that have originated in a phanerozonian stock not unlike Hudsonaster. The oldest Hudsonasters (see plates 1 to 6) are small animals about $10 \mathrm{~mm}$. in diameter, with thick, highly convex, closely adjoining plates, all of which are devoid of spines excepting the adambulacrals, which have simple, minute, articulating spines. On the ventral side there are in each radius double columns of rectangular ambulacralia, with the pieces of each ambulacrum arranged opposite to one another, or nearly so. Outside of these are single columns of adambulacralia of about the same number as the ambulacrals; they are, however, somewhat larger and more transverse. These are laterally bounded by much larger, highly convex, granulated, very prominent marginals, which, as they border the animals and are simple ossicles (there are not here two superposed marginalia as is so common in living forms), are the inframarginal columns. In the axils of the rays lies a single large marginal plate, the axillary, and these occupy the entire interbrachial areas. Around the inner sides of these axillaries the adambulacralia continue, the two basal pieces being the largest and the essential elements of the oral armature. All of the ventral ossicles are, therefore, seen to be of the primary skeleton.

On the dorsal side of Hudsonaster, the rays have medially prominent columns of radials, while on each side of these are other columns of thick ossicles, alternating with the radialia, and these are the supramarginals. The former ossicles continue closely adjoining to near the center of the disk, where lies a single large plate usually called in this memoir the central disk plate, or, more rarely, the centro-dorsal. In the same way, the supramarginals abut in the axils upon a single 50601-Bull. 88-15-3 
large ossicle, the basal supramarginal plate. It is thought that the ancestors of Hudsonaster had a dorsal disk skeleton made up of a centro-dorsal, a first ring of 5 primordial radials, and a second ring of 10 plates, 5 of which are the second radials, and 5 interradial pieces, the primordial supramarginals. In Hudsonaster, however, some progression has taken place in the disk in the way of increase of size. Therefore additional ossicles of the secondary skeleton have developed to take up this space, these accessory disk pieces being inserted between the centro-dorsal and the first ring of primordial radials. Such a development of a small number of accessory pieces here is a hint of future complexity and the rise of the secondary skeleton, and we shall see how in later and derived genera their number becomes multitudinous and their places of insertion nearly everywhere in the older portions of the skeleton between the columns of ossicles.

The supramarginals do not margin the animals, but lie inside the inframarginals and axillaries which do margin Hudsonaster and most of the Paleozoic asterids.

From Hudsonaster to all other progressive asterids of the Phanerozonia type, the change lies mainly in the increasing number of the ossicles, relative decrease in the size of the plates, introduction of many new series of åccessory pieces, absorption and removal of others, with a marked general tendency to break up the stiff and ponderous inherited skeleton into one of small pieces, thus affording greater flexibility and greater podial strength through the endless duplication of ambulacral parts. These developmental tendencies take place more especially on the dorsal area and are further accentuated through increase of body cavity, which demands an enlarged skeletal covering. The disk widens, and along with it the proximal parts of the rays, so that interbrachial areas are also affected, until finally in more than one phylum pentagonal asterids result. The interbrachial areas are dorsally increased by the insertion of accessory pieces between the infra- and supramarginalia, and ventrally by the crowding into these areas of, first, the single axillaries, and then more and more of the oldest inframarginals in pairs, assisted also here by the development of accessory ossicles.

Origin of the wriggling type of starfish.-From Hudsonaster to the other progressive asterids of the Cryptozonia type the evolutionary tendencies are in the same directions, but here even greater flexibility appears to be the main stimulus. Accordingly, the entire dorsal skeleton tends to break up into small loosely adjoining pieces and finally even into a spicular spinose mesh. In these forms the ossicles of the primitive columns are no longer discernible as such, and this tendency is very apt to be likewise true of the primordial disk plates. On the ventral side the inframarginals are no longer wholly present as such, but may be here mixed up with the dorsal skeletal complex. How- 
ever, some of these plates are at times retained in the interbrachial areas as large pieces, and in many forms they are still to be made out clearly on the sides of the growing distal ends of the rays. Here the inframarginals occur as columns of tiny closely adjoining ossicles situated directly beside the adambulacrals, and in a few cases the whole five primary dorsal columns (one radial, two supramarginal, and two inframarginal) can be made out without any accessory pieces between them. In other words, a Paleozoic cryptozonian may retain the marginals throughout life, but because of their small size and isolation one from another by accessory pieces or because of intense spiculization, they are no longer recognizable as such. The classificatory value of the presence or absence of marginalia is discussed elsewhere (under Cryptozonia), and as the inframarginals are seemingly or actually lost independently in a number of phyla the term is here used as expressive of this condition, and not necessarily of relationship.

Spencer (1914:9) takes up the origin of the wriggling habit from another point of view, that is, from a study of living Stelleroidea as described by MacBride. The former states that the living forms can be grouped into two divisions as follows:

The graspers.-Asteroid forms in which the tube-feet are used for walking, and for grasping and pulling open the bivalve shells of the mollusks upon which they usually feed. The ambulacralia form an arch to take the pull.

The wrigglers.- Ophiuroid forms in which the tube-feet have lost locomotory powers and become much reduced. The animals progress by wriggling movements of the arm, and the ossicles of the ambulacral groove are extensively modified for this purpose. The food is pushed into the mouth by the first two pairs of tube-feet, which become considerably enlarged and are known as buccal tentacles.

If we trace the history of the forms backward we find that the difference between them tends to disappear. Both the "graspers" and the "wrigglers" descended from a third group, which I call provisionally " the primitive Asterozoa."

The postulated "primitive Asterozoa" above referred to are based upon the earliest stages of growth of starfishes, and had the following characters. The animals were attached to the ground by a welldeveloped, flexible stalk (seen in Asterina and Asterias); the disk was small compared with the five arms. In connection with the water-vascular system there were two series of ossicles, (1) a double column of flooring pieces forming the sides of the ambulacrum, and (2) a paired covering series as a protection to the soft structures underneath. The podia emerged between the flooring pieces and these at first "were arranged not exactly opposite to each other, but slightly alternating, and in consequence we find that both the flooring and covering plates, which are in direct association with the podia, are not exactly opposite, but arranged alternately." 
The rays terminated in a single ossicle with an unpaired tube-foot that later developed at its outer end a pigment spot and finally an "eye."

At last the animal lost the stalk and moved about freely as the primitive asterozoon. The flooring plates changed into ambulacralia and the roofing plates into adambulacralia, while the tube-feet were used not for grasping and crawling but for passing small particles of food to the mouth.
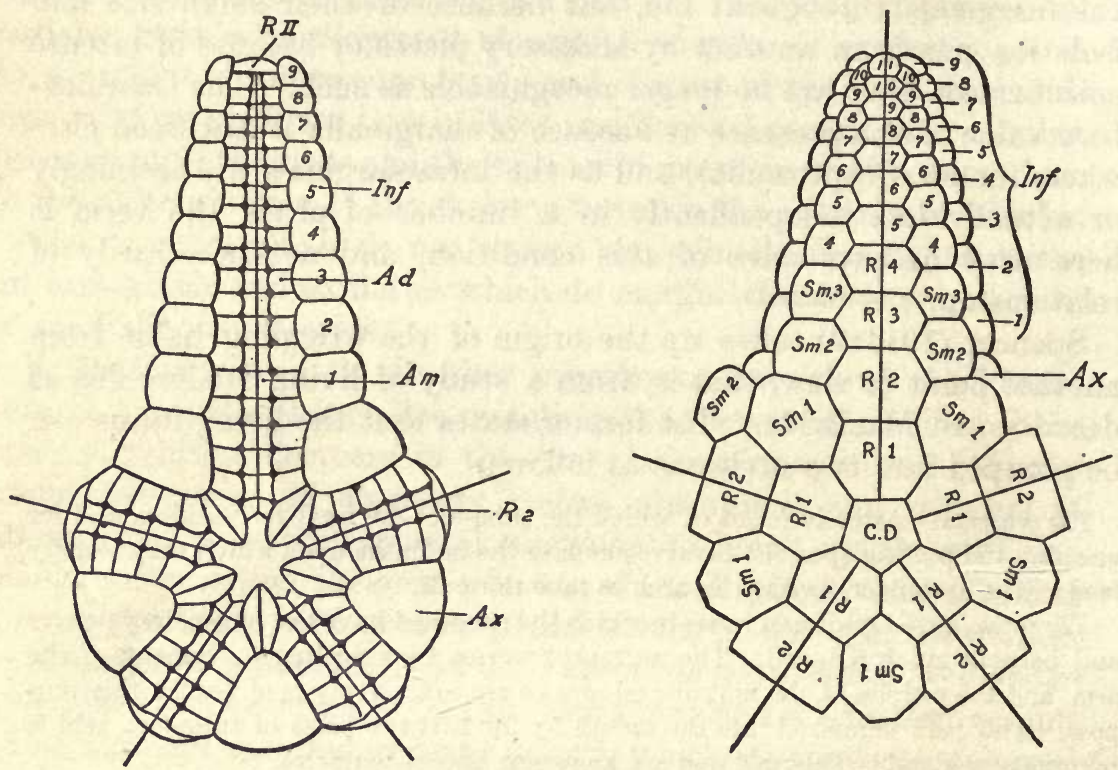

FIGS. 1 AND 2.-VENTRAL AND DORSAL VIEWS OF THEORETIC PHYLEMbRYo OF STELLEROIdeA, INDICA TING HOW THE RAYS ARE INTRODUCED. BASED ON HUDSONASTER. Ad, ADAMBULACRALS; A m, AMBULACRALS; $A x$, MARGINAL AXILLARIES; $C D$, CENTRO-DORSAL; Inf, INFRAMARGINALS; $R 1$,PRIMORDIAL RADIALS: $R 2$ TO $R 11$, SUBSEQUENT RADLAL; Sm1, DORSAL INTERRADIALS OR PRIMORDIAL SUPRAMARGINALS; Sm2 TO Sm10, SUBSEQUENT SUPRAMARGINALS.

The asterid radicle.-Hudsonaster is held to be very near the radicle that gave rise through modification and inheritance to all subsequent Stelleroidea. A study of the various species and specimens of Hudsonaster, reinforced by the chronogenesis of this genus and the developmental stages in the individuals, which are discernible in the youthful distal ends of the rays when contrasted with the mature proximal region of the same, has led the writer to speculate on the probable skeletal characters of the radicle of the Stelleroidea. An analysis of mature $H$. matutinus and of half-grown $H$. incomptus shows that their ancestors must have been devoid of all disk accessory pieces, or for that matter of all secondary ossicles, since it appears that it is on the disk that these plates first arise. Further, the same material indicates that the younger the individual specimen, or the older the species geologically, not only the smaller is the specimen, but the fewer plates has it in any column. As the 
ossicles, other than those of the disk, the interbrachial areas, and the accessory pieces, are introduced in all the columns at the distal ends of the rays, we are permitted, in theorizing as to the characters of the radicle, and from what has been learned from Hudsonaster, to eliminate all of the rays with their ventral and dorsal ossicles down to the disk. If this is done, there finally results a tiny depressed and mammillated spheroid, made up dorsally of 11 primary plates, and 5 marginal axillaries, and ventrally of a limited number of adambulacrals and ambulacrals around the mouth. To make this matter clearer, two diagrams are presented of the probable characters of the direct ancestor of Hudsonaster (see figs. 1 and 2).

By taking away the rays down to near their bases, i. e., to R2, and correspondingly decreasing the size of the primordial supramarginals, we get the dorsal structure of a late stage of the probable typembryo of the Stelleroidea, as illustrated in fig. 3.

If all of the ray plates are completely removed, we apparently get the typembryo of the class Stelleroidea, as illustrated in figs. 4 and 5. It should be stated here, however, that the number of the adambulacrals and ambulacrals in figure 5 is entirely conjectural, though these plates and those of the mouth frame are among the first to develop

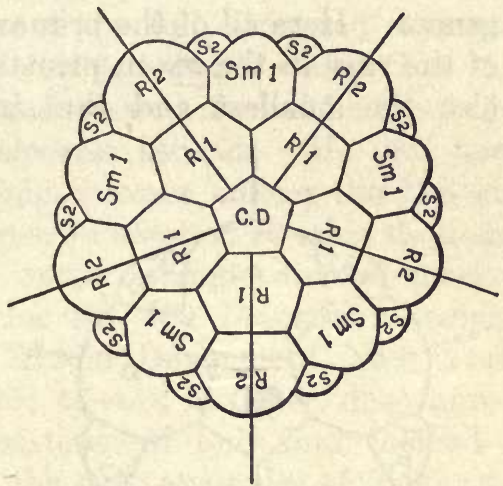

Fig. 3.-Dorsal view OF THEORETIC TYPEMBRYO OF STELLEROIDEA AT THE BEgINNING OF RAY DEVELOPMENT. THE PRTMORDLAL SUPRAMARGINALS HERE HAVE ON EACH SIDE THE BASAL PIECES OF TEN SUPRAMARGINAL COLUMNS. $C D$, CENTRO-DORSAL; $R 1$, PRMMORDIAL RADIAL; $R 2$, SECOND RADIAL; Sm1, DORSAL INTERRADIAL OR PRIMORDIAL SUPRAMARGINAL; S2, BEGINNING OF SUPRAMARGINAL COLUMNS. in living forms.

If the developmental views just stated are correct, it follows that the five branches of the water-vascular and nerve rings of the typembryo of Stelleroidea grow outward along the radii, developing as they grow the rays or arms with their dorsal and ventral skeletons. In other words, the growing tips of the radii spread outward beyond the disk, and each one gives rise to nine columns of ossicles (one radial, two supramarginal, two inframarginal, two adambulacral and two ambulacral). The radial plates continue as simple columns, while upon the primordial supramarginals and the axillaries rest pairs of columns, the supramarginals and inframarginals, respectively.

In Echini, however, the growing tips of the radii do not spread beyond the disk (apical disk of oculars and genitals) but remain internal and give rise to new ossicles, the ambulacrals (same ossicles in Stelleroidea) and interambulacrals (=adambulacrals of Steller- 
oidea), all of which appear from underneath the ventral edges of the oculars, each plate in turn being pushed orally ${ }^{1}$.

In any event, whatever the pre-Hudsonaster evolution was, we are on safe ground in indicating what the developmental changes were, starting with this genus. We will not take up all of the skeletal parts and discuss them in detail, but will attempt only the more essential portions.

Ontogeny.-Ontogenetic stages of development in the ossicles of asterids can readily be made out to some extent in any well preserved specimen. The variations can best be seen in those forms with the least number of plates and therefore in the more primitive genera. Here all of the primary ossicles are introduced at the tips of the rays in the seven primary columns. The youngest pieces are also the smallest and the simplest. At first they are globular,
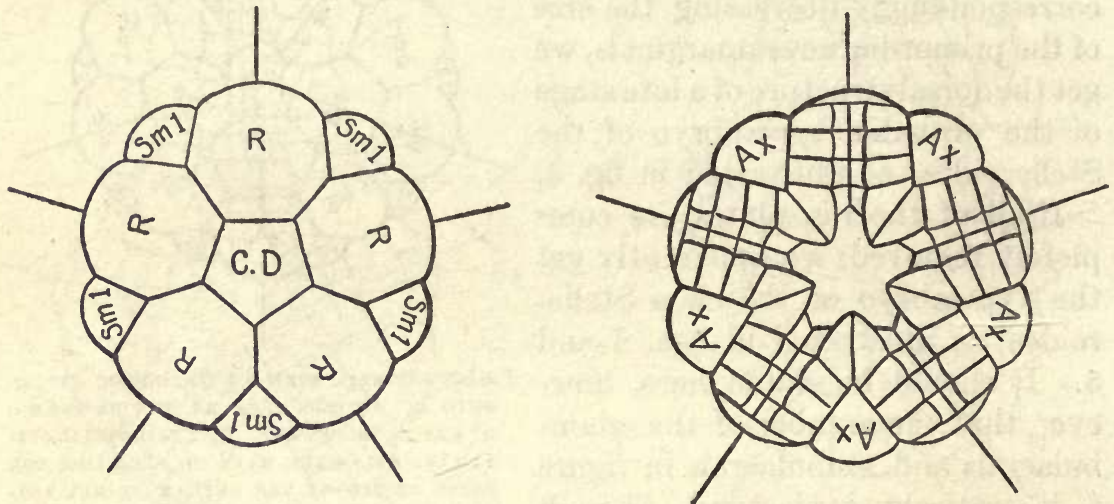

Figs. 4 AND 5.-DORSAL AND VENTRAL views of theoretic tYPEMbryo of Stelleroidea. $A x$, venTRAL OR MARGINAL AXILLARIES OR BASAL INFRAMARgINALS; $C D$, CENTRO-DORSAL; $R$, PRIMORDLAL RADIALS; Sm1, DORSAL INTERRADIALS OR PRIMORDIAL SUPRAMARGINALS.

smooth, and loosely adjoining. Tracing them down the columns, the specific characters are seen to develop and finally the basal pieces are found to be the most modified of all. This is particularly true of the dorsal columns where the most ornate plates are the oldest. In the different species of $H u d$ sonaster one can also trace the changes chronogenetically, as for instance in the basal radialia and supramarginalia. In the oldest species these plates are not at all, or but very slightly stellate, more so in $H$. incomptus, and most so in the youngest and largest species, $H$. rugosus.

In the stocks with more complex skeletons, the ontogenetic variations in the plates can be traced in the same way. However, as these forms almost always have more or less of accessory plates that are introduced nearly throughout the entire skeleton during the juvenile growth and even at maturity, the study is complicated by the intermixture of ossicles of varying age. 
Spinosity can also be studied ontogenetically because the youngest ossicles do not have spines, and when these appear they are smaller and less characterized than the older ones situated in the proximal portions of the columns.

Many of the ontogenetic changes observed by the writer are recorded throughout this work, and their significance in related species and genera has been made use of in discerning the phylogenetic lines of descent.

Regeneration.-Among living starfishes it is common to regrow arms that have been lost through accidental causes. From the base of the severed ray a new growing tip is established, forming a juvenile arm that gradually grows to full size and assumes mature characteristics. Schöndorf (1909a: 96-97) states that this habit has been pronounced since the Jurassic but that he has failed to find marked regeneration in Paleozoic asterids. He did, however, note partial replacement of minor losses among the Devonic species. Stürtz, who has handled more Paleozoic asterids than any other paleontologist, also has not noted a single case of marked regeneration. The same is true for the 400 Devonaster eucharis found in a limited area of the Middle Devonic of New York. Clarke, in describing this find (1912: 44-45), however, does note a few specimens "which show the existence of only four instead of the normal five arms." These are the only examples of four-rayed Paleozoic starfishes so far recorded.

The writer has also been unable to find a single case of regeneration, but in the Middle Ordovicic cryptozonian Urasterella ulrichi he describes a specimen with two normally developed rays and three short stumps. All of the arms are normal for the species, except for the length of three rays and their terminations, which are blunt. (See pl. 29, fig. 1.) It seems to him that this occurrence is not due to the accident of fossilization or weathering, but is an actual case of loss in life with subsequent healing of the wounds, but without regeneration of the lost parts.

During most of the Paleozoic, the starfishes could have had no carnivorous enemies other than the cephalopods; as for marine fishes, the armored Arthrodires did not appear until the Middle Devonic, while the ancient sharks were not common until Lower Carboniferous (Mississippic) time. It is possible that regeneration among the starfishes is connected with the rise of carnivorous enemies, but as the habit is so common among living forms it is more probable that this power has always been inherent in the class. Regeneration among the crinids has been noted in several cases where lost distal ends of arms were being replaced by immature growths. Such have been seen in the Lower Carboniferous (Burlington and Keokuk formations) of America. 
Number and character of rays.-In the geologically oldest and the most primitive asterids as well there are always 5 rays, no multirayed form being known back of the middle of Siluric time. In the most primitive genus of Phanerozonia, Hudsonaster, the rays are short and stout, there is a large disk without interbrachial arcs, and the skeleton is simple but ponderous. From this type originate those with 5 slender rays and also forms with more or less large interbrachial arcs, the pentagonal starfishes.

Long, slender, and flexible-rayed genera without marginalia are present as early as the most primitive Phanerozonia, i.e., as early as the older Middle Ordovicic, indicating that the two main types of asterid development arose still earlier. The same is true for the ophiurid ancestors (Auluroidea). In fact, slender-rayed Cryptozonia are more commonly seen in the Middle Ordovicic than are the Phanerozonia.

Multi-rayed Phanerozonia with primitive arm construction appear in the Middle Siluric (Wenlock) in Lepidaster. This genus has rays which are short and stout, reminding one in this respect strongly of the primitive 5-rayed forms. An insufficiently described 10rayed form (Trichotaster plumiformis) is recorded from the Middle Siluric (Wenlock) of England. In Helianthaster of the Lower Devonic there are from 14 to 16 rays and here they are long and slender, while in the Upper Devonic there is a form with only 11 rays. Lepidasterella of the Upper Devonic has 24 arms.

All of the multi-rayed Cryptozonia have slender rays and rather large disks. None are older than the Lower Devonic, where Medusaster has from 12 to 15 rays, Echinasterias 25, Palæosolaster 27 to 29 (an Upper Devonic species referred doubtfully to this genus has 24 or 25), Echinostella 28 or 29, and Echinodiscaster 29.

Curiously, no multi-rayed starfish is known in the Paleozoic later than the Devonic. Further, the arms may be either odd or even in number in the same genus or even species. How the living multirayed starfishes introduce their rays is explained under Palæosolasteridæ (p. 207).

Verrill (1914: 12-17) holds that the multi-rayed forms arose as " 'sports,' which have persisted by heredity and natural selection because they were advantageous." The advantage lay in "the increased number of ambulacral sucker-feet." Most of these forms are now living in shallow water among the rocks exposed to the surf. He states: "This is true of the seven species of Heliaster, with very numerous rays; and of Pycnopodia, with 20 to 24 rays; and of the various shallow-water and littoral species of Solaster and Crossaster, which usually have 9 to 15 rays (rarely 8 or less). It is also true of the numerous 6-rayed species of Asterias, Pisaster, and allied genera." 
On the other hand, the increase of rays is more probably due "to the advantage gained in holding their food securely, and in opening bivalves, than for holding to the rocks, though both go together."

"The ability to cling tenaciously to rocks may be perfected in other ways, involving equally an increased number of sucker-feet. This is often attained by lengthening the rays, * * * by crowding the suckers into more than four rows, $* * *$ and by increasing the size and strength of the suckers."

\section{Development of the Parts.}

Anus.-In all living starfishes the anus apparently lies in the next interradius to the right of the madreporite, or in the direction as the clock goes, but in no Paleozoic asterid is there positive evidence of an anal opening. However, it is extremely rare in these forms to find the disk so well preserved as to make it possible to locate so small an orifice. In certain specimens of Hudsonaster, immediately adjacent to the centro-dorsal plate, there is an open space that either is the anal opening or where a plate has dropped out in fossilization. Schöndorf has also failed to find this structure in the German Paleozoic asterids, but has indicated its probable position in Spaniaster (see fig. 8) and Calliasterella.

Madreporite.-In more than half of the Paleozoic asterids the madreporic plate has not been seen. In many cases this is due to the infallen condition of the disk skeleton and the jumbled state of the ossicles; in others it is due to the fact that it is so small as not to be readily distinguished among the mass of other small plates. Finally, a great number of asterids are known only from the actinal side.

The madreporite in size varies from minute to very large and ponderous. It may be round, oval, or many-sided, concave, and depressed beneath the disk pieces, or protruding cone-shaped (Petraster). As a rule, it is marked by striations that are coarse or very fine, straight or wavy lined, or it may be crenulostriate or with granular surface. In Petraster the surface canals enter into two spirals that carry the water into the stone canal. In living forms with more than six rays there may be two or more madreporites, but in no Paleozoic species has more than one been seen.

In all of the Paleozoic phanerozonians the madreporite appears to be always dorsal in position. In the most primitive genus, Hudsonaster, the plate may be large and conspicuous or at times can not be made out even when the disk is fairly well preserved. In no Mesopalæaster has this sieve plate been seen, although good specimens are at hand, a condition probably due to its small size among the small skeletal pieces of this genus. In Spaniaster it is very small. In Promopalxaster the madreporite is usually conspicuous and large, 
and the same is true for Xenaster and Agalmaster. The plate is also known in Palæaster, Devonaster, Neopalæaster, and Palasterina.

In multi-rayed phanerozonians the madreporite is unknown in Lepidaster and Lepidasterella. In Helianthaster it is large, conspicuous, and situated on the edge of the disk, more actinal than abactinal. On the other hand, in the cryptozonian multi-rayed genera the madreporite is apparently always actinal and more or less large, as in Palzosolaster and Echinodiscaster. This plate is probably also always actinal on large-disked Cryptozonia such as Palasteriscus (plate enormously large), and Cheiropteraster (here small and situated near the mouth).

Among the five-rayed Paleozoic cryptozonians the madreporite is known only in Monaster (large), Urasterella (medium), and Jaekelaster (small). In all it is always on the abactinal area.

From this evidence we see that in the five-rayed Phanerozonia, forms that are more or less rigid, the madreporite is always on the dorsal or upper side of the animals, this being true for the deeply stellate as well as for the pentagonal species. In the multi-rayed genera, however, there is a marked tendency for this plate to move outward to the edge of the disk. In the five-rayed cryptozonians the madreporite so far as known is always dorsal, but in the largedisked or pentagonal forms and the multi-rayed species this plate is apparently always ventral.

Spencer (1914:35-38) says that "many Paleozoic Asterozoa do not appear to have a madreporite" and he is "inclined to regard this, in these old forms, as usually a primitive feature." The present writer, it is true, states above that in more than half of the Paleozoic asterids the madreporic plate has not been seen. This is due in most cases, however, to poor preservation, and in others to the fact that the plate is so much like the other disk plates as not to be distinguishable from ihem. Spencer concludes further that it appears that the madreporite originated on the ventral side, or at least was marginal, in the primitive forms, and that it passed over in later Asteroidea to the dorsal side. In Hudsonaster we have the most primitive known starfish, and here in $H$. incomptus it is a large and conspicuous plate on the abactinal side. Further, the evidence of the Paleozoic starfishes (Phanerozonia), so far as the present writer knows them, is that this plate is always dorsal in position, and he is inclined to the view that all of them had the madreporite, that it originated on this side, and that in later cryptozonian multiradiate forms it moved outward to the margin of the disk or to the actinal surface. In regard to the Auluroidea, the writer has seen the madreporite so rarely that no deductions as to its original position in these forms can be made. 
Spinosity.-In general, it can be said that spines are least developed in the heavily plated Phanerozonia, more so in those forms where the dorsal skeleton is made up of small ossicles in abundance, and fully in most of the Cryptozonia stocks.

In primitive Hudsonaster, all of the plates other than the ambulacrals are more or less well tuberculated, and these granules do not now carry spines, if they ever did. In later forms, however, as Promopalraster, they may all have borne spines, some of them of large size. Small club-shaped spines occur here in considerable abundance along the sides of the inframarginals and the adambulacrals. In Palæaster there are brushes of delicate spines along the inner edge of the adambulacrals. In Mesopalæaster the ventral spines are better developed, fully so in Promopalæaster, and probably equally so in most post-Ordovicic forms.

Among the primitive cryptozonian genera Stenaster and Tetraster no spines are now seen, but undoubtedly such were present on the actinal side. In Urasterella the entire dorsal skeleton is more or less spinose, consisting of long, nonarticulating, slender rods, the dorsal extensions of the ossicles. In the multi-rayed Cryptozonia of the Devonic, spinosity is at its greatest development in the Paleozoic.

Ambulacratia.-Undoubtedly the most important skeletal parts of the Stelleroidea are the ambulacrals. In general they undergo the least alteration during geologic time of the entire asterid skeleton, and therefore any marked variation must be of broad classificatory value. Schöndorf ${ }^{1}$ is well aware of this fundamental value and has made full use of it in defining his three "classes," Asteroidea, Auluroidea, and Ophiuroidea. In the Asteroidea the ambulacralia of adjoining columns are nearly always placed directly opposite one another, with the podia issuing through openings that are not in the plates themselves, but laterally between two adjoining ambulacrals and the corresponding adambulacrals. Among the Paleozoic asterids one is not always certain whether the ambulacralia are arranged "opposite" or "alternate," because the specimens in nearly all cases have suffered more or less from distortion. In many good specimens they are very slightly alternate, but in all such cases the arrangement is said to be alternate. In other fine fossils they are now alternate, but a close study seems to show that originally they were practically opposite in arrangement. On the other hand, certain of the species with wide ambulacral furrows and large ambulacralia, as in Promopalxaster, Anorthaster, and Urasterella, have an alternate arrangement, while in other species of the first and last named genera they are just as certainly opposite. The writer therefore does not

1 Jahrb. nassauisch. Ver. Naturk., Wiesbaden, vol.63, 1910, pp. 206-256; Palæontographica, vol. 57, 1910, pp. 1-56. 
lay much stress upon this feature among the Ordovicic asterids, nor does he regard it even necessarily as of specific value, but in the later Asteroidea the arrangement is always opposite or nearly so. Verrill $(1914: 20)$ states that he has noticed the alternate arrangement in living Pycnopodia "as an abnormal variation in some of the rays, and also that it may occur from lateral bending." Evidently the alternate disposition is a fixed character among some Ordovicic forms, as in Anorthaster, but more will certainly be discovered in these old strata and probably rather among the Cryptozonia than the Phanerozonia. The writer is led to this view because of the alternate arrangement in many Auluroidea, a subclass of Stelleroidea that seems to have had its origin in some cryptozonian asterid. Out of the Auluroidea with opposite ambulacralia came the Ophiuroidea with their highly modified ambulacrals which are coossified into "vertebral ossicles." In the Auluroidea the arrangement of the ambulacrals is either alternate or opposite, but they are never coossified but are so modified as to suggest the Ophiuroidea rather than the Asteroidea. The structure of these plates is described elsewhere and need not be repeated here.

The ambulacrals are very variable in number throughout the genera. In Hudsonaster, Stenaster, and Tetraster there are as few as 10 in a column, while in Promopalæaster there are certainly 50 and possibly as many as 60. The cryptozonian genus Urasterella has certainly over 100 in a column. In general, these ossicles abut against each other, but in Urasterella and other genera they overlap proximally to a certain extent. As yet the writer has seen no Paleozoic asterid with more than 2 columns of ambulacrals, though in Promopalxaster magnificus the proximal areas of the rays for a short distance have 4 columns of podial openings. Here, however, the ossicles have not yet wedged themselves into 4 columns of ambulacralia.

In shape and surface contour there is also considerable variation among the ambulacralia. In Hudsonaster, Tetraster, and several Devonic genera they are more or less rectangular, either squarish or drawn out laterally. In other forms of Hudsonaster, along with Stenaster and Urasterella, the ossicles are $\vdash$-shaped, with the lateral shaft thin, thus allowing for large, elongate podial openings. The more primitive genera have the outer surfaces plain or slightly ridged, while in derived forms like Promopalæaster the ridges are high and straight or have their medial terminations orally directed. In $P$. magnificus, the ridges in the proximal region are arranged in pairs having the shape of a tuning fork; in $P$. wykoff one sees that these ridges approach one another in pairs transitional to their transformation into the tuning-fork form. 
Adambulacralia.-Adambulacralia are present in all Stelleroidea. They are best and typically developed in the Asteroidea, more or less modified in the Auluroidea, and completely altered into the thin scalelike side plates of the Ophiuroidea. In number and relative size they vary as do the ambulacralia, being least numerous and largest in the most primitive genera. Originally they probably bore no spines at all, the plates being practically smooth. In Hudsonaster and most Ordovicic and Siluric, and some Devonic genera, their surfaces are granular to tubercular. These protuberances in the younger genera may have borne small spines, but long before these appeared each adambulacral bore two or more stout or slender, comparatively long spines along its ambulacral edge.

In most of the Paleozoic genera there are in each column as many adambulacrals as there are ambulacrals, and both series are as a rule arranged opposite one another. In Anorthaster, however, there are fewer and therefore larger adambulacrals than ambulacrals, and these latter ossicles clearly alternate with one another.

In the Phanerozonia the adambulacrals never margin the rays but always lie inside of the bordering inframarginals. In the Cryptozonia, however, the adambulacrals margin the animals and here the ossicles are usually small, though at times they are relatively large and make a stout outer skeletal frame as in Stenaster, Tetraster, and Schcenaster (?) montanus. The same is true in Encrinaster of the Auluroidea.

The adambulacrals in probably all the Paleozoic Phanerozonia continue into the oral region and each two adjoining columns meet here in a pair of modified, elongate, pointed pieces, the most prominent ossicles of the oral armature. No other skeletal parts lie in front of these oral ossicles except in the phanerozonian Hudsonaster narrawayi (pl. 1, fig. 1) and in the young of the cryptozonian Urasterella ulrichi (pl. 30, fig. 7). Both are primitive forms of their respective phyla and whether these five pieces or tori are to be interpreted as five spines or whether they represent five primitive orals is not yet determinable.

Inframarginatia.-In the great majority of Paleozoic Phanerozonia the inframarginals alone margin the animals, and only in a few forms (Spaniaster, Miomaster, Rhenaster, and Neopalæaster) have the supramarginals moved outward and completely covered the inframarginals, so that the two columns together equally bound the rays and disk. That condition is a peculiarity common to most Paleozoic phanerozonians, while the wholly superposed arrangement distinguishes nearly all the Mesozoic, Cenozoic, and Recent genera of the same kind of Asteroidea.

The inframarginals are usually the most conspicuous ossicles of the Paleozoic Phanerozonia, and this is especially true where the 
skeleton is strong and devoid, or nearly so, of accessory ossicles. They are ponderous in Hudsonaster, Palæaster, Australaster, Devonaster, Xenaster, Trimeraster, Petraster, etc. When the smaller accessory plates are introduced, the inframarginals also reduce in size; this development is best seen when passing from the heavily plated Hudsonaster to the more abundantly plated Mesopalæaster and finally Promopatxaster. The next step in this phyletic line would be pronounced a cryptozonian because the infra- and supramarginals could not be distinguished from the abundance of accessory ossicles. In fact, it is not always easy to make out the various categories of plates even in Promopalxaster, and here one must resort at times to a study of the tips of the rays where the seven primordial columns are not yet disturbed by the introduction of accessory pieces.

In primitive Hudsonaster, where the inframarginals are comparatively very large, there are only half as many of these ossicles as there are of adambulacrals, but in the great majority of Paleozoic genera of Phanerozonia this marked difference tends to be less decided and toward equalization. In certain phyla, as, for instance, from Hudsonaster to Mesopalæaster and Promopalæaster, the equalization has gone on rapidly, in fact, in but a short part of Ordovicic time. In more conservative stocks, as from Hudsonaster to Devonic Xenaster and Trimeraster, the equalization is far slower, as is seen in the following figures: Hudsonaster, 12 inframarginals and 24 adambulacrals; Trimeraster, 14 and 23; and Xenaster, 20 and 32, respectively. In nearly all the genera these columns of plates alternate with one another. This of course must be so where the number of ossicles is different in the two columns, and complete alternation is retained even in certain species where the numbers of ossicles are alike, as for instance in Promopalzaster spinulosus. On the other hand, in Mesopalæaster shafferi, where there are 16 inframarginals and 18 adambulacrals, the plates alternate in the proximal half of the ambulacra and are opposite one another distally. A study of the growing ray tips shows that the various ossicles all appear practically of one size and where there are more adambulacrals than inframarginals, the former are crowded orally. The latter development appears to be the primitive type of growth, but this mode is rapidly changed to one in which the seven columns of primordial ossicles appear in cycles or rings. This type of growth is easily made out in primitive forms such as Hudsonaster and Mesopalæaster, and in some species of Promopaleaster. However, when accessory plates are developed in abundance, and especially in forms where the seven primordial columns of plates remain of one size, their introduction in cycles can only be made out in very young individuals or at the 
extreme tips of the rays, conditions not often attained among these fossils.

In the great majority of Paleozoic Phanerozonia the inframarginals and adambulacrals lie closely adjacent to one another. In typical asterids they are not separated by the introduction of accessory interbrachial pieces until in the Devonic. Here in Xenaster and Trimeraster isolated pieces, and finally a column of them, are inserted in the proximal half of the rays. In the large-disked asterids, this separation occurs much earlier, in the Middle Ordovicic in Petraster.

In Paleozoic Phanerozonia where the skeleton is made up of an abundance of more or less equal-sized ossicles, one notices also on the distal portions of the rays a tendency for the inframarginals to appear on the dorsal side and not to remain on the ventral, as in primitive stocks. This alteration brings the adambulacrals to the margin of the rays, and is a hint as to how Phanerozonia gradually change into Cryptozonia. It is best seen in Promopalxaster, Petraster, and Mesopalxaster. In Australaster it is a marked feature, in fact, one can say that the distal parts of the rays in that genus are cryptozonian while the bulk of the arms are still phanerozonian. This ontogenetic appearance is in harmony with phylogenetic development and chronogenesis. The living Echinaster sepositus is in youth also a phanerozonian, but at maturity is a typical cryptozonian. In so typical a cryptozonian as Urasterella, one still finds in half-grown $U$. ulrich $i$ a number of inframarginals in the interradial or axillary areas. The same retention of the first formed inframarginals is also met with among the multi-rayed Cryptozonia in Helianthaster, and even among the Auluroidea in Encrinaster.

It has just been pointed out how the inframarginal columns are eliminated as marginal plates. They are not, however, removed from the skeleton in these early forms by resorption or by failure of development, but for want of special growth. In other words, the inframarginals are probably present in all Paleozoic Asteroidea, but because of lack of specialization through the developmental tendency to greater skeletal flexibility, remain small and are lost as such in the mass of the dorsal plates. This apparent elimination of the inframarginals has gone on independently in various stocks as pointed out elsewhere, and therefore the absence of large marginals, either infra- or supramarginals, or both series, is not of ordinal value.

Supramarginalia.-In Hudsonaster the prominent supramarginal plates of the dorsal side are placed decidedly inside of the inframarginals, though the former clearly overlap the latter. This primitive position is retained in many Paleozoic genera, and apparently not before the Devonic do these two columns of ossicles come to lie wholly upon one another, and then they together margin the animals. 
It is apparently always a rare condition in the Paleozoic, but as the post-Devonic asterids are as yet little known, we can more accurately say that the modern type of Phanerozonia is unknown before Devonic time. It should be added here that complete superposition of the supra- upon the inframarginalia undoubtedly took place in more than one stock and at different times. Accordingly, to group all asterids with large marginalia into the "order" Phanerozonia is further proof that these terms cannot be used in the phyletic sense. Phanerozonia and Cryptozonia are, however, of use in a descriptive way.

The supramarginals, and the inframarginals as well, in primitive forms gradually attain larger size down the columns from the tips of the rays toward the disk and mouth. In other words, the older the ossicle in primitive genera, the larger is its size, and in all such forms the pairs of supra- and inframarginal columns terminate in single plates, the primary or basal supramarginals and the primary or basal inframarginals. The latter ossicles in the most primitive genera are situated in the axils of the rays and are therefore also known as axillary marginals, and in the more specialized genera the axillaries and even pairs of inframarginals are crowded orally into the interbrachial areas. The basal supramarginals in primitive forms always occur prominently on the disk, in derived genera they are, however, less conspicuous, and where the disk skeleton is made up of small ossicles, they are generally indistinguishable in the mass of plates.

We have seen that accessory interbrachial plates in some genera are developed between the inframarginals and adambulacrals, and to a greater extent the same is true of the development of ambital accessory pieces between the former columns and the supramarginals. In probably all cases where the rays and disk grow wider the additional space is largely covered in by the development of accessory plates. As it is in the disk area, and therefore necessarily in the basal portion of the rays as well, that the main increase of body extent takes place, here are developed the greatest number of these pieces. Rarely are the ambital accessory pieces crowded in between these columns beyond the proximal third of the rays. This is best seen in Devonaster and Xenaster, but in the large-disked forms, as Petraster, they extend farther out and are present to within the outer third of the rays. Ambital accessory plates may also be present in Mesopalzaster, but are more definitely so in Promopalxaster (especially in $P$. magnificus), and in both genera they occur throughout the greater part of the rays.

Radialia.-In many Paleozoic genera of Phanerozonia and even among some of the Cryptozonia, a more or less prominent column of ossicles is seen down the center of the dorsal side of the arms. These 
are the radial columns of ossicles, which are especially well seen in Hudsonaster, Spaniaster, Devonaster, Xenaster, Calliasterella, and less prominently in Mesopalæaster, Promopalæaster, and Petraster. The prominence of the radials is lost in the same way as has been described for similar reduction in the supramarginals and inframarginals.

In primitive genera the supramarginals and radials lie closely adjacent as prominent columns, but in the great majority of Paleozoic Asteroidea these columns are more or less extensively separated from one another by the introduction of radial accessory plates. The latter are always small pieces and in general one can say that their number increases with geologic time and with the evolutionary complexity of the various stocks. At first the accessory pieces appear singly between the plates in the proximal region of the rays, where, increasing in numbers, they separate the primary columns more and more and finally also crowd in between the individual ossicles, especially the proximal radials, pushing these apart more or less completely. This is true not only in chronogenesis but also in ontogenesis. It is best seen in a study of the dorsal areas beginning with Hudsonaster and Spaniaster, and proceeding to Mesopalxaster, Devonaster, Promopalxaster, and Urasterella. In the forms with great disks the development of accessory plates is extreme, as may be seen in Petraster speciosus.

The columns of radial plates are less persistent in development than any other of the primary columns. Like all of the primary plates, the radials are apt to lose their ponderosity and in the course of geologic time become smaller. In this way they may lose their individuality in the mass of dorsal plates, but in some cases radialia appear to fail to develop throughout the greater part of the rays, although one or more primordial ossicles of each radius are present on the disk. In certain species of Mesopalxaster, and more especially in Promopalxaster, the radialia are either not present or have been squeezed out of the mid line of each radius so as to be unrecognizable. In other forms of the latter genus they are well developed and arranged in linear columns. Promopaliaster as a rule has no radialia on the rays and the space between the supramarginals is occupied by many small accessory radial pieces. Among the Cryptozonia, radialia are usually not discernible as such on the rays, though present on the disk.

Accessory plates. - These small pieces of irregular form are space fillers between all of the primary columns of plates, with the exception of the ambulacrals and adambulacrals. As the body cavity grows larger, skeletal increase takes place either through enlargement of the seven primordial columns of ossicles or by the intercalation and formation of new pieces, the accessory plates. The former method 50601-Bull. 88-15-4 
is the one least often resorted to. The accessory pieces appear first chronogenetically on the disk, separating the primordial ossicles one from another in various ways, and as the body cavity grows larger in the course of geologic time, they wedge all of the primary columns apart proximally except the ambulacrals, which compensate for the widening of the rays by growing in size transversely. Some accessory plates also develop in the interbrachial areas separating the interbrachial marginals, as in Trimeraster and Xenaster, while in the large-disked forms, as Petraster, their number becomes excessive.

Ocular plates.-The large ocular plates seen in so many living Phanerozonia are very rarely developed in Paleozoic forms. In fact, the writer knows of but a single occurrence, in the Lower Carboniferous genus Neopalæaster.

It seems to the author that these ossicles should have considerable significance in phylogeny because their large growth indicates that they are much older plates than any of the small adjacent pieces. In other words, in all genera where the ocular or sensory tentacle does not lie in an enlarged and grooved plate, the newly developed ossicles of either the ventral or dorsal side appear distally to the previously borne pieces, i. e., at the tips of the rays, whereas in the stocks having ocular plates the new skeletal arrivals appear not at the tips of the rays but on the proximal side or inside of the eye ossicles Therefore, where ocular plates are present, these pieces are not only enlarged in size with age, but progressively pushed farther and farther outward as well by the growing ray tips that lie on their inner sides. This mode of growth may have originated once or several times, there being in the latter case parallel developments of ocular plates. This is a study that can not be pursued far among Paleozoic genera, but in the later forms may be productive in the discerning of phylogenetic lines.

After the above was written the writer read in Verrill (1914: 20-22) that Fewkes has shown the ocular plates to be the first to appear in the young, and that with growth they are pushed distally because of "the budding in of new plates between the apical plate and the one next to it." These observations on living starfishes are therefore in harmony with the study of Neopalæaster, and go to show that the bulk of Paleozoic starfishes insert the plates of the primary columns in a different way, i. e., always distally. On this ground alone most of the Paleozoic starfishes should be grouped by themselves and apart from most of the subsequent Phanerozonia.

Centro-dorsal. - In the center of the disk of many Paleozoic genera of Asteroidea and of some Auluroidea is seen a more or less prominent plate, which is thought to be the equivalent of the centro-dorsal of the embryo of the living crinid Antedon (Comatula). It is a prominent though small plate in most of the forms of Hudsonaster and in 
Palxaster; it is also well developed though less conspicuous in Mesopalæaster, Spaniaster, Xenaster, Agalmaster, Devonaster, Neopalæaster, Palasterina, Monaster, Calliasterella, and Urasterella.

As the disk plates are rarely well preserved, and as the centrodorsal has been seen in many Paleozoic species, the writer thinks. it will be found in most of the forms of this era.

Primary disk plates. - In the most primitive and oldest Paleozoic asterids the centro-dorsal is surrounded by a variable but small number of diminutive accessory disk pieces. In mature Hudsonaster they form a single ring, but in the young of the cryptozonian Urasterella ( $U$. ulrichi) and in mature Calliasterella there are none of these accessory pieces present. For these reasons it is thought that in the Ordovicic there will be found a small asterid, even more primitive than Hudsonaster, that will be devoid of accessory disk pieces.

Around the centro-dorsal of young Urasterella and in mature Calliasterella, there follows directly a ring of five larger plates. The same five plates are also seen outside of the single ring of accessory pieces in Hudsonaster and Spaniaster, and directly beyond the two rings of accessories in Mesopatzaster. These more or less large plates are radial in position and are the basal radialia above which continue the columns of successively formed radials.

Returning to Hudsonaster, we see that the first ring of prominent plates has 10 pieces, 5 of which are radial in position, the remainder interradial. The same is true for Spaniaster and Xenaster, while Calliasterella has an equal number of piates in the second ring. An analysis of these disks shows that 5 of the plates are either primary or secondary radialia, while the remainder are situated interradially, and upon them rest the 10 columns of supramarginals. The first prominent ring in Mesopalzaster shafferi and Devonaster and the second ring in Urasterella ulrichi each have 15 plates, 5 of which are radialia, while the other 10 are supramarginals. Simplifying these statements and cutting out the accessory pieces, we learn that the disks of these genera-and others could be added-are composed of a centro-dorsal, a first ring of 5 radialia, and a second one with 5 radialia and 10 basal supramarginalia. This, then, is the same structure postulated for the hypothetic phylembryo of Asteroidea and deduced through reduction of ossicles, as gleaned from a partial ontogenesis of Hudsonaster.

Axillary ossicles.- In the most primitive asterid, Hudsonaster, one sees in each axilla a single large plate, on either side of which adjoin the 10 columns of inframarginals. The same arrangement obtains in Siluraster, Palxaster, and Australaster (here the genus occurs in the Permo-Carboniferous, and the axillaries are very large contrasting with the smaller ones of the Ordovicic Hudsonaster). In no other Paleozoic genera does this same development hold, though the single 
axillaries occur in many other forms where they are, however, pushed orally into the skeleton of the interbrachial areas. Single, not double, axillaries, therefore, make the simplest and smallest type of interbrachial areas. Further complexity and enlargement of these areas are produced by crowding into them orally, first the axillaries and then one or more pairs of proximal inframarginals.

In Hudsonaster narrawayi one sees tiny single plates proximal to each axillary. These are clearly of no marked morphologic value and are to be interpreted as accessory plates. Similar single ossicles are also seen in genera with large interbrachial areas, as in Promopalxaster. They are regarded as space-fillers and without ancestral significance.

Interbrachial areas. - The simplest type of interbrachial area is that just described. Increase in size and complexity of interbrachial structure is a natural result from an eniarged body cavity. The first change in this direction is seen in Mesopalxaster, Spaniaster, Miomaster, and Devonaster, where the axillaries are crowded orally and surrounded distally by a pair of adjoining basal inframarginals, and proximally by a variable number of adambulacrals. The same development is seen but in somewhat modified form in the cryptozonian genera Orasterella (U. utrichi and $O$.girvanensis) and Calliasterella. Here the axillaries are present only in the young, but may be retained to maturity; in either case they may or may not be margined distally by basal inframarginals. As the inframarginals in these forms are vanishing (primitive Cryptozonia), we should expect to find related genera devoid of even the axillaries, and such is the case in Stenaster and Tetraster.

The next step in the enlargement of the interbrachial areas consists of the inward crowding of pairs of basal inframarginals, one or more at a time. In Trimeraster these areas have the single axillaries and a pair of basal inframarginals, with the second pair of proximal inframarginals making the margin of the axils. In Xenaster the first and second pairs of proximal inframarginals are enclosed, while in Promopalxaster there are from one to three pairs in each interbrachial area. As these areas enlarge, it follows that more and more of the adambulacrals must also take part in the expansion. These ossicles are therefore called interbrachial adambulacrals. Further enlargement, but not to any marked extent, takes place through the insertion of a variable number of accessory disk interbrachials. This is best seen in Trimeraster and Xenaster.

Abnormal enlargement, but to a small extent, of the interbrachial areas takes place through oral crowding entirely of adambulacrals in pairs and through the increase in size of some of these ossicles. This type of development is known only in Anorthaster.

It has been shown how enlargement of the interbrachial areas comes about through oral crowding of the axillaries, proximal inframarginals and adambulacrals-pieces of the primary skeleton-but the 
greatest expansion is brought about by the introduction of more and more accessory disk pieces between the adambulacrals and inframarginals. The beginning of this development of the secondary skeleton is seen in Petraster and is variously progressive in the different species. They finally crowd more and more distally into the rays, as may be seen in Uranaster and Palæostella. Among the large-disked Cryptozonia, as Schuchertia and the Palasteriscidæ, it is the ambital and abactinal accessory pieces that go to enlarge the ares and body cavity.

\section{CLASSIFICATION.}

A good history of the various attempts at classifying the fossil starfishes is given by Spencer (1914:39-52). How recent starfishes are classified may be learned from Verrill (1914:24), and it will be seen that his principles are not always applicable to fossil forms because of the loss of parts through fossilization. In subsequent pages the author will give his groupings up to superfamilies, but the time is not yet at hand for an ordinal classification applicable alike to fossil and recent starfishes.

Catalogue of Paleozoic Stelleroidea.-A catalogue of all Paleozoic starfishes was published by the writer in April, 1914, under the title "Fossilium Catalogus, Animalia, part 3, Stelleroidea palæozoica," pp. 53 (Junk, Berlin). It gives the entire bibliography of the genera and species up to that date, and an outline of the classification adopted. The actual date of several new genera is of the work above cited, although they are also printed in the present book as new. This Bulletin is there cited as of 1914 and is now to be corrected to 1915 . The above-mentioned catalogue will always be useful for ready reference to the literature, although the larger volume repeats all of the essential references, corrected to November, 1914.

\section{DESCRIPTION OF GENERA AND SPECTES.}

\section{Class STELLEROIDEA.}

\section{Subclass ASTEROIDEA.}

\section{PHANEROZONIA Sladen.}

Asteroidea nearly always with large marginal plates. These consist in the Mesozoic and later asterids of completely superposed inframarginals and supramarginals; in the Paleozoic the rule is that the inframarginals alone border the animal, while the supramarginals are always dorsal, generally alternate with the inframarginals, and are placed farther inward though resting more or less upon the latter.

Ambulacrals always present and opposite in arrangement in postPaleozoic forms. In the oldest and most primitive Paleozoic forms they are apt to be alternate throughout the rays, or only so distally in the young parts. By far the greater number of Paleozoic forms, however, have the opposite arrangement. 
Oral armature always with the adambulacral pieces most conspicuous.

This order is not known to appear before the Middle Ordovicic, and in the Paleozoic contains the following families:

Hudsonasteridæ.

Palæasteridæ.

Promopalæasteridæ.

Mesopalæasterinæ.

Promopalæasterinæ.

Anorthasterinæ.
Xenasteridæ.

Neopalæasteridæ.

Palasterinidæ.

Lepidasteridæ.

These seven families of Paleozoic asterids are all related to one another and seemingly had their origin more or less directly in Hudsonaster or a form very similar to it. Therefore the family Hudsonasteridæ is the primordial stock out of which all asterids progressively developed. Hudsonaster is massively and simply built, with the spines rudimentary and restricted to the adambulacrals and inframarginals; it is a small rigid asterid with few and comparatively large ossicles, nearly all of which are of the primary skeleton. From it the evolutionary tendency was to get rid of the rigidity and ponderosity through the comparative reduction in size of the plates and the introduction of many smaller secondary pieces, along with an abundance of spines. With this tendency once established, there arose several others: (1) elongation of rays, with greater flexibility and greater power of locomotion through the indefinite duplication of pairs of podia; (2) increase of body, cavity in three different ways. This took place through the development of interbrachial areas (a) by the inward crowding of the single interbrachial axillaries, followed by more and more pairs of proximal inframarginals; (b) through the insertion of an indefinite number of accessory ossicles between the adambulacrals and the inframarginals, forcing the latter more and more outward; and (c) through the introduction of supernumerary rays. The latter development is probably abnormal, in that the tendency arose in the later larval life as is explained elsewhere. (See p. 207.) With these changes of the actinal side naturally must arise compensating growths of the abactinal surface and accordingly here is seen the introduction of accessory ossicles in various places.

Starting with Hudsonaster, there is one phyletic line developed through the elongation of rays, flexibility, and the increase in size of the oral region by the (a) method from the primitive Hudsonasteridæ into the derived Palæasteridæ, Promopalæasteridæ, Xenasteridæ, and Neopalæasteridæ. This is the most satisfactory line of evolution, resulting in the greatest variety of genera. Again with Hudsonaster as the radicle, another phyletic line is established through the increase of the body cavity by the (b) method, giving 
rise to the Palasterinidæ. This line of change is not at all so productive of genera as the former. Finally, a third phyletic line is established through larval adaptation, causing a sixth ray to develop and thereafter pairs of rays, resulting in the multi-rayed asterids of the family Lepidasteridæ.

These phyletic lines may be expressed taxonomically as follows: Superfamily Promopalæasteracea, new.

Includes families Hudsonasteridæ, Palæasteridæ, Promopalæasteridæ, and

Xenasteridæ. The Neopalæasteridæ developed out of the Promopalæasteridæ. Superfamily Palasterinacea, new.

Includes family Palasterinidæ.

Superfamily Lepidasteracea, new.

Includes family Lepidasteridæ.

\section{HUDSONASTERID无, new family.}

Most primitive known Phanerozonia.

Small, five-rayed, heavily plated asterids, with narrow ambulacral furrows and slightly alternate ambulacralia. The incipient interbrachial arcs are occupied by single axillary marginal plates. Abactinally the rays have five columns of ossicles, the radials in the center being bounded on either side by the supramarginals and inframarginals; the latter margin the rays and the ossicles of adjoining columns alternate with one another. There are no accessory ray plates of any kind. The disk has a prominent central disk piece separated by a small number of accessory disk plates from a ring of five large basal radials and five large basal interradial ossicles. Spines rudimentary and apparently restricted to the adambulacrals and inframarginals.

This family contains the genera Hudsonaster Stürtz and Siluraster Jaekel.

\section{Genus HUDSONASTER Stürtz.}

Palæaster (part) of authors.

\section{Plates 1-6.}

Hudsonaster StüRTz, Verh. naturh. Ver. preuss. Rheinl., etc., vol. 56, 1900, pp. $224,225$.

Protopalæaster Hudson, Ottawa Naturalist, vol. 26, 1912, p. 25; vol. 27, 1913, pp. 77-84.-RAYMond, Ottawa Naturalist, vol. 26, 1912, p. 105 (genoholotype, P. narrawayi).-SPencer, Mon. Brit. Pal. Asterozoa, pt. 1 (Palæontgr. Soc. for 1913), 1914, p. 21.

The name is derived from the "Hudson River formation," an Ordovicic series of strata of long endurance. If the stratigraphic term is used correctly, then these rocks have as yet furnished no starfishes of this genus; for this reason Hudsonaster is a misnomer and has no significance, but under the rules of nomenclature it must be accepted.

Generic characters.-Disk small and without actual interbrachial arcs. Rays five, short, tapering rapidly. 
Abactinal area of rays occupied by three columns of large, thick, more or less tumid or carinate, closely adjoining, tuberculate plates; more or less of the inframarginal plates are also to be seen, making five visible columns of plates on each ray abactinally. There is, therefore, a single radial column bounded on each side by two columns of supramarginal and two of inframarginal plates. The latter columns are the marginal plates both actinally and abactinally, but on the dorsal side are overlapped by the supramarginals. In the center of the disk there is a small but very tumid plate (central disk plate) around which is a nearly complete circle of smaller accessory plates and an open space which may represent an anal opening. Outside of this first circle of accessory plates there is a ring of 10 very large plates that in the geologically later species are stellate on the surface, 5 of which are radial and 5 interradial in position. The radial plates are the basal radial plates of the 5 medial columns, while the 5 interradial plates give rise to the 10 larger and conspicuous supramarginal ossicles. The basal supramarginals adjoin one another in the axillary areas, and in the geologically later forms these also have stellate surfaces. Between each of the 5 interradial plates there is inserted a single plate, making a second but disconnected ring of accessory plates.

Madreporite abactinal, more or less large, adjoining one of the large interradial plates and between the basal plates of two supramarginal columns of ossicles of adjoining rays.

No accessory ambital or abactinal plates.

Spines appear to be absent everywhere except on the inframarginal and adambulacral ossicles. Otherwise the surface is granular or tuberculate.

Inframarginal plates well-developed, tuberculate, and common to both the actinal and abactinal areas. "These proximally adjoin the five isolated and large axillary marginals, each one of which occupies an axil of the rays. Each plate, except the axillary ones, bears on its outer edges one to three apparently smooth, small spines.

Axillary plates quite conspicuous, marginal, and one in each actinal axil. In at least one of the species there is a single tiny accessory piece orad to each axillary (H. narrawayi), and it is only seen on the inside of the skeleton.

Adambulacral plates numerous, one or two to each inframarginal plate and two on each side of each axillary marginal plate. All of these pieces bear at least two spines, one on the inner and another on the outer edges.

Oral armature consisting of at least five pairs of pointed and elongate basal adambulacral plates; each bears spines like the other ambulacrals. In rare cases issuing from beneath these ossicles may be seen five single stout spines or plates (tori) that are connected 
with the pairs of ambulacral armature pieces. In H. narrawayi above or dorsal to the pair of large oral pieces there is another but smaller and modified pair of ambulacral ossicles clearly also a part of the oral armature.

Ambulacral grooves originally narrow and regularly tapering. Ambulacral plates rectangular, practically opposite or very slightly alternating, one to each adambulacral plate. The ambulacralia of each column may be so closely adjoining as to leave almost no space for the podial openings, or there may be laterally between adjoining ossicles very large openings.

Genoholotype.-The genotype selected by Stürtz is Palasterina mugosa Billings. The above generic definition is, however, largely based upon Palæaster incomptus Meek and P. matutinus Hall.

Distribution.-Restricted to the middle and upper portion of the Ordovicic. The following are the known species:

H. matutinus (Hall). Trenton.

H. narrawayi (Hudson). Black River.

H. milleri, new species. Trenton.

H. incomptus (Meek). Maysvillian and Richmondian series.

H. rugosus (Billings). Lower Richmondian, Charleton formation.

H. batheri, new species. Upper Ordovicic, Girvan, Scotland.

Remarks. - Stürtz is unfortunate in selecting as the genotype of Hudsonaster, Palasterina rugosa Billings, a very poorly known starfish from the Richmondian of Anticosti Island. Therefore his original definition of Hudsonaster is not only very imperfect, but the specimen is wrongly interpreted. His characterization of the genus is as follows:

Of Palasterina rugosa only the abactinal side is known. On the disk occur ornamented, deeply crenulate, star-shaped plates. Four [the specimen is distorted and has forced into view one of the inframarginal columns, while the one on the other side of the ray is shoved out of sight] regular and decided columns mark the rays, and of these the outer rows are stronger than the inner columns. The outer columns consist of unmistakable marginal plates [one is inframarginal, the other is a supramarginal column]. According to Billings there are even traces of the actinal marginals to be seen from the abactinal side. Spines absent [the usual spines of this genus are also present here]. The arms terminate sharply in points.

Stürtz is correct in saying that this species can not be included in Palasterina and also that the genus has come to embrace a variety of unrelated genera. However, he does not say what are the actual generic characters of Hudsonaster, but as $P$. rugosa is not a Palasterina he concludes that as "new generic names are required I propose Hudsonaster for Palasterina rugosa Billings." This species is undoubtedly congeneric with Palæaster incomptus, a form fully described in this work both from the actinal and abactinal sides, and is therefore taken as the genotype for the above generic definition. 
The alopted genotype of Protopalæaster ( $P$. narrawayi) is described at length and in detail by Hudson, but, thinking the specimen showed the actinal side, he described the ambulacrals as epineural plates roofing over the ambulacral furrow, a character that he of course recognized as wholly anomalous for starfishes. Raymond later on showed that the actinal side of this specimen lies buried in the rock and that the entire abactinal plates are now gone, so that the view is of the actinal plates from their inner side, i. e., an internal view of the ventral skeleton (later Hudson combats this view). Under these circumstances nearly all of Hudson's generalizations are fallacious and especially his statement that "we are dealing with an unrecognized and very archaic morphological type which links the Edrioasteroidea with the Stelleroidea" (1912: 24). A proper interpretation of the specimen shows it to be a primitive but otherwise a normal early Paleozoic starfish. Even though Hudson's genus is far better determined generically than that of Stürtz, it must give way to the older name Hudsonaster. No one regrets this more than the writer, because the generic name Protopalxaster expresses the phyletic relationship of these primitive starfishes and is a name that he has had in manuscript for the past 15 years.

Hudsonaster has its nearest known relationship in Palæaster, but differs at once from the latter in that the rays have abactinally five columns of plates, while Patæaster has but four. In other words, Patraster has no radial columns of ray plates, but their place is occupied by numerous small accessory pieces. The abactinal disk of Palxaster is also quite different in having numerous small accessory ossicles, while in Hudsonaster this area is devoid of these pieces and instead there are disk plates that are larger, far less numerous, and with a definite arrangement.

The plate arrangement of Hudsonaster is simple and primitive in that it distinctly retains to maturity much of the larval plate structure of recent species and does not develop accessory ambital or accessory abactinal plates as do its descendants Mesopalxaster and particularly Promopalxaster. In Hudsonaster the axils are occupied by single, large, axillary marginals, against which rest the columns of inframarginal plates of adjoining rays. In the other two mentioned genera, interbrachial ares begin to develop by crowding orally the axillary marginals, when, as in Mesopalzaster, the proximal plates of the inframarginal series of adjoining rays abut against each other. In Promopalæaster this crowding of the inframarginal plates into the interbrachial areas is continued, always a pair of plates at a time passing orally. For other remarks on the development and distinction between these genera, see Mesopalxaster and Promopatzaster. 
In the Lower Carboniferous genus Neopalæaster the primitive disk structure of Hudsonaster is also retained in its essential features. Otherwise these genera are easily distinguished, as is pointed out in the remarks on Neopalxaster.

\section{HUDSONASTER MATUTINUS (Hall).}

Plate 2, fig. 2; plate 3, fig. 2; plate 5, figs. 1, 2.

Asterias matutina Hall, Nat. Hist. N. Y., Pal., vol. 1, 1847, p. 91, pl. 29, figs. $5 a, 5 b$.

Palæaster matutinus Hall, Twentieth Rep. N. Y. State Cab. Nat. Hist., 1868, p. 283 , pl. 9 , fig. 2 ; rev. ed., $1868=1870$, p. 325 , pl. 9 , fig. 2 .

Petraster rigidus (part) Brlings, Geol. Surv. Canada, Can. Org. Rem., dec. 3, 1858, pl. 10, fig. $3 b$ (not fig. $3 a$ ).-HaLl, Twentieth Rep. N. Y. State Cab. Nat. Hist.,1868, p. 294; rev. ed., $1868=1870$, p. 337 .

Original description.- "Body small, with five radiating arms, arms elongated (length twice and a half the width of the body), terete, acute, composed of three rows of plates [abactinally], which join above by their lateral margins. Beneath each upper lateral row of plates there is an inferior lateral range [inframarginal] visible, leaving the sulcus beneath the middle row, which is often depressed. The dorsal plates are somewhat hexagonal; those of the arms quadrangular; surface punctate or granulate, perhaps from the removal of the spines covering the surface.

"The specimen is considerably crushed, and two of the arms broken off at the base; the madreporiform tubercle upon the back is not visible in our specimen. From its condition, the structure can not be entirely made out, but it is sufficiently clear to enable any one to recognize the species."

Emended description.-Specimen of the usual size (No. 3, Mus. Comp. Zoöl.) measures: $\mathrm{R}=14 \mathrm{~mm}$., $r=3.5 \mathrm{~mm}$., $\mathrm{R}=4 r$. The largest specimen (Ottawa, Billings collection): $R=16 \mathrm{~mm} ., r=5 \mathrm{~mm}$, $\mathrm{R}=3.1 r$. The smallest New York specimen (No. 26, Mus. Comp. Zoöl.): $R=7 \mathrm{~mm}$., $r=2.5 \mathrm{~mm}$., $\mathrm{R}=2.8 \mathrm{r}$. Width of rays at base from $2.5 \mathrm{~mm}$. to $5.5 \mathrm{~mm}$.

Rays short, tapering rapidly, convex abactinally and flat actinally. Disk comparatively large, probably convex abactinally during life.

Abactinal area of rays consisting of 5 ranges of large, thick, and tumid granular plates. The 3 medial ranges, when not distorted by pressure, conspicuous, with the 11 to 12 plates of each column closely adjoining and considerably elevated above the inframarginal ranges. The proximal plates of each supramarginal range lie against the large interradial plates and are more or less superposed on the large axillary marginals. In the center of the disk there is a distinct highly convex plate, around which is arranged a nearly complete ring of seven smaller pieces 
and a vacant space which may be an anal opening. Five other small quadrangular plates are intercalated, one proximally to each of the large radial basal plates. Outside of these 12 intercalary plates there is a ring of 10 quite large and conspicuous plates, 5 of which are radial and 5 interradial in position. The radial plates are largest and are the basal pieces of 5 medial or radial columns, while against the 5 interradial plates rest the 10 inframarginal columns.

Madreporite abactinal, quite small, situated immediately above a large interradial plate and between two basal supramarginal plates. Its position in relation to the anal opening is apparently as in $P$. incomptus.

Inframarginal plates in mature examples about 14 to a column, and when not displaced completely, inclosing the adambulacral plates and margining the rays. The axils are occupied by a very large, oval, axillary marginal plate. Each inframarginal bears upon its outer surface one to three short, slender, pointed spines, which are finely striated longitudinally.

Adambulacral plates small, subquadangular in outline and about 19 in a column in specimens having 13 inframarginals. Each plate bears on both the outer and inner edges a single spine and is like those of the inframarginal ranges.

The oral armature consists of 5 pairs of elongate adambulacrals, each pair being situated directly orad of the large axillary marginal.

Ambulacral plates $\vdash$-shaped, practically opposite or but very slightly alternating, one to each adambulacral plate. In the expanded medial portion the ambulacralia are slightly superposed one above the other proximally, while the lateral portion of each plate is very slender, leaving between adjoining pieces comparatively large podial openings.

Locality and formation.-From the Trenton limestone, as follows: The type-specimen was found in the "shelly layers" at Trenton Falls, New York (Amer. Mus. Nat. Hist., No. 199), and another specimen was secured there by Mr. Rust (New York State collection). Dr. Walcott collected a slab with three individuals in the Lower Trenton at Rathbone Brook, near Newport, Herkimer County, New York; and Mr. Taylor got two specimens at Deerfield, Oneida County, in the same State (Mus. Comp. Zoöl., Nos. 26 and 3). Mr. W. R. Billings found a specimen in the Trenton at Lachine, Quebec, and another from Government House Bay, Ottawa.

Remarks. $-H$. matutinus is intermediate in structure between the older $H$. narrawayi and the younger $H$. incomptus. It is larger than the former, has more plates in each of the columns, while the ambulacrals are deeply cut out for the podia, which is not the case in $H$. narrawayi. As $H$. matutinus is most closely related to $H$. incomptus more detailed comparisons must be made between them. Actinally 
the former differs in the wider ambulacral grooves. The difference of greatest value, however, is found on the abactinal area of the disk. In both species there is a central disk plate surrounded by a ring of accessory plates. In $H$. matutinus there are eight plates in this ring and in H. incomptus there are seven. Between all the basal radials in the latter species there is an accessory plate, or these are five in number, while in the former there are only two such plates. Again, the proximal plates of the supramarginal columns in $H$. incomptus are larger than any others of the abactinal area, while in H. matutinus they are smaller than the basal radials and their form and ornamentation are quite different. The madreporites are also quite different. In general, $H$. incomptus is larger, stouter, the rays broader and the disk has a greater number of accessory pieces. These features are still more pronounced in $H$. rugosus (Billings). Viewing these differences developmentally, the distinctions are slight, which proves the three forms to be genetically related, but specifically the differences are sufficiently marked to be regarded both morphologically and geologically as of specific value.

Apotype.-Cat. No. 60603, U.S.N.M.

\section{HUDSONASTER NARRAWAYI (Hudson).}

Plate 1, fig. 1; plate 2, fig. 1; plate 4, fig. 1.

Protopalæuster narrawayi Hudson, Ottawa Naturalist, vol. 26, 1912, p. 25, pls. 1-3; vol. 27, 1913, pp. 77-84, pls. 8, 9.-RAYMOND, Ottawa Naturalist, vol. 26, 1912 , pp. 105-107.-Hudson, Bull. N. Y. State Mus., No. 164, 1913, pl. 5.Spencer, Mon. Brit. Pal. Asterozoa, pt. 1 (Palæontogr. Soc. for 1913), 1914, p. 21, fig. 19.

Description.-Specimens small, an average individual from St. Paul, Minnesota, measuring: $\mathrm{R}=5 \mathrm{~mm}$., $r=3 \mathrm{~mm}$., $\mathrm{R}=1.6 r$. Width of ray at base $2.7 \mathrm{~mm}$. The three good specimens show only the actinal side while the fourth free siliceous one is too poorly preserved to make out more than the form.

Inframarginal columns have from 6 to 9 plates, while the adambulacrals and ambulacrals each have from 11 to 12. Ambulacral plates large and solid, rectangular, with slightly rounded ends. As these plates are not $f$-shaped as in other species of this genus it may be shown that this character is of generic value, in which case Protopalxaster will have to be revived.

Inside of each of the large axillary plates lies a pair of oral armature pieces that are in form very much like the adjoining adambulacrals. From beneath these ossicles projects a stout and long, rounded, armature rod, the torus (a tooth or chisel), the 5 teeth meeting together in the center of the mouth. These armature rods and more especially the 10 pairs of ambulacral armature pieces are seldom seen in fossil starfishes, and none shows it more clearly than the Yale specimen 
of $H$. narrawayi. In the holotype of this species, here illustrated, are seen additional pairs of oral armature ossicles. These are situated directly above or dorsal to the pairs of large armature plates, and are probably overlapping ambulacralia modified into the actinostomial ring.

Locatity and formation.-In the Black River formation, as follows: The holotype was found by Mr. J. E. Narraway at City View, near the Central Experimental Farm at Ottawa, Canada; it is now in his private collection. An excellent specimen was found by $\mathrm{Mr}$. Townshend near Kirkfield, Ontario, and is now in the Peabody Museum of Yale University. Many years ago Dr. Ulrich found a fine specimen at St. Paul, Minnesota, and another good one in the Lower (Glade) Lebanon limestone of the Stones River series at Shelbyville, Tennessee. These two specimens are in the United States National Museum (Nos. 60602, 60619). Mr. Moritz Fischer secured a coarsely silicified individual of this genus at Curdsville, Kentucky, and this is now in the Beecher collection in the Yale Museum; it may, however, prove to be of another species, distinguished by its stouter appearance, wider disk, and smaller axillary plates.

Remarks.-Originally the writer included specimens of this form under $P$. matutinus, regarding them as but young individuals of Hall's species. However, as the specimens are all geologically older, are always smaller and stouter, and with fewer plates in all of the columns, Hudson's species is retained as valid. It is the ancestral form and the most primitive species of Hudsonaster and hence the most primitive Paleozoic starfish. It is primitive because of its extreme simplicity of structure, in that the columns and plates are reduced to the smallest number and all of them are closely adjoining and without intercalary plates of any kind. Then the spines are developed only on the actinal side and as protection for the podia. For further information see generic remarks under Hudsonaster.

Cat. Nos. 60602, 60619, U. S. N. M.

\section{HUDSONASTER MILERI, new species.}

Plate 4, fig. 2.

Description.-Of this form there is at hand but a single poorly preserved individual showing the actinal side. It is a more slender species than $H$. matutinus, has a larger and more rectangular axillary plate, and the proximal inframarginals have each about 13 to 15 plates and the adambulacrals from 18 to 20 . No ambulacrals are preserved. The specimen measures: $\mathrm{R}=$ about $12 \mathrm{~mm}$., $r=3 \mathrm{~mm}$. Width of ray at base $4 \mathrm{~mm}$., at mid-length $3 \mathrm{~mm}$.

Locality and formation.-Found by Prof. Arthur M. Miller, after whom the species is named, in the Lower Lexington (Wilmore) 
limestone of the Trenton, in Fayette County, Kentucky. The holotype is in the collection of the State University of Kentucky at Lexington.

\section{HUDSONASTER INCOMPTUS (Meek).}

Plate 6, figs. 1, 2.

"Goniaster" of Agassiz, Graham, Anthony, and James, Amer. Journ. Sci., ser. 2, vol. 1, 1846, p. 441 (nomen nudum).

Palæaster incomptus MeEk, Amer. Journ. Sci., ser. 3, vol. 4, 1872, p. 275; Geol. Surv. Ohio, Pal., vol. 1, 1873, p. 64, pl. 4, figs. $5 a, 5 b$.

Palæaster simplex MrLer and Dyer, Journ. Cincinnati Soc. Nat. Hist., vol. 1, 1878, p. 29, pl. 1, fig.6.-Mrluer, N. Amer. Geol. Pal., 1889, p. 266, fig. 380.

Palæaster clarkei MrLer, Journ. Cincinnati Soc. Nat. Hist., vol. 1, 1878, p. 102 , pl. 3 , fig. 5 .

Palæaster clarkana Mruler, Journ. Cincinnati Soc. Nat. Hist., vol. 3, 1880, p. 236.

Original description ( $P$. incomptus).- "Small; rays rather short, or only about once and a half as long as their breadth at their inner ends, and rapidly tapering to their outer extremities, which are somewhat obtusely angular. Disk equaling in breadth the length of the rays. Dorsal side of the rays composed each of three rows of pieces that are wider than long, about nine in each row, and increase rather rapidly in size inward to the margin of the disk, which is composed of smaller pieces; a few very minute pieces apparently sometimes occur between the rows on the dorsal side of the rays [none are apparent in our material]. Surface of the dorsal pieces a little granular, but apparently without spines. Madreporiform piece rather small, a little oval, or almost circular [or trapezoidal], nearly flat, and marked by fine, irregularly interrupted, radiating striæ. Ventral side unknown."

Emended description. $-\mathrm{R}=11 \mathrm{~mm}, r_{=} \mathrm{mm}$., $\mathrm{R}=1.8 \mathrm{r}$. Width of ray at base $6 \mathrm{~mm}$. Another larger specimen measures: $R=16 \mathrm{~mm}$., $r=7 \mathrm{~mm}$., $\mathrm{R}=2.3 r$. Width of ray at base $8 \mathrm{~mm}$. Smallest specimen: $\mathrm{R}=4.5 \mathrm{~mm}$., $r=2 \mathrm{~mm}$.

Rays short, stout, tapering rapidly, convex abactinally and longitudinally ridged, flat actinally. Disk large, probably very convex abactinally during life.

Abactinal area of rays consisting of five columns of large, thick, tumid, alternating, granulose plates. In the center of the disk there is a distinct, highly convex plate around which is arranged a nearly complete ring of seven smaller pieces and a comparatively large open space which possibly represents an anal opening. This ring is followed by another composed of five large interradial plates between each of which laterally and somewhat centrally is intercalated a smaller plate radial in position. Laterally and distally to each of the five large interradial plates are five large radial plates which are the basal pieces of the five radial columns. Against the basal plates of the medial ranges there adjoin laterally two large stellate ossicles, 
each of which is the proximal plate of a supramarginal column. The rays are margined by the inframarginal plates. There are 10 plates in each radial and 9 in each supramarginal column.

Madreporite abactinal, situated interradially and distally against the large interradial plate of the second ring, which is in front of the anal opening, and between two of the proximal supramarginal plates. It is trapezoidal in form, flat, and marked by very fine, dichotomous, radial striæ.

Inframarginal plates completely inclosing all other plates and common to both the abactinal and actinal surfaces. Usually there are 9 or 10 in a column, not counting the axillary plates. Spines are present at least along the inner edges of the inframarginals.

Abactinally the axillary marginals are not prominent but actinally they are very conspicuous. No spines appear to be connected with these ossicles.

Adambulacral plates small, subquadrate, usually 2 to each inframarginal or from 18 to 22 plates in each column. From 4 to 6 are situated around the inner edge of each axillary, of which the 2 central ones are largest, being one of the 5 pairs of plates making the oral armature. The adambulacral plates originally bore on their lateral and inner edges numerous, very short, thick spines.

Ambulacral plates nearly entirely concealed by the adambulacral plates, apparently as numerous as the latter, and, so far as can be determined, like those in $P$. matutinus Hall.

Locality and formation. - In the lower, middle, and upper beds of the Cincinnatic (Ordovicic). Ten specimens have been studied: Four in the Harris collection in the United States National Museum (No. 40882) from the Richmond formation (Waynesville division) about Waynesville, Ohio; another from the same place and formation in the University of Chicago Museum (Gurley collection, No. 10977); one from the hill quarries in the Maysvillian series (Vaupel collection, U. S. Nat. Mus., No. 60616) back of Cincinnati; another, said to be from Cincinnati, in the University of Toronto (Walker collection, No. $691 \mathrm{H}$. R.); the type-specimen, now in the Museum of Comparative Zoölogy, also from Cincinnati; one in the Ulrich collection of the United States National Museum (No. 60617), found back of Covington, Kentucky, in the Maysville formation, about 315 feet above low-water mark in the Ohio River; and the type of Patxaster simplex Miller, found near Raysville, Ohio (Faber collection, University of Chicago Museum, No. 8830). The holotype of $P$. clarkana Miller is in Professor Harper's collection at Cincinnati, while another specimen is in the Ulrich collection of the National Museum (No. 60618).

Remarks.-The writer has seen the type-specimen of Patzaster simplex Miller, which agrees with the description and figure given 
by its author, and it is like other specimens in the Harris collection known to be $H$. incomptus (Meek). Of the latter, Meek only described the abactinal area, while Miller's specimen shows the actinal side. The four specimens in the Harris collection unmistakably affirm that both forms are identical, and since Meek's name has priority it is here accepted.

For remarks as to the relationship of this species see $H$. matutinus.

Through the kindness of Prof. George W. Harper, principal of the Woodward High School, Cincinnati, Ohio, the writer was enabled to study the type of Palæaster clarkana Miller. The specimen is a little abraded, but shows all the characters of $H$. incomptus except that it is much smaller in size. The abactinal area on a cursory examination shows but three columns, but in several places can be seen projecting small parts of the inframarginal columns. The disk also shows the same general arrangement and number of plates as in $H$. incomptus. There is therefore nothing except the smaller number of plates in the columns to distinguish $P$. clarkana from $H$. incomptus. Bearing in mind that the former is but one-third the size of the latter, it is not remarkable that $P$. clarkana should have but 6 or 7 plates while $H$. incomptus has 9 to 10 plates in the same columns. The entire difference is accounted for when one regards $P$. clarkana as the young of $H$. incomptus.

Another small but very poorly preserved specimen showing the actinal area is in the Ulrich collection of the National Museum and agrees with the type of $P$. clarkana. Its measurements are: $\mathrm{R}=4.5 \mathrm{~mm}$., $r=2 \mathrm{~mm}$., $\mathrm{R}=2.2 r$.

The only ontogenetic character observable in these small specimens of $H$. incomptus is that the columns have fewer ossicles, and the same is true of the abactinal area of the disk. It has a central disk plate, the first ring of small plates and the second ring of basal radial and interradial plates. But no intercalated small plates radial in position are present. The second ring of 10 plates and the central plate are the most prominent. If one were theoretically to reduce the size of the animal still more, the plates of the first ring would be the first to go and the rays would be simultaneously very much shortened, probably obsolete, resulting in a hemispheric nonstellate starfish. The abactinal area seemingly will then have but a central disk plate and 10 others, 5 radial and 5 interradial in position. On the actinal side there will be but the 5 axillary marginal plates separated from one another by the ambulacral furrow and the ambulacralia. This hypothetic animal therefore closely resembles a very young Comatula without the stalk or column, and also the stage of living asterids following the brachiolarial.

Cat. Nos. 40882, 60616, 60617, 60618 U.S.N.M. 50601 - Bull. 88-15-5 
HUDSONASTER RUGOSUS (Billings).

Plate 3, fig. 1.

Palasterina rugosa Bulings, Geol. Surv. Canada, Rep. of Progress for 1853-1856, 1857, p. 291; Geol. Surv. Canada, Can. Org. Remains, dec. 3, 1858, p. 77, pl. 9 , figs. $2 a-c$.

Palasterina rugosa Wright, Mon. British Foss. Echinod., Oolitic, vol. 2, pt. 1 (Palæontogr. Soc. for 1861), 1862, p. 27.

Hudsonaster rugosa STÜRTz, Verh. naturh. Ver. preuss. Rheinl., etc., vol. 56, 1900, pp. 218, 224, 225.

Original description.- "Two inches [not over $47 \mathrm{~mm}$.] in diameter, rays five, acute at their apices and rapidly enlarging to a breadth of four lines [about $11 \mathrm{~mm}$.] at the disk, which is eight lines [about $17 \mathrm{~mm}$.] in width. The specimen shows the upper [or abactinal] side of the fossil only; some of the plates are absent from the center of the disk, but those which remain are very prominent in their centers, and roughly ornamented by four or five deep crenulations or furrows from near the center to the edges, producing a star-like appearance resembling a half-worn plate of Glyptocrinus decadactylus; their diameter is from one to two lines [largest diameter $4 \mathrm{~mm}$.].

"The rays are composed (at least the backs and sides of them) of four rows of plates [due to distortion, a careful analysis shows five columns] which are so very. prominent that they appear to be almost globular, and even pointed in their centers, the central [radial] rows are the smallest [as in $H$. incomptus]; the first four plates of the outer [supramarginal] row occupy three lines in length, and of the inner [radial] rows nearly as many. Toward the point of the arm all diminish rapidly in size.

"Beneath the outer [or supramarginal] rows two others can be seen [the inframarginal], which are probably the outer marginal plates of the under [or actinal side], corresponding to those of Petraster rigidus."

Locality and formation.-Richmondian series, Charleton formation, at Charleton Point, Anticosti Island. Two specimens collected by J. Richardson are now in the Victoria Memorial Museum at Ottawa, Canada (No. 1999).

Remarks. - The same description was republished in 1858 with the addition of three figures. These, and a direct examination of the two type-specimens, show that this species clearly belongs to $H u d s o n a s t e r$ and that it is closely related to $H$. incomptus. The smaller free specimen preserves a portion of the disk and parts of two rays and shows clearly the presence of a single large axillary plate. H. rugosus, however, attained a considerably larger growth, has a greater number of plates in each column and these are described as "almost globular," while in $H$. incomptus the abactinal plates are very convex but not globular. Then the basal supramarginal and 
radial plates are much more decidedly ornate. Each of the supraand inframarginal columns has 14 plates against 9 in $H$. incomptus, and of adambulacrals there are not less than 24 in a column against 18 to 22 in the same form. All of the ossicles are as strongly papillose but not more so than in $H$. incomptus. The detail of the disk is not determinable.

\section{HUDSONASTER BATHERI, new species.}

Plate 3, fig. 3.

Tetraster wyville-thomsoni Nicholson and Etheridge (part), Mon. Silurian Foss. Girvan Dist., Ayrshire, fasc. 3, 1880, p. 324, pl. 21, figs. 1, 2 (not the other figs.).

A small Hudsonaster. $\mathrm{R}=6 \mathrm{~mm} ., \quad r=2.7 \mathrm{~mm}$. The largest specimen: $\mathrm{R}=8 \mathrm{~mm}$.

Actinal side only known. Inframarginal columns the largest, with 8 or 9 distinctly tuberculate plates. Inside of these are the columns of narrower and slightly shorter adambulacrals that lie somewhat below the level of the inframarginals; there are 10 or 11 of these plates bounding the ambulacral grooves, and the pieces of adjacent columns are opposite or nearly opposite one another. The ambulacral grooves are very narrow and deep and no ambulacralia are discernible.

Formation and locality.-Dr. F. A. Bather made wax squeezes for the writer from three natural molds in the collection of. Mrs. Robert Gray, Edinburgh; the originals are from the Upper Ordovicic of Thraive, Girvan District, Scotland. The holotype is the specimen illustrated as above cited.

Remarks. - Nicholson and Etheridge confused at least one of these specimens with their Tetraster wyville-thomsoni, a species of totally different construction, a cryptozonian, described elsewhere in this work. Actinally the new species is in harmony with Hudsonaster and although the abactinal side is unknown, it is thought that it will be found to be like that in $H$. matutinus.

Cat. No. 60601, U.S.N.M.

\section{Genus SILURASTER Jaekel.}

\section{Text fig. 6.}

Siluraster JAEkeL, Zeits. geol. Ges., vol. 55, 1903, Protokol, p. 13 (106), figs. 2, 3, on p. 108.-Spencer, Mon. Brit. Pal. Asterozoa, pt. 1 (Palæontgr. Soc. for 1913), 1914, p. 18.

Description.-"A typical asterid with opposite ambulacralia and with well-developed marginalia, therefore a true form of Phanerozonia. The strongly folded madreporite lies dorsally in an interradius." 
From the two excellent illustrations the following is made out: Inframarginals conspicuous and as large as the adambulacrals. Both columns finely tuberculate, with the ossicles of each alternating with one another. Proximally the inframarginals of adjacent rays rest on a somewhat larger axillary plate. The interbrachial areas are therefore made up of single axillary ossicles (Jaekel's marginal oral) and in front of these lies a pair of pointed adambulacrals, the conspicuous pieces of the oral armature. These are perforated for the continuation of the ring canal. The podial openings as usual lie in the corners of four adjacent adambulacrals and ambulacrals,

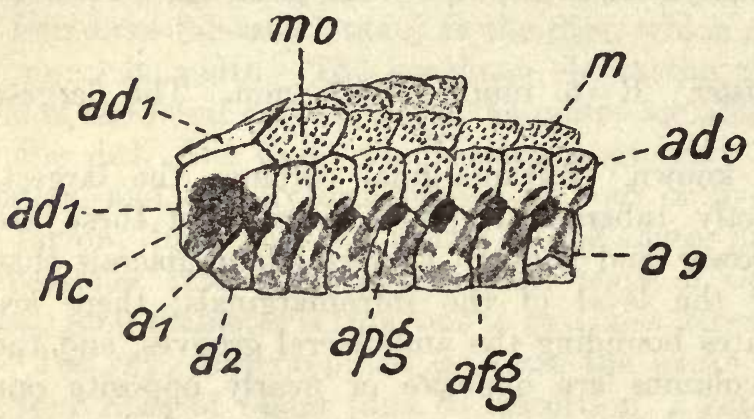

Fig. 6.-SilURASTER PERfectus (JAEKeL's Figure 3). $a_{1}$ to $a_{9}$, AMBULACRALIA OF ONE SIDE; ABOVE THESE $a d_{1}$ TO $a d_{9}$, THE ADAMBULACRALLA, $a d_{1}$ AS MOUTH CORNER PIECE; $a f g$, PODLAL GROOVES; $a p g$, PODLAL OPENINGS; $m$, INFRAMARGINALIA; mo, THE SINGLE AXILLARY INFRAMARGINAL; $R c$, RING-CANAL IN MOUTH CORNER PLATES.

Genoholotype and only species. -S. perfectus Jaekel. Ordovicic (D4), Zahorzan, Bohemia.

\section{Family PALAASTERID瓜 Gregory (emend.).}

Palæasteridæ (part) Mrller, N. Amer. Geol. Pal., 1889, p. 216.-Gregory, Geol Mag., dec. 4, vol. 6, 1899, p. 344 (contains Palæasterinæ, Xenasterinæ, and Lindstromasterinæ); Treat. Zool., vol. 3, Echinoderma, 1900, p. 250.

Palæasterinæ SchöNDoRF, Jahrb. nassauisch. Ver. Naturk., Wiesbaden, vol. 63, 1910 , p. 244.

Palægoniasteridæ (part) Stürtz, Palæontographica, vol. 36, 1890, p. 246 (contains Aspidosomella and Palæaster).

Primitive, derived, five-rayed Phanerozonia with the ambulacrals slightly alternate or opposite. Interbrachial arcs incipient or somewhat enlarged, and occupied by single axillary marginal plates. No accessory interbrachial or axillary interbrachial plates present, but there are developed accessory abactinal ray ossicles. Actinal plates consisting of ambulacrals, adambulacrals, and inframarginals. Madreporite abactinal.

Contains:

Palæaster Hall.

Australaster, new genus. 
Genus PALAASTER Hall (emend.).

Plate 7, figs. 1-4.

Palæaster Hall, Nat. Hist. N. Y., Pal., vol. 2, 1852, p. 247; Twentieth Rep. N. Y. State Cab. Nat. Hist., 1868, p. 282; rev. ed., 1868=1870, p. 324.-ZIтTEL, Handb. Pal., vol. 1, 1879, p. 452.

Palæaster Nicholson and Etheridge (part), Mon. Silurian Foss. Girvan Dist., Ayrshire, fasc. 3, 1880, p. 319.

(Not Palæaster SAlter, Ann. Mag. Nat. Hist., ser. 2, vol. 20, 1857, p. 323=Urasterella.)

(Not Palæaster of most AuTHors.)

Generic characters.-Disk small and without distinct interbrachial arcs. Rays five and slender.

Abactinal area of disk centrally occupied by a large plate, then a ring of 5 separated, somewhat smaller, radially situated ossicles, and inside the axillary pieces there are 5 subtriangular interradial plates, against which lie 10 very large and conspicuous proximal supramarginal plates. Between the central, radial, and interradial plates are numerous small accessory pieces which separate the primary ossicles one from another. These accessory plates also continue to crowd from the disk into the rays between the supramarginals, and thus take the place of the radial columns, but are absent in the distal third of the rays. Each ray has therefore 4 conspicuous columns of plates, the 2 supramarginals situated inwardly of the 2 marginal inframarginals. The former columns terminate in 10 very large proximal plates situated in the axils of the disk, while the inframarginals rest against the 5 very large actinal axillary marginal pieces. All of the large plates are centrally smooth, bordered by a pustulose area.

Madreporite abactinal, of medium size, circular in outline, and radially striate. It lies on top of two proximal supramarginal plates and the adjoining interradial plate.

Inframarginal plates thick and large, about as many in a column (13) as in those of the supramarginals (13 or 14). The latter do not completely overlie the inframarginals, since these bound the rays both actinally and abactinally. The inframarginal plates, like the plates of the abactinal area, have each a large, smooth, central space encircled by a pustulose area. From their inner sides articulate short, thick, blunt spines, of which there are apparently not more than 2 to each inframarginal plate.

Axillary marginal plates large, hexagonal, one in each axil and common to both sides of the disk axils.

Adambulacral plates small, tumid, alternating in the main with the inframarginal plates throughout the distal two-thirds of the rays, but toward the mouth there are a few more adambulacrals than inframarginals. (In the type-specimen there are 13 of the latter in a column to 16 of the former.) Oral armature consists of at least 5 pairs of drawn out and pointed basal adambulacrals. Along the inner 
side of each adambulacral plate there is a linear brush of from 5 to 7 short, slender spines.

Ambulacral grooves very narrow, tapering but very slowly. Ambulacral plates obscured by the rock but apparently very short, one to each adambulacral and placed opposite one another.

Genoholotype (type by monotypy) and only species. - P. niagarensis Hall. Siluric (Rochester shale).

Remarks.-To this genus has been erroneously referred a multitude of Paleozoic starfishes. It is to the starfishes what Terebratula and Rhynchonella used to be among the brachiopods - a general dumping ground for Paleozoic forms. This lack of generic conception regarding Palxaster lies somewhat in the fact that Hall's original diagnosis is very meagre and that he did not describe nor illustrate the abactinal surface, probably the most important area amongst Paleozoic asterids for specific and generic differentiation. Of the twenty-four American species listed under Palæaster by S. A. Miller ${ }^{1}$ only one now appears to belong there, the genotype. All others are here referred to Hudsonaster, Urasterella, Mesopalæaster, Promopalæaster, Anorthaster, Devonaster, and Neopalæaster.

No new material of this genus accessible to the writer appears to have been found since Colonel Jewett discovered the original two specimens of Palxaster niagarensis. The writer therefore had to make the most of this material, and to determine the structure of the abactinal area he worked away much of the blue shale from the back of the one good specimen. The finer detailed structure was then revealed by cleaning with caustic potash.

In 1858 Billings proposed the genus Stenaster ${ }^{2}$ and writes that "as it has been suggested that the two species hereinafter described should be referred to Palæaster, I give the following figure of the genus in order to show the difference." This figure is a good reproduction of Hall's figure 27. Billings then points out that "if the large plates which border the grooves in Palxaster be adambulacral, then there are only five oral plates, whereas in Stenaster there are ten. But if tbey be not adambulacral but marginal plates, then Palæaster must have both marginal and adambulacral [the correct view], while Stenaster has only the latter."

Hall's generic description is very meager and his figures give the impression that the rays bear but a single column of marginal spiniferous plates. With this evidence one can understand why Billings was in doubt as to whether these plates are inframarginals or adambulacrals and therefore the uncertainty as to the nature of the five large axillary marginal plates. If, however, he had read Hall's accurate specific description, Billings would have seen that an important discrepancy existed between the description and figures. 
Hall writes: "Lower side of arms showing two ranges of plates on each side of the avenue, the outer range composed of strong hexagonal plates, with an inner range of smaller ones alternating, the latter usually covered by tufts of spines." The type-specimen clearly shows columns of adambulacral and inframarginals bordering the ambulacral grooves and that in each axil there is a single large axillary marginal plate. This matter need not here be followed further than to add that Stenaster originally included two generic types, both of which are widely different from Palæaster. On the other hand, Hall ${ }^{1}$ is in error in regarding all of Stenaster as synonymous with Urasterella McCoy, a name never properly defined and finally abandoned by its author. Billings originally referred to Stenaster, S. salteri, and $S$. pulchellus. The latter is certainly congeneric with the type of Urasterella as illustrated by Salter, but the former is quite different, as is pointed out elsewhere in the remarks on Stenaster, which is a good genus.

Palæaster in many respects reminds one of Hudsonaster, and the actinal generic characters may be regarded as alike in both. The abactinal area is also similar, but in Hudsonaster there are five columns with decidedly fewer plates, while in Patraster there are no radial columns. The former genus is the more primitive one and the progression in differentiation toward Palxaster appears to be as follows: In Hudsonaster, the rays throughout are composed of five columns of plates, two inframarginals, two supramarginals, and one radial. In Palxaster, there are but four columns in the outer third of the rays, two infra- and two supramarginals, but in the proximal two-thirds where the radials are also absent, their place is occupied by numerous small, irregular accessory plates. This introduction of numerous supplementary plates also takes place to a far greater extent on the disk, where they are crowded in between the larger central and the five basal radial plates.

The primitive disk structure of Palæaster is in large part again repeated in Neopalxaster, but otherwise the two genera are different.

\section{PALEASTER NIAGARENSIS Hall.}

Plate 7, figs. 1-4.

Palæaster niagarensis Halu, Nat. Hist. N. Y., Pal., vol. 2, 1852, p. 247, pl. 51, figs. 21-23 (not p. 352, pl. 85, figs. 8-10, possibly an undescribed species).-Billings, Geol. Surv. Canada, Can. Org. Rem., dec. 3, 1858, p. 78, fig. 1.-Hall, Twientieth Rep. N. Y. State Cab. Nat. Hist., 1868, p. 282; rev. ed., $1868=1870$, p. 324 .-Quenstedt, Petrefactenkunde Deutschlands, vol. 4, 1876, p. 73, pl. 92, figs. 32, 33.-Hudson, Bull. N. Y. State Mus., No. 164,1913 , pls. $9,10,12,13$.

Original description.- "Body stellate; disk small; arms short, terete with a deep avenue on the lower side, which is margined by strong short spines; centre of plates (in the fossil) nearly smooth, margins 
strongly granulate; lower side of arms showing two ranges of plates on each side of the avenue, the outer range composed of strong hexagonal plates, with an inner range of smaller ones alternating, the latter usually covered by tufts of spines; a large pentagonal plate inserted at the base of the arms, on the lower side.

"In this species, the arms are about twice as long as the width of the disk. There are about 15 or 16 plates in each range from the base to the apex of the arms. The range of the plates margining the avenue are usually not visible, the whole being covered by the short spines, which also partially fill the avenue."

In 1870 Hall added the following important observations:

"I have distinctly recognized the two ranges, marginal and adambulacral plates; but the inner ones are not shown in the figure as they should have been, while the large plate at the axil of the ray (though the adjacent small oral plates of the inner range are not seen) is evidently part of an incomplete series, and clearly belongs to the marginal range.

"The genus Palraster has two ranges of plates on each side of the ambulacral groove; marginal and adambulacral plates on the lower side, besides ambulacral or poral plates. The upper or dorsal side has three or more ranges of plates."

Emended description.-Measurements: $\mathrm{R}=18 \mathrm{~mm} ., \quad r=5 \mathrm{~mm}$. Width of ray at base $5 \mathrm{~mm}$.

Rays long, slender, tapering slowly; abactinally strongly convex and longitudinally ridged; flat actinally. Disk comparatively large, strongly convex and probably abruptly elevated above the rays abactinally. There are no interbrachial ares, but the five axillary marginal plates occupy the axils and are also partially visible abactinally.

Abactinal area of rays consisting of 4 columns of large, thick, convex plates. These are the supra- and inframarginal columns. The supramarginal plates of each ray are distally in contact with one another along the mid-line, but proximally they are forced more and more apart by a series of small, irregular, accessory plates. In the center of the disk there is a small, convex disk plate around which are situated radially 5 other small ossicles, all of which are separated from each other apparently by a considerable number of minute intercalary pieces. Just inside of the axils are 5 large, subtriangular, interradial plates and adjoining these directly are 10 large and conspicuous ones, the proximal plates of the supramarginal columns. In each column there are about 13 plates, not counting the proximal piece. Between all of the larger plates of the disk and for twothirds the length of the rays between the supramarginals, there are numerous small, convex, irregularly shaped, accessory plates. All 
the larger ossicles of both sides are centrally smooth, surrounded by a finely pustulose border.

Madreporite situated interradially and distally upon the three large plates just inside an axillary marginal plate, two of which are the proximal plates of supramarginal columns of adjoining rays. It is circular in outline, flat, and radially striated.

Inframarginal plates occupying the outer edges of both the actinal and abactinal areas; from 13 to 15 plates in each column. The supramarginal plates are situated above and inside the inframarginals, which inwardly bear short, thick, club-shaped spines.' Otherwise they are ornamented like the abactinal plates.

Adambulacral ossicles small, subquadrate, each one alternating distally with an inframarginal plate, but proximally they are somewhat more numerous, there being from 17 to probably 20 in a column. On these plates lie two series of spines - the two short, thick, clubshaped ones of each inframarginal plate - while on the inner side of each adambulacral there is inserted a linear brush of from five to seven slender, short spines that are outwardly and laterally directed.

Ambulacral grooves very narrow, deep, and gradually tapering. Ambulacral plates not well seen but apparently very short, one to each adambulacral and directly opposite one another.

Axillary marginal plates five in number, very large and conspicuous actinally, also showing slightly abactinally.

Locality and formation. - The only good specimen was found many years ago by Col. E. Jewett in the Siluric (Rochester shale) at Lockport, New York. A fragment of the ray of a much larger individual, nearly twice the size of this type, was found by the same gentleman at the same place. These specimens are now in the paleontological museum of Cornell University (No. 7331) and were presented by Hon. Ezra Cornell. Long after the study of the form was completed another specimen preserving two rays and showing the actinal side was learned of in the University of Toronto (Walker collection, No. 1008). It was found at Grimsby, Ontario.

Remarks. - This species has never been well described nor figured, and has accordingly led to endless generic confusion. Almost any Paleozoic starfish with large marginal plates has been referred to Palxaster. This lack of generic conception was partially due, as stated above, to the fact that the abactinal side remained unknown. The specimen lies imbedded in blue shale showing the actinal area, and the abactinal side was revealed by the writer by cutting away the slab to the starfish and then developing the individual plates with caustic potash.

In a general way Palæaster niagarensis resembles several species but all are distinguished by generic characters. The nearest one is Hudsonaster incomptus from the Cincinnatic strata, but it differs at 
once in having five instead of four columns of large abactinal plates. There are also a far less number of the accessory plates so numerous on the disk and the proximal medial areas of the rays in Palxaster niagarensis.

Hall $^{1}$ refers a fragment to this species which clearly is of quite another species. It is very far removed from $P$. niagarensis and for the present need not be considered. The specimen has not been seen by the writer.

\section{AUSTRALASTER, nevv genus.}

\section{Plate 4, fig. 4.}

Palæaster (Monaster) Etheridge, jr. (part), Mem. Geol. Surv. New South Wales, Pal., No. 5, pt. 2, 1892 , p. 74.

Monaster GreGorX, Geol. Mag., dec. 4, vol. 6, 1899, p. 345 (not of Etheridge, jr.). Australaster Schuchert, Fossilium Catalogus, Animalia, pt. 3, April, 1914, p. 12.

Austral=southern and aster. A Paleozoic starfish restricted to Australia.

Generic diagnosis.-Animal attaining a very large size, with five long; slender, almost straight-sided rays, terminating bluntly. Interbrachial areas comparatively small, widely concave, and occupied by ponderous, single, axillary marginals and inframarginal plates.

Abactinal area unknown (see $A$. (?) stutchburii).

Actinally the animal is bounded by inframarginal plates which however do not appear to be present in the distal third of the rays. If such plates are present in these outer regions, they are either very small or gradually pass from the actinal to the abactinal area, the latter condition occurring in related genera. The inframarginals in the outer third of the rays are small, subquadrangular, and rounded, thence they increase rapidly in size proximally, become decidedly transverse, and in the axils the columns abut against a very large axillary inframarginal. The largest plate is the axillary marginal, orad to which occur the pairs of enlarged oral armature ossicles. The inframarginals appear to be nearly smooth and devoid of spines.

The adambulacrals in the distal third of the rays are numerous, very short, but quite wide-that is, are decidedly transverse, and decrease rather rapidly in breadth toward the tips of the rays. Proximally these plates also decrease quickly in width and rapidly pass inside of the inframarginals. Inside of the axillary marginals the plates are again prominent and especially the pairs of oral armature pieces. Each adambulacral plate bears prominent tubercles for the articulation of stout but short spines. The columns have the pieces arranged with a decided slant outward and distally. 
Ambulacral furrows deep, slender and tapering slowly. Ambulacral plates unknown. Oculars not present.

Genoholotype.-Palxaster (Monaster) giganteus Etheridge, jr. The specific description and the bibliographic references are included in the generic diagnosis.

Restricted to the Lower Marine series of the "Permo-Carboniferous" of New South Wales.

\section{AUSTRALASTER(?) STUTCHBURUI (Etheridge, jr.).}

Palæaster (Monaster) stutchburii Etheridge, jr., Mem. Geol. Surv. New South Wales, Pal., No. 5, pt. 2, 1892, p. 73, pl. 13, fig. 1.

Monaster stutchburii GREGORY, Geol. Mag., dec. 4, vol. 6, 1899, p. 346.

This species is found associated with $A$. giganteus and its preservation is such that the form is very imperfectly known. In some respects it resembles that species and may prove to be a smaller specimen of it, but until the disk marginals are known the differences will remain obscure.

If $A$. (?) stutchburii has the large disk marginals of Australaster, it then seemingly will have the essential structure of that genus. Regarding this the writer wrote Professor Etheridge in 1900 and he replied that "axillary plates are not visible in the specimen".

Since the abactinal area of $A$. giganteus is unknown, it is desirable to give here the abactinal structure in $A$. (?) stutchburii, as it may prove to be congeneric with $A$. giganteus.

"Abactinal surface moderately convex, bearing several (five or six) rows of small convex polygonal plates, inclusive of the marginal pieces, and becoming much crowded at the apices of the rays, where they form oblique rows." If these plates throughout the rays are as figured by Etheridge for the distal ends, the strongly quincuncial arrangement of the polygonal, closely adjoining plates is another good generic character for Australaster.

\section{PROMOPALÆASTERIDÆ, new family.}

Progressive Phanerozonia with distinct columns of inframarginal plates. Interbrachial areas more or less complex, composed either of inframarginals, axillary interbrachials and ambulacrals, or of these with the addition of interbrachial marginals and accessory interbrachials, or entirely of adambulacral plates. Ambulacrals as a rule opposite, but they may also be slightly alternating. Podial openings through the sutures in the lateral corners of the ambulacral plates, but proximally a few alternate pores may gradually pass medially, when there are four columns of podial openings in each ambulacral furrow.

Madreporite abactinal.

Abactinal plates very numerous, generally small, either in distinct columns or rows or without either arrangement. The radial 
and supramarginal columns may be very distinct or may be obscured as such. Accessory ossicles always more or less abundantly developed.

Contains:

Mesopalæasterinæ.

Promopalæasterinæ.

Anorthasterinæ.

MESOPAI AEASTERIN AE, new subfamily.

Palæocomidæ Gregory, Treat. Zool., vol. 3, Echinoderma, 1900, p. 254.

Primitive Promopalæasteridæ with the interbrachial areas small, composed of one pair of inframarginals, single axillary interbrachials, and the adambulacral plates.

Contains:

Mesopalæaster, new genus.

Spaniaster Schöndorf.

Miomaster Schöndorf.

Devonaster, new genus.

MESOPALAASTER, nev genus.

Plates 7-11.

Palæaster (part) of AuTHoRs.

? Argaster HALL, Twentieth Rep. N. Y. State Cab. Nat. Hist., 1868, p. 287: rev. ed., $1868=1870$, p. 329 .

Mesopalæaster Schuchert, Fossilium Catalogus, Animalia, pt. 3, April, 1914, p. 24.

Meso $=$ middle, and Palæaster. Not the largest of Palæasters of authors.

Generic characters.-Rays five, slender and tapering. Disk small, with incipient interbrachial arcs.

Abactinal area with distinct columns of radial and supramarginal plates, between which are inserted rows of accessory pieces, one or two on each side of the medial columns. In mature specimens the radial columns are less prominent proximally than distally. The accessory columns proximally may also have here and there inserted on each side a smaller piece, when the area between the supramarginals has not only three or five columns of plates but also other additional small plates. The inframarginal columns margin the rays, while the supramarginals lie somewhat inside and above the former. Between the two columns of marginals there may be a row of accessory ambital plates. The arrangement of the plates of the disk appears to be as follows: In the center there is a small plate around which is a first ring of 7 pieces, followed by a second ring having not less than 14 plates, and these are nearly of one size. The medial ray columns terminate on the disk in 5 
large radial plates, but inside of the proximal supramarginals there is no basal interradial plate as in Hudsonaster.

Madreporite unknown.

Inframarginal and adambulacral plates as in Hudsonaster, excepting that two of the former and a single axillary plate are in each interbrachial area. Oral armature so far as preserved adambulacral, consisting of five pairs of basal adambulacrals.

A single, pentagonal, axillary interbrachial plate is present in each area, orad to the two axile inframarginal plates.

Ambulacral grooves deep and almost closed by the adambulacral columns. Ambulacral plates carinate and apparently one to each adambulacral ossicle. Their relation to one another is not definitely determinable, but apparently they are slightly alternate or nearly opposite.

\section{Genoholotype.-Palæaster shafferi Hall.}

Distribution.-The species of Mesopalæaster are restricted to America in the upper portion of the Ordovicic and the lower portion of the Siluric. A species doubtfully referred to this genus occurs in the Lower Devonic of Germany, and another in the Upper Devonic of Maryland.

The following are the species of Mesopalzaster:

M. shafferi (Hall). Middle and upper beds of the Cincinnatic series. Possibly also in the Utica formation of New York.

$M$. intermedius, new species. Maysville formation.

$M$. finei (Ulrich). Eden formation.

$M$. (?) lanceolatus, new species. Utica formation.

$M$. proavitus, new species. Eden formation.

M. (?) wilberanus (Meek and Worthen). Richmond series.

$M$. (?) dubius (Miller and Dyer). Upper Trenton.

M. (?) antiquus (Troost). Upper Trenton.

M. (?) parviusculus (Billings). Siluric (Lower Arisaig).

$M$. (?) cataractensis, new species. Siluric (Cataract formation).

$M$. granti (Spencer). Siluric (Cataract formation).

$M$. bellulus (Billings). Siluric (Rochester shale).

$M$. caractaci (Gregory). Caradoc of England.

$M$. (?) acuminatus (Simonovitsch). Lower Devonic of Germany.

M. (?) clarki (Clarke and Swartz). Upper Devonic (Jennings formation).

Remarks.-Mesopalæaster apparently developed directly out of $H$ udsonaster in that the single axillary marginal plates are in the former genus in nearly all the species pushed inward (interbrachial) and their former place occupied by the proximal plates of adjoining inframarginal columns. The same generic feature also distinguishes Mesopalæaster from Palæaster. Further, in Hudsonaster there are no abactinal accessory ray plates, but in Mesopalxaster one or two more or less completely developed columns are inserted on each side 
of the radial columns or, in other words, between the radials and supramarginals. Between the inframarginal and supramarginal plates in Mesopalxaster there are also either a few incipient accessory plates, which in young specimens are wholly absent, or there is a complete column of these ambital plates. The accessory and axillary interbrachial plates are additions to the generic structure of Hudsonaster and Palæaster, and further distinguish Mesopalæaster from both. This progression toward a greater number of columns of abactinal plates attains its maximum in Promopalæaster and is most marked in $P$. magnificus, which has not less than 28 columns at the base of a ray and 5 interbrachial marginal plates in each interbrachial area. The ambulacral furrows, which are very narrow in Hudsonaster, are likewise so in Mesopalæaster, but are wide in Promopalæaster. Spinosity, which is practically absent abactinally in Hudsonaster, is developed in Mesopatxaster and very pronounced in some forms of Promopalxaster ( $P$. spinulosus and $P$.dyeri). This is apparently also true for the spines of the actinal area.

The youthful plate structure of recent species seems to be retained to maturity in Hudsonaster and somewhat so also in the genotype of Mesopalæaster but in Promopalæaster the central area of the disk is occupied by numerous very small plates and no definite arrangement is discernible, though this is in large part due to their displacement through fossilization. However, it is certain that the basal radials and interradials do not increase nor maintain a relative size as in Hudsonaster and in the genotype of Mesopalxaster (here radials only), but must have diminished to that of the accessory plates from which they are now not distinguishable. From Hudsonaster through Mesopalxaster into Promopalxaster the animals are constantly increasing in size, and this also continues in the species of the latter genus, attaining culmination in P. magnificus and $P$.dyeri.

While the generic abactinal differences between Hudsonaster and Mesopalzaster are easily made out, this is not so readily accomplished between the latter and Promopalxaster. All of the abactinal generic characters of Mesopalæaster are more pronounced in Promopalxaster excepting that in the former the ambital accessory plates are almost always undeveloped as columns, while in the latter these plates are always well developed in one or more columns.

When the actinal area is shown, Mesopalxaster is at once distinguished from Promopalæaster in that it has but one axillary interbrachial plate in each interbrachial area, while the latter has always two or more up to five (=interbrachial marginals) in each area.

Devonaster in some respects is closely related to Mesopalxaster and may be in the line of descent from the latter. However, the disk in Mesopalxaster has far fewer abactinal plates, and there are no distinct interbrachial arcs with numerous small accessory plates 
as in Devonaster. The pieces of the radial columns in Mesopalzaster adjoin one another and are not separated by intercalary plates, nor are these nearly so numerous between the radial and supramarginal columns as in Devonaster. These accessory plates in Devonaster are also irregularly disposed and not in columns as in Mesopalxaster.

The name Argaster has not been defined nor is it mentioned in such a way that anyone will recognize that Hall intended it for a new genus or subgenus. In addition, its genotype (Asterias antiqua=Mesopalæaster (?) antiquus) is a poorly known species. Under these circumstances, and the additional one that the name Argaster never has had any standing as a genus, it should not now be rehabilitated by paleontologists.

\section{MESOPALAASTER SHAFFERI (Hall).}

Plate 8, figs. 1, 2.

Palæaster shafferi Hall, Twentieth Rep. N. Y. State Cab. Nat. Hist., 1868, p. 284; rev. ed., 1868=1870, p. 326, pl. 9, fig. 1.-MEex, Geol. Surv. Ohio, Pal., vol. 1, 1873 , p. 66 , pl. 4 , fig. 1 .

Original description. - "Body of about medium size composed of five tapering, acutely pointed rays, which, in the specimen examined, measure seven-eights of an inch from the center of the disk to the extremity. The lower side of the ray is formed of two ranges of plates bordering the ambulacral groove. The marginal range consists of moderately convex plates which gradually decrease in size from the base to the extremity of the ray, 22 or 23 in number [not more than 20 exist in any ray of the type-specimen], besides a small terminal one at the angle of the range; each plate of the marginal range is marked on its outer surface by a comparatively large cicatrix for the attachment of a strong spine. The inner range of plates (adambulacral) are somewhat smaller, about the same in number, alternating with those of the marginal range; the basal pair (oral plates) are elongate-triangular, and slightly constricted near the middle. Ambulacral areas narrow, composed of a double range of poral plates, which at the middle of the ray are about of equal length and breadth. Pores not observed. [The writer could not make out these plates in the type-specimen and believes those described to be the inner sides of the actinal plates.] Upper surface of the ray composed of three ranges of subnodose plates, the outer ranges bearing a strong spine on each plate; the central range apparently destitute of spines. No spines have been observed, but the plates are strongly carinate or pointed."

Emended description.-The largest specimen in the Harris collection measures: $\mathrm{R}=19 \mathrm{~mm}$., $r=5.5 \mathrm{~mm}$., $\mathrm{R}=3.5 r$. Another specimen of the same collection: $R=16 \mathrm{~mm} ., r=5 \mathrm{~mm}$., $R=3.1 r$. The smallest known specimen in the Vaupel collection: $R=6.5 \mathrm{~mm}$, 
$r=2.5 \mathrm{~mm} ., \mathrm{R}=2.6 r$. The type-specimen, which is the largest known example, measures: $\mathrm{R}=21 \mathrm{~mm}$., $r=6 \mathrm{~mm}$., $\mathrm{R}=3.5 r$. Width of ray at base in various mature examples $5 \mathrm{~mm}$. to $7 \mathrm{~mm}$.

Rays more or less long, slender, abactinally slightly convex, with marked longitudinal ridges, actinally flat or concave. Disk of medium size, abactinally convex and without interbrachial arcs.

Abactinal area of rays occupied by a central range of radial plates, on each side of which there is a range of accessory ossicles which however do not attain the distal portion of the rays. In mature rays there are in the proximal region also inserted a few plates on each side of the intercalary columns. Outside of the latter are the ranges of well-defined supramarginal plates which slightly overlap the inframarginals. The marginal and radial plates are most prominent, and all are highly carinate or pointed. There is a single large spine on the apex of all radial and accessory plates and several smaller ones are also arranged around it. The supramarginal plates have numerous granules which bore articulating spines. The plates of the disk can not be clearly made out, but in a small specimen somewhat distorted there appears to be a small central plate surrounded by a first ring of 7 ossicles followed by a second ring of 14 plates. These pieces are all nearly of a size. The medial ray columns terminate in 5 large basal radial plates, while inside of the proximal inframarginals there is no large interradial plate as in Hudsonaster incomptus.

Ambital area very illy defined, but in the angles between the large infra- and supramarginal plates there are here and there inserted tiny accessory pieces. In a young individual there are none of these accessory plates.

Madreporite unknown.

Inframarginal plates distinctly granulated, completely inclosing all other abactinal plates and common to both the abactinal and actinal areas. In mature specimens there are from 15 to 20 plates on each side of a ray. Laterally each plate has a well-marked small pit, probably the place of attachment for rather strong spines, none of which however have been observed.

Interbrachial areas with single, hexagonal, axillary interbrachial plates.

Adambulacral plates slightly elongate-subquadrangular, of which there are from 18 to 20 on each side of a ray; distally they appear to pass over and to cover completely on the actinal side the inframarginal plates. Between the adambulacral columns there is a more or less wide ambulacral furrow. Each adambulacral plate bears on its inner edge a rather thick but short, slightly striate spine and several minute ones. Orad to each axillary interbrachial there is a pair of prominent elongate-triangular adambulacral plates bearing spines, 
one of the five pairs constituting a part of the oral armature. In other words, the adambulacral columns of adjoining rays are continued around the axillary interbrachials by two modified plates.

Ambulacral grooves deep, nearly closed by the adambulacralia. Ambulacral plates not well shown but apparently carinate, one to each adambulacral ossicle, and whether alternate or opposite can not be stated.

Locality and formation. - In the middle and upper stages of the Cincinnatic group (Ordovicic). The type-specimen (No. 1195, Amer. Mus. Nat. Hist.) was found by Mr. D. H. Shaffer at Cincinnati, Ohio, probably in the Maysville formation. Mr. Vaupel found a young individual showing the abactinal area (No. 60605, U.S.N.M.); another young one was secured by Mr. Faber (No. 9568, University of Chicago), and Mr. George Oeh found an excellent matured individual preserving the actinal area (now in the Yale Museum), all from the Maysville formation on the hills back of Cincinnati. Two good specimens and another small poor one are in the Harris collection of the United States National Museum (No. 59391) and were found in the Waynesville division of the Richmond formation near Waynesville, Ohio.

A small asterid preserving two rays and a portion of the disk is in the United States National Museum collection (No. 23540) and was found by Mr. W. P. Rust in the Utica shales one and a half miles east of Rome, Oneida County, New York. It is associated with Trinucleus concentricus, Dalmanella testudinaria multisecta, and other species. The abactinal area only is shown, and appears to be that of Mesopalxaster shafferi. It does not appear to be a Promopalxaster because of the fewer columns of abactinal accessory plates, and the axillary structure makes it almost certain that there is here but a single axillary interbrachial plate. For the present it may be provisionally referred to this species and attention is thus directed to it so that local collectors may be on the lookout for other material.

Remarks.-This species has actinally much the appearance of Hudsonaster incomptus, but the latter is at once distinguished by not having the five axillary interbrachial plates of Mesopalxaster shafferi. $M$. (?) parviusculus (Billings) is smaller, with far less plates in all the columns than in M. shafferi. $M$. (?) parviusculus and M. granti differ also abactinally and ambitally in the better developed accessory plates.

Cat. Nos. 60605, 59391, 23540, U.S.N.M.

\section{MESOPALEASTER INTERMEDIUS, new species.}

Plate 9, fig. 4.

This species is perplexing in its generic construction because of its intermediate or transitional characters on the one hand (but least) to Hudsonaster, and on the other (more decidedly) to Mesopalxaster $50601^{\circ}-$ Bull. $88-15-6$ 
and prophetic of Promopalxaster in the conspicuous ambulacral furrows.

Rays long and slender, elongate-petaloid, disk small. $\mathrm{R}=$ about $14 \mathrm{~mm}$., $r=4 \mathrm{~mm}$.

The interbrachial areas each have but a single, large, finely granulated, axillary plate that margins the axils, and in this agree best with Hudsonaster, but the rest of the known skeleton is that of Mesopalxaster. In the former genus the ambulacral furrows are always very narrow and the ambulacralia are rarely seen, while in $M$. intermedius the furrows are wide and the ossicles are rather like those of Promopalxaster, though the same kind of ambulacralia is also known in Mesopalxaster. Orad to the axillary plates there were two small oral armature pieces that belong to the adambulacral columns. These are not now present in the specimen, but the distinct and large facet of the proximal side of the axillaries leaves no doubt on this construction.

Inframarginal columns well-developed proximally, though never very prominent, and becoming rapidly smaller distally. The four proximal pieces are the largest, beyond which there are at least 14 other ossicles, and all are closely in contact and alternate with the adambulacrals. Another feature of these inframarginals is that not more than six can be seen from the actinal surface, while the rest pass on to the sides and distally even somewhat over to the abactinal area. All of the plates are finely granulated.

Adambulacral columns the most prominent of the actinal skeleton, margining the distal half of the rays, and in the proximal portion pass more and more inside of the inframarginals, diminishing slowly in size and finally depressed beneath the axillaries. There are 22 plates in a column, all more coarsely granulated than the inframarginals, largest and most transverse near mid-length of the rays, and all are drawn out inwardly into blunt points that adjoin the high ridges of the ambulacralia. Therefore the adambulacral and the adjacent ambulacral columns have the ossicles directly opposite one another, but the adjacent ambulacral rows are slightly alternating.

Ambulacral furrows conspicuous and wide, widest in the proximal third but converging somewhat quickly in the mouth area and far more gradually distally. Therefore the furrows are elongate-petaloid in shape. There are about 20 ambulacralia in a column. Proximally the columns unite around and beneath the small adambulacral oral armature pieces. Ambulacralia square to transversely rectangular, each with a high L-shaped crest that laterally adjoins the points of the adambulacrals and medially bends orally. Podial openings large between the corners of pairs of ambulacrals and adambulacrals. There is a well-developed groove down the center of the ambulacral furrows. 
Abactinal area unknown, but probably that of Mesopalzaster and nearest to $M$. shafferi.

Formation and locality. - The holotype was found by Faber in the Maysville formation at Cincinnati, Ohio, about 350 feet above the Ohio River. The type is in the University of Chicago Museum (No. 9575).

Remarks.-This interesting species need be compared only with $M$. shafferi. It differs in having the axillaries in the axils of the rays and not inside the basal inframarginals as in the latter form. Then in $M$. shafferi the inframarginals are actinal in position throughout, while in $M$. intermedius they are more on the sides. Further, in the new form the ambulacral furrows are well developed with large ambulacralia, while in $M$. shafferi the furrows are narrow and the ossicles rarely seen.

\section{MESOPALEASTER FINEI (Ulrich).}

Plate 7, fig. 5; plate 9, fig. 5 .

Palæaster finei Ulrich, Journ. Cincinnati Soc. Nat. Hist., vol. 2, 1879, p. 19, pl. 7, figs. $15-15 b$.

Original description.- "Small; rays five, of medium length, rather broad, pointed and narrower where they are attached to the much contracted body [probably due to distortion], than they are about the center of their length.

"Dorsal side of rays composed of four [about seven, the supra- and inframarginals, radials, and two intercalary columns] rows of pieces, that are quite close [?] fitting, as wide as long, from 12 to 14 in each row, and increase in size inward to the disk, which is composed of irregularly shaped and prominent pieces, some of which are smaller and others larger than those composing the rays; the pieces in the marginal rows [four columns infra-and supramarginals] are more prominent than the two [there are three, radials and two intercalary] rows between them, and have a small pit in the center, probably for the articulation of a spine [all of the plates originally bore several short slender spines]. Madreporiform body rather small, circular, very prominent, and marked by strong striæ, which become more numerous toward the margin by intercalation.

"Marginal [inframarginal] pieces on the ventral surface, convex, quite as long as wide, and numbering in different specimens on each side from 11 to 12 [probably not more than 8 or 9 ]; the piece at the junction of the rays is three times as large as any other of the series, subcircular and very convex. [It appears that this large plate is an axillary interbrachial since upon it proximally rest two basal plates of the inframarginal series.] 
"Adambulacral plates more prominent [less prominent than the inframarginal plates], slightly wider than long, and numbering, on each side, from 9 to 10 [probably not less than 16 in each column]. Ambulacral pieces a little wider than long, not alternating with the adambulacral plates, and each provided with a rather sharp ridge across most of its width.

"There are 10 oral plates [oral armature] formed by the junction of the adambulacral rows, which in form and size are scarcely distinguishable from the other plates of those series.

"Greatest breadth measuring between the opposite extremities of the rays, 0.7 inch; breadth of rays at their inner ends, 0.1 inch; length of same, 0.3 inch; diameter of madreporiform piece, 0.02 inch."

Formation and locality. - This small species appears to be common at a very restricted horizon near the base of the Eden formation (Fulton beds), exposed at low water mark in the Ohio River in the eastern portion of Cincinnati, Ohio.

Remarks.- Not one of the twenty examples seen is well preserved and all the plates are more or less separated. The general structure seems to be that of Mesopalæaster. The composition of the axillary area is not positively ascertainable but one specimen shows what appears to be a large axillary interbrachial plate (see pl. 7, fig. 5), distally surmounted by two somewhat smaller inframarginals. This is probably the true structure since it is so in all the smaller Mesopalæasters, as $M$. lanceolatus, $M$. parviusculus, $M$. granti, and $M$. proavitus.

The differences between $M$. finei and $M$. proavitus are not great. The former is a smaller species with less plates in all of the ranges, more prominent axillary inframarginal and axillary interbrachial plates, and is also found at a lower geological horizon. $M$. finei differs from the small species $M$. parviusculus of the earliest Siluric in having more plates in all of the columns. $M$. granti is a larger species and with smaller and more numerous plates than in $M$. finei. $M$. lanceolatus is probably the most closely related to $M$. finei but is distinguished abactinally by the diagonal arrangement of the plates on each side of the radial columns.

Cat. No. 60604, U.S.N.M.

MESOPALAEASTER(?) LANCEOLATUS, new species.

Plate 4, fig. 3.

Measurements: $\mathrm{R}=4.5 \mathrm{~mm}$., $r=1.3 \mathrm{~mm}$., $\mathrm{R}=3 r$.

Rays short, stout, distinctly lanceolate actinally and rapidly tapering abactinally. Disk comparatively large, abactinally convex. Interbrachial arcs distinct but small.

Abactinally the disk has a ring of large, strongly stellate plates which are the basal plates of the radial and supramarginal columns. 
Inside the ring the plates can not be made out, due to the small size of the specimen. Rays each with a column of radials and two supramarginals between which are inserted columns of diagonally arranged accessory plates. A few ambital accessory plates are probably also present. The arrangement of the ossicles on the abactinal areas of the rays is like that in Promopalæaster magnificus.

Madreporite small, subconical, situated near the edge of the disk, depressed between adjoining basal plates and marked by 10 or 11 sharp, somewhat spirally arranged ridges.

Inframarginal plates large, about six in each column proximal to the very large single axillary interbrachial plate. These columns in the distal half can not be seen actinally as they pass over on the dorsal side.

Axillary interbrachial plates large, one in each axil, and not completely inclosed outwardly by the basal inframarginals. In this character the form is still in the Hudsonaster stage.

Adambulacral plates small, subquadrangular, with 16 plates in each column. The plates of the adambulacral oral armature are larger and wedge-shaped, and are situated directly inside of the axillary interbrachial plates.

Ambulacral plates one to each adambulacral, apparently opposite and with proximally converging ridges. Podial openings apparently along the outer edge between the sutures of adjoining plates.

Formation and locality. - Two specimens were found by the late Prof. Charles E. Beecher near Rome, New York, in the Triarthrus bed of the Utica formation that preserves the entire ventral anatomy of these trilobites. The cotypes are in the Museum of Yale University. Mr. W. S. Valiant in a letter states that they are common in a layer 2 to 3 inches above the Triarthrus bed.

Remarks. - This species is most closely related to $M$. finei, from which it is readily distinguished abactinally. Here there are more and smaller plates than in $M$. lanceolatus, the interpolated plates are arranged diagonally and not radially as in $M$. finei, while the basal plates of the former are apparently much larger and are strongly stellate. Actinally there are in $M$. lanceolatus more adambulacral plates in each column, although the specimens are only half the size of $M$. finei.

\section{MESOPALEASTER PROAVITUS, new species.}

$\mathrm{R}=18 \mathrm{~mm}$., $r=$ about $4.5 \mathrm{~mm}$. The specimens are distorted, however, and no exact measurements can be given.

On the distal abactinal portion of the rays the infra- and supramarginal and radial plates closely adjoin. Proximally, however, between the two marginal series there is inserted a column of intercalary plates gradually increasing in size and two other similar rows of plates are placed between the supramarginal and radial columns. 
There are therefore at the base of the rays no less than 11 columns of plates. The radial columns proximally have a tendency to become less distinct and indistinguishable from the accessory pieces. The plates in general are highly convex, granular and abundantly spinebearing. There are not less than 20 plates in each supramarginal series.

Madreporite highly convex, broadly oval in outline and radially striated.

Inframarginal plates finely granular, highly convex, subquadrangular in outline and increasing in size slowly proximally. About 23 in each column.

Adambulacral plates like the inframarginals but not increasing much in size proximally, with about 29 in each column. As in other species of this genus, each plate bears three prominent spines, two laterally and one ambulacrally.

Ambulacral plates one to each adambulacral plate, and with a sharp ridge which medially bends abruptly orally. Podial openings as in other forms of Mesopatzaster.

Interbrachial areas occupied by single axillary interbrachial plates, upon each of which rest proximally two axillary inframarginals.

The specimens are not figured, as an illustration can not readily be made.

Formation and locality.-Three more or less entire specimens and fragments of four rays were found by Dr. E. O. Ulrich in the Eden shale exposed back of Covington, Kentucky, at an horizon about 100 feet above low water in the Ohio River. All the specimens are now in the Herzer collection, a part of the late Prof. James Hall's private collection, recently purchased by the University of Chicago.

Remarks. $-M$. proavitus and $M$. granti are closely related, since both have 11 columns of abactinal plates, including the marginals, and they are nearly alike actinally. However, the former is twice as large and appears to have more conspicuous radial and supramarginal columns than the latter. These differences and the further fact that one occurs in the Utica and the other in the earliest Siluric will serve to distinguish the two species for the present. M. proavitus may prove to bo identical with $M$. (?) wilberanus, which see for further remarks.

\section{MESOPALAEASTER (?) WILBERANUS (Meek and Worthen).}

Petraster wilberianus Meex and Worthen, Proc. Acad. Nat. Sci., Philadelphia, for 1861 , vol. 13, 1862, p. 142.

Palæaster wilberanus HaLL, Twentieth Rep. N. Y. State Cab. Nat. Hist., 1868, p. 285 ; rev. ed., $1868=1870$, p. 328 .

Original description.- "This beautiful starfish resembles rather closely Petraster rigidus of Billings, ${ }^{1}$ but is smaller, and has more 
slender rays, with more angular spaces between. It also differs in having but two ranges of plates on each side of the ambulacral grooves, on the under side, instead of three. These pieces are about of the same size in each row, and sometimes appear to alternate; they are all rather prominent, and those of the outer range project a little laterally in the form of small nodes. Toward the outer extremities of the rays, however, the lateral ranges are contracted behind the others, so as to be scarcely visible from below. About 23 of these pieces may be counted on each side of the ambulacral furrow in each ray. The ambulacral furrows are very narrow, and indeed seem to be closed toward the extremities of the rays, by the gradual approximation of the inner rows of pieces on each side, which alternate and appear to fit together.

"Our specimen only shows the under side, but along the outer margins of two of the rays, there is some appearance either of the overlapping of some of the dorsal parts by pressure, or of a slightly developed disk. This part does not seem to have any distinct range of marginal plates, but appears to be made up of small pieces, covered with granules, or bases of small spines.

"We take pleasure in dedicating this interesting species to Prof. C. D. Wilber, of the Illinois State Normal School, to whom we are indebted for the use of the only specimen we have seen.

"Greatest diameter about 1 inch; smaller diameter 0.33 inch.

"Locality and position.-Oswego, Kendall County, Illinois, in rocks of the age of the Trenton or Hudson River Group of the New York series." Probably equivalent to the Richmond beds of the highest Ordovicic. The whereabouts of the type-specimen is not known.

Remarks.-Hall pointed out that this species is not a Petraster because $P$. wilberanus has but two columns of plates on each side of the ambulacral groove, while Petraster has in addition "a few disk plates on the ventral side." He therefore referred it to Palzaster. However, Meek and Worthen describe the abactinal area as having no "distinct range of marginal plates, but appears to be made up of small pieces, covered with granules, or bases of small spines." The characters as far as mentioned appear to be those of Mesopalxaster. Should there prove to be in $P$. wilberanus single axillary interbrachial plates, then all of the characters will be in harmony with Mesopalzaster and $M$. proavitus may prove to be a synonym of it. This can not be proven at present since we have not been able to locate the type-specimen.

MESOPALEASTER (?) DUBIUS (Miller and Dyer).

Palæaster dubius MrLLER and Dyer, Cont. to Pal., No. 2, 1878, p. 5, pl. 4, fig. 8.

Original description.- "Pentagonal; rays longer than the diameter of the body, and uniformly tapering. The ambulacral groove is sharply angular in the middle, formed by two series of plates having 
their ends together in such manner as to make an angular gutter [the plates of adjoining columns are arranged practically opposite]. The length of these plates is three times as great as the diameter. The plates are placed with the length across the rays. There are 15 plates on each side of the groove in each ray, in the length of one quarter of an inch [this is an error as there are about 20 plates in a column]. The diameter of the body is three-tenths of an inch.

"This species is founded upon a single specimen, in Mr. Dyer's collection, which shows only part of the ventral side. The ends of the rays [most of the adambulacrals] and marginal plates are destroyed [each axillary area appears to bear one axillary interbrachial plate]. The parts preserved seem to distinguish it from any species hitherto described."

Formation and locality.-In the original description the locality is given as Cincinnati, Ohio, but the character of the rock shows that it is from the uppermost portion of the Trenton limestone, probably opposite Cincinnati, in the river quarries at Ludlow, Kentucky. The type (No. 25) is in the Museum of Comparative Zoölogy, Harvard University.

Remarks. - This specimen preserves well the very wide ambulacrals but almost no other plates. The adambulacrals are nearly all removed and but very little is to be seen of the marginals. In three of the axillary areas there are single interbrachial plates, one of the essential features of Mesopalaaster. It is referred to this genus provisionally, as nothing is known of the abactinal side.

\section{MESOPALEASTER (?) ANTIQUUS (Troost).}

Asterias antiqua Troost (not Hisinger 1837), Trans. Geol. Soc. Penn., vol. 1, 1835, p. 232, pl. 10, fig. 9; Proc. Amer. Assoc. Adv. Sci., vol. 2, 1850, p. 59 (cat. name).

Petraster (?) antiqua Shumand, Trans. St. Louis Acad. Sci., vol. 2, 1866, p. 386 (catalogue name).

Palæaster (Argaster) antiqua Hald, Twentieth Rep. N. Y. State Cab. Nat. Hist., 1868 , p. 287 ; rev. ed., $1868=1870$, p. 329 .

Palæaster antiquus MrLet, N. Amer. Geol. Pal., 1889, p. 265 (cat. name).

Argaster antiqua GreGory, Geol. Mag., dec. 4, vol. 6, 1899, p. 345 (gen. ref.).

Palæaster antiqua Wood, Bull. U. S. Nat. Mus., No. 64, 1909, p. 105, pl. 8, fig. 1.

Although this is the first recorded American fossil starfish, very little is known about it and that little is mostly of a misleading nature. The specimen lies on a limestone slab and is very badly weatherworn or it may have been treated with hydrochloric acid so that now it is nothing more than a polished section of a starfish. An illustration that will show its actual characters can not be made.

Professor Hall errs in stating that Asterias antiqua has "ambulacral grooves occupied by a single row of subquadrate ossicula, which extend across and alternate with the adambulacral plates of each margin. * * * It is possible that this character may prove to be of generic importance." It may have been this character on which 
Hall thought of basing the genus Argaster, but he does not characterize it nor even mention that the name in parenthesis is intended as a new term with Asterias antiqua Troost as the genotype. This species, like all other Paleozoic starfishes, has double columns of ambulacral plates. This the specimen clearly demonstrates on the edge of the slab where the distal parts of the rays are broken away. Argaster should therefore be regarded as a nomen nudum, and should $A$. antiqua prove to be a Mesopalxaster, it should not be made to displace this genus.

Asterias antiqua has about 15 inframarginal plates in each column and about 32 in each adambulacral column. Two of the latter plates meet as usual in a pair of triangular oral armature pieces.

Each axil is occupied by two large, quadrangular, basal inframarmarginal plates. Between these proximally there is a large, widely triangular, interbrachial plate the apex of which may or may not attain the margin. Proximal to each axillary interbrachial plate and between the four or five pairs of axillary adambulacral plates, there is in the specimen an open space in each of the five areas. What additional plates, if any, occupied this area is not determinable. It may be that the axillary interbrachial plates occupied the entire interbrachial areas and that the present hiatus is due to the worn condition of the specimen. This appears to be the most natural interpretation as it is the normal interbrachial structure of Mesopalæaster. In Promopalæaster there are always two, three, five, or seven interbrachial marginal plates in each area, a fact which excludes Asterias antiqua from that genus.

The abactinal area is not visible, but many of these plates are squeezed beyond the inframarginals, showing the presence of numerous small plates recalling Mesopalæaster and Promopatraster.

Formation and locality. - Troost's label reads: "Lower limestone on Harpeth River, Davidson County, Tennessee." His manuscript reads: "It was found * * * on Harpoth River, Davidson County, Tennessee. Associated with Spirifer lynx [Platystrophia biforata], Cyathoph[y]lla [=Streptelasma], Orthis [testudinaria], etc." This is apparently the same horizon as that about the city reservoir in Nashville, which is now regarded as of Upper Trenton (Catheys) age. The specimen is in the United States National Museum.

Cat. No. 39914, U.S.N.M.

MESOPALAEASTER(?) PARVIUSCULUS (Billings).

Plate 9, fig. 1.

Palæaster parviusculus Brluıngs, Canadian Nat. and Geol., vol. 5, 1860, p. 69, figure.-Dawson, Acadian Geology, 2d ed., 1868, p. 594, fig. 197.-Hudson, Bull. N. Y. State Mus., No. 164, 1913, pls. 1-4.

Original description. - "The specimen is about six lines in diameter. The rays are two lines in length and one and a half in width at the 
base, tapering at an angle of a little less than $45^{\circ}$. The five oral plates are subpentagonal, about half a line in width. The first adambulacral plates of each pair of adjacent rays are in contact with each other outside of the oral plates, and not completely separated as they are in $P$. niagarensis. There are six or seven adambulacral plates on each side of the ambulacral groove in each ray, and they gradually decrease in size from the oral plate outward to the point of the ray. The width of the ambulacral groove is equal to one-third the width of the ray and consequently the adambulacral rows of plates are also each equal to one-third the whole width of the ray. In each groove there are two rows of small and apparently nearly square ambulacral plates, 12 or 14 in each row, and they seem to be continued round on the inner margin of the oral plates; the mouth is about one line wide."

Emended description.-Measurements: $\mathrm{R}=6 \mathrm{~mm} ., \quad r=2.5 \mathrm{~mm}$., $\mathrm{R}=2.4 \mathrm{r}$. Width of ray at base $3 \mathrm{~mm}$.

Rays short, stout, tapering rapidly. Disk comparatively large, and without interbrachial arcs.

Abactinal area unknown.

Inframarginal plates at the base of the rays very large and thick, highly convex, diminishing rapidly distally, usually quadrangular in form and seven on each side of a ray.

Just within each axil, inside of the basal inframarginals, there is a single, large, very convex, pentagonal, axillary interbrachial plate.

Adambulacral plates gradually sinking below the inframarginals proximally, convex and quadrangular in form. There are 13 plates in each column adjoining the very narrow ambulacral furrow, or nearly two plates to each inframarginal ossicle. Two of these plates (oral armature) are situated in front of each axillary interbrachial, uniting the adambulacral columns of adjoining rays.

Ambulacral plates unknown.

Locality and formation.-The type-specimen, a natural mold, was found by Rev. D. Honeyman in the Lower Arisaig of the Siluric (=Clinton) rocks at Arisaig, Nova Scotia. The holotype is in Redpath Museum of McGill University, Montreal, Canada, and the illustration is taken from a gutta-percha squeeze kindly made for the United States National Museum by Sir William Dawson.

Remarks. - The general actinal appearance of this little asterid reminds one much of Palæaster and Hudsonaster. It differs, however, at once in a little detail of considerable importance, in that each axillary area has three plates, while in Palæaster and Hudsonaster there is but one. In other words, the large axillary plate of those genera has in $M$. (?) parviusculus been pushed orally and is here an interbrachial plate, while the axils of the rays are occupied by two basal inframarginal plates. For further remarks on this species see M. granti (Spencer). 
So long as the abactinal area of $M$. (?) parviusculus remains unknown its generic position will be doubtful. For the present its relations appear to be nearest to Mesopalxaster and to $M$. (?) cataractensis.

Cat. No. 60620, U.S.N.M.

MESOPALAEASTER (?) CATARACTENSIS, new species.

Plate 9, fig. 2.

The specimen of this species has been confused with $M$. (?) granti, from which it differs in being smaller and in having far fewer plates in the columns. The actinal side of $M$. (?) cataractensis alone is known, whila of $M$. (?) granti only the abactinal, but even so the above comparison can still be made because the size of plates is relativelv about the same in species of Mesopalxaster.

Measurements: $\mathrm{R}=9 \mathrm{~mm}$., $r=3 \mathrm{~mm}$., $\mathrm{R}=3 r$.

The species is most closely related to $M$. (?) parviusculus, but differs in being larger with more plates in the columns. Of $M$. (?) cataractensis only the actinal side is known, with 12 to 13 plates in each inframarginal column (7 in $M$. (?) parviusculus) and about 19 in the adambulacrals ( 13 in $M$. (?) parviusculus). Then the inframarginals increase very rapidly in size proximally, while in $M$. (?) cataractensis there is but little enlargement.

A single small, pentagonal, axillary interbrachial plate occurs in each area immediately beneath the basal inframarginals. These are much smaller relatively than those in $M$. (?) parviusculus.

Ambulacral plates unknown. Ambulacral furrows deep, nearly completely closed by the adambulacral columns.

Formation and locality. - In the base of the Siluric (Cataract formation) at Hamilton, Ontario. The holotype was found by $\mathrm{Mr}$. Elliott near the city reservoir and is in the collection of the Hamilton Natural History Society. It was loaned to the writer by the late Col. Charles Coote Grant.

\section{MESOPALAEASTER GRANTI (Spencer).}

Plate 9, fig. 3.

Palæaster granti Spencer, Bull. Mus. Univ. Missouri, No. 1, 1884, p. 53, pl. 7, fig. 1.

Original description. - "Body stellate and small with short arms, about 2 centimeters across; disk less than 1 centimeter wide, and apparently formed by the junction of the rays; rays 5 millimeters wide at base, tapering slowly, and terminating in rounded extremities, at about 8 millimeters from junction of their base with the disk; upper surface of rays composed of 5 [not less than 9 in mature specimens at mid-length of rays] ranges of highly convex or tuberculiform plates (the marginal [supramarginal] and ventral [inframarginal] 
rows being the most conspicuous) and separated from each other by minute plates (becoming fewer on approaching the extremities of the rays).

"The ellipsoid [supra] marginal tuberculiform plates number about 12 [20 in mature examples] for each complete side of the rays, and the central range [radial] is composed of a similar number, but in form these plates are more circular. The disk between the terminal central [radial] row of plates of the rays is crushed and structureless, except a slight elevation in the center. The terminal [proximal] plates of the marginal series are larger than the others of the range. The madreporiform tubercle is of a spherical form and relatively large, being nearly 2 millimeters in diameter, and is situated at the axil of two rays. Both the tuberculiform plates and the madreporiform tubercle have a granulated surface.

"The ventral side is unknown.

Emended description.-A mature specimen measures: $\mathrm{R}=16 \mathrm{~mm}$., $r=5 \mathrm{~mm}$., $\mathrm{R}=3.3 r$.

Rays short, stout, tapering rapidly, and with very small interbrachial ares.

Abactinal area of disk unknown. Along the center of each ray there is a radial column of small, highly convex plates bounded on each side, at about the mid-length of the rays, by two columns of smaller, strongly tumid, accessory plates. The radial column is, however, not distinctly differentiated from those adjoining. Outside of these are the supramarginal columns, each with about 20 plates which are larger and more easily distinguished than the radial plates. Distally the rays have only the ossicles of the infra-and supramarginal and radial columns, with none of the accessory plates as yet developed.

Ambital area with one column of very small accessory plates like the marginal plates on each side of them. These accessory pieces disappear before attaining the apex of the rays.

Madreporite spherical in form and relatively large, nearly 2 millimeters in diameter, and situated at the axil of two rays between two adjoining supramarginal columns.

Formation and locality.-From the Cataract formation, the basal deposits of the Siluric system, near the reservoir in the city of Hamilton, Ontario. Col. Charles C. Grant, after whom the species is named, discovered most of the specimens, which are six in number, two in the Spencer collection, now destroyed by fire, one in the Redpath Museum of McGill University, Montreal, another in the Geological Survey of Canada at Ottawa, and two in the Grant collection, one of which has generously been donated to Yale University.

Remarks.-This species is apparently closely related to $M$. bellulus, which see for comparison. 
MESOPALAEASTER BELLCLUS (Billings).

Text fig. 7.

Petraster bellulus Billings, Geol. Surv. Canada, Pal. Foss., vol. 1, 1865, p. 393, fig. 368.-Mrller, N. Amer. Geol. Pal., 1889, p. 269, fig. 389.

Original description.- "Deeply stellate, about 18 lines across; disk 5 lines wide; width of rays, at the base, half the width of the disk, uniformly tapering to their extremities; ambulacral grooves, narrow and deep, with about 30 adambulacral plates on each side. These plates are strongly convex and nearly square [distally, but proximally are wider than long]. Outside of these there is a row of [about 21 infra] marginal plates, which appear to [actually do] extend to the extremities of the rays, but on this point there is some doubt, as the specimen is not perfect. [The four proximal pieces increase rapidly in size so that they are considerably larger than the others. All of the actinal plates are granular.] There appear to be one or two [there is but one axillary] small disk plates between the [basal adjoining infra] marginal and adambulacral plates just outside of the oral angles.

"Locality and formation.-Township of Grimsby [Ontario]; in the Niagara shale [ = Rochester shale $]$.

"Collector.-Johnson Pettit, Esq., Grimsby." The holotype is in the Victoria Memorial Museum, Ottawa, Canada (No. 2665).

Remarks.-The holotype and only known specimen of this species was seen

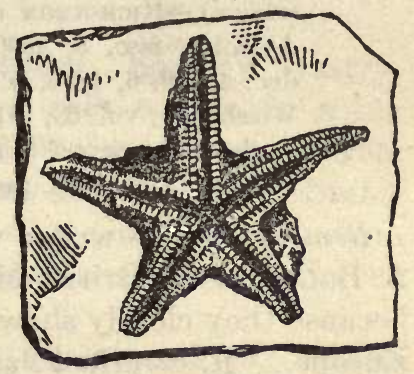

Fi G. 7. -The ORIGiNal Figure of MESOPALEASTER BELLULUS, AFTER BLLINGS. NATURAL SIZE. THE SPECIMEN HAS STLL TOO MUCH SHALE ADHERING TO IT $\triangle$ ND BESIDES IS CONSIDERABLY DISTORTED, PREVENTING ITS BEING SATISFACTORILY PHOTOGRAPHED. by the writer at Ottawa, and has now been freed from the rock so that the abactinal side can also be studied. The generic characters are those of Mesopalxaster and one is impressed at once by the almost specific identity of the abactinal side of the specimen with that of $M$. granti. However, as the specimens show slight differences and come from different Siluric formations, it is thought best to recognize them as distinct species. Moreover, the actinal side of $M$. granti is still unknown.

Abactinally all of the skeletal pieces are of about the same size, small, each ossicle irregular in outline, and more or less stellate. There are about 17 in the length of one-half inch. This skeleton is more or less disturbed and it is impossible to clean off all the adhering shale, so that it is difficult to make out the detailed arrangement. The following, however, can be made out: There is no true disk as in Petraster, and the parts that appear as such are either adhering shale or displaced ossicles due to distortion during sedimentation, 
Distally the rays have columns of small radial pieces, and outside of these are the two supramarginal rows. Proximally between these primary columns there appear accessory pieces, one column of which wedge in between the radials and supramarginals and from one to three between the latter and the inframarginals. In this way finally as many as 13 columns can be counted at the base of a ray.

The madreporite is situated near the margin between adjoining supramarginal columns, and is conspicuously protruded and large when compared with the small adjacent ossicles. It is a large, radially striate, irregularly circular plate about six times larger than the adjoining pieces.

\section{MESOPALEASTER CARACTACI (Gregory).}

Plate 9, fig. 6 ; plate 11 , fig. 1 .

Palæaster caractaci SAlter, Cat. Foss. Mus. Practical Geology, 1865, p. 30 (nomen nudum).-Nrcholson and Etheridge, Mon. Silurian Foss. Girvan Dist., Ayrshire, fasc. 3, 1880, p. 321 (no description).-Gregory, Geol. Mag., dec. 4, vol. 6, 1899, p. 344.-ScHöNDoRF, Jahrb. nassauisch. Ver. Naturk., Wiesbaden, vol. 63,1910, p. 227.

Protopalæaster caractaci Spencer, Mon. Brit. Pal. Asterozoa, pt. 1 (Palæontogr. Soc. for 1913), 1914, pp. 21, 30, pl. 1, fig. 5 .

Remarks.-The writer was greatly pleased to receive from Dr. F. A. Bather of the British Museum wax squeezes of the type-specimens, because they clearly show that the genus Mesopalxaster is present in Europe. $M$. caractaci has its closest relationship in $M$. shafferi, the genotype of Mesopalxaster. The differences are easily to be seen on the abactinal side, as illustrated in this work.

Rays long and slender, abactinally flattened. $R=12.5 \mathrm{~mm}$., $r=3.8 \mathrm{~mm}$., $\mathrm{R}=3.3 \mathrm{r}$. Radialia small and no larger than the pieces of the accessory columns on either side of them; the former alternate in position with the pieces of the latter and all of them are more or less spicular in outline. Basal radials slightly larger than the others. The ossicles of the supramarginal columns large and solid, the most prominent of the abactinal side, very large proximally and exceedingly small distally; there are about 14 in a column. Basal inframarginals most conspicuous of all abactinal plates, with each pair occupying the axils, and together with the smaller basal radialia form a ring bounding the disk. The disk has fallen in but still shows a few small pointed plates.

"Madreporite is large, and placed close by one of the interradial angles" (Gregory).

Inframarginal ossicles almost smooth, large and prominent proximally, decreasing rapidly in size so that not more than 9 can be seen actinally, where the tiny pieces pass somewhat over to the abactinal surface, or better the lateral sides; Gregory states that there are 12 in a column. The basal pieces of adjacent columns do not as a rule touch one another in the axils. 
Interbrachial areas with single, large, hexagonal, axillary interbrachial plates.

Adambulacral pieces quadrangular, fairly uniform in size for twothirds the length of the rays and then become gradually smaller distally; there are about 15 in a column. A peculiarity. of this species is that the ambulacralia do not continue around the axillary interbrachials, but cease with the basal inframarginals. There are, therefore, in $M$. caractaci no adambulacral oral armature pieces.

Ambulacral furrows moderately wide, with as many rectangular ambulacralia as there are adambulacrals, plus probably four more in each column, and these continue around the axillary interbrachial. Therefore, the oral armature consists entirely of ambulacralia. All of these ossicles are directly opposite one another and have high medial crests that are continuous across the ambulacral furrow. Podial openings large laterally between the plates and the adambulacrals.

Locality and formation.-Caradoc sandstone, Soudley quarry, Church Stretton, England. The holotype, a split nodule, is in the British Museum (Natural History), No. 48206; wax squeezes from which the photographs have been made are in the United States National Museum. Other specimens, Bather states, are in the Museum of Practical Geology, London; these are from Marshbrook and occur at a somewhat higher geological level.

Remarks.-Gregory wrote in 1899 that "the nearest ally of this species is $P$. matutina (Hall)," but the illustrations here presented will show that the relationship is with Mesopalæaster shafferi and not with Hudsonaster matutinus.

Cat. No. 60606, U.S.N.M.

\section{MESOPALAEASTER (?) ACUMINATUS (Simonovitsch).}

Asterias acuminatus Srmonovitsch, Sitzb. d. mat.-naturw. Classe Akad. Wiss., Wien, vol. 64, Abt. 1, 1871, p. 100, pl. 3, figs. 2-2d.

Asterias acuminata SchöNDoRf, Palæontographica, vol. 56, 1909, pp. 72, 109, pl. 11, figs. 7, 8.-SchöNDORF, Jahrb. nassauisch. Ver. Naturk., Wiesbaden, vol. 62,1909, p. 32 , pl. 5 , figs. 4,5 .

Roemeraster (?) acuminatus STÜRTZ, N. Jahrb. für Min., etc., 1886, vol. 2, p. 154.

Actinally this small and slender species is nearly in harmony with the generic characters of Palxaster and Hudsonaster, differing only in that the axillary interbrachial plates barely extend to the margin of the disk, while in those genera they are prominent and marginal in the axils. In Asterias acuminatus they are as yet not crowded so far orally as in most species of Mesopalæaster. It is a difference of degree, not of kind; therefore this species has more the actinal character of Mesopalæaster than Hudsonaster. Ambulacral plates unknown.

Abactinally Simonovitsch's species is said to have six columns of tumid plates, all alike and persisting throughout the rays. If the 
outermost columns of each ray are regarded as the inframarginals and the ones immediately inside as supramarginals, two medial columns remain to be homologized with those in Mesopalxaster. If Simonovitsch is correct, then by this interpretation there are two columns between the supramarginals. Both can not be radials and to regard one as such will leave a unilateral and apparently an unnatural development. If five or seven columns of abactinal plates were present, this species would be in harmony with Mesopalæaster. Since Simonovitsch's work is of the best, we have at present the only alternative of supposing that the radials in Asterias acuminatus are suppressed and that its two medial columns are homologous with the intercalary abactinal plates of other starfishes. Among Paleozoic asterids this development is rare and is found only in Encrinaster and Palxaster. In that event, $A$. acuminatus is not a Mesopalæaster.

A single example of this species was found in the Lower Devonic (probably Upper Coblenzian) near Braubach, Germany.

In his revision of the Lower Devonic starfishes of Germany, Schöndorf was not able to discover the whereabouts of the type-specimen and therefore had to leave this species as determined by Simonovitsch. The former states that actinally the structure reminds one of Spaniaster latiscutatus, the genotype of Spaniaster, and closely related to Mesopalxaster. For further remarks see Spaniaster.

MESOPALEASTER (?) CLARKI (Clarke and Swartz).

Plate 10, figs. 1, 2.

Palæaster clarki Clarke and Swartz, Maryland Geol. Surv., Upper Devonian, 1913, p. 543, pl. 46, figs. 3,4 .

Original description.- "This species is represented in the collections by a single specimen affording a pretty sharp cast of both sides of a very regular and complete individual. In general structure and appearance the species is quite similar, especially on the oral surface, to Palxaster eucharis Hall of the sandy Hamilton shales of central New York, but the latter is a much larger form.

"The disk is small, rays long and slender, thecal plates all prominently developed. The ambulacral surfaces are represented only by a narrow linear depression beneath which the ambulacral plates are concealed. These depressions are bordered by thickened and somewhat elevated quadrangular or pentangular adambulacra. The marginal plates are in single rows, much thickened, with generally quadrangular outline and convex surface, each projecting on the margin of the ray. At each axilla is a single pear-shaped plate with its apex outward, these plates being the largest in the individual. The a bactinal surface is tessellated by rows of strong convex plates of similar size to the marginal plates. Of these there are three rows, a median row of narrow oval ones between the ends of which are interlocked the edges of the much larger plates of the lateral rows which are highly convex and 
thickened in the center and greatly depressed to the sutures. Thus each plate has a cushioned surface. Between the ends of each plate of the middle row are two minute accessory plates lying in the angles at which the lateral plates enter. At the base of each ray and upon the disk is a single large plate whose surface rises into a high clavate node. Between each two of these is one of less height. The central portion of the aboral area is destroyed and no trace of madrepore is seen.

"The width of this specimen from tip to tip is $33 \mathrm{~mm}$.

"Occurrence: Jennings formation, Chemung member. Yellow sandstone on the road northeast of Oakland, Garrett County [Maryland], where it is associated with Spirifer disjunctus.

"Collection: Maryland Geological Survey."

Remarks.-This clearly determined species is a late survival of early Paleozoic primitive asterids. The characters so far as determinable in the natural mold are those of Meso-

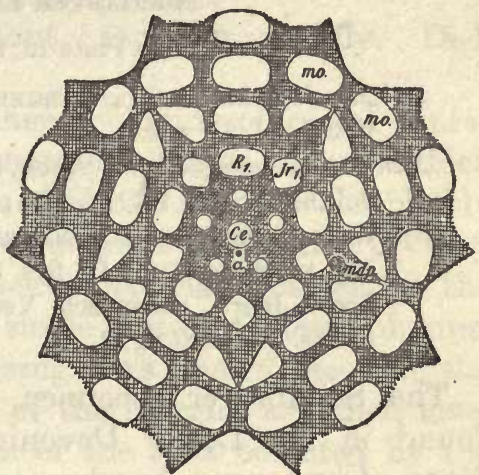

Fig. 8. - Spantaster latiscutatus, after SCHONDORF. SCHEMATIC ARRANGEMENT OF THE ABACTINAL PLATES. $a$, PRESUMABLE POSITION OF ANUS; Ce, CENTRAL PLATE; $J r_{1}$, BASAL INTERRADIALL; $m d p$, PROBABLE POSITION OF MADREPORITE; MO, SUPRAMARGINALIA; $R_{1}$, BASAL RADLLIA. palæaster, but as the disk skeleton is not preserved, it is very probable that when this feature is known the form will be seen to belong to a new genus.

\section{Genus SPANIASTER Schöndorf.}

Plate 12, figs. 1, 2; text fig. 8.

Colaster Sandberger (not Agassiz 1835), Verst. d. rheinischen Schicht. Nassau, 1855, p. 381.

Spaniaster ScHöNDoRF, Jahrb. nassauisch. Ver. Naturk., Wiesbaden, vol. 60, 1907, p. 176; vol. 62, 1909, p. 30; Palæontographica, vol. 56, 1909, pp. 73, 109.

Remarks. - This genus with its single very small species has its nearest relations with Mesopalxaster, in that it has a single axillary interbrachial plate in each actinal axillary area, but differs from it in that there are many more adambulacral and ambulacral plates than there are inframarginals. The marked and generic difference, however, is on the abactinal side, where there are but three columns of plates, one radial and two suuramarginal, of large and thick ossicles arranged in parallel rows, the pieces of which do not alternate with one another; further, the supramarginals are almost completely superposed upon the inframarginals, the two columns together, but more particularly the inframarginals, bounding the rays and not the inframarginals alone, and not so pronouncedly as in Mesopalzaster. The disk is also more primitive in its construction, in that the central 
disk plate is encircled by a ring of but 5 small accessory disk pieces, separating the former from the next ring of 10 much larger plates that are the primary pieces of the radial and supramarginal columns.

Genoholotype and only species.-Colaster latiscutatus Sandberger. Restricted to the Lower Devonic of Germany.

SPANIASTER LATISCUTATUS (Sandberger).

Plate 12, figs. 1, 2; text fig. 8.

Colaster latiscutatus SANdBerger, Verst. d. rheinischen Schicht. Nassau, 1855, p. 381 , pl. 35 , figs. 1, $1 a$.

Xenaster simplex Srmonovirsch, Sitz. d. mat.-naturw. Classe Akad. Wiss., Wien, vol. 64 , Abt. I, 1871, p. 97, pl. 3, figs. 1, 1a.

Spaniaster latiscutatus ScHöNDORF, Palæontographica, vol. 56, 1909, pp. 73-82, 109 , pl. 8 , fig. 2 ; pl. 10, figs. 2, 9, 10; pl. 11, fig. 9 (complete synonymy given here); Jahrb. nassauisch. Ver. Naturk., Wiesbaden, vol. 62, 1909, p. 31, pl. 5 , figs. 1-3, text fig. 2 .

The Sandberger specimen, showing only the abactinal side, was found in the Lower Devonic Spiriferensandstein at Unkel, near Bonn, Germany. Another specimen from the Lower Coblenzian quartzite has been recently found at Bienhorntale, near Coblenz; this shows both sides. Still another is from the Lower Coblenzian at Oberstadtfeld in the Eifel. The holotype of $X$. simplex is from the Upper Coblenzian at Niederlahnstein on the Rhine.

\section{Genus MIOMASTER Schöndorf.}

Plate 8, fig. 3.

Miomaster drevermanni ScHöNDORF, Jahrb. nassauisch. Ver. Naturk., Wiesbaden, vol. 62 , 1909, p. 38, pl. 3, fig. 4 ; pl. 4 , fig. 3 .

Remarks.-This genus is most closely related to Spaniaster, in that both have the single axillary interbrachial plates and the inframarginals and supramarginals are directly superposed. They differ from one another mainly on the abactinal side, though this area is so poorly preserved in Miomaster that almost nothing definite can be said. Schöndorf illustrates a section through the rays that shows the presence of single columns of very small accessory pieces between the radialia and supramarginalia. In the description, however, he states: "One can not positively determine whether the supramarginal plates are separated from the median pieces by small accessory ossicles, or whether the three dorsal columns were closely adjoining." The central disk area is also too much disturbed to make out the skeletal arrangement. There appear to have been small interbrachial abactinal areas. Under these circumstances, the genus Miomaster can not be said to be well established, and its final disposition is dependent on finding better preserved material.

Genoholotype and only species.-M. drevermanni Schöndorf (as cited above). A single example was found by Drevermann in the Upper Coblenzian at Miellen-on-the-Lahn, Germany. The holotype is in the Senckenberg Museum, Frankfort-on-the-Main. 
DEVONASTER, nev genus.

Plates 11 and 12.

Palæaster (part) of AuTHors.

Xenaster (?) or new genus Gregory, Geol. Mag., dec. 4, vol. 6, 1899, p. 346.

Devonaster Schuchert, Fossilium Catalogus, Animalia, pt. 3, April, 1914, p. 14.

A characteristic starfish of the American Devonic.

Generic characters.-Rays five, stout, tapering rapidly. Disk large, with small interbrachial arcs.

Abactinal area of rays with prominent columns of radial supramarginals and less prominent inframarginal plates, all of which bear numerous small pustules. The radial columns are completely separated from the supramarginals by a great abundance of very small, conical, irregularly arranged, accessory plates which in the proximal region may also force apart single plates of these columns. The supramarginal columns of adjoining rays nearly meet in the axillary areas a short distance inside of the margin, at which level the radial columns also cease. Inside of the area bounded by the proximal plates of the radial and supramarginal columns, the disk has numerous small accessory plates like those of the rays. In the center of the disk is a plate somewhat more prominent than those surrounding it, and just inside of the adjoining proximal supramarginals is a small but distinct plate interradial in position.

Ambital accessory plates abundantly developed between the marginal ossicles in the axillary areas. These plates are like the other accessory plates and do not extend beyond the third or fourth proximal inframarginal pieces, where the ambital areas cease and the supramarginal ossicles come to lie more and more completely over the inframarginals.

Madreporite flat or concave, situated between two proximal supramarginal ossicles and outside of one of the small interradially situated plates.

Inframarginal pieces large and thick, increasing rapidly in width proximally, so that the two wedge-shaped proximal plates are nearly three times as wide as long. The plates are pustulose, and the proximal ones bear several slender spines.

Adambulacral plates more numerous than the inframarginals, continuing around the axillary interbrachial plates, in front of which the columns meet in two triangular and enlarged adambulacral oral armature plates. Each piece bears two short, obtusely pointed spines.

Ambulacral grooves narrow and deep, either straight or very slightly petaloid. Ambulacral plates equaling in number the adambulacrals and arranged in directly opposed, closely adjoining columns. Podial openings in two columns through the sutures in the lateral part of the furrows. 
Axillary interbrachial plates large, a single one situated in each area between the adambulacral and inframarginal columns. Each bears short, thick, blunt spines.

Mouth plates (tori) minute, one situated in front of each pair of oral armature plates.

Genoholotype.-Palæaster eucharis Hall.

Distribution.-Restricted to the Hamilton and Chemung of the American Devonic. The species are:

D. eucharis (Hall). Hamilton.

$D$. chemungensis, new species.

Remarks.-This genus is readily distinguished from Hudsonaster in having well-developed radial and ambital accessory plates, in the numerous very small plates of the disk and in the presence of interbrachial axillary plates.

Devonaster differs from Palxaster in having radial columns of plates and in the presence of three plates in each interbrachial area against one in Palæaster. There are also other differences. From Neopalxaster it differs in having ambital accessory plates and no ocular plates; while the proximal supramarginals and radials are very large in the former, they are small in Devonaster, particularly the supramarginals, which are not readily distinguished from the accessory disk plates. In Mesopalæaster and Promopalaaster the accessory plates are always arranged in columns or rows and the ambital accessory plates are not restricted to the axillary areas as in Devonaster. Further, in those genera (excepting in the smaller forms of Mesopalxaster) there are always from two to five interbrachial marginal plates, while Devonaster has but one axillary marginal in each interbrachial area.

Devonaster greatly resembles abactinally Xenaster of the Lower Devonic of Germany, but is readily distinguished actinally in that the latter has more large interbrachial plates, and especially in the addition of numerous accessory interbrachial pieces. These differences are pointed out in more detail in the remarks on Xenaster.

\section{DEVONASTER EUCHARIS (Hall).}

Plate 12, figs. 3-5.

Palæaster eucharis Hall, Twentieth Rep. N. Y. State Cab. Nat. Hist., 1868, p. 287, pl. 9, figs. 3-3a (?4); rev. ed., 1868=1870, p. 330, pl. 9, figs. 3-3a (?4).Quenstedt, Petrefactenkunde Deutschlands, vol. 4, 1876, p. $71, \mathrm{pl} .92$, fig. 29.-Zrtwel, Handb. Pal., vol. 1, 1879, p. 452, fig. 323.-Cole, Bull. Geol. Soc. America, vol. 3, 1892, p. 512, pl. 15.-Clarke, Bull. N. Y. State Mus., No. 158, 1912, pp. 44-45, 6 pls.

Xenaster eucharis ScHöNDORF, Jahrb. nassauisch. Ver. Naturk., Wiesbaden, vol. 66,1913 , pp. 87-96, pl. 3, figs. 1, 2, text figs. 1-3.

Original description. - "Body rather large; the largest individual being one inch and seven-eighths from the center of the body to the extremities of the rays; the whole having a robust aspect; rays 
acutely pointed at the extremity. Upper [abactinal] surface of rays composed of three [radial and two supramarginal] ranges of large, highly convex or tuberculiform plates which are nearly circular at the bases of the rays, becoming quadrate and widened towards the extremities; separated from each other in the lower part by numerous minute [accessory] plates or granules, which become fewer near the middle of the ray, and before reaching the extremity. The central portion of the disk is occupied by an elevated pentagon, the angles of which are formed by the abrupt termination of the central row of plates of each ray: the whole composed of very minute, highly convex plates, which vary in size, the larger ones pentagonally arranged. The angles between the rays have a few [numerous] small [accessory ambital] plates outside of the outer ranges of tuberculose [supramarginal] plates on the upper side, uniting with the inframarginal plates below [and not extending beyond the third or fourth inframarginal proximal plate]. Madreporiform tubercle distinct, situated laterally at the bases of the outer [supramarginal] range of large plates of two adjacent rays. Ventral surface having deep ambulacral grooves, bordered by two ranges of strongly tuberculose plates; the outer [infra] marginal range consisting of 27 or 28 plates, besides a large, round [or elliptical], terminal or axillary [interbrachial] plate; the others are wider than long in the basal portion of the ray, becoming gradually shorter towards the extremity where they are rounded. All the [infra] marginal plates are visible from the upper [abactinal] side, and usually appear as an additional range of plates on each margin of the ray, making five with the three properly belonging to the upper surface. Those of the inner range bordering the ambulacra (adambulacral plates) are smaller than the marginal plates, about 38 to 40 in number; the basal or oral plates [oral armature] are triangular, those of the adjacent rays uniting by their longer margins; and with a single minute plate situated at these points. The plates of the exterior surface, both upper and lower, present a granulose or striato-granulose surface which appears to have been produced by short setæ or spines; and at the angles of the rays the marginal plates are armed by a few spines, which are as long or longer than the transverse diameter of the plates. Ambulacra composed of a double range of short, broad poral plates (ossicula), equal in number to the adambulacral plates; their outer ends excavated on the posterior border, forming a comparatively large pore, just within its junction with the adambulacral plate. There appears to have been [is] but one range of pores in each set of ossicula, but these are large, distinct, and pass between [through and not between] the plates."

The following additional description is that of Mr. Cole. The surface of the axillary interbrachial plate "is granulose and bears 
three short, thick, blunt pointed spines. The [infra] marginal plates bordering each reëntrant angle bear similar but more slender spines, which are not 'as long as the transverse diameter of the plates.' The spines are arranged in a row near the distal margin of the plates and number five on the plates at the angle, the number and size decreasing until they disappear at the sixth or seventh plate from the angle. All the [infra] marginal plates are nearly smooth on the free margin and become gradually more granulose toward the line of junction with the adambulacral plates. * * *

"The adambulacral plates are apparently less numerous than stated in the original description, and 'the single minute plate [mouth plates]' at the points of the pairs of the oral plates [oral armature] is visible in this specimen and is armed with two relatively long, slender spines which are apparently but a part of the full armature. The adambulacral plates, including the triangular oral [armature] plates bear well-defined spines, which are shorter than the diameter of the plates to which they are attached. Each plate bears two spines so near to the distal margin that the impressions of the short and obtusely pointed spines frequently bridge the well-defined groove between the adjacent adambulacral plates and terminate near the proximal margin of the next plate. The spines decrease in size toward the end of the ray and a few plates show only one spine. The plates of this range are thick, equaling twothirds to three-fourths the depth of the groove. The vertical angle of the faces forming the lateral walls of the groove are beveled, so that lateral extensions of the groove are formed between each two plates on the same side. These lateral expansions are narrow and shallow at the oral surface, deeper and wider inward; so that the faces of the adambulacral plates near their junction with the poral [ambulacral] plates are reduced to a narrow edge which projects inward and nearly touches the corresponding plate on the other side of the groove. The general appearance of the fossil as well as the outline of the rays at the points where the broken block presents a transverse section of them indicates that the plates have their normal position, not having suffered distortion by pressure.

"The ambulacral plates are shown by a well-defined mold of their under or external surface. The soft matrix which filled the ambulacral furrow pressed upon the membranes connecting the ambulacral plates and occupying their pores, and as these membranes decayed it was forced by gentle pressure into the pores and between the edges of the plates. The mold of the groove is less than one-eighth of an inch in width in a ray measuring five-eighths at its base. The upper surface of the mold bears a narrow longitudinal median ridge which marks the junction of the two ranges of ambulacral plates. Similar transverse ridges, which are continuous with the lines mark- 
ing the junction of the inner faces of the adambulacral plates, mark the proximal and distal margins of the ambulacral plates. These ridges do not cross at right angles to the median line, but include between their proximal sides an angle of about $125^{\circ}$. These ridges indicate that the ambulacral and adambulacral plates were equal in number, and that the former were united in pairs along a straight median line rather than in an alternate right and left arrangement along a zigzag line, as is shown in Dr. Hall's figures. The pores described as being 'excavated in the posterior border of the ambulacral plates and just within their junction with the adambulacral plates' are not clearly shown on this specimen, although there are irregular and inconstant markings at some of the points of the molds of the lateral extensions of the groove. A series of pores near the median line is indicated by a series of small rounded prominences on each side of the median ridge and very close to it. These prominences are opposite the lateral expansions of the groove, and one is found on the mold of each ambulacral plate. The pores appear to have perforations very near the edges of the plates, or excavations in their margins."

Abnormal development.-Among the 400 specimens of this species recently found near Saugerties, New York, there are a few individuals each with but four rays, though otherwise they appear to be of normal development. This is the first discovery of a fourrayed starfish in the Paleozoic.

Formation and locality. - In the Hamilton of the Middle Devonic near Hamilton, Summit and Cooperstown, New York, Two separated rays of apparently this species were found by the writer in the lower third of the Hamilton near Bartletts Mills, south of Thedford, Ontario. Two other fragments from the same locality are in the University, of Toronto (Walker collection, No. 1610H). The type and other specimens are in the American Museum of Natural History, one is in Colgate University, another at Wesleyan University, and two in Yale University Museum.

Recently the New York State Survey collected in the Hamilton sandstone at Mount Marion, near Saugerties, New York, over 400 examples of this fine starfish. They occur in a limited area and are often found in association with Grammysia and in such manner that Doctor Clarke believes the starfishes were feeding on the bivalves. This is probably the most remarkable find of Paleozoic starfishes, and is certainly so for America.

DEYONASTER CHEMUNGENSIS, new species.

Plate 11, fig. 2.

Of this species only the actinal side is known, and its general structure so far as can be made out is that of D. eucharis (Hall). 
It differs from the latter in that each axillary interbrachial plate bears one stout spine, while $D$. eucharis has three. Further, in $D$. eucharis six or seven of the proximal inframarginal plates of each column bear on their outer side a number of small, slender spines. In $D$. chemungensis these spines may also be present but in addition each plate bears centrally a prominent tubercle for the articulation of a large spine.

Formation and locality.-The type is in the Museum of Columbia University, New York City (No. 6228G). It is from the Spirifer disjunctus sandstone of the Chemung of "Central Pennsylvania."

\section{NEW GENUS.}

NEW SPECIES.

In the University of Chicago collection there is a specimen (No. 14397) collected by Professor Weller in the St. Louis limestone on Fountain Creek, at Waterloo, Illinois. This five-rayed asterid is small, shows only the abactinal side, and has very long but narrow marginals and not over six or possibly seven in a column; the basal plates of adjoining columns make the axils. Otherwise the abactinal skeleton of the rays consists of many small, loosely adjoining pieces whose arrangement can not be made out. Nor can the disk structure be determined.

The relationship of this specimen seems to be with the Promopalæasteridæ, with possible nearest affinity to the genus Mesopalæaster.

Measurements: $R=$ not less than $10 \mathrm{~mm} ., r=4 \mathrm{~mm}$.

PROMOPALAEASTHRIN AE, new subfamily.

Progressive Promopalæasteridæ with the interbrachial areas complex and composed of the single axillary interbrachials, more than one pair of interbrachial marginals, and adambulacral plates. Podial openings in each ambulacral furrow mainly in two columns, but proximally there may be two additional ones in a length never more than one-third the rays.

Contains:

Promopalæaster, new genus.

PROMOPALAEASTER, new genus.

Plates 13 to $23,25$.

Palæaster (part) of AutHors.

Promopalæaster SchucherT, Fossilium Catalogus, Animalia, pt. 3, April, 1914, p. 24.

Promos, chief, and aster. The largest and chief starfishes of the American Ordovic.

Generic characters.-Disk above medium size, with distinct and angular interbrachial arcs. Rays five, slender to stout, more or less long, and tapering. Some species attain a large growth. 
Abactinal area of rays with numerous columns of small, more or less tumid, closely adjoining or reticulated, spine-bearing plates. A medial radial and two lateral or supramarginal columns of plates are usually more conspicuous than the accessory columns; however, the radial plates may be also inconspicuous. The longitudinal arrangement in columns is usually most pronounced, but sometimes the plates on each side of the radial column may have a decided diagonal arrangement. Small accessory plates are usually inserted between the columns of ossicles or between the individual pieces both distally and proximally. Disk with numerous small accessory plates like those of the rays, with no apparent definite arrangement except the supramarginal columns, which continue over the disk and unite angularly in the axillary areas. The larger plates bear several short articulating spines of which the one on the apex is the largest.

Ambital areas well developed, there being one or more columns of small plates like the radial accessory columns both in form and arrangement.

Madreporite usually conspicuous, radially striated, and situated near the margin of the disk between the adjoining columns of supramarginal plates.

Inframarginal plates small and numerous distally like the adambulacrals, but proximally they usually increase rapidly in width and assist in forming the small interbrachial arcs. Each ossicle has numerous small granules which probably bore short, smooth, articulating, blunt spines.

Adambulacral plates distally like the inframarginals, increasing in width proximally and continuing around the plates of the interbrachial areas. The two proximal plates of adjoining columns are the pairs of plates in the oral armature. Each adambulacral plate has a more or less well-developed narrow ambulacral extension which unites with the carina of the ambulacral plates. These extensions belong to the adambulacral plates, apparently always so distally, but proximally they are often separated from the adambulacral plates by sutures; throughout the greater portion of the rays they are situated medially, but in the proximal region they are either on the distal or proximal edge, each alternate plate having the extension from the same corner a little longer. Each plate has more or less numerous spine-bearing granules in addition to the three larger articulating spines which are inserted one on the ambulacral and two on the lateral edge.

Ambulacral furrows generally very wide and regularly tapering. In each ray there are two columns of these plates which are slightly alternating or opposite. The plates are as numerous as those of the adambulacral columns, highly carinated, about as wide as long in the extreme distal portion of a ray, increasing rapidly in width proximally 
and at the base of the rays may be four times as wide as long. The podial openings, one to each plate and in single ranges, are at the extreme lateral edges excavated between the sutures of adjoining plates and beneath the adambulacrals. Proximally, however, every other podial opening progresses inwardly with the joined carinæ and issues where these begin to fork. Here there are, therefore, four columns of podial openings in each ambulacral furrow. This change is indicated by the changed position of the adambulacral plate extensions and also by the pairs of forked carinæ of the ambulacral plates. Throughout the greater portion of a ray the carinæ are regular and alike on each plate, but toward the mouth they change rapidly in direction and soon they are arranged in forked pairs, one curving distally, the other proximally, with the lateral portions of each pair in contact and uniting with the extensions of the adambulacral plates. The most proximal plate of each ambulacral column is usually considerably modified, longer than wide, and more or less triangular in outline, between which there is sometimes inserted a small quadrangular ossicle. These pieces belong to the oral armature.

Interbrachial areas of medium size, with the interbrachial marginal plates usually arranged in pairs but in some forms the series may be terminated by single ossicles. The number of these plates in an area varies in different species, there being two, three, or five inside the marginal inframarginals, and all seem to be derived from the inframarginal series by inward crowding.

Genoholotype.-Palæaster granulosus Meek (not Hall=P. speciosus Meek).

Distribution.-Restricted to the Middle and Upper Ordovicic of America, chiefly within a radius of 50 miles about Cincinnati, Ohio. The following are the known species:

P. wilsoni (Raymond). Black River (Lowville).

$P$. prenuntius, new species. Trenton.

$P$. sp. undet. ?Young of $P$. speciosus Meek. Maysvillian.

$P$. speciosus (Meek). Maysvillian.

$P$. granulosus (Hall). Lower Richmond.

$P$. bellutus, new species. Richmond.

$P$. spinulosus (Miller and Dyer). Richmond.

$P$. exculptus (Miller). Richmond.

P. wykoffi (Miller and Gurley). Richmond.

$P$. dyeri (Meek). Maysvillian.

P. magnificus (Miller). Maysvillian and Richmond.

Remarks.-Eight of the ten species here referred to Promopalxaster have been described as Palxaster. They have little direct relationship with the latter genus in that the species are much larger, have well developed ambital areas, numerous accessory plates, well defined 
interbrachial arcs, and from two to five interbrachial marginal plates in each interbrachial area. Promopalreaster is a direct development from Mesopalxaster, in that it preserves the generic characters of the latter, which is in turn a descendant of Hudsonaster. In Hudsonaster there are no interbrachial plates, accessory or ambital columns. In Mesopatæaster the single axillary marginal plate of Hudsonaster has been crowded orally and is no longer a marginal but an axillary interbrachial. Further, the radial and both marginal columns are more or less completely separated from one another by accessory columns of smaller plates. In Promopalxaster this addition of columns of small plates is carried to its greatest development. The character, however, which is relied upon to distinguish it from Mesopalzaster is that Promopalzaster always has two or more interbrachial marginal plates in each interbrachial area, while the former genus has one, the axillary interbrachial, and Hudsonaster has none. "The position and number of axillary and interbrachial marginal plates will readily distinguish these genera, but if the abactinal area of a new form alone is seen it will be difficult to determine whether it is a Mesopatæaster or Promopalxaster. Small size and few accessory columns, especially ambital, will help somewhat to distinguish Mesopalxaster from Promopalæaster.

Accepting Promopatxaster as a descendant of Mesopalxaster, it is seen that the axillary interbrachial plates of the latter have in $P$. exculptus been followed by two proximal pieces of adjoining inframarginal columns. The same is probably true of $P$. spinulosus, but here no axillary interbrachial has been observed. In $P$. speciosus and $P$. bellulus, another pair of proximal inframarginals have become interbrachial plates, but the axillary interbrachial is also unknown in this species. In $P$. dyeri and $P$. magnificus the axillary interbrachial is present along with two pairs of interbrachial marginals. In other words, there is in Promopalæaster a constant increase in the size of the interbrachial area produced by the crowding of pairs of proximal inframarginal plates.

$P$. speciosus and $P$. bellutus are closely related species, and so far as can be determined have but two interbrachial marginal plates, while our theoretic development requires three. There is, however, in each area orad to the interbrachial plates a small hiatus which in some cases appears to be filled by extensions from the adambulacral plates. It seems therefore probable that the axillary interbrachial plate may be retained, but is not now discernible on account of its small size or adhering clay; it may also have dropped out or have been absorbed and its place occupied by the adjoining adambulacral plates.

In a general way it can be stated that there is also a regular increase in the number of accessory plates from Mesopalxaster to Promopalxaster through $P$. spinulosus, $P$. speciosus, $P$. bellulus, $P$. dyeri into 
P. magnificus. It seems probable from the mature material studied that the most differentiated species of Promopalxaster, P. magnificus, passed through ontogenetic stages comparable to Hudsonaster, Mesopalxaster granti, and Promopalæaster bellulus.

$P$. magnificus at present stands alone in its beautiful diagonal and longitudinal arrangement of abactinal plates.

PROMOPALAEASTER WILSONI (Raymond).

Plate 13, figs. 1, 2.

Palæaster? wilsoni RAYMond, Ottawa Naturalist, vol. 26, 1912, p. 77, pl. 5, figs. $1-4$.

Original description. - "The specimen is exposed from the abactinal side, and preserves the greater part of one arm, the disk, and the stumps of the other four arms. The diameter of the specimen, when complete, must have been about $75 \mathrm{~mm}$. ( 3 inches), and the diameter of the disk is $20 \mathrm{~mm}$. This is large for a starfish from the lower Ordovician. The arms are quite convex, with a gentle taper, reminding one somewhat of the common recent starfish, Asterias vulgaris, and as in that species, the arms were probably somewhat flexible. The greater part of the abactinal side of the disk and arms is covered with small convex, overlapping, V-shaped plates, which are arranged with the point of the $V$ directed toward the margins. Along the crest of each arm there is a single row of larger plates (radial column). These plates are quite large and hexagonal in outline near the disk, but become smaller, triangular, and alternate in position farther out on the arm. There are two rows of marginals [supra and infra] these plates being larger and flatter than the other plates, and covered with minute tubercles, which may be spine bases. Close to the disk, the supramarginals and [infra] marginals seem to be of the same size, both rectangular, and the plates of the supramarginal row directly over those of the marginal series. Farther out on the arms, the plates are pentagonal, those of the two rows alternating in position, and dove-tailing, and the supramarginals are smaller than the marginals. One of the marginals, about halfway out on the arm, is $1.25 \mathrm{~mm}$. high and of about the same breadth. The smaller triangular plates which cover the greater part of the arm average about 0.5 to $0.6 \mathrm{~mm}$. in height. On one of the arms, the small triangular plates seem to be arranged in rows parallel to the axis of the arm, but the plates on the longer arm seem to be more irregular, although a general arrangement in rows can be seen. On this arm there are a number of very small plates scattered about, especially on the top of the arm, thus adding to the irregularity. The triangular shape of these plates gives the arm a neat pattern, the plates making diagonal rows backward and forward from the row of large plates along the top of the arm. The madreporite, which is nearly circular in outline, and $2 \mathrm{~mm}$. in diameter, is in position, but slightly 
tipped down at the inner side, in an interradius, and not far from the center of the abactinal side of the disk. The surface is probably worn, for it appears perfectly smooth."

In places the abactinal ossicles are removed, "disclosing the ambulacral plates. These plates, which are long and rather thick, seem to be alternate in position. Two of the plates seem to be pierced by pores near their proximate ends, two pores piercing each plate vertically. Near the outer end of the more perfect arm there is a space where a few of the small triangular plates are missing, and here also the ambulacral plates can be seen from the upper side. Each plate has a narrow keel on that side. Other details of the plates of the actinal side are unknown."

Formation and locality. - In the Lowville limestone at City View, near Ottawa, Canada, where this interesting asterid was found by Miss A. E. Wilson, in whose collection the holotype now is.

Remarks.-It is interesting to note that this fully developed Promopalzaster, one closely related to $P$. magnificus of the highest Ordovicic, occurs in much older rocks; that is, in the Black River formation. This occurrence again brings out the fact often noted by the writer, that Paleozoic asterids are slow to change in characters accessible to the paleontologist.

$P$. magnificus, like $P$. wilsoni, Raymond states, "has two rows of large marginals and a row of large plates along the top of each arm, while the greater part of the surface is covered with small convex triangular plates. Miller found the plates to be spine-bearing, a point which can not be definitely decided in the present species. From the photograph (submitted by Schuchert) it appears that there are spaces between the small triangular plates on the abactinal surface in Palæaster? magnificus, while in P.? wilsoni these plates actually overlap each other."

PROMOPALEASTER PRENUNTIUS, new species.

Plate 13 , fig. 3 ; plate 15 , fig. 5 .

Remarks. - This species is represented by a good specimen showing the actinal side, the other adhering to the limestone. $\mathrm{R}=$ somewhat less than $30 \mathrm{~mm}$., $r=7 \mathrm{~mm}$. Width of ray at base about $9 \mathrm{~mm}$.

$P$. prenuntius is closely related to $P$. speciosus, but is distinguished therefrom by the smaller size, less pustulose ornamentation of the plates, and the lower position in the geological column. The plates of the axial area are also more regular in size and there are in the proximal region nearly always two adambulacrals to each inframarginal; at about mid-length of the rays the plates of each of the two columns are about equal in number, but every now and then there is some duplication among the adambulacrals. $P$. prenuntius is equally as spinose as $P$. speciosus and the former is undoubtedly the ancestor of the latter. 
Formation and locality.-The holotype was collected by Mr. Wendt near Frankfort, Kentucky, apparently in the Lower Trenton. The writer's attention was called to it by Prof. Arthur M. Miller, who has it in his charge at the State University of Kentucky at Lexington.

PROMOPALEASTER, species undetermined.

Plate 14, figs. $1,2$.

Asterias primordialis ANoNYmous, two lithographic figures sent out by the Western Academy of Sciences previous to 1872 without description or known author.

Nothing more is known of this species than the two good original illustrations reproduced here. These figures were sent to F. B. Meek on May 18, 1872, by Mr. D. H. Shaffer, of Cincinnati, Ohio, with the following comment (they were found in the Meek correspondence kept in the United States National Museum): "The lithograph inclosed of this Asterias was found here, and in the possession of Joseph Clark (deceased). I saw it, and this is a faithful picture of it. I think the fossil is either in the possession of his nephew or in the cabinet of Maxwell's Female Seminary, which now is the owner of Mr. Clark's cabinet. I think it is worthy a place with Palxaster shafferi in the illustrations of the Ohio Geological Survey."

From the illustration one sees that this form had on the abactinal side of the rays about nine columns of ossicles. Of these the radial, supra- and inframarginals are largest. Between the marginals there is a single column of tiny ambital pieces, while on each side of the radials are two columns of small accessory pieces. The structure of the disk pieces can not be made out.

The interbrachial areas are small and do not appear to have more than two inwardly crowded inframarginals, but there may also be present single very small axillary pieces.

The adambulacral and inframarginal columns appear to have not more than 20 ossicles in a column. Of ambulacrals there are somewhat more, about 25 , and these alternate slightly with one another.

"Asterias primordiatis" appears to be the young of Promopalxaster speciosus (Meek), and the differences can all be explained as due to incomplete development; that is, the former has fewer ossicles and fewer secondary columns of plates.

Formation and locality. - From the hills of Cincinnati, in the Maysville formation. The present whereabouts of this fine specimen is unknown. A still smaller and younger specimen is in the Faber collection of the University of Chicago (No. 9567), and was collected at 350 feet above the Ohio River at Cincinnati. It has but a single axillary plate in each interbrachial area, and about 15 adambulacrals in a column. It is interesting to note that in these young individuals of Promopalzaster, the smaller they are the more they approach Mesopalzaster and suggest Hudsonaster. 
PROMOPALEASTER SPECIOSUS (Meek).

Plate 14, figs. 3,4 ; plate 15 , figs. $1-4$.

Asterias antiquata Locke (not $A$. antiqua Troost), Proc. Acad. Nat. Sci., Philadelphia, for 1846-47, vol. 3, 1848, p. 32, fig. on p. 33.

Palæaster antiquata Hall, Twentieth Rep. N. Y. State Cab. Nat. Hist., 1868, p. 286.

Palæaster antiquatus HaLL, Twentieth Rep. N. Y. State Cab. Nat. Hist., rev. ed., $1868=1870$, p. 328 .

Palæaster granulosus Mesk (not Hall 1868), Amer. Journ. Sci., ser. 3, vol. 4, 1872, p. 276; Geol. Surv. Ohio, Pal., vol. 1, 1873, p. 60, pl. 4, figs. $3 a-c$.

Palæaster speciosus MEek, Amer. Journ. Sci., ser. 3, vol. 4, 1872, p. 277 (name at end of description); Geol. Surv. Ohio, Pal., vol.1, 1873, p. 61 (name at end of description).

Also see Promopalæaster, sp. undet., page 108.

Original description by Meek (1873).- "Attaining a large size; rays (as a little depressed by accident) slightly more than twice as long as their breadth at their inner ends; and tapering regularly from the disk to their free ends, which are rather acutely angular; breadth of the disk a little less than that of the inner ends of the rays. Marginal pieces convex [bearing numerous small spines], nearly or quite as long as wide, numbering on each side, in the whole length of each ray (1.40 inch), 31. Adambulacral pieces, a size smaller, as long as wide, convex, and numbering on each side 39 to 40 ; like those of the [infra] marginal series, each bearing a small spine [several spines], the largest of which are each about 0.14 inch in length and 0.02 inch in thickness [between each two adambulacral plates just above the podial opening is inserted a large and thick spine]. Ambulacral pieces very short, or nearly three times as wide as long, apparently not alternating with the adambulacral pieces, and each provided with a rather sharp ridge across nearly its entire breadth. Dorsal side of disk and rays composed of small tuberculiform pieces, of which about 16 rows may be counted at about half way between the inner and outer ends of each ray, along the middle of which those of two [always two] or three of the rows are a little larger than the others; each dorsal piece bearing a minute, very short spine [they are numerous and like those of the marginal plates]. Surface of all the pieces minutely granular, one of the central granules always being somewhat larger than the others for the articulation of a spine [all of these granules bear spines]. Oral pieces and madreporiform body unknown."

Emended description.-Rays regularly tapering. $\mathrm{R}=44 \mathrm{~mm}$., $r=11 \mathrm{~mm}$., $\mathrm{R}=4 r$. Width of ray at base $14 \mathrm{~mm}$.

Abactinal area of rays covered by small, highly convex, tuberculated plates, each bearing numerous short slender spines. These ossicles are arranged in longitudinal columns, of which there are 15 on each ray at about its mid-length. The plates of one or 
two median columns are larger and more convex than the three columns immediately on each side, while the pieces of the fourth column are again more pronounced than those on each side of it, and probably represent the supramarginals. Between the supramarginals and the inframarginals are from one to three columns of ambital plates, and between these are inserted here and there some small extra pieces. The extra pieces are mainly developed beside the supramarginal columns. Plates of the disk like those of the rays, but their arrangement is unknown.

Madreporite unknown.

Inframarginal plates very convex, about as wide as long excepting near the base of the columns where they are about twice as wide as long. There are about 31 of these ossicles in a column, and they have numerous small, slender, sharp spines articulating on welldeveloped tubercles.

Adambulacral plates greatly resembling the inframarginals. They are largest near the mid-length of each ray, diminish in size distally, but proximally they hold their width and decrease in length and therefore are more numerous. There are 43 plates in each column besides those in the oral armature. Ambulacrally each adambulacral plate has a short attenuate extension which articulates with the crests of the ambulacral plates. Between all the adambulacral ossicles there is inserted in the suture facing the ambulacral groove a single large, thick spine, excepting for a short distance proximally where such are inserted in every other suture. The lateral surface of the adambulacral plates in the distal half of the columns bears numerous small spines like those of the inframarginal series, but proximally these spines are gradually displaced by two or possibly more larger ones like those on the ambulacral face.

Ambulacral furrows wide and deep. Ambulacral plates of adjoining columns opposite, two or three times as wide as long, and slightly overlapping proximally. Upon each plate there is a high median ridge which arises at the inner end of the plate and abuts against the short extension of the adambulacral plate. The porial openings are between the plates and beneath the sutures of the adambulacral plates, excepting near the base of the rays, where they occur in every other suture. The ridges here are sigmoid and not straight, as they are more distally. There appear never to be more than two rows of podia in an ambulacrum.

In each axillary area inside of two large inframarginal plates and between the converging adambulacral columns are inserted two pairs of wedge-shaped interbrachial marginal plates ornamented like the inframarginals.

Formation and locality. - The holotype and only known specimen was collected by Mr. Charles B. Dyer in the Maysvillian at Cin- 
cinnati, Ohio. It is now in the Dyer collection, Museum of Comparative Zoölogy (No. 22), Harvard University. The original of Asterias antiquata Locke was found at Cincinnati, but the specimen appears to be lost.

Remarks.-Meek (1873) in describing this specimen, provisionally referred it to Palxaster granulosus Hall and commented as follows:

"Although this fine Star-fish agrees pretty well in most of its characters with the description of Palæaster granulosus of Hall (which has not yet been figured), I am far from being entirely satisfied that it is really the same, as it seems to differ in some important respects. For instance, the rays of $P$.granulosus are described as being 'obtusely rounded at the extremities'; while in the form under consideration they are rather acutely rounded, if not angular. Again, instead of having 25 of the marginal pieces on each side, in a space of one inch and a quarter from the apex of each ray, and 42 or 43 of the adambulacral, it shows in this space 28 marginal and only 32 adambulacral pieces. The number of the latter being about 10 less on each side in the same space-a rather decided difference, showing the inner row to consist of proportionally larger pieces. Its ambulacral ossicula seem to have the same proportional breadth and length as in the type of $P$. granulosus and also have each a similar ridge across the middle; but these ridges do not show the zigzag arrangement mentioned in the description of $P$. granulosus. Prof. Hall does not say how many rows of pieces are seen on the dorsal sides of the rays of his species; but he states that it is probably the same species that the Western Academy of Sciences sent out lithographs of under the name Asterias primordialis. One of these lithographs, now before me [reproduced here on plate 14, figs. 1,2], represents from 8 to 10 rows of these dorsal pieces, which is 6 or 8 less than may be counted near the middle of the rays of our specimen.

"In noticing this form in the Am. Jour. Sci., vol. 3 (3d series), p. 277, I proposed, in case it should be distinct from $P$. granulosus, to call it $P$. speciosus."

With such marked differences between $P$. granulosus and $P$. speciosus, and since the type-specimen of the former can not be located to determine the interbrachial structure, it is deemed advisable to adopt Meek's name $P$. speciosus for the specimen described above.

In the upper portion of the Ordovicic in the Richmond formation occurs another closely related species, $P$. bellulus, which is distinguished from $P$. speciosus in having more slender rays and usually a greater number of plates in the actinal columns. The greatest difference, however, is that it has seven pairs of adjoining adambulacral plates proximal to the interbrachial plates, while in $P$. speciosus there are but two or three pairs of adambulacrals. In other words, the adambulacral oral extensions are far longer in $P$. bellulus than in $P$. speciosus. 
The illustration of Asterias antiquata Locke referred to above by Meek is very poor, and yet it seems to be the same species which the latter described as $P$. granulosus $\mathrm{Hall}=P$. speciosus Meek. This, however, can not now be established since the whereabouts of Locke's specimen is unknown. Both specimens are from Cincinnati and are of about the same size. Hall comments on this species (1870) as follows:

"This species was noticed by Dr. Locke, as cited above, but without specific description, and expressing a doubt whether it was or was not identical with the Asterias antiqua of Troost. The figure would indicate a distinct species from that of Dr. Troost."

\section{PROMOPALAEASTER GRANULOSUS (Hall).}

Palæaster granulosa HaLL, Twentieth Rep. N. Y. State Cab. Nat. Hist., 1868, p. 285.

Palæaster granulosus HaLl, Twentieth Rep. N. Y. State Cab. Nat. Hist., rev. ed., $1868=1870$, p. 327 .

Original description.- "Body of medium size, five rayed; rays a little more than twice as long as their breadth at base; obtusely rounded at the extremities. Upper surface of rays composed of numerous very small tuberculose or subspinose plates; the madreporic tubercle large, quite distinct, situated laterally at the base of two of the rays. Under surface of rays composed of a [infra]marginal range of small tuberculose plates, about 25 on each side in a ray measuring one inch and a quarter from base to apex; and an inner (adambulacral) range of smaller plates, of which about 42 or 43 can be counted on the same ray; the terminal or oral [armature] plates are small, elongate, subtriangular, in pairs at the base of the adjacent rays. Ambulacral areas composed of a double series of short, broad, slightly curved poral plates (ossicula), each plate marked by a sharply elevated ridge along its entire breadth, commencing on the one plate at the outer posterior angle and terminating on the anterior inner angle, and running in the opposite direction on the adjacent plate. When the outer ridged surface of the poral plate is ground away, the narrow openings or pores are visible between the plates, apparently in two rows in each series, making four ranges of pores in each ambulacral area. (The marginal ranges of pores are obscure, and may only be apparent [there is probably an error here in regarding the inner openings as podial openings].) On the under surface, near the bases of the rays, the tubercles bear short spines some of which are still in place."

"Some figures of a Patraster, closely allied to or identical with this one, from Cincinnati, Ohio, have been circulated by the Natural History Society of that place, under the name of Asterias primordialis; but no description of it has ever been published, so far as I know, nor 
do I find it at all recognized in the catalogues." These original figures are here reproduced as Promopalæaster, sp. undet. (pl. 14, figs. 1,2$)$. The specimen is probabiy an immature individual of P. speciosus.

Formation and locality. - The holotype was found by Mr. J. Kelly O'Neall in the Lower Richmond formation near Lebanon, Ohio, and was loaned to Hall for description. The whereabouts of the specimen can not now be located. Some years ago the writer asked the late Professor Whitfield about it and he answered that Hall had returned it to O'Neall, but the latter in turn wrote (Aug. 27, 1896) that he had not received it.

Remarks. -This species seems to be distinguished by the smaller number of plates in the inframarginal columns, as the following table shows. However, until the nature of the interbrachial areas is known, the relationship of $P$. granulosus to other Paleozoic forms can not be stated.

\begin{tabular}{|c|c|c|c|c|}
\hline & $\begin{array}{l}\text { Inframar- } \\
\text { ginals. }\end{array}$ & $\begin{array}{l}\text { Adambu- } \\
\text { lacrals. }\end{array}$ & $\begin{array}{c}\text { Inter- } \\
\text { brachials. }\end{array}$ & $\begin{array}{l}\text { Adambu- } \\
\text { lacrals } \\
\text { orad to } \\
\text { inter- } \\
\text { brachials. }\end{array}$ \\
\hline P. granulosus (Hall). & 25 & $42-43$ & & \\
\hline P. speciosus (Meek) .............................. & 31 & 43 & 4 & 4 \\
\hline P. bellutus, new species................ & $31-38$ & 48-55 & 4 & 8 \\
\hline P. magnificus (Miller)... & 45 & $50-52$ & 5 & $5-6$ \\
\hline
\end{tabular}

PROMOPALEASTER BELLULUS, new species.

Plate 15, figs. 6-8; plate 16, fig. 1; plate 18, figs. 4, 5 .

$\mathrm{R}=36 \mathrm{~mm}$., $r=10 \mathrm{~mm}$., $\mathrm{R}=3.6 r$. Width of ray at base, $11.5 \mathrm{~mm}$. A first view of this species gives the impression of $P$. speciosus (Meek). Of the latter but a single specimen is known and it is now lost, while of $P$. bellulus there are numerous examples, all of which have the same specific characters. The specimens preserved in limestone have the rays more slender, while those from soft shale are as stout as in P. speciosus.

In the holotype of $P$. bellulus from limestone there are 55 adambulacral and 38 inframarginal plates in each column, while in $P$. speciosus there are 43 and 31 plates, respectively, in the same columns. Shale specimens of $P$. bellutus have less plates in a column. One of these, a somewhat smaller specimen than the holotype, has 31 inframarginal plates, the same number as in $P$. speciosus, and about 48 adambulacrals in each column. $P$. bellulus has therefore from 31 to 38 inframarginal plates and from 48 to 55 adambulacral plates in each column. 
A more important distinguishing character exists in the interbrachial areas. In $P$. bellulus and $P$. speciosus there are two pairs or four interbrachial marginal plates, while the number of adjoining adambulacral plates is greater. In the latter there are four of these on each side, while in the former there are eight. In other words, the interbrachial areas in $P$. bellulus are much more elongated orally than in $P$. speciosus and the interbrachial ares are also greater.

Abactinally on the rays the arrangement and number of columns of plates appear to be very much like those in $P$. speciosus. The individual plates are, however, less convex, cruciform, more like those of $P$. spinulosus, and have stronger and more abundant spines. The spines in $P$. bellulus are very numerous, short, and slender, and are inserted one on the apex of each plate and a number around the sides in the angles between the radial extensions. In $P$. speciosus the spines are grouped over the convex area of the plate and around the larger central spine. The arrangement of the plates of the disk appears to have no marked pattern and consists of very numerous small plates like those of the rays.

The adambulacral plates each bear three spines as in $P$. speciosus and increase in size toward the base of the rays. One is inserted on the inner or ambulacral face of the plate and the two closely adjoining ones immediately above and laterally on the rounded surface.

Ambulacral plates as in $P$. speciosus.

Madreporite of medium size, subcircular in outline, with numerous straight, sharp, radiating ridges. It is inserted proximally between two adjoining columns of supramarginal plates.

A development occurring only in this species of Promopalxaster is a single plate oral to the proximal adambulacrals. This plate has been seen in four axillary areas. It may be a modified ambulacral and may correspond to a similar plate, which is an ambulacral, in P. exculptus.

Formation and locality.-Of this species quite a number of specimens were secured by Mr. Harris in the Waynesville beds of the Richmondian. They are all in the United States National Museum. One excellent specimen (the holotype) showing the actinal area, and two smaller poorer specimens are attached to limestone, while eleven fair specimens and fragments of eight other individuals are from a soft blue shale associated with Zygospira modesta and Ptilodictya shafferi (upper form). All were secured in the vicinity of Waynesville, Ohio. The shale specimens were exhumed from one small area, showing that probably many starfishes could be similarly secured by collectors, since these soft specimens in weathering out are broken up and lost; more asterids will be found when they are dug or quarried for. Another good specimen is in the Gurley collection of the University of Chicago (No. 10983) and was found at Versailles, Indiana. 
Remarks. - The similarity and difference between $P$. bellulus and $P$. speciosus are pointed out above. Another related species is $P$. spinulosus, which has the same kind of abactinal plates and madreporite as $P$. bellulus. In the former the rays are far longer and narrower, with fewer ambital plates and columns between the supramarginals. Actinally $P$. spinulosus is at once distinguished from $P$. bellulus in the much smaller interbrachial areas, in that it does not have more than two interbrachial marginal plates while $P$. bellutus has four. In the latter species there are also far more adambulacral plates around the interbrachial pieces.

It will always be difficult to distinguish fragments of $P$. bellulus, $P$. speciosus, and $P$. spinulosus from one another, even with good material, since at least two specimens of $P$. bellulus were identified as Palæaster granulosus Hall=Promopalæaster speciosus (Meek).

Cat. No. 40879, U.S.N.M.

PROMOPALAEASTER SPINULOSUS (Miller and Dyer).

Plate 16, fig. 2 ; plate 17, figs. 1, 2; plate 18, figs. 1-3.

Compare with Promopalæaster exculptus (Miller).

Palæaster spinulosus Mrller and Dyer, Journ. Cincinnati Soc. Nat. Hist., vol. 1,1878, p. 32 , pl. 2, figs. 12-12b.

Palzaster longibrachiatus MrLLER, Journ. Cincinnati Soc. Nat. Hist., vol. 1, 1878, p. 102 , pl. 3, fig. 4 .

Original description (of Palxaster spinulosus).-."Pentagonal; rays longer than the diameter of the body; marginal plates globular near the apices of the rays, but lengthened toward the junction with the body. Six of these plates measure from the body on a ray three-tenths of an inch. Two wedge-shaped plates form the junction of the marginal plates with the body.

"Adambulacral plates a little smaller [in width] than the marginal pieces, and possessed of two or three [four or more] spines to each plate. These spines taper to a fine point, and are longer than the diameter of the plates. The oral pieces are not determined [they are like those in $P$. exculptus]. The ambulacral plates have their greatest length across the rays, and are possessed of a sharp ridge in the middle which seems to be [is] connected at one end with the adambulacral pieces. [The entire number of plates in each range can not be given, since the rays are imperfect.]-

"The dorsal side is covered with plates united by angular extensions. They are of unequal size, and strongly tuberculated or spinous.

"The madreporiform tubercle on its upper face is an oblate spheroid, much depressed, and marked by fine radiating strix, which become more numerous by intercalation, without bifurcation. [This plate is interpolated between the proximal plates of two ad- 
joining columns of supramarginal ossicles and about medially between the margin and the center of the disk.]"

Supplementary description. $-\mathrm{R}$ unknown, $r=7 \mathrm{~mm}$. Width of ray at base $9 \mathrm{~mm}$.

Abactinal area of rays margined by inframarginals, above and inside of which are columns of large, bipyriform, multispinous, supramarginal plates of which there are five in $5 \mathrm{~mm}$. at the base of a ray. The columns of adjoining rays unite in the axillary areas. Inside of the supramarginal columns the rays and disk have numerous smaller accessory plates, usually triangular in outline or variously stellate. They lie upon or against each other, each ossicle bearing at least one small spine, and leave between them numerous abactinal openings. Outside of the supramarginal plates in the ambital areas are spicular ambital plates which cover the abactinal side of the inframarginals.

Description of the type of Palxaster longibrachiatus. $-\mathrm{R}=38 \mathrm{~mm}$., $r=7 \mathrm{~mm}$., $\mathrm{R}=5.4 \mathrm{r}$. Width of ray at base $9 \mathrm{~mm}$.

Rays large, slender, tapering slowly; actinally somewhat convex at their outer ends, but elsewhere concave.

Abactinal area unknown.

Inframarginal plates granular, large, decreasing gradually in size distally, highly convex, in outline tetragonal or pentagonal and common to both the abactinal and actinal areas. From 28 to 30 plates in a column on each side of a ray.

Axillary areas occupied by the proximal plates of adjoining inframarginal columns, and in the interbrachial areas there are two subquadrangular or subtriangular interbrachial marginal plates. There may be an additional small single plate in each area.

Adambulacral plates greatly resembling the inframarginal ossicles. Distally they progressively overlap the inframarginal plates considerably, while proximally they gradually increase in size and are entirely inside and depressed beneath the plane of the marginal columns. Orally the columns of adjoining rays unite in two wedgeshaped modified adambulacrals (oral armature pieces).

Ambulacral furrows deep and gradually tapering. Ambulacral plates unknown.

Formation and locality. - The type of Palæaster spinulosus (No. 16, Mus. Comp. Zoöl.) is said to have been found at Cincinnati, Ohio. This is probably an error, since its color and preservation indicate the Richmond formation and that it comes from some locality considerably to the north of Cincinnati. The only other known specimen, the type of $P$. longibrachiatus, was found in the Richmond formation near Clarksville, Ohio, and is in the Harris collection, United States National Museum.

Remarks. - The type-specimen of Patxaster spinulosus, which is free, preserves but the disk and a small proximal portion of the rays. 
Comparing it with the actinal area of $P$. longibrachiatus Miller, it is evident that both forms are identical. In the latter the rays are complete, very long and slender, and there is nothing to show that they were dissimilar in P. spinulosus Miller and Dyer. Both types are nearly of the same size and the actinal plates are identical in form and arrangement. The abactinal area in $P$. longibrachiatus is not known, but since its actinal structure is that of Promopalaaster spinulosus it is safe to assume that the abactinal structure is alike in both.

$P$. spinulosus actinally is also closely related to $P$. exculptus (Miller). The latter appears to have shorter and more rapidly tapering rays and in general seems to be a more robust species. Another character by which these species can be separated is that the interbrachial areas in $P$. spinulosus have two, while $P$. exculptus has three interbrachial marginal plates. It is possible that the former species also has three interbrachial marginal plates, but as yet the small single piece of each area has not been observed, while in $P$. exculptus it is distinctly present in each of the five areas. Should $P$. spinulosus also prove to have three interbrachial plates, it would be difficult to distinguish it actinally from $P$. exculptus.

$P$. dyeri and $P$. magnificus are far larger species and have five interbrachial marginal plates in each area.

Cat. No. 40881, U.S.N.M.

PROMOPALEASTER EXCULPTUS (Miller).

Plate 18, fig. 7 ; plate 20, fig. 2.

Compare with Promopalxaster spinulosus (Miller and Dyer).

Palæaster exculptus Mrller, Journ. Cincinnati Soc. Nat. Hist., vol.4, 1881, p. 69, pl. 1 , fig. 1.

Original description.- "Pentagonal; rays a little longer than the diameter of the body; diameter of the body, about 0.93 inch; length of ray measuring to the center of the body or disk, about $1 \frac{1}{2}$ inches; breadth of a ray at the junction with the body, about 0.57 inch; rays obtusely pointed.

"The [infra-] marginal range consists of somewhat quadrangular plates, having a width a little greater than the length; the first 8 of these have a length of one-half inch, and there are about 18 in the length of an inch, and not far from 25 in each range, though the specimen does not permit us to make the count with certainty. The surface is strongly tubercular, and was probably spinous [originally covered with numerous small spines].

"The adambulacral range consists of about 28 [25] plates, on each side of a ray; they are narrower than the marginal plates, but have about the same length. Each plate [has a short ambulacral extension conforming with the ridge of the ambulacral plates and] bore 
strong spines, and some of them, preserved on our specimen, have a length greater than the length of a plate. * * *

"The ambulacral plates have their greatest length across the rays, thus providing a wide ambulacral furrow. Each plate is furnished with a sharp ridge in the middle, that curves slightly outward, from the center toward the adambulacral range, increasing in height until it approaches or abuts against the adambulacral plate. *** The appearance of having been carved out, which is presented by the ambulacral plates, suggested the specific name. [The plates of adjoining columns are opposite one another or slightly alternate.]

"The dorsal side and madreporiform tubercle unknown."

Supplementary description. $-\mathrm{R}=37 \mathrm{~mm} ., \cdot r=12 \mathrm{~mm}$., $\mathrm{R}=3.1 r$. The specimen is very much flattened and the exact width of a ray can not be given but appears to have been about $10 \mathrm{~mm}$. at the base.

In the axils of the rays the proximal inframarginal plates of adjoining rays rest against each other, inside of which are two wedge-shaped interbrachial marginal plates. Orad to these and adjoining the pairs of proximal adambulacrals (oral armature pieces) is situated a single subquadrate ossicle, making three interbrachial marginal plates in each interbrachial area.

The podial openings in the ambulacral grooves are between the sutures of adjoining adambulacral and ambulacral plates along the line where these two columns adjoin. The proximal ambulacral plates orad to the axial adambulacrals are considerably modified and are to be considered as parts of the oral armature. A single rather large plate is here partially wedged between the pair of terminating adambulacrals, and on each end of it abuts a single broadly triangular plate, a modified ambulacral, completing the oral ends of the ambulacral columns (see drawing, pl. 20, fig. 2).

Formation and locality. - In the Richmond formation near Waynesville, Ohio. The holotype and only specimen is in the Harris collection of the United States National Museum.

Remarks. - This species is near $P$. spinulosus, but apparently had wider, shorter, and more rapidly tapering rays. There appear to be but two interbrachial marginal plates in $P$. spinulosus, while $P$. exculptus has three in each area. Should the former species also prove to have three plates, a possibility, $P$. exculptus will be actinally identical with $P$. spinulosus. The wider and more rapidly tapering rays of $P$. exculptus can then be explained by the fact that the typespecimen is considerably distorted, since the adambulacrals and inframarginals now lie wholly outside of the ambulacrals, which are completely exposed, an unnatural condition. So long as the abactinal area of $P$. exculptus remains unknown the species had best be retained.

Cat. No. 60608, U.S.N.M. 
PROMOPALEASTER WYKOFTI (Miller and Gurley).

Plate 18, fig. 6; plate 19, fig. 2.

Palæaster wykoffi Mruler and Gurley, Bull. No. 12, Illinois State Mus. Nat. Hist., 1897, p. 46, pl. 3, fig. 27.

Original description.- "Species medium size $[\mathrm{R}=26 \mathrm{~mm}$., $r=8 \mathrm{~mm}$. Width of ray at base $10 \mathrm{~mm}$.] Rays pateliform; length about one and a half times the diameter of the body; breadth of a ray at the place of junction with the body, about two-thirds the diameter of the body; obtusely pointed.

"Marginal [inframarginal] plates wider than long and numbering about 15 in the length of half an inch from the body [or about 28 in a complete column]. The [infra] marginal plates curve regularly around the tips of the rays. The adambulacral range curves around the ends of the rays within the marginal plates and consists of subquadrate plates, wider than long. They are a little shorter than the marginal plates, so that there are about 18 in the length of half an inch [about 35 in a complete column]. There are 10 oral plates [oral armature] at the junction of the adambulacral rows, which present triangular extensions toward the center of the ventral cavity. A single irregular axillary plate rests between the terminal marginal plates and the angle formed at the junction of the adambulacral plates [this description is inadequate, see beyond for the detail]. The ambulacral plates have their greatest length across the rays, thus providing a wide ambulacral furrow. Each plate is furnished with a sharp ridge in the middle, extending from the middle furrow to the adambulacral plates.

"Our specimen exposes only the ventral side and no spines are preserved. It is a well-marked and beautiful species."

Formation and locality.-Found in the Richmond formation "near Madison, Indiana, by Charles W. Wykoff, in whose honor we have proposed the specific name." The holotype is now in the Gurley collection of the University of Chicago (No. 6066).

Remarks.-Each interbrachial area begins orally with a pair of elongate triangular basal adambulacrals (the oral armature pieces) distally to which there are two pairs of adjoining adambulacrals followed by a single axillary ossicle and usually one but also more or less of a second pair of interbrachial marginal plates. $P$. wykoffi is therefore distinguished from $P$. exculptus in that it has orally to the single interbrachial plate two pairs of proximal adambulacrals instead of one as in the last-named species. These differences are not decided, and it may eventually be seen when more well-preserved material is at hand that they are either individual variations or due to differences in age. 
$P$. wykoffi also greatly resembles Anorthaster miamiensis, but the interbrachial areas in the latter are entirely composed of adambulacral plates, there being no interbrachial marginals present. While both species attained a similar size, another difference is that the former has a greater number of plates in the adambulacral and inframarginal columns.

PROMOPALEASTER DYERI (Meek).

Plate 18, fig. 8 ; plate 20 , figs. $3-6$; plate 25 , fig. 1 .

Palæaster dyeri Mеєк, Amer. Journ. Sci., ser. 3, vol. 3, 1872, p. 257; Geol. Surv. Ohio, Pal., vol. 1, 1873, p. 58, pl. 4, figs. $2 a-2 f$.

Original description (1873).- "Among the specimens loaned to me for study and description by Mr. Dyer, there is a very imperfect example of one of the largest known species of Silurian Starfishes. When entire, it could scarcely have measured less than 5 inches in diameter $[\mathrm{R}=$ probably 3 inches, or $75 \mathrm{~mm}$.] across from end to end of the rays on opposite sides; and it presents a breadth of disk (as flattened by pressure) of about 2 inches $[r=$ probably seven-eighths inch, or $22 \mathrm{~mm}$.]. Its state of preservation is, unfortunately, such as not to admit of systematic description, but I think enough of its character can be given to enable the student to identify it, by the additional aid of figures.

"The dorsal side of both disk and rays is composed of numerous small pieces [with stellate extensions], with the pores between them apparently so large that these pieces only seem to touch at three to four salient points of each, so as to form a kind of reticulated structure; while they each bear a little central tubercle, with a minute pit in its top for the articulation of small, short [blunt] spines, generally about 0.07 to 0.09 inch in length, and about 0.02 to 0.03 inch in thickness. [Each plate bears but one of these spines and there appear to be no other smaller spines.]

"In one of the axilla between two of the rays the so-called madriporiform body can be seen near the margin of the disk. It is nearly flat, of an obtusely subtrilobate form [probably cruciform], with a breadth or transverse diameter of $0.30 \mathrm{inch}$, and a diameter at right angles to the same of 0.24 inch [not less than $10 \mathrm{~mm}$.]. Its lobed edge is directed inward toward the middle of the disk, and its middle lobe is largest, and shows the little divisions between the slits or furrows, diverging and bifurcating inward like the nervation in the pinnules of some kind of ferns; while in the smaller lateral lobes these markings diverge outward.

"The ventral side is also much obscured by the adhering matrix, and numerous detached and confusedly mingled spines. A row of comparatively small, tumid, nearly square [infra] marginal pieces, 
however, can be seen in places, on each side of the ambulacral furrows, and alternating with a row of similar but slightly smaller adambulacral pieces, the number of pieces in each side of these being about the same. [In the proximal portion of a ray there are 19 marginal plates in $40 \mathrm{~mm}$.]. The marginal pieces seem each to connect with the adjacent range of dorsal pieces, at places in the rays, by a little central salient point only, while those of both series are roughened by numerous comparatively coarse granules [all of which bear small spines], and each piece (especially [only] of the marginal row) also shows a small central pit for the articulation of a spine. These spines are larger than those connected with the dorsal pieces, being generally about 0.22 inch in length and 0.05 inch in thickness; they are smooth, straight, rounded, slightly thickened at the attached end, and tapering at the free end to a slightly blunted point. [The adambulacral plates also possess these large spines, which are inserted on the distal inner edge of each plate.]"

In each interbrachial area there are two pairs of wedge-shaped pieces and a single diamond-shaped interbrachial marginal plate. There are at least 4 (and may be as many as 10) pairs of adambulacral plates orally or in the actinal interbrachial areas, the terminal pair being of the oral armature.

Ambulacral plates much wider than long, increasing rapidly in width toward the mouth. Each plate is carinated as in $P$. speciosus and proximally as in $P$. magnificus, with the podial openings confined to the extreme outer edge of the ambulacral furrows.

Formation and locality.-Found at Cincinnati, Ohio, in the Maysville beds, about 200 feet below the top of the hills. The holotype is in the Dyer collection of the Museum of Comparative Zoölogy, Harvard University (No. 13). Another specimen from near the top of the Maysville at Cincinnati, preserving only the disk and showing best the actinal area, is in the Gurley collection of the University of Chicago (No. 10989). Originally this individual appears to have been larger than the holotype.

Remarks. - The relationship of this species is with $P$. spinulosus, but the larger size, greater development of both dorsal and ventral spines, absence of columnar arrangement of the abactinal plates, and the presence of five instead of two or three interbrachial marginal plates will readily separate $P$. dyeri from the latter species. Even though this form appears to have attained a larger growth than $P$. magnificus, which it resembles in some characters, it differs in being more ponderous in its skeleton and in the far stouter and longer actinal spines.

Regarding the generic position of Palæaster dyeri, Meek wrote:

"Possibly I should have called it Petraster dyeri, for if the apparent presence of a few disk plates on the ventral side between the mar- 
ginal pieces and the adambulacral, is not deceptive, it would, in that respect, conform to the structure of that group, and differ from Patæaster, as now understood; though I am inclined to think this appearance due to the accidental displacement of the parts at the point where there are some indications of a few disk pieces." These pieces are not to be correlated with the accessory interbrachial plates of Petraster, for in this genus accessory plates consist of two short columns situated between the adambulacral and marginal plates and uniting in the axillary areas. In P. dyeri, however, the four interbrachial marginal plates are continuous with the inframarginal columns and evidently were derived from that series, and are not accessory interbrachials. It is true that all interbrachial plates increase the size of the disk, but in one they are derived from the inframarginal series. by crowding and in the other they are interpolated, newly developed plates that force apart the columns of plates in the rays sometimes almost to the distal ends.

\section{PROMOPALAEASTER MAGNIFICUS (Miller).}

Plate 21, fig. 1; plate 22, fig. 1; plate 23, figs. 1-3.

Palæaster magnificus MrrLen, Journ. Cincinnati Soc. Nat. Hist., vol. 7, 1884, p. 16, pl. 4, figs. $3,3 a$.

Original description.- "The diameter or breadth of the disk is one and one-fourth inches, and the distance from the point of one ray to the point of the opposite one, if the rays were wholly preserved in the specimen under examination, would be fully 6 inches. ***

"The plates upon the dorsal side are very convex, and part of them, at least, were spine-bearing, though it would seem that there was not more than one spine upon any single plate. The arrangement of the plates on the dorsal side of the rays is very ornamental. A single series of highly convex or conical plates, larger than the others, and each evidently bearing a central spine, occupies the middle of each ray; on either side near the margin of each ray there is a similar series, and the two intervening spaces are filled with smaller, convex plates arranged in rows which are directed diagonally forward from the plates of the side series to the plates of the central series, forming angles with each plate in the central series occupying an angle. This disposition of the plates on the dorsal side of the rays will, so far as known, serve to distinguish this species from any hitherto described.

"The plates covering the dorsal side of the body or disk have been so much disturbed in our specimen that one can not correctly define them.

"The ambulacral furrows are wide. The marginal plates are hexagonal, about the size of the larger plates on the dorsal side of 
the rays, and separated from the side series by intervening smaller plates. Each bore several small spines, as shown by the small pits for their articulation. * * *

"The adambulacral plates are hexagonal and much wider than long. They are more numerous than the marginal plates near the disk, but toward the apices of the rays they interlock alternately with the marginal plates. The number on each side of a furrow in a complete ray would be 50 or more. The pits for the articulation of the spines are as numerous as they are on the marginal plates. These two series on the ventral side of the species, with numerous spines upon each plate, are in striking contrast with the plates on the dorsal side of the rays, where no plate bears more than a single spine.

"The ambulacral plates have their greatest length across the rays, and seem to be about as numerous as the adambulacral ones. An angular depression marks the center of each ambulacral furrow, upon each side of which a sharp ridge arises upon each ambulacral plate, and curving forward and outward abuts against an adambulacral plate."

Emended description.-The largest specimen, the holotype, measures $\mathrm{R}=$ (about) $67 \mathrm{~mm}$., $r=17 \mathrm{~mm}$., $\mathrm{R}=$ nearly $4 r$. Another specimen: $\mathrm{R}=58 \mathrm{~mm} ., r=15 \mathrm{~mm}$., $\mathrm{R}=$ nearly $4 r$.

Abactinal surface very ornamental. Medially along each ray there is a radial column of highly convex plates, and two columns of similar plates, the supramarginals, are situated near the margin. Between the inframarginal, supramarginal, and radial columns are very numerous diagonal rows of smaller conical or angular plates, from 2 at the apex of the ray to 14 at base of same in each row on each side of the radial column. This may be stated in another way. Between the radial and supramarginal columns and again in the ambital area, or between the supramarginals and inframarginals, the diagonal rows have from one to seven plates in each area. These rows are directed diagonally and distally across the rays from the sides to the median column, the apex of the angle thus formed being occupied by the larger plates of the radial column. All of these smaller plates apparently bore a single short spine. Between all of the diagonal rows are inserted both proximally and distally numerous minute, conical, irregular-shaped plates. The supramarginal columns continue across the disk and those of adjoining rays unite in the axillary areas. The radial columns also extend over the disk but do not attain the center, and the diagonal arrangement of the small plates ceases near the proximal portion of the rays. The pattern arrangement of the disk plates can not be made out since their original position is disturbed.

Madreporite quite large, quadri-lobate in outline, depressed, convex and very finely radiately striate. It is situated in one of the axillary 
areas, less than $4 \mathrm{~mm}$. from the margin. Against it rest two columns of supramarginal plates.

The inframarginal plates, of which there are at least 45 in each column, are distally small and subquadrate but proximally increase rapidly in size and at the base of the columns are three to four times as wide as long. These plates bear numerous pitted pustules upon which articulated short, sharp, smooth spines. The columns of adjoining rays meet in the axils and continue into the interbrachial areas.

The adambulacral plates are like the inframarginals but do not increase so rapidly in width as those plates and are somewhat more numerous, there being in a complete ray about 52 in a column. Proximally some of the large plates are broken into two or three often very convex ossicles. In addition to the small spines like those of the inframarginals, each plate bears on its ambulacral edge a prominent socket in which articulated a long, thick, smooth spine. The adambulacral plates in the proximal third of the rays each have a small, more or less wedge-shaped, carinated, accessory adambulacral plate. In this region these ossicles separate the adambulacrals from the ambulacrals and beneath the accessory adambulacral plates are the podial openings. Five or six adambulacral plates of each column abut against the interbrachial marginal plates, while five or six pairs continue orally, the terminating pieces being of the oral armature.

Ambulacral furrows wide, increasing in width proximally. An angular median sinus marks each ambulacral furrow. Ambulacral plates short but wide, slightly overlapping proximally, and one to each adambulacral plate. All of the plates are strongly carinated, the carina in the distal two-thirds converging medially and proximally. In the proximal third the carinæ gradually are changed in form and are there arranged in forked pairs. In other words, the carinæ adjoin the accessory adambulacrals, are arranged in pairs, continuing adjoining and straight for a short distance, and then diverge in broad curves, terminating near the center of the ambulacral groove. This arrangement produces in the proximal portion of the ambulacral furrows four columns of ovoid pits, all terminating laterally into podial openings. Every other podial opening belongs to the same column, one series beneath the adambulacrals, the other gradually. passing medially in the ambulacral grooves. In the distal two-thirds, however, the podial openings are arranged in single columns, one to each ambulacral plate and issuing from underneath the adambulacrals.

Interbrachial areas with seven plates, each composed of two proximal inframarginals, beneath which are two pairs of interbrachial marginals and a single diamond-shaped axillary marginal plate. All bear similar spines and ornamentation on the inframarginals. Sometimes one of the distal interbrachial marginals may be divided and 
the arrangement of the interbrachial plates made irregular. In a specimen from Jefferson County, Indiana, there are 3 pairs of interbrachial marginals instead of 2 as in the Ohio individuals. Therefore there are also more adambulacrals here, 14 pairs against 10 in the typical specimens.

Formation and locality. - Two free specimens of this magnificent starfish were found in the Richmond formation near Waynesville, Ohio. Originally pieces of these two individuals were glued together as one specimen, which is the cause of our figures being less perfect than Mr. Miller's. Fragments of seven other individuals were found in the vicinity of Waynesville. In the University of Chicago collection (No. 10981) there is a specimen from Jefferson County, Indiana, apparently of this species. Mr. Vaupel secured the distal portion of a ray of an apparently young example of this species in the Maysville beds on Rohs Hill, Cincinnati, Ohio, and Mr. Ulrich has fragments of four individuals from the Maysville strata about Cincinnati, and Covington, Kentucky.

Remarks. - This species is readily separated from the other species of Promopalxaster by the marked diagonal rows of abactinal plates. Actinally $P$. magnificus is readily distinguished from $P$. exculptus and $P$. spinosus in having five instead of three interbrachial marginal plates in each area, in the rapidly increasing size of the plates in the inframarginal and adambulacral columns, and in the proximal ambulacral plates. $P$. speciosus differs at once from $P$. magnificus in that its abactinal plates are arranged in regular longitudinal columns, are far less numerous, larger and are all nearly of a size.

This is one of the largest and best preserved of American Paleozoic starfishes. P. dyeri may be a larger species but is distinguished abactinally not only by the arrangement and difference in the forms of the plates but also by the short, thick, blunt spines which now appear to have no definite arrangement, while $P$. magnificus has all of its very fine spines arranged in diagonal rows like the plates.

Cat. Nos. 40883, 60621, 60622, U.S.N.M.

ANORTHASTERIN AE, new subfamily.

Aberrant Promopalæasteridæ with the axillary and interbrachial areas composed entirely of adambulacral pieces.

Contains:

Anorthaster.

ANORTHASTER, new genus.

Plate 13, fig. 4 ; plate 20, fig. 1.

Anorthaster Schuchert, Fossilium Catalogus, Animalia, pt. 3, April, 1914, p. 11.

$A+o r t h o s+a s t e r=$ out of the regular, in reference to the completely adambulacral nature of the interbrachial areas. 
Generic characters.-Disk small, with apparently small interbrachial arcs. Rays five, of moderate length and tapering at first slowly and then rapidly distally.

Abactinal area unknown.

Inframarginal plates small, the columns not attaining the axils, but resting upon the second enlarged axillary adambulacral plate.

Adambulacral plates distally like the inframarginals, increasing in size slowly proximally until near the axillary region, where four plates suddenly attain great width, terminating in the axils of the rays and here suppressing the inframarginal plates. Eight interbrachial adambulacrals of varying form are situated orally to the two large axillary adambulacral plates, and at first give one the impression of slender interbrachial areas of the same nature as in Promopalzaster. These plates, however, are not interbrachial marginals, as in other genera, and derived by the oral crowding of proximal inframarginals. They are distinctly adambulacral ossicles, forming slight interbrachial areas, and, with the axillary adambulacrals, form small ares. For the shape and position of these plates see figure 1, plate 20 .

Ambulacral plates alternating, slightly carinated, and very short but wide. In the distal region they are as long as the adambulacral plates, but proximally decrease in length where there are nearly two of them to one adambulacral ossicle. Podial openings between every other plate through the sutures of adjoining pieces at their outer edge and immediately beneath the inner edge of the adambulacral ossicles. The proximal plates of each column are modified into oral armature pieces that are slightly tumid, as long as wide, and subtriangular in outline. Between the proximal ambulacrals and orad to the proximal interbrachial adambulacrals are situated additional single, very small, quadrangular oral armature plates.

Genoholotype and only species.-Palæaster miamiensis Miller.

Distribution.-Ordovicic, Richmond formation, near Waynesville, Ohio.

Remarks. - The suppression of the inframarginal plates in the axils of the rays by two of the adambulacral plates of each column and the oral continuation beneath the latter of four pairs of adambulacral plates holding an interbrachial position distinguish this genus from Promopalæaster, to which it otherwise seems very closely related. This character also distinguishes it from all other associated genera.

The interbrachial structure of Anorthaster appears abnormal. In Mesopalæaster and Promopalæaster the proximal inframarginal plates are crowded orally and form interbrachial areas; in Anorthaster their formation is effected in the opposite way, not by the inframarginals, but by the adambulacrals. This character is seen in a single specimen, but it is so regularly developed and well preserved as to indicate a normal and not a pathologic or abnormal condition. 
ANORTHASTER MIAMIENSIS (Miller).

Plate 13, fig. 4; plate 20, fig. 1.

Palæaster miamiensis Mrrler, Journ. Cincinnati Soc. Nat. Hist., vol. 3, 1880, p. 143 , pl. 4 , fig. 3.

Original description.- "Pentagonal; rays about one and a half times the diameter of the body, or about nine-tenths of an inch; diameter of the body about six-tenths of an inch; breadth of a ray at the point of junction with the body a little more than half the diameter of the body, or about seven-twentieths of an inch; rays obtusely pointed.

"Marginal plates wider than long, and numbering about 12 in the length of half an inch from the body. Two marginal plates form the junction of the rays. Ambulacral furrow wide, the plates being more than twice as long as wide. There are about 18 ambulacral plates in a length of one-half inch, and each one is provided with an angular ridge tapering from the marginal plates to the furrow."

Emended description. $-\mathrm{R}=23 \mathrm{~mm}$, $r=7 \mathrm{~mm}$., $\mathrm{R}=3.2 r$. Width of rays at base $8 \mathrm{~mm}$.

Rays tapering very slowly in the proximal half, but more rapidly distally.

\section{Abactinal area unknown.}

Inframarginal plates about 16 in each column and subquadrangular in outline. These ossicles do not continue into the axils, but rest upon the second large axillary adambulacral plate.

Adambulacral plates about 18 in each column, like the inframarginal pieces, increasing in size proximally, while the two axillary ones are suddenly enlarged, extend to the margin of the disk, and have the position of marginal ossicles. Orally to the latter the adambulacral plates continue as interbrachial ossicles. The distal pair is large and both are wedge-shaped, followed by two pairs of quite small quadrangular plates and a final pair of long and narrow plates; in all there are, therefore, 22 adambulacral plates in each column. The interbrachial adambulacral plates are terminated by a single quadrangular oral plate wedged in between the proximal ambulacrals.

Ambulacral furrows very wide, broadly gutter-shaped. Ambulacral plates about 30 in a column, slightly alternating, decidedly wider than long proximally, increasing in length distally, and finally becoming about as wide as long near the apex of a ray. Each plate is slightly carinated, the ridges crossing the plates from the lateral distal edge to the medial proximal edge. The proximal ambulacral plates are modified, conspicuous, and subtriangular in outline. Podial openings between two adjoining plates in alternate sutures at $50601^{\circ}-$ Bull. $88-15-9$ 
their extreme outer edges and immediately inside of the adambulacral plates.

Formation and locality. - In the Richmond formation, near Waynesville, in Montgomery County, Ohio. The holotype is in the Harris collection of the United States National Museum.

Remarks. - This species has a general resemblance to some of the Promopalæasters, particularly $P$. bellulus and $P$. wykoffi, but the peculiar arrangement of the axillary and interbrachial adambulacral plates will distinguish it not only from them but from all other Ordovicic asterids.

Cat. No. 40880 , U.S.N.M.

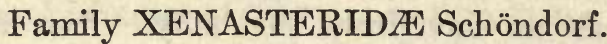

Xenasteridæ GreGory, Geol. Mag., dec. 4, vol. 6, 1899, p. 346; Treat. Zool., vol. 3, Echinoderma, 1900, p. 250.

Palægoniasteridæ Stü rTz, Palæontographica, vol. 36, 1890, p. 247 (not opp. 246).

Xenasteridæ SchöNDORF, Palæontographica, vol. 56, 1909, p. 105; Jahrb. nassauisch. Ver. Naturk., Wiesbaden, vol. 62, 1909, p. 25; vol. 63, 1910, pp. 244, 250.

Progressive Phanerozonia having the general characters of the Promopalæasterinæ, with the addition of accessory interbrachials. The ambulacral and adambulacral plates are directly opposite one another and do not waver between the slightly alternate and opposite arrangement in the Promopalæasterinæ. Podial openings in two columns in each ambulacral furrow, the apertures lying between each four adjoining plates, that is, between two adambulacrals and two ambulacrals.

Contains:

Xenaster Simonovitsch.

Agalmaster Schöndorf.

Rhenáster Schöndorf.

Eifelaster Schöndorf.

Trimeraster Schöndorf.

Schöndorf defines the family as follows (leaving out much of his detail):

Lower Devonic starfishes with well-developed supramarginals and usually still largerinframarginals; the latter are somewhat more numerous than the former, causing them to be unequally superposed. Ambulacra opposite one another and opposite the adambulacrals; podial openings in two rows. Actinally each interradius has either three or five interbrachial plates; abactinally this area is filled with small accessory plates and margined only by inframarginals. Disk skeleton consisting of small separated pieces, a central disk plate, five primary radialia, five primary interradialia, and more or less of accessory disk 
ossicles. Rays with three columns of plates, one radial and two supramarginal, that may or may not be separated from one another by small accessory pieces. Madreporite dorsal and interradial.

\section{Genus XENASTER Simonovitsch emend. Schöndorf.}

Plate 24.

Archæasterias MülleR, Verh. naturh. Ver. preuss. Rheinl., etc., vol. 12, 1855, pp. 6, 8 (Archæasterias founded in error).

Xenaster Simonovitscr, Sitzb. mat.-naturw. Classe Akad. Wiss., Wien. vol. 64, Abt. 1, 1871, p. 88.-SchöndoRF, Palæontographica, vol. 56, 1909, pp. 42, 105 (complete synonymy given here); Jahrb. nassauisch. Ver. Naturk., Wiesbaden, vol. 62,1909 , p. 26.

Generic characters.-Xenaster has its nearest relationship in Devonaster. No detailed description need be given, since the splendid illustrations of Schöndorf give all the necessary characters. It differs from Devonaster as follows:

In Devonaster there is but a single interbrachial plate in each actinal axil, the axillary interbrachial, while in Xenaster there are two pairs of interbrachial marginals and a single axillary interbrachial plate; in other words, five interbrachial platès instead of one $(1+2+2)$. In addition to these plates in Xenaster, the interbrachials are more or less surrounded by small accessory pieces, and then other similar plates separate the inframarginal and adambulacral columns to near the outer third of the rays. The inframarginal plates in Xenaster do not increase so rapidly in width proximally as do these plates in Devonaster, and while the interbrachial areas are of about the same size in both genera, the space occupied by the additional interbrachial marginal and accessory interbrachial ossicles in the former is taken up in the latter genus by the increased size of the inframarginal pieces.

Abactinally Xenaster has the generic characters of Devonaster. The plates in all the columns of the former genus are more prominent and rounder, particularly the accessory plates, of which there appear to be less than in Xenaster. The center of the disk in both genera is occupied by a small central disk plate, but there are many more accessory plates around it in Devonaster than in Xenaster. In both genera the supramarginal columns converge proximally, producing small disk areas between the infra- and supramarginal plates occupied by ambital accessory plates.

Madreporite large and striate in Xenaster.

Genotype. $-X$. margaritatus Simonovitsch. 
Distribution.-Restricted to the Lower Devonic of Germany. The species are:

$X$. margaritatus Simonovitsch.

$X$. dispar Schöndorf.

$X$. elegans Schöndorf.

$X$. (?) rhenanus (Müller).

Remarks.-Müller in his description of Asterias rhenana, ${ }^{1}$ the genotype of Archrasterias, notes that the adambulacral plates of adjoining columns alternate and that the ambulacral columns "have the appearance also of alternating," which if established would be very remarkable, and would justify the creation of a distinct genus Archrasterias for this asterid of the Rhine grauwacke. Schöndorf shows that these statements of Müller's are very faulty and further that the genus Archrasterias has not been defined so as to be recognizable. Under these circumstances it was best for Simonovitsch to disregard Archæasterias and to establish a new generic name for his species margaritatus. There is no Paleozoic genus of starfishes better described or illustrated than this one by Simonovitsch, and should it ever prove that Asterias rhenana Müller is identical with Xenaster margaritatus, a possibility, the latter should not be made to give way to the former on the ground of priority. It is an injustice to extend the law of priority indiscriminately to all work, and to reject Archrasterias is no reflection on the work of Müller, as his material was very poor and his work of early date in paleontology. He published at a time when it was very desirable to learn anything whatever about Paleozoic starfishes.

As pointed out above, Xenaster has much of the structure of Devonaster, yet it differs in the important character of having numerous accessory interbrachial plates. This feature seemingly relates it with forms like Palasterina which have a great abundance of accessory interbrachials, yet in no interbrachial area of this genus are there axillary interbrachials or interbrachial marginals. In other words, the Palasterina type of disk is made by the intercalation of accessory plates between the inframarginals and adambulacrals, whereas in Devonaster it is accomplished by the greater width of the inframarginals and by the oral crowding of a plate which in primitive forms is an axillary marginal. Devonaster although from younger strata is more primitive than Xenaster because of its simpler interbrachial actinal structure. If it were not for the accessory interbrachials, Xenaster would be closely related to Promopalxaster which also has a number of proximal inframarginals crowded into the interbrachial areas. It is the Promopalxaster stock out of which Xenaster probably developed, while Devonaster apparently came through Mesopalæaster.

1 Verh. naturh. Ver. preuss. Rheinl., etc., vol. 12, 1855, pp. 6, 8. 


\section{XENASTER MARGARITATUS Simonovitsch emend. Schöndorf.}

Plate 24, figs. 1, 2.

Xenaster margaritatus (part) Srmonovitsch, Sitzb. mat.-naturw. Classe Akad.

Wiss., Wien, vol. 64, Abt. 1, 1871, p. 88, pls. 1, 2.-SchöNdorf, Palæontographica, vol. 56,1909 , pp. 43, 106, pl. 7, figs. 1, 3, 4; pl. 8, fig. 1; pl. 11, figs. $2,3,10,11$ (complete synonymy given here); Jahrb. nassauisch. Ver. Naturk., Wiesbaden, vol. 62, 1909, p. 26, pl. 2, figs. 1, 2.-Spencer, Mon.

Brit. Pal. Asterozoa, pt. 1 (Palæontogr. Soc. for 1913), 1914, p. 30.

This species is one of the best described and illustrated of Paleozoic starfishes and does credit to its author, and to its subsequent reviser, Schöndorf. It occurs rarely in the Lower Devonic (Upper Coblenzian) as natural molds at Niederlahnstein on the Rhine, Germany.

\section{XENASTER DISPAR Schöndorf.}

Xenaster margaritatus (part) SrmonoviTscH, Sitzb. mat.-naturw. Classe Akad.

Wiss., Wien, vol. 64, 1871, Abt. 1, pl. 2, figs. 2, $2 a, 2 b$.

Xenaster dispar SchöNDORF, Palæontographica, vol. 56, 1909, pp. 50, 84, 106,

pl. 9, fig. 1; pl. 11, fig. 13; Jahrb. nassauisch. Ver. Naturk., Wiesbaden, vol.

62,1909 , p. 28 , pl. 3 , fig. 3.

From the Upper Coblenzian at Niederlahnstein, and Miellen, Germany.

\section{XENASTER ELEGANS Schöndort.}

Xenaster margaritatus Foldmann (not Simonovitsch), Jahrb. naturh. Ver. preuss. Rheinl., etc., vol. 48, 1891, p. 150.

Xenaster elegans ScHöNDORF, Palæontographica, vol. 56, 1909, pp. 53, 107, pl. 9, figs. 2,3 ; pl. 11, figs. 4, 12; Jahrb. nassauisch. Ver. Naturk., Wiesbaden, vol. 62,1909, p. 40, pl. 4 , figs. 6,7 .

From the Lower Devonic (Coblenz quartzite) at Königstuhl, near Rhens, Germany.

\section{XENASTER (?) RHENANUS (MUIler).}

Asterias (Archæasterias) rhenana MüLLER, Verh. naturh. Ver. preuss. Rheinl., etc., vol. 12, 1855, p. 6, pl. 1, figs. 4-6.

Xenaster (?) rhenana ScHöNDORF, Palæontographica, vol. 56, 1909, pp. 55, 107, text fig. 2 (complete synonymy given here); Jahrb. nassauisch. Ver. Naturk., Wiesbaden, vol. 62, 1909, p. 28.

This species is based upon incomplete material and can not be made out fully. It seems probable that it is a species of Xenaster and closely related to $X$. margaritatus Simonovitsch. The examples are in the Berlin Museum and were found in the Lower Devonic at Winningen, near Coblenz, and Kemmenau, near Ems, Germany.

\section{Genus AGALMASTER Schöndorf.}

\section{Text fig. 9.}

Agalmaster SchöNDoRF, Palæontographica, vol. 56, 1909, pp. 58, 107; Jahrb. nassauisch. Ver. Naturk., Wiesbaden, vol. 62, 1909, p. 29.

Original remarks.-Agalmaster differs from Xenaster in the following characters: Forms larger, broader rayed, with flat actinal but highly arched abactinal plates. Supramarginals much stronger than the large inframarginals and projecting considerably beyond these. 
Abactinal interbrachial area small, and occupied in the main by two axillary inframarginals; actinally this area has the same structure as Xenaster. Madreporite dorsal.

Genoholotype (the writer here selects the first species).-A. miellensis Schöndorf. Other species are $A$. grandis Schöndorf and $A$. intermedius Schöndorf, both from the Lower Devonic of Germany.

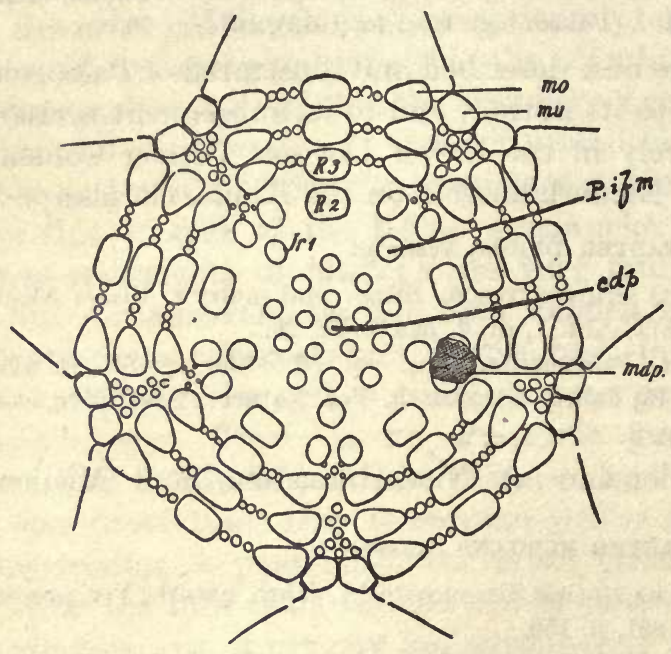

Fig. 9.-Agalmaster Miellensis, AFTER SchöNdoRf. Schematic ARRANGEMENT OF ABACTINAL PLATES. $R_{2}$ AND $R_{3}$, SECOND AND THIRD PROXIMAL RADLALIA; $J r_{1}$, PRIMARY INTERRADLALIA; $c d p$, CENTRAL PLATE; $m d p$, MADREPORITE; mo, SUPRAMARGINALIA; mu, INFRAMARGINALIA; Pifm, PRIMARY INTERRADIALIA.
Remarks. - The only character that may be of generic value and that at present distinguishes Agalmaster from Xenaster is that in the former genus the supramarginals margin the rays instead of the inframarginals, as is the case in the latter genus. In a second species $(A$. grandis) the small accessory interbrachials crowd in between all the pairs of interbrachial marginals and, further, there are far more of these pieces between the inframarginals and adambulacrals; in fact, there are three to four columns of these instead of one (as in $A$. miellensis).

\section{AGALMASTER MIELLENSIS Schöndorf.}

Text fig. 9 .

Agalmaster miellensis ScHöNDoRF, Palæontographica, vol. 56, 1909, pp. 58, 107, text fig. 3 ; pl. 8. fig. 4 ; pl. 9, fig. 4; pl. 11, figs. 1, 5; Jahrb. nassauisch. Ver.' Naturk., Wiesbaden, vol. 62, 1909, p. 29, pl. 3, fig. 2 ; pl. 4, figs. 1, 2.

A single specimen with the rays about $43 \mathrm{~mm}$. long was found in the Lower Devonic (Upper Coblenzian) at Miellen-on-the-Lahn, Germany.

\section{AGALMASTER GRANDIS Schöndorf.}

Xenaster margaritatus Srmonovitsch (part), Sitzb. mat.-naturw. Classe Akad. Wiss., Wien, vol. 64, Abt. 1, 1871, pl. 2, figs. 3, $3 a$.

Agalmaster grandis SchöNDORF, Palæontographica, vol. 56, 1909, pp. 62, 108, pl. 9, fig. 5; Jahrb. nassauisch. Ver. Naturk., Wiesbaden, vol. 62, 1909, p. 29, pl. 3 , fig. 1.

One specimen (Xenaster margaritatus Simonovitsch, part) from the Lower Devonic (Upper Coblenzian) at Niederlahnstein on the Rhine, Germany. 
AGALMASTER INTERMEDIUS Schöndorf.

Agalmaster intermedius ScHöNDoRF, Palæontographica, vol. 56, 1909, pp. 82, 108, pl. 11, fig. 14; Jahrb. nassauisch. Ver. Naturk., Wiesbaden, vol. 62, 1909 , p. 30 .

From the Upper Coblenzian at Miellen-on-the-Lahn, Germany.

\section{Genus RHENASTER Schöndorf.}

Text fig. 10.

Rhenaster SchöNdoRf, Palæontographica, vol. 56, 1909, pp. 65, 108, pl. 8, fig. 3; pl. 10, figs. 1, 4.

Remarks.-Rhenaster is a small form and differs from Xenaster, Agalmaster, and Devonaster in the complete absence of all abactinal accessory plates, allowing the radial and supramarginal pieces to adjoin one another closely. Dorsal axillary disk areas not completely but almost absent, supramarginals in the main lying wholly upon the inframarginals and the two columns of plates together margining the rays. There also are no accessory plates of any kind on the actinal side. Otherwise the generic struc-

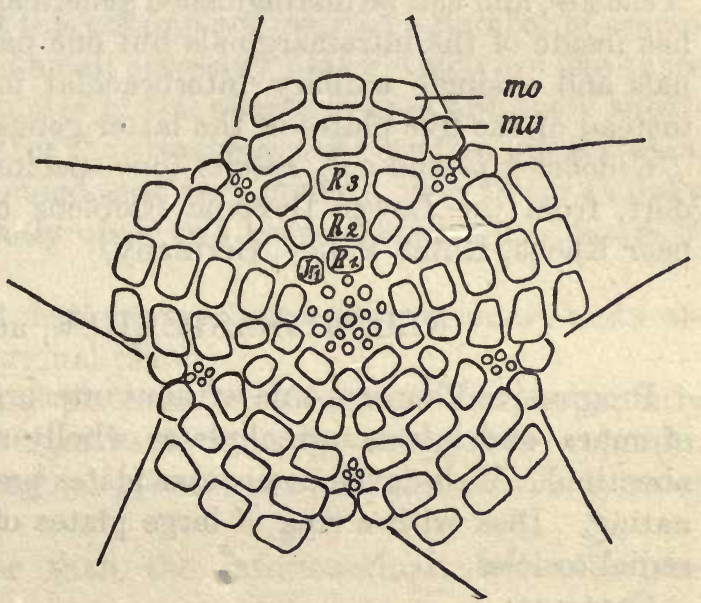

Fig. 10.-REENASTER SCHWERd, AFTER SCHÖNDORF. ScHEMATIO ARRANGEMENT OF ABACTINAL PLATES. SYMBOLS AS IN FIG. 9. ture is that of Xenaster, except that in Rhenaster the first pair of interbrachial marginals are not yet pushed so much orally and they almost take part in margining the axils. Madreporite unknown.

Genoholotype and only species (one specimen).- $R$. schwerdi Schöndorf, from the Lower Devonic (Upper Coblenzian) at Dörrbachtal, near Coblenz, Germany.

\section{Genus EIFELASTER Schöndorf.}

Eifelaster SchöNDoRF, Palæontographica, vol. 56, 1909, pp. 70, 108, pl. 10, figs. $7,8$.

Remarks. - This genus is very closely related to Rhenaster and differs only in that there are small dorsal interbrachial areas between the adjoining proximal portions of the supramarginal columns, and these are filled with a small number of accessory ambital pieces. The outer portion of these ambital areas is made up of the two basal inframarginals that occupy the axils of the ventral side. 
The genoholotype and only species, E. follmanni, occurs in the Lower Devonic (Lower Coblenzian) at Landscheid, near Wittlich, in the Eifel, Germany. Plastotypes of the holotype were made for the writer by Professor Jaekel, of Greifswald, and these are now in the Yale University collection.

\section{Genus TRIMERASTER Schöndorf.}

Plate 19, fig. 1.

Trimeraster ScHÖNDoRF, Palæontographica, vol. 56, 1909, pp. 68, 108, pl. 7, fig. 2 ; pl. 10, figs. 5,6 .

Remarks.-Trimeraster is a small form, very closely related to $X$ enaster, and can be distinguished generically only in that the former has inside of the inframarginals but one.pair of interbrachial marginals and a single axillary interbrachial in each interbrachial field instead of the five plates of the latter genus.

Genoholotype and only species (one specimen).-T. parvulus Schöndorf, from the Lower Devonic (Coblenz quartzite) at Königstuhl, near Rhens, Rhine Valley, Germany.

\section{NEOPALÆASTERIDÆ, new family.}

Progressive Phanerozonia without interbrachial arcs. The columns of supra- and inframarginal plates wholly superposed. Madreporite abactinal. Well-developed ocular plates present. Ambulacrals alternating. Disk with a ring of large plates of basal, radial, and interradial ossicles.

Contains:

Neopalæaster, new genus.

The origin of this family is uncertain, but it seems to be related to the Promopalæasteridæ, since its essential characters are those of the Mesopalæasterinæ. In the latter the supramarginals do not completely overlie the inframarginals making one consolidated column as in Neopalzeaster. It is, so far as known, the oldest family developing ocular plates. This fact is of considerable importance for it means that the oculars were originally basal radialia, and that they have progressively wandered from the disk and then remained at the tip of the rays.

NEOPALAEASTER, new genus.

Plate 13, fig. 5 ; pl. 23, fig. 4 .

Neopalæaster ScHUchert, Fossilium Catalogus, Animalia, pt. 3, April, 1914, p. 26.

Generic characters.-Disk of medium size, without interbrachial arcs. Rays five, short and tapering rapidly.

Abactinally the disk has a small central plate surrounded by numerous smaller plates. Bounding the smaller accessory disk 
plates is a ring of very large, thick, tumid, variously shaped, radial and interradial plates. Of the latter there may be one plate inside of the basal supramarginals of adjoining columns, or this plate may be divided, when the pieces appear as inwardly crowded supramarginals. Laterally and distally upon the interradials are situated the large basal radial plates. The rays are bounded laterally by columns of large, thick, subquadrate, tubercular supramarginals terminated distally by single ocular plates. These plates appear to be common to both the actinal and abactinal areas and must therefore be the united infra- and supramarginal columns. Between the supramarginals distally appear single small isolated plates which proximally become larger and continuous, forming an inconspicuous column of radial ossicles. On each side of this column are inserted a number of apparently irregularly arranged small accessory plates which are like those of the disk. All of the plates of the abactinal area are finely tuberculose, these points being for the attachment of very fine, short spines.

Madreporite small, rounded, not very convex, very finely radially striated and resting directly upon two basal supramarginal plates of adjoining rays.

Ocular plates small but distinct, one terminating each ray and resting against the distal marginal plates.

Supra- and inframarginal plates large and conspicuous, apparently firmly united and indistinguishable laterally as separate columns. Abactinally the supramarginal plates are wider and overlie more or less the adambulacrals.

Adambulacrals smaller than the inframarginals but otherwise resemble the latter.

Ambulacral grooves narrow. Ambulacral plates alternating, about as numerous as the adambulacrals, $\vdash$-shaped, with the podial openings between adjoining plates.

All other actinal characters unknown.

Genoholotype and only known species.-Palxaster crawfordsvitlensis Miller. From the Keokuk crinid beds near Crawfordsville, Indiana. Remarks. - Neopalæaster retains a very primitive abactinal plate structure and calls to mind Hudsonaster, Palxaster, and typical Mesopalæaster. It is distinguished from these early Paleozoic genera by the complete consolidation of the supra- and inframarginal plates into one column, and the presence of ocular plates. The interbrachial area is unknown in Neopalxaster, but its abactinal structure seems to indicate a single interbrachial plate in each area bounded distally by two basal inframarginal plates. If this interpretation is correct, then this character will further distinguish Neopalæaster from Hudsonaster and Palæaster. 
NEOPALAEASTER CRAWFORDSVILLENSIS (Miller).

Plate 13, fig. 5; plate 23, fig. 4.

Palæaster crawfordsvillensis MnLer, Journ. Cincinnati Soc. Nat. Hist., vol. 2, 1880, p. 256, pl. 15, fig. 3; N. Amer. Geol. Pal., 1889, p. 265, fig. 379.

Original description. - "This species is founded upon the dorsal view of a single specimen. The rays are longer than the diameter of the body, and not of uniform size. They are flattened or depressed in the middle, as is also the central part of the body. Many of the plates possess a central tubercle or small spine, and probably all of them did.

"The marginal plates are large, somewhat elliptical in outline, and have their shorter diameters in the direction of the length of the rays. There are about 12 plates on each side of a ray, and they come together at about the eighth plate from the body, though in the ray opposite the madreporiform tubercle they come together at the seventh. The space between the marginal plates of each ray is filled with smaller plates; three of these unite the larger plates at the body, but they diminish in number toward the apex of the ray, and cease at the eighth plate. In addition to the two large plates which form the junction of the rays with the body, a few large plates cover the outer part while the central part is covered by smaller plates. The madreporiform tubercle is supported by three plates, two of them are large marginal plates, which form a junction between two rays, and the other is a large plate within, forming part of the covering of the body."

Emended description.-The type-specimen measures: $\mathrm{R}=22 \mathrm{~mm}$., $r=7 \mathrm{~mm}$., $\mathrm{R}=3.1 r$. Width of rays at base $7 \mathrm{~mm}$. Another specimen in the Museum of Comparative Zoölogy has rays $3 \mathrm{~mm}$. longer.

Rays short, tapering rapidly. Disk rather large for a small species.

Abactinally the disk has a central circular plate surrounded by numerous small, conical, irregularly disposed, accessory plates, among which are a few larger pieces usually adjacent to the large interradial plates. Outside of the small disk plates is a ring of very large, irregularly shaped, radial and interradial plates. Five of these are interradial in position, and are situated just within the basal plates of adjoining supramarginal columns. These plates may remain normal as a single plate or may be divided into two plates, when they somewhat resemble inwardly crowded supramarginals. Upon these laterally and distally rest five large radial pieces, the basal plates of the radial columns. It is very probable that the radial columns are continuous from the basal plate to near the distal portion of the ray, where a few of these plates are much reduced in size and are 
separated and wedged in between the adjoining four supramarginal ossicles. There appear to be 10 or 11 of these in a column. On each side of the radial columns in the proximal half of each ray are a number of small accessory plates arranged in irregular columns. All of the abactinal plates are more or less convex and bear numerous small pustules clustered around a larger central one, all of which bore small spines.

Supramarginal plates very conspicuous, subquadrangular in outline, generally a little wider than long, with numerous small pustules, among which toward each lateral edge is a large one upon which probably articulated prominent spines. There are from 11 to 13 of these plates in each column. In the distal third of a ray both columns approximate and adjoin each other closely. Each supramarginal plate lies wholly and directly over an inframarginal and the pieces appear as one consolidated plate with the abactinal side convex and the actinal nearly flat. The supramarginals are the widest and extend in part over the adambulacrals.

Madreporite small, circular in outline, slightly convex and very finely radially striated. It lies directly upon two basal supramarginal plates of adjoining rays and directly outside of one of the large interradial plates.

An ocular plate terminates each ray.

Inframarginals apparently like the supramarginals excepting distally, where they are nearly twice as long as wide.

Adambulacral plates smaller than the inframarginals, nine in the space occupied by five of the latter, somewhat wider than long; convex, and covered with numerous small pustules.

Ambulacral grooves very narrow in the distal region. The ambulacral plates appear to be as numerous as the adambulacrals, and are 1 -shaped, with the podial openings between the plates in about the mid-width of the column.

All other actinal characters are unknown, since the two specimens expose the abactinal area, though one has portions of the plates removed, revealing the actinal characters described.

Formation and locality. - The type-specimen is in the Harris collection of the United States National Museum, and another specimen is in the Dyer collection of the Museum of Comparative Zoölogy (No. 4). Both were found in the crinid beds of the Keokuk group of the Lower Carboniferous at Crawfordsville, Indiana.

Remarks. - There is no Carboniferous asterid with which Neopalæaster crawfordsvillensis can be confounded.

Cat. No. 60607, U.S.N.M. 


\section{Family PALASTERINIDE Gregory (emend.).}

Palæasterinidæ GREGory (part), Geol. Mag., dec. 4, vol. 6, 1899, p. 348 (contains Palasterina, Schoenaster, and Schuchertia); Treat. Zool., vol. 3, Echinoderma, 1900, p. 250.

Lindstromasterinæ GreGory (part), Geol. Mag., dec. 4, vol. 6, 1899, p. 346 (contains Lindstromaster and Uranaster).

Palæasterinidæ Stü RTz, Palæontographica, vol. 36, 1890, p. 246.

Progressive Phanerozonia developing large interbrachial arcs. Ambulacral plates more or less alternate. Madreporite abactinal. Disk large, pentagonal, and the rays separated by well-developed interbrachial arcs. The inframarginal plates bound the animal and are separated from the adambulacrals more or less completely by a varying number of interbrachial plates.

Abactinal surface with longitudinal columns of radial, supramarginal and accessory columns of plates, or the radial columns may be reduced or even replaced by transverse rows of small accessory pieces. The central region of the disk may retain a ring of larger basal radial and supramarginal pieces.

Contains:

Petraster Billings.

Lindströmaster Gregory.

Palasterina McCoy.

Uranaster Gregory.

Palæostella Stürtz.

Pseudopalasterina Stürtz.

Genus PETRASTER Billings.

Plates 23, 26, 27.

Petraster Brurnas, Geol. Surv. Canada, Can. Org. Rem., dec. 3, 1858, p. 79.Hall, Twentieth Rep. N. Y. State Cab. Nat. Hist., 1868, pp. 283, 294; rev. ed., $1868=1870$, pp. 325,337 .

Palæaster (part) ZrTteL, Handb. Pal., vol. 1, 1879, p. 452.

Palæasterina of some AutHors.

Generic characters.-Disk and interbrachial arches more or less large. General shape pentagonal. Rays fire, short and slender or stout and tapering rapidly.

Abactinal area of rays distally with one medial radial, two supramarginal and two inframarginal columns of plates. Between the radial and supramarginal columns proximally are inserted columns of accessory plates: In $P$. speciosus there are five on each side of the radial column. Between the supramarginal and inframarginal columns in the axillary and basal ray regions are inserted columns of ambital plates. In $P$. speciosus there are three. The plates are more or less stellate, with numerous subcircular openings in the angles between adjoining plates. 
Inframarginal plates bounding the entire outer edge of the animal, conspicuous, closely adjoining, not stellate and common to both the actinal and abactinal areas.

Madreporite radially striate, abactinal.

Adambulacrals closely adjoining the inframarginals in the distal portion of the rays but proximally the former are separated from the latter by more or less numerous, small, accessory interbrachial plates.' The adambulacrals may be of nearly the same size, or considerably wider than long in the mid-length of the column. The adambulacrals of adjoining columns meet orally in a pair of larger triangular plates, the oral armature.

Interbrachial areas more or less large and the space between the inframarginal and adambulacral columns filled with a variable number of accessory interbrachial plates.

Ambulacrals slightly alternating, about as numerous as the adambulacrals, each with an L-shaped, proximally converging carina. Podial openings through the outer proximal corner of the plate and proximal to the carina. Grooves narrow, regularly tapering.

Genoholotype (type by monotypy).--Petraster rigidus Billings. The above diagnosis is based on the genotype and Palrasterina speciosa Miller and Dyer.

Distribution.-Ordovicic of North America, Siluric of Australia. The species are:

$P$. rigidus (Billings). Trenton.

P. speciosus (Miller and Dyer). Maysville, Richmond.

$P$. (?) americanus (D'Orbigny). Maysville.

P. smythi McCoy. Siluric of Australia.

Remarks. - While Billings has correctly pointed out the diagnostic characters of Petraster, yet the genus has been very imperfectly understood. This may partly be accounted for in that he later also included a specimen of Hudsonaster matutinus (Hall), which of course fails to have the essential generic character of Petraster, namely, the interbrachial accessory plates. The following is Billings' original description:

"This genus has both marginal and adambulacral plates, with a few disk-plates on the ventral side. The general form is deeply stellate, and the rays long and uniformly tapering. A single specimen has been collected, and as it shows the underside only, the characters of the dorsal surface can not be given. The structure of the mouth is also unknown. Generic name from petra, a stone.

"It differs from Palasterina by the presence of large marginal plates outside of the disk-plates [that genus has small marginals], and still more from Stenaster, which has neither disk nor marginal plates. It is allied to Astropecten." 
Professor Hall at first recognized the distinctness of Petraster, since he wrote as follows (1870):

"The character of Petrasier here described, and illustrated in the figure (3a, pl. 9), gives an intercalated partial range of disk-plates, between the adambulacral and marginal plates, which will separate these forms from any of the Palæasters in my collection."

On a later page, after an examination of the genotype, he added a "Note on the genus Petraster" in which he concludes that the specimen was injured during life, as shown by the unequal distribution of the accessory interbrachial plates, and further that one ray is "without intercalated plates on either side." He adds: "This view is sustained by the fact that the other parts have the ordinary structure of Palxaster, and in all other respects the specimen agrees with the typical Patraster matutina." The genotype was studied at Ottawa by the present writer and found to be as described by Billings. The accessory interbrachial plates, though somewhat irregular in development in different areas in the type species of Petraster, are normal in position and a similar but more complete development also appears in Lindströmaster and Palasterina.

Petraster is distinguished from Palasterina as follows: The most important feature is that the inframarginal plates of the former are prominent, closely adjoining and short but wide, while in Palasterina they are small, not conspicuous, and globular, or subquadrate. The next important difference is on the abactinal disk, where in Palasterina there is an irregular ring of prominent basal radial, and supramarginal plates. These are absent in Petraster. The accessory interbrachial ossicles in the latter genus never attain the distal region of the rays as in Palasterina where these pieces are also more numerous. Palasterina is also more abundantly spinose than Petraster.

Schuchertia has no inframarginals as marginal plates, which at once distinguishes it from both Petraster and Palasterina. It is true that in Schuchertia inframarginals are also present but they are usually not well developed and remain adjoining the adambulacrals. These two columns are therefore not separated from one another by accessory interbrachial plates as in Petraster and Palasterina:

The primary structure of Petraster is that of Hudsonaster. So many of the generic characters are common to both that the former genus appears almost certainly to have been derived through the latter. It is true that the central abactinal area of the disk in Petraster is devoid of the large basal plates, a marked character in Hudsonaster, but the other generic characters are all present in the former. Petraster adds more or less numerous columns of radial accessory ambital and accessory interbrachial plates, none of which are present in Hudsonaster. It is these accessory ossicles which differentiate these 
genera and show the line of development from the deeply stellate primary form to the pentagonal genera with well-developed interbrachial arcs.

\section{PETRASTER RIGIDUS (Billings).}

Plate 27, fig. 5.

Palasterina rigidus Bminnas, Geol. Surv. Canada, Rep. of Progress, 1853-1856, 1857, p. 291.

Petraster rigidus Brunngs, Geol. Surv. Canada, Can. Org. Rem., dec. 3, 1858, p. 80 , pl. 10, fig. $3 a$ (not fig. $3 b=$ Hudsonaster matutinus).-WRIGHT, Mon. British Foss. Echinod., Oolitic, vol. 2, pt. 1 (Palæontogr. Soc. for 1861), 1862, p. 29.-Hall, Twentieth Rep. N. Y. State Cab. Nat. Hist., 1868, p. 294 ; rev. ed., $1868=1870$, p. 337 .

Description of 1858.- "This species has much the aspect of an Astropecten; the disk is one-fourth the whole diameter, the rays rather slender and uniformly tapering, the angles between the bases of the rays rounded. The plates [of the actinal side] which appear to be adambulacral [increase very little in size from the tips of the rays toward the mouth], are quadrate and a little convex; [the adambulacral columns terminated in the mouth area by a pair of pointed oral plates and not by a single plate as shown in the original illustration], the marginal [inframarginal] plates oblong, and also convex [certainly not less than 16 and probably 20 in each column, increasing rapidly in size toward the axils, where there is a single large axillary plate]; the disk plates [accessory interbrachials] consist of three at each angle [one orally and two distally], and a single row [of not more than seven plates] on each side of the ray, but extending only onethird or one-half of the length of the ray; they all lie between the [infra] marginal and adambulacral plates. [Abactinal side unknown.] The specimen figured was about 2 inches [or $50 \mathrm{~mm}$.] in diameter when perfect; width of disk half an inch, and of rays at the base about three lines."

Formation and locality.-Trenton limestone, Ottawa, Canada. Holotype No. $1401 a$ is in the Victoria Memorial Museum, Ottawa. The species has also been identified by Springer in the Lower Trenton (Kirkfield) at Kirkfield, Ontario.

Remarks.-Hall and Billings discussed their asterid genera and species at different times and finally the former examined Billings's material. In this connection Hall showed that figure $3 b$ of Petraster rigidus was based on the actinal side of Hudsonaster matutinus. Regarding figure $3 a$, which is the holotype of this species, he in 1870 wrote as follows:

"The specimen illustrated in figure $3 a$ has a fow small intercalated plates between the marginal and ambulacral [adambulacral] ranges in two of the axils of the rays, and there are a smaller number of granules in a similar position but unequally distributed on one side of 
another axil, while two of the axils do not show any such intercalated plates or granules. In one of the rays, at least, the ambulacral, adambulacral, and marginal plates are distinctly visible, without intercalated plates on either side.

"The presence of these unequally distributed plates or granules is apparently an abnormal structure, probably the result of accident during the growth of the animal; and this view is sustained by the fact that the other parts have the ordinary structure of Palæaster, and in all other respects the specimen agrees with the typical Palxaster matutina."

The holotype was examined by the writer and although imperfect was found to have a normal development, with the plates in their proper places in at least two of the rays and axils. It certainly is not an abnormal development of "Palæaster matutina" but represents a normal individual of a distinct genus and species diverging from Hudsonaster matutinus toward the forms with large disks and great axillary areas, as in Linḋtrömaster and Palasterina. Hall seemingly was led to make the erroneous remarks above quoted through the fact that Billings had also included in his description and illustration (3b) an individual of Hudsonaster matutinus, an error due to the undoubtedly close relationship of this form with Petraster rigidus.

PETRASTER SPECIOSUS (Miller and Dyer).

Plate 23, figs. 5-7; plate 26, fig. 1; plate 27, figs. 1-4.

Palæasterina speciosa Mruler and DYER, Journ. Cincinnati Soc. Nat. Hist., vol. 1, 1878, p. 30, pl. 1, fig. 7.-Mwler, N. Amer. Geol. Pal., 1889, p. 266, fig. 381.

Palæasterina approximata MrLuer and Drer, Journ. Cincinnati Soc. Nat. Hist., vol. 1, 1878, p. 30, pl. 1, fig. 8.

Original description of Palæasterina speciosa.- "Pentagonal; rays obtuse at their apices; greatest distance from point to point about $2 \frac{1}{2}$ inches; breadth of body between rays about $1 \frac{1}{3}$ inches, and distance from tip of ray to next adjoining tip on either side about $1 \frac{1}{2}$ inches.

"The [infra] marginal plates are small and somewhat hemispherical near the termination of the rays, they gradually enlarge and become square, and then rectangular as they approach the disk, until at the narrowest part of the disk or body of the fossil they are twice as long as wide. There are about 50 marginal plates between the apex of one ray and the next one adjoining, or, in a perfect specimen of this size, about 250 .

"The back or dorsal side is covered with numerous plates (probably in a complete specimen of this size there would be 1,000 or more), which are very prominent in the center or somewhat conical, and seem to have been joined together with deeply serrated edges: The plates have from three to eight of these indentations, which give them a beautiful starlike appearance. 
"The ambulacral grooves are narrow and deep, as shown by the sharp ridges on the back of the specimen. The small dorsal plates which cover the ambulacral pieces are exfoliated in some places, and show two rows of ambulacral plates coming evenly together and forming the sharp ridge.":

Original description of Palxasterina approximata.- "Pentagonal; rays more slender than in $P$. speciosa; greatest distance from point to point in the specimen figured 1.15 inches and breadth of the body one-half inch; another specimen from the collection of Mrs. M. P. Haines, of Richmond, Ind., measures from point to point 2.5 inches, and has a breadth of body of nine-tenths inch.

"The [infra] marginal plates have about the same form, and are about as numerous as they are in $P$. speciosa. The adambulacral plates are arranged with their length across the rays. The oral plates are very prominent. [This statement is somewhat in error. The five prominent points around the mouth are each formed of one large interbrachial plate and a pair of proximal adambulacrals.] The space between the [infra] marginal plates and the oral ones [adambulacrals] is filled with numerous small [accessory interbrachial] pieces. The ambulacral grooves are narrow. Ambulacral ossicles unknown.

"The dorsal side is covered with small conical pieces, which give it a coarsely granular appearance. The madreporiform tubercle is prominent, conical, and longitudinally striated.

"This species is distinguished from $P$. speciosa by its narrower rays, more contracted body, and smaller dorsal plates."

Emended description.-The holotype of $P$. speciosa measures: $\mathrm{R}=33 \mathrm{~mm} ., r=18 \mathrm{~mm}$. The holotype of $P$. approximata measures: $\mathrm{R}=15 \mathrm{~mm} ., r=6.5 \mathrm{~mm}$.

Rays in young specimens slender distally, but with age they become obtuse and very wide proximally and here merge into the large disk. Interbrachial ares very large.

The abactinal area of disk and rays is bounded by columns of very prominent inframarginal plates. Beginning at the apex of each ray they are very small and globular, soon they become quadrate and gradually shorter but wider, so that near the middle of each interbrachial arc they have a crowded appearance. In a full-grown specimen there are about 50 and in a half-grown example about 45 of these plates between the distal ends of adjoining rays. In the distal region these plates are rounded and nearly smooth but gradually become granular and strongly convex, each with one prominent point for an articulating spine, none of which, however, have been observed. On the actinal side these inframarginals are also very prominent and pustulose but here are flat. They are most prominent near the center of the interbrachial arcs. 
The supramarginal columns begin at the very apex of the rays and for more than one-third of their length adjoin the inframarginals where ambital plates begin to appear. The supramarginal columns are continuous over the disk in a broad curve, with about 18 to 20 in a column, or from apex to apex of adjoining rays there are from 35 to 40 of these plates. In the axillary areas they are separated from the inframarginals by three or four rows of ambital plates. At the apex of the rays the supramarginals are highly convex and nearly circular in outline but soon pass into more and more distinctly stellate plates. This is the form of all the abactinal plates inside of the inframarginals; they are stellate, highly convex, each with a central node for an articulating spine and a few granules that are the bases for smaller spines.

Each radial column appears immediately beneath the two terminal or rather distal supramarginal plates and then continues as a column to near the center of the disk. They are more prominent than the other columns excepting the marginals and have not less than 25 plates in each one. On each side of the radials are five columns of radial accessory plates which appear to continue as columns over the disk in broad curves joining those of the next ray. Between these columns in the axillary areas are additional accessory plates. These columns of accessory plates appear singly, first on one side and later on the other, and not in pairs simultaneously, one on each side of the radial columns.

Ambital areas well developed in the axillary region, where there are about three columns of these plates. The columns pinch out rapidly distally and none are present in the outer third of the rays.

The plate arrangement of the central part of the disk can not be made out.

Madreporite of medium size, highly conical, and conspicuous, with numerous sharp single or bifurcating ridges; on the under side are seen two outwardly directed spiral cones (the white lines of the drawing representing the spiral tubes in the madreporite), reminding one of the brachia in Atrypa (pl. 27, fig. 4).

Adambulacral plates depressed, convex, subquadrangular in outline in young specimens, but in fully grown individuals a number of these in the central region of the column are much drawn out laterally and are here two or three times as wide as long. In a half-grown individual there are about 20 of these plates in a column, but in a mature specimen there appear to be not less than 26 . These plates end inwardly in an apex, against which terminate the ridges of the ambulacral plates. The adambulacral and inframarginal columns are closely adjoining in the distal two-thirds of the rays but proxi- 
mally they are separated from each other by numerous accessory interbrachial plates, of which there appear to be not less than 30 in each area. The apexes of these interbrachial areas form the oral armature and each consists of two adambulacral plates, back of which is a rather large interbrachial plate.

Ambulacral grooves narrow, tapering, and deeply V-shaped. Ambulacral plates slightly alternating, about as long as wide, and proximally superposed, with about 26 in each column. Each plate has an L-shaped ridge with the point proximally directed. The podial openings are situated in the outer proximal corner of the plates and between the inner angles of two adambulacrals.

Formation and locality.-Richmond and Maysville formations of the Upper Ordovicic. The holotype of $P$. speciosa was found by Mr. W. C. Barnhart, on Twin Creek, near Winchester, in Preble County, Ohio, and is now in the Dyer collection of the Museum of Comparative Zoölogy, Harvard University (No. 14). Four other less well-preserved specimens are in the Harris collection of the United States National Museum and were found in the vicinity of Waynesville, Ohio. The holotype of $P$. approximata and another similar-sized specimen but not so well preserved are also from the vicinity of Waynesville, Ohio. The first is in the Dyer collection of the Museum of Comparative Zoölogy (No. 15), and the other in the United States National Museum. There is a slab with two young individuals much etched with acid but otherwise excellent, showing the actinal side, in the Gurley collection of the University of Chicago (No. 10979). Finally there are two fine specimens, not fully grown, showing well the actinal and abactinal sides, in the Haines collection of the same university (Nos. 10839 and 10840), found near Hamilton, Ohio; these are apparently from the very top of the Maysville formation.

Remarks. - $P$. speciosa is described by Miller and Dyer from the abactinal side and $P$. approximata from the actinal side. These writers point out that the rays are more slender and the disk more contracted in the latter, but when one considers that it is less than half the size of the former and that during growth these forms continually add accessory plates, this difference in form is seen to be one of growth. The "smaller dorsal plates" noted by these writers in Mrs. Haines's specimen of $P$. approximata are a character which the present writer does not regard as of value unless they be constant at this lower geologic horizon (Maysville at Hamilton), in which event this specimen can later on be distinguished by another specific name.

Cat. No. 60609, U.S.N.M. 
PETRASTER (?) AMERICANUS (D'Orbigny).

Plate 26, fig. 2.

Asterias Graham, Anthony, and James, Amer. Journ. Sci., ser. 2, vol. 1, 1846, p. 441, figure but no description.

Colaster americanus D'OrBIGNY, Prodr. de Paleont., vol. 1, 1849, p. 22 (name proposed).

Asterias anthonii DANA, Manual Geol., ed. 1, 1863, p. 221, with figure but no description.

Palasterina (?) jamesi Dana, Amer. Journ. Sci., ser. 2, vol. 35, 1863, p. 295; Manual Geol., ed. 2, 1864, p. 221, with figure but no description.

Palæaster jamesi Hall, Twentieth Rep. N. Y. State Cab. Nat. Hist., 1868, p. 286; rev. ed., 1868=1870, p. 329.-MEex, Geol. Surv. Ohio, Pal., vol. 1, 1873, p. 62 , pl. 4 , fig. 4 .

Meek's description.- "Through the kindness of Mr. U. P. James, of Cincinnati, the discoverer of this fossil, I have now before me the original typical specimen, which I found not in a condition to be fully and systematically characterized, nor perhaps to afford the means of determining, beyond doubt, its generic affinities. It evidently attained a large size, and has a comparatively large disk, with its five rays rather broad at their inner ends, somewhat rapidly tapering, and apparently longer than the diameter of the disk. It evidently lies [does lie] in the matrix in such a manner as to show the ventral side [the inner dorsal aspect of the ventral plates], but presents the appearance of having the marginal and disk plates of this side removed [they are present]. The five pairs of oral pieces [proximal adambulacral plates] are seen in place, and proceeding outward from these can be seen a row of adambulacral pieces on each side of each of the rather wide [narrow] ambulacral furrows. These latter pieces are [proximally] nearly three times as long as their diameters in the direction of the length of the rays, and quite prominent at their inner ends, where they are articulated together by little processes and corresponding sockets or sinuses; while the outer two-thirds of each is flattened and distinctly more depressed than their inner ends. Outside of, and alternating with, the outer flattened ends of these adambulacral pieces, a row of [inframarginal] nearly square, or more or less oblong pieces, may be seen all along the margins of the rays, and connecting at their axilla in such a manner as to leave room for several disk [or interbrachial] plates between them and the oral and inner adambulacral pieces."

In each interbrachial area there are inserted between the inframarginals and adambulacrals interbrachial plates as follows: Proximally one hexagonal plate upon which rest two similar plates margined by the inframarginals.

"At some places within the [narrow] ambulacral furrows, remains of ambulacral ossicula can be seen deeply interlocking with the inner ends of the adambulacral pieces, but their exact form, and the 
position and arrangement of the ambulacral pores, can not be clearly made out in the specimen studied.

"The two oral pieces [proximal adambulacrals] of each of the five pairs are separated by deep sutures, and have an irregular form, being longer than wide, and, like the adambulacral pieces, which they somewhat exceed in size, flattened and depressed at their outer ends, and elevated into crestlike prominences farther in, with a lateral process or thickening on the outer side of each, in which a more or less distinct pit may be seen." Between the pairs of oral adambulacral plates are inserted small, single, subquadrangular plates, the proximal plate of each pair of ambulacral ossicles. Orad to each pair of oral armature plates are situated single hemispheric plates.

"The surface, and the arrangement of the dorsal parts, are unknown; but they were probably armed with short spines, as some remains of little spines are seen in the matrix at the margin of the disk, at one place.

"As the extremities of none of the rays can be clearly seen, the exact breadth of the whole fossil, between the ends of opposite rays, can not be exactly given, but it is evident that the length of one of the rays, measuring from the middle of the disk, must have been a little more than 2 inches, and consequently that the diameter across from the extremities of opposite rays could not be less than about 4 inches. The breadth of the disk is 1.20 inches; and that of the rays at their inner ends, 0.70 inch."

Formation and locality. - The single specimen was found in the Maysville formation (Ordovicic), by Mr. U. P. James, on or near Vine Street hill, Cincinnati, Ohio, and is now in the James collection of the Walker Museum of the University of Chicago.

Remarks. - This large species is quite distinct from any other starfish in having three rows of interbrachial plates, one piece in the proximal, two in the medial, and five or possibly more in the distal row. While the arrangement of these interbrachial plates is different than in the other species of Petraster, their position is that of this genus. Therefore this species is for the present referred to Petraster. The preservation of this specimen is such that its generic and sperific characters will remain in obscurity until other material is found. It lies with the actinal side buried in the limestone while all of the abactinal plates have been worn away. What one sees is therefore the inner or dorsal aspect of the ventral skeleton.

\section{PETRASTER SMYTHI MCCOY.}

Petraster smythi McCoy, Geol. Surv. Victoria, Prodr. Pal. Victoria, dec. J, 1874, p. 41 , pl. 10, figs. 1-16.

Original description.- "Five broad semielliptical lobes meeting at slightly rounded reentering angles, leaving the length and the 
width at base of the rays nearly equal and less than the width of the disk. The upper surface is covered with crowded irregularly polygonal tumid plates. Madreporiform tubercle very large ( $1 \frac{1}{3}$ lines in diameter), irregularly porous, and rugged with branching vermicular ridges, excentric toward base of the two posterior rays. Ambulacral groove very narrow, bordered with a row of large transversely oblong adambulacral plates, wider than long, about 6 in 2 lines at middle of ray; margin of the rays bordered with a rather smaller row of similar marginal plates; between the row of adambulacral and marginal plates an intercalary row of small irregular plates. Width of disk between the rays, 7 lines; from tip to tip of rays, about 1 inch 2 lines; length of ray, about $5 \frac{1}{2}$ lines.

"Very rare in the fine sandy Upper Silurian rocks of Moonee Ponds, Flemington, a little north of Melbourne [Australia]."

Remarks. - The holotype exposes the abactinal side, but the plates of two of the rays are absent, exposing the actinal skeleton, which is therefore seen from its inner side. So far as one can judge of the description and illustration, the species is a small but genuine Petraster. Abactinally the rays have conspicuous radial and supramarginal columns, each with about 17 ossicles, that are tumid and are all closely adjoining. Outside of these in the distal portion of the rays are the equally conspicuous inframarginals, and they margin not only these parts but the entire animal; proximally the inframarginals separate more and more from the supramarginals, forming small ambital areas, occupied by a number (can not be determined) of rounded plates that now appear not to have been closely adjoining.

Madreporite large, radiately striate, situated in an interradius and well inside the ambital area.

Ambulacralia large, about 12 in a column, and opposite one another. Adambulacrals smaller, about 14 in a column. Interbrachial structure unknown.

\section{Genus LINDSTRÖMASTER Gregory.}

Lindstromaster GREGoRY, Geol. Mag., dec. 4, vol. 6, 1899, pp. 344, 346.

Hisingeraster StürTz, Verh. naturh. Ver. preuss. Rheinl., etc., vol. 56, 1900, pp. 224, 225 (same genoholotype as for Lindströmaster).

Original description.- "Palæasterinidæ with flat pentagonal disk and five short blunt rays.

"The plates of the disk are large, polygonal, tuberculate, and crowded into a close tessellate pavement, which completely covers the interradial areas. 
"Marginal [inframarginal] plates well developed and conspicuous, and but slightly smaller than the adambulacrals. Both supra- and inframarginals appear to be present.

"The abactinal [actinal] furrows are large and subpetaloid. They are bounded by large tuberculate adambulacral plates. The ambulacral plates are boot-shaped [and slightly alternating]. The pores for the podia are large, and occur on the suture between the adambulacrals and ambulacrals.

"The adambulacral elements in the oral armature are prominent, and consist of five pairs of subtriangular plates.

"Type-species: Asterias antiqua, Hisinger 1837. Silurian: Gotland." No other species of this genus is known.

Remarks. - Of this genus only the actinal side is known and the published figure from a drawing by Mr. George Lilejevall is one of the best of Paleozoic starfishes. Lindströmaster differs from Petraster in but one generic character, if it be a generic one, in that the ambulacral furrows are large and subpetaloid in the former and narrow and slowly tapering in Petraster. However, since the abactinal area is unknown in Lindströmaster there probably will be discovered in this area differences distinguishing it from Petraster. It is also probable that the marginals in Lindströmaster which Gregory thinks are "both supra- and inframarginals" lying directly superposed are only inframarginals. In Siluric starfishes these plates have not attained the superposed position so marked in recent genera. The supramarginals are here never true marginals and always lie more or less inside the inframarginals, which are the true marginals of these early genera. For other remarks see Palæostella.

The name Hisingeraster was published after Gregory's name and is based on the same genotype.

When more material is obtained and the genus is restudied, comparisons should also be made with Palasterina primæva, as the two forms appear to have much in common.

\section{LINDSTRÖMASTER ANTIQUUS (Hisinger).}

Asterias antiqua HIsINGER, Lethæa Suecia, 1837, p. 89, pl. 26, fig. 6.

Lindstromaster antiqua Gregory, Geol. Mag., dec. 4, vol. 6, 1899, pp. 343, 347, pl. 16, figs, $1 a, 1 b$ (complete synonymy given here).-ScHöNDoRr, Jahrb. nassauisch. Ver. Naturk., Wiesbaden, vol. 63, 1910, p. 225.

A single specimen is known from "Bed C," Mount Hoburg, Gotland, corresponding to the Wenlock of England. It is in the Angelin collection of the Mineralogical Museum at Copenhagen. 


\section{Genus PALASTERINA McCoy.}

Palasterina MoCor, British Pal. Foss., 1851, p. 59 (not defined).-Salter, Ann. Mag. Nat. Hist., ser. 2, vol. 20, 1857, pp. 324, 327.-Buluings (part), Geol. Surv. Canada, Can. Org. Rem., dec. 3, 1858, p. 76.-Zrtrel, Handb. Pal., vol. 1, 1879, p. 453.-STÜrTz (part), Palæontographica, vol. 36, 1890, p. 226; (part), Verh. naturh. Ver. preuss. Rheinl., etc., vol. 50, 1893, pp. 43, 60.ScHÖNDORF, Jahrb. nassauisch. Ver. Naturk., Wiesbaden, vol. 63, 1910, p. 220.

Palæasterina Gregory, Geol. Mag., dec. 4, vol. 6, 1899, p. 349 (complete synonymy here).

The term Palasterina was used by McCoy in the following words: "Before I was aware Prof. Forbes had described them [the three species named below] it seemed to me that the $U$ [rasterella] ruthveni and $U$. hirudo, as well as the similar American species, might be easily separated from the great starfishes forming the recent genus Uraster, by their small size and much more simple skeletons, and I had named the genus Urasterella in my manuscript. The U. primævus I thought generically distinct from the other two, as the rays were not contracted at base, etc.; and I had named it Palasterina, from its resemblance to the recent genus Asterina."

The three species mentioned by McCoy had been described by him in manuscript, but on learning that descriptions had been previously published by Forbes, the former, in his "British Palæozoic Fossils," adopted the names of Salter. In writing of these three forms, as above quoted, he uses the generic name Palasterina (not Palrasterina, the generally accepted form), and while a type-species is selected, yet McCoy did not point out a single generic character of present value. His statement that "the rays were not contracted at base" is a feature which at that time distinguished Palasterina from Urasterella, but now many Paleozoic genera are known having rays "not contracted at base."

While McCoy does not strictly propose the generic name, Salter is the first to accept and define Palasterina, which he does in the following words:

"Pentagonal, depressed, the arms a little produced, with three or five principal rows of tubercles above, combined with a plated disk which fills up the angles; ambulacra rather shallow, of subquadrate or slightly transverse ossicles, bordered by a single row of squarish large plates, the lowest of which (ad-oral adambulacral plates, Huxley; angle-ossicula, Forbes) are large and triangular, bearing combs of spines (Upper Silurian)."

Recently Gregory, in a paper entitled "On Lindstromaster and the classification of the Palæasterids"” (1899), redefines the genus, basing his definition largely on $P$. bonneyi. In this connection he writes:

"The species [P. bonneyi] is of interest, as the structure is better preserved than in the type of the genus [P. primæva], and thus we are 
largely dependent upon it for our knowledge of the generic characters" (p. 350).

Emended description.-Disk large, with moderately developed interbrachial arches. Rays five, short, and tapering more or less rapidly. " $\mathrm{R}$ about twice as great as $r . "$

Abactinal area of rays distally with one medial column of large, thick, and subquadrangular radial plates, on each side of which are similar columns of supramarginal and inframarginal pieces. In this region the columns adjoin and the ossicles are crowded, but proximally between the radial and supramarginal and between the latter and the inframarginal columns (ambital areas) are inserted numerous accessory smaller plates. The latter are most numerous in the ambital areas and at the base of the rays. The ossicles are packed into a tessellate parement. In the center of the disk there seems to be a prominent central disk piece and at the bases of the rays there is a somewhat disconnected ring of ten most prominent plates, the five basal pieces of the radial and five interradial that give rise to the ten supramarginal columns. Inside of this ring there are probably numerous, very small pieces with no definite arrangement. A number of the proximal plates of both the radial and supramarginal columns may be separated from one another by small accessory pieces.

Madreporite abactinal.

Inframarginal plates bounding the entire outer edge and common to both sides of the animal. These plates are, however, small (smaller than the adambulacrals) and bear tufts of small spines.

Adambulacrals subquadrangular, and closely adjoining, each plate bearing on its outer lateral edge a tuft of three spines. Oral armature consists of five pairs of triangular adambulacral plates which have slender spines on the inner edges.

Interbrachial areas extending to near the distal ends of rays and occupied by numerous "isolated rounded or subangular [accessory interbrachial] plates bearing [single] small spines."

Ambulacrals slightly alternating and about as numerous as the adambulacrals. Each plate has an L-shaped ridge, posteriorly directed. The podial openings are on the sutures between the ambulacrals and adambulacrals.

Genoholotype.-Uraster primzovus Forbes. The above diagnosis is, however, based largely upon Palasterina bonneyi Gregory. Dr. Bather sent the writer a number of wax squeezes of the genoholotype, and while the parts preserved are clear and sharp, yet the specimens are not complete enough to work out the generic characters. Therefore, for the present, $P$. bonneyi is taken as the genoholotype.

Distribution.-Ludlow shales (Upper Siluric) of Great Britain. 


\section{Contains:}

P. primæva (Forbes). Ludlow of England.

$P$. bonneyi Gregory. Ludlow of England.

$P$. (?) ramseyensis Hicks. Tremadoc of Wales.

For other remarks see Palæostella.

Since the foregoing was written, Schöndorf's work cited above has come to hand. He studied wax squeezes of $P$. primæva and determined that the genotype is devoid of marginalia, and therefore refers Palasterina to the Cryptozonia. He writes: "Special marginalia appear not to be present, at least the marginal rows are in no way distinguishable from the other intermediary [accessory interbrachial] plates. Accordingly Palasterina primæva Forbes sp. does not belong as stated by Gregory (p. 349) to the asterids with distinct marginal plates, the Phanerozonia, but with the asterids having inconspicuous or no marginalia, the Cryptozonia" (p. 222).

The present writer holds that there are inframarginalia present all along the edge of the interbrachial areas and the rays, and that they are most typical along the distal portion of the rays. Here the inframarginalia are ontogenetically youngest and less affected by subsequent growth displacement and alteration than are the older ones in the interbrachial areas. In the latter region it is true that the marginalia are not conspicuous, but so long as one can make them out to be inframarginalia, size alone can not be the criterion that will permit of the conclusion that no marginalia are present in Palasterina. However, the difference in interpretation between Schöndorf and the writer is not a great one, as neither lays great taxonomic value on whether the marginalia are prominent or "not prominently developed" (p.223). So long as the inframarginalia are more or less prominent, one of the generic characters of Palasterina, a phanerozonian, is present, and when they are so inconspicuous as not to be made out among the other ossicles, we have one of the generic characters of Schuchertia, a cryptozonian.

Schöndorf also states that the ambulacralia, and the adambulacralia as well, are all opposite and do not alternate with one another. The present writer states that the ambulacrals are "slightly alternating," and throughout this work he has given the arrangement of these ossicles his special attention. In a great many cases, and especially in the Ordovicic species, he has had difficulty in ascertaining what was their actual position in the living animals, for nearly all the fossils have been squeezed more or less. He has always given their arrangement as they impressed him in the fossil when no evident distortion could be seen. The writer would not lay special stress upon slight alternation among the ambulacralia, for in many Ordovicic species there is some variation in each ray from opposite to slightly alternate. Of course, when the alternation or opposite arrangement 
is complete and fixed throughout the rays, he would lay great value on the character. It may be said that in the earliest Asteroidea the chronogenetic tendency is from slight alternation to complete and fixed opposite arrangement among the ambulacral ossicles.

\section{PALASTERINA PRIMAEV (Forbes)。}

Uraster primævus Forbes, Mem. Geol. Surv. Great Britain, vol. 2, pt. 2, 1848, p. 463; Mem. Geol. Surv. United Kingdom, dec. 1, 1849, p. 2, pl. 1, figs. $2 a, 2 b$; in McCox, Brit. Pal. Foss., 1851, p. 60.-Murchison, Siluria, 1854, p: 221 , fig. 39.

Palasterina primævus McCor, Brit. Pal. Foss., 1851, p. 59 (nomen nudum).Salter, Ann. Mag. Nat. Hist., ser. 2, vol. 20, 1857, p. 327, pl. 9, figs. 2a-2c.Wright, Mon. British Foss. Echinod., Oolitic, vol. 2, pt. 1 (Palæontogr. Soc. for 1861), 1862, p. 26, fig. 16a.-Quensted, Petrefactenkunde Deutschlands, vol. 4, 1876, p. 74, pl. 92, fig. 35.-STürtz, Verh. naturh. Ver. preuss. Rheinl., etc., vol. 50, 1893, p. 44; vol. 56,1900 , pp. 214, 224.-ScHöNDORF, Jahrb. nassauisch. Ver. Naturk., Wiesbaden, vol. 63, 1910, p. 220.

Palæasterina primæva Gregory, Geol. Mag., dec. 4, vol. 6, 1899, p. 349.-SpENCER, Mon. Brit. Pal. Asterozoa, pt. 1 (Palæontogr. Soc. for 1913), 1914, pp. 37, 38 , fig. 30 .

Formation and locality.-A common species in the Ludlow rocks. Underbarrow, Kendal, Westmoreland, and Leintwardine, Shropshire, England.

Remarks.-Dr. Bather furnished the author with wax squeezes of specimens Nos. E4990-E4993 (E61 is quite another species and abactinally more closely related to Hudsonaster) in the British Museum (Natural History). They are from the Lower Ludlow at Kendal, Westmoreland. These show little of value abactinally, but actinally are well preserved along the ambulacra. Unfortunately, however, none of the marginals are present and-but little of the interbrachial areas. When better material is at hand a comparison should be made also with Lindströmaster antiquus (Hisinger), as the two look suspiciously alike.

\section{PALASTERINA BONNEYI Gregory.}

Palæasterina bonneyi Gregory, Geol. Mag., dec. 4, vol. 6, 1899, pp. 349, 350, text figs. 1-3, and pl. 16, figs. 2a, 2b.-ScHöNDORF, Jahrb. nassauisch. Ver. Naturk., Wiesbaden, vol. 63, 1910, p. 223.

"This species has hitherto been included in $P$. primæva, the typespecies of the genus, from which it differs by having shorter and blunter rays, more numerous actinal interbrachial plates, and more adambulacral plates in each series; the character of the abactinal ray plates is also different in the species, the longitudinal series being widely separated at the proximal end of the rays in $P$. bonneyi" (Gregory).

Formation and locality.-Ludlow shales. Leintwardine, Shropshire. Types in British Museum (Natural History). 


\section{PALASTERINA (?) RAMSEYENSIS Hicks.}

Palasterina ramseyensis HIcks, Quart. Journ. Geol. Soc. London, vol. 29, 1873, p. 51, pl. 4, figs. 21-23.-Woodward, Geol. Mag., dec. 2, vol. 1, 1874, p. 96.

This starfish needs to be restudied in the light of modern knowledge. The specimens represented by Hicks's figures 21 and 22 seem to be referable to Petraster rather than to Palasterina, while that of figure 23 appears to be nearer Mesopalæaster.

Formation and locality. - Said to be from the Tremadoc, but the development of the starfish seems to be in harmony with Upper Ordovicic time. The specimens are from Ramsey Island and St. Davids, Wales, and are in Mr. Lightbody's collection.

\section{Genus URANASTER Gregory.}

Uranaster GREGORY, Geol. Mag., dec. 4, vol. 6, 1899, p. 347.-ScHöNDORF, Jahrb. nassauisch. Ver. Naturk., Wiesbaden, vol. 63, 1910, p. 225.

The name is "from Uranus, the grandfather of Pluto; the starfish resembles the living genus Plutonaster."

Generic description.-Animal deeply pentagonal, above medium size, with well-developed interbrachial arches, and five long slender rays.

Inframarginal plates marginal, large, and elongated in the direction of the rays. These plates are apparently common to both the actinal and abactinal areas. Abactinally adjoining the inframarginals is another column of large submarginal plates (?supramarginals) alternating with the former, and sometimes there are smaller accessory pieces between these columns in the angles of the plates. The rays have no medial or radial columns of prominent plates, but the entire space between the submarginal columns is occupied by numerous closely fitting, convex, or tubercular plates which are arranged in alternate transverse rows, each having from three to four pieces on each side of a ray.

Interbrachial accessory plates numerous, polygonal, and, according to Baily's figure of U. kinahani, arranged in crescentic rows conforming to the shape of the disk margin. These plates do not appear to extend between the marginals and adambulacrals beyond the midlength of the rays.

Adambulacral plates tubercular, subquadrangular in outline, and widest transversely in the medial third of the column.

Ambulacral furrows very narrow, deep, and tapering gradually. Ambulacral plates traversed by strong transverse ridges.

Madreporite unknown.

Genoholotype.-Palasterina kinahani Baily. Upper Ordovicic. A second species is $U$. elizæ Spencer, also from the Ordovicic of Great Britain.

Remarks.- Uranaster differs from Petraster, Palasterina, and Lindströmaster in having the abactinal area of the rays between the 
two pairs of marginal columns filled with small tuberculate plates arranged in transverse rows. The other genera have the plates in longitudinal columns.

\section{URANASTER KINAHANI (Baily).}

Palasterina kinahani BaILY, in KrNaHAN, Man. Geol. Ireland, 1878, pp. xv, 26, pl. 2, fig. 1; Mem. Geol. Surv. Ireland, Expl. Mem. Sheets Nos. 169, 170, $180,181,1879$, pp. 58, 59, fig. 6.

Uranaster kinahani GreGorx, Geol. Mag., dec.4, vol.6, 1899, p. 348.-ScHöNDORF, Jahrb. nassauisch. Ver. Naturk., Wiesbaden, vol. 63, 1910, p. 225.

This species occurs abundantly as natural molds in the Caradoc (Upper Ordovicic), near Ballymadder Point and Bannow, Wexford, Ireland. A specimen is in the British Museum (Natural History), No. E 194.

URANASTER ELIZAE Spencer.

Uranaster elizæ Spencer, Mon. Brit. Pal. Asterozoa, pt. 1 (Palæontogr. Soc. for 1913), 1914, pp. 18, 20, 23, figs. 18, 23.

From the Ordovicic of Great Britain.

Genus PALAEOSTELLA Stürtz.

Palæostella Stü RTz, Palæontographica, vol. 36, 1890, p. 230, pl. 31, figs. 42, 43; Verh. naturh. Ver. preuss. Rheinl., etc., vol. 50, 1893, pp. 42, 58, pl.1, figs.5-8,

Palænectria Stürtz, Verh. naturh. Ver. preuss. Rheinl., etc., vol. 50, 1893. p. 12 (genoholotype the second specimen of Palæostella solida).

Description.-Animal attaining a large size, with large pentagonal interbrachial arcs. Rays five, stout. Ambulacral grooves wide and apparently regularly tapering.

Abactinally the inframarginals are also the marginals for this area. Near the distal ends of the rays the supramarginals adjoin and lie either partially over or inside of the inframarginals and continue nearly to the axillæ. There also seems to be a single radial column, confined, however, to the distal third of the rays. Otherwise the abactinal skeleton consists of very numerous, small, irregularly shaped, loosely interlocking plates without definite arrangement.

Madreporite abactinal.

Actinally the animal is bounded by subquadrate, numerously spine-bearing, inframarginal plates which increase rapidly in size towards the axillæ, where they are ponderous and nearly twice as wide as long. Ambulacral plates alternating, L-shaped, with single columns of podial openings. Adambulacrals subquadrate, prominent, increasing regularly in width proximally and bearing spines like the marginals. Interbrachial areas large, reaching to near the distal ends of rays, widely separating the inframarginals from the adambulacrals in the axillary region, and the space occupied by very numerous, small, spine-bearing, apparently irregularly disposed plates. 
Genoholotype and only species.-P. solida Stürtz. Two specimens are known from the Lower Devonic roofing slates, Bundenbach, Germany.

Remarks. - The starfishes from the Bundenbach roofing slates are at best but poor fossils and were it not for the great skill of Mr. Stürtz in cleaning them out of the matrix their systematic position could not well be determined. At best they are compressed to almost paper thickness and distorted during solidification and shortening or elongation of the slates. Under these circumstances it appears best to redescribe the detailed abactinal characters as given by Stürtz. He mentions numerous paxillæ and finds many characters common to both Palæostella and the living Nectria.

Palæostella is closely related to Palasterina, also to Lindströmaster, and may be a descendant of the latter. The actinal structure in Lindströmaster and Palxostella is nearly alike, both having large inframarginals and adambulacrals, but the interbrachial areas in the former are occupied by large closely adjoining plates, while in the latter these are small and somewhat loosely interlocking. Abactinally they can not be compared, since that side is unknown in Lindströmaster. The greatest difference between Palasterina and Palæostella is that the former has small inframarginals while in the latter they are very large. Then the supramarginal and radial columns in Palasterina are better developed and comparatively larger, while in Palxostella they are shorter and most prominent in the distal half of the rays. In the latter genus the central region of the disk has no ring of fifteen basal radial and supramarginal plates as in Palasterina.

From this evidence it seems probable that the line of descent is from Petraster to Lindströmaster to Palæostella in maintaining prominent columns of inframarginals, while the line from Petraster to Palasterina tends toward the reduction or elimination of these plates as a conspicuous skeleton element.

Palrnectria is based on the second specimen, and the genus is described as follows: "Should the described starfish [the second specimen of Palæostella solida Stürtz] prove not to be identical with Palxostella, which is possible, even though not probable-the other specimen is in the British Museum-I propose for it the new name Palænectria devonica." Unless the author takes the time to work out his new forms, or decides the problem presented for himself, he should not expect some one else to do this for him. Under these circumstances the genus and species are regarded as not defined.

\section{Genus PSEUDOPALASTERINA Stürtz.}

Pseudopalasterina StÜRTz, Verh. naturh. Ver. preuss. Rheinl., etc., vol. 56, 1900, pp. 219, 224.

Genoholotype and only species.-Palasterina follmanni Stürtz. 


\section{PSEUDOPALASTERINA FOLLMANNI (Stürtz).}

Palasterina follmanni Stürtz, Palæontographica, vol. 36,1890, p. 226, pl. 29, figs. 29-31a.

Pseudopalasterina follmanni StüRTz, Verh. naturh. Ver. preuss. Rheinl., etc., vol. 56, 1900, pp. 219, 224.

Actinally this species has ambulacrals and narrow adambulacrals and outside of the latter the interbrachial and abactinal areas consist of a membrane with small spine-bearing plates. It has no inframarginal nor radial and supramarginal columns, features characterizing Palasterina.

Formation and locality.-Lower Devonic of Bundenbach, Germany.

\section{NEW GENUS.}

NEW SPECIES.

Prof. Weller got on Fountain Creek, at Waterloo, Illinois, in the St. Louis limestone, a small pentagonal asterid (No. 14396, University of Chicago collection) showing only the actinal side, that differs from all other known forms of the large-disked genera. The five rays are completely within the pentagon, with the interbrachial areas large and straight-sided. These areas are made up of a few large tesselate plates, of which it seems that seven compose the interbrachial margins and inside these there seem to be transverse rows, each with five, three, two, and one ossicles. It could not be made out whether the inframarginals and supramarginals are directly superposed, but this may be so.

Ambulacral furrows exceedingly narrow, a mere line. These are bounded by columns of large, very ornate adambulacrals, each with seven ossicles. Those of opposite columns alternate decidedly with one another and on its outer side each bears two short but distinct spines.

Adambulacral oral armature in five very prominent pairs of pieces, long and pointed, and about twice as long as any other adambulacrals.

Measurements: $\mathrm{R}=8.5 \mathrm{~mm}$., $r=7 \mathrm{~mm}$.

\section{Family LEPIDASTERID无 Gregory (emend.).}

Lepidasteridæ Gregory (part), Geol. Mag., dec. 4, vol. 6, 1899, p. 352 (includes Lepidaster and Etheridgaster); Treat. Zool., vol.3, Echinoderma, 1900, p. 255. Helianthasterinæ Gregory, Geol. Mag., dec. 4, vol. 6, 1899, p. 258.

Helianthasteridæ StürTz, Verh. naturh. Ver. preuss. Rheinl., etc., vol. 56, 1900, p. 204.-SchöndorF, Jahrb. nassauisch. Ver. Naturk., Wiesbaden, vol. 63, 1910, p. 235.

Primitive multi-rayed Phanerozonia apparently with the general structure of Palæasteridæ, but with as many as 24 rays. Madreporite known only in Helianthaster, where it is interbrachial and on the 
edge of the disk, more actinal than abactinal. Inframarginals or supramarginals bounding the rays.

Contains:

Lepidaster Forbes.

Helianthaster Roemer.

Lepidasterella, new genus.

Remarks.-For a discussion as to why there are multi-rayed-that is, more than the normal five-rayed-asterids, see the family Palæosolasteridæ.

\section{Genus LEPIDASTER Forbes.}

Lepidaster Fonbes, Mem. Geol. Surv. United Kingdom, British Org. Rem., dec. 3, 1850, p. 1, pl. 1, figs. 1-3.-Wright, Mon. British Foss. Echinod., Oolitic, vol. 2, pt. 1 (Palæontogr. Soc. for 1861), 1862, p. 35.-WoodWARD, Geol. Mag., dec. 2, vol. 1, 1874, p. 9.-Zrrtel, Handb. Pal., vol. 1, 1879, p. 454.-STÜRTz, Palæontographica, vol. 36, 1890, p. 222, pl. 28, figs.19-20; Verh. naturh. Ver. preuss. Rheinl., etc., vol. 50, 1893, pp. 52, 72.

Generic description.-Disk very large, over $50 \mathrm{~mm}$. in diameter, and apparently composed of heavy, closely set, polygonal plates. Rays 13 in number, fairly stout, not slender, and tapering fairly rapidly in the distal half. $R=52 \mathrm{~mm}$., $r=25 \mathrm{~mm}$. A little more than half the length of the rays extends beyond the disk.

Actinally, the rays are bounded on each side of the very narrow ambulacral furrow by two columns of strong, tumid, closely adjoining, transversely oblong, adambulacral and inframarginal plates. The latter are also the marginals for the abactinal side. The adambulacrals are tuberculate and probably bore small spines; there are 25 ossicles in each column. Ambulacrals unknown, but the arrangement of the adambulacrals indicates that they were slightly alternate.

Madreporite and interbrachial areas unknown.

Abactinally little is known. The rays are described as having "numerous small polygonal nearly flat ossicula, closely set, and of various sizes." To judge by similar rays in other genera, it would appear that Lepidaster may have had radial and supramarginal columns of ossicles.

Genoholotype and only species.-L. grayi Forbes. The holotype was found in the quarries of Wenlock limestone in the Castle Hill at Dudley, England.

Observations.-Forbes's illustration leads the writer to believe that the abactinal plates have been deranged and that originally the larger pieces were arranged in supramarginal columns, while the smaller ones composed the radial row of ossicula. This type of structure generally goes with the actinal arrangement as here seen in Lepidaster, a duplicate of the same structure in Hudsonaster, Palaaster, and Mesopalxaster. Stürtz compares the abactinal skeleton of 
Lepidaster with the recent Scythaster, which is made up of plates of various sizes without regular arrangement. It seems more natural to compare Lepidaster with Siluric and Ordovicic genera than with recent forms, and particularly when nearly identical structures are found in the genera mentioned.

Forbes also describes Lepidaster as having the ambulacral grooves "towards the extremity, in some instances partially filled up by small polygonal intervening plates." His figures show a few of these plates arranged in single columns. This anomalous structure is undoubtedly best explained by accepting Stürtz's conclusion, that they are the separated ambulacral pieces, since otherwise none of these plates appear to be present. As a fifth actinal, or a single ambulacral column, the structure is out of all"harmony with starfishes.

\section{Genus HELIANTHASTER Roemer.}

Helianthaster Roemer, Palæontographica, vol.9, 1863, p.147, pl. 28.-QUENSTEDT, Petrefactenkunde Deutschlands, vol. 4, 1876, p. 82, pl. 93, fig. 32.-ZrTTEL, Handb. Pal., vol. 1, 1879, p. 453.-STürTz, N. Jahrb. für Min., etc., 1886, vol. 2, p. 148; Palæontographica, vol. 32, 1886, p. 81; vol. 36, 1890, p. 218 , pl. 27; Verh. naturh. Ver. preuss. Rheinl., etc., vol. 50, 1893, pp. 12, 30.-Gregory, Treat. Zool., vol. 3, Echinoderma, 1900, p. 258.-Clarke, Bull. N. Y. State Mus., No. 121, 1908, p. 61, pl. 10.-ScHöNDoRF, Jahrb. nassauisch. Ver. Naturk., Wiesbaden, vol. 62, 1909, p. 34.

Generic characters.-Disk large; rays 14 to 16 in the genotype. Interbrachial actinal areas well developed but not over-large for a many-rayed asterid, either integumentary or granular, distally concavely cut out and margined by several small inframarginals, about seven on each side of a larger axillary piece.

Madreporite marginal, large, more actinal than abactinal, radiately striate, interbrachial, and situated immediately outside of the inframarginals. In the fossils it appears to be of the actinal surface.

Rays long and slender, protruding beyond the disk more than twice the length inside the disk. Adambulacrals opposite one another, with small lateral spines, prominent and large, wider than long, bounding the rays, and terminating proximally in pairs of modified pieces. These make the adambulacral parts of the oral armature. Ambulacral grooves narrow, ambulacral ossicles not seen but probably arranged opposite one another.

Abactinally the disk appears to have a scale-like covering. The rays have median columns of radialia, outside of which are stout columns of supramarginal ossicles.

Genoholotype (type by monotypy).-H.rhenanus Roemer (citations as above). Lower Devonic of Bundenbach, Germany. The above definition is based on the illustrations of Stürtz. There is a second species in Germany, and $H$. filiciformis occurs in England.

$50601^{\circ}-$ Bull. $88-15-11$ 


\section{HELIANTHASTER FILICIFORMIS Woodward.}

Helianthaster filiciformis WoodwaRD, Geol. Mag., dec. 2, vol. 1, 1874, pp. 7-10, fig. on p. 8.

A natural mold in sandstone measuring about $45 \mathrm{~mm}$. in total diameter. Has 11 rays. The disk "must have measured 10 $\mathrm{mm}$. in breadth. The arms are $17 \mathrm{~mm}$. in length, and near their junction with the body are $5 \mathrm{~mm}$. broad." The specimen needs to be restudied and modernized.

The holotype is from the Upper Devonic at Great Inglebourne, Harberton, South Devon, England, and is now in the collection of Mr. Champernowne.

\section{LEPFDASTERELLA, new genus.}

Plate 25, fig. 2.

Lepidasterella Schuchert, Fossilium Catalogus, Animalia, pt. 3, April, 1914, p. 23.

Much like Lepidaster, but with 24 rays instead of 13 as in that genus. Rays extending considerably beyond the disk. The abactinal side only is known, but it shows that the rays have slender radial columns, the ossicles of which are disposed alternatingly with the larger and more prominent supramarginals. Outside of these in some rays may be seen the edges of the inframarginalia, and these have well developed but slender, rather long spines.

There appear to be no ambital areas, as the inframarginals of adjoining rays meet and at their junction begins the disk. The disk appears to have been made up of more or less closely adjoining polygonal plates whose arrangement is not discernible in the specimen.

The madreporite and its position are unknown.

Actinal area unknown.

Genoholotype and only species.-L. babcocki, new species.

Remarks.-The essential difference between Lepidaster and Lepidasterella is that the former has 13 rays while the latter has 24 .

\section{LEPIDASTERELLA BABCOCKI, new species.}

\section{Plate 25, fig. 2.}

Helianthaster, new species Clarke, Fifty-ninth Rep. N. Y. State Mus., 1906, p. 37, and plate.

Helianthaster gyalum Clarke (part), Bull. N. Y. State Mus., No. 121, 1908, p. 61 (not pls. 12, 13=Palæosolaster (?) gyalum).

Description.-Rays, 24. Length of best preserved ray in the holotype, $28 \mathrm{~mm}$. Width of ray at base, $3 \mathrm{~mm}$. Width of disk, probably not less than $20 \mathrm{~mm}$.

Rays slender and regularly tapering. Their structure is only known abactinally, from a natural mold in a fine sandstone. Medially there is a narrow but high column of radial plates, each one of 
which alternates with those of the supramarginal plates. The latter are slightly tumid, subquadrate in outline, regular in size, but decreasing gradually distally. Outside of these and margining the rays may be seen a little of the inframarginalia, which bear pairs of short, slender, and finely striated spines. There are from 31 to 33 closely adjoining plates in each one of the abactinal columns; there appear to be no accessory plates of any kind in the rays.

Disk circular in outline, somewhat tumid and covered by small many-sided plates that originally appear to have been closely adjoining.

Remarks.-As this is the only American starfish with more than five rays, it is readily distinguished from all others. The abactinal arm structure is practically that of Hudsonaster, with the difference that in $L$. babcocki the inframarginals do not project beyond the supramarginals and are therefore not seen as a rule from the dorsal side in the natural casts.

Locality and formation.- The holotype, an excellent specimen, was found in the lower part of the Upper Devonic, near Ithaca, New York, by Mrs. G. W. Babcock, after whom the species is named; it is in her possession. The writer's attention was called to this interesting specimen by Prof. H. S. Williams of Cornell University. Some years after this starfish was described in manuscript, Clarke directed attention as above cited to two others found in the Cashaqua shales of the Portage in Hunt's quarry, at Interlaken, New York.

Cat. No. 60627 (cast), U.S.N.M.

\section{FAMILY, unknown.}

Genus ASTROPECTEN Link.

The genus Astropecten is based upon living species, and it is not probable that the Devonic forms are identical.

\section{ASTROPECTEN (?) SCHLÜTERI Stūrtz.}

Astropecten schlüteri SтÜRTz, Palæontographica, vol. 32, 1886, p. 87, pl. 10, figs. 1, $1 b, 2,2 a$; Verh. naturh. Ver. preuss. Rheinl., etc., vol. 50, 1893, pp. 51, 71.

In the roofing slates of the Lower Devonic at Bundenbach, Germany. A single very much distorted and compressed example is the basis of this species.

\section{Genus ATAXASTER Jaekel.}

Ataxaster JAE KEL, Zeits. geol. Gesell., vol. 55, 1903, Protokol, p. 14 (106).

Genoholotype and only spécies.-A. pygmæus Jaekel. Ordovicic $\left(\mathrm{D}_{1}\right)$, St. Benigna, Bohemia.

Description.- "A small asterid whose ambulacrals in the distal parts are alternate, but in the proximal are opposite."

Remarks.-The above is all that is known about Ataxaster, and for the present the genus has no value. 


\section{CRYPTOZONIA Sladen.}

Specialized Asteroidea without true marginal plates. In other words, there are no large and conspicuous marginal plates bordering the animals, but in primitive forms large adambulacrals do margin the species. In other primitive forms more or less of the inframarginals may be present, but if so they remain adjoining the adambulacrals.

Ambulacrals alternating or directly opposite one another.

Oral armature generally with the adambulacral elements the most conspicuous; more rarely the ambulacral elements are most prominent.

Contains the following families:

Stenasteridæ.

Monasteridæ.

Urasterellidæ.

Calliasterellidæ.

Compsasteridæ.
Schuchertiidæ.

Palasteriscidæ.

Schœnasteridæ.

Palæosolasteridæ.

Remarks. - This widely accepted order, which appears as if founded in nature on a single grand phylum, probably has no such value. In other words, asterids without either one or both of the marginal columns bounding the animal developed several times. Therefore, the absence of these ossicles is no indication of direct phyletic relationship, but such are simply cases of parallel development. As long as asterids retain the primitive characters of few columns of rather strong ossicles and the adambulacral type of oral armature, they are clearly Phanerozonia, but when the ponderous skeleton breaks up into a more flexible one of small pieces, then the marginal and abactinal columns vanish as such in the mass of small plates. On the other hand, ponderosity may even be retained with the loss of the inframarginals alone. In all of these Paleozoic forms, the adambulacral type of oral armature is the rule.

Among the Paleozoic "Cryptozonia" it seems certain that at least the families Stenasteridæ, Urasterellidæ, Schuchertiidæ, and Palæosolasteridæ had independent origins in Phanerozonia stocks. The Urasterellidæ and Calliasterellidæ apparently had a single origin in the Phanerozonia subfamily Mesopalæasterinæ by the adoption of marked flexibility. On the other hand, the families Stenasteridæ and Monasteridæ retained rigidity and primitive characters, and more probably arose in the Hudsonasteridæ through the loss of the inframarginals alone. The Schuchertiidæ also had their origin directly in some Phanerozonia stock and one naturally looks for it in forms developing large interbrachial areas as in the Palasterinidæ. vo In this family, however, the accessory plates are introduced between the adambulacrals and inframarginals, while in the former family they 
are introduced outside of the inframarginals and the entire abactinal skeleton is broken up into an abundance of tiny pieces. Therefore, one must go back for their origin at least as far as the Palæasteridæ. In this case it was not primarily flexibility that led to this supposed ordinal change, but it was due to increase of body cavity and enforced enlarging of the skeleton in the interbrachial and ambital areas, making the more or less pentagonal disk. It is probable that the Palasteriscidæ were their descendants, while the Schœnasteridæ may have been the final Paleozoic representatives of the same phyletic line. The Palæosolasteridæ seemingly arose in the Phanerozonia family Lepidasteridæ by the adoption of a flexible skeleton.

It would, therefore, seem that the Paleozoic families of supposed Cryptozonia construction are to be grouped as follows:

Superfamily Stenasteracea, new.

Includes families Stenasteridæ and Monasteridæ.

Superfamily Urasterellacea, new.

Includes families Urasterellidæ, Calliasterellidæ, and Compsasteridæ.

Superfamily Schuchertiacea, new.

Includes families Schuchertiidæ, Palasteriscidæ, and Schœnasteridæ.

Superfamily Palæosolasteracea, new.

Includes family Palæosolasteridæ.

STENASTERIDÆ, new family.

Rigid, small, primitive, five-rayed Cryptozonia, with rapidly tapering or petaloid rays. Ambulacrals few in number and opposite in arrangement. Interbrachial areas consisting of the single pairs of large basal adambulacral oral armature plates.

Abactinal skeleton unknown, but in some forms seemingly integumentary. No spines as yet known. It is probable that this family will be referred to the Auluroidea.

Contains:

Stenaster Billings.

Tetraster Nicholson and Etheridge.

Genus STENASTER Billings (emend.).

Plate 32, fig. 1 .

Stenaster Brulings; Geol. Surv. Canada, Can. Org. Rem., dec. 3, 1858, p. 77.StüRtz, Palæontographica, vol. 36,1890 , p. 220.-Gregory, Geol. Mag., dec. 4, vol. 6, 1899, p. 352.-Spencer, Mon. Brit. Pal. Asterozoa, pt. 1 (Palæontogr. Soc. for 1913), 1914, p. 22.

Urasterella Srürrz (not McCoy), Verh. naturh. Ver. preuss. Rheinl., etc., vol. 50,1893, pp. 40, 41, 56.

Generic characters. - Small rigid asterids, the largest example having $\mathrm{R}=20 \mathrm{~mm}$., $r=4.5 \mathrm{~mm}$. Disk small, without interbrachial arcs. Rays five, short, stout, lanceolate or petaloid.

Abactinal area devoid of a preservable skeleton. For this reason when this side is at hand it is nearly always mistaken for the actinal, so nearly alike are the two. 
Madreporite unknown.

Adambulacral plates with granular surfaces, few in number, never more than 17 in a column, subquadrangular and thick, greatest width about the middle of the rays, rapidly diminishing in size distally and making the margin of the rays and disk. The great proximal adambulacrals are the orals, occupying the axils in pairs, acutely triangular, more or less pointed, and terminating orally.

Ambulacral plates large, directly opposite one another and the adambulacrals as well, $\vdash$-shaped, with the widest portion in the perradial center of the rays; there are as many as 16 or 17 ambulacrals in a column. Laterally each plate is more or less excavated, both distally and proximally, thus leaving very large, subcircular podial openings.

Spines of any kind are so far unknown.

Genoholotype (the first species and the one selected by subsequent workers).-Stenaster salteri Billings.

Remarks.-This genus has not had a good standing, due largely to the fact that Palxaster Hall was poorly known when Billings described Stenaster and further because he included two distinct generic types in his genus. A careful reading of Stenaster, however, reveals that Billings actually based his genus on $S$. salteri, the first form following the generic description, and this selection has been followed since. Later on, McCoy applied the name Urasterella in a loose manner to the second species (Palraster pulchellus), and although it is a form of this genus it is not the genotype. Hall (1868) directed attention to this work of McCoy, but erroneously assumed that all of Stenaster was synonymous with Urasterella. It is true, as stated by Hall, that Billings's second species is congeneric with Urasterella, but the first species and genotype is certainly quite distinct from McCoy's genus. Stürtz (1890) also points out the same thing and gives a short and emended diagnosis of "Urasterella (Stenaster)." In 1893 the same writer applied McCoy's name Urasterella to Stenaster salteri and made $S$. pulchellus the genotype of Urasterella, a proceeding that violates the rules of nomenclature.

Stenaster as here restricted differs from Urasterella in being more decidedly rigid and not so flexible as the latter, while the rays are far shorter and petaloid in form. For these reasons, Stenaster has comparatively few adambulacrals and ambulacrals, while there are many more of these ossicles in Urasterella. Finally, the former reveals no abactinal plates or spines of any kind, while the latter has a skeleton of small plates that terminate in long inarticulate spines or rods.

Actinally Stenaster is closely related to Tetraster, and the only marked difference is that the former has petaloid rays and more pronounced adambulacral oral jaws. 
There would be no need to point out here the difference between such distinct genera as Stenaster and Palæaster were it not that Hall regarded the former as a synonym of the latter. In Stenaster the rays are petaloid and not slender and regularly tapering, as in Palzaster. The most marked distinction, however, is the fact that these two genera belong to different orders, for Palæaster has columns of inframarginals that are completely absent in Stenaster. Further, in the last-named genus, the interbrachial areas are made up each of two pairs of oral armature pieces, while in Palæaster there are, distally to these, additional large single axillary interbrachials.

Stenaster and the related genus Tetraster are very primitive in construction. Actinally they are seen to have the structure of Hudsonaster minus the inframarginal columns and the single axillary interbrachials. It is this difference that makes the former genera members of the order Cryptozonia, while Hudsonaster is the most primitive of Phanerozonia. Until the abactinal area is known in Tetraster and Stenaster, positive phyletic relationship can not be stated, but in a number of specimens of the latter genus the evidence at hand indicates decided specialization through the complete removal of the heavily plated skeleton of Hudsonaster.

Distribution.-Ordovicic of America. The following are the known species:

S. salteri Billings. Black River and Trenton.

S. (?) obtusus (Forbes). Bala of Ireland and Wales.

S. (?) coronella (Salter). May Hill sandstone (Siluric) of England. S. (?) confluens Trautschold. Upper Carboniferous of Russia.

STENASTER SALTERI Billings.

Plate 32, fig 1.

Stenaster salteri Brulings, Geol. Surv. Canada, Can. Org. Rem., dec. 3, 1858, p. 78 , pl. 10, figs. 1a, 1b.-Wright, Mon. British Foss. Echinod., Oolitic, vol. 2, pt. 1 (Palæontogr. Soc. for 1861), 1862, p. 28, fig. 15 (2) on p. 24.

Original description.- "This species has rather short, broad rays, which are narrower where they are attached to the very contracted body than they are at about the center of their length. In consequence of this form, the sides of the rays are not parallel, but a little curved outward. As however only two specimens have been collected, and both appear to be a little flattened by vertical pressure, it may be that this leaflike shape of the rays is accidental [an abundance of specimens show this form to be the natural one]. * * * The adambulacral plates are oblong [granular and from 7 to 17 in each column in the smallest and largest examples], and the sutures between them are nearly at right angles to the ambulacral grooves; those next the body are a little sloping outward. 
Their length is about twice their breadth, and they are so disposed that the greater dimension is transverse or at right angles to the groove; the extremities which lie next to the grooves are angular, and some of them appear to have the contiguous pores partly excavated in them. The oral plates [adambulacrals] are acutely triangular, the sharpest angle being toward the mouth [and form the interbrachial areas]. The plates are smooth [the adambulacrals are all distinctly granular]. The ambulacral pores are very large, and the ossicles are much contracted in the middle and greatly expanded along the median line of the bottom of the groove." These plates are directly opposite one another and the adambulacrals, and in number equal those of the latter.

The type-specimen figured by Billings measures: $R=14 \mathrm{~mm}$, $r=3.5 \mathrm{~mm}$., $\mathrm{R}=4 r$. Width of a ray at base about $4 \mathrm{~mm}$., at about mid-length $5 \mathrm{~mm}$. The largest specimen: $\mathrm{R}=20 \mathrm{~mm}$., $r=4.5 \mathrm{~mm}$.

In the University of Toronto there is a specimen that in every way, except one, has the characters of Stenaster salteri. It was found associated with many other individuals at Kirkfield. It differs from its associates in having what appears to be a distinct disk, rather large, with concave sides, filling in the spaces between the rays. One looks in vain, however, for plates or spines, as the interbrachial areas are nothing more than an amorphous mass of calcium carbonate. These areas are very distinct and stand out prominently, but because they do not reveal any plated or spiniferous structure the writer regards them as false characters, produced during the permineralization of the specimen. This conclusion is further supported by the fact that otherwise the characters are those of $S$. salteri.

Formation and locality.-Three specimens (the type, No. 1398, and two fragments) are from the Trenton limestone at Belleville, Ontario, and are now in the Museum of the Canadian Survey. Another specimen in that museum is on the same slab with Petraster rigidus and has been labeled Palxaster matutina. In Mr. Ulrich's collection there are four isolated rays of this species obtained by him from the Black River limestone at Curdsville, Kentucky. A further specimen preserving two rays, from Government House Bay, Ottawa, was found by Mr. Walter R. Billings. In the Museum of Comparative Zoölogy there is still another individual which appears to be of this species; it was found by Mr. J. B. Perry at Panton, Vermont. Finally, an abundance of material was obtained in the Black River limestones at Kirkfield, Ontario; there are more than twenty specimens from this locality in the Walker collection of the University of Toronto, gathered by Mr. Townshend.

Cat. No. 60628, U.S.N.M. 
STENASTER (?) OBTUSUS (Forbes).

Asterias primæva Salter and Sowerby, Quart. Jour. Geol. Soc. London, vol. 1, 1845, p. 8, 20 (table) (nomen nudum).

Uraster obtusus Forbes, Mem. Geol. Surv. Gt. Britain, vol. 2, pt. 2, 1848, p. 463; Mem. Geol. Surv. United Kingdom, dec. 1, 1849, p. 2, pl. 1, fig. 3.-MurchIson, Siluria, 1854, p. 182, fig. 17.

Palæaster obtusus SAlter, Ann. Mag. Nat. Hist., ser. 2, vol. 20, 1857, p. 326.-

Wright, Mon. British Foss. Echinod., Oolitic, vol. 2, pt. 1 (Palæontogr. Soc. for 1861), 1862, p. 24.-Salter, Mem. Geol. Surv. Gt. Britain, vol. 3, 1866 , p. 289 , pl. 23, fig. 1.

Stenaster (?) obtusus STÜ RTz, N. Jahrb. für Min., etc., 1886, vol. 2, p. 153; Verh. naturh. Ver. preuss. Rheinl., etc., vol. 50, 1893, pp. 41, 56.

Stenaster obtusus Spencer, Mon. Brit. Pal. Asterozoa, pt. 1 (Palæontogr. Soc. for 1913), 1914, pp. 22, 23, 31, text fig. 21, pl. 1, figs. 6, 7 .

The little that is known of this species appears to be in harmony with the characters of Stenaster as here defined. It occurs in the Caradoc beds (Ordovicic) at Drumcannon, Waterford, Ireland, and in the Bala rocks west of Bala Lake (Moel-y-Garnedd), North Wales.

STENASTER (?) CORONELLA (Salter).

Palæaster coronella SAuter, Ann. Mag. Nat. Hist., ser. 2, vol. 20, 1857, p. 326.-

Wright, Mon. British Foss. Echinod., Oolitic, vol. 2, pt. 1 (Palæontogr.

Soc. for 1861), 1862, p. 25.

Stenaster (?) coronella STÜ RTz, N. Jahrb. für Min., etc., 1886, vol. 2, p. 153.

The description of this species is very short and almost nothing is known of its characters. It occurs in the May Hill sandstone (Siluric) at Gunwick Mill, Malvern, England.

\section{STENASTER (?) CONFLUENS Trautschold.}

Stenaster confluens Trautschord, Nouv. Mém. Soc. Imp. Nat. Moscou, vol. 14, 1879, p. 11, pl. 2, fig. 5.-ScHö NDORF, Palæontographica, vol. 56, 1909, p. 337.

Based on a fragment of the distal part of a ray. Appears to be a cryptozonian. Generic position unknown. From the Upper Carboniferous (Moscovian) of Moscow, Russia.

Genus TETRASTER Nicholson and Etheridge (emend.).

$$
\text { Plate 33, fig. } 4 .
$$

Tetraster Nicholson and Erheridge, Mon. Silurian Foss. Girvan Dist., Ayrshire, fasc. 3 , 1880, p. 324 , pl. 21; figs. 3-8 (not figs. 1-2=Hudsonaster batheri, and 9-10= Urasterella girvanensis).

The name has reference to the four columns of actinal plates of the rays.

Remarks. - The authors of Tetraster distinguished their genus from Palæaster on the ground that it had on the actinal side but four columns of plates, while that genus as typified by $P$. matutinus, now Hudsonaster matutinus, has six. In this definition they are correct, but they complicated their good intentions not only by referring to 
Tetraster another Cryptozonia form (Urasterella girvanensis, new species), but also by confusing with their genotype specimens that certainly have the character of Palxaster so far as six columns of actinal ossicles are concerned. This latter admixture the writer has taken out of the genotype and has described it in this work as Hudsonaster batheri. The adjusting of this matter has been made possible through the kindness of Dr. Bather, who made for this work wax squeezes of the various specimens. After seeing these and the other material originally referred to Tetraster by Nicholson and Etheridge, their various drawings became clear. Their figures are fairly good, but in places do not bring out all the characters, but it was the mixture of three generic forms under Tetraster that made it for a time impossible to determine on what the genus should stand.

Emended description.-Small, five-rayed asterids, $\mathrm{R}=$ about $5 \mathrm{~mm}$., $r=$ about $2 \mathrm{~mm}$. Abactinal side unknown. Actinally convex and in its general expression reminding much of living species with large marginals, but in Tetraster the comparatively massive margining plates are adambulacralia.

Adambulacrals compose the entire outer actinal areas of Tetraster and margin the entire animal. Distally the pieces are small and the 12 ossicles of each column increase rapidly in size with the largest basal pieces of adjoining columns making the prominent interbrachial areas. Ambulacrally all are somewhat excavated, stand high above the furrow and each ossicle terminates in a ridge that joins those of the ambulacrals. All of these plates are abundantly granular.

Ambulacral furrows not wide but rapidly becoming very deep proximally, with excavated adambulacral sides. The columns meet in front of the two largest interbrachial adambulacrals. Podial openings are large and issue deeply from beneath the adambulacrals and between the lateral sutures of the ambulacralia. The pieces of the ambulacral columns are as many as there are adambulacrals and are placed directly opposite one another. Medially the ambulacralia are elevated, roof-like, and without a central gutter.

While the abactinal area is unknown, it appears that the adambulacrals also margin this side of the animal. The nature of the skeleton inside of these columns may be of small pieces as in Urasterella, or, what seems more probable, consist of large radial and supramarginal ossicles, without accessory pieces.

Spines of any kind are unknown.

Genoholotype.-Tetraster wyville-thomsoni Nicholson and Etheridge as above emended. $T$. (?) imbricatus (Salter) is also placed under this genus for the present.

Tetraster as now defined is so distinct in its great adambulacral development that it will not be confused with any other Paleozoic genus except Stenaster. Both genera, so far as the actinal area is 
concerned, are closely related. The differences, however, are worthy of generic rank. In Stenaster the rays are petaloid, with the adambulacrals largest at the mid-length of the rays, while in Tetraster the rays are triangular, with the greatest ossicles in the axils.

At first the genotype looks as if one had a direct representative of living Phanerozonia, but a little study quickly shows that the large actinal margining plates are not marginals or inframarginals, but adambulacrals, and therefore indicate a cryptozonian form. For a while it seemed that these large plates must be inframarginals, but then adambulacrals should be present, and they were looked for along the vertical ambulacral walls, but even here there are no diminutive pieces of these columns. Among Paleozoic asterids the writer has not seen a form without adambulacrals, and when there are but four actinal columns it is always the inframarginals that are diminutive or absent.

This species may be identical with $T$. (?) imbricatus (Salter), which see for further remarks.

Distribution.- Restricted to the Upper Ordovicic at Thraive, Girvan, Scotland. The specimens occur as very sharp natural molds in a micaceous sandstone, from which good wax squeezes can be made, revealing all the skeletal characters. The originals are in the collection of Mrs. Robert Gray, Edinburgh, Scotland.

TETRASTER (?) IMBRICATUS (Salter).

Palæaster imbricatus SAlter, Mem. Geol. Surv. Gt. Britain, vol. 3, 1866, ”. 289 , pl. 23, fig. 8 .

Original description. - "P. rigidus, uncialis. Radii breves conici, nec ad basin valde expansi, subcarinati, tuberculis seu jugis obliquis remotiusculis asperi.

"Ray conical, its length about five lines, its breadth at base less than two lines. Only two rays are preserved; these are convex, slowly tapering, somewhat carinate above (we do not see the lower side), and ornamented by tubercles gathered into curved oblique rows, which run forward from the avenues toward the carina above, and are separated from each other by a space little more than their own breadth.

"Locality: Caradoc rocks, Llanfyllin, Montgomeryshire [Wales]. The specimen is in the collection of Mr. Prosser."

Remarks.-As the writer has not seen the holotype, his conclusions are based on the lithographic figure, which adds but little knowledge to that in the description. As there are but two columns of dorsal ray plates, it hardly seems that the species is a phanerozonian. In general it looks most like Tetraster, but as the dorsal side of this form is unknown, no direct comparisons can be made between them. On the other hand, the imbrication of the plates, their large size, 
and completely opposite arrangement suggest that $T$. (?) imbricatus may be an auluroid. Until the original specimen is restudied no definite assignment can be given it.

\section{MONASTERIDE, new family.}

Progressive but primitive five-rayed Cryptozonia, with massive plates, especially the adambulacrals, which are common to the actinal and abactinal areas. Ambulacrals opposite. Interbrachial areas consist of a number of pairs of adambulacrals crowded orally Abactinally the radial and supramarginal columns consist of large, closely adjoining plates, and are similar to those of Hudsonaster.

Contains:

Monaster Etheridge.

\section{Genus MONASTER Etheridge.}

Palæaster (Monaster) Etheridge, jr. (part), Mem. Geol. Surv. New South Wales, Pal., No. 5, pt. 2, 1892, pp. 70, 71.

Etheridgaster GrEgory, Geol. Mag., dec. 4, vol. 6, 1899, p. 353 (genoholotype, Palæaster clarkei).

Emended description.-Animal large, very stout, with five thick petaloid rays. Disk very large, with marked ray angles.

Abactinal area of rays with prominent radial, and supramarginal columns of large, contiguous, strongly convex, hexagonal plates, densely covered with small granules radially arranged. The ossicles of the radial columns alternate with those on each side and are largest in the mid-length of the rays, decreasing in size both distally and proximally, but most rapidly distally. This growth gives the ray columns a decided petaloid form. Outside of the supramarginals the animal is bounded by single columns of prominent, short, but very wide plates, which are the abactinal aspect of the actinal adambulacrals. These plates bear numerous spiniferous tubercles. The ossicles of the axillary disk region are not determinable. In the center of the disk there appear to be five distinct radials and a central disk plate, and around these probably were numerous small accessory pieces.

Madreporite abactinal, large, oval, radially striate, and situated near the axillary margin.

Actinally the rays consist almost entirely of the adambulacrals, which are numerous, abundantly tuberculate, short, and very wide. These columns increase rapidly in width, join and form angular axillæ, and leave between themselves deep petaloid ambulacral grooves. The interbrachial areas consist of the oral extensions of adjoining columns of adambulacrals, of which there are a great number of pairs, terminating in the mouth in five small pairs, the oral armature. 
Ambulacrals in two columns, opposite, short but wide, and about as numerous as the adambulacrals. Podial openings unknown.

Genoholotype.-Palxaster clarkei De Koninck. This is also the only species of Monaster and occurs in the "Upper and Lower Marine series" of the "Permo-Carboniferous" of New South Wales.

Remarks.-Mr. Etheridge proposed Monaster as a subgenus of Palæaster, from which it differs so radically as to give it easily the rank of a genus. He defines the group as follows: In Palæaster "the adambulacral plates, bordering the ambulacral avenues, are small and quadrangular, followed by large transverse marginal plates. In our Permo-Carboniferous species, on the contrary the adambulacral plates are transversely elongated, and occupy nearly the whole of the actinal surface on each side the avenues. The marginal plates [having reference to the plates along the margins which consist of adambulacrals, and also form part of the abactinal skeleton], in contradistinction to those of Hall's Silurian species, are here smaller and subdorsal in position. The question now presents itself, of what value in a classificatory sense is this character? Hall lays particular stress on the position of these plates on the actinal side of Palæaster. He says it 'has two ranges of plates on each side of the ambulacral groove; marginal [inframarginal] and adambulacral plates on the lower side, besides ambulacral or poral plates. The upper or dorsal side has three or more ranges of plates.' In the case of our specimens, only one set of plates, excepting those of the ambulacral grooves, are, as before stated, absolutely actinal; the marginals [same usage as before] are strictly so, or, at the least sub-dorsal. Under these circumstances, I purpose distinguishing our Australian species under the subgeneric name of Monaster (from the one or single row of adambulacral plates on each side of an ambulacral avenue)."

The original definition is here givon at length to show that it can only apply to the structure in Palæaster clarkei De Koninck, which is also the first species following the generic discussion. The author in the same work describes a new species which he also refers to Monaster, Palæaster (Monaster) giganteus, but its structure is radically different and does not conform with the subgeneric definition by Etheridge. Elsewhere in this work it is taken as the genotype of the now genus Australaster. Gregory in the serial above cited takes as the genotype of Monaster the last named species, the third of Etheridge, and transposes the former as the genotype to his new genus Etheridgaster. This the writer holds can not be done even though Etheridge selected no genotype for Monaster. That author's genotype, as the name implies, refers to a species with but a single column of plates on each side of the ambulacrum. The species selected by a subsequent author should have the structure implied in the 
original generic definition and when none actually applies, then the first species following the generic diagnosis. That Gregory fully appreciated the structural difference between Palxaster clarkei and $P$. (M.) giganteus is shown in his reference of the former to the order Phanerozonia and the latter to the Cryptozonia. Our disagreement is not as to structure but in the interpretation of the rules of nomenclature. Under these circumstances P. clarkei is retained as the genotype of Monaster, since it appears that $P$. giganteus has both inframarginals and adambulacrals on the actinal side, a structure quite different from that described for and present in Monaster Etheridge.

After the above was written in 1900, the writer explained by letter to Professor Etheridge what Gregory had done. Etheridge replied under date of June 6, 1900: "The laws of zoological nomenclature should have guided Doctor Gregory to have selected the first species described, as the subgeneric type, in the absence of any statement to the contrary on my part. As you say, Etheridgaster is certainly a. synonym of Monaster."

Monaster is most like Hudsonaster. It retains the primitive ponderous skeleton of the latter, but curiously has lost the inframarginal columns of ossicles, although the supramarginals are present.

MONASTER CLARKEI (De Koninck).

Palæaster clarkei De Konınck, Mém. Soc. roy. Sciences, Liège, ser. 2, vol. 2, 1877, p. 166, pl. 7, figs. 6, 6a; (David), Mem. Geol. Surv. New South Wales, Pal. No. 6,1898, p. 127, pl. 7 , figs. $6 a, 6 b$.

Palæaster (Monaster) clarkei Etheridge, jr., Mem. Geol. Surv. New South Wales, Pal. No. 5, pt. 2, 1892, p. 71, pl. 14, figs. 1, 2; pl. 15, fig. 4.

Etheridgaster clarkei GREGORY, Geol. Mag., dec. 4, vol. 6, 1899, p. 353.

Of this species three natural molds have been found in the "Upper Marine" and "Lower Marine" series (Carboniferous) of Northumberland County, New South Wales. The holotype in the Clarke collection was destroyed by fire.

The species attained a large size, the rays from the center of the disk to their extremities are not less than $5 . \mathrm{cm}$., and in another specimen are $6.5 \mathrm{~cm}$.

\section{URASTERELLIDÆ, new family.}

Tæniasteridæ GreGory (part), Geol. Mag., dec. 4, vol. 6, 1899, p. 351 (includes Tæniaster, ?Stenaster, Urasterella, Protasteracanthion, Salteraster).

Roemerasterinæ Gregory, Treat. Zool., vol. 3, Echinoderma, 1900, p. 255.

Specialized Cryptozonia, with alternate ambulacra, and with adambulacral type of oral armature. Rays five, rather flexible, long and gently tapering, proximally united without forming interbrachial areas. No inframarginals discernible as such at maturity, the actinal margin being occupied by well-developed adambulacrals. Abactinal area composed of numerous small plates arranged in columns and 
quincunx. The radial and supramarginal columns may be discornible in somewhat larger plates. Adambulacrals many, like coins set on edge.

Contains:

Urasterella McCoy.

Genus URASTERELLA McCoy (emend.).

Plates 27 to 30 .

Urasterella McCoy, British Pal. Foss., 1851, p. 59 (not defined).-HaLl, Twentieth Rept. N. Y. State Cab. Nat. Hist., 1868, p. 289; rev. ed., 1868=1870, p. 332.McCox, Geol. Surv. Victoria, dec. 1, 1874, p. 42.-Zittel, Handb. Pal., vol. 1, 1879, p. 453.-SтÜRTz, N. Jahrb. für Min., etc., 1886, vol. 2, p. 152; Palæontographica, vol. 36, 1890, p. 219.-GREGORY, Geol. Mag., dec. 4, vol. 6, 1899, p. 352.

Stenaster Brluings (part), Geol. Surv. Canada, Can. Org. Rem., dec. 3, 1858, p. 77.-STÜRTz, Verh. naturh. Ver. preuss. Rheinl., etc., vol. 50, 1893, pp. $40,56$.

Roemeraster StüRTz, Palæontographica, vol. 32, 1886, p. 85 (genoholotype, Asterias asperula Roemer); vol. 36, 1890, p. 220; Verh. naturh. Ver. preuss. Rheinl., etc., vol. 50, 1893, pp. 52, 73.

Protasteracanthion StükTz, Palæontographica, vol. 32, 1886, p. 90 (genoholotype, $P$. primus Stürtz=Asterias asperula Roemer); Verh. naturh. Ver. preuss. Rheinl., etc., vol. 50, 1893, pp. 54, 75.

Palasteracanthion StüRTz, N. Jahrb. für Min., etc., 1886, vol. 2, p. 153 (genoholotype, "A. primus"=Asterias asperula Roemer).-STüRTz, Verh. naturh. Ver. preuss. Rheinl., etc., vol. 50, 1893, p. 75 .

Salteraster StürTz, Verh. naturh. Ver. preuss. Rheinl., etc., vol. 50, 1893, pp. 43, 60 (genoholotype, Palæaster asperrima Salter).

?Eoactis Spencer, Mon. Brit. Pal. Asterozoa, pt. 1 (Palæontogr. Soc. for 1913), 1914, p. 30 (genoholotype, E. simplex Spencer=? Urasterella girvanensis).

Generic characters.-Disk very small, without interbrachial ares. Rays five, very long and slender at maturity, but shorter and rapidly tapering when immature.

Abactinal side with very numerous small stellate plates, all of which, excepting one or three medial columns, are drawn out into more or less long, blunt, stout, erect, nonarticulating rods. The disk is occupied by a central plate and a first ring with five plates, which in some species are seen to be the basal radial plates, followed by a second ring with 15 plates. Five of the latter are the second proximal radial plates, and 10, basal plates of the supramarginal columns. Between the central plate and the first ring there may be inserted a few accessory, much smaller pieces. These disk ossicles may remain more prominent throughout life or may have the size of the other abactinal plates, in which case their arrangement is not plainly made out. In the center of the ray the adial column may be the more conspicuous throughout life or it may be more or less completely suppressed when the supramarginals adjoin and these may then 
be the more prominent columns. Or the entire abactinal area of the rays may be composed of ossicles arranged in columns and in quincunx when the plates are of nearly equal size. The number of columns varies with age and in different species, the greatest number observed being 13 at the base of a ray.

Ambital plates often not readily distinguishable at maturity from the radial and supramarginal columns. The growing distal tips of the rays of Urasterella have no ambital plates, but shortly after their introduction they begin to develop the rodlike extension so characteristic of this genus. Of these columns there may be as many as four at the base of a ray on each side of the supramarginals.

Inframarginals, as such, usually not distinguishable at maturity from the ambital plates. Their position is rather abactinal than actinal. At the distal end of rays, however, these plates lose their ambital character, passing over somewhat to the actinal side, and closely adjoin the adambulacrals. In the young of $U$. utrichi the inframarginals are well developed in the axillary regions and here there is also a single interbrachial marginal plate. More distally, however, the inframarginals have the character of the ambital plates. In none of the mature specimens have been seen well-developed or larger axillary inframarginals or interbrachial marginal plates. In $U$. asperula the axils have actinally single plates which may be remnant inframarginals.

Madreporite abactinal, of medium size, slightly convex, depressed and granulostriate.

Adambulacral plates very numerous, coin-shaped, and arranged on edge with the actinal surface pustulose. Each plate on its actinal surface bears two or three short, thick spines, and on its ambulacral side there is another similar spine. Along the outer edge of these plates toward the abactinal side there is another row of spines, in pairs, which are long and slender, flat, and longitudinally grooved on two sides. The adambulacral columns terminate in small triangular plates of the oral armature. In the young of $U$. ulrichi five very stout, short, pointed spines (tori) are inserted inside of the plates of the oral armature.

Ambulacral columns with the ossicles generally slightly alternating, but they may also be opposed, one plate to each adambulacral piece, more or less wedge- or club-shaped, and those of each column partially overlapping. Medially the columns loosely adjoin. Each plate is excavated laterally, along the proximal edge, leaving a more or less long, slender podial opening between adjoining plates.

Genoholotype.- Uraster ruthveni Forbes. The above diagnosis, however, is based on Stenaster grandis Meek, a form thought to be in generic harmony with the genotype. 
Distribution.-The species occur in North America and Europe and range from the Ordovicic to the Upper Carboniferous. The following are the known species:

U. pulchella (Billings). Trenton.

U. grandis (Meek). Richmond.

U. huxleyi (Billings). ?Chazy.

U. utrichi, new species. Lowville.

$U$. girvanensis, new species. Upper Ordovicic of Scotland.

$U$. (?) asperrima (Salter). Bala of Wales.

$U$. (?) constellata (Thorent). Siluric of France.

U. ruthveni (Forbes). Ludlow of England.

U. hirudo (Forbes). Ludlow of England.

U. selwyni McCoy. Siluric of Australia.

U. asperula (Roemer). Lower Devonic of Germany.

$U$., new species. Ithaca beds. Upper Devonic.

U. montana (Stschurowsky). Upper Carboniferous of Moscow, Russia.

Remarks.--McCoy in suggesting the name Urasterella did it in the following words:

"Before I was aware Prof. E. Forbes had described them it seemed to me that the U. [raster] Ruthveni and U. Hirudo, as well the similar American species, might be easily separated from the great starfishes forming the recent genus Uraster, by their small size and much more simple skeletons, and I had named the genus Urasterella in my manuscript."

This is all that McCoy did to establish the genus Urasterella, abandoning his manuscript definition on learning that Forbes had described the species as those of Uraster. Salter ${ }^{1}$ in 1857 paid no attention to this name, although he was the first to recognize and define Palasterina, which McCoy proposed at the same time and in the same manner. It seems that Hall (1868, p. 332) was the first to revive the name Urasterella and regarded Billings's Stenaster as a synonym by taking his second species, $S$. pulchella, as the genotype. Hall's remarks are as follows: "Mr. Salter, apparently overlooking my description of Patraster niagarensis, has placed both the abovecited European species [Uraster ruthveni and U. hirudo] under Palæaster, as defined by himself; but as it has been shown that this genus has two ranges of plates on each side of the ambulacral groove, these forms can not with propriety be arranged with typical Palæasters.

"There was the same reason for adopting the generic term Urasterella as for adopting Palasterina, both of which were proposed by McCoy at the same time, and the typical forms of each were specified. Mr. Salter has for some reason recognized the genus Palæaster pro-

${ }^{1}$ Ann. Mag. Nat. Hist., ser. 2, vol. 20, 1857, p. 326.

$50601^{\circ}-$ Bull. $88-15-12$ 
posed by me a little earlier, but probably published after that of McCoy; and has given the two species of Urasterella to that genus. Now that there seems no reason for continuing them under that generic term, they should be restored to their proper position as indicated above. The two species of Forbes must either be placed under Urasterella as proposed by McCoy, or fall under the later genus Stenaster of Billings. Were the latter genus of my own proposing I should nevertheless return to Urasterella, and I have no doubt that Mr. Billings will accord with this view."

Palxaster pulchellus is a true Urasterella, but this does not make the genus Stenaster a synonym of Urasterella, since S. salteri Billings has quite another structure and is here accepted as the genotype of Stenaster.

Meek ${ }^{1}$ also recognizes McCoy's name, but because of certain peculiarities in S. salteri, which he recognizes as the genotype, and also since he had not seen the dorsal side of McCoy's $S$. grandis, he prefers to retain Stenaster for the latter.

McCoy returned to his genus in 1874, after going to Australia, and described a new form, U. selwyni. It is important to quote here his remarks:

"Genus Urasterella (McCoy)=Stenaster (Billings).

"Gen. Char.: Small starfishes, with five moderate rays, narrowed at the base, and without disk. Ambulacral grooves narrow, bordered on the under side, with only one row of large (adambulacral) plates; no marginal plates. Upper surface with numerous rows of small tubercular plates. Confined to Silurian rocks.

"The late Mr. Salter and Mr. Billings refer the starfishes of this type to the subsequently published genus Patraster of Hall; but, as Prof. Hall objects that his genus Palxaster has ambulacral, adambulacral, and marginal plates, and the types of my genus $U$. ruthveni and $U$. hirudo of the English Ludlow rock, like our Australian species and the American Palæaster or Stenaster pulchella, have only one row of plates on each side of the ambulacral groove, I return to the use of my old generic name."

Zittel $^{2}$ says that Stenaster is a synonym for Urasterella and defines the latter genus. Stürtz ${ }^{3}$ points out the errors in the diagnosis of Billings and that of Zittel, redefines the genus, and correctly states that Stenaster Billings contains species of two genera, that is, Stenaster salteri, the genotype of Stenaster, and S. pulchella, which he refers to Urasterella. In this way the genus Urasterella has come to be recognized.

The figure and description of Uraster ruthveni given by Forbes* appears to be of a species generically identical with the American

1 Pal. Ohio, vol. 1, 1873, p. 67.

2 Handb. Pal., vol. 1, 1879, p. 453.
3 Palæontographica, vol. 36, 1890, p. 219.

British Org. Rem., dec. 1, 1849, p. 1, pl. 1, fig. 1. 
Stenaster pulchellus Billings and this is the general consensus of opinion. The writer unfortunately had no material of the genotype of Urasterella for study. However, since $U$. grandis is closely related to $U$. pulchella and shows so much more detail, it is here accepted as the genotype for the time being.

Professor Hall (1870) wrote: "In Stenaster = Urasterella, however, we have the absence of adambulacral plates." This is nevertheless not the case, for the coin-shaped marginal series in S. pulchellus are the ambulacral plates, since well-developed inframarginal plates, as in Palxaster, are absent in mature Urasterella. The inframarginals are, however, seen to be present in U. pulchella or in the distal ends of the rays in other species, though proximally they are so modified as not to be readily distinguishable from the ambital plates. In the axils of the young of U. utrichi the inframarginals are well developed, along with single interbrachial marginal plates, but in mature specimens of other species none have been seen.

Of Roemeraster the writer has seen three excellent specimens skilfully prepared by Stürtz which clearly show that this genus has the generic structure of Urasterella. Stürtz ${ }^{1}$ describes this genus as having "strong marginal plates" inside of the "small, cornered adambulacrals." Our specimens do not show such plates, and if present they can not be adambulacrals. This fact can be demonstrated in a well-preserved distal end of a ray, where two columns are present on each side of the ambulacrals. The innermost column of closely adjoining plates increase in size, retain their position beside the ambulacrals, and become the most prominent of the entire animal, while the outermost column soon change in aspect, the plates become separated and assume the characters of the ambital pieces. This is likewise true in the young of $U$. ulrichi where the axillary areas also have distinct interbrachial marginal and two larger proximal inframarginal plates. Passing distally, the latter also soon change their form, are separated one from another and are not distinguishable from the ambital plates. Stürtz further describes and figures five interbrachial ossicles in mature Urasterella asperula which are also well developed in the young of $U$. utrichi. Urasterella is an easily recognized genus and the triangular ambital plates drawn out into short blunt erect rods are peculiar to it, a character again repeated in Roemeraster. Under these circumstances the latter appears to be indistinguishable from Urasterella. For other remarks see U. asperula. On the other hand, Gregory regards Roemeraster as a good genus and places it erroneously among the ophiuridlike asterids in the family Tæniasteridæ. 
In regard to Protasteracanthion Stürtz, see remarks under Urasterella asperula, and for Salteraster Stürtz see U. asperrima.

Urasterella differs from Stenaster as redefined in this work in having long, slender, flexible rays which are never short and petaloid as in the latter genus. Again, the adambulacral pieces of Urasterella are very numerous, thin, and coin-shaped, while in Stenaster they are few in number and comparatively thick; the ambulacral plates are wholly different.

The long, slender and flexible rays, the apparent absence of inframarginal columns, and the absence of distinct interbrachial plates (these are not the same as the single axillary pieces seen in $U$. asperula) at maturity readily distinguish this genus from all other Paleozoic genera.

For the origin of Urasterella see U. utrichi.

Eoactis.-After this book was completed appeared the work of Spencer, with the new genus Eoactis. It is probable that the genus is good and can be distinguished from Urasterella, but the necessary comparisons can not now be made.

\section{URASTERELLA PULCHELLA (Billings).}

Plate 28, figs. 3 , 4; plate 30 , fig. 5 .

Palæaster pulchellus Brinngs, Geol. Surv. Canada, Rep. Progress for 1853-1856, 1857, p. 292.

Stenaster pulchellus Burnvas, Geol. Surv. Canada, Can. Org. Rem., dec. 3, 1858, p. 79, pl. 10, fig. 2.-Wright, Mon. British Foss. Echinod., Oolitic, vol. 2, pt. 1 (Palæontogr. Soc. for 1861), 1862, p. 28.

Urasterella (Stenaster) pulchellus Hall, Twentieth Rep. N. Y. State Cab. Nat. Hist., 1868, p. 289; rev. ed., 1868=1870, p. 332 .

The largest specimen from Middleville, New York (Hall collection), measures: $R=52 \mathrm{~mm}$., $r=11 \mathrm{~mm}$., $\mathrm{R}=4.8 \mathrm{r}$. An individual of the usual size from Trenton Falls, New York (Mus. Comp. Zoöl., No. 31), measures: $\mathrm{R}=30 \mathrm{~mm} ., \quad r=4 \mathrm{~mm}$., $\mathrm{R}=7.2 r$. One from Ottawa (Geol. Surv. Canada collection) measures: $R=25 \mathrm{~mm}$., $r=4 \mathrm{~mm}$., $\mathrm{R}=6.1 r$. The smallest specimen seen (Mus. Comp. Zoöl., No. 36) measures: $R=7 \mathrm{~mm}$., $r=1.5 \mathrm{~mm}$., $\mathrm{R}=4.7 \mathrm{r}$. Width of rays at base in mature examples from $4.5 \mathrm{~mm}$. to $7 \mathrm{~mm}$.

Original description.- "Diameter, $2 \frac{1}{4}$ inches; rays subcylindrical, $2 \frac{1}{2}$ lines in width at the base, with a length of 1 inch; disk $3 \frac{1}{2}$ lines in diameter; grooves narrow, bordered throughout by narrow oblong plates, nine in the length of two lines; the length of these plates in a direction transverse to the rays is about 1 line; near the disk there appears to be but one row of marginal plates."

Formation and locality.-Restricted to the Trenton limestone. Most abundant at Trenton Falls, New York. From this locality 
there are two specimens in the New York State Museum and six in the Museum of Comparative Zoölogy, Harvard University, collected by Dr. C. D. Walcott (Nos. 31-36). The American Museum of Natural History has one specimen from Canajoharie, New York (No. 660); in the Hall collection, Albany, there is a specimen from Middleville, New York. At Hull, Canada, Mr. W. R. Billings collected two specimens; the type and another specimen were found by E. Billings at Ottawa, Canada; these are now in the Museum of the Geological Survey of Canada at Ottawa.

Remarks.-This graceful species has the essential structure of $U$. grandis and will therefore not require a detailed description. $U$. pulchella is from a lower geological horizon, is probably the ancestor of $U$. grandis and has far less numerous abactinal plates, which on the disk reveal a primitive arrangement reminding one of Hudsonaster. In the center of the disk there is a single plate around which is a first ring of 5 basal radial plates followed by another with 15 plates. The plates of the second ring are a little more conspicuous than any other abactinal plates and are disposed as follows: Five are radial in position and are the second basal plates of the 5 radial columns, while the other 10 are disposed interradially in pairs immediately on each side of the second basal radials. The plates interradial in position are the basals of the supramarginal columns. Between the central ossicle and first ring there appear to be a few small accessory plates.

The arrangement of the disk pieces above described is plainly preserved in a very young example (No. 36, Mus. Comp. Zoöl.). The radial columns remain the most prominent while the supramarginals a little distally from the base of the rays are not readily distinguishable from the other columns. Here and there an accessory piece may be inserted between the radials and supramarginals but the greater width of the rays is attained by increasing the size of these columns and by the introduction of ambital columns outside of the supramarginals. In a mature ray on each side of the radials proximally, there appear to be not more than four columns of plates but it is possible that a few pieces of a fifth column may be developed. The form and spinosity of the abactinal plates is as in $U$.grandis, except that the nonarticulating spines are less long in $U$. pulchella.

Inframarginal columns at first view do not appear to be present but a careful examination near the distal end of a ray reveals two columns of nearly equal-sized plates on each side of the ambulacral furrow. Here these plates closely adjoin, the adambulacrals are elongate subquadrangular and the inframarginals quadrangular in shape. Proceeding proximally. the former become more prominent and wider but remain throughout closely adjoining. The inframarginals, however, gradually pass over to the abactinal side although 
they remain beside the adambulacrals, become more and more spinose, longer than wide, and eventually stellate in form and then are inseparable from the abactinal plates. There are about 42 adambulacrals in each column.

$U$. pulchella is readily distinguished from $U$. ulrichi and $U$. grandis in being smaller, with more slender and graceful rays, and in its fewer columns of plates. From $U$. huxleyi it is distinguished by the less convex rays and the far smaller number of plates.

Cat. No. 60610, U.S.N.M.

\section{URASTERELLA GRANDIS (Meek).}

Plate 27, figs. 6-8; plate 28, figs. 1, 2; plate 30, figs. 1-4.

Stenaster grandis MEEK, Amer. Journ. Sci., ser. 3, vol. 3, 1872, p. 258; Geol. Surv. Ohio, Pal., vol. 1, 1873, p. 66, pl. 3 bis, figs. $7 a-7 c$.-Mrtuer, N. Amer. Geol. Pal., 1889, p. 283, fig. 432.

Urasterella grandis Mesk, Geol. Surv. Ohio, Pal., vol. 1, 1873, p. 67.

Palæaster harrisi Mnler, Journ. Cincinnati Soc. Nat. Hist., vol. 2, 1879, p. 117, pl. 10, figs. $2,2 a$.

Original description.- "Attaining a very large size, with the body or disk comparatively small, or only of the breadth of the united inner ends of the five rays. Rays long, slender, gradually tapering, and very flexible, widest at their immediate connection with the body, where they seem to be more or less depressed, but becoming more nearly terete farther out. Dorsal side of body and arms composed of numerous subtrigonal pieces that rise into pointed tubercles, or sometimes assume almost the character of short spinules, and are arranged in quincunx, so as to form about eight rows near the middle of the rays; those of the outer two rows being a little larger than the others. Dorsal pores apparently rather large, and passing through between the concave sides of contiguous pieces. Ventral side of body unknown. That of the rays composed of the usual single row of transverse adambulacral pieces on each side of the well defined, rather deep, and moderately wide ambulacral furrows. Adambulacral pieces rather more than twice as long as wide, with their longer diameters at right angles to the ambulacral furrows, and rounding over from end to end so as to be most prominent in the middle; while they do not connect with each other by flat sides, but have little projecting processes, and corresponding sinuses, apparently for the purpose of imparting greater flexibility to the rays."

Emended description.-The largest specimen being doubled over actinally does not permit of exact measurements, but it is, as near as can be determined, as follows: $R=93 \mathrm{~mm}$., $r=9 \mathrm{~mm}$., $\mathrm{R}=10.3 r$. Another specimen spread flatly measures: $R=49 \mathrm{~mm}$., $r=6.5 \mathrm{~mm}$, $\mathrm{R}=7.6 \mathrm{r}$. The smallest specimen (holotype of Palzaster harrisi) 
measures: $\mathrm{R}=10 \mathrm{~mm}$., $r=2.5 \mathrm{~mm}$., $\mathrm{R}=4 r$. Width of rays at base in mature examples from $7 \mathrm{~mm}$. to $8.5 \mathrm{~mm}$.

Rays at maturity very long, depressed subcylindrical in outline, slender and tapering slowly. Disk very small, formed by the united inner ends of the rays.

Abactinal area reticular, consisting of very numerous, highly conical, stellate plates, the radial columns and the plates of the disk most prominent, while the other ray plates (supramarginal and ambital) are smaller and irregularly triangular in form. All plates are more or less drawn out into stout, blunt, nonarticulating spines which are best preserved along the sides of the rays. On the disk the ossicles are arranged in a few concentric rows while on the rays they are in columns and in quincunx. Near the base of a ray in the largest specimen there are about 13 columns, diminishing to about 4 at the distal ends.

Madreporite of medium size, lobate, radially crenulostriate, situated between two adjoining rays and about midway between the margin and center of disk.

Adambulacral plates slightly overlapping the ambulacral columns, diminishing in size distally, coin-shaped, arranged on edge, and varying in different specimens from 60 to 110 in each range. In the youngest known example there are about 20 plates in a column. Each piece bears three or four short, finger-shaped, articulating spines, two or three outwardly disposed, and one placed near the inner base between adjoining plates. Along the outer margin of the adambulacral plates and abactinally to the thick finger-shaped spines there is a row of long, slender, flattened and longitudinally grooved spines, two to each ossicle. Orally the coin-shaped adambulacral plates are somewhat modified, stand less erect and terminate in pairs of subquadrangular oral armature pieces.

Ambulacral grooves wide, shallow, and furrowed medially by a narrow angular gutter. Ambulacral plates of adjoining columns opposite or very slightly alternating, the pieces narrow, equaling in number the adambulacrals, slightly overlapping each other proximally and partially interlocking in the medial gutter. The ambulacral plates continue in undiminished size to the comparatively small mouth, are highly convex and club-shaped, with the attenuated ends laterally disposed. The podial openings are between the attenuated ends of adjoining plates.

Locality and formation. - In the Richmond formation at Richmond, Indiana (type-locality), and in the vicinity of Waynesville, Ohio, where Mr. Harris secured six more or less mature and three young individuals, besides numerous fragments. A ray of this species was found by Mr. U. P. James near Dayton, Ohio. In the Gurley collection of the University of Chicago there is a young specimen (No. 10978) from near Ridgeville, Warren County, Ohio. 
Remarks. - The type-specimen of Palæaster harrisi Miller is undoubtedly a Urasterella, and there are no characters other than size by which this individual can be separated from $U$. grandis. Of about the same age are three specimens in the Harris collection and another in the University of Chicago, and all were originally referred to $P$. harrisi. One of these is nearly again as large as the type, is about one-half the size of $U$.grandis, and measures $49 \mathrm{~mm}$. along the greater radius. The only marked difference between $P$. harrisi and $U$. grandis is the smaller number of adambulacral plates in the former, a feature common to the young of many fossil starfishes when compared with the adults of the same species. In fact, the variation in the number of these plates in the two largest examples (64 and 110) is nearly as great as between the type of Palxaster harrisi (22) and the smaller of the two largest specimens of $U$. grandis (64).

$U$. grandis is closely related to $U$. pulchella (Billings) of the Trenton limestone. These species are, however, easily distinguished, not only by the different geological occurrences, but in that $U$. grandis attains a much larger and more robust growth. The latter has also many more abactinal ossicles with longer nonarticulating spines, and the adambulacral columns have from 60 to 110 plates, instead of from 36 to 60 as in $U$. pulchella. $U$. grandis appears to be a direct descendant of the latter and has varied only in attaining a larger size and a greater number of plates.

$U$. grandis is also closely related to $U$. ulrichi, and both are nearly of one size. The latter, however, has the rays highly convex abactinally, the plates are smaller but as strongly. spinose, and there are two columns of larger central plates, instead of ono as in $U$. grandis. In the latter in the mid-length of the ray there are about 9 plates in a column in $10 \mathrm{~mm}$., while in $U$. utrichi there are from 11 to 12 in the same space.

Cat. Nos. 40885, 40887, U.S.N.M.

\section{URASTERELLA HUXLEYI (Billings).}

Plate 29, fig. 2.

Stenaster huxleyi Brumngs, Geol. Surv. Canada, Pal. Foss., vol. 1, 1865, p. 213, fig. 197.

$\mathrm{R}=58 \mathrm{~mm}$., $r=5.5 \mathrm{~mm}$., $\mathrm{R}=10.5 r$. Width of ray at base, $6 \mathrm{~mm}$.

Original description.- "Deeply stellate, 4 or 5 inches across; body small, less than half an inch in diameter; rays long; flexuous, subcylindrical, apparently angulated along the medium line on the upper side, uniformly tapering to an acute point. On the dorsal side the rays are covered by a multitude of small subangular plates, each from one-fourth to one-third of a line wide. The central part of the body is not well preserved in the only specimen collected; but it is 
evident from a view of the plates which remain that they are here larger and more convex than those of the rays.

"Diameter of the body, five lines. Length of each ray, $1 \frac{7}{8}$ inches. Width of the rays at their junction with the body, 3 lines. Depth of the rays from the dorsal to the ventral side of the body apparently somewhat less than the width. The total breadth of the specimen, if the rays were straightened out, would thus be about $4 \frac{1}{4}$ inches.

"From the manner in which the rays are curved, it is evident that they possessed a considerable amount of flexibility. The specimen is somewhat distorted by pressure, but a small portion of one of the rays near the body seems to retain its natural shape, and it is here obtusely angulated along the median line. The transverse section of the ray should be, therefore, subpentagonal. There is still, however, some doubt on this point. The under side is unknown." In places where the specimen is broken the adambulacrals are seen to be as in other species of Urasterella; there appear to be about 60 or more of these plates in each column.

Locality and formation.-The only specimen of this species was found by Mr. J. Richardson in strata of Chazy age (bed I of the Newfoundland section) at Point Rich, Newfoundland. The holotype (No. 554) is in the Museum of the Geological Survey of Canada, at Ottawa, which has furnished the photograph illustrating the specimen.

Remarks. - The holotype was seen at Ottawa and the original illustration found to be a fairly accurate reproduction of the characters of the fossil. The abactinal side of the disk has a central disk plate that is large and tumid. Around it is a circle of six smaller, highly convex plates, and at the base of each ray medially there is another single large tumid plate, the basal radial. The abactinal side of the rays is highly convex and somewhat angulated medially. The ossicles are small and distinctly arranged in quincunx, of which there are about six plates in each diagonal row near the base of a ray. In other words, the abactinal characters of $U$. huxleyi are very much like those of $U$. ulrichi, with the differences that in the latter species the prominent disk plates are smaller and there are more columns of smaller ossicles on the stouter and longer rays. Further, in $U$. ulrichi there are two columns of larger abactinal plates along the central area of the rays, while in $U$. huxleyi all the ray ossicles are of equal size.

D. pulchellus has less convex and more slender rays, and far fewer abactinal plates.

URASTERELLA ULRICHI, new species.

Plate 29, fig. 1 ; plate 30 , figs. 6,7 .

The smallest specimen measures: $\mathrm{R}=14 \mathrm{~mm}$., $r=4 \mathrm{~mm}$., $\mathrm{R}=3.5 r$. The best preserved specimen measures: $R=45 \mathrm{~mm}$., $r=7.5 \mathrm{~mm}$, $\mathrm{R}=6 r$. The largest specimen measures: $\mathrm{R}=78 \mathrm{~mm}$., $r=12 \mathrm{~mm}$., 
$\mathrm{R}=6.5 \mathrm{r}$. Width of ray at base in the different individuals $4,7.5$, and $9 \mathrm{~mm}$., respectively.

Rays short and tapering rapidly when young but at maturity very long, highly convex abactinally, and tapering very slowly. Disk comparatively large in the young but small at maturity and formed by the united ends of rays.

Abactinal area of disk and rays composed of numerous small, tumid, or highly spinose plates which in the rays are arranged distinctly in columns and in quincunx. In the angles between all of the plates are left subcircular small openings. On the rays medially there are two columns of large convex plates, variously stellate and not produced into short, blunt rods. These are the supramarginals, and between them are a few widely separated plates of the radial columns. In the young the two proximal radial plates are separated from each other by from one to three supramarginals, while the third plate is separated from the second by three or four supramarginals. In a mature specimen there appear to be about eight of these radial plates on each ray and distally they are separated from one another by five supramarginal ossicles. On each side of the supramarginal columns are from one (distally) to five (proximally) columns of smaller or accessory ambital plates. In a full-grown specimen there are 11 to 12 in $10 \mathrm{~mm}$., triangular in outline, and drawn out into short, stout, blunt rods. In the center of the disk in the youngest specimen (probably also at maturity) there is a single large depressed plate around which is a first circle with 6 plates followed by a second having 16 pieces. Of the latter, 5 are basal radials, 10 basal supramarginals, and 1 the madreporite. All of the disk plates are variously stellate, and are the largest plates of the abactinal area, the size gradually diminishing distally along the rays.

Madreporite concentrically striate, somewhat smaller than the basal supramarginals, between two of which it is placed.

Adambulacral plates seen only in the young specimen, very strong, carinated, subquadrate, wider than long, and about 19 or 20 in each column $10 \mathrm{~mm}$. long, not counting the oral armature pieces, which are subtriangular in outline. Inside of each pair of oral armature plates is placed a very stout but short subcircular spine which has not been observed in other species. No other spines are preserved.

Ambulacral furrows very narrow and deep, concealing the ambulacral plates.

In the axils of the youngest specimen, outside of the adambulacrals, are situated three prominent plates, the proximal one being the smallest. On each side of these along the ray is a single column of plates which rapidly diminish in size and separate with increasing interspaces distally. Their number can not be made out, but they appear to continue to the tips of the rays, where plates occur that 
are not ambital. In the mid-length of the ray, however, these plates greatly resemble the ambitals. Judging from the manner in which they appear distally, their form and constant position beside and outside the adambulacrals leads to the conclusion that they are the inframarginals. Whether the inframarginals and interbrachial marginals are present at maturity cannot be determined.

Formation and locality.- Three specimens from the top of the Black River limestone immediately beneath the Black River shale, or from the Vanuxemia bed of the Black River (Mohawkian) group at Minneapolis, Minnesota. The specific name is after the distinguished paleontologist, Dr. E. O. Ulrich, who found all the specimens. They are in the United States National Museum.

Remarks.-This species is distinguished from other Ordovicic Urasterellas by the few and widely separated plates of the radial columns, and by the prominence of the supramarginal columns, which in the other species are not distinguishable from the ambitals. The convexity of the rays abactinally is also greater than in the other species excepting $U$. huxleyi, but that species is further distinguished in that it has smaller plates, there being from 7 to 10 in $5 \mathrm{~mm}$., while in $U$. utrichi there are only 5 to 6 in the same space.

$U$. utrichi and $U$. grandis attained a similar large size. The former, however, is from a much lower horizon, has very convex rays abactinally, two columns of larger central plates (supramarginals) instead of one (radial), and the plates are smaller and therefore more numerous.

The young of this species are very interesting in that they show distinctly the presence of large inframarginal and interbrachial marginal plates in the axils. In $U$. pulchella none of these plates have been seen in the axils, but the inframarginals are believed to be present in the very small plates which are indistinguishable from the ambital pieces situated along the greater length of the rays outside of the adambulacrals. The same appears to be true for $U$. grandis. The young of $U$. ulrichi in its general structure reminds one much of Mesopalxaster shafferi, and it is probable that Mesopalæaster and Urasterella are derived from the same stock, which also gave rise to Hudsonaster. The latter retains throughout life the primitive plate structure, while Mesopalæaster, and particularly Urasterella, develop in various ways an abundance of accessory plates.

The best preserved specimen of $U$. ulrichi (pl. 29, fig. 1) has two nearly fully grown rays and three short stumps. One of these short rays is so well preserved as to indicate that this condition is not due to poor preservation, but is apparently a case of accidental loss of parts during life. The wound has been healed, but no regeneration of lost parts has taken place, as is so common in similar losses among the living starfishes.

Cat. No. 60612, U.S.N.M. 
URASTERELLA GIRVANENSIS, new species.

Plate 28, fig. 5.

Tetraster, sp. ind., Nicholson and Etheridge, Mon. Silurian Foss. Girvan Dist., Ayrshire, fasc. 3, 1880, p. 325, pl. 21, figs. 9, 10.

? Eoactis simplex Spencer, Mon. Brit. Pal. Asterozoa, pt. 1 (Palæontogr. Soc. for 1913), February, 1914, p. 30, pl. 1, fig. 4.

Urasterella girvanensis Schuchert, Fossilium Catalogus, Animalia, pt. 3, April, 1914, p. 44.

Description by $N$. and E.- "Body stellate, with slowly tapering arms, which increase little in width throughout their whole length [the distal ends being unknown]; upper surface unknown, but the body was convex and probably granular. [The pieces of the disk are seen through the mouth and consist of many tiny plates arranged in more or less regular circles about the slightly larger central ossicle.] Avenues of the arms broad, and not bridged over by any of the plates [this is a slip of the pen, for the ridged ambulacralia lie horizontal and deep in the grooves and are directly opposite one another; the podial openings are fairly large and in the usual position laterally]; marginal ambulacral plates [=adambulacrals] moderately convex, transversely elongated, or oblong in form, and less in width than the ambulacral plates; those in the angles of the rays are the largest, and somewhat more elongated than the others; oral plates not visible." The interbrachial areas are structurally very interesting because in each one there is a single narrow but long axillary interbrachial ossicle that distaily margins the axil, and in front of this is a minute pair of adambulacral oral armature pieces. On either side of the axillary interbrachial are the most prominent adambulacrals, about five in number, being larger than the other distal ones, which are considerably narrower and of fairly uniform size throughout the rays.

Formation and locality.-A single specimen from the Upper Ordovicic at Thraive Glen, Girvan, Scotland. A good wax squeeze of the holotype was furnished by Doctor Bather. The original is in the collection of Mrs. Robert Gray, at Edinburgh, Scotland.

Remarks.-This species is clearly a Urasterella, a fact which was also noted by Nicholson and Etheridge, as they state: "In some of its characters it approaches very closely to $T$. (?) asperrimus, Salter, sp." In its interbrachial skeleton U. girvanensis retains youthful generic characters, seen in the well-developed interbrachial axillary ossicles. After the above was written appeared Spencer's paper above cited. Before the writer was aware of this work he had proposed the name $U$.girvanensis. If we are treating of the same species Spencer's name takes precedence.

Cat. No. 60611, U.S.N.M. 
URASTERELLA (?) ASPERRIMA (Salter).

Palæaster asperrima SAlter, Ann. Mag. Nat. Hist., ser. 2, vol. 20, 1857, p. 325, pl. 9, fig. 1.-Wright, Mon. British Foss. Echinod., Oolitic, vol. 2, pt. 1 (Palæontogr. Soc. for 1861), 1862, p. 24, fig. 15 (1).

Palæaster asperrimus Salter, Mem. Geol. Surv. Gt. Britain, vol. 3, 1866, p. 289, pl. 23, fig. 2.

Palæaster (?) asperrimus STÜRTZ, Palæontographica, vol. 32, 1886, p. 91.

?Tetraster asperrimus Nicholson and Etheridge, Mon. Silurian Foss. Girvan Dist., Ayrshire, fasc. 3, 1880, pp. 320, 321, 324.

Salteraster asperrimus STÜRTz, Verh. naturh. Ver. preuss. Rheinl., etc., vol. 50, 1893, pp. 43, 60 .

Nicholson and Etheridge wrote of this species as follows: It "is an unsatisfactory species. The specimens in the Museum of Practical Geology have the large transverse ossicles very apparent; but as to whether there is a row inside or outside these, or both, we are by no means certain. It appears, however, to have possessed only four rows." Under Tetraster they compare this species with their "T. sp. ind.," which is a true Urasterella (U. girvanensis).

It seems best under these circumstances to refer this species to Urasterella, it being apparently near $U$. grandis. It is found in the Caradoc or Bala sandstones (Ordovicic), near Welshpool, North Wales. Should it prove to be generically different from Urasterella, then the name Salteraster Stürtz can be revived, as he names $P$. asperrimus as the genoholotype.

URASTERELLA (?) CONSTELIATA (Thorent).

Asterias constellata Thorent, Mém. Soc. géol. de France, vol. 3, 1838, p. 259, pl. 22 , fig. 7 .

The original figure of this species does not permit of determining its generic position. It is described as having but one range of plates on each side of the ambulacral grooves, and the figure seems to indicate the presence of a large disk with well-defined interbrachial arcs. It seems to have more of the characters of Urasterella than of any other genus.

The specimen was found in the Siluric (? Lower) strata in northern France (Mondrepuis, L'Aisne).

\section{URASTERELLA RUTHVENI (Forbes).}

Uraster ruthveni FonBes, Mem. Geol. Surv. Gt. Britain, vol. 2, pt. 2, 1848, p. 436; Mem. Geol. Surv. United Kingdom, dec. 1, 1849, p. 1, pl. 1, fig. 1; in McCor, British Pal. Foss., 1851, p. 59.-Murchuson, Siluria, 1854, fig. 39-3.

Palæaster ruthveni SAlter, Ann. Mag. Nat. Hist., ser. 2, vol. 20, 1857, p. 326.Wrighr, Mon. British Foss. Echinod., Oolitic, vol. 2, pt. 1 (Palæontogr. Soc. for 1861), 1862, p. 25.

Urasterella ruthveni Forbes, in McCor, British.Pal. Foss., 1851, p. 59.

This, the genotype of Urasterella, is unfortunately not well known, but appears to be congeneric with $U$. grandis and $U$. pulchella. It occurs in the Upper Ludlow beds (Siluric), near Kendal, Westmoreland, England. 


\section{URASTERELLA HIRUDO (Forbes).}

Uraster hirudo FonBes, Mem. Geol. Surv. Gt. Britain, vol. 2, pt. 2, 1848, p. 464; Mem. Geol. Surv. United Kingdom, dec. 1, 1849, p. 3, pl. 1, fig. 4; in McCoy, British Pal. Foss., 1851, p. 59.-Murchison, Siluria, 1854, p. 221, fig. 39-2. Palæaster hirudo Salter, Ann. Mag. Nat. Hist., ser. 2, vol. 20, 1857, p. 326.Wright, Mon. British Foss. Echinod., Oolitic, vol. 2, pt. 1 (Palæontogr. Soc. for 1861), 1862, p. 25.

Urasterella hirudo Forbes, in McCoy, British Pal. Foss., 1851, p. 59.

This small species has much the appearance of being the young of $U$. ruthveni. The form is said to be gregarious and is associated with that species.

\section{URASTERELLA SELWYNI McCoy.}

Urasterella selwyni McCoy, Geol. Surv. Victoria, Prodr. Pal. Victoria, dec.1, 1874, p. 42 , pl. 10, figs. $2,2 a, 3,3 a$.

Original description.- "Rays five, elongate, gradually tapering from a little beyond the base, which is slightly contracted, angulated on the upper side by a prominent ridge along the middle of each ray, having a row of conical tubercular plates (about eight in two lines), each side sloping on the dorsal aspect from the middle with about three rows of conical tubercular plates rather smaller than the middle row. The five axil plates small, ovate, triangular, very tumid. Adambulacral plates large, axtending to the tubercular margin, transversely oblong, about twice as wide as long (about nine in two lines). Ambulacral plates small, in a deep ambulacral groove. Length of ray from mouth to tip, six lines; greatest width near base, $1 \frac{1}{4}$ lines. Surface of plates granular.

"This beautiful species is easily known by its strongly angulated rays on the dorsal side. The traces of oral plates are so very minute and indistinct that I can not give their character.

"This is the first fossil starfish seen in Australia, and I dedicated it to my old friend Mr. Selwyn, formerly Director of the Geological Survey of Victoria, and now Director of the Geological Survey of Canada, who collected it.

"This species is most nearly related to the Uraster ruthveni of Forbes from the Upper Silurian grits of Kendal in Westmoreland.

"Common in the fine sandy Silurian beds of range on E. side of commonage reserve, Kilmore."

Remarks. - This is clearly a species of Urasterella. Actinally it has in each axil one fairly large axillary interbrachial and in this recalls the same structure in $U$. girvanensis, new species.

URASTERELLA ASPERULA (Roemer).

Asterias asperula Roemer, Palæontographica, vol. 9, 1863, p.146, pl. 24; pl. 26, fig. $6 ;$ pl. 27.

Roemeraster asperula STü RTz, Palæontographica, vol. 32, 1886, p. 85, pl. 9, figs. 4, 5.

Protasteracanthion primus Stü RTz, Palæontographica, vol. 32, 1886, p. 90, pl. 11, figs. $3,3 a$.

Remarks. - Of this species there are two specimens in the United States National Museum purchased of Stürtz, and two more are 
in the Yale Museum Collection. These show both sides of the species. O. asperula is said to be common in the roofing slate of the Lower Devonic at Bundenbach, Germany.

There can be no doubt that Asterias asperula Roemer is a true Urasterella. All the generic characters are shown, even the longitudinally grooved spines and the rodlike extensions of the ambital plates. For further remarks on this species see generic discussion.

The abactinal structure of Roemeraster asperulus reminds one much of Urasterella pulchella of the Trenton, which is the least specialized species of the genus. The single interbrachial plate retained to maturity reminds one of the young of U. ulrichi. In this character U. asperula appears to be primitive. In the proximal third of the rays in $U$. asperula the radial columns are the most marked and the plates continue to increase in size toward the disk. The supramarginals are also well developed proximally, but the two or three proximal plates are smaller and depressed, so that the ten basals along with the five radials do not make so prominent a ring of large ossicles as in $U$. pulchella or in the young of $U$. utrichi. Distally the rays in $U$. asperula have the plates of nearly equal size, although the columnar and quincuncial arrangement is retained. The center of the disk is occupied by a prominent central disk-plate and the first ring consists of five radial plates as in $U$. pulchella.

Cat. No. 59382, U.S.N.M.

URASTERELLA, net7 species.

In the paleontological muselisi of Cornell University there is a large slender-rayed specimen having the general form and structure of Urasterella. There is, however, so little of the actinal detail preserved that nothing more can be done than to indicate the presence of this species.

The specimen was found by Mr. J. B. Woodworth at Brookton, near Ithaca, New York, in the Upper Devonic.

\section{URASTERELLA MONTANA (Stschurowsky).}

Palæaster montanus ScHöNdoRf, Palæontographica, vol. 56, 1909, p. 324, pl. 23, fig. 1; pl. 24, figs. 20-22 (complete bibliography cited here).

In general this form recalls $U$. grandis but is somewhat smaller and stouter. The actinal side alone is known, showing a wide ambulacral furrow bordered by stout columns of narrow adambulacrals. All of the ossicles of the ambulacrals and adambulacrals are opposite one another. Oral armature decidedly adambulacral in composition. Interradial areas described as having "a few plates." A section through a ray (Schöndorf's fig. 22) shows that abactinally on each side of the radialia there are four columns of ossicles, or nine in all.

Dimensions, about: $\mathrm{R}=35 \mathrm{~mm}$., $r=6-7 \mathrm{~mm}$., $\mathrm{R}=6 r$. Width of ray at mid-length about $6 \mathrm{~mm}$. 
Formation and locality. - The holotype is from the oldest Upper Carboniferous (Moscovian) of Mjatschkowa, near Moscow. The specimen is now in the Bergakademie at Berlin, Germany.

\section{CALLIASTERELLIDÆ, new family.}

Calliasteridx ScHöNDoRF, Jahrb. nassauisch. Ver. Naturk., Wiesbaden, vol. 63, 1910, p. 251.

Cryptozonia with ophiurid expression; a small disk with primitive plate arrangement and five long, very flexible rays, with radialia and supramarginalia. No interbrachial areas. Ambulacrals opposite.

Contains:

Calliasterella, new name.

\section{Genus CALLIASTERELLA, new name.}

Plate 31, fig. 3, text fig. 11 .

Calliaster mirus Trautschold (not Calliaster Gray 1840, Echinoderma), Nouv. Mém. Soc. imp. Nat. Moscou, vol. 14, 1879, p. 108, pl. 13, figs. $3 a-3 h$, 4.ScHöndoRF, Palæontographica, vol. 56, 1909, p. 327, pl. 23, figs. 2-5; pl. 24, figs. 1-18; text fig. on p. 328.

Calliasterella Schuchert, Fossilium Catalogus, Animalia, pt. 3, April, 1914, p. 14.

A cryptozonian asterid with the general expression of the ophiurid Onychaster.

Description.-Disk relatively small, primitive, with rather large, decidedly spiculate ossicles. Rays five, long and slender, round in section. $\mathrm{R}=$ about $120 \mathrm{~mm}$., $r=30$ to $35 \mathrm{~mm}$., $\mathrm{R}=4 r$. Width of ray at mid-length about $15 \mathrm{~mm}$.

Abactinal disk plates in form and position as in figure 11. There is a small central five-rayed plate with the rays in the position of the five arms. Around the central plate is a first ring of five larger basal radial plates. Then comes a second ring of ten platos, five of which are the second basal radialia; the other five are interradial in position and give rise in the next ring to the ten basal inframarginal ossicles. The third ring has five radialia and ten basal inframarginals. All of the ossicles in the three rings are variously six-rayed, with large rounded openings between the adjoining spicular ends. Between each pair of basal inframarginals are inserted single elongate interradial disk plates.

\section{Madreporite unknown.}

The rays abactinally have a medial column of transverse radialia, and alternating with these on either side are columns of supramarginals. These ossicles are of peculiar construction, enabling the rays to flex about as in Onychaster. 
Ambulacralia small, adambulacralia larger, both very numerous in each column and in their disposition opposite one another. There are no inframarginals.

Oral armature of Cryptozonia construction and very much as in living Asterias glacialis.

Ocular plates probably not present.

Genoholotype and only species.-C. mirus (Trautschold) (citations as above). The holotype and three other fragments are from

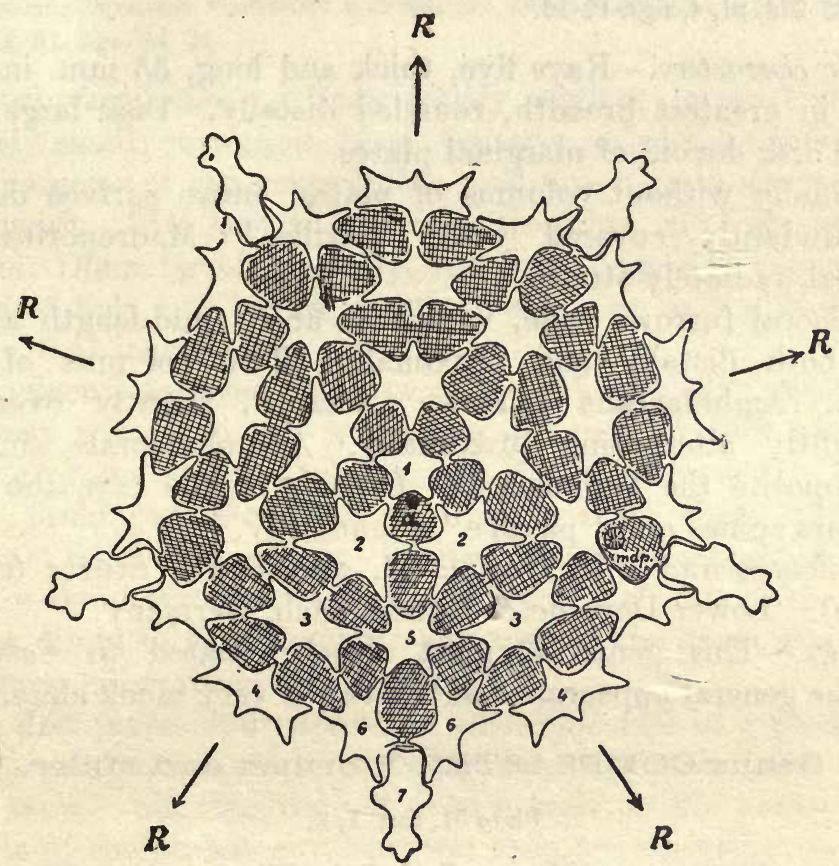

Fig. 11. - The plates of the disk of Califasterella mira. Schematic. After Schödorf. 1. CenTRODORSAL; 2, BASAL RADIALIA; 3, SECOND RADIALIA; 4, THIRD RADIALIA; 5, BASAL INFRAMARGINALS; 6, PAIRED INFRAMARGINALS; $a$, POSSTBLE POSITION OF ANUS; $m d p$, PROBABLE POSITION OF MADREPORITE.

the Upper Carboniferous (Moscovian), at Mjatschkowa, near Moscow. The holotype is in the University of Petrograd.

Remarks. - There is no other Paleozoic asterid worked out in such detail as is Calliasterella. Not only is the gross skeleton known, but the detailed construction of all of the essential ossicles and spines as well. Quarto pages of text and two plates are devoted to the skeleton.

The dorsal skeleton retains primitive construction, and although the ossicles are much modified, their general orientation is that of the older Phanerozonia.

COMPSASTERID $A$, new family.

Specialized Cryptozonia with decidedly spicular abactinal skeleton, recalling that of Asterias. Ambulacra opposite or slightly $50601^{\circ}-$ Bull. $88-15-13$ 
alternating. Rays five, long, thick, and rounded in section. Disk not large.

This family contains:

Jaekelaster Stürtz.

Compsaster Worthen and Miller.

\section{Genus JAEKELASTER Stürtz.}

Jaekelaster StüRTz, Verh. naturh. Ver. preuss. Rheinl., etc., vol. 56, 1900, pp. 235-236, pl. 4, figs. 13-16.

Generic characters.- Rays five, thick and long, $55 \mathrm{~mm}$. in length, $16 \mathrm{~mm}$. in greatest breadth, rounded distally. Disk large. Both rays and disk devoid of marginal plates.

Abactinally without columns of plates, entire surface decidedly and abundantly covered with "paxillæ." Madreporite small, subcentral, radiately striate.

Ambulacral furrows wide, widest at about mid-length and narrowing both distally and proximally. Two col mns of podial openings. Ambulacralia narrow, L-shaped, slightly overlapping and slightly alternating proximally. Adambulacrals small, directly opposite the ambuiacrals. Outside of the rays the integument bears spines and "paxillæ" abundantly.

Genoholotype and only species.-J. petaliformis Stürtz (citations as above). Lower Devonic of Bundenbach, Germany.

Remarks.-This genus is most closely related to Compsaster, in fact the general appearance of the two is very much alike.

\section{Genus COMPSASTER Worthen and Miller.}

\section{Plate 31, figs. 1, 2.}

Compsaster Worthen and MrrLer, Geol. Surv. Illinois, vol. 7, 1883, p. 327.

Original description.- "Body stellate; central area or disk comparatively small; rays large, long, more or less fusiform; grooves deep and bordered by numerous thin, subcircular, adambulacral plates. The ventral side of the typical species shows about six rows of plates upon each side of the ambulacral furrows, which have a regular, transverse as well as longitudinal arrangement.

"This genus is distinguished from all others in the family [their Palæasteridæ] by the number and form of the adambulacral plates, by the great number of disk plates upon each side of the ambulacral furrows, and by the general form of the body and rays."

* Genoholotype.-C. formosus Worthen and Miller. It is also the only named species of the genus.

The adambulacral plates in Compsaster appear to be much as in Urasterella and both genera agree in having no distinct inframar- 
ginal plates. The ambital plates are very numerous, showing a distinct progression to far more numerous columns of plates than in Urasterella. They also appear like those in this genus. It is probable that the abactinal area when it is known will be seen to have spicular ossicles like those of the ambital areas.

\section{COMPSASTER FORMOSUS Worthen and Miller.}

Plate 31, figs. 1, 2.

Compsaster formosus Worthen and MrLLeR, Geol. Surv. Ill., vol. 7, 1883, p. 327, pl. 31 , figs. $2 a, 2 b$.

Original description.- "Body deeply stellate; central disk comparatively small; rays rigid, large, fusiform, more than twice as long as the diameter of the central disk, and terminating abruptly in an obtuse point. The typical specimen furnishes the following measurements: Diameter of the body, 0.72 inch; length of ray from central part of disk, 1.78 inches; diameter of the ray at its junction with the body, 0.41 inch.

"Ambulacral grooves deep; ossicles rather small; adambulacral plates very numerous, and consisting of series of thin plates upon each side of the ambulacral furrows, which are rounded upon the exterior, prolonged below, and each bear a short, sharp spine on the upper part of the inner side, directed toward the apex of the ray. There are about eighty adambulacrals upon each side of the furrows, and they diminish very slowly in size toward the apex, after passing the fusiform enlargement of the ray.

"The disk-plates abut upon the adambulacrals in a straight line; they are subquadrangular, or polygonal, and each bears a strong central spine. Six longitudinal rows appear on the ventral side on each side of the ambulacral furrows; they are somewhat uniform in size, arranged in transverse, as well as longitudinal order, and are about two-thirds as numerous in a longitudinal row as the plates in an ambulacral series.

"Oral plates, madreporiform tubercle, and dorsal side unknown, except so far as we may judge of the spinous character of the plates from those visible on the ventral side.

"This large and beautiful species is so distinct from any hitherto described that no comparison is necessary for the purpose of identification.

"Position and locality.-Okaw bluffs, between Chester and Kaskaskia, Randolph county, Illinois; from the second division of the Chester limestone.

"Illinois State collection of 1880 , by A. H. Worthen, No. 2476."

The writer has not been able to consult the type-specimen. 
COMPSASTER, new species.

Professor Weller collected an excellent asterid at Fountain Creek, Waterloo, Illinois (No. 14395, University of Chicago collection), showing the entire actinal side of a form that is nearest to $C$. formosus. It is, however, a smaller and more slender species, but until the abactinal surfaces of both species are known, one can not say that they are certainly of the same genus.

Measurements: $\mathrm{R}=20.5 \mathrm{~mm}$., $r=4.5 \mathrm{~mm}$.

\section{SCHUCHERTIID瓜, new family.}

Specializing Cryptozonia with well-developed pentagonal interbrachial arcs. Inframarginals well developed in the proximal regions where they remain adjoining the adambulacrals. Interbrachial and abactinal areas composed of small, more or less closely adjoining plates without regular arrangement.

Madreporite unknown.

Contains:

Schuchertia Gregory.

Remarks. - This family is the most ancient and primitive of all large-disked or pentagonal starfishes devoid of marginals. In Schuchertia the first appearing inframarginals are retained throughout life and remain adjoining the adambulacrals in the axillary regions. These columns distally become less distinct and in the outer third of the rays are not distinguishable as inframarginals from the other smaller ossicles of the interbrachial areas. This therefore indicates that during the growth of Schuchertia the inframarginals are in the process of elimination and in later forms seem to be completely disguised or lost. Then the plates of the interbrachial and abactinal areas, while small, are usually strong, rarely spicular or stellate but never decidedly so, while in later genera the ossicles either break up into smaller and smaller plates, even into granules, or are spicular or thorny pieces. Even the adambulacrals which are well developed in Schuchertia may become greatly modified and almost eliminated.

In seeking for an ancestor for this family, it is plain that it came from a stock like Hudsonaster. This genus actinally has columns of ambulacral, adambulacral, and inframarginal plates; abactinally, inframarginal, supramarginal, and radial columns of plates. In addition there are five axillary marginals, and on the disk a ring of five basal radial and five interradial plates giving rise to the radial and supramarginal columns. The first step from Hudsonaster toward Schuchertia would be a form of the former genus introducing small ambital plates. This type is as yet unknown, but is suggested in Urasterella. The progressive introduction of ambital plates and no 
development of small interbrachial pieces will tend to keep the inframarginals beside the adambulacrals. This is the case in Schuchertia where the axillary marginals are also retained, but this genus has progressed considerably beyond this stage, since the inframarginals fail to develop in the later growth, while the supramarginals and radials, as columns, are no longer distinguishable as such in any part of the individuals. The tendency of departure from Hudsonaster therefore seems to be toward the breaking up and elimination of its essential structure into a mass of variously arranged small pieces, except the ambulacrals, which remain as columns of stout plates.

\section{Genus SCHUCHERTIA Gregory.}

Plates 32 and 33.

Palasterina Brluings (part, not McCoy or Salter), Geol. Surv. Canada, Can. Org. Rem., dec. 3,1858, p. 76.

Schuchertia Gregory, Geol. Mag., dec. 4, vol. 6, August, 1899, p. 351.

Trentonaster Stürtz, Verh. naturh. Ver. preuss. Rheinl., etc., vol. 56, 1900, pp. 224, 225 (based on same genoholotype as Schuchertia).

Original description.- "Palæasterinidæ with tessellate exoskeleton; the rays are short and the general shape is pentagonal. $\mathrm{R}: r$ as $2: 1$. Interradial plates numerous, polygonal. Adambulacral plates large and hexagonal. Ambulacral furrow tapering uniformly toward the distal end.

"Allied to Patxasterina by the general form of the body and the absence of the marginal plates."

Emended description.-Rays five, short and slender. General form pentagonal. Disk large, with well-developed interbrachial arcs.

Abactinal area composed of very numerous, small, tumid, nonstellate plates which are arranged in quincunx or columns. There are no radial, supramarginal, or ambital plates recognizable as such, nor is the margin bounded by columns of inframarginals.

Madreporite indistinguishable amongst the abactinal plates.

Actinally the ambulacral furrows are very narrow, bounded by columns of adambulacral plates. Adjoining these in the proximal regions are distinct "axillary marginals" and inframarginals, the latter distally becoming smaller, and these continue either closely adjoining or are separated from one another by increasing interspaces. In the latter case they are not readily distinguished from the interbrachial accessory plates.

Interbrachial areas occupied by numerous small accessory plates and like those of the abactinal area with which they are continuous.

Ambulacral plates apparently slightly alternating.

Genoholotype (of both Schuchertia and Trentonaster).-Palasterina stellata Billings. The generic description is, however, largely based on S. laxata, new species. 
Distribution.-Ordovicic and Siluric of North America. Contains the following species:

S. stellata (Billings). Trenton, Ottawa, Canada.

S. Zaxata, new species. Richmond of Ohio.

S. ordinaria, new species. Basal Siluric. Girardeau limestone, Alexander County, Illinois.

Remarks. - Schuchertia need only be compared with Petraster and Palasterina. The former differs in that the incomplete columns of inframarginals adjoin the adambulacrals and are not separated from them by interbrachial accessory plates as in the other two genera. Petraster is readily distinguished by the prominent columns of inframarginals bounding the entire animal and abactinally by the distinct columns of radial, supramarginal, and ambital plates. In Schuchertia the plates of the abactinal and interbrachial areas are alike and not distinguishable into the kinds of columns just mentioned for Petraster.

The fact that in Schuchertia the "axillary marginals" and inframarginals remain beside the adambulacrals seems to indicate its origin in forms like Hudsonaster. The generic structure of the latter is retained in Schuchertia, to which is added along the margin (mainly axillary) a series of interbrachial accessory plates. The generic structure of Hudsonaster is also retained in Petraster, but here, unlike those in Schuchertia, the interbrachial accessory plates are developed between the inframarginals and adambulacrals, forcing these columns apart. The phylum starting in Schuchertia is not a prolific one, but the other, Palasterinidx, whose inframarginals are true marginals, is not only more prolific in genera but also has a longer geological range. Beginning in Petraster of the Ordovicic, it is continued in the Siluric in Lindströmaster and Palasterina.

\section{SCHUCHERTIA STELLATA (Billings).}

Plate 32, fig. 2; plate 33, fig.1.

Palasterina stellata Bulırngs, Geol. Surv. Canada, Rep. Progress for 1853-1856, 1857, p. 290; Geol. Surv. Canada, Can. Org. Rem., dec. 3, 1858, p. 76, pl. 9, figs. 1a, 1b.-Wright, Mon. British Foss. Echinod., Oolitic, vol. 2, pt. 1, (Palæontogr. Soc. for 1861), 1862, p. 27, fig. $1 b$ on p. 26.-QUENSTEDT, Petrefactenkunde Deutschlands, vol. 4, 1876, p. 74, pl. 92, fig. 34 .

Trentonaster stellata StüRTz, Verh. naturh. Ver. preuss. Rheinl., etc., vol. 56, 1900, pp. 217, 224, 225.

Description of 1858. - "Pentagonal; disk about one-half of the whole diameter; ambulacral grooves narrow and deep, bordered on each side by a row of small, nearly square adambulacral plates; a second row consisting of disk plates extends nearly to the end of each ray, the remainder of the disk covered with smaller plates. All of these plates are solid and closely fitted together; the disk plates in the 
angles in contact with the oral plates are much larger than any of the others.

"In the only specimen in the collection the length of the rays measured along the ambulacral grooves is three lines; number of adambulacral plates on each side of the grooves sixteen; the rays diminish somewhat rapidly in size, and terminate in a rounded point; diameter of the disk four lines. The plates are all a little worn, so that the character of their surfaces can not be observed; they were probably nearly smooth."

Emended description.-Measurement of the immature type-specimen: $\mathrm{R}=6 \mathrm{~mm}$., $r=3 \mathrm{~mm}$. Larger specimen: $\mathrm{R}=9 \mathrm{~mm}$., $r=4 \mathrm{~mm}$.

Abactinal area composed of a series of plates which are more or less closely adjoining and on the rays are arranged in distinct but twisted columns. This twisting is due to the insertion of new columns of plates, always on the right side, crowding the older ones to the left. The plates on the rays are subquadrangular to elongate subquadrangular, increasing in size proximally, and on the disk are largest and generally subcircular in outline, or faintly stellate. The plates appear to be smooth. At the apex of the ray are two somewhat larger plates followed by three columns and on each side of these there are two other columns of ossicles. Near the beginning of the interbrachial ares the rays have from seven to eight columns of plates.

Madreporite not distinguished among the abactinal plates.

Actinally the most conspicuous columns are the adambulacrals bounding the very narrow ambulacral grooves. These ossicles are subquadrangular in outline near the base of the column, but become wider than long distally; there are about 15 in a column, terminating proximally in two larger, prominent, wedge-shaped plates of the oral armature. Interradially upon each pair of oral pieces is placed a large, single, pentagonal plate (holds the position of axillary interbrachials), against which rest two diverging inframarginal columns, each with 13 or 14 ossicles, and these columns continue adjoining the adambulacrals. Before attaining the distal ends of the rays they gradually become smaller and pass over to the abactinal side. Other actinal disk plates are also present, but apparently are arranged in quincunx, and are smooth like those of the abactinal side.

Ambulacrals unknown.

Formation and locality.-Ordovicic. The holotype (No. 1399, Geol. Surv. Canada collection) showing the actinal area was found by $\mathrm{Mr}$. E. Billings, at Ottawa. Another specimen, also in the Museum of the Geological Survey of Canada, and showing the abactinal area, was found by Mr. J. S. Stewart on Governor General Bay, near New Edinburgh, Canada.

Remarks. - This little Ordovicic asterid is distinguishable from other species with large interbrachial ares in that it is devoid of all marginal and radial columns of plates. From S. laxata it is differ- 
entiated by its smaller size, less numerous plates, and by the relatively greater size of the disk ossicles.

SCHUCHERTIA LAXATA, new species.

Plate 32 , fig. $3^{*}$; plate 33 , figs. $2,3$.

The best specimen measures: $\mathrm{R}=18 \mathrm{~mm} ., r=6 \mathrm{~mm}$., $\mathrm{R}=3 r$. The University of Chicago individual: $R=23 \mathrm{~mm}$., $r=$ about $8 \mathrm{~mm}$. $\mathrm{R}=2.8 r$. Other specimens indicate a growth twice as large as the former one.

Rays short and slender. Disk and interbrachial arcs large but not nearly so large as in Petraster speciosus. Six specimens are known, four of which are poorly preserved and but a jumble of plates. The specific name is given to indicate the generally separated condition of the plates.

Abactinal areas of rays and disk composed of very numerous, small but irregularly sized, subquadrate or diamond-shaped, slightly pustulose plates. The arrangement is mainly in quincunx but a columnar arrangement is also noticeable.

Madreporite not distinguishable amongst the abactinal plates.

Ambulacral furrows very narrow, hardly revealing the carinated ambulacral plates. The podial openings are between the plates along their lateral corners.

Adambulacral plates very convex, a little wider than long, with the inner edge more or less pointed, against which terminates the carina of the ambulacral pieces. There are about 15 of the former plates in $15 \mathrm{~mm}$. along the base of the columns. Actinally the adambulacral columns are the most conspicuous, since the inframarginals beyond the mid-length of the former columns appear not to be separable from the adjoining interbrachial pieces. The inner side of the adambulacrals bears tufts of short blunt spines.

Inframarginals recognizable as such only within the axils where they adjoin the adambulacral columns. Just within each axil there is a large single plate (axillary marginal) against which rest the inframarginal columns. These plates decrease rapidly in size distally and are soon separated from one another so that the tenth piece from the axil is indistinguishable in shape and size from the interbrachials.

Interbrachial accessory plates very numerous, smallest in the inner axillary areas and thence increasing rapidly to a size maintained throughout the interbrachial areas. In form they are either diamondshaped or subquadrate, centrally tumid, and each plate seems to have borne one central and two or three lateral spines.

Formation and locality.-Five specimens are in the Harris collection, all from the Richmond (Waynesville), in the vicinity of Waynesville, Ohio. A fine specimen showing the abactinal area (University of Chicago collection, No. 10982) was found 7 miles north of Hamilton, 
Ohio. Another fragment was found by Mr. E. H. Vaupel at Oxford in the same State.

Remarks. - The only Upper Ordovicic species with which Schuchertia laxata can be confounded is Petraster speciosus. However, there is one fundamental difference between them, so that even fragments can be distinguished. In $P$. speciosus the inframarginals are very conspicuous and bound the outer margin of the entire animal, while in S. laxata there are no columns of marginal plates, since the inframarginals closely adjoin the adambulacrals. In other words, in the former species the interbrachial accessory plates are between the adambulacrals and inframarginals, while in the latter form these pieces, which are also far more numerous, are all outside of the inframarginals. The generally disjointed condition of the plates in S. laxata will probably always distinguish it from $P$. speciosus.

Cat. Nos. 60613, 60623, U.S.N.M.

\section{SCHUCHERTIA ORDINARIA, neW species.}

A regular species of Schuchertia.

The holotype shows the abactinal side only. $\mathrm{R}=11 \mathrm{~mm} ., r=$ about $6.3 \mathrm{~mm}$.

This species is most closely related to $S$. laxata, but is smaller and with a comparatively larger disk. Therefore the rays do not protrude beyond the disk so far as in the latter form. Abactinal skeleton consists of minute tumid ossicles that are more cut along their edges than in S. laxata, and therefore more spicular.

The specimen can not be freed of the adhering clay sufficiently to make an instructive photograph, and is therefore not illustrated.

Formation and locality. - The holotype is from the basal Siluric Girardeau limestone, Alexander County, Illinois. It is in the Gurley collection of the University of Chicago (No. 10992).

\section{Family PALASTERISCIDÆ Gregory.}

Palæbrisingidæ StüRTz, Palæontographica, vol. 36, 1890, p. 246.

Palæchinasteridæ Stürtz, Palæontographica, vol. 36, 1890, p. 246, also p. 247.

Palasteriscidæ Gregory, Treat. Zool., vol. 3, Echinoderma, 1900, p. 257.

Specialized Cryptozonia with very large interbrachial ares. Abactinal and interbrachial areas either with a smooth membrane or granular and thorny. No radial or supramarginal columns of ossicles. Inframarginals not present in any position. Madreporite probably always actinal. Ambulacrals alternating or opposite; adambulacrals more or less modified, but remain adjoining the ambulacrals.

Contains:

Palasteriscus Stürtz.

Echinasterella Stürtz.

Loriolaster Stürtz.

Cheiropteraster Stürtz.

For remarks on the course of development, see Schuchertiidæ. 


\section{Genus PALASTERISCUS Stürtz.}

Palasteriscus Stürtz, Palæontographica, vol. 32, 1886, p. 95, pl. 14, fig. 1; vol. 36, 1890 , p. 223, pl. 28, figs. 23-23b; pl. 29, fig. 24; Verh. naturh. Ver. preuss. Rheinl., etc., vol. 50, 1893, pp. 44, 61.

This genus differs from Loriolaster in being more decidedly stellate, with longer and more slender rays and less extensive interbrachial arcs. The abactinal and interbrachial areas are made up of innumerable, small, variously shaped, loosely interlocking, stellate plates. These areas in Loriolaster appear to be smooth.

Madreporite very large, actinal.

The genoholotype, $P$. devonicus (same citations as above), is the only species and is very rare in the Lower Devonic roofing slates of Bundenbach, Germany.

Cat. No. 59389, U.S.N.M.

\section{Genus ECHINASTERELLA Stürtz.}

Echinasterella Stürtz, Palæontographica, vol. 36, 1890, p. 225, pl. 28, figs. 26, 26a, 27; Verh. naturh. Ver. preuss. Rheinl., etc., vol. 50, 1893, pp. 53, 73.

This form seems to be closely related to Palasteriscus, and without material for examination it is difficult to point out the differences supposed to be generic. Stürtz describes the ambulacrals as opposite, but his figures 26 and 27 show that they are slightly alternating.

The genoholotype, of which three imperfect examples are known, is $E$. sladeni (same citations as above). It is from the Lower Devonic of Bundenbach, Germany. Another form which probably belongs here is E. (?) darwini Clarke, from the Devonic of Brazil.

\section{ECHINASTERELLA (?) DARWINI Clarke.}

Echinasterella ? darwini Clarke, Monog., I, Serv. Geol. Min. Brasil, 1913, p. 315, pl. 27, figs. 9-12; Bull. N. Y. State Mus., No. 164, pl. 34, figs. 1-3.

Original description.- "Of this fine starfish the collections contain two specimens, one, that from which our illustrations are taken, a sharp cast of an oral surface with the arms extended, in a shale sufficiently compact to permit a squeeze to be made of the entire exposure. The other is a considerably distorted individual also chiefly with oral exposure. I have placed the species only provisionally with Stürtz's genus Echinasterella, which was described from the Bundenbach slates, feeling that in all probability both this species and its associated Aspidosoma? pontis will be found on close analysis by expert students of the Asteroidea to pertain to other genera. The structural features presented by E.? darwini are as follows: The oral surfaces of the arms are very broad, the ambulacral grooves narrow, and the plates arranged opposite each other. The ambulacral plates are turned obliquely inward and are broadened at their inner ends. As preserved these show only their upper edges except where 
turned somewhat more obliquely along the food groove. At the edges of these very broad ambulacral areas the adambulacral plates project in a single row on each margin, as rounded nubs or thickened elongated ridges, from each of which project not less than two and probably three spines. In no place is the aboral surface of the starfish presented, but the madrepore plate is distinctly shown in one of the axillae, indicating its ambulacral position. This plate is round, convex, obscurely radiopunctate, and somewhat ridged. The oral apparatus is indicated by thickened plates at the axillae, but their structure in detail can not be made out. The example serving as the type of this species has a radial length from center of mouth to tip of longest arm of $54 \mathrm{~mm} . "$

Formation and locality.-From the Devonic of Ponta Grossa, Brazil.

\section{Genus LORIOLASTER Stürtz.}

Loriolaster StüRTz, Palæontographica, vol. 32, 1886, p. 94, pl. 12, figs. 3, 3a, 4; pl. 13, figs. $1,1 a, 2,2 a$; vol. 36,1890, p. 208, pl. 26, figs. $3 b, 4 a$; Verh. naturh. Ver. preuss. Rheinl., etc., vol. 50, 1893, pp. 47, 63.

Generic description.-Animal large, five-rayed, widely pentagonal, with very large interbrachial arcs entirely inclosing the rays. No marginal plates and seemingly with a parchment-like integument on the abactinal side and in the large interbrachial areas. The plates seen on the abactinal side resemble the aspect of the actinal plates.

Madreporite unknown.

Ambulacral plates alternating, numerous, considerably wider than long, with the podial openings indeterminate.

Adambulacrals about as numerous as the ambulacrals, sickleshaped, greatly elongated laterally and bearing club-shaped carinæ (the regular arrangement of the latter seems to preclude their being articulating spines) which have on their outer lateral ends needle-like spines.

Oral armature pieces large, described as ambulacral.

The only known species is L. mirabilis Stürtz (same citations as above), from the Lower Devonic of Bundenbach, Germany. It is not a common species.

Cat. No. 59380, U.S.N.M.

Remarks.-All of the Bundenbach material has been subjected to great pressure so that nearly all of the finer details have been obliterated and obscured by the adhering slate. However, L. mirabilis can not be confounded with any of the associated species because of the constant absence of the marginal plates and the smooth abactinal and interbrachial membrane. The latter may have been made up of very small calcareous pieces now obliterated by the great pressure to which these fossils have been subjected. Also see Cheiropteraster. 


\section{Genus CHEIROPTERASTER Stürtz.}

Cheiropteraster STüRTz, Palæontographica, vol. 36, 1890, p. 228, pl. 29, fig. 33;

pl. 30, fig. 32; Verh. naturh. Ver. preuss. Rheinl., etc., vol. 50, 1893, pp. 49, 68.

This genus has its nearest relationship in Loriolaster, from which it differs in having a far larger oral opening and markedly different ambulacral columns. These are small plates, in shape like the vertebræ in teleost fishes, which alternate in adjoining columns and do not closely adjoin medially. Podial openings unknown.

Madreporite small, actinally situated near the mouth.

Abactinal and interbrachial integument granular and thorny.

Oral armature pieces small, described as ambulacral.

Genoholotype and only species.-C. giganteus Stürtz (same citations as above). This large species is very rare in the Lower Devonic roofing slates of Bundenbach, Germany.

Cat. No. 59381, U.S.N.M.

SCHCENASTERIDA, new family.

Specialized Cryptozonia with well-developed interbrachial arcs. Abactinal area reticular, composed of numerous small plates. Interbrachial areas with distinctly imbricating plates. Oral armature adambulacral. Adambulacrals well developed in the form of a rope (hence the name, from schoinos, a rope). Ambulacral plates and madreporite unknown.

Contains:

Schœnaster Meek and Worthen.

\section{Genus SCHCEASTER Meek and Worthen.}

\section{Plates 32, 33, 35.}

Schonaster Meek and Worthen, Proc. Acad. Nat. Sci. Philadelphia, vol. 12, 1860, p. 449; Geol. Surv. Illinois, vol. 2, 1866, p. 277.-Zrrtel, Handb. Pal., vol. 1, 1879, p. 453.

Original description.- "Animal consisting of a flattened pentagonal disk, with the angles more or less produced in the form of rays or arms, and the margins between the rays concave in outline, and fringed with short, flattened, spine-like appendages, which are also continued part of the way out along the lateral margins of the rays. Upper side of rays composed of a number of alternating solid plates, with the dorsal pores passing between them, while the angles between the rays are filled with similar plates, forming the upper side of the disk. Under side of the disk composed of numerous small plates, very distinctly imbricating inward and laterally toward the ambulacra. Ambulacral furrows (in the typical species) wide, deep, with on each side a single row of comparatively stout, squarish, or oblong adambulacral pieces, having an obliquely outward, imbricating arrangement, so as to present somewhat the appearance of a twisted 
cord, as seen from below; farther out these become the marginal pieces of the free rays. There is, however, no regular row of marginal pieces to the disk between the rays. [In other words, there are no infra-or supramarginals.] Oral pieces ten, anchylosed (?) in pairs, so as to look like five pieces merely emarginate at the outer and inner ends. (Other characters unknown.)

"Of course it is not possible to give a systematic diagnosis of a genus like this, of which only imperfect fossil species are known. All that can be done, in cases of this kind, is to give such of the more prominent characters as happen to be visible in the particular specimens accessible; while we can not always be sure, until better specimens are obtained, and other species known, whether some of the characters given may not be merely specific, or in other cases of more than generic importance. At the same time, we have to regret our inability to give any information in regard to some of the more delicate parts that would be the first to claim the attention of the zoologist in describing existing starfishes.

"In first publishing a description of the beautiful species forming the type of this genus, we referred it provisionally to McCoy's genus Palasterina, under the subgeneric name Schœnaster. Later comparisons, however, have satisfied us that it can not properly be retained in that genus; and as it seems to present equally important differences from all the other established genera known to us, we now propose to separate it as a distinct genus, under the name Schœnaster. It is probably most nearly allied to the Silurian genus, Palasterina, but differs in the peculiar oblique, outward, imbricating character of its row of plates on each side of the ambulacral furrows, and the distinct inward imbricating character of the minute, scale-like plates covering the under side of the disk. There are likewise differences in the arrangements of the plates and pores of the dorsal side of the free arms, as seen in our figure $7 b, \mathrm{pl} .19$.

"As the disk is not seen in the specimen from which figure $7 d$, of the plate just alluded to, was drawn, it presents so different an appearance from fig. $7 a$ of the same plate, showing the upper side of the fossil, that, looking at these figures alone, doubts might arise whether or not they belong to the same type. An examination, however, of the upper side of the same specimen from which $7 d$ was drawn, as well as of other fragments, shows them to be the same. A fragment of the same specimen from which fig. $7 d$ was drawn also shows portions of the under side of the disk.

"Another species, apparently of this genus, from the Burlington limestone, with much narrower ambulacral furrows ${ }^{1}$, shows numerous

\footnotetext{
1 "We should explain here, that the ambulacral furrow of the enlarged ray, represented by fig. ic of plate 19 , is proportionally too broad, in consequence of the accidental flattening of the specimen, and in part to the adambulacral pieces being represented proportionally too small. These furrows are more nearly natural in fig. $7 d$, but even in that specimen they are proportionally wider than in undistorted examples."
} 
little, short, flattened, spine-like appendages protruding from these furrows, with an outward imbricating arrangement or inclination towards the extremities of the rays. There may have been other little spines over the outer surface, in addition to those fringing the margins of the disk, though the specimens retain no traces of them."

Genoholotype.-S. fimbriatus Meek and Worthen. Lower Carboniferous (St. Louis) of Illinois.

The other three species referred to Schcnaster probably do not belong in this genus. The specimens have not been studied.

\section{SCHCENASTER FIMBRIATUS Meek and Worthen.}

Plate 35, figs. 1-4.

Palæasterina (Schœnaster) fimbriata Meek and Wonthen, Proc. Acad. Nat. Sci., Philadelphia, vol. 12, 1860, p. 449.

Schoenaster fimbriatus MeEK and Worthen, Geol. Surv. Illinois, vol. 2, 1866, p. 278, pl. 19, figs. $7 a-7 d$.

Original description.- "Body regularly pentagonal star-shaped, with the rays produced into rather acutely pointed arms, which are convex above, and about equal in length to the diameter of the disk. Plates of the upper side of the arms and disk, convex, or even tumid; near the disk those of the rays hexagonal, heptagonal, or irregular in form, alternating, and consisting of about five or six longitudinal rows, with a few much smaller intermediate pieces. Farther out the rays, they gradually pass into two mesial ranges of oblong, alternating pieces, with their longer diameter parallel to that of the rays; while on each side of these, minute irregular pieces fill the space between them and the marginal pieces. Toward the extremities of the rays, these little intermediate pieces diminish in size and at last become obsolete, leaving only the two middle and outer, or adambulacral rows. Ambulacral furrows, in apparently undistorted specimens, deep and nearly or quite twice as wide as the row of pieces on either side; adambulacral pieces rather thick and strong, and liable to present considerable differences in their obliquity and breadth of surface exposed, in consequence of the compression or distortion of the specimen. Plates of the under side of the disk, very much smaller than the adambulacral, closely crowded together, and owing to their imbricating arrangement, presenting much the appearance of the scales of a fish; immediately on each side of the rays, they imbricate toward the latter, but near the middle of the space between any two ambulacra, the imbrication is inward toward the mouth, so that in tracing the rows parallel to their longer diameter, across between the rays, they are found to describe a nearly semicircular curve, with a slight angularity near the middle.

"Near the extremities of the rays, the dorsal pores are seen to pass between the ends of the two mesial ranges of oblong pieces, 
but farther in toward the disk they are more irregularly distributed. Our enlarged figure $7 b$, pl. 19 , represents these pores and the dorsal plates, as seen in one of the rays, with the convex outer portion of the plates ground away, in which condition the pores probably appear larger than natural. In specimens with the tumid portion of these plates unremoved, the pores are not readily seen, and the whole dorsal side then seems to be made up of solid, closefitting pieces. Greatest diameter across between the extremities of the opposite rays, about 2.37 inches; diameter of disk, 1 inch; breadth of ambulacral furrows, about $0.10 \mathrm{inch}$; length of little flattened marginal spines, near 0.08 inch.

"Locality and position.-St. Clair County, Illinois; in the St. Louis division of the Subcarboniferous series."

The specimen has not been studied.

\section{SCHCENASTER (?) WACHS̀MUTHI Meek and Worthen.}

Plate 33, fig. 6.

Schonaster wachsmuthi Merk and Worthen, Proc. Acad. Nat. Sci., Philadelphia, vol. 18, 1866, p. 259; Geol. Surv. Illinois, vol. 3, 1868, p. 499, pl. 17, fig. 4.

Original description. - "Body flattened or much depressed, with a regular, distinctly pentagonal outline, the angles being produced into five rather attenuated rays, which are a little convex above, and apparently as much as two-thirds as long as the diameter of the disk, if not more. Disk concave in outline on the margin between the rays, and imparting a slightly alate character to the latter by extending a little along their margins; like the dorsal side of the rays, composed above of numerous small, slightly convex plates. Dorsal pores moderately distinct between the plates. Plates of the under side of the disk about as large as those of the dorsal side, but flattened, scalelike, crowded, and having the inward imbricating character of the genus strongly marked. Ambulacra (as seen in a compressed specimen) very narrow, their marginal plates moderately large, oval-oblong, comparatively thin, and very strongly imbricating outward. Between these, two rows of short, flattened, spinelike scales are seen arising from the ambulacral furrow, and all inclining outward or toward the extremities of the rays. (Other characters unknown.)

"Diameter of disk, 1.32 inches; rays apparently extending as much as 0.90 inch or more beyond the margins of the disk.

"This species will be readily distinguished from our S. fimbriatus, of the St. Louis limestone, the only other species of the genus known to us, by its smaller and less convex plates on the dorsal side, as well as by its much thinner, less oblique, and more strongly imbricating row of plates along each side of the ambulacra, and particularly by its much narrower ambulacral furrows. We have not seen any 
traces of the row of short, flattened, marginal spines seen around the disk of $S$. fimbriatus, in the form under consideration; nor have the similar little appendages arising in a double row from the ambulacra of the latter been seen in S. fimbriatus. These, however, may be rather generic than specific characters, and consequently be found common to both species.

"The specific name is given in honor of Mr. Charles Wachsmuth, of Burlington, Iowa, the discoverer of the only specimen we have seen."

Formation and locality.-Burlington limestone, Burlington, Iowa. The specimen has not been seen; it is in the Museum of Comparative Zoölogy, Harvard University (No. 7).

\section{SCHCNASTER (?), new species.}

In the Gurley collection of the University of Chicago there is a small specimen (No. 10993) from the Chester formation of Pope County, Illinois. According to the older classification it would be referred to Schœnaster, but until this genus is thoroughly revised nothing of generic value can be done with these Carboniferous asterids. The specimen under discussion seems to be most closely related to $S$. (?) wachsmuthi.

Measurements: $\mathrm{R}=$ about $10 \mathrm{~mm} ., r=$ about $3.5 \mathrm{~mm}$.

\section{SCHGNASTER (?) LEGRANDENSIS Miller and Gurley.}

Plate 32, figs. 4-6.

Schoenaster legrandensis Mriler and GurLex, Descr. new gen. and sp. Echinod., 1890, p. 56, pl. 9, figs. 7-9.-MmLER, Sixteenth Rep. Geol. Surv. Indiana, 1891, p. 371, pl. 9, figs. 7-9; N. Amer. Geol. Pal., App. 1, 1892, p. 682, fig. 1246.

Original description.- "Body thin, regularly pentagonal, sides concave, with long, nar ow, gradually tapering convex arms. Plates on the dorsal side of the disk in our specimen apparently anchylosed, and spines, if any belonged to the margin, broken away. Ventral side depressed and flat between the arm furrows, where it consists of very small plates, and if they imbricate inward the overlap must be very slight. Ambulacral furrows wide, deep; two rows of subquadrangular, ambulacral plates form the bottom of each furrow, on each side of which there is a row of oblong adambulacral plates, having an obliquely inward imbricating arrangement, presenting somewhat the appearance of a twisted cord; these are continued to the ends of the arms with the same obliquely inward imbricating arrangement. Five pairs of oral plates.

"This species is small in comparison with the two heretofore described, has sides less convex, and narrower arms."

Formation and locality.-Kinderhook limestone at Le Grand, Iowa. The specimen has not been seen; it may be in the Gurley collection of the University of Chicago. It is certainly not a form of Schœnaster. 
SCHCENASTER (?) MONTANUS Raymond.

Plate 33, fig. 5.

Schœnaster? montanus RAYMoND, Ottawa Naturalist, vol. 26, 1912, p. 80, fig. 3 on p. 81.

Original description.- "Animal small, about an inch in diameter. Rays short, slender, extending about one-half their length beyond the disk. Disk large, pentagonal, the margin slightly concave between the rays. The five proximal plates of the adambulacral series function as orals, while on the arms beyond the disk the adambulacrals become marginals. The adambulacral plates are rather small, oval, placed with the long axis diagonal to the axis of the arm. On the most perfect arm there are 16 of these plates on each side of the groove, not counting the proximal and distal plates.

"The ambulacral ossicles are small, arranged alternately. On this specimen they are mostly displaced. The plates on the disk between the rays are few and small. The marginals are small, rounded, and do not appear to bear spines, but this appearance may be due to poor preservation.

"Locality. - This species is described from a single specimen collected by the writer in the Madison limestone at Spring Canyon in the Ruby Mountains, near Alder, Montana. The type is in the Carnegie Museum, Pittsburgh, Pennsylvania."

PALAOSOLASTERID $Æ$, new family.

Specialized multiradiate Cryptozonia with as many as 29 rays, large disk, and actinal madreporite. Ambulacralia opposite or slightly alternating.

Contains:

Palæosolaster Stürtz.

Echinasterias Stürtz.

Echinodiscaster Delage and Hérouard.

Echinostella Stürtz.

Medusaster Stürtz.

How rays are introduced in multi-rayed asterids.-For paleontologic purposes it is not necessary to go deeply into this matter, but it is desirable to know when, where, and how the supernumerary rays are introduced in living forms so that we may be guided in our generic studies.

Ritter and Crocker ${ }^{1}$ have recently summed up what is known on this subject, and to their paper the reader is referred for further study.

In nearly all cases the multi-rayed forms have the rays of equal development, and for this reason it is the general belief that

1 Ritter and Crocker, Multiplication of rays and bilateral symmetry in the 20-rayed starfish, Pycnopodia helianthoides (Stimpson), Proc. Washington Acad. Sci., vo . 2, 1900, pp. 247-274.

$50601^{\circ}-$ Bull. 88-15-14 
adults have the full complement of rays characteristic of a species. In some forms there are individuals with smaller immature arms, but it is not certain that these are newly introduced rays, or that "this disparity in size is due to the regeneration of the halves of automatically bisected animals" (p. 248). It is true that certain species start with the full complement of rays and introduce none in later growth. Others certainly deviate from this rule, and a species with as many as 37 rays has one small specimen with only 24 plus 2 young sprouting rays. It is therefore plain that "in Heliaster rays are added until far in adult life," and it is also probable that "they are added in pairs" (p. 249). In Labidiaster as many as six new rays may bud simultaneously at intervals around the entire circumference of the disk.

An adult Pycnopodia has from 20 to 24 rays, and "this variation does not depend upon the size of the specimen. * * * The number is generally even, * * * but a few specimens with 21 have been found" (p. 250). The smallest specimen had six equal arms and two much smaller budding rays, one larger than the other. Between these two extremes all intervening stages occur. At least the original five and probably six rays are of larval origin, all the others being postlarval. When the sixth ray is introduced is unknown; the rest as a rule appear in bilateral order-that is, in pairs. They are all developed "in a budding area adjacent to I and II" on the side toward the sixth ray until late in adult life. When the arms are of unequal number it is due to the suppression of a ray. In Pycnopodia, therefore, ray multiplication goes on through a considerable part of adult life, but not the whole of it, and is variable with the individuals. All of the rays, whether of larval or postlarval origin, have the same structural characters.

Finally, it seems that the sixth ray in Pycnopodia has its origin in, or at least "is in some intimate way related with the larval organ of the embryo" (p. 268). Therefore multiradiation among asterids has its origin in late larval life.

In Heliaster, Clarke states, " "the formation of new rays is fundamentally different from that in Pycnopodia." They do not develop in distinct generations, but appear entirely independently of each other. "A considerable number may develop at approximately the same time, often as many as six or seven and sometimes eight or nine in $H$. polybrachius, but they show no definite relation to each. other."

The evidence seems "to show that they tend to arise in all four quadrants of the circumference of the starfish about equally, but successively rather than simultaneously." 
In Heliaster the original number is five, and the new rays are not as a rule disposed bilaterally (pp. 63-66).

Verrill (1914) states that Heliaster and allied living forms strikingly resemble Helianthaster of the Devonic, "and may indicate a continuous descent from these ancient forms" (p.13). He also says, "I am inclined to believe that the increase in number of rays has been due more to the advantage gained in holding their food securely, and in opening bivalves, than for holding to the rocks, though both go together" (p. 16).

\section{Genus PALAEOSOLASTER Stürtz.}

Plate 34.

Palæosolaster Stürtz, Verh. nat. Ver. preuss. Rheinl., etc., vol. 56, 1900, pp. 226-229, pl. 2, figs. 1-3.

Helianthaster ClARKE (part), Bull. N.Y. State Mus., No. 121, 1908, p. 64, pl. 11.

Generic characters.-Disk very large, with -27 to 29 rays in the genotype, which project one-third their length beyond the disk. Animal large, up to $190 \mathrm{~mm}$. in greatest diameter. Disk and rays without marginalia. Length of rays $95 \mathrm{~mm}$., width of rays $7 \mathrm{~mm}$.

Abactinal area decidedly and abundantly spinous and devoid of all columns of plates.

Actinally the great disk is also decidedly spinous. Rays slender, with wide ambulacra; ambulacral plates very narrow, seemingly alternating, but more probably opposite, $\vdash$-shaped, with large podial openings in two rows in each ambulacrum. The rays are bounded by narrow columns of small adambulacral ossicles that bear spines on their outer sides. Mouth circular and very large. The nature of the stout oral armature can not be made out.

Madreporite actinal, placed near the mouth, interbrachial, very large, striate, more or less oval, about $34 \mathrm{~mm}$. in greatest width.

The general aspect is said to be much like the living Solaster affinis Brandt.

Genoholotype.-P. gregoryi Stürtz (citations as above). Lower Devonic of Bundenbach, Germany. Another species occurs at this locality and a third is found in the Upper Devonic of New York.

Remarks.-For present purposes we may state that Palæosolaster has from 25 to 29 rays and that the ambulacralia are arranged opposite one another; the other Stürtz genera, Echinasterias, Echinodiscaster, and Echinostella, are so much like Palæosolaster that they may be disregarded.

Clarke recently erroneously referred another very well preserved species of this genus to Helianthaster ( $H$. roemeri Clarke), but it plainly has no direct relationship with $H$. rhenanus. This is seen in the greater disk, larger number of rays, decidedly actinal position 
of the madreporite and the absence of interbrachial inframarginals. It is clearly a Palæosolaster.

\section{PALAEOSOLASTER (?) GYALUM (Clarke).}

Plate 34, fig. 1.

Helianthaster gyalum ClARke, Bull. N. Y. State Mus., No. 121, 1908, p. 63, pls. $12,13$.

Original description.-The New York specimens, "Helianthaster gyalum nov. are smaller than $H$. rhenanus. The arms are more numerous and appear to be quite uniformly 24-25. Compared to $H$. rhenanus they are relatively short, but very long compared with the size of the disk, which is much suppressed, and on none of the specimens, all showing the oral surface, is any distinct evidence of it visible, so deeply do the arms cut into it and so closely do they lie together. Notwithstanding this apparent retreat of the disk the madreporiform plate is very large. This organ is preserved in but one example, but here it overlaps two adjoining interbrachial angles and the mouth parts pertaining thereto. Instead of being a flat or concave elongate plate, as in $H$. rhenanus, it is highly convex and circular; its surface markings less distinct and coarse in that species.

"The great oral aperture is margined by a series of pronounced 'jaws' or sharp projecting elevated angles the sides of which take origin from the margins of adjoining arms. These oral projections are slightly expanded at their tips into blunt points comparable to but smaller than the 'Höcker' of $H$. rhenanus, but like them carry small spines projecting inward. The solidity and strength of these mouth parts is indicated by their prominence and elevation as shown in figure. *** The reentrant angle at the base of each arm is narrow, long, and acute, much more extreme in these respects than in $H$. rhenanus and very much more elevated."

Actinally the rays have two columns of plates of which the ambulacrals are by far the most prominent, are opposite one another or slightly alternate, and occupy the comparatively wide ambulacral furrows. The adambulacrals are narrow columns and apparently as many in number as the ambulacrals. Laterally each adambulacral bears several spines.

Locality and formation.-A slab with three individuals from the Portage (Upper Devonic) at Earl's quarry, Ithaca, New York, is now in Cornell University.

Remarks. - The writer has not seen these specimens, but the illustrations seem to indicate that the "pronounced jaws" are made up of small ossicles of which there are at least five in each column. Further, that these ossicles are more probably the continuation of the narrow adambulacrals than of the ambulacral columns into the great oral area, and that proximally to these lie the minute pairs of oral armature pieces. 
The madreporite in $P$. (?) gyalum, as in the forms of Palxosolaster, is very large, actinal in position, and placed even closer to the mouth than in any other species. Not only this, but it lies completely covering one proximal ambulacral furrow and across parts of two adjacent rays. Its general position and size are in harmony with Palæosolaster and not at all with Helianthaster.

That $P$. (?) gyalum can not be referred to Helianthaster is therefore seen in the different position of the madreporite, the greater number of rays, the wider ambulacral furrow, and the improbability of its having three columns of abactinal ray plates in place of an integument bristling with spines. All of these differences are in harmony with Palzosolaster. Further, if $P$. (?) gyalum had interbrachial inframarginals as does Helianthaster, they should show somewhere on these five specimens, all of which preserve the actinal side. While these differences may not appear to be great, they make of Helianthaster a phanerozonian and of Palæosolaster a cryptozonian.

PALAEOSOLASTER ROEMERI (Clarke).

Heliarthaster roemeri Clarke, Bull. N. Y. State Mus., No. 121, 1908, p. 64, pl. 11.

From the Lower Devonic of Bundenbach, Germany. The holotype is in the New York State Museum.

\section{Genus ECHINASTERIAS Stürtz.}

Echinasterias Stürtz, Verh. nat. Ver. preuss. Rheinl., ete., vol. 56, 1900, p. 230, pl. 2 , fig. 4 ; pl. 3 , fig. 5 .

The genotype has 25 rays, but otherwise appears to have all the generic characters of Palæosolaster.

Genoholotype and only species.-E. spinosus Stürtz (citations as above). Lower Devonic of Bundenbach, Germany.

Genus ECHINODISCASTER Delage and Hérouard.

Echinodiscus STÜRTz (not Echinodiscus Worthen and Miller 1883, Echinoidea), Verh. nat. Ver. preuss. Rheinl., etc., vol. 56, 1900, pp. 231-233, pl. 3, figs. 6-10.

Echinodiscaster Delage and Hérouard, Traité de Zoologie Concrète, 1904.

Echinodiscites Schuchert, Fossilium Catalogus, Animalia, pt. 3, 1914, p. 15.

One of the specimens has 29 rays and a greatest diameter of 160 $\mathrm{mm}$. The writer fails to see how this genus is to be distinguished from Palæosolaster. It may be more abundantly spinose, and the madreporite is somewhat smaller and more coarsely striate, but these characters can hardly be of generic value.

Genoholotype and only species.-Echinodiscus multidactylus Stürtz (citations as above). Lower Devonic of Bundenbach, Germany.

Cat. No. 59386, U.S.N.M. 


\section{Genus ECHINOSTELLA Stürtz.}

Echinostella Stứrtz, Verh. nat. Ver. preuss. Rheinl., etc., vol. 56, 1900, pp. 233-235, pl. 3, fig. 11; pl. 4, fig. 12.

The only specimen has 28 or 29 rays and a greatest diameter of $150 \mathrm{~mm}$. Abactinally the rays and the central area of the disk stand out rounded above the remainder of this side of the animal, which is not the case in Palæosolaster; otherwise the two genera are very much alike.

Genoholotype and only species.-E. traquairi Stürtz (citations as above). Lower Devonic of Bundenbach, Germany.

\section{Genus MEDUSASTER Stürtz.}

Medusaster StüRTz, Palæontographica, vol. 36, 1890, p. 229; pl. 31, figs. 34,35;

Verh. naturh. Ver. preuss. Rheinl., etc., vol. 50, 1893, pp. 54, 73.

A form with from 12 to 15 rays. Thought to have relationship with living Solaster.

Genoholotype and only species.-M. rhenanus Stürtz (citations as above). Lower Devonic, Bundenbach, Germany.

Cat. No. 59385, U.S.N.M.

\section{PALEOZOIC OPHIURIDS.}

A great deal has been written about these animals, but in general the true structure of some of them was not known until very recently. Authors have described these delicate and generally poorly preserved fossils in such broad terms that a complete restudy of all of the material is required before it can be said that most of the genera or even the species are established. The way has been successfully blazed by Schöndorf in Europe, and his methods of study and results need to be applied to the American fossils. It was the writer's hope to do this, but it is now plain that his present duties will prevent his doing so.

In general it may be said that but few Paleozoic so-called ophiurids are true Ophiuroidea. They are ophiurid-like animals, with open ambulacral furrows, but without the essential characters of the Asteroidea. Nor are they transitional in structure between the Asteroidea and Ophiuroidea. Therefore Schöndorf has separated them under the term Auluroidea. It seems to the writer that they originated in the Asteroidea early in the Ordovicic in some cryptozonian stock near Urasterella, with large and square ambulacralia. (Stenaster and Tetraster are probably true aulurids.) Out of the Auluroidea, probably in late Devonic time, arose the true Ophiuroidea.

The essential differences between the Auluroidea and Ophiuroidea will become plainer to the student after a study of the text and figures presented in this work. 


\section{Subclass AULUROIDEA.}

Auluroidea ScHöNDoRF, Palæontographica, vol. 67, 1910, p. 60; Jahrb. nassauisch.

Ver. Naturk., Wiesbaden, vol. 63, 1910, pp. 234, 247, 251.-SPEncer, Mon.

Brit. Pal. Asterozoa, pt. 1 (Palæontogr. Soc. for 1913), 1914, pp. 24, 48.

Protophiuroidea and Euophiuroidea Sollas and Soluas, Philos. Trans. Roy. Soc.

London, ser. B, vol. 202, 1912, pp. 214, 222.

Auluroidea are Paleozoic brittle-stars, with a more or less welldeveloped central disk, whose border between the rays is more often concave than convex; in otherwords, star-shaped. The rays appear always to be five in number, simple, long and slender, and more or less sharply marked off from the disk as appendages. This means that the body cavity does not extend from the disk into the rays as in Asteroidea. On the actinal side the rays have open ambulacral furrows with the ambulacralia never anchylosed into vertebræ; they are arranged in two columns, the pieces of which are either alternate or opposite one another.

\section{Original definition.- "The ambu-} lacral water-vascular system lies in

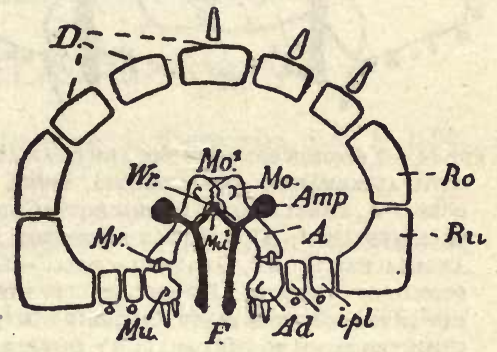

Fig. 12.-A SECTION THROUGH THE ARM OF AN ASTERID, AFTER SCHÖNDORF. A, AMBULACRALIA; $A d$, ADAMBULACRALIA; $A m p$, AMPULLA; $D$, DORSAL SKELETON; $F$, PODIA; $i p l$, ACCESSORY OSSICLES; MO, ATTACHMENT FOR UPPER LONGITUDINAL MUSCLES; Mo1, UPPER TRANSVERSE MUSCLE; $M U$, ATTACHMENT FOR LOWER LONGITUDINAL MUSCLE; MU1, LOWER TRANSVERSE MUSCLE; $M v$, VeRTICAL MUSClE; Ro, UPPER MARGINALIA; $R u$, LOWER MARGINALIA; Wr, RADIAL WATER-VESSEL. a circular canal that is situated wholly within the ambulacralia medially between the adjoining columns of ossicles. From it diverge short side branches that either partially penetrate the substance of the

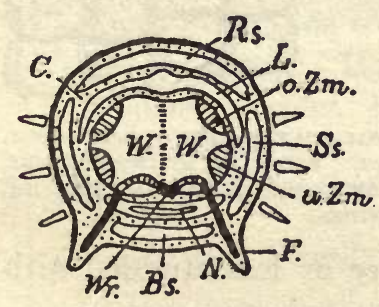

Fig. 13.-A SECTION THROUGH THE ARM OF A TRUE OPHIURID, AFTER SCHÖNDORF. BS, VENTRAL SHIELD; $C$, CUTIS; $F$, PODIA; $L$, BODY CAVITY; $N$, NERVE-RING; $O Z m, u Z m$, UPPER AND LOWER INTERMEDIARY VERTEBRAL MUSCLES; $R s$, DORSAL SHIELD; $S s$, LATERAL SHIELD; $W$, VERTEBRE; $W r$, RADLAL WATERVESSEL. individual ambulacrals, or lie in the suture between adjoining ambulacrals; in either case they extend into the ventrally open, broad ambulacral furrow. Ambulacrals free, not coossified, those of adjoining columns either alternate or opposite, but always directly opposite the adambulacrals. Ambulacrals ventrally composed of a medially situated, internally concavely hollowed-out body, which, as the plates of the two columns are normally united, forms the medial ambulacral canal; and of a lateral process extending to the adambulacrals, with depressions on both sides of it in the ventral surfaces of the ambulacrals and adambulacrals [see fig. 14]. [These large lateral depressions are not podial openings through or between the plates as in asterids, but appear to be cavities for the ampullæ or for these and podial insertions. Dorsally the ambulacrals 
are covered with spines and tubercles.] Disk with concave, or convex (?) margins, with or without marginal ossicles. When the latter are present, they never extend along the rays, but are wholly restricted to the disk. The rays on both sides are margined by the adambulacrals. Ventrally the rays have broad open ambulacral fur-

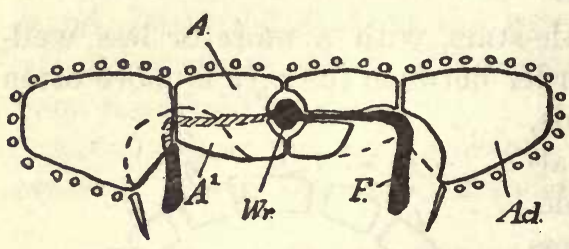

FIG. 14.-A SECTION THROUGH THE ARM OF AN AULURT, WITH ALTERNATTNG AMBULACRALIA, AFTER SCHÖNDORF. A, AMBULACRALIA OF THE DORSAL AND VENTRAL SKELETON; $A^{1}$, VENTRAL EXTENSION OF THE AMBULACRALIA; $A d$, ADAMBULACRALIA = LATERAL SHIELDS OF OPHURIDS; $F$, PODIA, ON LEFT THE CANAL PASSES THROUGH THE PLATE, ON RIGHT THE PLATE IS DISSECTED DOWN TO THE CANAL; $W r$, INTERSKELETAL RADIAL WATER-VESSEL. rows, bounded laterally by the adambulacrals. A typical madreporite [probably always] lies in one of the ventral interradii.

"The group [subclass] is restricted to the older Paleozoic."

Remarks. - This subclass of Stelleroidea appears to be an independent development whose structure partakes of that of the Asteroidea and the Ophiuroidea, though more like the latter. The Auluroidea agree with the asterids in having open ambulacral furrows, and a true madreporite, which is, however, ventrally situated, but otherwise the class is more like the ophiurids, since the body cavity does not extend into the rays as in true starfishes. However, the water-vascular canal in the Auluroidea does not lie outside of the ambulacrals as in the Asteroidea, but within these ossicles along the mid-line of the ambulacrum in a canal that is cut out of the sides of adjoining ambulacral columns. On the other hand, the Ophiuroidea have the ambulacralia coossified and modified into vertebral ossicles; there are no open ambulacral furrows, and the entire rays are covered by four
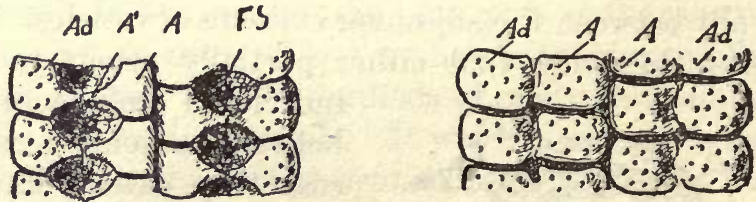

FIgs. 15 AND 16.-VENTRAL AND DORSAL ARM STRUCTURE OF AULUROIDEA, WITH THE AMBULACRA ALTERNATING. SCHEMATIC, AFTER SCHÖNDORF. $A$, AMBULACRALLA; $A^{1}$, VENTRAL EXTENSTONS OF AMBULACRALL; $A d$, ADAMBULACRALIA; FS, PODIAL CAVITIES.

columns of shields or by an integument more or less studded with calcareous plates and granules.

It appears that the Auluroidea all have dorsally four columns of plates, of which the two medial ones are the most prominent. These are undoubtedly the dorsal aspect of the thickened ambulacrals. Outside of the disk they are usually convex and more or less ornamented with granules, but within the disk are less prominent and take on other expressions, commonly with concave surfaces. The plates outside of these margin the rays and are the adambulacrals; while in some forms they are prominent and tuberculate, usually they are made up of narrow vertical pieces that bear spines along the ventral or only the distal ventral edge. 
The Auluroidea can be divided into two orders on the basis of whether the ambulacrals on each side of the median line are arranged alternately (the Lysophiuræ), or are opposite to one another (the Streptophiuræ). The following classification is a modification of the one offered by Gregory in 1897, and his work was in turn a modification of that of Bell in 1892.

After the present work was written, its author first became aware of the works of Sollas and Sollas, and Spencer. The reader should consult those papers for important studies on the Auluroidea.

\section{Order LYSOPHIURA Gregory.}

Encrinasteriæ Brons (part), Klassen u. Ordnungen d. Tierreichs, vol. 1, 1859, p. 287.-SchöNDoRf, Palæontographica, vol. 57, 1910, p. 61.

Ophio-Encrinasterix StÜRTz, Verh. naturh. Ver. preuss. Rheinl., etc., vol. 56, 1900, p. 198.-ScHöNDORF, Jahrb. nassauisch. Ver. Naturk., Wiesbaden, vol. 63,1910, pp. 234, 237.

Lysophiuræ Gregory, Proc. Zool. Soc. London for 1896, 1897, p. 1030 (contains Protasteridæ and Palæophiuridæ); Treat. Zool., vol. 3, Echinoderma, 1900, p. 274.-Sollas and Sollas, Philos. Trans. Roy. Soc. London, ser. B, vol. 202,1912 , p. 223.

Ophiurasteriæ ScHöNDORF, Jahrb. nassauisch. Ver. Naturk., Wiesbaden, vol. 63, 1910, p. 251.

Auluroidea in which the ambulacral ossicles of adjoining columns are alternate to one another. The individual plates are separate and not coossified into vertebræ.

Remarks. - The Lysophiuræ are Paleozoic or primitive Auluroidea, that is, ophiurid-like animals, with wide and open ambulacral furrows in which the ambulacralia are free and alternately arranged. The ambulacralia are common to the actinal and abactinal sides.

This order contains the following families:

Protasteridæ. Have boot-shaped ambulacralia ventrally.

Palæophiuridæ. Have subquadrate ambulacralia ventrally.

Encrinasteridæ. Have boot-shaped ambulacralia ventrally and large disks that are bordered by marginalia.

\section{Family PROTASTERID瓜 Miller.}

Protasteridæ Mrller, N. Amer. Geol. Pal., 1889, p. 216.-Gregory, Proc. Zool.

Soc. London for 1896, 1897, p. 1031; Treat. Zool., vol. 3, Echinoderma, 1900, p. 274.-PARKs, Trans. Canadian Inst., vol. 8, 1908, p. 366.

Palæophiomyxidæ StürTz, Verh. naturh. Ver. preuss. Rheinl., etc., vol. 56, 1900, p. 202.

"Lysophiuræ with boot-shaped ambulacral ossicles, each composed of a 'body' in the median line of the arm, and a lateral 'wing' at right angles to it" (Gregory). There is either a well-marked scale-covered or granular disk, and five flexible arms. The adambulacral plates are rather stout, with many lateral spines. 
Schöndorf states that Gregory's family Palæophiuridæ has no value and is to be merged into the one under discussion. The reasons for this are given beyond under the former family heading.

The family contains:

Tæniaster Billings. •

Eophiura Jaekel.

Bohemura Jaekel.

Palæura Jaekel.

Protaster Forbes.

Alepidaster Meek.

Gregoriura Chapman.

Bundenbachia Stürtz.

Palæophiomyxa Stürtz.

\section{Genus TANIASTER Billings.}

Plate 36, figs. 1-3.

Tæniaster Brulrngs, Geol. Surv. Canada, Can. Org. Rem., dec. 3, 1858, p. 80.Chapman, Canadian Journ., n. ser., vol. 6, 1861, p. 517.-Wright, Mon. British Foss. Echinod., Oolitic, vol. 2, pt. 1 (Palæontogr. Soc. for 1861), 1862, pp. 24, 34.-HALL, Twentieth Rep. N. Y. State Cab. Nat. Hist., 1868, p. 300; rev. ed., $1868=1870$, p. 338.-Zrrtel, Handb. Pal., vol. 1, 1879, p. 445.STÜRTz, N. Jahrb. für Min., etc., 1886, vol. 2, p. 150; Palæontographica, vol. 32, 1886, pp. 78, 83.-Miller, N. Amer. Geol. Pal., 1889, p. 285.-Gregory, Geol. Mag., dec. 3, vol. 6, 1889, p. 26.-SrüRTz, Verh. naturh. Ver. preuss. Rheinl., etc., vol. 50, 1893, p. 20.-J. F. JAMEs, Journ. Cincinnati Soc. Nat. Hist., vol. 18, 1896, p. 138. -Gregorx, Proc. Zool. Soc. London for 1896, 1897, p. 1035; Treat. Zool., vol. 3, Echinoderma, 1900, p. 250.-Spencer, Mon. Brit. Pal. Asterozoa, pt. 1 (Palæontogr. Soc. for 1913), 1914, pp. 8, 19.

Tæniura Gregorx, (not Tæniura Müller and Heule 1837, sting-ray), Proc. Zool. Soc. London for 1896, 1897, p. 1035.

Original description of Tæniaster.- "Generic Characters.-Body deeply stellate; no disk [there is a disk] or marginal plates; rays long, slender, flexible, and covered with small spines; two rows of large ambulacral pores; adambulacral plates elongated and sloping outward so that they partly overlap each other; ambulacral ossicles contracted in the middle, dilated at each end. Generic name from tainia, a riband."

Genolectotype (the first species of Billings is here selected as the genolectotype).-Palæocoma spinosa Billings.

Remarks.-Hall restudied the type-material of Tæniaster and records his observations as follows:

"In reviewing the characters of Protaster and Eugaster, I became satisfied that there was an intimate relation between these and Tæniaster of Billings, and in order to satisfy myself on this point, I have * * * received from Sir William E. Logan, permission to examine specimens of Trniaster spinosus and T. cylindricus.

"An examination of the specimen illustrated in fig. 3 (ut sup.) reveals what I conceive to be a disk not at all unlike the disk of Protaster, but less extended than in the Lower Helderberg species. The structure of the ray is precisely of the same character as the ray of 
that species which I have named Protaster forbesi, the proportions of plates and relations of parts showing specific differences."

"Mr. Billings remarks, under the description of $T$. spinosus, that 'the ambulacral ossicles appear in some places to alternate with each other, but this is owing to a distortion; those on one side of the furrow are opposite to those upon the other.'

"Now the specimen of this species which I have examined, and which I suppose to be the one figured upon Plate $\mathrm{X}$, figures $3 a, b$, has the ambulacral plates alternating * * *.

"In the specimen of $T$. cylindricus examined the ambulacral plates are less distinctly alternate, but the relation of the adambulacral plates and the pores are the same as in the other form. Not having seen the specimen showing the dorsal view, figure $4 a$ of plate X, I can only remark that the structure of the rays is very similar to that of Protaster."

Without restudying the type-material of Tæniaster, or paying attention to Hall's statements that $T$. spinosus has what he conceived "to be a disk not at all unlike the disk of Protaster," Gregory (1897) regarded Tæniaster as a Cryptozonia starfish and made of Billings's second species, T.cylindricus, a new genus, Tæniura. The latter he correctly refers to the primitive ophiurids. Under these circumstances it is desirable to repeat here what Gregory wrote about Tæniaster.

Tæniaster "was described as diskless, which in respect to the type species $T$. spinosus is correct. In that species the oral skeleton consists of five pairs of large adambulacrals, as in ordinary Asterids. The affinities of the true Tæniaster appear to me to be with such forms as Palæaster ruthveni [= Urasterella ruthveni]. It is asteroid in the oral armature, in its alternately arranged ambulacral ossicles, and in the absence of a disk. I therefore consider Tæniaster a genus of Asteroidea. The second species placed by Billings in this genus has, however, a well-marked disk, and has the oral armature composed of five pairs of Ophiuroid syngnaths. It must, therefore be included among the Ophiuroidea."

To adjust this matter, the writer restudied the genotype of Tæniaster at Ottawa (two specimens, No. 1404, the originals of figures $3 a-3 d$ of Billings's Plate X). There can be no doubt that we have here a genuine lysophiurid. There is a small disk present in the individual figured as $3 a$ and $3 b$, but it is not one with a round outline, as in typical ophiurids, but is concave along the margin between the rays. Actinally this disk is abundantly covered with prominent but slender spines.

The ambulacrals are distinctly alternate throughout the rays and appear as in the sketch presented on page 218; this condition is not due to distortion or other causes. The side plates are narrow, and each 
bears three spines (see fig. 17B); toward the mouth the two columns diverge far more than one would assume from the original figure, and in consequence there are long and slender syngnaths and not the asterid-like mouthpieces figured in the illustration. (See fig. 17C.)

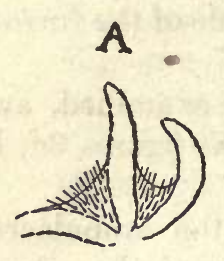

B
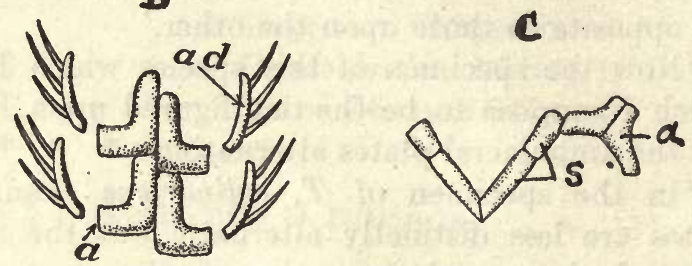

Fig. 17.-Diagrams of Tentaster spinosus (BILLINGS). A, To SHow the SPINose disk With CONCAVE

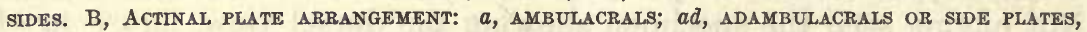
WITH THEIR SPINES. C, MOUTH PLATES: $a$, AMBULACRALS; s, SYNGNATH.

The specimen of figures $3 c$ and $3 d$ is too poorly preserved to add anything further. Associated with these types there is another and much larger specimen with a well-marked disk, of which Billings said nothing in his original description. This form is clearly of another species (probably $T$. cylindricus), and is mentioned here so that other workers will not confound it with the original material of $T$. spinosus.

In 1900 Gregory referred Tæniaster to the asterid family Tænias teridæ, and placed here as well the unrelated genera Stenaster, Salteraster, and Urasterella. From what has been stated above it is plain that Tæniaster can not be closely related to the cryptozonian genus Urasterella, since the latter has an abundance of narrow ambulacralia, asterid in type, while these ossicles in the former are far fewer in number and of the form seen in other and related Lysophiuræ. It is very probable that Tæniaster arose in the same stock that gave rise to Urasterella and Stenaster, but the former genus is clearly one of the aulurids.

In 1896 Gregory took out of Tæniaster the second species of Billings ( $T$. cylindricus) and based on it the new genus Tæniura. As will be seen, this name can have no standing, as the generic characters are those of Tæniaster, and, further, the name is preoccupied since 1837.

Thinking $T$. cylindricus most closely related to the primitive ophiurids Palæophiura and Stürtzura, Gregory defined Tæniura as follows:

"Diagnosis: Palæophiuridæ with a small pentagonal disk, not bounded by marginal ossicles. The ambulacral furrow is broad. The oral skeleton is conspicuous and the syngnaths each composed of two separate pieces. The two jaws of each oral angle are closely attached; the mouth frames are separated, and each of them is a short, thick, slightly bent bar." 
Genotype and only species.-Palxocoma cylindrica Billings.

"Remarks: This genus differs from Palæophiura by the absence of marginal ossicles from the disk, and from Sturtzura by the smaller size of the disk and the form of the syngnaths. In Sturtzura the jaws end bluntly against a jaw plate, whereas in Tæniura they appear to taper to a point and have no jaw plate."

The two cotypes of T.cylindricus (1405a) were lost for many years, but have recently been rediscovered in the collections at Ottawa. In addition, there is another specimen in that Museum under this name, and it is probable that it was so identified by Billings (No. 1405). This was the only specimen studied, and its generic characters agree very well with the originals of the cotypes (figs. $4 b$ and $4 c$ of pl. X), and appear to be in harmony with the genotype of Trniaster. The only important difference is that here the ambulacralia are directly opposite one another, and not slightly alternating, as in T. spinosus (see fig. 18), a difference, it seems to the writer, not in itself alone worthy of being the base of a new genus distinct from Tæniaster.

Tæniaster has the following species:

T. spinosus (Billings). Lower Trenton.

T. cylindricus (Billings). Trenton.

T. schoharix Ruedemann. Upper Trenton.

T. elegans Miller. Richmondian (Waynesville).

T. meafoadensis Foerste. Richmondian.

\section{TAENIASTER SPINOSUS (Billings).}

Plate 36, fig. 1; text fig. 17.

Palæocoma spinosa Brlunvas, Geol. Surv. Canada, Rep. Progress for 1853-1856, 1857, p. 292.

Tæniaster spinosus Brlurnas, Geol. Surv. Canada, Can. Org. Rem., dec. 3, 1858, p. 81, pl. 10, figs. 3a-3d.-MmLer, N. Amer. Geol. Pal., 1889, p. 285, fig. 439.

Revised description by Bitlings. - "The specimens collected are about seven lines in diameter; the rays linear-lanceolate, one line in width at the base, and covered at the sides with numerous small spines.

"In the view of the enlarged specimen (pl. X, 3в), the ambulacral ossicles appear in some places to alternate with each other, but this is owing to a distortion. Those on one side of the furrow are opposite those upon the other. The adambulacral plates are elongated, and so placed that the outer extremity of the one lies upon the inner extremity to the next. The rays are flexible."

For remarks on this species, see the discussion under Tæniaster.

Formation and locality.-Two specimens from the Lower Trenton, Falls of Montmorency, east of Quebec, Canada. The original of figures $3 a$ to $3 d$ is in the Victoria Memorial Museum, Ottawa (No. 1404). 
TENIASTER CYLINDRICUS (Billings).

Plate 36, figs. 2, 3; text fig. 18.

Palæocoma cylindrica Bulungs, Geol. Surv. Canada, Rep. Progress for 18531856, 1857, p. 292.

Tæniaster cylindricus Bmurngs, Geol. Surv. Canada, Can. Org. Rem., dec. 3, 1858 , p. 81, pl. 10, figs. 4a-4c.-Wright. Mon. British Foss. Echinod., Oolitic, vol. 2 , pt. 1 (Palæontogr. Soc. for 1861), 1862, p. 34.-PARKs, Trans. Canadian Inst., vol. 8, 1908, p. 371.

Tæniura cylindrica Gregory, Proc. Zool. Soc. London for 1896, 1897, p. 1035. Lapworthura cylindrica PARKs, Trans. Canadian Inst., vol. 8, 1908, p. 371.

Original description.- "One inch and a half in diameter; rays five [very flexible], covered with spines, subcylindrical, regularly

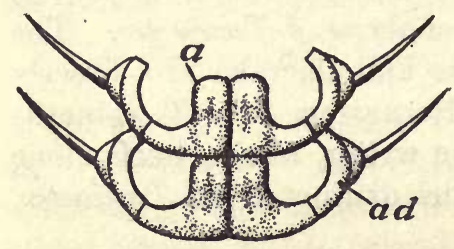

Fig. 18.-DIAGRAM OF ACTINAL RAY-PLATES OF TANIASTER CYLINDRICUS BLLINGS. a, AMBULACRAL; ad, SIDE PLATES. rounded on the upper side, flattened on the lower, about one line in width at base, and regularly tapering to an acute point."

Formation and locality. - In the Trenton limestone at Ottawa, Canada. The cotypes (1405a), along with a third specimen (1405), are in the Victoria Memorial Museum at Ottawa.

TENIASTER SCHOHARIAE Ruedemann.

Tæniaster schohariæ RuedemanN, Bull. N. Y. State Mus., No. 162, 1912, p. 88, pl. 3, fig. 1.

Original description.-The holotype "is small, the arms about 15 $\mathrm{mm}$. long, and it is without a disk. The arms are slender and flexible, about $1.3 \mathrm{~mm}$. wide at the base, and almost as high in lateral view, originally probably cylindrical. The ventral view shows a straight or slightly zigzagged ambulacral canal, and on both sides of this squarish depressions surrounded by the ambulacral and adambulacral ossicles, the covering lower arm plates not being retained if they existed. The inner (ambulacral or vertebral) ossicles appear as narrow and outwardly curved ridges, the outer or adambulacral ossicles as ridges bent in the opposite direction with a projection in the middle of the outer arch. The ambulacral ossicles are not directly opposite nor regularly alternating, but those of the right side on the ventral view advanced about one-third the length of the ossicles beyond those of the other side.

"The lateral view of one other arm exhibits the ossicles as vertical bars, that are thickened at both ends resembling vertebræ and terminating at the dorsal side with a flat surface and forming there an apparently continuous layer. They appear almost twice as wide as the intervening spaces. The dorsal surface bears bundles of obliquely forward directed spines, one bundle corresponding to each ossicle. These spines appear in the right arm to proceed from 
small spine-bearing plates attached to the adambulacrals, as in the closely related Bundenbachia. On one arm two bundles are seen to proceed from each segment, one oblique, the other vertical to the arm. The oral skeleton consists of stout, bifid pieces, much resembling the oral pairs of adambulacrals of the genotype."

Formation and locality.-Upper Schenectady formation, the eastern shale phase of the Upper Trenton limestones. From near Schoharie Junction, New York. The holotype is in the New York State collection at Albany.

\section{TAENIASTER ELEGANS Miller.}

Tæniaster elegans MrLLer, Journ. Cincinnati Soc. Nat. Hist., vol. 5, 1882, p. 41, pl. 1, figs. 6-6c.-J. F. JAMES, Journ. Cincinnati Soc. Nat. Hist., vol. 18, 1896, p. 139.-PARKs, Trans. Canadian Inst., vol. 8, 1908, pp. 365, 371.

Protaster elegans PArks, Trans. Canadian Inst., vol. 8, 1908, p. 368.

Original description.- "This species is founded upon more than 30 specimens occurring on a single slab, but showing only the ventral side, with the exception of the ends of some of the rays.

"The body is deeply stellate, and the rays long, slender, and flexible, and margined on either side with a row of spines.

"From the length of some of the rays, a complete specimen, properly spread, would probably have a diameter of an inch and a quarter, or more. The rays taper to a sharp point, are rounded on the dorsal side, and margined on the ventral side by a row of spines, one spine arising from each plate. Only two rows of plates seem to form the dorsal side of a ray. The ventral side of each ray is marked by a furrow in the middle, separating two series of plates or ossicles. These plates are a little longer in the direction of the ray than wide, and alternately break joints at the middle, where they are slightly contracted."

Formation and locality. - This extraordinary slab is in the Harris collection of the United States National Museum. It was found near Waynesville, Ohio, in the Richmond formation of the Ordovicic period.

Cat. No. 40878 , U.S.N.M.

TAENIASTER MEAFORDENSIS Foerste.

Tæniaster meafordensis Foerste, Bull. Sci. Lab. Denison Univ., vol. 17, 1914, p. 326 , pl. 4, figs. 5-7.

The reference to this species is inserted as this book is going through the press, The form appears to be common in the lowest Richmondian on Workman Creek, three miles southeast of Meaford, Ontario, Canada. The types are probably in the Victoria Memorial Museum, Ottawa, Canada. 


\section{Genus EOPHIURA Jaekel.}

Text figs. 19, 20.

Eophiura JAEKEL, Zeits. geol. Gesell., vol. 55, 1903, Protokol, p. 14 (107), figs. $1,4$.

Genoholotype.-Eophiura, species not named. To give this genus proper standing according to the rules of nomenclature, the form is here named $E$. bohemica, new species. It is the only species of the genus, and occurs in the Ordovicic $\left(\mathrm{D}_{1}\right)$ at Osek, Bohemia.

The genus is not defined in the regular manner, but from the general discussion and the illustrations the following has been made out:

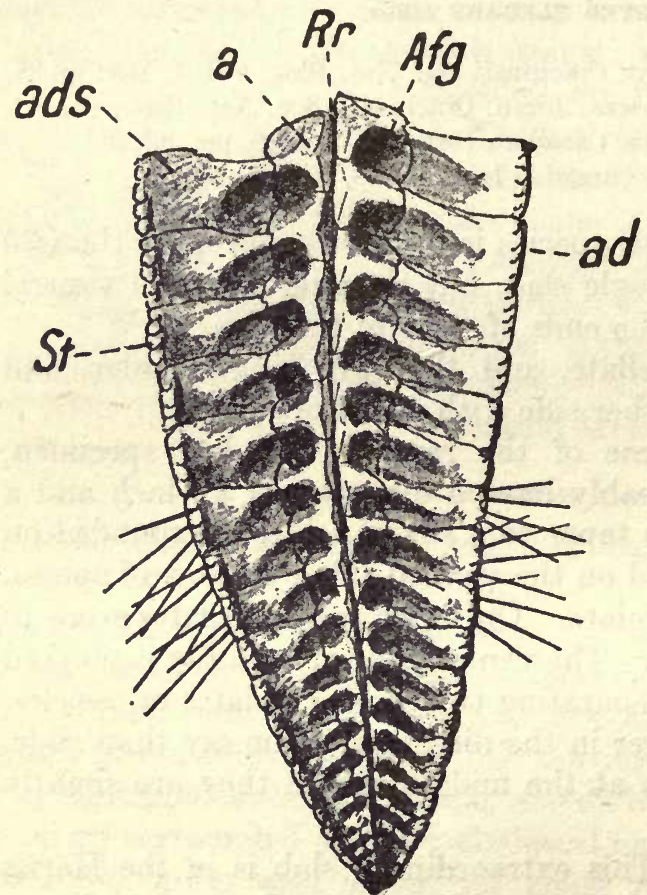

FIG. 19.-END OF A RAY OF EOPHIURA BOHEMICA, MUCH ENLARGED, AFTER JAEKEL. $a$, AMBULACRALIA; $a d$, ADAMBULACRALIA; $A f g$, PIT OF PODIA; ads, LATERAL EXTENSION OF ADAMBULACRALIA; $R r$, RADIAL FURROW; $S t$, SPINE BASES.

Rays outside of the disk, apparently petaloid in form, with wide-open ambulacral furrows, having narrow alternating ambulacralia that are - -shaped, with the podial openings excavated on each side of the lateral extensions. The adambulacrals are very large, drawn out laterally, rectangular, liehorizontally, and in no way resemble the side plates of typical ophiurids, or, for that matter, even the Lysophiuræ. The lateral edges of these ossicles are slightly elevated, tuberculated, and each bears about four long and very slender spines. Inside of the disk the adambulacrals are narrow and stand vertically as in Paleozoic ophiurids; the columns first diverge and then converge in the mouth area. The two proximal pieces of each column make the adambulacral mouth extensions, with the terminal ossicles of adjacent columns side by side but not coalesced, forming the syngnaths. The two most proximal ambulacrals rapidly decrease in size, enlarging the mouth area, with none of these ossicles on each side of the two final adambulacrals.

The disk seems to be small, with concave interbrachial sides. Actinally these areas are covered with scale ossicles. Madreporite ventral, in the outer and lateral part of an interradius. Immediately outside of the syngnaths occur interradially two small ossicles, reminding one of vestigia! inframarginalia. 
Genus BOHEMURA Jaekel.

Text fig. 21.

Bohemura JAEKeL, Zeits. geol. Gesell., vol. 55, 1903, Protokol, p. 18 (111), fig. 6.

This genus, like the foregoing, is not defined in the regulation way. Jaekel's fine drawing shows that it is closely related to Eophiura, differing mainly in that the rays do not end bluntly, but have slowly tapering whip-like terminations. These ends are of course ontogenetically young and reveal the progressive ray development. Here

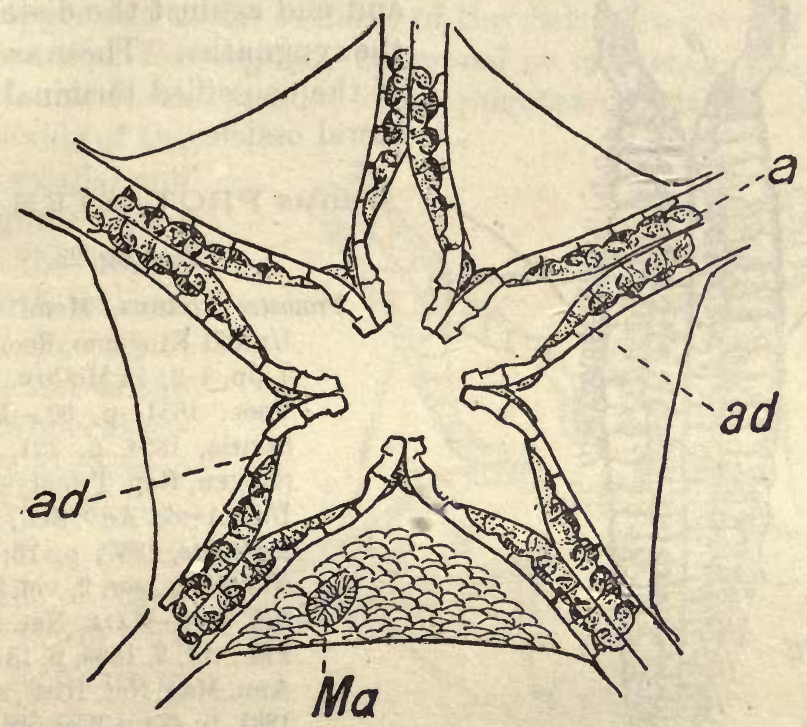

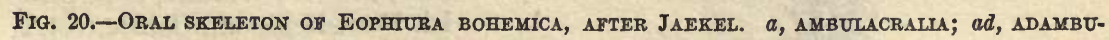
LACRALIA; Ma, MADREPORITE AMONG THE SCALE PLATES.

the rays are made up of overlapping and alternating adambulacrals that distally have no ambulacral grooves. Gradually an ambulacral groove is developed and it becomes rapidly wider as one examines the rays more and more proximally, and the adambulacrals turn over and flatten out, finally making the great open ambulacral furrows. The illustration here reproduced, figure 21 on page 224 , will show the generic characters as drawn by Jaekel.

Genoholotype and only species.-B. jahni Jaekel. Ordovicic $\left(\mathrm{D}_{4}\right)$ at Zahorzan, Bohemia.

\section{Genus PAL $\notin U$ URA Jaekel.}

Text fig. 22.

Palæura JAEKEL, Zeits. geol. Gesell., vol. 55, 1903, Protokol,p.16(109)-17(110), fig. 5.

Genoholotype.-Palæura, species not named. No species is again mentioned, nor is it stated that the generic name is new. To give the name standing, the form figured is here named $P$. neglecta, new genus, new species. It occurs in the Ordovicic $\left(D_{1}\right)$ of Bohemia; the exact locality is not given, but may be Osek. 
Jaekel here again fails to diagnose his genus, but some of the characters can be clearly made out from his excellent drawing. The disk is small and tends to have convex interbrachial areas. So far as the oral disk area is concerned, the general structure is that of Eophiura, with this marked difference-the opposite and asteridlike ambulacralia of the rays do not vanish proximally as in that

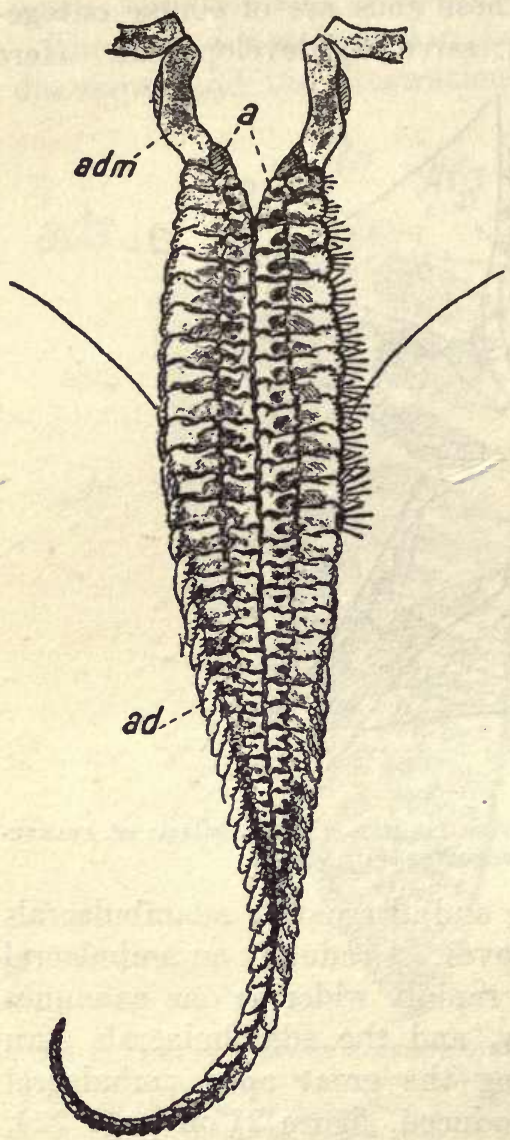

Fig. 21.-VENTRAL VIEW OF A RAY OF BOHEMURA JAHNI, ENLARGED ABOUT $\times 2$, AFTER JAEKEL. $a$, АMBULACRALIA; ad, ADAMBULACRALIA WITH THEIR LATERAL EXTENSIONS; adm, SYNGNATHS. genus but crowd over and finally rest wholly upon the adambulacrals, and end against the distal edges of the syngnaths. These are made up of the coossified terminal adambulacral ossicles.

\section{Genus PROTASTER Forbes.}

Text fig. 23.

Protaster Fonbes, Mem. Geol. Surv. United Kingdom, dec. 1, 1849, pl. 4, pp. 1-2; in McCox, British Pal. Foss., 1851, p. 60.-Murchison, Siluria, 1854, p. 221, fig. 39-4.Salter, Rep. Twenty-sixth Meet., Brit. Assoc. Adv. Sci., Notices and abstracts, 1857, p. 76; Ann. Mag. Nat. Hist., ser. 2, vol. 20, 1857, pp. 325,330 - Hall, Nat. Hist. N. Y., Pal., vol. 3, 1859, p. 134.-SALTER, Ann. Mag. Nat. Hist., ser. 3, vol. 8, 1861, p. 484.-Wright, Mon. British Foss. Echinod., Oolitic, vol.2, pt. 1 (Palæontogr. Soc. for 1861), 1862, pp. 23, 31.-HaLl, Twentieth Rep. N. Y. State Cab. Nat. Hist., 1868 , p. 293 ; rev. ed., $1868=1870$, p. 335.-Quenstedt, Petrefactenkunde Deutschlands, vol. 4, 1876, p. 133, pl. 95, fig. 11.-STÜRTZ, N. Jahrb. für Min., etc., 1886, vol. 2, pp. 148, 150.-Gregory, Geol. Mag., dec. 3, vol. 6, 1889, p. 26.StửRTz, Verh. naturh. Ver. preuss. Rheinl., etc., vol. 50, 1893, p. 18.J. F. JAMES, Journ. Cincinnati Soc.

Nat. Hist., vol. 18, 1896, y. 137.-GrEgorry, Proc. Zool. Soc. London for 1896, 1897, p. 1031, fig. 1.-WhidBorne, Palæontogr. Soc., 1898, p. 206.-PARKs, Trans. Canadian Inst., vol. 8, 1908, pp. 363, 366.-ScHöNDORF, Jahrb. nassauisch. Ver. Naturk., Wiesbaden, vol. 63, 1910, p. 238.-SoluAs and SoluAs, Philos. Trans. Roy. Soc. London, ser. B, vol. 202, 1912, p. 223.-SPEncer, Mon. Brit. Pal. Asterozoa, pt. 1 (Palæontogr. Soc. for 1913), 1914, p. 35.

Encrinaster (part) HAECKEL, Gen. Morphologie, vol. 2, 1866, p. Ixvii (no definition). Also see Stürtzura. 
Original description.-"(Order Ophiuridæ. Family Euryales.) Body circular, covered with squamiform plates; genital openings in the angles of junction of the arms beneath; arms (simple) formed of alternating ossicula."

Genoholotype.- "Species Unica. Protaster sedgwickii. Forbes."

Original description of $P$. sedgwickii. - "The disk is circular, and shaped like that of an Ophiura. The arms are five in number, very narrow, equidistant, and similar.

"The upper and under surfaces of the disk were covered by small, similar, more or less regular, polygonal or crescentic plates, imbricated in scale-fashion, and having punctated surfaces. Those of the under side of the body are smaller and more regular $t h$ an those of the upper. The mouth is central, and rather small in proportion to the disk. The buccal apparatus is composed of ten parts or processes, arranged in pairs; half of each springs from the origin of each arm in a diverging manner, and meets the corresponding half to form a lanceolate toothlike projection, deeply indenting the

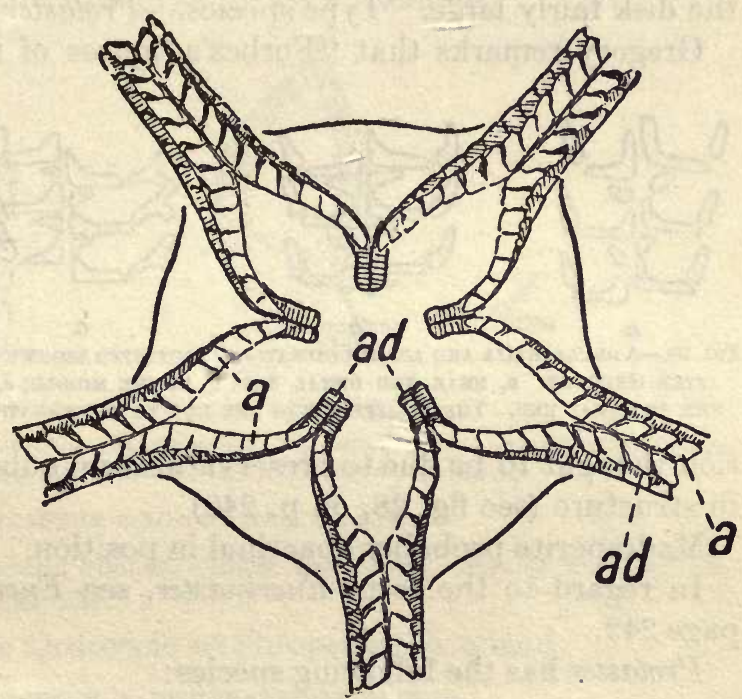

Fig. 22.-Oral SKELEToN OF PALEURA NEGLecta, MUCH ENLARged, AFTER JAEKEL. a, AMBULACRALIA; ad, ADAMBULACRALIA.

cavity of the mouth. Of how many separate ossicles each of the buccal processes was composed the specimen affords but very indistinct indication. They seem to affect a slightly falcate form at their extremities. The arms were composed of alternating, somewhat quadrate ossicula, the sides of which were deeply indented superiorly, in order to form spiniferous crests. The spines were apparently short, and not equal in length to the length of an ossicle, obtuse, and few in a row. The under surfaces of the brachial ossicula were not indented laterally. The central portions of the upper surfaces of the brachial ossicles were hollowed out slightly, and the sutures between them deeply impressed. About 12 of the brachial ossicles were imbedded in the disk, and the parts of the dorsal surface of the latter, corresponding to the arms and central skeleton, do not present traces of scales, a feature seen in existing Euryales. 
"The dimensions of Prof. Sedgwick's specimens are as follows:

"Breadth of disk, 0 8/12ths inch.

"Average breadth between arms, 0 5/12ths inch. Breadth of an arm, at its junction with the body, 0 1/12th inch.

"Locality and geological horizon.-Silurian, from Ludlow rocks at Docker Park, near Kendal, Westmoreland (specimen figured), associated with Encrinites, and at Benson Knot, also near Kendal, in hard sandstones, full of characteristic Ludlow fossils."

Gregory restudied this genus and in 1897 defined it as follows: "Protasteridæ with a well-marked disk; long, tapering, very flexible arms. Some of the adambulacral ossicles are Y-shaped. Scales of the disk fairly large. Type species.-Protaster sedgwickii, Forbes."

Gregory remarks that "Forbes's figures of the arm-structures are

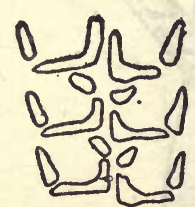

a

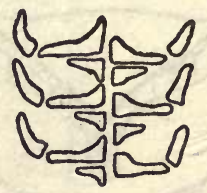

b

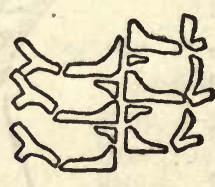

a.

Fig. 23.-AMBULACRALIA AND ADAMBULACRALIA OF PROTASTER SEDGWICKI, AFTER GREGORY. $a$, NEAR THE DISTAL END; $b$, IN THE MIDDLE; $c, \Delta T$ THE PROXIMAL END. THESE DIFTERENCES ARE DUE TO PRESERVATION. not satisfactory," and their apparent nature is shown in figure 23 as drawn by the former. This illustration shows each set of ambulacralia differently, a condition thought to be due to preservation and adhering rock rather than to structure (see fig. 28, on p. 242).

Madreporite probably abactinal in position.

In regard to the term Encrinaster, see Encrinaster (Aspidosoma), page 242.

Protaster has the following species:

P. sedgwickii Forbes. Ludlow of England.

$P$. biforis Gregory. Wenlock of Wales.

$P$. groomi Sollas and Sollas. Ordovicic of England.

$P$. (?) whiteavesianus Parks. Black River.

$P$. (?) salteri (Salter). Ordovicic of Wales.

$P$. (?) stellifer Ringueberg. Rochester.

\section{PROTASTER BIFORIS Gregory.}

Text figs. 24, 25.

Protaster biforis Gregony, Proc. Zool. Soc. London for 1896, 1897, p. 1032, figs. 2,3 on p. 1033.-ScHöNDORF, Jahrb. nassauisch. Ver. Naturk., Wiesbaden, vol. 63,1910 , p. 238.

Original description.- "Disk fairly large; interbrachial outlines concave. The syngnaths are simple, prominent, and stout. The ambulacral ossicles consist of a thick body and a stout curved wing. The distal margin of the ossicles is notched by a depression for a ventral muscle-field, which also cuts into the proximal margin of the adjoining ossicle. Owing to these muscular depressions the arm has apparently two series of pores. 
"The adambulacral ossicles are massive and taper slightly to their distal ends; they are closely attached and form a regular series of marginal plates.

"Arms very flexible.

"Dimensions:

Length of longest arm .................................. $18 \mathrm{~mm} .+x$ Diameter of arm at the base.............................. $2.5 \mathrm{~mm}$.

Diameter of arm near the distal end.......................... I $\mathrm{mm}$.

Diameter of mouth...................................... $1.5 \mathrm{~mm}$.

Length of syngnath..................................... $1 \mathrm{~mm}$.

Width of ambulacral furrow at edge of disk.................... $1.25 \mathrm{~mm}$.

"Distribution.-Wenlock Shale, Castell Dinas, Bran, near Llangollen," Wales. Museum Practical Geology, London.

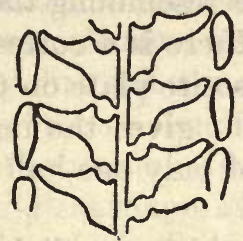

24

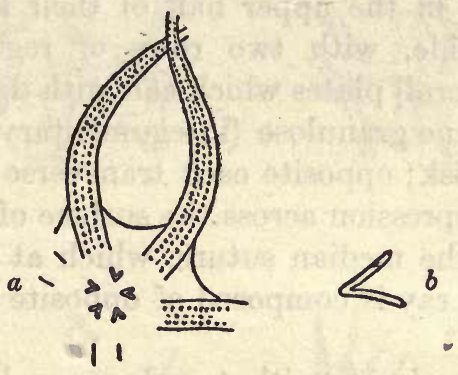

25

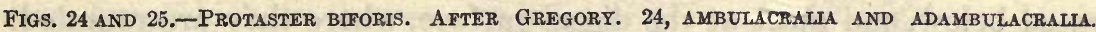
$25, a$, OUTLINE OF THE DISK AND ARMS; $b, a$ PAIR OF SYNGNATHS.

PROTASTER GROOMI Sollas and Sollas.

Protaster groomi Solitas and Sollas, Philos. Trans. Roy. Soc. London, ser. B vol. 202, 1912, pp. 223, 224.

Occurs in the Middle Ordovicic of Shropshire, England.

\section{PROTASTER (?) WHITEAVESIANUS Parks.}

Protaster whiteavesianus PARKs, Trans. Canadian Inst., vol. 8, 1908, p. 368, figs. 1-6.

This is a large form with a disk $15 \mathrm{~mm}$. across and with rays $60 \mathrm{~mm}$. long. It is described in too much detail to quote here. The ambulacralia are distinctly alternate and boot-shaped.

Formation and locality.-In the Lower Trenton (Kirkfield), at Kirkfield, Ontario, Canada. The cotypes (five) are in the University of Toronto (No. 638 T.).

\section{PROTASTER (?) SALTERI (Salter).}

Ophiura salteri SALter and Sowerby, Quart. Journ. Geol. Soc. London, vol. 1. 1845 , pp. 9, 20 (table) (nomen nudum).

Protaster salteri WrIGHT, Mon. British foss. Echinod., Oolitic, vol. 2, pt. 1 (Palæontogr. Soc. for 1861), 1862, p. 33 (nomen nudum).-Salter, Mem. Geol. Surv. Great Britain, vol. 3,1866 , p. 289 , pl. 23 , fig. 3 (is inclined to refer it to Tæniaster).-PARKs, Trans. Canadian Inst., vol. 8, 1908, pp. 364, 367.

Formation and locality. - The holotype is from the Ordovicic, near Cerrig-y-Druidion on the Holyhead road, Wales. 


\section{PROTASTER (?) STELLIFER Ringueberg.}

Protaster stellifer Ringueberg, Bull. Buffalo Soc. Nat. Sci., vol. 5, 1886, p. 7, pl. 1, fig. 2.

Generic relations not established.

Original description.- "Disk of medium size, flat, circular, slightly flexible, distinct from the rays on the dorsal side, and has on that side a quinque-dentate, stellate, central elevation, which again has a central, stellate depression of about one-half the lateral extension of the stellate elevation upon which it is impressed. The points of the star-like figure are opposite the several rays and extend about two-thirds across the disk.

"Surface finely granulose. Rays slender, almost imperceptibly tapering in the upper half of their known length; rounding on the dorsal side, with two rows of regular, quadrilateral, alternating [ambulacral] plates which can with difficulty be made out, and which have a fine granulose [integumentary] surface resembling the surface of the disk; opposite each transverse suture there is a corresponding linear depression across the surface of the opposite plate on the other side of the median suture, which at first sight gives the impression that the ray is composed of opposite plates of only one-half the real length.

"Ventral side with ten short, oral plates which are slightly separated below, and meet at the discal surface, where they are rounded.

"Ambulacral series long, regularly quadrilateral; alternately arranged.

"Adambulacrals indistinct in the only specimens found showing the ventral surface.

"Marginal series slightly imbricating; spiniferous; spines rather short."

Formation and locality.-Three specimens were collected in the Rochester shale of the Siluric at Lockport, New York. They are in the author's collection. Two other fine specimens were found by C. J. Sarle at Lockport and are now at Yale University. Another good specimen is in the Walker collection of the University of Toronto (No. 1007); it was found at Grimsby, Ontario.

\section{Genus ALEPIDASTER Meek.}

Plate 36, fig. 4; text fig. 26.

Alepidaster MEex, Amer. Journ. Sci., ser. 3, vol. 4, 1872, p. 275; Geol. Surv. Ohio, Pal., vol. 1, 1873, p. 68, at end of specific description.

Protasterina Ulrich, Journ. Cincinnati Soc. Nat. Hist., vol. 1, 1878, p. 95.-J. F. JAMES, Journ. Cincinnati Soc. Nat. Hist., vol. 18, 1896, p. 139 (genoholotype, $P$. fimbriata Ulrich).

Original description.- "The only specimen I have seen that is certainly known to belong to this species $[P$. ? granuliferus] is very 
imperfect, being merely an incomplete disk, and the inner ends of the rays. It does not conform to the characters of Protaster given in Prof. Forbes's diagnosis, in all respects, since its disk, especially on the upper side, is covered by an integument composed of a vast number of very minute grains of calcareous matter, instead of distinct imbricating scales. It is therefore not improbable that perfect specimens would show other characters that would warrant the establishment of a new genus or subgenus for such forms, in which case the name Alepidaster might be applied to the group."

Genoholotype.-Protaster (?) granuliferus Meek.

Original description of Protasterina.-"Rays five, slender, flexible, and extending much beyond a circular and minutely granular disk, which is provided with short, slender, and
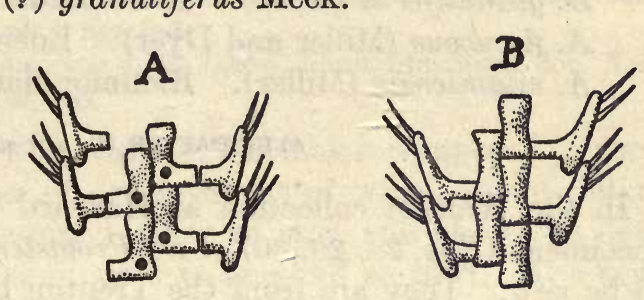
outwardly directed spines; inner ray pieces [ambulacra]regularly alternating, of an hour-glass shape, and interlocking along the median line, which is therefore not straight but zigzag; outer ray pieces elongated [adambulacrals or side plates], directed obliquely outwards, so as to partly overlap each other; two rows of large pores between the inner [ambulacral] and outer [side plates] ray pieces; in the type-species these pores appear to have been occupied by loosely-fitting subpyramidal plates, some of which have a deep depression in the top, as though they were perforated; their true nature, however, is very uncertain. Oral pieces ten, each pair being formed by two of the outer ray pieces. Type, P. fimbriata."

When the original material of Alepidaster and Protasterina is restudied, it may be shown that the latter is not a synonym of the former, but at present the writer does not see any generic differences.

Alepidaster is easily distinguished from Protaster, not only by its greater geologic age, but also in that its disk is minutely granular and spiniferous while that of the latter is scale-bearing. Further, when the exact shape of the ambulacrals is determined, it is probable that other differences 'will be found there. Particular attention should be paid to Ulrich's statement that in Protasterina the podial openings "appear to have been occupied by loosely fitting, sub- 
pyramidal plates." If these extra plates existed, Protasterina will be a good genus, differing not only from Protaster, but also from Alepidaster.

Apparently no one has actually seen the abactinal side of the rays. The writer also fails to see it in the few specimens studied. It would, therefore, seem that there are no dorsal plates and that the dorsal covering is integumentary or finely granular.

This genus contains the following species:

$A$. (?), new species. Trenton.

A. granulifërus (Meek). Richmondian.

A. flexuosus (Miller and Dyer). Eden and Maysville.

A. miamiensis (Miller). Richmondian (Waynesville).

ALEPIDASTER (?), new species.

In the Walcott collection at Harvard University there are three specimens (Nos. 28, 29, 30) of a "Protaster" that probably will prove to be new. They are from the Trenton limestone at Trenton Falls, New York.

\section{ALEPIDASTER GRANULIFERUS (Meek).}

Text fig. 26.

Protaster? granuliferus (Alepidaster at end of description) MEek, Amer. Journ. Sci., ser. 3, vol. 4, 1872, p. 274; Geol. Surv. Ohio, Pal., vol. 1, 1873, p. 68, pl. 3 bis, figs. $8 a, 8 b$.-J. F. James, Journ. Cincinnati Soc. Nat. Hist., vol. 18, 1896, p. 138.-PARKs, Trans. Canadian Inst., vol. 8, 1908, p. 368.

Original description.- "Disk small, apparently circular; rays rather slender, and of unknown length. Dorsal surface of disk and rays covered by an integument composed of innumerable minute grains of calcareous matter. Ventral side of disk not well exposed in the specimen but apparently provided, in the interradial spaces, with minute spines directed outward. Oral pieces not well exposed in the specimen. Arm pieces [ambulacrals] regularly alternating, but apparently rectangular at their inner ends, and not interlocking along the minute mesial impressed line, longer transversely than in the direction of the length of the rays; each largely excavated at its anterior outer end so as to form a large pore, or porelike depression, and divided transversely by a furrow into two parts, the anterior of which is very short, and the posterior longer, and marked by a minute [muscle] pit at its inner end; about eight or nine of these pieces in each range of each ray included within the margin of the disk. Outer arm [or ray] pieces (adambulacral of some) smaller than those of the the inner ranges, and placed edge upward, with an oblique outward direction so as to imbricate outward or toward the extremities of the rays, each bearing one or more minute articulating spines.

"Breadth of disk, about 0.43 inch; breadth of arms at their inner ends, 0.10 inch." 
Formation and locality. - In the lower part of the Richmondian at Moore's Hill, Indiana. It was found by C. B. Dyer, and is now in the Museum of Comparative Zoölogy, Harvard University (No. 21).

\section{ALEPIDASTER FLEXUOSUS (Miller and Dyer).}

Plate 36, fig. 4.

Protaster flexuosus MrLuen and Dyen, Journ. Cincinnati Soc. Nat. Hist., vol. 1, 1878, p. 31, pl. 2, figs. 1, 1a.-Mrluer, N. Amer. Geol. Pal., 1889, p. 276, fig. 409.-PARKs, Trans. Canadian Inst., vol. 8, 1908, p. 368.

Protasterina ("Protaster" lapsus) fimbriata ULRICH, Journ. Cincinnati Soc. Nat. Hist., vol. 1, 1878, p. 95, pl. 4, figs. 9-9c.

Protasterina flexuosa and P. fimbriata J. F. JAmes, Journ. Cincinnati Soc. Nat. Hist., vol. 18, 1896, pp. 139, 140.

Original description of $P$. flexuosus. - "The disk is composed of very thin, small plates, the order of arrangement of which is not determined. The specimens examined differ in size, and show the disk varying in diameter from one-quarter to one-half an inch. The rays were very flexuous when living, and are found winding and turning and thrown in different directions in different specimens.

"Four series of plates are seen upon the dorsal side of each ray near the disk. The two inner series [the ambulacrals seen from the dorsal side] form an angular ridge, each plate is concave at the uniting surface, the arrangement is alternate, and the appearance, therefore, of the top of the ray, is something like the alternate arrangement of two series of hourglasses. The outer series, or marginal [side] plates, are spinous, the spines directed toward the point of the ray. A weathered ray shows three series of pores - one row between the inner series of plates, and one between the marginal plates and inner series, upon each side of the ray [probably the plates are worn through by weathering; there should be but two rows of podial openings, the others being either muscle pits or weathering holes]. The plates are a little the longest in the direction of the length of the ray, and in this direction there are about four to the line. The rays cross the disk on the dorsal side and unite near the center of it, but the specimen figured, Plate II, figure 1, has this part of the rays removed. Plate II, figure $1 a$, illustrates the ventral side of a specimen, which is too indistinct to show the arrangement of the plates. Small pieces, showing the ventral side of the rays, from other specimens, have two rows of spines springing from the marginal plates on each side of the rays."

Original description of $P$. fimbriata. ${ }^{\text {- }}$ "Disk of medium size, circular. Dorsal side of disk, and rays to margin of disk, covered with a granular integument. Ventral surface of disk provided with a large number of outwardly directed, short and slender spines. Oral 
pieces 10, subrhomboidal in outline, arranged in pairs, each pair being formed of two of the marginal series of ray plates; on the lower inner edge there are five spines, and extending from each pair, over the mouth, is a bundle of rather long ones.

"Rays apparently very flexible, contracted toward the mouth; six series of plates are exposed on the ventral side of each ray. The two middle series [ambulacrals] alternate regularly, and interlock along the mesial line; they are about twice as long in the direction of the ray, than measuring transversely; each piece is contracted in the middle on the inner side to admit the wide ends of the two pieces immediately opposite, and on the outer side to form a porelike impression, between them and the outer series of plates; four [five or possibly six] of these plates in each range of each ray are included within the disk, and the series terminate abruptly at a distance of one and a half lines from the inner end of the oral plates; from the margin of the disk to the extremity of the ray there are about 16 pieces in each range. The pores mentioned above, are occupied by a series of loosely fitting, obtusely conical or pyramidal plates, some of which distinctly show a deep depression in the top, and may have been perforated. Outer or marginal pieces [side plates] flat, placed on edge, and directed obliquely outward so as to overlap each other; the two free edges, that is, the one toward the point of the rays and the one seen on the ventral surface, are lined with from 10 to 12 short club-shaped spines, varying somewhat in length. The marginal [side plates] and middle [ambulacral] series of plates articulate by means of corresponding prolongations from the sides of the plates. These prolongations arise from near that end of the plate which is directed toward the mouth.

"Dorsal side of rays composed of two rows of alternating and interlocking plates, which near the disk are very deeply sculptured and about as wide as long, becoming gradually less excavated, and longer in proportion to the width, toward the point of the rays; on each side they articulate with the upper edge of the oblique marginal series of plates [these are the ambulacral plates seen from the dorsal side, either because there were no dorsal plates or because there was an integument].

"Breadth of disk, 0.60 inch; breadth of arm at margin of disk, 0.16 inch; length of same from oral plates, 0.88 inch. This species is related to Protaster flexuosus."

Formation and locality. - "This species has been found at different elevations from near low-water mark in the Ohio River [that is, in basal Eden] to the top of the hills at Cincinnati," in the upper Maysville beds. The type-specimens of $P$. flexuosus were found by Mr. C. B. Dyer and are now in the collection of Harvard University (Nos. 17, 18). Those of $P$. fimbriata were obtained by 
Ulrich in the lower Eden at about 100 feet above low-water mark in the Ohio River at Covington, Kentucky. This material is now in the Ulrich collection of the United States National Museum. Other poor specimens from a still lower level in the Eden and associated with Triarthrus are from the first ward, eastern Cincinnati. Two specimens are at Yale University.

Cat. No. 60615, U.S.N.M.

\section{ALEPIDASTER MIAMIENSIS (Miller).}

Protaster miamiensis Mrluer, Journ. Cincinnati Soc. Nat. Hist., vol. 5, 1882, p. 116 , pl. 5, figs. 6-6b.-J. F. JAMEs, Journ. Cincinnati Soc. Nat. Hist., vol. 18, 1896, p. 138.-PakKs, Trans. Canadian Inst., vol. 8, 1908, p. 368.

Original description. - "This species is large, with a proportionally small disk. A specimen having a disk four-tenths of an inch in diameter, has rays an inch in length. Five specimens have been examined, all showing the ventral side. The dorsal side is unknown. Only that part of the disk between the rays is visible in any of the specimens, and the plates are so anchylosed together that no special definition of them can be given. The rays are long and coarser and stronger than usual in this genus, though they were quite as pliable and flexuous when living as others. Two series of subquadrangular plates, or ambulacral ossicles, alternating with each other, constitute the bottom of each ambulacral furrow; these are bordered by spinous adambulacral plates, which terminate at the angles of the mouth in only five oral plates."

Formation and locality. - In the Richmond formation, about Waynesville, Ohio. The specimens are in the Harris collection of the United States National Museum.

Cat. No. 40886, U.S.N.M.

\section{Genus GREGORIURA Chapman.}

Gregoriura Chapman, Proc. Royal Soc. Victoria, n. ser., vol. 19, 1907, p. 24, pl.6, fig. 1 ; pl. 8, figs. 1, 3.-ScHöNDORF, Jahrb. nassauisch. Ver. Naturk., Wiesbaden, vol. 63, 1910, p. 238.

Original definition.- "A Protasterid in which the usual bootshaped ambulacrals are laterally developed, and modified into a subtriangular form. Ossicles on each side of the ambulacral canal subalternate, excepting at the junction with the mouth frames, where they are parallel. Adambulacral ossicles narrow, slender, extending laterally in a line with the proximal border of the ambulacral ossicle. Spine-bearing plates, slender, at right angles to the adambulacrals, carrying (in the genotype) two conspicuous spines. Oral skeleton having jaw plates three-fourths the length of the mouth frames; teeth thick and prominent. No traces of a disk preserved in the specimen on which the genus is founded. Arms very slender and very flexible." 
Genoholotype and only species.-G. spryi Chapman (same references as above).

Found in the Siluric (Melbournian) shale at South Yarra, Victoria, Australia.

\section{Genus BUNDENBACHIA Stürtz.}

Text fig. 27.

Bundenbachia Stürtz, Palæontographica, vol. 32,1886 , p. 83 ; vol. 36,1890 , p. 216.-Gregory, Proc. Zool. Soc. London for 1896, 1897, p. 1033, fig. 4 on p. 1034.-PARKs, Trans. Canadian Inst., vol. 8, 1908, p. 367.- -АснӧNDORF, Palæontographica, vol. 57, 1910, p. 57.

Rays five, short, basally wide, terminally pointed or blunt. Disk large, soft and delicate, with concave interradial margins.

Abactinally the disk is covered with symmetrical scales, and medially there is a pentamerous rosette (the oral armature squeezed through), from the points of which the rays originate. Rays covered

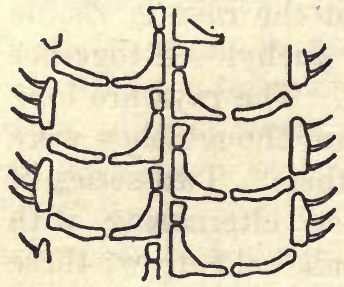

Fig. 27.-VENTRAL ARM STRUCTURE OF B UNNDENBACHIA. ENLARGED. AFTER GREGORY. with a granular integument.

Gregory states: "Ambulacral ossicles with a dumbbell-shaped body and thin tapering wing. The body of the ossicle is apparently divided into two pieces by a transverse depression. The adambulacral plates are small and narrow, and support a triangular spinebearing plate. [There is only one plate here, the adambulacral. There are no lateral pieces as in Ophiuroidea.]

"The syngnaths are curved, narrow bars."

Genoholotype and only species. - B. beneckei Stürtz.

Remarks. - "Bundenbachia differs from Protaster by the irregular nature and soft plating of the disk, by the presence of spine-bearing plates attached to the adambulacral ossicles, and by the different form of the ambulacral ossicles." (Gregory.)

\section{BUNDENBACHIA BENECKEI Stürtz.}

Bundenbachia beneckei STürTz, Palæontographica, vol. 32, 1886, p. 83, pl. 8, figs.7, 7a; pl. 9, figs. 1, 1a.-Gregory, Proc. Zool. Soc. London for 1896, 1897, p. 1034, figs. 4.

Formation and locality.-Occurs in the Lower Devonic roofing slates of Bundenbach, Germany.

\section{Genus PALAEOPHIOMYXA Stürtz.}

Palæophiomyxa Stürtz, Verh. naturh. Ver. preuss. Rheinl., etc., vol. 56, 1900, p. 202.

Palæophiomyxidæ Stürtz, Verh. naturh. Ver. preuss. Rheinl., etc., vol. 56, 1900, p. 202.-ScнӧNDoRF, Jahrb. nassauisch. Ver. Naturk., Wiesbaden, vol. 63, 1910, p. 235.

Genoholotype and only species.-P. grandis (Stürtz). 


\section{PALAEOPHIOMYXA GRANDIS (Stiirtz).}

Bundenbachia grandis StüRTz, Palæontographica, vol. 32, 1886, p. 84, pl. 9, figs. $2,2 a, 3,3 a$.

Palæophiomyxa grandis StüRTz, Verh. naturh. Ver. preuss. Rheinl., etc., vol. 56, 1900, pp. 196, 202.

Formation and locality.-Lower Devonic roofing slates of Bundenbach, Germany.

Cat. No. 59388, U.S.N.M.

\section{Family PALÆOPHIURIDÆ Gregory.}

Palæophiuridæ Gregory, Proc. Zool. Soc. London for 1896, 1897, p. 1034; Treat. Zool., vol. 3, Echinoderma, 1900, p. 274.-ScHöNDORF, Jahrb. nassauisch.

Ver. Naturk., Wiesbaden, vol. 63, 1910, p. 237.

"Lysophiuræ in which the [alternate] ambulacral ossicles consist of a bar-shaped or subquadrate 'body' without wings." (Gregory, 1900.)

Remarks. -This family differs from the Protasteridæ in "having the ambulacral ossicles longer than wide, and never divided transversely by muscular depressions. The ambulacral ossicles are either bar-shaped or thickened to a subquadrate form. They are never boot-shaped." (Gregory, 1897.)

Schöndorf states that Gregory established the families Protasteridæ and Palæophiuridæ on the form of the ambulacralia. He says: "The first family has boot-shaped, and the second family bar-shaped or subquadrate ambulacrals. The form of the latter is nothing more than a poor development of the boot-shaped type of ambulacrals. Accordingly the second family has no value and is to be withdrawn." In addition the forms of Stürtzura have bootshaped ambulacrals, and these "are so little alternate in arrangement that their alternation appears to me more than questionable." (Schöndorf, 1910.)

Contains the following genera:

Palrophiura Stürtz.

Stïrtzura Gregory.

Eugasterella, new name.

Ptilonaster Hall.

\section{Genus PALAEPHIURA Stürt.}

Palæophiura Stürtz, Palæontographica, vol. 36, 1890, p. 233.-GrEGoRY, Proc. Zool. Soc. London for 1896, 1897, p. 1034.

"Palæophiuridæ with the disk surrounded by rod-shaped marginal ossicles. The ambulacral ossicles are rods lying parallel to the arm." (Gregory.)

Genoholotype and only species.-P. simplex Stürtz (citations as above). Lower Devonic, Bundenbach, Germany. 


\section{Genus STÜRTZURA Gregory.}

Sturtzura Gregory, Proc. Zool. Soc. London for 1896, 1897, p. 1034.-ScHöNDORF, Jahrb. nassauisch. Ver. Naturk., Wiesbaden, vol. 63, 1910, pp. 215, 237.

?Rhodostoma Soluas and Sollas, Philos. Trans. Roy. Soc. London, ser. B, vol. 202, 1912, p. 225 (genoholotype, Protaster leptosoma Salter.)

"Palæophiuridæ having thick, subquadrate, ambulacral ossicles and narrow adambulacral plates. The disk is fragile, and its plates are small and thin: it has no marginal plates. The mouth-frames are narrow and separate.

"Distribution.-Silurian, England and Australia."

Genoholotype.-Protaster brisingoides Gregory.

"Remarks. - This genus differs from Palæophiura, as the ambulacral ossicles are thick and subquadrate, instead of being in the form of narrow bars; also by the absence of the strong marginal plates round the disk." (Gregory.)

Chapman in 1907 refers the genotype back to Protaster, adding: "In consequence of this determination Sturtzura leptosoma may now be considered as the type of the genus." This is in violation of the rules of nomenclature and the generic name will stand or fall on the basis of Protaster brisingoides.

Schöndorf states: "The ambulacra of $S$. brisingoides are not at all bar-shaped or subquadrate, if the figures of Chapman (1907, pl. 8, fig. 2) are correct, but are also essentially boot-shaped and alternate in arrangement. S. leptosoma also has alternating ambulacra. Their identity with Lapworthura miltoni ranges them with the Auluroidea, where $S$. brisingoides undoubtedly also belongs. That this form and with it also the genus Sturtzura is to be retained as valid is very questionable, but the final answer may as well wait until the originals are restudied. In any event it is plain that both forms can not belong to the Lysophiuræ."

Contains the following species:

S. brisingoides (Gregory). Siluric of Australia.

S. leptosoma (Salter). Ludlow of England.

S. leptosomoides Chapman. Siluric of Australia.

\section{STÜRTZURA BRISINGOIDES (Gregory).}

Tæniaster australis McCox, see CHApMAN 1907, p. 23 (nomen nudum).

Protaster brisingoides GreGory, Geol. Mag., dec.3, vol. 6, 1889, pp. 24-27, fig. 1.-

Chapman, Proc. Roy. Soc. Victoria, n. ser., vol. 19, 1907, p. 22, pl. 6, fig. 2 ; pl. 8 , fig. 2 .

Sturtzura brisingoides Gregory, Proc. Zool. Soc. London for 1896, 1897, p. 1034.

Formation and locality.-From Siluric sandstones at Moonee Ponds Creek, Flemington, near Melbourne, Australia. The type-material is in the British Museum (Natural History), London. Other specimens from the same locality and from the parish of Yering, Upper Yarra district. Victoria, are in the National Museum at Melbourne. 
STURTZURA LEPTOSOMA (Salter).

Protaster leptosoma SALter, Ann. Mag. Nat. Hist., ser. 2, vol. 20, 1857, p. 331, pl. 9, fig. 5.-Wriant, Mon. British Foss. Echinod., Oolitic, vol. 2, pt. 1 (Palæontogr. Soc. for 1861), 1862, p. 33.-Quenstedt, Petrefactenkunde Deutschlands, vol. 4, 1876, p. 133, pl. 95, fig. 12.-STÜrTz, Palæontographica, vol. 32, 1886, p. 79; N. Jahrb. für Min., etc., 1886, vol. 2, p. 148.

Sturtzura leptosoma Gregory, Proc. Zool. Soc. London for 1896, 1897, p. 1035.Chapman, Proc. Roy. Soc. Victoria, n. ser., vol. 19, 1907, p. 26, pl. 8, fig. 5.ScHöNDORF, Jahrb. nassauisch. Ver. Naturk., Wiesbaden, vol. 63, 1910, p. 215.

Rhodostoma leptosoma Sollas and Sollas, Philos. Trans. Roy. Soc. London, ser. B, vol. 202, 1912, p. 223, text fig. 4C, pl. 9, figs. 3, 4.

Formation and locality.-Common in the Siluric, Ludlow formation, at Leintwardine, Shropshire, England.

Remarks.-Schöndorf says $S$. leptosoma is but a miniature edition of Lapworthura miltoni, both forms being completely identical. The disk margin is not convex but concave between the radii.

\section{STURTZURA LEPTOSOMOIDES Chapman.}

Sturtzura leptosomoides Chapman, Proc. Roy. Soc. Victoria, n. ser., vol. 19, 1907, p. 26, pl. 7, figs. 1, 2; pl. 8, fig. 4.

Formation and locality.-In the Siluric (Melbournian), Moonee Ponds Creek, Flemington, near Melbourne, Australia.

\section{Genus EUGASTERELLA, new name.}

Eugaster HaLl (not Eugaster Seville 1839, Orthoptera), Twentieth Rep. N. Y. State Cab. Nat. Hist., 1868, p. 290; rev. ed., 1868=1870, p. 332.-ZirTteL, Handb. Pal., vol. 1, 1879, p. 444.-StürTz, N. Jahrb. für. Min., etc., 1886, vol. 2, p. 151.-Mrller, N. Amer. Geol. Pal., 1889, p. 244.-Stürtz, Verh. naturh. Ver. preuss. Rheinl., etc., vol. 50, 1893, p. 20.-Gregory, Proc. Zool. Soc. London for 1896, 1897, p. 1035.

Eugasterella SchUCHert, Fossilium Catalogus, Animalia, pt. 3, April, 1914, p. 19.

Original description.- "Body stellate, consisting of a central alated disk, and five long, slender, somewhat flexuous rays. Disk composed of small, polygonal tuberculose or subspinose plates on the ventral side. Rays consisting of a double series of alternating subquadrate ambulacral ossicles, and a series of curved adambulacral plates bordering the grooves, and forming the margin of the ray; the outer ends overlap the edge of the next plate in advance. Oral plates ten, arranged in pairs, forming the terminal plates of the adambulacral ranges. Pores large, arranged in two rows in each ray; penetrating the ray at the junction of the ambulacral and adambulacral plates in such a manner that four different plates border each perforation. Adambulacral and disk-plates bearing spines. Dorsal surface unknown."

Genoholotype.-E. logani (Hall). 
Gregory comments on this genus as follows:

"Palæophiuridæ in which the ambulacral ossicles are subheptagonal in form, the central suture along the arm being zigzag, while the outer angles of the ossicles are cut away for the reception of the podia. The adambulacral ossicles have a flat base, and thence bend forward crescentically. The mouth frames are massive, and those of each pair meet along the middle line of the oral angle.

"This genus I only know from Prof. James Hall's figures, and, in spite of their clearness, I feel much doubt as to the wisdom of diagnosing it from these alone. Its affinities are clearly with the Palæophiuridæ, but it approaches the Protasteridæ in one respect, for, owing to the deep depressions in the outer angles of the ambulacral ossicles, the outer side forms a short rudimentary wing. The genus differs from all the Protasteridæ by the absence of a muscular groove across the ambulacral ossiclos.

"Among the Palæophiuridæ it differs from Palæophiura by the absence of marginal ossicles, and from Sturtzura and Tæniura by the massive nature of the mouth frames."

Contains :

E. logani (Hall). Hamilton.

$E$. (?) concinna (Ringueberg). Rochester.

EUGASTERELLA LOGANI (Hall).

Eugaster logani HaLL, Twentieth Rep. N. Y. State Cab. Nat. Hist., 1868, p. 290; rev. ed., $1868=1870$, p. 333, pl. 9, figs. 7, 8 .

Original description.- "Body stellate, with a small disk and long attenuate flexuose rays. Disk composed of numerous small polygonal plates with radiated surfaces; the diameter, measured from the sinus to its extension on the opposite ray, is about half as great as the length of the ray measured from the center of the disk. Rays, as seen from the ventral side, narrow, attenuate, with the ambulacral plates curving, and near the base of the rays a little wider than long, and toward the extremities longer than wide, with a strong elevated transverse ridge. There are about eight pairs of plates inclosed within the limits of the disk. Pores penetrating the interstices near the outer extremities of the plates, while near the inner end there is a depression or pit resembling a partially excavated pore. The adambulacral plates as seen from below are extremely narrow and very convex on their outer surfaces, forming the margins of the ray. Oral plates in pairs, narrow and elongate.

"This specimen measures, from the center of the disk to the extremities of the rays, about one inch and a half; the widest part of the ray, which is near the margin of the disk, is about an eighth of an inch in diameter. The rays toward their extremities have the ambulacral field covered by the curving of the marginal plates over the 
groove, and which, closely uniting by their margins, give a teretiform termination of nearly one-third the entire length, each one having the aspect of a slender crinoidean proboscis.

"Geological formation and locality.-In the Hamilton group, near Fenner, in Madison County, New York. The specimen was collected during the geological survey, and is now in the State Museum."

EUGASTERELLA (?) CONCINNA (Ringueberg).

Eugaster concinnus Ringueberg, Bull. Buffalo Soc. Nat. Sci., vol. 5, 1886, p. 8, pl. 1 , fig. 3.

This species does not belong to Eugasterella, but until the holotype is restudied it can remain in this genus. It is from the Rochester shale at Lockport, New York, and is in Dr. Ringueberg's collection.

Original description.- "Disk flat, thin, alated, composed of very fine granulose plates. Rays broad at their base; flattened, rapidly tapering for two-thirds of their length; terminal third attenuate, rounded; plates, if any, undefinable.

"Dorsal side with four series of plates; two median and two lateral; the transverse sutures dividing the outer series are continuous with every other transverse suture dividing the central series. Medial series with twice the number of plates of the outer, and are raised above them.

"Sutures depressed. Surface of the plates rounded and finely granular.

"The lateral series of plates decrease regularly in size after reaching the disk until they ond in a pronounced elevation formed by the last pair of the medial series at a point about halfway from the border toward the center of the disk-measuring at the narrowest part-where both series end. Between these elevations the disk has a shallow, stellate depression with the points opposite the several rays. The two outer rows of plates apparently disappear toward the attenuate tip before the median does so. The imperfect cast of the upper part of one of the rays is all that is known of the ventral side; this shows traces of an alternating series of ambulacral plates.

"Marginal plates spiniferous.

"Length of ray, one-half inch."

\section{Genus PTILONASTER Hall.}

Ptilonaster Hall, Twentieth Rep. N. Y. State Cab. Nat. Hist., 1868, pp. 291-292; rev. ed., 1868=1870, p. 334.-LütkeN, Dansk. Vid. Selsk. Skrift., ser. 5, vol. 8 , pt. 3,1869, p. 82 .-STÜRTz, Palæontographica, vol. 32,1886, p. 83 ; N. Jahrb. für Min., etc., 1886, vol. 2, p. 152.-Gregory, Proc. Zool. Soc. London for 1896, 1897, p. 1036.-SтürTz, Verh. natưrh. Ver. preuss. Rheinl., etc., vol. 56,1900 , p. 188.

Palæocoma Mruler (part), N. Amer. Geol. Pal., 1889, p. 266.

Original description.- "Form and general features as in Eugaster, but differing in the plates of the rays. Rays composed of an ambu- 
lacral, adambulacral and marginal series, which are united by their edges, and apparently not imbricating, the projecting or oblique anterior face of the marginal plates bearing spines which are inclined toward the extremity of the ray. Margins of the rays alated by the extension of the disk.

"I had originally united this form with Eugaster, but further examination has shown the ray to have a range of marginal plates outside of the adambulacral plates, and I am unable to discover any such feature in Eugaster logani.

"This and the preceding genus [Eugasterella] belong to the Ophiuridæ, to which may also be referred the genus Protaster."

"Note.-It is only as these pages are going to press that my attention has been directed to the similarity of structure in the ray of Palæocoma of Salter with that of the proposed genus Ptilonaster. In this illustrated species of the former genus (Palæocoma marstoni) the disk is proportionately larger, and the rays much shorter, while the outer range of plates is represented as imbricating; but being characterized by a double row of plates bordering the ambulacral area, it must be regarded as very nearly related if not generically identical with Ptilonaster."

Gregory comments on Ptilonaster as follows: "This genus is an ally of Eugaster; * * * it is, however, generically distinct. I only know it from Hall's figures, and therefore prefer to leave the preparation of a formal diagnosis to an American palæontologist."

Genoholotype and only species.-P. princeps Hall.

\section{PTILONASTER PRINCEPS Hall.}

Ptilonaster princeps HaLL, Twentieth Rep. N. Y. State Cab. Nat. Hist., 1868, p. 292 ; rev. ed., $1868=1870$, p. 334 , pl. 9 , fig. 9 .

Palæocoma princeps Mruler, N. Amer. Geol. Pal., 1889, p. 267.

Original description.- "The specimen consists of the impression of the greater part of one ray, with parts of two others, and intervening portions of the disk. The disk has extended along the ray nearly an inch from the center of the body; the plates are small, and have been furnished with slender spinules. The ray is strong and extremely elongate, having been at least $4 \frac{1}{2}$ inches in length; its greatest width is outside of the disk, where it measures seven-sixteenths of an inch. The ventral side of the ray shows three series of plates-ambulacral, adambulacral, and marginal - on each side of the center; of these at least seven ranges have been included within the disk. The ambulacral plates are a little wider than long, arranged in alternating order. The pores penetrate the interstices near the outer extremity of the plates, while the partial or obsolete pores are obscure, becoming deeper and more conspicuous toward the extremity of the ray. Near the base of the ray there are 12 plates in the length of an inch, 
and 14 plates in the same distance in the central portion, while toward the extremities there are 20 or more in the same space. The marginal plates are subhexagonal, a little longer than wide, and ornamented by long slender spines on their outer margins.

"This is a much larger and more robust species than the Eugaster logani, and in its entire condition it is the largest star-fish known in our palæozoic rocks.

"Geological formation and locality. - In the Chemung group. The specimen is in a brownish-gray sandstone, which weathers to a very light ashen color. It was received from Henry S. Randall, Esq., of Cortlandville [New York], in the vicinity of which place it was obtained."

The holotype, an imprint, is in the American Museum of Natural History, No. 4472.

\section{Family ENCRINASTERID无, new name.}

Aspidosomatidæ Gregory, Geol. Mag., dec. 4, vol. 6, 1899, p. 351; Treat. Zool., vol. 3, Echinoderma, 1900, p. 250.-ScHöNDoRf, Palæontographica, vol. 57, 1910, pp. 55-61.

Palægoniasteridoe STÜRTZ (part), Palæontographica, vol. 36, 1890, p. 246 (contains Aspidosomella and Palæaster).

Lysophiuræ with boot-shaped ambulacralia ventrally, and large disks that are bordered with simple marginalia. Apparently only. the inframarginals are present.

As Aspidosoma Goldfuss is preoccupied, this name can no longer be used for the family name. Encrinaster Haeckel replaces it and therefore becomes the base of the family designation.

The family has the single genus Encrinaster.

\section{Genus ENCRINASTER Haeckel.}

Plate 35, text fig. 28, 29.

Aspidosoma GoldFuss (not Aspidosoma Fitzinger 1843, Reptilia), Verh. naturh. Ver. preuss. Rheinl., etc., vol. 5, 1848, pp. 145-146.-Srmonovrrsch, Sitzb. d. mat.-naturw. Classe Akad. Wiss., Wien., vol. 64, Abt. 1, 1871, p. 103.Zitrel, Handb. Pal., vol. 1, 1879, p. 451, fig. 322.-Stürtz, Palæontographica, vol. 32,1886 , p. 92; N. Jahrb. für Min., etc., 1886, vol. 2, p. 151; Verh. naturh. Ver. preuss. Rheinl., etc., vol. 50, 1893, pp. 38, 55.-ScHöNDORF, Jahrb. nassauisch. Ver. Naturk., Wiesbaden, vol. 62, 1909, p. 35; Palæontographica, vol. 57, 1910, pp. 1-63.-Spencer, Mon. Brit. Pal. Asterozoa, pt. 1 (Palæontogr. Soc. for 1913), 1914, pp. 23, 24, 49.

Encrinaster HAECKEL, Gen. Morphologie, vol. 2, 1866, p. Ixvii (genolectotype Aspidosoma arnoldi Goldfuss).

Diagnosis.-Animals attaining large size, with a comparatively large disk. Rays five, more or less petaloid, slender and long, with wide and open ambulacral furrows. 
"Ambulacrals alternating in adjoining columns, while the neighboring ambulacrals and adambulacrals are directly opposite each other. The margin of the disk is concave and limited by a row of more or less conspicuous simple [not two rows of superposed] marginalia restricted to the disk. The sides of the free rays are bounded by adambulacrals. These and the ambulacrals are [common to the two sides of the animals, and abactinally are] roughly sculp-

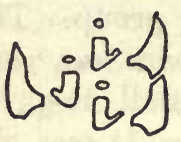

a.

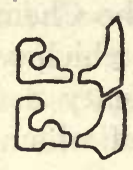

$b$.

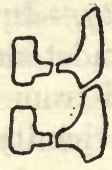

$c$. tured, usually naked, and only in rare cases were adambulacral spines observed. Madreporite actinal, situated near the peristome in one of the interradial areas nearest to the left adamFig. 28.-AMBULACRaLu aNd ADAMBULACRaLu or bulacrals of a radius." (SchönENCRINASTER ROEMERI, AFTER SCHÖNDORF. $a$, APPEARANCE OF THE PLATES WHEN CRUSHED OR OBSCURED BY CLAY. EACH AMBULACRAL HERE APPEARS AS IF OF TWO PIECES; $b$, SAME BETTER PRESERVED OR MORE CLEANED; $c$, THE ACTUAL FORM OF THE OSSICLES WHEN WELL PRESERVED AND COMPLETELY CLEANED OF CLAY.

dorf, 1910.)

Genolectotype.-Aspidosoma arnoldi Goldfuss. Genus restricted to the Lower Devonic of Rhenish Germany.

Remarks. - This well-known genus has been referred to the asterids and to the ophiurids, and though it has most often been placed among the true starfishes, it now appears to belong to neither of these orders. Schöndorf has restudied the material with great care and has made out the detail of the ambulacralia, with the result that he erects for Aspidosoma the order Auluroidea. In the work of 1910 cited above the matter is set forth in great detail, and all that can be done here is to direct attention to the more important of his illustrations, with their descriptions, reproduced in part here and on pages 213 and 214.

As Aspidosoma was first used for a genus of reptiles, it can not, under the rules of nomenclature, be used again for another group of animals. It is possible, however, under the Fra. 29.-ORAL sKELETron or rules to make use of Encrinaster, but in doing so the proceeding should first be explained.

Encrinaster was proposed by Haeckel as fol-

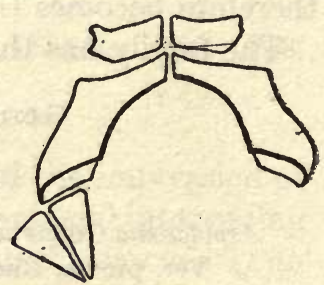
ENCRINASTER GOLDFUSSI AS SEEN FROM THE DORSAL SIDE, MUCH ENLARGED. AFTER SCHÖNDORF. lows: In defining his sixth order of asterids, the Crinastra or lily stars, forms that he said already had crinoid characters, he cited as examples of it Protaster sedgwickii and $P .=A$ spidosoma arnoldi. These forms, he added, are so different from Protaster miltoni "that we here separate the former as Encrinaster (E. sedgwickii, E. arnoldi, etc.)." Under ordinary circumstances it would be best to disregard the name because of the inadequate definition, but as Aspidosoma is preoccupied, we are obliged to propose another name to take its 
place. The first mentioned genotype of Encrinaster is Protaster sedgwickii, but as this is also the type-species of Protaster, a genus in good standing, we may accept the second named species, Aspidosoma arnoldi. Therefore it is here proposed to replace Aspidosoma Goldfuss (not Fitzinger) by Encrinaster Haeckel, with Aspidosoma arnoldi Goldfuss as the genolectotype.

\section{ENCRINASTER ARNOLDI (Goldfuss).}

Aspidosoma arnoldi Goldfuss, Verh. naturh. Ver. preuss. Rheinl., etc., vol. 5, 1848, pp. 145-146, pl. 5.-Müller, Verh. naturh. Ver. preuss. Rheinl., etc., vol. 12, 1855, p. 4, pl. 1, figs. 1-3.-SтÜRTz, Palæontographica, vol. 32, 1886, p. 93.-ScHÖNDORF, Jahrb. nassauisch. Ver. Naturk., Wiesbaden, vol. 62 , 1909, p. 38; Palæontographica, vol. 57, 1910, pp. 4, 62, pl. 1, fig. 2; pl. 2, figs. 6, 7; pl. 3, figs. 7-9; Jahrb. preuss. geol. Landesanst., Berlin, vol. 29, 1908, p. 706.-Spencer, Mon. Brit. Pal. Asterozoa, pt. 1 (Palæontogr. Soc. for 1913), 1914, p. 40.

Encrinaster arnoldi HAeckeL, Gen. Morphologie, vol. 2, 1866, p. lxvii.

Formation and locality.-This species is common in the grauwacke of the Lower Coblenzian at Winningen, on the Mosel, Germany.

\section{ENCRINASTER GOLDFUSSI (Schönđorf).}

\section{Text fig. 29.}

Aspidosoma goldfussi Schöndorf, Palæontographica, vol. 57, 1910, pp. 11, 62, pl. 3 , figs. 1,6 .

Formation and locality.-A common form found associated with E. arnoldi about Winningen, Germany.

\section{ENCRINASTER PETALOIDES (Simonovitsch).}

Plate 35, figs. 5, 6 .

Aspidosoma petaloides Srmonovitsch, Sitzb. mat.-naturw. Classe Akad. Wiss., Wien., vol. 64, Abt. 1, 1871, p. 106, pl. 4, figs. 1-3.-Zirtel, Handb. Pal., vol. 1, 1879, p. 453, text fig. 322.-STÜRTz, Palæontographica, vol. 32, 1886, p. 92.-SchöndoRF, Jahrb. nassauisch. Ver. Naturk., Wiesbaden, vol. 62, 1909, p.37, pl. 4, figs. 4, 5; Palæontographica, vol. 57, 1910, pp. 14, 63, pl. 1, figs. 3,4 ; pl. 2 , fig. 4 ; pl. 3 , figs. 10-16 (complete synonymy given here).

This species is described in great detail by its author and by Schöndorf, and is well illustrated. Here as elsewhere the abactinal skeleton is that of the actinal area seen from the dorsal side.

Four specimens of this species were found in grauwacke of Upper Coblenzian age, in the old quarry back of the Hohenrheiner furnace at Niederlahnstein, Rhenish Germany.

\section{ENCRINASTER PETALOIDES GOSLARIENSIS (Halfar).}

Aspidosoma petaloides, var. goslariensis HaLFAr, Jahrb. preuss. geol. Landesanst., Berlin, vol. 13, 1893, p. 186, pl. 10, figs. 1, 1a.-ScHöNDORF, Palæontographica, vol. 57, 1910, pp. 21, 63, pl. 2, fig. 5; Jahrb. preuss. geol. Landesanst., Berlin, vol. 29, 1908, p. 707.

Formation and locality.-The holotype is from the Lower Devonic of the Harz, Germany. 
ENCRINASTER TISCHBEINIANUS (Roemer) emend. Stürt.

Aspidosoma tischbeinianum Roemer, Palæontographica, vol. 9, 1863, pp. 144-146, pl. 23.-Quenstedt, Petrefactenkunde Deutschlands, vol. 4, 1876, p. 76, pl. 92, fig. 39.-Stürtz, Palæontographica, vol. 32, 1886, p. 92, pl. 12, figs. 1, 2.-SchöNDorF, Palæontographica, vol. 57, 1910, pp. 23, 62, pl. 1, fig. 1; pl. 3, figs. 4, 5 (complete synonymy given here).

Formation and locality.-Common in the roofing slates of the Rhenish Lower Devonic at Bundenbach, near Birkenfeld, Germany. As many as 60 individuals have been found on a slab.

Cat. No. 35117, U.S.N.M.

\section{ENCRINASTER ROEMERI (Schöndorf).}

Text fig. 28.

Aspidosoma tischbeinianum Roemer (part), Palæontographica, vol. 9, 1863, pl. 25, fig. 11.

Aspidosoma roemeri ScHöndoRf, Palæontographica, vol. 57, 1910, pp. 28, 62, pl. 2 , fig. 3 ; pl. 3 , figs. 2,3 .

Formation and locality. - Found associated with E. tischbeinianus at Bundenbach, Germany.

ENCRINASTER SCHMIDTI (Schöndorf).

Aspidosoma schmidti ScHöNdoRf, Palæontographica, vol. 57, 1910, pp. 31, 63, pl. 1, fig. 6 ; pl. 3, figs. 17, 18 (complete synonymy given here).

Formation and locality.-A slab with six specimens from the Lower Devonic (Herdorfer zone of the Siegen) at Oberdielfen, Germany.

ENCRINASTER EIFELENSIS (Schöndorf).

Aspidosoma eifelense ScHöNDorf, Palæontographica, vol. 57, 1910, pp. 34, 63, pl. 1 , fig. 5 .

Formation and locality.-Known by several examples from the Lower Coblenzian at Oberstadtfeld, Eifel, Germany.

\section{ENCRINASTER PONTIS (Clarke).}

Aspidosoma? pontis Cluarke, Monog., I, Serv. Geol. Min. Brasil, 1913, p. 312, pl. 27, figs. 1-8; Bull. N. Y. State Mus., No. 164, 1913, pl. 35, figs. 1-4.

Original description. - "This very graceful starfish occurs in abundance in the soft gray shales of Ponta Grossa, sometimes in clustered groups with its long and slender arms curled and intertwined, more often as single individuals lying in beds with shells of Orbiculoidea and various lamellibranchs. I have counted 20 individuals among the specimens at my command and, singularly, every one of these is preserved with its ambulacral face up. The removal of all calcareous matter has left only internal casts of this surface from which it has been possible to gain an idea of external structures from carefully 
made impressions. No specimen gives any clue to the dorsal exterior save one arm which has been turned sidewise showing a part of that surface.

"The striking character of this starfish is the unusual delicacy of its arms, which are very slender and long for a true asteroid and present an appearance very suggestive of an ophiuran. These slender arms are usually so exposed as to show only the alternating ambulacral plates which increases the effect of slenderness; but the adambulacrals are occasionally present and give the arms increased width. These arms are all clearly sulcate, the median groove being sharply marked in all casts by a thin elevated ridge running the entire length of the arm. The soft shale holding these specimens is not a very satisfactory matrix from which to take the special structures of the animal but in good part these can be made out. The ambulacral plates are quadrate in outline, alternate in position along the arm groove, and together are arched so that normally the ambulacral surface is an arched ridge rising above the rest of the surface. These plates, in their arched position, are slightly spaced or displaced along adjoining edges leaving passages from the ambulacra. They are usually broken down or slipped over each other in compression so that the arm seldom shows them in the true position. The surface of these plates is finely granular. The adambulacrals constitute one (or more?) lateral rows and are so seldom well defined that I am not able to represent them with precision but each of them seems to carry one short spine and all to be granulated on the surface. The body of the animal is deeply incut by the arms, which radiate from a narrow center, sharply quinquepartite by the buccal cavity. The oral apparatus is pretty well made out. The oral frames, one for each arm, are very conspicuous, though varying in size in different individuals. Each is broadly saddle-shaped, split medially, the distal parts joined by a suture, the proximal ends spreading apart at a sharp angle which opens into the oral cavity. Their surface is rounded and granulate, the distal ends elevated, and often each half is inclined downward toward the other along the median suture. At each proximal angle lies a sharp jaw or tooth. The whole of the body surface is occupied by the oral rosette composed of the five buccal divisions."

Formation and locality.-From the Devonic of Ponta Grossa and Jaguariahyva, Brazil.

\section{ENCRINASTER (?) GRAYAE (Spencer).}

Aspidosoma grayæ Spencer, Mon. Brit. Pal. Asterozoa, pt. 1 (Palæontogr. Soc. for 1913), 1914, pp. 23, 24, 33, 38, text figs. 22, 24, pl. 1, fig. 8.

Occurs in the Caradoc of Great Britain. 


\section{Order STREPTOPHIURAE Bell.}

Streptophiuræ BeLL, Proc. Zool. Soc. London for 1891, 1892, p. 179.-GREgory, Proc. Zool. Soc. London for 1896, 1897, p. 1036; Treat. Zool., vol. 3, Echinoderma, 1900, p. 274.

Protophiureæ SтÜRтz, Verh. naturh. Ver. preuss. Rheinl., etc., vol. 56, 1900, p. 200.-SchöNdorf, Jahrb. nassauisch. Ver. Naturk., Wiesbaden, vol. 63, 1910, pp. 234, 239, 251.

Ophiurasteriæ ScHöNDORF, Palæontographica, vol. 57, 1910, p. 61.

Diagnosis by Gregory (1897).-Auluroidea "in which the ambulacral ossicles are opposite and are generally fused into vertebral ossicles. In such cases the vertebral ossicles articulate by a more or less simple ball-and-socket joint."

"Remarks. - The main character of this order is that the ambulacral ossicles are paired, but primitive. The order differs from the preceding [Lysophiuræ] by having the vertebral ossicles always opposite instead of alternate. In some of the simplest members of the order, as Ophiurina, the ossicles are not fused, there are no ventral arm shields, and an ambulacral furrow runs along the ventral side of the arm. In the next higher family, as in the genus Lapworthura, the ambulacral ossicles are fused, but have plain articulating surfaces, and there is an ambulacral furrow."

Contains the families:

Ophiurinidæ.

Lapworthuridæ.

Eoluidiidæ.

Aganasteridæ.

Cholasteridæ.

\section{Family OPHIURINID瓜 Gregory.}

Ophiurinidæ Gregory, Proc. Zool. Soc. London for 1896, 1897, p. 1037; Treat. Zool., vol. 3, Echinoderma, 1900, p. 275.-Stürtz, Verh. naturh. Ver. preuss. Rheinl., etc., vol. 56, 1900, p. 201.-SchöNDORF, Jahrb. nassauisch. Ver. Naturk., Wiesbaden, vol. 63, 1910, p. 234.

Original diagnosis. - "Streptophiuræ with ambulacral ossicles, only slightly united, and without ventral arm plates."

Contains the genera:

Ophiurina Stürtz.

Tremataster Worthen and Miller.

\section{Genus OPHIURINA Stürtz.}

Ophiurina Stürtz, Palæontographica, vol. 36, 1890, p. 232.-Gregory, Proc. Zool. Soc. London for 1896, 1897, p. 1037.

Gregory's diagnosis reads as follows: "Disk circular, with marginal plates. Ambulacral ossicles long, narrow bars. Syngnaths rod-shaped. Adambulacral plates absent or altogether lost from the fossil." 
Genoholotype and only species.-0. Tymani Stürtz (citations as above). Lower Devonic, Bundenbach, Germany.

\section{Genus TREMATASTER Worthen and Miller.}

Tremataster Worthen and MrLLen, Geol. Surv. Illinois, vol. 7, 1883, p. 330.Muller, N. Amer. Geol. Pal., 1889, p. 286.-Gregory, Proc. Zool. Soc. London for 1896, 1897, p. 1037.

Original description. - "Body stellate, central part discoid, rays long, flexuous, and gradually tapering. Rays consisting of a double series of ambulacral plates, forming, together, a subcuneiform series, with the tapering ends directed toward the apices of the rays and uniting with the larger ends of the succeeding double plates, upon each side of which there is a series of curved adambulacral plates, which form the margins of the rays. The pores are large and situated between the contracting sides of the ambulacral plates and the concave sides of the curving adambulacrals. Four plates border upon each pore though nearly surrounded by two of them. Plates 10. Dorsal surface unknown.

"This genus is distinguished by the parallel arrangement of the ambulacrals and adambulacrals, instead of the alternate order, and by the large pores."

Gregory's diagnosis is as follows: "Disk with concave interbrachial outlines. No marginal plates. Ambulacral ossicles short. Adambulacrals present."

Genoholotype.-T. difficilis Worthen and Miller. T. (?) decheni (Dewalque) may also belong here.

TREMATASTER DIFFICHIS Worthen and Miller.

Tremataster difficilis WorTHEN and MrLLER, Geol. Surv. Illinois, vol. 7, 1883, p. 330 , pl. 31 , figs. $3 a, 3 b$.

Original description.- "Body stellate, disk small, rays long, flexuous, and gradually tapering. Ambulacral plates subtrigonal, elongated, and united upon their straight faces in parallel order, so as to form a series of subcuneiform sections at the bottom of the ambulacral groove, with the tapering end of each directed toward the apex of the ray, and uniting with the larger end of the next succeeding double plate.

"Adambulacral plates parallel with the ambulacrals, and each forms a curve from the larger end of an ambulacral toward the apex of the ray, to unite with the next succeeding adambulacral as it curves away from its attachment to the ambulacral. By this order of construction the adambulacrals are fixed, at one end, to the ambulacrals, while the other end moves upon the curved surface of an adambulacral so as to allow the same lateral flexibility of the rays, secured in other genera by the alternate arrangement of 
the plates. The pores are large and situated between the contracting sides of the ambulacral plates, the concave sides of the adambulacrals, and the attaching ends of the succeeding plates, so that they are bounded by four plates while nearly surrounded by two.

"The oral plates form, in pairs, elongated triangles, with the acute angle directed toward the center of the visceral cavity. The apices are joined by a suture with the basal portions, which are partly separated by a dividing furrow. A single genital pore perforates each basal section of the oral plates. Dorsal side unknown.

"Locality and position: Prairie du Long Creek, Monroe County [Illinois], Chester limestone.

"No. 2479, Illinois State collection of 1878."

\section{TREMATASTER (?) DECHENI (Dewalque).}

Protaster decheni Dewalque, Ann. Soc. géol. Belgique, vol. 8, 1880, pp. 52-54, pl. 3, figs. 1, 2.

Tremataster (?) decheni Gregory, Proc. Zool. Soc. London for 1896, 1897, p. 1037, footnote.

Formation and locality.--Upper Devonic at Walcourt (Namur) and Tohogne (Luxemburg), Belgium.

\section{Family LAPWORTHURIDÆ Gregory.}

Lapworthuridæ Gregory, Proc. Zool. Soc. London for 1896, 1897, p. 1037.STÜRTz, Verh. naturh. Ver. preuss. Rheinl., etc., vol. 56, 1900, p. 203.Gregory, Treat. Zool., vol. 3, Echinoderma, 1900, p. 275.-ScHÖ̀nDORF, Palæontographica, vol. 57, 1910, p. 58; Jahrb. nassauisch. Ver. Naturk., Wiesbaden, vol. 63, 1910, pp. 235, 239.

Furcasteridæ Stürtz, Verh. naturh. Ver. preuss. Rheinl., etc., vol. 56, 1900, p. 203.-SchöNDORF, Jahrb. nassauisch. Ver. Naturk., Wiesbaden, vol. 63, 1910, p. 235.

Palæospondylidæ Stürtz, Verh. naturh. Ver. preuss. Rheinl., etc., vol. 56,1900 , p. 201.-ScHöNDORF, Jahrb. nassauisch. Ver. Naturk., Wiesbaden, vol. 63, 1910, p. 235.

Original diagnosis. - "Streptophiuroida without ventral armplates or buccal shields; ambulacral ossicles fused, but their articulating surfaces are plain. Madreporite dorsal." Schöndorf states that this plate is on the ventral side, and that the ambulacrals are not fused (p. 239).

Contains the genera:

Squamaster Ringueberg.

Lapworthura Gregory.

Stürtzaster Etheridge.

Bdellacoma Salter.

Rhopalocoma Salter.

Hallaster Stürtz.

Sympterura Bather.

Furcaster Stürtz.

Palastropecten Stürtz. 
Stürtz proposes that the family Lapworthuridæ be divided into three families. In the original family will remain Squamaster, Lapworthura, Hallaster, and Sympterura. The family Furcasteridæ has Furcaster, while the Palæospondylidæ embraces Patæospondylus, the latter name being later changed to Palastropecten by Stürtz, as it was preoccupied; the family name will, therefore, have to be changed to Palastropectinidæ, as was done by Bather in 1905 (p. 168).

Genus SQUAMASTER Ringueberg.

Squamaster Ringueberg, Bull. Buffalo Soc. Nat. Sci., vol. 5, 1886, p. 5.

Original description.- "Body small. Rays long, slender, tapering, flexible, and divided into annular segments.

"Ventral side of ray with two series of paired, opposite ambulacral plates, divided by a straight median line; they are irregularly subquadrilateral, with one short side, and are arranged in pairs in each series, so that two long and two short sides are joined alternately; consequently there is a long transverse suture regularly alternating with a short one. This disposition gives dentate lateral margins to the ambulacral series. The lateral ends of the long transverse sutures curve away from each other, leaving a small notch between the inferior plates of each pair and the superior plates of the adjoining pairs. This notch receives the inner lateral corners of the squamose dorsal plates. Between the dentate elevations of the ambulacral plates and the lateral margins of the dorsal plates there are large triangular openings, which constituted, or in which were placed, the pores.

"Dorsal side composed of large, quadrangular, squamose plates, that encircle the arm as far as the ambulacral groove of which they form the margin. They are divided in the upper portion of the ray by a median suture.

"Dorsal, ray plates fimbriated on the free margins.

"All plates are perforated by minute, closely arranged pores." Genoholotype and only species. - S. echinatus Ringueberg.

\section{SQUAMASTER ECHINATUS Ringueberg.}

Squamaster echinatus RINGUEBeRG, Bull. Buffalo Soc. Nat. Sci., vol. 5, 1886, p. 6, pl. 1, fig. 1 .

Original description.- "Body small. Rays long, slender, not widening at the base; regularly tapering to a subobtuse point. Dorsal side covered by thin imbricating plates, with free external margins which are edged on the outer and lateral sides with closely arranged, long, . slender, filiform spinules, that articulate into minute rounded sockets, which are scalloped out of the margin of the plate; they are slightly longer than the exposed portion of the plate, and are placed about their own diameter apart 
"Ray divided into about 40 segments or articulations by the encircling, dorsal plates; these grow rapidly narrower near the body, and are divided by a dorsal suture running along a raised median ridge which extends about two-fifths of the length of the ray from the body out, where it gradually disappears with the last divided plate; the rest are entire. These plates are quadrangular, and have their inner corners articulated into the socket formed in the dentate lateral extensions of the ambulacral series. They are ornamented on each side by two or three closely arranged, subparallel, very fire ridges, that commence near the dorsal line at the free margins and extend diagonally backward across the plate toward the inner lateral articulated corner. Ambulacral groove furnished with opposite, irregularly quadrilateral, ambulacral plates, divided by a median suture which is crossed alternately by one long and one short suture.

"The superior plate of each pair has the greatest extension laterally, while in the inferior it is the direction of the median line, it being about twice as long as the superior, which, however, is but slightly broader.

"Between the lateral margins of the dorsal plates and the dentate elevations of the ambulacral plates are large subtrigonal open spaces.

"The plates, are punctured by very closely arranged minute perforations."

Formation and locality. - In the Rochester shale, at Lockport, New York. The holotype is in the collection of Dr. Ringueberg. At least one (No. 1110) and probably two other specimens (No. 465) are in the Walker collection of the University of Toronto. They are from the Rochester shale, at Grimsby, Ontario.

\section{Genus LAPWORTHURA Gregory.}

Text fig. 30.

Lapworthura Gregory, Proc. Zool. Soc. London for 1896, 1897, p. 1037, fig. 5.ScHöNDORF, Palæontographica, vol. 57, 1910, p. 58; Jahrb. nassauisch. Ver.

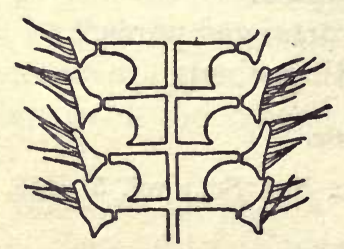

FIG. 30.-VENTRAT STRUCTURE OF ARM OF LAPWORTHURA, ATTER GREGORY.

Naturk., Wiesbaden, vol. 63,1910, p. 208.-Sollas and Soluas, Philos. Trans. Roy. Soc. London, ser. B, vol. 202, 1912, p. 213.-Spencer, Mon. Brit. Pal. Asterozoa, pt. 1 (Palæontogr. Soc. for 1913), 1914, pp. 25, 32, 40, 49.

Original diagnosis.-- "Disk circular, well marked. Arms very flexible, broad; at first uniform in width and then tapering slowly. Ambulacral ossicles with the distal and proximal margins parallel; with lateral wings curving round the podial pores. Madreporite large," dorsal.

Genoholotype.-Protaster miltoni Salter.

Schöndorf remarks as follows (1910b:58):

The ossicles of Lapworthura have been described several times, but never correctly. The ambulacrals are undoubtedly opposite, 
and both dorsally and ventrally have the structure of Encrinaster. The adambulacrals are also opposite to the ambulacrals, and have long forward directed spines. In regard to the dorsal position of the madreporite, he states that the abactinal area has been mistaken for the actinal, and that therefore the madreporite lies upon the ventral side.

The disk is not circular in outline, but concave between the interradii.

\section{LAPWORTHURA MILTONI (Salter).}

Protaster miltoni Salter, Ann. Mag. Nat. Hist., ser. 2, vol. 20, 1857, p. 330, pl. 9, fig. 4.-Wright, Mon. British Foss. Echinod., Oolitic, vol. 2, pt. 1 (Palæontogr. Soc. for 1861), 1862, p. 32, fig. 18.-QUENSTEDT, Petrefactenkunde Deutschlands, vol.4, 1876, p. 75, pl. 92, fig. 36.-STÜRTz, N. Jahrb. für Min., etc., 1886, vol. 2, p. 148; Palæontographica, vol. 32, 1886, pp. 79, 94, pl. 8, fig. 6.

Lapworthura miltoni GREGory, Proc. Zool. Soc. London for 1896, 1897, p. 1037, fig. 5.-ScHöNDORF, Palæontographica, vol. 57, 1910, p. 58; Jahrb. nassauisch. Ver. Naturk., Wiesbaden, vol. 63, 1910, p. 208.-Sollas and Sollas, Philos. Trans. Roy. Soc. London, ser. B, vol. 202, 1912, p. 214, text figs. 1, 2, 4 D, pl. 9, figs. 1, 2; pl. 10, figs. 1-4.-Spencer, Mon. Brit. Pal. Asterozoa, pt. 1 (Palæontogr. Soc. for 1913), 1914, pp. 25, 32, 35, 36, pl. 1, fig. 9.

Formation and locality.-Abundant in the Lower Ludlow of the Siluric at Leintwardine, England. See elsewhere in this work (p. 237) under Stürtzura leptosoma, which Schöndorf states is but the young of $L$. miltoni. The same author states further that the latter species either embraces several species or the form has a long geologic range, for a number of species and genera appear to be identical with $L$. miltoni.

Cat. No. 59394, U.S.N.M.

LAPWORTHURA SOLLASI Spencer.

Lapworthura sollasi Spencer, Mon. Brit. Pal. Asterozoa, pt. 1 (Palæontogr. Soc. for 1913), 1914, pl. 1, fig. 10.

Occurs in the Siluric of Great Britain.

LAPWORTHURA (? "probably n. gen.") species (Miller and Gurley).

Aganaster (?) sp., Miller and Gurder, Sixteenth Rep. Geol. Surv. Indiana, 1891, p. 372 , pl. 9, figs. 12 , 13; authors' extracts, 1890, p. 58.-GREGORY, Proc. Zool. Soc. London for 1896, 1897, p. 1038.

Original description.- "We have figured this fragment to show the anchylosis of the oral plates, and the pores passing through the ambulacral plates, and also those passing between them. It will be observed that one pore passes through each plate near the marginal end, while a double row of pores passes between the plates in the central part of the arm furrow. We believe this is an Aganaster, from the depth of the central part of the disk, and the arrangement of the plates in the arm furrows; but the specimen is larger than any 
Aganaster gregarius we have seen and the rays are wider, and as we do not know the position of the pores in the rays of Aganaster, it may be our specimen does not belong to this genus."

Remarks. - "Seems to me to be allied to Lapworthura, and at least a member of the same family. It apparently has no ventral armplates, but an open furrow, and thus differs widely from Aganaster. It is probably a new genus." (Gregory.)

Formation and locality.-Not given. The specimen may be in the Gurley collection of the University of Chicago.

\section{Genus STÜRTZASTER Etheridge.}

Palæocoma Salter (not D'Orbigny 1850), Rep. Brit. Assoc., 1857, Trans. of sections, p. 76; Ann. Mag. Nat. Hist., ser. 2, vol. 20, 1857, pp. 324, 327.-Wright, Mon. British Foss. Echinod., Oolitic, vol. 2, pt. 1 (Palæontogr. Soc. for 1861), 1862, pp. 23, 29.-Quenstedt, Petrefactenkunde Deutschlands, vol. 4, 1876, p. 81, pl. 92, fig. 43.-Zirtel, Handb. Pal., vol. 1, 1879, p. 453.-STürtz, N. Jahrb. für Min., etc., 1886, vol. 2, p. 152; Verh. naturh. Ver. preuss. Rheinl., etc., vol. 50, 1893, pp. 45, 62 .

Sturtzaster Etheridge, Rec. Australian Mus., vol. 3, 1899, p. 129.-SchöNdorf, Jahrb. nassauisch. Ver. Naturk., Wiesbaden, vol. 63, 1910, p. 217.

Genoholotype.-Palæocoma marstoni Salter.

Remarks.-Palæocoma=Stürtzaster, Bdellacoma, and Rhopalocoma, all of Salter, are very poorly known, due to the fact that the specimens, though not rare, occur in a calcareous shale and are pressed flat till they have become a thin film of plates greatly obscured by an abundance of spines. Of $P$. marstoni, the genotype, the writer has seen five examples, presented to the United States National Museum by W. R. Billings. On the basis of the characters revealed by these specimens, he was inclined to leave the genus among the Asteroidea and in close association either with the Mesopalæasterinæ (nearest Mesopalæaster, a phanerozonian), or the Schuchertiidæ (near Schuchertia, a cryptozonian).

The long, slender and serrated spines of Stürtzaster are peculiar to the genus. In their abundance and character they remind one more of ophiurids than of asterids.

The figures of Salter and Wright, if correct, recall the large-disked cryptozonian genus Schuchertia, and it was this character that probably also led Stürtz to refer Stürtzaster to the same group in association with the genera Palasteriscus, Loriolaster, and Cheiropteraster.

Etheridge in 1899 called attention to the fact that D'Orbigny proposed in $1850^{1}$ the new generic name Palrocoma for Ophiura mülleri Phillips of the Lias. A name once proposed can not be used again in another sense, and therefore Mr. Etheridge is within the rules of nomenclature in substituting for Salter's second usage of Palrocoma

${ }^{1}$ Prodome, vol. 1, p. 240. 
the name of Stürtzaster, with Palæocoma marstoni Salter as the genotype.

In 1910 Schöndorf was able to study "several right good examples" of S. marstoni, and strangely the form turns out not to be an asterid but an aulurid, with the essential ambulacral characters of Lapworthura miltoni. He states that the ambulacrals are not alternate, as stated by Salter, but opposite one another. Therefore the ambulacrals and the adambulacrals are also opposite. The adambulacrals bear two or three spines on their outer edges, and Salter's statement and figures showing two columns of ossicles outside of the ambulacrals appear to be very wrong. Schöndorf states that the peculiar preservation of the arm skeleton has given rise to this statement of Salter, and that there are only ambulacrals and adambulacrals present. The oral skeleton is distinctly adambulacral. A madreporite is not determinable.

On the dorsal side, all that can be clearly made out is the presence of ambulacrals and adambulacrals, all of which are arranged in transverse rows.

\section{STÜRTZASTER MARSTONI (Salter).}

Palæocoma marstoni Salter, Ann. Mag. Nat. Hist., ser. 2, vol. 20, 1857, p. 328, pl. 9, figs. 3a-3c.-Wright, Mon. British Foss. Echinod., Oolitic, vol. 2, pt. 1 (Palæontogr. Soc. for 1861), 1862, p. 30, fig. 17.-Quenstedt, Petrefactenkunde Deutschlands, vol. 4, 1876, p. 81, pl. 92, fig. 43.

Sturtzaster marstoni ScHöNDORF, Jahrb. nassauisch. Ver. Naturk., Wiesbaden, vol. 63,1910, p. 217.

Formation and locality.-Common in the Lower Ludlow of Church Hill, Leintwardine, England. Specimens are in many museums, the United States National Museum and the Yale Museum both having individuals. See S. colvini and S. cygnipes.

Cat. Nos. 60624, 60625, U.S.N.M.

\section{STÜRTZASTER COLVINI (Salter).}

Palæocoma colvini SAlter, Ann. Mag. Nat. Hist., ser. 2, vol. 20, 1857, p. 328.Wright, Mon. British Foss. Echinod., Oolitic, vol. 2, pt. 1 (Palæontogr. Soc. for 1861), 1862, p. 30 .

Sturtzaster colvini ScHöNDORF, Jahrb. nassauisch. Ver. Naturk., Wiesbaden, vol. 63,1910 , p. 219.

Formation and locality. - In the Lower Ludlow, Leintwardine, England. "Probably completely identical with S. marstoni." (Schöndorf.)

\section{STÜRTZASTER CYGNIPES (Salter).}

Palæocoma cygnipes Salter, Ann. Mag. Nat. Hist., ser. 2, vol. 20, 1857, p. 329.Wright, Mon. British Foss. Echinod., Oolitic, vol. 2, pt. 1 (Palæontogr. Soc. for 1861), 1862, p. 30 .

Sturtzaster cygniceps (aic) ScHöNDORF, Jahrb. nassauisch. Ver. Naturk., Wiesbaden, vol. 63, 1910, p. 219.

Formation and locality.-Lower Ludlow, Leintwardine, England. "Probably completely identical with S. marstoni." (Schöndorf.) 


\section{STÜRTZASTER (?) MITCHELLI Etheridge, jr.}

Sturtzaster (?) mitchelli ETHE RIDGe, jr., Rec. Australian Mus., vol. 3, 1899, p. 128.

Formation and locality.-A single specimen from the Upper Trilobite bed of the Siluric (Wenlock series) at Bowning, New South Wales.

\section{Genus BDELLACOMA Salter.}

Palæocoma (Bdellacoma) SAlter, Ann. Mag. Nat. Hist., ser. 2, vol. 20, 1857, p. 324.-Wright, Mon. British Foss. Echinod., Oolitic, vol. 2, pt. 1 (Palæontogr. Soc. for 1861), 1862, p. 31.-ZirTeL, Handb. Pal., vol. 1, 1879, p. 453.-Stü rTz, Palæontographica, vol. 32, 1886, p. 96.

Bdellacoma Stü RTz, Verh. naturh. Ver. preuss. Rheinl., etc., vol. 50, 1893, pp. 46, 63.

Genoholotype and only species.-P. (B.) vermiformis Salter. Lower Ludlow, Leintwardine, England.

Remarks. - Until this form is restudied and brought up to date the supposed subgenus of Palæocoma has no value.

\section{Genus RHOPALOCOMA Salter.}

Palæocoma (Rhopalocoma) SAlter, Ann. Mag. Nat. Hist., ser. 2, vol. 20, 1857, p. 329.-Wright, Mon. British Foss. Echinod., Oolitic, vol. 2, pt. 1 (Palæontogr. Soc. for 1861), 1862, p. 31.-ZrTteL, Handb. Pal., vol. 1, 1879, p. 453.STÜ RTz, Palæontographica, vol. 32, 1886, p. 96.

Rhopalocoma StüRTz, Verh. naturh. Ver. preuss. Rheinl., etc., vol. 50, 1893, pp. 46,63 .

Genoholotype and only species.-P. (R.) pyrotechnica Salter. Lower Ludlow, Leintwardine, England.

Remarks.-This form also requires modernization, and until then the supposed subgenus has no value.

\section{Genus HALLASTER Stürtz.}

Protaster HaLl (not Forbes), Nat. Hist. N. Y., Pal., vol. 3, 1861, p. 134; Twentieth Rep. N. Y. State Cab. Nat. Hist., 1868, p. 293; rev. ed., 1868= 1870 , p. 336.

Hallaster StüRTz, N. Jahrb. für Min., etc., 1886, vol. 2, p. 150.

Original description (Stürtz).- "Ambulacral plates alternating [they are opposite]; the podial pores lie between these and the side plates. The dorsal skeleton consists of two columns of dorsal plates and two of lateral plates, of which the former adjoin medially along the rays. For $P$. forbesi Hall of the Silurian of North America I propose the generic name Hallaster, because on the one hand Forbes did not sufficiently characterize his Protaster, and on the other the above species in the sense of Salter's Protaster is not congeneric with it."

Genoholotype and only species.-Protaster forbesi Hall.

Remarks. - This genus appears to be most closely related to Lapworthura, with the most obvious difference in the shape of the am- 
bulacral ossicles. In Hallaster the lateral wings of the plates curve round the podial openings proximally, while in Lapworthura they do so distally. Further, the side plates of the latter genus bear spines along their sides, while in the former genus they are restricted to the distal ends of the plates.

\section{HALLASTER FORBESI (Hall).}

Text fig. 31 .

Protaster forbesi HALL, Nat. Hist. N. Y., Pal., vol. 3, 1861, p. 134, pl. 7 A, figs. 8-10; Twentieth Rep. N. Y. State Cab. Nat. Hist., 1868, p. 293, pl. 9, figs. 5, 6 ; rev. ed., $1868=1870$, p. 336 , pl. 9 , figs. 5, 6.-Quenstedt, Petrefactenkunde Deutschlands, vol. 4, 1876, p. 134, pl. 95, fig. 13.-STÜ RTZ, Palæontographica, vol. 32,1886, pp. 78, 83.

Hallaster forbesi STürTz, N. Jahrb. für Min., etc., 1886, vol. 2, p. 150.

The original description will not be repeated here because it is faulty and was later corrected by Hall.

Hall's description of 1868.-P. forbesi "has a circular disk, composed of squamiform spiniferous plates and five long flexuous rays. These rays I have [originally] represented as composed, on the lower side, of a double range of [adambulacral] plates, as described and represented by Professor Forbes, but finding outside of these a range of small ossicles [side plates] to which are attached the spine bases, these have been shown as a part of an articulating

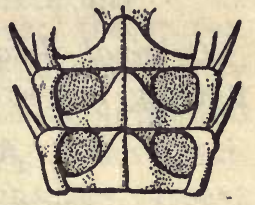

Fig. 31.-ActinaL raY PLATES OF HALLASTER FORBEST (HALL). OPPOSTTE AMBULACRALS, AND THE SIDE PLATES. spine (in the illustration, plate $7 A^{1}$ ), an unnatural representation, which I am now able to correct.

"In the species from the Lower Helderberg group, Protaster forbesi, the ventral surfaces of the rays are composed of an ambulacral and adambulacral series of plates on each side [there are no ventral ray plates]. The ambulacral plates are obliquely quadrangular and alternating in a slight degree [in the type they are opposite]; the adambulacral plates as seen from the lower side are narrow, elongate, oblique, and laterally imbricating, presenting the appearance of an oblique ridge with the anterior extremity projecting, and forming the point of attachment for the spines, with which each one is furnished. [These spines are striated longitudinally.] When the ray is abruptly curved, these plates project outward, sometimes almost rectangularly; and when at the same time the ambulacral area is obscured by adhering matrix, these plates might readily be mistaken for appendages of the inner ranges. The pores are comparatively large, truncating the outer adjacent angles of the ambulacral plates, while the base of one adambulacral plate and the side of another form the exterior margin. The centers of the upper sides of the rays are composed of 
two ranges of subimbricating [dorsal] plates, which are closely joined along the median line; the marginal plates are the upper edges of the adambulacral plates, which bear on their anterior ends one, two, or three short spines."

Formation and locality.-From the Coeymans member of the Helderbergian series of the Lower Devonic, at Jerusalem Hill, near Litchfield, New York. The holotype is in the American Museum of Natural History, No. 2302. There are two good specimens and a single arm in the Beecher collection at Yale University.

\section{Genus SYMPTERURA Bather.}

Text fig. 32 .

Sympterura BAtHer, Geol. Mag., dec. 5, vol. 2, 1905, pp. 161-169, pl. 6, figs. 1, 2, 3, 6.-SchöNDoRF, Jahrb. nassauisch. Ver. Naturk., Wiesbaden, vol. 63, 1910 , p. 216.

Original diagnosis. - "A Lapworthurid with spinulose disk extending to second arm segment, with oral skeleton of teeth, long
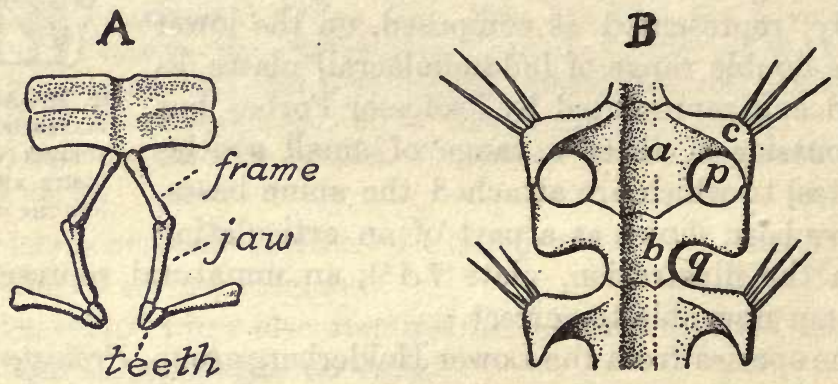

Fig. 32.-SYMPTERURA MTNVERI, AFTER BAtHer. A. SEMIDIAGRAMMATIC RECONSTRUCTION OF SYNGNATHS, $\times$ 10. B. RECONSTRUCTION OF SEVENTH AND EIGHTH ARM SEGMENTS, $\times 18: a$, DISTAL, AND $b$, PROXIMAL PORTION OF VERTEBRA; $c$, 'ADAMBULACRALIA; $p$, PODIAL DEPRESSION; $q$, INTERSPACE, OCCUPIED, AT LEAST IN PABT, BY INTERVERTEBRAL MUSCLES.

jaws, and short mouth frames (torus not seen), with free arm segments containing a vertebral ossicle, possibly compound, grooved ventrally and provided on each side with two wings, to the distal of which is attached an adambulacral spiniferous element."

Genoholotype and only species.-S. minveri Bather (same references as above). The holotype was found in the Devonic (?Lower) at Epphaven, near Padstow, North Cornwall, England.

As this specimen presents in the ambulacralia characters of great value in the morphology of the Ophiurid vertebræ, it is advisable to quote here somewhat extensively from Bather's statements.

"The median body of each segment is undoubtedly the equivalent of the normal Ophiurid vertebra. On the accepted theory that this vertebra was evolved by the fusion of a pair of ossicles originally alternating, then opposite, and finally joined along the middle or 
radial line, the present specimen may be described as in a stage of development later than the fusion, but possibly retaining in the median groove a trace of the primitive distinctness of the ossicles. Those ossicles are usually described as ambulacral, and that term may be accepted so far as it denotes homology with the ossicles so named in an Asterid. * * *

"As a rule among Ophiurids in this stage of evolution, each vertebra has on each side a single side process on which abuts an outer ossicle, the so-called adambulacral, and these adambulacrals, which bear the lateral spines, alternate with the ambulacral ossicles or vertebræ. It is a little difficult to interpret the appearances of the present specimen in harmony with such an arrangement. On the assumption that each segment should contain one ambulacral pair (here fused) and one adambulacral pair bearing spines, ray $i$ has been assigned nine segments. But each such segment is seen to have two processes on each side, and the distal one of these bears the spines. For this reason, and because of the appearances in segment 8 , it may be supposed that the outer spiniferous portion of the distal process ( $c$ in fig. 1 ) is an adambulacral element. What, then, is the proximal side process? To this question two possible answers present themselves.

"The appearance of a transverse division in the vertebra, between the proximal and distal processes, suggests that each segment really consists of two ambulacral pairs, of which only the distal one is associated with adambulacrals, the proximal pair of adambulacrals being suppressed. Each of these supposed ambulacral pairs possesses a single pair of lateral processes, but those of the distal pair are partly overlaid by the adambulacral elements. In the distal region of the ray the proximal and distal halves of the vertebra are distinguishable; but nearer the disk and within it they have come closer together, the transverse division has disappeared, and the side processes are reduced to structures which appear as bars, but are probably flattened laminæ. Thus the vertebræ seen in ray $v$ are, on this explanation, of compound origin.

"Now, comparison of the vertebræ of recent Ophiurids with the arm segments, especially the proximal ones, of our fossil leaves no room for doubt that the depression marked $p$ is for the reception of a podium, while that marked $q$ is for the insertion of the ventral intervertebral muscles. A single arm segment of a recent Ophiurid, such as Ophiarachna or Amphiura, is therefore homologous with any one of the whole segments here numbered 1-8. If one of these is really composed of $a$ distal and a proximal half (lettered $a$ and $b$ respectively in figs. 1 and 2) the same statement would apply to the recent Ophiurid, and some trace of this origin might be seen in the development. 
The observations of Prof. Ludwig ${ }^{1}$ and Mr. J. W. Fewkes ${ }^{2}$ on Amphiura squamata have shown that the two lateral halves of each vertebra unite first at the proximal and distal ends, leaving a space between. This is suggestive of an origin from proximal and distal elements. On the other hand each lateral half springs from a single center of calcification, from which it stretches out in a distal direction, so that the incipient ambulacral element is thicker at its proximal end. This last-mentioned feature is paralleled by the boot-shaped proximal portions of the ambulacral ossicles in the Protasteridæ. At a slightly later stage the ambulacral of Amphiura broadens at the distal end, which thus comes to resemble the distal portion of the Protasterid ambulacral. If this distal portion in Amphiura were, as indicated by Prof. Ludwig's observations, merely an extension of the proximal portion, then it might be inferred that the whole structure, both here and in the various Paleozoic forms alluded to, represented a single ambulacral pair and not two successive pairs. In such case one would accept Dr. Gregory's suggested explanation ${ }^{3}$ 'that the smaller pieces are only triangular, distal portions of the ambulacral ossicles, apparently separated from the proximal portion[s] by a groove.' Dr. Gregory further suggests that these grooves or depressions 'were for the lodgment of the ventral muscles which moved the arms.' A far more probable explanation surely is that they were for the reception of the branches from the radial water-vessel to the podia. This explanation, however, consonant as it is with the facts of development of Amphiura, reminds one of another difficulty. Prof. Ludwig ${ }^{4}$ has pointed out that, whereas the so-called ambulacrals of Asterids lie at right angles to the perradius and between the successive branches and podia, those of Ophiurids lie parallel to the perradius and across the branches to the podia. Now, if, as we have every reason to believe, the Ophiurids were derived from Asterids, it is hard to see why this change should have taken place. That is the difficulty, but it is a difficulty that disappears if we suppose that the vertebra is really compounded of two successive ambulacral pairs in the manner outlined above. The remaining objection to this latter hypothesis is that, as Dr. Gregory has pointed out, it postulates the suppression of alternate podia. Nevertheless, similar fusion and concomitant suppression are not so unknown among Echinoderms as to render this objection a fatal one.

"The suggestion that the vertebræ of Ophiurids are composed of two successive ambulacral pairs certainly can not be proved with 
the evidence at our disposal. But it is doubtful whether it can be disproved, and I therefore make it to promote a search for further evidence pro or con.

"Two other features in the present specimen need discussion, and may perhaps throw light on the problem just posed. The first of these is the fact that the broadest and stoutest portion of each arm segment appears to be the distal half (marked $a$ in fig. 1), whereas in the developing Amphiura and in the adult Protasteridæ the reverse is the case. This character is also found in Furcaster palæozoicus as figured by Mr. Stürtz, in Ptilonaster princeps of J. Hall, and in Lapworthura Mittoni, as interpreted by Dr. Gregory. (See our fig. 4 [30].) In the Epphaven fossil the feature is to some extent accounted for by the supposed fusion of a spiniferous adambulacral element with the distal wing of the ambulacral; but in Lapworthura and Furcaster this wing, while unconnected with the adambulacral, is still more preponderant. In some other early Palæozoic genera, e. g. Eugaster, J. Hall, and Eophiura, Jaekel, the wing is neither distal nor proximal, but arises half way up the ambulacral, so that one can not say to which of two successive segments the podium belongs; in fact, the structure is in this respect absolutely that of an Asterid. ${ }^{1}$ These differences call for some explanation. Starting from the indifferent Ordovician type of Eophiura, we may suppose that in one series of genera (e. g. Protasteridæ) the wing moved toward the mouth, while in another series (e. g. Lapworthuridæ) it moved away from the mouth. In both series the podium ultimately became inclosed within the substance of (apparently) a single ossicle; but, if this took place by a subsequent lateral outgrowth of stereom, then in the former case the vertebra must have inclosed a podium distal to itself, and in the latter case a podium proximal to itself. Thus the relations of the vertebræ to the podia would be fundamentally different in the two lines of descent. On the other hand, alternate podia may, as suggested on a previous page, have been inclosed by the union of successive pairs of vertebræ, and this type of structure may be the one seen in process of development in the arm segments of our fossil, and the one that persisted to the present day.

"The second feature worthy of attention is the considerable space that seems to intervene between the distal wing of one segment and the proximal wing of the next. This is conspicuous in the distal region of ray $i$, where, further, the depression ( $q$ in fig. 1 [32 B]) markedly resembles the podial depression ( $p$ in fig. 1 ), and differs from it mainly in being rather nearer the axis of the arm. The theory that the Ophiurids are descended from Asterids does not 
explain the evolution of such an interspace, and the general tendency to shortening and approximation of the vertebræ, shown in the history of the Ophiurids, leads one to inquire why there should ever have been introduced a stage in which, as in the Devonian Ophiurina, the recent deep-sea Ophiohelus, and the young Amphiura, the vertebræ have so far departed from the primitive type as to become axially elongate. This stage has been regarded as primitive by Lyman, Ludwig, and other zoologists, but in theory and fact it is 'primitive' only so far as the later forms are concerned, while with reference to the complete series it is 'intercalated.'

"Recurring to the hypothesis that the vertebræ are compounded of successive pairs of ambulacrals, we find in it an explanation not merely of this curious elongation of the arm segments in general, but of the interspaces between them in this genus (lettered q). An objection to the hypothesis was the necessity for assuming the suppression of alternate podia. Here, it may be, is evidence of a stage in which those podia were not yet suppressed, though perhaps somewhat atrophied. If both depressions ( $p$ and $q$ ) were for the reception of podia, then their alternate approximation to and renoval from the perradius may be compared with the similar phenomenon in Asterids.

"Whether the features just discussed be or be not accepted as evidence in favor of the compound origin of the Ophiurid vertebra, they demand some explanation; and it may be added that the same hypothesis will perhaps furnish an equally needed explanation for the hitherto unexplained differences that obtain between Palæozoic genera of Ophiurids in the relations of the adambulacrals to the ambulacrals.

"The origin of the Ophiurid mouth-skeleton also may be illuminated by the preceding hypothesis, which is in full harmony with the opinion that many more arm segments enter into the composition of that structure than is the case in Asterids, an opinion based on embryological research by Dr. O. zur Strassen, ${ }^{1}$ and on palæontological investigation by Dr. O. Jaekel in the paper quoted above. In this region of the ray, at any rate, adambulacrals and podia must have been suppressed in all Ophiurids. We may here note the apparent absence from our specimen of the adambulacral elements known as side mouth-shields, as well as of the peristomial plates. The latter are wanting in most early Ophiurids, a fact confirmatory of Dr. zur Strassen's conclusion that they are not ambulacral elements, but 'secondary calcifications confined to the interradial region.'"

Schöndorf states that the structure of the arms is like that in Lapworthura miltoni and the oral armature as in Encrinaster. 


\section{Genus FURCASTER Stürtz.}

Furcaster STÜRTz, Palæontographica, vol. 32, 1886, p. 79; N. Jahrb. für Min., etc., 1886, vol. 2, p. 148; Verh. naturh. Ver. preuss. Rheinl., etc., vol. 50, 1893, p. 25.-GREGORY, Proc. Zool. Soc. London for 1896, 1897, p. 1038; Treat. Zool., vol. 3, Echinoderma, 1900, p. 275, fig. 31.

Disk small, circular. Rays five, short, narrow, tapering gradually, and slightly flexible. Actinally flat and abactinally rounded. There is a dorsal median column of slightly projecting plates and two lateral ranges of side plates. The dorsal plates are medially depressed, with their outer sides extended into ears, into which fit the spine-bearing side plates.

"Ambulacral ossicles [opposite] of a long central body and two short wings, which are attached only to the anterior cormer of the ossicle." (Gregory.) Buccal scutes small.

Genoholotype.-F. palæozoicus Stürtz. F. (?) daoulasensis (Davy) may also belong here.

Remarks. - "In Stürtz's description he refers to the existence in this genus of ventral arm plates, and even figures them. His typespecimens are now in the British Museum, but I can not verify the existence of any ventral arm plates." (Gregory.)

\section{FURCASTER PALAEOZOICUS Stïrtz.}

Furcaster palæozoicus Stürtz, Palæontographica, vol. 32, 1886, p. 79, pl. 8, figs. 4, 5; N. Jahrb. für Min., etc., 1886, vol. 2, p. 148; Palæontographica, vol. 36, 1890, p. 214.-Gregory, Proc. Zool. Soc. London for 1896, 1897, p. 1038.

Formation and locality.-In the Lower Devonic roofing slates, Bundenbach, Germany. There are three specimens of this species at Yale University.

Cat. No. 59383, U.S.N.M.

\section{FURCASTER (?) DAOULASENSIS (Davy).}

Protaster daoulasensis DAvy, Bull. Soc. géol. France, ser. 3, vol. 14, 1887, pp. 182187, text figs.-Gregory, Proc. Zool. Soc. London for 1896, 1897, p. 1038, footnote ("is an ally of Furcaster").

Formation and locality.-From the Lower Devonic, Rumguen, near Brest, France.

\section{Genus PALASTROPECTEN Stürtz.}

Palastropecten STürtz, Palæontographica, vol. 32, 1886, p. 88, pl. 10, figs. 3, 4; vol. 36,1890 , p. 213, pl. 26, figs. 12, 13.-Gregory, Proc. Zool. Soc. London for 1896,1897, p. 1038.

Palæspondylus StứRT, Verh. naturh. Ver. preuss. Rheinl., etc., vol. 56, 1900, p. 190.

Palæospondylus StrưrTz, Verh. naturh. Ver. preuss. Rheinl., etc., vol. 56, 1900, pp. 191, 202.

Diagnosis by Gregory. - "Disk circular, large (badly preserved in the specimens; probably originally soft and irregular). Arms thick, 
broad, and somewhat lanceolate in shape. Ambulacral ossicles narrow, the lateral wings resting on the whole body of the ossicle."

Genoholotype and only species. - P.zitteli (Stürtz) (citations as above). In the Lower Devonic, Bundenbach, Germany.

\section{Family EOLUIDIID无 Gregory.}

Eoluidïdæ Gregory, Proc. Zool. Soc. London for 1896, 1897, p. 1038.

Eophiuridæ StürTz, Verh. naturh. Ver. preuss. Rheinl., etc., vol. 56, 1900, p. 203.-SchöNDorf, Jahrb. nassauisch. Ver. Naturk., Wiesbaden, vol. 63, 1910, p. 235.

Original diagnosis.- "Streptophiuræ with the ambulacral ossicles united to form vertebral ossicles. Ventral arm plates present, but there are no buccal shields. (Dorsal arm plates present only in the highest genus.)

"Remarks.-This family includes three Devonian genera, which differ from the previous families of this order by the presence of ventral arm plates and by having vertebral ossicles, which articulate (? always) by simple rounded pits and processes. The family differs from living Streptophiuræ by the absence of buccal shields and the simplicity of the oral armature."

Contains the genera:

Eoluidia Stürtz.

Eospondylus Gregory.

Miospondylus Gregory.

\section{Genus EOLUIDIA Stirtz.}

Asterias asperula Roemer (part), Palæontographica, vol. 9, 1863, p. 146, pl. 24, figs. $1-5$; pl. 26 , fig. 6 ; pl. 27.

Eoluidia StürTz, Palæontographica, vol. 32, 1886, p. 89, pl. 11, figs. 1, 2; vol. 36, 1890 , p. 211 , pl. 26 , figs. $10,11 .-$ Gregory, Proc. Zool. Soc. London for 1896, 1897, p. 1038.-Sollas and Sollas, Philos. Trans. Roy. Soc. London, ser. B, vol. 202 , 1912, p. 226, fig. $4 \mathrm{E}$.

Eophiurites STÜRTz, Verh. naturh. Ver. preuss. Rheinl., etc., vol. 56, 1900, p. 190.

Diagnosis.- "Disk rather large; the interbrachial outlines are deeply concave. [Rays very long, slender, and fragile.] Each syngnath consists of pairs of mouth frames and jaws; a jaw plate is present. The vertebral ossicles are small and the union of the two lateral elements incomplete; the lateral wings are thin. The adambulacral plates are triangular and each of them bears several spines. The pores for the podia occur at the middle of the lateral margin of the ventral arm shields." (Gregory.)

Genoholotype and only species. - E. decheni Stürtz (citations as above). Lower Devonic, Bundenbach, Germany.

Cat. No. 35116, U.S.N.M. 


\section{Genus EOSPONDYLUS Gregory.}

Ophiurella Strürtz (not Agassiz, 1834), Palæontographica, vol. 32, 1886, p. 77.

Eospondylus Gregory, Proc. Zool. Soc. London for 1896, 1897, p. 1039.

Original diagnosis.- "Disk circular. Ambulacral ossicles completely fused into vertebral ossicles, each of which, however, is traversed by a pore. The adambulacral ossicles are somewhat pearshaped. The podial pores are at the posterior angles of the ventral arm plates."

Genoholotype and only species.-Ophiurella primigenia Stürtz.

\section{EOSPONDYLUS PRIMIGENIUS (Stürtz).}

Ophiurella primigenia Stürtz, Palæontographica, vol. 32,1886, p. 77, pl. 8 , figs. 1,2 ; vol. 36,1890, p. 210, pl. 26 , figs. 6,7 .

Eospondylus prmigenia Gregory, Proc. Zool. Soc. London for 1896, 1897, p. 1039.

Formation and locality.-Lower Devonic, Bundenbach, Germany.

\section{Genus MIOSPONDYLUS Gregory.}

Ophiura rhenana Stürtz, Verh. naturh. Ver. preuss. Rheinl., etc., vol. 50, 1893, p. 29 , pl. 1, figs. 1-3.

Miospondylus rhenanus Gregory, Proc. Zool. Soc. London for 1896, 1897, p. 1039.-Sollas and Sollas, Philos. Trans. Roy. Soc. London, ser. B, vol. 202, 1912, p. 226.

Original diagnosis (Gregory).- "Disk circular. Ambulacral ossicles completely united; each half of the vertebral ossicle is bootshaped. The oral angles each consist of a pair of syngnaths without jaw plate. The ventral arm plates are small and are not notched by podial pores."

Genoholotype and only species.-Ophiura rhenana Stürtz (citations as above). Lower Devonic, Bundenbach, Germany.

Remarks.-Eospondylus and Miospondylus "agree in family characters with Eoluidia, but differ from it in the structure of both the ambulacral and adambulacral plates." (Gregory.)

\section{Family AGANASTERIDE Stürtz.}

Aganasteridæ Stürtz, Verh. naturh. Ver. preuss. Rheinl., etc., vol. 56, 1900, p. 203,-SchöNDORF, Jahrb. nassauisch. Ver. Naturk., Wiesbaden, vol. 63, 1910, p. 235.

Genus AGANASTER Miller and Gurley.

Aganaster Mrller and Gurley, Sixteenth Rep. Geol. Surv. Indiana, 1891, p. 372; authors' extracts, 1890 , p. 57.-Gregory, Proc. Zool. Soc. London for 1896, 1897, p. 1039.

* Ophiopege Böнм, Zeit. geol. Gesell., vol. 45, 1893, p. 159 (same genoholotype as for Aganaster).

Original description.- "In 1869 Meek and Worthen described an Ophiuroidea, in the Proceedings of the Academy of Science of 
Philadelphia, page 169, under the name of Protaster gregarius, which they redefined and illustrated in the Geological Survey of Illinois, volume 5, page 509, under the name of Protaster (?) gregarius. They had numerous specimens 'in the condition of casts and molds, in a very fine, somewhat granular matrix, that did not show the details of its structure very clearly,' but they said, 'It will probably be found to be generically distinct from the Silurian typical forms of Protaster, but we prefer to place it provisionally in that genus for the present.' In the collection of Mr. Gurley there are several specimens belonging to this species, and they show a few characters not observed by Meek and Worthen, and demonstrate very clearly this species does not belong to the genus Protaster; we therefore propose to include this species in a new genus, Aganaster, and describe the characters, so far as known, as follows:

"General outline, a central circular disk with five long, narrow rays; the circular disk on the dorsal side is covered with small polygonal plates which are not interrupted by the presence of the rays, thus showing the disk had a depth greater than the depth of the rays; rays very narrow and convex or half cylindrical, spine bearing, gradually tapering, and from the dorsal side appear as if composed of plates arranged exactly opposite each other; the ventral side shows a rather deep central disk with marginal plates. There are 10 oral plates in the central part of the disk."

Genoholotype and only species.-Protaster gregarius Meek and Worthen.

Remarks.-Aganaster "has nothing to do with Protaster and is clearly a member of the Streptophiuræ. As far as its characters are known to me it must be included among the Eoluidiidæ. It differs from the rest of this family by the presence of dorsal arm plates. * * * Böhm has founded the genus Ophiopege on the type species of Aganaster." (Gregory.)

\section{AGANASTER GREGARIUS (Meek and Worthen).}

Protaster? gregarius Meen and Worthen, Proc. Acad. Nat. Sci. Philadelphia, vol. 21, 1869, p. 169; Geol. Surv. Illinois, vol. 5, 1873, p. 509, pl. 16, fig. 5. Alepidaster gregarius MeEx, Amer. Journ. Sci., ser. 3, vol. 4, 1872, p. 275 (gen. ref. only).

Aganaster gregarius MrLLER and GURLEX, Sixteenth Rep. Geol. Surv. Indiana, 1891, p. 372 , pl. 9, figs. 10, 11; authors' extracts, 1890 , p. 57 , pl. 9, figs. 10 , 11.-Mnter, N. Amer. Geol. Pal., 1st. App., 1892, p. 673, fig. 1208.

Description of 1873. - "The disk of this species is circular in outline, slightly convex above, and measures from 0.20 to 0.30 inch in diameter. In most cases it looks as if merely covered by a smooth, membranaceous integument. Some casts of its external surface, however, seem to show traces of flat, nearly smooth, imbricating scales above. The five arms are slender, flexible, and rather long 
in proportion to breadth. In a specimen with a disk measuring 0.25 inch in breadth, the diameter of the arms near the disk is only 0.05 inch. None of the specimens show the entire length of the arms, though some fragments of them were seen lying detached in the matrix, about 0.55 inch in length, without being complete at eicher end. From the breadth and gradual taper of these, it would seem probable that when entire they may have been 0.75 to 1 inch in length. Their impressions in the matrix give no indications of a longitudinal furrow along the under side, but show that there were about six pairs of arm pieces in a length of 0.16 inch. These pieces appear to be nearly though not exactly opposite, and each one provided below with a comparatively large, round, deep pit, or pore, near the middle of its anterior side. Along their lateral margins there appear to be impressions in the matrix of very small spines (one to each arm piece), though if such, they must have been extremely short. Impressions of the upper side of the slender arms show them to have been somewhat rounded above, with the nearly square arm pieces slightly alternating. Some of the impressions seem to show traces of central pores or pits, one at the middle of each pair of pieces, though in others no traces of these are visible."

Formation and locality.-Common as molds in a fine impure sandstone and in the famous crinid bed at Crawfordsville, Indiana, in the Keokuk formation of the Mississippic.

There are two specimens (No. 6) of this species in the Wachsmuth collection at Harvard University. At Yale University there are four specimens.

\section{Family CHOLASTERID $Æ$ Worthen and Miller.}

Cholasteridæ Worthen and Miller, Geol. Surv. Illinois, vol. 7, 1883, p. 328.

Original definition.-Cholaster "is so widely different from those heretofore discovered that we think it belongs to a distinct family, which might very appropriately be designated the Cholasteridæ, but until other specimens have been found showing other parts of the body, we prefer to let the family remain undefined."

Contains the genus:

Cholaster Worthen and Miller.

Genus CHOLASTER Worthen and Miller.

Cholaster WortheN and Mrluer, Geol. Surv. Illinois, vol. 7, 1883, p. 328.Gregory, Proc. Zool. Soc. London for 1896, 1897, p. 1040.

Original description.-Dorsal side alone known. "Body truncated pentagonal, central area circular, deep and large in proportion to the rays; rays distant, small, short and abruptly truncated. 
"Dorsal side possessing a rather large centro-dorsal plate, which is surrounded by five plates occupying the position of radials, while the other part is covered with numerous small disk plates."

Genotiolotype and only species.-C. peculiaris Worthen and Miller.

Gregory states that Cholaster "appears to be allied to Aganaster, but the structure of the ambulacral ossicles is unknown."

CHOLASTER PECULIARIS Worthen and Miller.

Cholaster peculiaris Worthen and Mrluer, Geol. Surv. Illinois, vol. 7, 1883, p. 329 , pl. 31, figs. 4a, 4b.

Original description. - "The general form of the body is that of a truncated pentagonal star, with a large circular disk. A centrodorsal plate is surrounded by five others, all of which are much larger than other plates of the body, and occupy a centro-dorsal depression. The position of these five plates is that of radials, resting upon a basal, and therefore all other plates of the body might be regarded as radials and interradials, the latter being very numerous, because of the wide separation of the rays at their junction with the body. The interradials are polygonal, convex, or subspinous plates, without much variation in size whether filling the larger or smaller interradial spaces. The plates following the larger radial plates, as above defined, in the direction of the rays, are not, however, by their form or arrangement to be distinguished from the interradials, though differing from those forming the rays. The plates covering the dorsal side are thus divided into three kinds, viz.: First, the larger plates filling the centro-dorsal depression; second, the disk plates which cover all other parts of the body except the rays, and, third, the plates which cover the rays proper, which in this species are oasily distinguished from the central disk plates.

"The rays are short, abruptly truncated, and slightly expanded at the apices by reason of an enlargement of the terminal plates. They are widely separated from each other, though not at uniform distances, and present the appearance of having been stuck on the central disk, instead of having grown from it, an appearance more marked, by reason of the change in the form of the plates, from the disk to the rays.

"One of the interradial spaces is much greater than the others, so that a line may be drawn across the disk, leaving three entire rays upon the smaller half. The back of each ray is covered by a series of transversely elongated plates separated from the side series by a longitudinally impressed line. A single series of plates covers either side of a ray, interlocking with the transverse dorsal series and directed backward toward the disk.

"The oral plates are unknown, and no madreporiform tubercle has been detected.' 
Formation and locality.-Okaw Bluffs, between Chester and Kaskaskia, Illinois, in the Chester formation of the Upper Mississippic. The holotype is in the Mlinois State collection, No. 2480.

\section{Subclass OPHIUROIDEA.}

These animals are not present in the older Paleozoic, may have appeared in the late Devonic, and do not seem to have been abundant

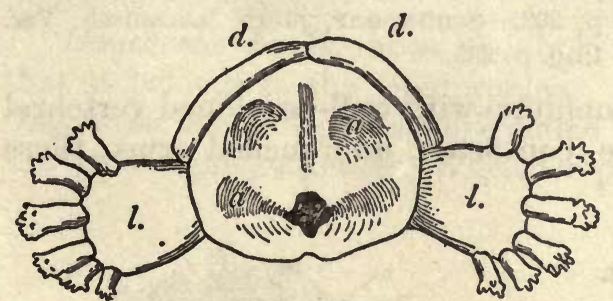

Fig. 33.-Ophioteresis. After Bell from Gregort. ABORAL SURFACE OF AN ARM OSSICLE: $a$, ARTICULAR CAVITIES; $d$, THE DOUBLE DORSAL SHIELDS; $l$, LATERAL ARM PLATES.

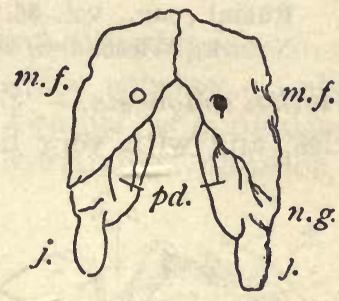

Fig. 34.-SYNGNATHS OF OPHIURA cTIARIS. AFTER MULLER FROM GREGORY. $j$, JAW; m.f., MOUTHFRAME; $n . g .$, GROOVE FOR CIRCUMGESOPHAGEAL NERVE-RING; p.d., PORE AND DEPRESSION FOR ORAL TENTACLE.

before the Triassic, since which time they occur more and more commonly. In the present oceanic waters they are popularly known as sand-stars, brittle-stars, branching-stars, or basket starfish. They range from shallow and estuarine waters to abyssal depths. Typical Ophiuroidea differ from typical Asteroidea in having the arms sharply marked off from the disk as appendages, and in the absence of grooves along the actinal side of the arms. This means that the body cavity which in the Asteroidea extends out into the rays is restricted in the Ophiuroidea to the disk.

The subclass Ophiuroidea is defined by Schöndorf as follows:

"Ambulacral water-vascular system situated in a small groove at the base of the ray ossicles, and ventrally covered by a single column of ventral shields. From the radial canal outside of the ambulacrals arise simple lateral branches that never have ampullæ, as a rule curve upward, pass into and through the substance of the ossicles, and finally open out laterally between the ventral and side shields as the ambulacral podia. Ambulacrals opposite, each right and left piece coossified into a vertebra with complicated articular surfaces [see figs. 34-36]. Adambulacrals transformed into lateral shields. Vertebræ dorsally covered by a single column of dorsal shields." Disk circular in outline, "without marginal plates, and sharply separated from the rays, that as a rule are rounded. There is no typical madreporic plate. One of the ventrally situated mouth shields serves as madreporite" (1910a: 246). 
In ophiurids the oral skeleton, or syngnaths, is composed of three pairs of adambulacrals and ambulacrals. Of these the two first pairs alone are prominent and preserved. The third pair remains internal, small, and rudimentary.

\section{Family ONYCHASTERID压 Miller.}

Onychasteridæ Mrluer, N. Amer. Geol. Pal., 1889, p. 216.-Gregory, Proc. Zool. Soc. London for 1896, 1897, p. 1040.-STürTz, Verh. naturh. Ver. preuss. Rheinl., etc., vol. 56,1900 , p. 202.-ScHöNDORF, Jahrb. nassauisch. Ver. Naturk., Wiesbaden, vol. 63, 1910, p. 235.

Original diagnosis. - "Streptophiuræ with well-developed vertebral ossicles, and with very flexible, contorted, unbranched arms; there

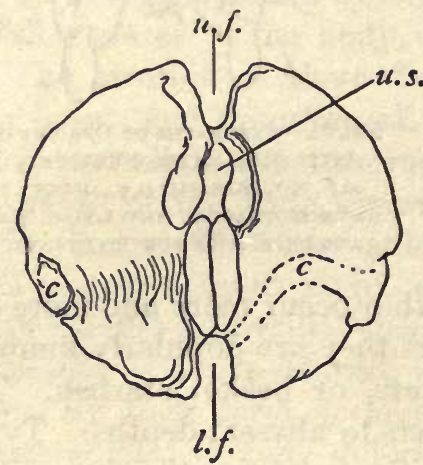

35

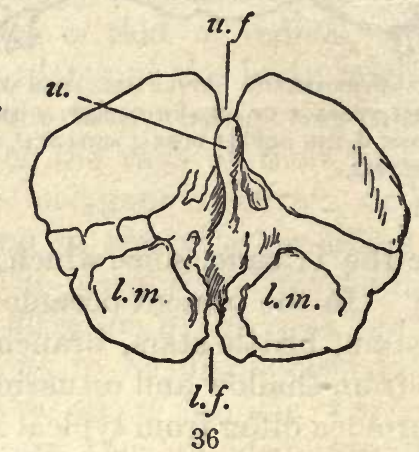

36

Figs. 35 aNd 36.-Vertebral ossicle of OpHura chlaris. AFter MUller from Gregory. 35; ABORAL SURFACE; 36, ADORAL SURFACE. C, CANAL FOR THE PODION (SHOWN BY REMOVAL OF A PART OF MUSCLE FIELD ON RIGHT STDE); l.m., LOWER MUSCLE FIELD; l.f., LOWER AND u.f., UPPER CANAL FURROWS, u., UMBO; $u .8 .$, UMBONAL SOCKET.

are no external arm plates, the integument, containing granules only."

Contains the genus:

Onychaster Meek and Worthen.

\section{Genus ONYCHASTER Meek and Worthen.}

Onychaster Meex and Worthen, Geol. Surv. Illinois, vol. 3, 1868, p. 526; Proc. Acad. Nat. Sci. Philadelphia, vol. 21, 1869, p. 82; Geol. Surv. Illinois, vol. 5, 1873, p. 474.-Zittel, Handb. Pal., vol. 1, 1879, p. 443.-MrLler, N. Amer. Geol. Pal., 1889, p. 264.-STÜRTz, Verh. naturh. Ver. preuss. Rheinl., etc., vol. 50, 1893, p. 30.-Gregory, Proc. Zool. Soc. London for 1896, 1897, p. 1040.-STÜ RTz, Verh. naturh. Ver. preuss. Rheinl., etc., vol. 56, 1900, p. 183. -ScRöndoRF, Jahrb. nassauisch. Ver. Naturk., Wiesbaden, vol. 62, 1909, pp. 47-61, vol. 63, 1910, p. 240; Palæontographica, vol. 57, 1910, p. 59.Spencer, Mon. Brit. Pal. Asterozoa, pt. 1 (Palæontogr. Soc. for 1913), 1914, pp. 26, 50.-I. B. J. Soluas, Philos. Trans. Roy. Soc. London, ser. B, vol. 204, 1913, p. 51.-SchöNDORF, Jahrb. nassauisch. Ver. Naturk., Wiesbaden, vol. 66,1913 , pp. $97-114$. 
Genoholotype.-O. Alexilis Moek and Worthen.

For generic description, see under $O$. flexilis.

Remarks by Gregory.--"This interesting genus has hitherto been placed among the Euryalidæ, of which it has been regarded as the best known fossil representative. As Prof. Bell, however, has remarked, Meek and Worthen's clear figures of the vertebral ossicles show that the articular surfaces are Streptospondyline and not Cladophiuroid."

Schöndorf in 1909 restudied Onychaster in detail, and came to the following conclusions:

"Onychaster flexilis shows plainly in the structure of its arm ossicles that it belongs to the Ophiuroidea. As in this subclass, so also in Onychaster the arm ossicles originated from two halves (ambulacrals) that grew tightly together. When compared with living Ophiurids, this

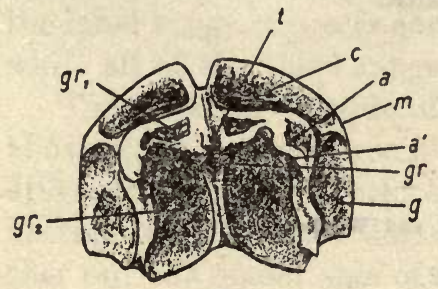

37

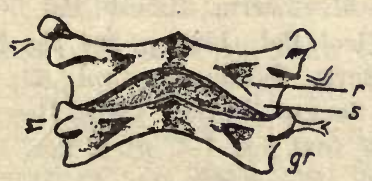

39

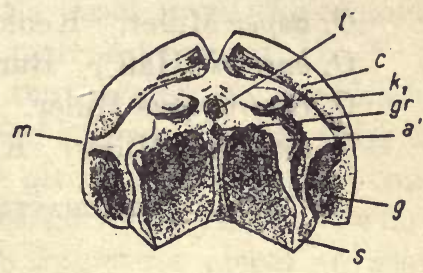

38

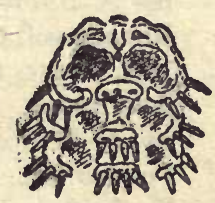

41

Figs. 37-41.-ONYchaster flexilis. AfTer Schöndorf. 37 and 39, ProxmMal vertebra seen FBom THE ABORAL AND ADORAL SURFACES. 39, VENTRAL VIEW OF TWO PROXIMAL VERTEBRA, ORIENTED WITH THE ABORAL SIDE UP AND THE ADORAL DOWN. 40, SIDE VIEW OF SAME. ADORAL SIDE ON LEFT, ABORAL ON RIGHT. 41, VENTRAL VIEW OF SEVERAL SUCCESSIVE VERTEBRAE WITH THE ABORAL SIDE AT THE TOP. $a$, UPPER LATERAL ARTICULAR KNOB; $a^{\prime}$, SOCKET FOR KNOB OF ADORAL SIDE; $c$, INSERTION FIELD FOR THE UPPER, AND $g$, FOR THE LOWER INTERMEDIARY VERTEBRAL MUSCLES; $g r$, MEDIAN UNPAIRED DEPRESSION; $g r_{1}$, SMALL DEPRESSION FOR THE KNOB, $k_{1}$, OF THE ADORAL SIDE; $g r_{2}$, LARGE DEPRESSION OF THE CENTRAL AREA OF VERTEBRA; $m$, BARRIER SEPARATING THE UPPER AND LOWER INTERMEDIARY VERTEBRAL MUSCLES; $r$, LATERAL, GROOVE (? FOR LATERAL BRANCHES OF WATERVASCULAR SYSTEM); $s$, VENTRAL PROJECTION OF THE LATERAL KNOBS OF ADORAL SIDE; $t$ AND $t^{\prime}$, UNPAIRED MEDIAN ARTICULAR KNOB AND SOCKET.

amalgamation of the two arm ossicles in Onychaster is still plainly to be seen. The equivalent skeleton of the adambulacrals in the asterids is not yet completely separated from the arm ossicles nor developed into independent side or lateral shields; on the contrary, they still remain attached and in articulation with the arm ossicles on their ventral outer margin. On their somewhat fluted outer margin they bear a few spines. The arm ossicles are not externally naked but are covered by smaller additional plates that bear flat calcareous particles. Individual large dorsal shields do not appear to be present, for on the large Berlin specimen the arm ossicles lie directly beneath the small flat dorsal plates. Only in the distal part of the rays does one observe some rows of 
apparently independent dorsal plates, that overlie one another in a scalelike manner, but this determination needs to be substantiated on better preserved material. AJong the median line of the arm ossicles there lies ventrally a single column of ventral plates, that bear spines and externally cover the radial canal of the water vascular system. The lateral branches from the radial canal to the ambulacral podia do not penetrate the substance of the arm ossicles as in living ophiurids, but lie between each pair of vertebræ. The oral skeleton consists of five interradially placed mouth-corner pieces. Each one of these is made up of three elements, the two outer of which are united into pairs" (pp. 60-61).

Contains the following species:

O. flexilis Meek and Worthen. Keokuk.

0 . asper Miller. Keokuk.

0 . barrisi (Hall). Burlington.

O. confragosus Miller. Keokuk.

O. demissus Miller. Keokuk.

\section{ONYCHASTER FLEXIIIS Meek and Worthen.}

Text figs. 37 to 42 .

Onychaster flexilis MEEK and Worthen, Geol. Surv. Illinois, vol. 3, 1868, p. 526, figs. A-D; Proc. Acad. Nat. Sci. Philadelphia, vol. 21, 1869, p. 83; Geol. Surv. Illinois, vol. 5, 1873, p. 510, pl. 16, figs. 3a-3l.-ZrTteL, Handb. Pal., vol. 1, 1879 , p. 444 , fig. 314 .-MrLler, N. Amer. Geol. Pal., 1889, p. 264, fig. 374.ScHöNDORF, Jahrb. nassauisch. Ver. Naturk., Wiesbaden, vol. 62, 1909, pp. 47-61; vol. 63, 1910, p. 240.-I. B. J. Soluas, Philos. Trans. Roy. Soc. London, ser. B, vol. 204, 1913, pp. 51-62, text figs. 1-4, pl. 8, figs. 1-6.SchöNDORF, Jahrb. nassauisch. Ver. Naturk., Wiesbaden, vol. 66, 1913, pp. 97-114, text figs. 1, 2, pl. 3, figs. 3-9.-Spencer, Mon. Brit. Pal. Asterozoa, pt. 1 (Palæontogr. Soc. for 1913), 1914, pp. 26, 50.

Original description.- "The interesting fossil on which we propose to found this genus and species seems to differ so widely, in some of its characters, from the true starfishes, as well as from the Ophiurians, as to leave doubts whether it can be properly placed in either of these groups as now understood. * * * In habit and general appearance it most nearly resembles the Ophiurians, from which, however, it differs widely in structure. It is composed of a rather small subdiscoid body, and five long, slender, rounded, flexible arms or rays. In nearly all of the specimens yet found the arms are folded together like the claws of a bird when grasping some small object. A few of them, however, have the arms opened out more or less; so as to show that they were very flexible, or capable of being moved about in all directions. They usually increase slightly in thickness for a short distance from the body, then taper very gradually to their extremities, being about 2.50 inches in length, and 0.22 inch in breadth, at the widest part. 
"On the dorsal side of the body * * * there is seen a comparatively large circular area or disk, composed of an outer circle of ten rather prominent pieces, united together in five pairs by close-fitting sutures, each piece being pierced by a round ovarian? pore. Immediately within this circle there is, apparently, another circle of ten smaller pieces, also united in five pairs, but without pores; and within this latter circle there is a third range of five still smaller, nonporiferous pieces, surrounding a central anal? opening; the whole reminding one of the apical disk of an Echinoid, though differing in structure from this part of the known types of that group. It is also worthy of note that there is some analogy between this disk and the body of a crinoid, excepting that there is a central opening, and that the first division of the radial series takes place immediately on the inner range of pieces corresponding to the basal pieces of a crinoid, while all of the third range of pieces are pierced by pores. * * *

"Immediately outside of the circle of ten pore pieces, mentioned above, each pair of these pieces is succeeded by two or three pairs of diflerently formed, interlocking, transverse pieces, in direct range, connecting them with the dorsal side of each of the five rays. A little farther out the dorsal side of the rays, these transverse pieces are seen to become disconnected by more or less wide spaces, and gradually pass into pairs of lanceolate pieces, deeply furrowed longitudinally, while between the inner ends of the two pieces of each pair there appears to be a porelike opening. These latter disconnected pieces continue all the way out to the extremities of the rays, and, with numerous smaller intervening ossicles, form together, as it were, the skeleton or framework of the long flexible rays. It is only, however, when an outer granular integument has been removed that this skeleton structure can be seen. In some parts of some of our specimens this outer granular covering remains, and is seen to be composed of numerous small, rounded, rather prominent ossicles, regularly arranged in qui[n]cunx, so as to give the surface a chagreenlike roughness. These ossicles were doubtless attached to, and secreted by, a soft dermal envelope, covering the whole surface, while the larger pieces within formed the frame, as it were, of the whole structure, and probably furnished points of attachment for the muscles that moved the rays.

"None of our specimens show clearly the inner side or ambulacral furrows of the rays, nor the under side of the body-consequently we know nothing of the nature or position of the mouth or of the ambulacra. In several instances, however, we have seen the remains of one or more rows of small, short, longitudinally striated spines along the inner side of the arms.

$50601^{\circ}-$ Bull. $88-15--18$ 
"The entire breadth of a mature individual, across between the extremities of the rays on opposite sides, if these rays were straightened out, would be about 5 to 6 inches."

Formation and locality. - This species occurs quite commonly in the famous crinid bed at Crawfordsville, Indiana, in the Keokuk formation of the Mississippic. Specimens are in several American museums; two are at Yale University, others in the United States National Museum.

Cat. No. 59392, U.S.N.M.

\section{ONYCHASTER ASPER Miller.}

Onychaster asper Mruler, Seventeenth Rep. Geol. Surv. Indiana, 1892, p. 684, pl. 12, figs. 3-5; advance extras, 1891, p. 74, pl. 12, figs. 3-5.-MmLER, N. Amer. Geol. Pal., App. 1, 1892, p. 680, fig. 1240; App. 2, 1897, p. 749, fig. 1366.-Keyes, Missouri Geol. Surv., vol. 4, 1894, p. 131.

Original description.- "Dorsal side covered with an integument of small plates and numerous short spines. Central disk rather large, circular, convex, inflated from the point of contact with the arms. The outer integument covers the whole surface of the central disk, leaving no orifice exposed. Where the outer integument is worn off the disk is composed of rather large, polygonal spine bearing plates. The spines do not arise from the center of the plates, but laterally from little pits or sockets at the sutures. These sockets give the plates a somewhat sculptured appearance. The spines have a bulb at the base and taper to an obtuse point above.

"The arms are long, rounded on the dorsal side, and very flexible. Figure 4 shows the arms abruptly folded from the middle over the ventral part, while figures 3 and 5 have the arms folded like the claws of a bird grasping some small object. There is a row of spines on each side of the arm furrows.

"This species is so different from the type that the generic reference is very doubtful."

Formation and locality.- In the Keokuk formation of the Mississippic, at Boonville, Missouri. The specimens are said to be in the Miller and F. A. Sampson collections.

\section{ONYCHASTER BARRISI (Hall).}

Protaster ? burrisi HaLL, Desc. N. Sp. Crinoidea, 1861, p. 18.

Onychaster ? barrisi Meek and Worthien, Proc. Acad. Nat. Sci. Philadelphia, vol. 21, 1869, p. 83; Geol. Surv. Illinois, vol. 5, 1873, p. 476, pl. 10, figs. 1a-1d.

Hall's original description. - "A fragment of an Asterias, among the Burlington fossils, presents, in the rays and in the oral plates, some characters in common with Protaster; but I can discover no evidence of a central disk. The fragment preserves the center of the lower side and parts of four rays. All that remain of the rays are two distinct ranges of plates, which, near the base, are separated by a 
wide groove, but farther on appear to come in contact on their inner margins. These plates consist of joints closely articulated together, with a longitudinal foramen: their lower sides are marked lengthwise by a comparatively wide but not deep groove. The body of the plate has, on each side, a lateral arching process which is jointed at the two extremities, and separated in the center by a pore-like perforation. There are ten oral plates, two from each division of the ray: these plates are expanded vertically; their extreme points have the inner edges slightly curving; the lower external faces are slightly indented, or crenulate; the surface of attachment is wide and strong, and constricted at the base by a distinct groove, beyond which it again expands.

"This form, if really without a disk, differs essentially from Protaster; and there are also other differences, which may make it necessary to constitute a distinct genus when better specimens shall be obtained."

Formation and locality.--In the Burlington limestone at Burlington, Iowa. There are three specimens of this species in tlee Wachsmuth collection (Nos. 10, 11, and 12) at Harvard University.

ONYCHASTER CONFRAGOSUS Miller.

Onychaster confragosus MrrLer, Seventeenth Rep. Geol. Surv. Indiana, 1892, p. 684 , pl. 12, figs. 6,7 ; advance extras, 1891, p. 74, pl. 12, figs. 6,7 .

Original description.- "This species is so different from the one ast described [O. asper], and also from the type of this genus, that it may not be congeneric with either of them. I have no doubt that it belongs to the same family. I have seen only the dorsal side of the disk and the dorsal and lateral sides of the rays. There is no such integument of small plates covering the dorsal side as belongs to 0 . asper, but the surface is covered with short spines.

"The central part of the disk is somewhat injured in our specimens; and its character can not be definitely determined. It is surrounded by large, centrally convex, six-rayed plates. These rays seem to be the elevated ridges that separate the sockets for the insertion of the spines. Outside of this circle of ten six-rayed plates, there is a circle of quadrilateral plates more or less sculptured by the sockets for the spines, and here the radials may be said to commence. The dorsal side of each ray consists of three series of plates, and there is one series upon each side, or five series in an arm. The first plates are connected laterally by smaller ones, in the angular depressions, between the commencement of the rays, which form part of the disk. All of the radial plates are more or less sculptured by the depressions for the insertion of the spines. The spines are longer than the diameter of a plate, bulbous at the lower end, and taper to an obtuse point. The arms are long, round on the dorsal side, flexible and capable of being rolled up on the ventral side or being twisted laterally. No 
such ovarian pores piercing the plates of the disk, as described and illustrated in O. flexilis, have been discovered."

Formation and locality. - In the Keokuk formation, at Boonville, Missouri. The cotypes are said to be in the Miller collection.

\section{ONYCHASTER DEMISSUS Miller.}

Onychaster demissus MruLER, Seventeenth Rep. Geol. Surv. Indiana, 1892, p. 685, pl. 12, figs. 8-10; advance extras, 1891, p. 75, pl. 12, figs. 8-10; N. Amer. Geol. Pal., App. 1, 1892, p. 680, fig. 1241.

Original description.- "This species hangs its arms down and folds them like the claws of a bird grasping some small object, and in these respects is more like $O$. flexilis than either of the preceding species. The central disk is slightly concave, subpentagonal in outline, and the rays drop down at right angles to the circumference of the disk.

"In the center of the disk there is a low, subcircular elevation, in which I have been unable to find any sutures, or to determine whether or not there is an opening of any kind; it appears to consist of a single plate. It is surrounded by a series of ten plates that form the subpentagonal rim of the central disk. These plates are large, very convex, radiately sculptured, and bent down in the direction of the radial series as well as curving in to unite with the central plate. The sculpturing is due to the sockets for the insertion of the rays. The radial series commence from this circle of plates. The rays are angular on the dorsal side or obtusely rounded. The dorsal side of each ray consists of three series of plates, and there is one series on each side, or five series in an arm. The first two plates in each ray are connected laterally by smaller ones, which form part of the disk, in the angular depressions, between the commencement of the rays. All of the radial plates are more or less sculptured or pitted by the depressions for the insertion of the spines.

"The arms are longer, more angular, and have rather smaller spines than either of the preceding spocies. I have been unable to detect any ovarian pores, but spine sockets very müch resembling pores are indicated in figure 8 , but they occur in the sutures and are readily distinguished from pores that pierce the plates."

Formation and locality.-In the Keokuk formation, at Boonville, Missouri. The three cotypes are said to be in the Miller collection. There are two good specimens (No. 10994) in the Gurley collection at the University of Chicago, and another specimen, from Crawfordsville, Indiana, in Yale University.

FORMS WHOSE RELATIONSHIPS ARE UNKNOWN.

CRIBELLITES CARBONARIUS Tate.

Cribellites carbonarius Tate, Rept. Brit. Assoc. Adv. Sci., for 1863, 1864, Notices and abstracts, p. 88.

Original description. - "This Asteroid, the first recorded from the Mountain Limestone, is an impression of the upper surface, in a 
fine-grained micaceous sandstone. It is named Cribellites carbonarius; and the following characters are observable: Rays five, rounded, lanceolate, five times as long as the disk, ridged in the center, covered with longitudinal rows of reticulating tubercles; disk small and tuberculated. The disk is only 0.3 of an inch in diameter, while the rays are 1.5 inches in length. A circular impression in the disk may be the impression of the Madreporiform nucleus. In the form of this Asteroid, and in the characters observable, it is similar to Cribella rosea, Müller; but the rays are proportionally longer, the disk smaller, and the tubercles much nearer to each other than in the recent analogue. The sandstone from which the fossil Sea-star was obtained lies 20 feet above the Shilbottle coal, and about 600 feet below the base of the millstone grit, being in the upper part of the Mountain Limestone formation, which, in Northumberland, is about 3,000 feet in thickness. In this sandstone there also occur Strophomena crenistria and the remains of carboniferous plants."

\section{Order OPHIOCISTIA Sollas.}

Ophiocistia Solmas, Quart. Journ. Geol. Soc. London, vol. 55, 1899, pp. 692, 700.Soluas and Soluas, Philos. Trans. Roy. Soc. London, ser. B, vol. 202, 1912, pp. 214, 222.

An anomalous order of free Echinoderma.

"The Ophiocistia are Ophiuroidea with five paired series of appendages, proceeding from the ventral surface of a plated test; and in which vertebral ossicles are absent or insignificant" (p. 700).

Contains but one family, the Eucladiidæ.

Remarks. - That Eucladia and Euthemon, the genera belonging to this order, are ophiurids is said to be apparent from the following: "The absence of any openings on the dorsal surface, and of any indication of an anus, the ventral position of the madreporite, and the sharp distinction of the arms from the test." On the other hand, they differ from all known ophiurids in several important particulars:

"The structure and disposition of the arms is unlike anything known among either the Ophiuræ or the Euryalæ, and finds no parallel among any group of fossil Opniuroidea. If we consider the disposition of the arms first, we find as a constant character among the rest of the Ophiuroidea the extension of five of these appendages over the ventral surface of the disk as far as the buccal aperture; the vertebral ossicles of the arms are also serially represented in the buccal armature. In the Eucladiidæ also the arms are given off from the ventral surface of the test, and the first pair have their origin in the outer distal angle of the jaws; if, however, we are to regard the serial arms of Eucladiidæ as the free extremities of lateral 
branches given off in pairs from a median hypothetical arm, then we must admit that the branching takes place within the test to an extent otherwise unknown within the class. If we turn next to the structure of the arms, we find no less striking peculiarities. No decisive evidence exists to prove that vertebral ossicles are present, but if they are they must be out of all proportion small compared with the lumen of the arm. Since the cavity of the arm is almost entirely unoccupied by skeletal structures, the question naturally arises as to the nature of the soft parts which it contained. The distal arms are so large that they might well have afforded room for extensions of the digestive viscera from the test. The absence of visible apertures in the arms is another very puzzling feature, and one is almost tempted to inquire whether the paired appendages are to be compared with arms at all.

"The nature of the buccal armature is very different from that of any other Ophiuroid, though there is a certain amount of correspondence in the paired structure of its five pieces. The absence of any opening that could be taken for bursal apertures is noteworthy."

\section{Family EUCLADIID $\circledast$ Gregory.}

Eucladiidx Gregory, Proc. Zool. Soc. London for 1896, 1897, p. 1040.-SoldAS, Quart. Journ. Geol. Soc. London, vol. 55, 1899, p. 692.-STÜrTz, Verh. naturh. Ver. preuss. Rheinl., etc., vol. 56, 1900, p. 204.-SснӧNDoRf, Jahrb. nassauisch. Ver. Naturk., Wiesbaden, vol. 63, 1910, p. 236.

Contains the genera:

Eucladia Woodward.

Euthemon Sollas.

\section{Genus EUCLADIA Woodvard.}

Plates 37, 38.

Eucladia johnsoni H. WoodWard, Geol. Mag., vol. 6, 1869, p. 241, pl. 8.-ZrTTEL, Handb. Pal., vol. 1, 1879, p. 443.-STürTz, Verh. naturh. Ver. preuss. Rheinl., etc., vol. 50, 1893, p. 30.-Gregory, Proc. Zool. Soc. London for 1896, 1897, p. 1040, fig. 6 on p. 1041.-Sollas, Quart. Journ. Geol. Soc. London, vol. 55, 1899, p. 692.-STürTz, Verh. naturh. Ver. preuss. Rheinl., etc., vol. 56,1900 , p. 183.-ScHöNDORF, Jahrb. nassauisch. Ver. Naturk., Wiesbaden, vol. 62, 1909, p. 47; vol. 63, 1910, p. 240.-Soluas and Soluas, Philos. Trans. Roy. Soc. London, ser. B, vol. 202, 1912, pp. 214, 222.-SPEncer, Mon. Brit. Pal. Asterozoa, pt. 1 (Palæontogr. Soc. for 1913), 1914, p. 50.

This genus has seven pairs of arms in each radius, or 35 in all. These are covered with finely scaly integument.

Genoholotype.-E. johnsoni Woodward (citations as above), Lower Ludlow formation, at Sedgley, near Dudley, England. Other species are $E$. woodwardi Sollas, also from the Lower Ludlow, at Leintwardine, England, and $E$. ? beecheri, new species, from the Lower Devonic Coeymans limestone, New York. 
EUCLADIA WOODWARDI Sollas.

Plate 37, figs. 1, 2.

Eucladia woodwardi Soluss, Quart. Journ. Geol. Soc. London, vol. 55, 1899, p. 695 , figs. 1 and 2 on p. 694.

Original description.-Ten specimens "agree in presenting five paired series of appendages, proceeding from the ventral surface of the body, which now possesses a more or less oval outline. The specimens are all of nearly the same size, the central body measuring about 2 by $3 \mathrm{~cm}$, the longest arms $2.5 \mathrm{~cm}$. in length, and about $3 \mathrm{~mm}$. in breadth where broadest. Not more than four, possibly only three, pairs of arms can be traced in connection with each radius, but an additional pair may have existed close to the buccal armature, and have since become crushed out of recognition.

"The dorsal surface [fig. 1].-This is completely covered by numerous rounded polygonal or irregular scales, about $0.2 \mathrm{~mm}$. thick and not exceeding $5 \mathrm{~mm}$. in diameter; their surface is richly granulated. They are not arranged according to any discoverable law, though there may be a tendency to run parallel with the ambitus. In their present state they overlap each other to such an extent that one plate may be half concealed by another; no doubt they were imbricated during life, but the excessive overlap now presented is probably due in part to crushing. The direction of the imbrication is upward, that is, in the direction opposite to that of tiles on a roof, and thus resembles the imbrication of the dorsal surface of a recent Ophiuroid. The plates are all of the same nature, and there are no openings on the dorsal surface.

"The ventral surface [fig. 2].-In the center the powerful buccal armature is a very conspicuous object. It consists of five pairs of strong plates or ossicles, precisely similar in their form and arrangement to those of Eucladia johnsoni. Around the armature are numerous small plates, irregularly disposed; from their form and size these may be regarded as elements of the test, though they may possibly include remains of crushed arms. If, as judging from analogy we might suppose, minute arms proceeded from the outer angles of the jaws, they have since disappeared.

"Outside the irregularly scattered small plates larger ones are seen arranged; along the five radii these are escutcheon-shaped, imbricated, and form a single series of three. Distally, each plate is produced into three processes, a single median and two lateral; the angle formed by the side of the plate and each lateral process is rounded and thickened to form one side of a circular aperture for the passage or insertion of the arm, and the other half of the aperture is completed by the thickened margin of a similarly exca- 
vated adjacent or adradial plate. The adradial plates form a pair, which meet in the interradius. The arrangement is similar to that which occurs in the genus Euthemon, to be next described; in the latter, however, the plates are not overlapping, but tesselated. The overlapping of the plates is less on the ventral than on the dorsal side, a difference which is probably due to the less amount of displacement suffered by the ventral plates; and this, again, is explicable on the assumption that the ventral surface was flatter than the dorsal.

"The arms.- The arms of this species do not exhibit that marked increase in size, as their position in the series becomes more distal, which is characteristic of Eucladia johnsoni. Their average length is $25 \mathrm{~mm}$. Near their tapering extremities the arms present on both dorsal and ventral surface three plates, two of which are lateral and one median, recalling the characteristic plating of an Ophiuroid arm; but nearer the origin the number of conspicuous plates on either surface is increased to four or even more, and smaller supplemental plates are inserted between them in a manner precisely similar to that already described in the case of Eucladia johnsoni. The larger plates, swollen at first and becoming mucronate finally, are produced into a short awn-like termination.

"A search, which proved unsuccessful, was made for some trace of vertebral ossicles; had these structures been present originally, they must either have been very small or some traces would still be discernible. In Lapworthura, which occurs in the same rocks, the vertebral ossicles are the most obvious elements in the brachial skeleton.

"The distinction of Eucladia woodwardi from $E$. johnsoni rests on the smaller number of arms possessed by the former and the closer approach of these to equality in dimensions. The specimen selected as the 'type' is exhibited in the Oxford University Museum, and bears a label stating where its description may be found."

Formation and locality.-In the Lower Ludlow, Leintwardine, England.

\section{EUCLADIA (?) BEECHERI, new species.}

\section{Plate 38, fig. 1.}

As this problematic fossil is of considerable interest, it is thought best to make it known in this work, even though the preservation is not good. The general characters are easily seen in the specimen, however, and much better than can be shown by photography, but in detail very little can be made out. The fossil lies in a dense dark limestone beneath the surface of a parting between two beds 
of stone. Originally but a few of the arms showed, and it was at once seen by the late Professor Beecher that he had found something very different from a crinid. He bestowed a great deal of skill and labor on the fossil later on, bringing it out to its present relief, and in this condition it has remained since 1901, the year of its collection. It seemed to both Professor Beecher and the writer that it was an early form of branching or basket star, recalling the living Astrophyton. Recently, since reading the work of Sollas on Eucladia, it became clear that this view could not be maintained.

The specimen seemingly shows the ventral side.

The disk is large and distinctly pentagonal, and from its five corners radiate the more or less coiled rays. Disk composed of decidedly thick plates, apparently closely adjoining, but their arrangement is too much disturbed and crystalline to make out. $\mathrm{R}=$ ? about $13 \mathrm{~mm}$., $r=10.5 \mathrm{~mm}$., $\mathrm{R}$ to edge of rays averaging $22 \mathrm{~mm}$.

Rays apparently completely circular in outline and corered by an abundance of imbricating scales, of which there are about five across the diameter of a ray. The average diameter of the rays is between 1.5 and $2 \mathrm{~mm}$. As the rays are crystalline the nature of the internal skeleton can not be made out further than that there are vertebræ present. Each radius appears to have 4 pairs of arms, there being therefore 40 in all, but their-situation in the disk and how they appear during growth cannot be made out. Three pairs are of the same size throughout, while the fourth pair, which lies upon the others, seems to be about half grown, and if there is no decided distortion of the disk plates, these appeared alternately, first on one side and then on the other. In Eucladia the 30 rays are practically all alike, but in Euthemon the 20 arms are equally divided between full and half grown ones.

Formation and locality.-From about the middle of the Coeymans limestone of the Helderbergian (Lower Devonic), at Jerusalem Hill, Litchfield, Herkimer County, New York. The holotype is in the Peabody Museum of Yale University.

\section{Genus EUTHEMON Sollas.}

Euthemon igerna Sollas, Quart. Journ. Geol. Soc. London, vol. 55, 1899, p. 696, figs. 3 and 4 on p. 698. - Sollas and Sollas, Philos. Trans. Roy. Soc. London, ser. B, vol. 202, 1912, p. 222.

This genus is very similar to Eucladia, but differs at once in having but 4 arms in each radius, or 20 in all; 10 of these are more than twice as long ( 12 to $13 \mathrm{~mm}$.) as the others ( $5 \mathrm{~mm}$.).

Genoholotype and only species.-E. igerna Sollas, from the Wenlock limestone, Croft farm, Malvern, England. 


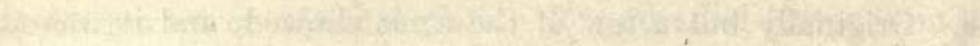

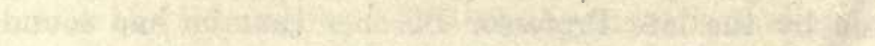

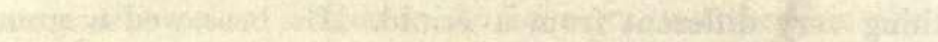
2. The

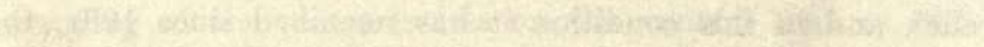

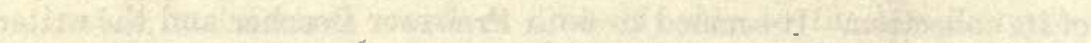

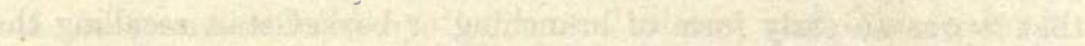

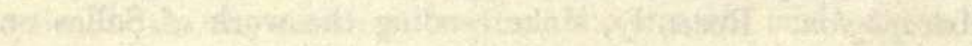

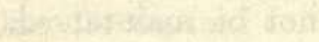

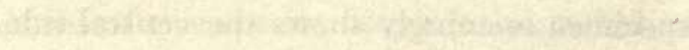




\section{BIBLIOGRAPHY. ${ }^{1}$}

BAILY, W. H.

1878. In KINAHAN, Manual of the geology of Ireland. (Palasterina kinahani.)

1879. Palaeontological notes. Mem. Geol. Surv. Ireland, Expl. Mem. Sheets $169,170,180,181$, pp. 5-60.

BATHER, F. A.

1905. Sympterura Minveri, n. g. et sp.: a Devonian Ophiurid from Cornwall. Geol. Mag., dec. 5, vol. 2, pp. 161-169, pl. 6; and Trans. R. Geol. Soc. Cornwall, vol. 13, pp. 71-85, pl. 2.

BeLL, F. J.

1892. A contribution to the classification of Ophiuroids, with descriptions of some new and little-known forms. Proc. Zool. Soc. London for 1892, pp. 175-183, pls. 11, 12. (Important for classification.)

BILLINGs, E.

1857. New species of fossils from the Silurian rocks of Canada. Geol. Surv. Canada, Rept. Progress for 1853-1856, pp. 256-345. (Palasterina stellata, P. rigidus, $P$. rugosus, Palæaster pulchellus, Palæocoma spinosa, P.cylindrica.)

1858. On the Asteriadæ of the Lower Silurian rocks of Canada. Geol. Surv. Canada, Canadian Organic Remains, dec. 3, pp. 75-85. (Stenaster, S. salteri, Petraster, Tæniaster.)

1860. Description of a new Palæozoic starfish of the genus Palæaster, from Nova Scotia. Canadian Nat. and Geol., vol. 5, pp. 69-70, fig. (P. parviusculus.)

1865. Palæozoic fossils, vol. 1. Geol. Surv. Canada. (Btenaster huxleyi, Petraster bellulus.)

Chapman, $\mathrm{F}$.

1907. New or little-known Victorian fossils in the National Museum. Part 8. Some Palæozoic brittle-stars of the Melbournian series. Proc. Roy. Soc. Victoria, new ser., vol. 19, pt. 2, pp. 21-27, pls. 6-8. (Gregoriura, G. spryi, Sturtzura leptosomoides.)

Clarke, John M.

1906. Second report, Director of the Science Division, N. Y. State Mus., for 1905, p. 37.

1908. A Devonic brittle-star. Bull. N. Y. State Mus., No. 121, pp. 61-64, pls. 10-13. (Helianthaster gyalum, H. roemeri.)

1912. A remarkable occurrence of Devonic starfish. Bull. N. Y. State Mus., No. 158, pp. $44-45,6$ pls.

1913. Fosseis devonianos do Paraná. Monog. Serv. Geol. Min. Brasil, vol. 1. (Aspidosoma ? pontis, Echinasterella? darwini.)

Clarke, John M., and Swartz, C. K.

1913. Systematic paleontology of the Upper Devonian deposits of Maryland. Echinodermata. Maryland Geol. Surv., Middle and Upper Dev., pp. 543-544, pl. 46, figs. 3, 4. (Palæaster clarki.)

Cole, A. H.

1892. Palæaster eucharis, Hall. Bull. Geol. Soc. America, vol. 3, pp. 512-514, pl. 15.

DAVY, L.

1887. Note sur un ophiure (Protaster daoulasensis) du Dévonien inférieur de la rade de Brest. Bull. Soc. géol. de France, sér. 3, vol. 14, pp. 182-187, 5 text figs.

1 Genera and species listed in parentheses after a paper cited are those the original description of which is to be found in that paper. 
Dewalque, G.

1880. Fragments paléontologiques. Ann. Soc. géol. Belgique, vol. 8, pp. 43-54, pls. 1-3. (Protaster decheni.)

Etheridge, R., jr.

1891. On the occurrence of the genus Palæaster in the Upper Silurian rocks of Victoria. Rec. Australian Mus., vol. 1, No. 10, pp. 199-200, pl. 30.

1892. A monograph of the Carboniferous and Permo-Carboniferous Invertebrata of New South Wales, pt. 2, Echinodermata, Annelida and Crustacea. Mem. Geol. Surv. New South Wales, Pal., No. 5, pp. 65-133, pls. 12-22. (Palæaster (Monaster) stutchburii and $P$. (M.) giganteus.)

1899. On the occurrence of a starfish in the Upper Silurian series of Bowning, New South Wales. Rec. Australian Mus., vol. 3, No. 5, pp. 128-129. (Proposes Sturtzaster for Palæocoma Salter; S. (?) mitchelli.)

Foerste, A. F.

1914. Notes on the Lorraine faunas of New York and the Province of Quebec. Bull. Sci. Lab. Denison Univ., vol. 17, pp. 247-340, pls. 1-5. (Tæniaster meafordensis.)

Forbes, E.

1848. On the Asteriadæ found fossil in British strata. Mem. Geol. Surv. Great Britain, vol. 2, pt. 2, pp. 457-482. (Uraster hirudo, U. obtusus, U. primævus, U. ruthveni.)

1849. British organic remains. Mem. Geol. Surv. United Kingdom, dec. 1, pls. 1, 4. (Protaster, P. sedgwickii.)

1850. British organic remains. Mem. Geol. Surv. United Kingdom, dec. 3, pl. 1. (Lepidaster, L. grayi.)

1851. In McCoy, British Palæozoic fossils, pp. 59-61.

Goldfuss, A.

1848. Ein Seestern aus der Grauwacke. Verh. naturh. Ver. preuss. Rheinl., etc., vol. 5, pp. 145-146, pl. 5. (Aspidosoma, A. arnoldi.)

Gregory, J. W.

1889. On a new species of the genus Protaster ( $P$. brisingoides) from the Upper Silurian of Victoria, Australia. Geol. Mag., dec. 3, vol. 6, pp. 24-27, woodcut.

1897. On the classification of the Palæozoic echinoderms of the group Ophiuroidea. Proc. Zool. Soc. London for 1896, pp. 1028-1044, text figs. (Important for classification. Tæniura, Sturtzura, Eospondylus, Lapworthura, Miospondylus, Protaster biforis.)

1899. On Lindstromaster and the classification of the Palæasterids. Geol. Mag., dec. 4, vol. 6, pp. 341-354, pl. 16, text figs. (Lindstromaster, Uranaster, Etheridgaster, Schuchertia, Palasterina bonneyi, Palæaster caractaci.)

1900. In Lankester, A treatise on Zoology, pt. 3, Echinoderma, Chapter 14. (Important for classification and structure.)

HAECkel, E. H.

1866. Generelle Morphologie der Organismen. (Encrinaster.)

HALFAR, A.

1893. Die erste Asteride aus den paläozoischen Schichten des Harzes. Jahrb.

k. preuss. geol. Landesanst. u. Bergakad., Berlin, 1892, vol. 13, pp. 186199, pl. 10. (Aspidosoma petaloides goslariensis.)

HALL, J.

1847. Natural history of New York. Palæontology, vol. 1. (Asterias matutina.) 1852. Natural history of New York. Palæontology, vol. 2. (Palæaster, P. niagarensis.)

1859. Natural history of New York. Palæontology, vol. 3. (Protaster forbesi.)

1861. Descriptions of new species of Crinoidea. Preliminary notice. (Protaster ? 
HaLL, J.-Continued.

1868. Contributions to palæontology. 12. Note on the genus Palæaster and other fossil starfishes. Twentieth Rept. New York State Cab. Nat. Hist., pp. 282-303, pl. 9; also revised edition, 1868-1870, pp. 324-345, pl. 9. (Palæaster shafferi, P. granulosus, $P$. eucharis, Ptilonaster, $P$. princeps, Eugaster, E. logani.)

Hrcks, H.

1873. On the Tremadoc rocks in the neighborhood of St. David's, South Wales, and their fossil contents. Quart. Journ. Geol. Soc., London, vol. 29, pp. 39-52, pls. 3, 4. (Palasterina ramseyensis.)

HuDson, G. H.

1912. A fossil starfish with ambulacral covering plates. Ottawa Naturalist, vol. 26, pp. 21-26, 45-52, pls. 1-3. (Protopalæaster, P. narrawayi.)

1913a. The use of the stereogram in paleobiology. Bull. New York State Mus., No. 164, pp. 103-130, pls. 1-13. (Stereograms of Mesopalæaster parviusculus, Hudsonaster narrawayi, and Palzaster niagarensis.)

1913b. Does the type of Protopalæaster narrawayi present the oral or aboral aspect? Ottawa Naturalist, vol. 27, pp. $77-84$, pls. 8,9 .

JAEKEL, O.

1903. Asteriden und Ophiuriden aus dem Silur Böhmens. Zeits. d. d. geol. Gesell., vol. 55, Protok., pp. 13-20 (106-113), text figs. (Ataxaster, A.

JAMES, J. F. pygmæus, Siluraster, S. perfectus, Bohemura, B. jahni, Eophiura, Palæura.)

1896. Manual of the paleontology of the Cincinnati group, pt. 7. Journ. Cincinnati Soc. Nat. Hist., vol. 18, pp: 115-140.

DE KONINCK; L.

1878. Recherches sur les fossiles paléozoiques de la Nouvelle-Galles du Sud (Australie), pt. 3. Mem. Soc. Roy. Sci., Liège, sér. 2, vol. 7, pp. 1-255, pls. 5-24. (Palæaster clarkei.)

1898. Descriptions of the Palæozoic fossils of New South Wales (Australia). Mem. Geol. Surv. New South Wales, Pal., No. 6.

\section{LOCKE, J.}

1848. [Notice of an Asterias from the Blue Limestone of Cincinnati]. Proc. Acad. Nat. Sci., Philadelphia, for 1846-1847, vol.3, pp.32-34, text fig. (Asterias antiquata.)

McCor, F.

1874. Prodromus of the palæontology of Victoria. Geol. Surv. Victoria, dec. 1.

MEeK, F. B. (Petraster smythi, Urasterella selwyni.)

1872a. Description of two new star-fishes, and a crinoid, from the Cincinnati group of Ohio and Indiana. Amer. Journ. Sci., ser. 3, vol. 3, pp. 257-262. (Palæaster? dyeri, Stenaster grandis.)

1872b. Descriptions of a few new species and one new genus of Silurian fossils from Ohio. Amer. Journ. Sci., ser. 3, vol. 4, pp. 274-281. (Protaster? granuliferus, Palæaster incomptus, $P$.granulosus, $P$. speciosus, Alepidaster.)

1873. Descriptions of the invertebrate fossils of the Silurian and Devonian systems. Geol. Surv. Ohio, Pal., vol. 1, pp. 1-243, pls. 1-23, text figs.

Meek, F. B., and Worthen, A. W.

1861. Descriptions of new Carboniferous fossils from Illinois and other Western States. Proc. Acad. Nat. Sci., Philadelphia, for 1860, vol. 12, pp. 447-472. (Schonaster, S. fimbriatus.)

1862. Descriptions of new Palæozoic fossils from Illinois and Iowa. Proc. Acad. Nat. Sci., Philadelphia, for 1861, vol. 13, pp. 128-148. (Petraster wilberanus.) 
Meex, F. B., and Worthen, A. W.-Continued.

1866a. Descriptions of invertebrates from the Carboniferous system. Geol. Surv. Illinois, vol. 2, pp. 145-411, pls. 14-32.

1866b. Contributions to the palæontology of Illinois and other Western States. Proc. Acad. Nat. Sci., Philadelphia, for 1866, vol. 18, pp. 251-275. (Schœnaster wachsmuthi.)

1868. Palæontology. Geol. Surv. Illinois, vol. 3, pp. 291-565, pls. 1-20, text figs. (Onychaster, O. flexilis.)

1869a. Descriptions of new Crinoidea and Echinoidea from the Carboniferous rocks of the Western States, with a note on the genus Onychaster. Proc. Acad. Nat. Sci., Philadelphia, for 1869, vol. 21, pp. 67-83.

1869b. Descriptions of new Carboniferous fossils from the Western States. Proc. Acad. Nat. Sci., Philadelphia, for 1869, vol.21, pp. 137-172. (Protaster? gregarius.)

1873. Palæontology of Illinois. Geol. Surv. Illinois, vol. 5, pp. 323-619, pls. 1-32. MrLLeR, S. A.

1878. Description of a new genus and eleven new species of fossils. Journ. Cincinnati Soc. Nat. Hist., vol. 1, pp. 100-108, pl.3. (Palæaster longibrachiatus, $P$. clarkei.)

1879. Description of twelve new fossil species, and remarks upon others. Journ. Cincinnati Soc. Nat. Hist., vol. 2, pp. 104-118, pls. 9, 10. (Palæaster harrisi.)

1880a. Description of two new species from the Niagara group, and five from the Keokuk group. Journ. Cincinnati Soc. Nat. Hist., vol. 2, pp. 254-259, pl. 15. (Palæaster crawfordsvillensis.)

1880b. Description of four new species of Silurian fossils. Journ. Cincinnati Soc. Nat. Hist., vol. 3, pp. 140-144, pl. 4. (Palæaster miamiensis.)

1880c. Description of four new species and a new variety of Silurian fossils, and remarks upon others. Journ. Cincinnati Soc. Nat. Hist., vol. 3, pp. 232-236, pl. 7. (Palæaster clarkana.)

1881. Description of some new and remarkable crinoids and other fossils of the Hudson River group. Journ. Cincinnati Soc. Nat. Hist., vol. 4, pp.69-77, pl. 1. (Palæaster exculptus.)

1882a. Description of two new genera and eight new species of fossils from the Hudson River group, with remarks upon others. Journ. Cincinnati Soc. Nat. Hist., vol. 5, pp. 34-44, pls. 1,2. (Tæniaster elegans.)

1882b. Description of three new species, and remarks upon others. Journ. Cincinnati Soc. Nat. Hist., vol. 5, pp. 116-117, pl.5. (Protaster miamiensis.)

1884. Description of a beautiful star fish and other fossils. Journ. Cincinnati Soc. Nat. Hist., vol. 7, pp. 16-20, pl. 4. (Palæaster magnificus.)

1889. North American geology and palæontology. First appendix, 1892; Second appendix, 1897.

1892. Palæontology. Seventeenth Rept. Geol. Surv. Indiana, pp. 611-705, pls. 1-20; Advance extras, 1891. (Onychaster asper, O. confragosus, and 0. demissus.)

Mruler, S. A., and Dyer, C. B.

1878a. Contributions to palæontology. Journ. Cincinnati Soc. Nat. Hist., vol. 1, pp. 24-39, pls. 1-2. (Palæaster simplex, P. spinulosus, Palæasterina approximata, P. speciosa, Protaster flexuosus.)

1878b. Contributions to palæontology, No. 2. Privately printed. (Palæaster dubius.)

Muler, S. A., and Gurlete, W. F. E.

1891. Description of some new genera and species of Echinodermata from the Coal Measures and Subcarboniferous rocks of Indiana, Missouri, and Iowa. Sixteenth Rept. Geol. Surv. Indiana, pp. 327-373, pls. 1-10; Advance extras, 1890. (Schoenaster legrandensis, Aganaster.) 
Miller, S. A., and Gurley, W. F. E.-Continued.

1897. New species of crinoids, cephalopods, and other Palæozoic fossils. Bull.

MÜLLER, J. Illinois State Mus. Nat. Hist., No. 12. (Palæaster wykoffi.)

1855. In Zeiner and Wirtaen, Bemerkungen über die Petrefacten der ältern devonischen Gebirge am Rheine, etc.; Verh. d. naturh. Ver. preuss. Rheinl., etc., vol. 12, pp. 1-28, pls. 1-9a. (Asterias rhenana.)

Murchison, R. I.

1854. Siluria.

Nicholson, H. A., and Etheridge, R., JR.

1880. A monograph of the Silurian fossils of the Girvan District in Ayrshire, fasc. 3. (Tetraster, T. wyville-thomsoni.)

D'Orbigny, A. D.

1849. Prodrome de Paléontologie, vol. 1. (Cœlaster americanus.)

Parks, W. A.

1908. Notes on the ophiuran genus, Protaster, with description of a new species.

Trans. Canadian Inst., vol. 8, pp. 363-372, 1 pl. (Gives summary of history of genus. $P$. whiteavesianus.)

Quenstedt, F. A.

1876. Petrefactenkunde Deutschlands, vol. 4, Asteriden und Encriniden.

RAYMOND, P. E.

1912a. On two new Paleozoic starfish (one of them found near Ottawa), and a new crinoid. Ottawa Naturalist, vol. 26, pp. 77-81, pl. 5, 2 text figs. (Palæaster? wilsoni, Schœnaster? montanus.)

1912b. On the nature of the so-called "covering plates" in Protopalæaster narrawayi. Ottawa Naturalist, vol. 26 , pp. 105-108, pl. 6.

Ringueberg, E. N. S.

1886. New genera and species of fossils from the Niagara shales. Bull. Buffalo Soc. Nat. Sci., vol. 5, pp. 5-22, pls. 1,2. (Squamaster, S. echinatus, Protaster stellifer, Eugaster concinnus.)

ROEMER, F.

1863. Neue Asteriden und Crinoiden aus devonischem Dachschiefer von Bundenbach bei Birkenfeld. Palæontographica, vol. 9, pp. 143-152, pls. 2329. (Aspidosoma tischbeinianum, Asterias asperula, A. spinosissima, Helianthaster, H. rhenanus.)

Ruedemann, R.

1912. The Lower Siluric shales of the Mohawk valley. Bull. N. Y. State Mus., No. 162. (Tæniaster schohariæ.)

SALTER, J. W.

1857. On some new Palæozoic star-fishes. Ann. Mag. Nat. Hist., ser. 2, vol. 20, pp. 321-334, pl. 9. (Palæocoma, P. marstoni, $\Gamma$. colvini, P. cygnipes, Bdellacoma, B. vermiformis, Rhopalocoma, R. pyrotechnica, Palæaster asperrimus, $P$. coronella, Palasterina, Protaster miltoni, $P$. leptosoma.)

1861. Additional notes on some new Palæozoic star-fishes. Ann. Mag. Nat. Hist., ser. 3, vol. 8, pp. 484-486, pl. 18, figs. 9-11.

1866. On the fossils of North Wales. Mem. Geol. Surv. Great Britain, vol. 3, App., pp. 240-381, pls. 1-28. (Palæaster imbricatus.)

Salter, J. W., and Sowerby, J. de C.

1845. In SEDGwick, On the Older Palæozoic (Protozoic) rocks of North Wales. Quart. Journ. Geol. Soc., London, vol. 1, pp. 5-22. (Ophiura salteri and Asterias primæva listed in table, without description.)

SANDberger, G., and Sandberger, F.

1850-1856. Die Versteinerungen des rheinischon Schichtensystems in Nassau. (Colaster, C. latiscutatus.) 
ScHöNDORF, F.

1907a. Ueber einen fossilen Seestern Spanister latiscutatus Sandb. spec. aus dem Naturhistorischen Museum zu Wiesbaden. Jahrb. nassauisch. Ver.f. Naturk., Wiesbaden, vol.60, pp. 170-176, 3 text figs. (Spaniaster.)

1907b. Ueber Archæasterias rhenana Joh. Müller und die Porenstellung paläozoischer Seesterne. Centralb. f. Mineral., etc., pp. 741-750, 6 text figs.

1909a. Paläozoische Seesterne Deutschlands. I. Die echten Asteriden der rheinischen Grauwacke. Palæontographica, vol. 56, pp. 37-112, text figs., pls. 7-11. (Agalmaster, A. grandis, A. intermedius, A. miellensis, Rhenaster, R. schwerdi, Trimeraster, T. parvulus, Eifelaster, E. follmanni, Xenaster dispar, $X$. elegans.)

1909b. Die Asteriden des russischen Karbon. Palæontographica, vol. 56, pp. 323-338, text fig., pls. 23, 24.

1909c. Die fossilen Seesterne Nassaus. Jahrb. nassauisch. Ver. f. Naturk., Wiesbaden, vol. 62, pp. 7-46, text figs., pls. 2-5. (Discusses skeletal structure of asterids; Miomaster, M. drevermanni.)

1909d. Organization und Aufbau der Armwirbel von Onychaster. Jahrb. nassauisch. Ver. f. Naturk., Wiesbaden, vol. 62, pp. 47-63, pl. 6.

1910a. Ueber einige "Ophiuriden und Asteriden" des englischen Silur und ihre Bedeutung für die Systematik paläozoischer Seesterne. Jahrb. nassauisch. Ver. f. Naturk., Wiesbaden, vol. 63, pp. 206-256, text figs. (Important for classification.)

1910b. Paläozoische Seesterne Deutschlands. II. Die Aspidosomatiden des deutschen Unterdevon. Palæontographica, vol. 57, pp. 1-63, pls. 1-3. (Discusses structure and systematics of group in much detail. Erects a new order, Auluroidea. Aspidosoma goldfussi. A.roemeri, A. eifelense.)

1910c. Aspidosoma schmidti nov. spec. Der erste Seestern aus den Siegener Schichten. Jahrb. k. preuss. geol. Landesanst. und Bergakad., Berlin, vol. 29, 1908, pt. 1, pp. 698-708, 1 pl.

1913a. Palaeaster eucharis Hall aus dem nordamerikanischen Devon. Jahrb. nassauisch. Ver. f. Naturk., Wiesbaden, vol. 66, pp. 87-96, text figs. 1, 2, pl. 3, figs. 1, 2.

1913b. Ueber Onychaster, einen Schlangenstern aus dem Karbon. Jahrb. nassauisch. Ver. f. Naturk., Wiesbaden, vol. 66, pp. 97-116, text figs. 1, 2, pl. 3, figs. 3-12.

Schuchert, C.

1914. Fossilium Catalogus, I : Animalia, pars 3, Stelleroidea palaeozoica.

Stmonovitsch, S.

1871. Ueber einige Asterioiden der rheinischen Grauwacke. Sitzb. d. mat.naturw. Classe d. k. Akad. d. Wiss., Wien, vol. 64, Abt. 1., pp. 77-122, pls. 1-4. (Xenaster, $X$. margaritatus, $X$. simplex, Asterias acuminatus, Aspidosoma petaloides.)

Sollas, I. B. J.

1913. On Onychaster, a Carboniferous brittle-star. Philos. Trans. Roy. Soc. London, ser. B, vol. 204, pp. 51-62, text figs. 1-5, pls. 8, 9.

Sollas, W. J.

1899. Fossils in the University Museum, Oxford: I. On Silurian Echinoidea and Ophiuroidea. Quart. Journ. Geol. Soc., London, vol. 55, pp. 692-715, text figs. (Erects new order, Ophiocistia. Eucladia woodwardi, Euthemon, E. igerna.)

Soluas, W. J., and Soluas, I. B. J.

1912. Lapworthura: a typical brittle-star of the Silurian age. Philos. Trans.

Roy. Soc. London, ser. B, vol. 202, pp. 213-232, text figs. 1-5, pls. 9, 10.

(Rhodostoma, Protaster groomi.) 
SPencer, J. W.

1884. Niagara fossils, Pt. 3. Bull. Mus. Univ. State Missouri, No. 1, pp. 52-61, pls. 7,8. (Palæaster granti.)

Spencer, W. K.

1914. A monograph of the British Palæozoic Asterozoa. Pt. 1. Palæontogr. Soc. for 1913, pp. 1-56, text figs. 1-31, pl. 1. (Eoactis, E. simplex, Uranaster elizæ, Aspidosoma grayæ, Lapworthura sollasi.)

STSCHUROWSKY.

1874. Nachr. d. Moskauer Gesell. d. Liebhaber d. Naturges. (Asterias montanus.) Not seen.

STürtz, B.

1886a. Ueber paläozoische Seesterne. N. Jahrb. f. Mineral., etc., vol. 2, pp. 142-154. (Hallaster.)

1886b. Beitrag zur Kenntniss paläozoischer Seesterne. Palæontographica, vol.32, pp. 75-98, pls. 8-14. (Ophiurella, O. primigenia, Roemeraster, R. asperula, Astropecten schlüteri, Eoluidia, $E$. decheni, Protasteracanthion, P. primus, Furcaster, F. palæozoicus, Bundenbachia, B. beneckei, B. grandis, Palastropecten, P. zitteli, Loriolaster, L. mirabilis, Palasteriscus, $P$. devonicus.)

1890. Neuer Beitrag zur Kenntniss paläozoischer Seesterne. Palæontographica, vol. 36, pp. 203-247, pls. 26-31. (Echinasterella, E. sladeni, Cheiropteraster, C. giganteus, Medusaster, M. rhenanus, Palæostella, P. solida, Ophiurina, O. lymani, Palæophiura, P. simplex, Palasterina follmanni. Describes additional material of forms dealt with in 1886, revises other species, discusses structure, systematics, habits, etc., of Paleozoic ophiurids and asterids.)

1893. Ueber versteinerte und lebende Seesterne. Verh. naturh. Ver. preuss. Rheinl., etc., vol. 50, pp. 1-92, pl. 1. (Salteraster, Ophiura rhenana, Palænectria, $P$. devonica.)

1900. Ein weiterer Beitrag żur Kenntniss paläozoischer Asteroiden. Verh, naturh. Ver. preuss. Rheinl., etc., vol. 56, pp. 176-240, pls. 2-4. (Reviews Gregory's work of 1896 and gives classification of Ophiuroidea with definition of families. Hisingeraster, Trentonaster, Hudsonaster, Pseudopalasterina, Eophiurites, Palæophiomyxa, Palæospondylus, Palæosolaster, $P$. gregoryi, Echinasterias, E. spinosus, Echinodiscus, E. multidactylus, Echinostella, E. traquairi, Jaekelaster, J. petaliformis.)

\section{Thorent.}

1838. Mémoire sur la constitution géologique de la partie nord du Departément de l'Aisne. Mem. Soc. géol. de France, vol. 3, pp. 239-260, pl. 22. (Asterias constellata.)

Trautschold, H.

1879. Die Kalkbrüche von Mjatschkowa, Theil 3. Mém. Soc. imp. Nat. Moscou, vol. 14, pp. 101-180, 7 pls. (Calliaster, C. mirus, Stenaster confluens.)

Troost, G.

1835. Description of a new species of fossil Asterias (Asterias antiqua). Trans. Geol. Soc. Pennsylvania, vol. 1, pp. 232-235.

ULRICH, E. O.

1878. Descriptions of some new species of fossils from the Cincinnati group; Journ. Cincinnati Soc. Nat. Hist., vol. 1, pp. 92-100, pl.4. (Protasterina, P. fimbriata.)

1879. Descriptions of new genera and species of fossils from the Lower Silurian about Cincinnati. Journ. Cincinnati Soc. Nat. Hist., vol. 2, pp. 8-30, pl. 7. (Palæaster finei.)

$50601^{\circ}$-Bull. 88-15-19 
VerRILI, A. E.

1914. Monograph of the shallow-water starfishes of the North Pacific coast from the Arctic Ocean to California. Smithsonian Institution, Harriman Alaska ser., vol. 14.

WOODWARD, H.

1869. On Eucladia, a new genus of Ophiuridæ, from the Upper Silurian, Dudley. Geol. Mag., vol. 6, pp. 241-245, pl. 8. (Eucladia, E. johnsoni.)

1874. Description of a new species of starfish from the Devonian of Great Inglebourne, Harberton, South Devon. Geol. Mag., dec. 2, vol. 1, pp. 6-10, 96, 238, 432. (Helianthaster filiciformis.)

Worthen, A. W., and Miller, S. A.

1883. Descriptions of new Carboniferous Echinoderms. Geol. Surv. Illinois, vol. 7, pp. 327-331, pl. 31. (Compsaster, C. formosus, Cholaster, C. pe-

WRIGHT, T. culiaris, Tremataster, T. difficilis.)

1862. A monograph on the British fossil Echinodermata from the Oolitic formations, vol. 2, pt. 1. Palæontogr. Soc. for 1861. (Contains a diagnosis of nine Paleozoic genera with species.)

1873. On a new genus of Silurian Asteriadæ. Quart. Journ. Geol. Soc., London, ZrTTEL, K. von. vol. 29, p. 421. (Trichotaster, T. plumiformis.)

1879. Handbuch der Paläontologie, vol. 1. 


\section{EXPLANATION OF PLATES.}

\section{Plate 1.}

Fig. 1.-Hudsonaster narrawayi (Hudson) (also see plates 2 and 4).

A greatly enlarged photograph of the genoholotype of Protopalæaster narrawayi Hudson. The inner ventral side of the specimen is here seen with all of the dorsal skeleton weathered away except one of the basal supramarginalia. Note the well-preserved oral armature and in places the ambulacralia. The latter are the "covering plates"- of Hudson.

Photograph by Prof. George H. Hudson.

Middle Ordovicic (Black River). Ottawa, Canada.

Collection of Mr. J. E. Narraway.

\section{Plate 2.}

Fic. 1.- Hudsonaster narrawayi (Hudson) (also see plates 1 and 4).

A photograph $\times 6$ of the actinal side. Note the five long spines (tori) of the oral armature.

Middle Ordovicic (Black River). Kirkfield, Ontario, Canada.

Collection of Peabody Museum, Yale University.

FIg. 2.-Hudsonaster matutinus (Hall) (also see plates 3 and 5).

A photograph $\times 3$ of three specimens showing the actinal area as preserved on a piece of black limestone.

Middle Ordovicic (Trenton). Rathbone Brook, near Newport, Herkimer County, New York.

Collection of Museum of Comparative Zoölogy, Harvard University (No. 26).

Plate 3.

Fig. 1.-Hudsonaster rugosus (Billings).

A photograph $\times 2$ of the abactinal area of a cotype.

Upper Ordovicic (Richmondian). Charleton Point, Anticosti Island, Gulf of St. Lawrence, Canada.

Collection of the Geological Survey of Canada (No. 1999).

Fig. 2.-Hudsonaster matutinus (Hall) (also see plates 2 and 5).

A retouched photograph $\times 2$ showing the abactinal side.

Middle Ordovicic (Trenton). Trenton Falls, New York.

Collection of the Museum of Comparative Zoölogy, Harvard University (No. 3).

Fig. 3.-Hudsonaster batheri, new species.

A diagram $\times 3$ of the actinal side made from a wax squeeze by Bather, now in the United States National Museum (Cat. No. 60601).

Upper Ordovicic. Thraive, Girvan, Scotland. 


\section{Plate 4.}

FIG. 1.-Hudsonaster narrawayt (Hudson) (also see plates 1 and 2).

A camera lucida drawing $\times 8$ of the actinal side. The granules are drawn somewhat too strongly.

Middle Ordovicic (Black River). St. Paul, Minnesota.

Ulrich collection of the United States National Museum (Cat. No. 60602).

FiG. 2.-Hudsonaster milleri, new species.

A diagram, considerably enlarged, of an axillary area from the actinal side.

Middle Ordovicic (Trenton). Fayette County, Kentucky.

Collection of the State University of Kentucky.

Fig. 3.-Mesopalæaster (?) lanceolatus, new species.

Camera lucida drawing of one ray from the actinal area, $\times 2$. The central furrow in the ambulacrum is decidedly V-shaped.

Upper Ordovicic (Utica). Near Rome, New York.

Collection of Peabody Museum, Yale University.

Frg. 4.-Australaster giganteus (Etheridge).

An axillary area and part of two rays somewhat reconstructed from the original figure. Natural size. Note the single very large axillary plate, the enlarging adambulacrals, and the diminishing inframarginals.

"Permo-Carboniferous" (Lower Marine). Farley, Northumberland County, New South Wales.

Collection of the Mining and Geological Museum, Sydney.

\section{Plate 5.}

Fias. 1 and 2.-Hudsonaster matutinus (Hall) (also see plates 2 and 3).

1. Camera lucida drawing $\times 3.5$ of the actinal side of one of the specimens photographed on plate 2, fig. 2 .

Middle Ordovicic (Trenton). Near Newport, New York.

Collection of Museum of Comparative Zoölogy, Harvard University (No. 26).

2. Camera lucida drawing $\times 4.5$ of the abactinal area of a specimen in which the ossicles are somewhat displaced.

Middle Ordovicic (Trenton). Lachine, near Montreal, Canada.

Collection of the United States National Museum (Cat. No. 60603).

Collected by W. R. Billings.

\section{Plate 6.}

Fias. 1 and 2.-Hudsonaster incomptus (Meek).

1. Camera lucida drawing $\times 4$ of the actinal side.

Upper Ordovicic (Richmondian). Near Waynesville, Ohio.

Harris collection of the United States National Museum (Cat. No. 40882).

2. Camera lucida drawing $\times 4$ of the abactinal area in a well preserved specimen. The anal opening may have been in the first circle of small plates adjacent to the centro-dorsal piece and in the same interradius as the madreporite.

Upper Ordovicic (Richmondian). Near Waynesville, Ohio.

Harris collection of the United States National Museum (Cat. No. 40882). 
Puate 7.

Figs. 1-4.-Palæaster niagarensis Hall.

1. Camera lucida drawing $\times 4$ of the abactinal side in its present preservation. Holotype.

2. Abactinal side of the holotype restored, $\times 4$. The drawing probably has too many accessory disk pieces.

3. Camera lucida drawing $\times 4$ of the actinal side of one of the rays of the holotype. Since this drawing was made the rock in the ambulacral furrow has been dug away down to the ambulacral plates, which are small and deep-seated.

4. A few of the inframarginals and supramarginals from the abactinal side to show the smooth central areas surrounded by granular borders, $\times 4$.

Siluric (Rochester shale). Lockport, New York.

Collection of Cornell University (No. 7331).

Frg. 5.-Mesopalæaster finei (Ulrich) (also see plate 9).

Camera lucida drawing $\times 16$ of one of the rays. The ossicles are always more or less displaced in this species.

Upper Ordovicic (Eden shales). Cincinnati, Ohio.

Ulrich collection of the United States National Museum (Cat. No. 60604).

Plate 8.

FIas. 1 and 2.-Mesopalæaster shafferi (Hall).

1. Camera lucida drawing $\times 8$ of the abactinal side of a one-third adult-sized specimen. As the medial disk pieces are displaced in the individual, they are here drawn in in their probable natural arrangement all should be pointed like the central disk plate.

Upper Ordovicic (Maysvillian, Corryville member). Cincinnati, Ohio.

Vaupel collection of the United States National Museum (Cat. No. 60605).

2. Camera lucida drawing $\times 3$ of the actinal area of a mature individual.

Upper Ordovicic (Richmondian). Waynesville, Ohio.

Harris collection of the United States National Museum (Cat. No. 59391).

Fra. 3.- Miomaster drevermanni Schöndorf.

Actinal side as reconstructed by Schöndorf. Natural size.

Lower Devonic (Upper Coblenzian). Miellen, Germany.

\section{Plate 9.}

Frc. 1.-Mesopalæaster (₹) parviusculus (Billings).

Camera lucida drawing $\times 5$ of a gutta-percha squeeze of the holotype, actinal side.

Siluric (Lower Arisaig). Arisaig, Nova Scotia.

Original at McGill University; gutta-percha squeeze in United States National Museum (Cat. No. 60620).

FIG. 2.-Mesopalæaster (?) cataractensis, new species.

Photograph $\times 3$ of the well-preserved holotype.

Siluric (Cataract formation). Hamilton, Ontario.

Collection of the Hamilton Natural History Society.

Fiq. 3.-Mesopalæaster (?) granti (Spencer).

Photograph $\times 2$ of a specimen showing the dorsal side.

Siluric (Cataract formation). Hamilton, Ontario.

Collection of Peabody Museum, Yale University. 
Fic. 4.-Mesopalæaster intermedius, new species.

Photograph $\times 3$ of the holotype. Between the two rays lies an arm of

a crinid, giving the impression that this form has a large disk.

Upper Ordovicic (Maysvillian). Cincinnati, Ohio.

Collection of the University of Chicago (No. 9575).

Fro. 5.-Mesopalæaster finei (Ulrich) (also see plate 7).

Ulrich's original figures. Fig. 5, one of the cotypes from the abactinal side $\times 2$; fig. $5 a$, the madreporite $\times 6$; fig. $5 b$, a ray from the actinal side $\times 3$.

Upper Ordovicic (Eden). Cincinnati, Ohio.

Ulich collection of the United States National Museum (Cat. No. 60604).

Fig. 6.-Mesopalæaster caractaci (Gregory) (also see plate 11).

Retouched photograph $\times 3$ of a wax squeeze by Bather, now in the

United States National Museum (Cat. No. 60606). Actinal area.

Ordovicic (Caradoc). Church Stretton, England.

Phate 10.

Figs. 1 and 2.-Mesopalæaster clarki (Clarke and Swartz).

1. Drawing of the actinal side of the holotype $\times 1.5$.

2. Abactinal area $\times 1.5$. Note the few accessory pieces in the angles between the radials.

Upper Devonic (Chemung). Near Oakland, Maryland.

Collection of the Maryland Geological Survey.

Plate 11.

FIG. 1.-Mesopalæaster caractaci (Gregory) (also see plate 9).

Retouched photograph $\times 3$ of a wax squeeze by Bather, now in the

United States National Museum (Cat. No. 60606). Abactinal area.

Ordovicic (Caradoc). Church Stretton, England.

FIG. 2.-Devonaster chemungensis, new species.

Photograph of the natural mold of the actinal side of the holotype, natural size.

Upper Devonic (Chemung). "Central Pennsylvania."

Collection of Columbia University (No. 6228G).

\section{Plate 12.}

Fros. 1 and 2.-Spaniaster latiscutatus (Sandberger).

1. Abactinal side.

2. Actinal side.

After Schöndorf.

Lower Devonic. Germany.

Figs. 3-5.-Devonaster eucharis (Hall).

3. Abactinal side, natural size.- $a$, the madreporite. After Hall.

4. Actinal side, natural size. After Hall. The tiny ambulacral plates should have been drawn as opposite one another and not alternate.

5. Hall's diagram ( $3 a$ ) of the actinal plate arrangement. The ambulacrals are incorrectly drawn, as their arrangement is opposite and not alternate. $a$, ambulacralia; $a a$, adambulacralia; $m$, inframarginalia; 0 , pairs of oral armature ossicles; $p$, podial openings, but drawn a little too large; $t m$, the single interbrachial axillaries.

Middle Devonic (Hamilton). Near Hamilton, New York. 
Plate 13.

Figs. 1 and 2.-Promopalæaster wilsoni (Raymond).

1. Photograph $\times 1.5$ of the holotype, showing the abactinal side.

2. One of the rays of the holotype $\times 3$.

Middle Ordovicic (Lowville). City View, Ottawa, Canada.

Collection of Miss A.E. Wilson.

FIG. 3.-Promopalæaster prenuntius, new species (also see plate 15).

Photograph, natural size, of the actinal side of the holotype.

Middle Ordovicic (Lower Trenton). Frankfort, Kentucky.

Collection of the State University of Kentucky.

FIG. 4.-Anorthaster miamiensis (Miller) (see also plate 20).

Retouched photograph, natural size, of the actinal side of the holotype.

Upper Ordovicic (Richmondian). Waynesville, Ohio.

Harris collection of the United States National Museum (Cat. No. 40880).

Fig. 5.--Neopalæaster crawfordsvillensis (Miller) (see also plate 23).

Retouched photograph, natural size, of the holotype, showing the abactinal area.

Mississippic (Keokuk). Crawfordsville, Indiana.

Harris collection of the United States National Museum (Cat. No. 60607).

\section{Plate 14.}

Figs. 1 and 2.-Promopalraster speciosus (Meek)?

Reproduction, natural size, of the original lithograph of "Asterias primordialis." Probably the young of $P$. speciosus.

Upper Ordovicic (Maysvillian). Cincinnati, Ohio.

The specimen is now lost.

FIgs. 3 and 4.-Promopalreaster speciosus (Meek) (also see plate 15).

Photographs, natural size, of the abactinal and actinal sides of the holotype.

Upper Ordovicic (Maysvillian). Cincinnati, Ohio.

Dyer collection of the Museum of Comparative Zoölogy, Harvard University (No. 22).

\section{Plate 15.}

Figs. 1-4.-Promopalæaaster speciosus (Meek) (also see plate 14).

1. Camera lucida drawing $\times 4$ of an interbrachial area.

2. Camera lucida drawing $\times 4$ across a ray at about its mid-length.

From the actinal side, showing the ambulacrals, podial openings, adambulacrals, inframarginals, and supramarginals.

3. Two adambulacral spines near oral region, $\times 7$.

4. A part of the abactinal area of a ray near its mid-length, $\times 2.5$.

All drawn from the holotype.

Upper Ordovicic (Maysvillian). Cincinnati, Ohio.

Dyer collection of the Museum of Comparative Zoölogy, Harvard University (No. 22).

FIg. 5.-Promopalxaster prenuntius, new species (also see plate 13).

Diagram of the actinal interbrachial plate arrangement. 
Figs. 6-8.-Promopalæaster bellulus, new species (also see plates 16 and 18).

6. Camera lucida drawing $\times 4$ of an interbrachial area. The adambulacrals are in natural position, but the interbrachial axillaries and the inframarginals are somewhat displaced. Taken from the specimen on plate 16 , fig. 1 .

7. Camera lucida drawing $\times 7$ of the abactinal area of a ray. The ossicles are all displaced, but originally they were united in a spicular and partially overlapping mesh.

8. Madreporite $\times 7$.

Upper Ordovicic (Richmondian). Waynesville, Ohio.

Harris collection of the United States National Museum (Cat. No. 40879).

\section{Plate 16.}

Fig. 1.-Promopalæaster bellulus, new species (also see plates 15 and 18).

Retouched photograph, natural size, of the actinal side. The specimen is in limestone.

Upper Ordovicic (Richmondian). Waynesville, Ohio.

Harris collection of the United States National Museum (Cat. No. 40879).

Fis. 2.-Promopalæaster spinulosus (Miller and Dyer) (also see plates 17 and 18).

Retouched photograph, natural size, of the actinal side of the holotype of Palxaster longibrachiatus Miller. The well-preserved columns are the inframarginals, but in places some of the adambulacrals are also shown.

Upper Ordovicic (Richmondian). Near Clarksville, Ohio.

Harris collection of the United States National Museum (Cat. No. 40881).

\section{Plate 17.}

Fras. 1 and 2.-Promopalæaster spinulosus (Miller and Dyer) (also see plates 16 and 18).

Retouched photographs $\times 3$ of the actinal and abactinal sides of the holotype.

Upper Ordovicic (Richmondian). Probably near Waynesville, Ohio.

Dyer collection of the Museum of Comparative Zoölogy, Harvard University (No. 16).

\section{Plate 18.}

Fras. 1-3.-Promopalæaster spinulosus (Miller and Dyer) (also see plates 16 and 17).

1. Camera lucida drawing $\times 2$, somewhat restored, of the holotype of Palæaster longibrachiatus Miller.

2. Camera lucida drawing $\times 7$ of the abactinal area of a ray near its base. Shows the large infra- and supramarginals and ambital pieces. Center of ray has spicular ossicles.

3. Madreporite $\times 7$.

Upper Ordovicic (Richmondian). Near Clarksville, Ohio.

Harris collection of the United States National Museum (Cat. No. 40881). 
Figs. 4 and 5.-Promopalxaster bellulus, new species (also see plates 15 and 16).

4. Adambulacralia and their spines, $\times 7$. The ambulacrum lies to the left.

5. A few abactinal spines, $\times 7$.

Upper Ordovicic (Richmondian). Waynesville, Ohio.

Harris collection of the United States National Museum (Cat. No. 40879).

Fig. 6.-Promopalæaster wykoffi (Miller and Gurley) (also see plate 19).

Diagram $\times 3.5$ of one of the interbrachial areas.

From the holotype.

Upper Ordovicic (Richmondian). Near Madison, Indiana.

Collection of the University of Chicago (No. 6066).

Fig. 7.-Promopalæaster exculptus (Miller) (also see plate 20).

Adambulacral and ambulacral plates at about mid-length of a ray, $\times 4$.

From the holotype.

Upper Ordovicic (Richmondian). Near Waynesville, Ohio.

Harris collection of the United States National Museum (Cat. No. $60608)$.

Fia. 8.-Promopalæaster dyeri (Meek) (also see plates 20 and 25).

Five inframarginal plates $\times 4$. To show the articulations for the stout spines that lie on the right. Also note the smaller spines. The plate extensions to the left connect with the vertical ridges on the ambulacral plates.

From the holotype.

Upper Ordovicic (Maysvillian). Cincinnati, Ohio.

Dyer collection of the Museum of Comparative Zoölogy, Harvard University (No. 13).

\section{Plate 19.}

FIG. 1.-Trimeraster parvulus Schöndorf.

Reconstruction $\times 1.75$ of the actinal side. After Schöndorf.

Lower Devonic (Coblenzian). Near Rhens, Germany.

Fir. 2.-Promopaleaster wykoffi (Miller and Gurley) (also see plate 18).

Photograph $\times 2$ of the holotype, showing the actinal side. One of the finest of Paleozoic specimens.

Upper Ordovicic (Richmondian). Near Madison, Indiana.

Collection of the University of Chicago (No. 6066).

\section{Plate 20.}

FIG. 1.-Anorthaster miamiensis (Miller) (also see plate 13).

Camera lucida drawing $\times 5.5$ of one of the interbrachial areas of the holotype. The only Paleozoic form known with the area wholly made up of adambulacrals.

Upper Ordovicic (Richmondian). Waynesville, Ohio.

Harris collection of the United States National Museum (Cat. No. 40880).

Fig. 2.-Promopalæaster exculptus (Miller) (also see plate 18).

Camera lucida drawing $\times 4$ of an interbrachial area. Note the modified ambulacral plates in connection with the oral armature. Holotype.

Upper Ordovicic (Richmondian). Near Waynesville, Ohio.

Harris collection of the United States National Museum (Cat. No. 60608). 
Fras. 3-6.-Promopalæaster dyeri (Meek) (also see plates 18 and 25).

3. One of the interbrachial areas with the ossicles displaced and the adjoining adambulacral plates with their spines, $\times 4$.

4. Madreporite $\times 4$. The rest of the plate is covered.

5. Two abactinal spines, $\times 7$.

6. Five different abactinal ossicles, $\times 7$.

All drawn from the holotype.

Upper Ordovicic (Maysvillian). Cincinnati, Ohio.

Dyer collection of the Museum of Comparative Zoölogy, Harvard University (No. 13).

Plate 21.

FIG. 1.-Promopalæaster magnificus (Miller) (also see plates 22 and 23).

Photograph, natural size, of the actinal side of one of the cotypes. This specinen is probably the best preserved of Paleozoic starfishes and is one of the largest species.

Upper Ordovicic (Richmondian). Near Waynesville, Ohio.

Harris collection of the United States National Museum (Cat. No. 40883).

Plate 22.

Frg. 1.-Promopalæaster magnificus (Miller) (also see plates 21 and 23).

Abactinal side of the same specimen illustrated on plate 21.

Plate 23.

Figs. 1-3.-Promopalæaster magnificus (Miller) (also see plates 21 and 22).

1. Camera lucida drawing $\times 3.5$ of an interbrachial area. Additional tube-feet probably also came out at the junction of the forked crests.

2. Camera lucida drawing $\times 4$ of the actinal area of one of the rays toward the distal ends. Large adambulacrals bound the rays distally, while the smaller pieces outside are the inframarginals.

3. A distal portion of the abactinal area, $\times 3.5$.

All drawn from the cotypes.

Upper Ordovicic (Richmondian). Near Waynesville, Ohio.

Harris collection of the United States National Museum (Cat. No. 40883).

Fra. 4.-Neopalæaster crawfordsvillensis (Miller) (also see plate 13).

Camera lucida drawing $\times 4$ of the abactinal area of the holotype. Accessory disk pieces are drawn in; in the specimen they are all displaced. The madreporite should be more finely striate. In places the dorsal skeleton is lost, exposing the ambulacrals.

Mississippic (Keokuk). Crawfordsville, Indiana.

Harris collection of the United States National Museum (Cat. No. 60607).

Frgs. 5-7.-Petraster speciosus (Miller and Dyer) (also see plates 26 and 27).

5. The ambulacral, adambulacral and inframarginals of a ray at its mid-length, $\times 4$. Seen from the actinal side.

6. Inframarginal, accessory interbrachial, and adambulacral pieces, $\times 4$. Seen from the dorsal side.

7. Ambulacral and adambulacrals, $\times 4$. Seen from the dorsal area. 
Plate 24.

Fias. 1-2.-Xenaster margaritatus Simonovitsch.

1. Reconstruction, somewhat enlarged, of the abactinal side. The structure of the medial portion of the disk is based upon Agalmaster miellensis.

2. Reconstruction, somewhat enlarged, of the actinal area. After Schöndorf.

- Lower Devonic (Upper Coblenzian). Niederlahnstein, Germany.

Plate 25.

Fig. 1.-Promopalzaster dyeri (Meek) (also see plates 18 and 20).

Retouched photograph, natural size, of the actinal side of the holotype.

Upper Ordovicic (Maysvillian). Cincinnati, Ohio.

Dyer collection, Museum of Comparative Zoölogy, Harvard University (No. 13).

Fia. 2.-Lepidasterella babcocki, new species.

Photograph $\times 1.5$ of the holotype. A natural mold of the abactinal area in sandstone.

Upper Devonic (Lower Chemung). Near Ithaca, New York.

Collection of Mrs. G. W. Babcock.

\section{Plate 26.}

Fro. 1.-Petraster speciosus (Miller and Dyer) (also see plates 23 and 27).

Retouched photograph, natural size, of the abactinal area of the holotype.

Upper Ordovicic (Richmondian). Near Winchester, Ohio.

Dyer collection of the Museum of Comparative Zoölogy, Harvard University (No. 14).

Fig. 2.-Petraster (?) americanus (D'Orbigny).

Reproduction, natural size, of Meek's original figure. The specimen is seen from the abactinal side, exposing, however, the inner surface of the actinal skeleton, which is deeply embedded in limestone.

Upper Ordovicic (Maysvillian). Cincinnati, Ohio.

Collection of the University of Chicago.

\section{Plate 27.}

Fras. 1-4.-Petraster speciosus (Miller and Dyer) (also see plates 23 and 26).

1. Camera lucida drawing $\times 4$ of the abactinal side of a ray. Holotype The inframarginals border the animal, with the supramarginals immediately inside of them. The radial column is readily distinguished along the center of the rays.

2. Camera lucida drawing $\times 6$ of an interbrachial area in a young individual (Harris collection, Cat. No. 60609, U.S.N.M.). The inframarmarginals are above and the adambulacrals below to the right. The rest rest of the plates are accessory interbrachials.

3-4. Madreporite from the side and from the lower or under surface, $\times 8$.

Fia. 5.-Petraster rigidus (Billings).

Outline tracing of the actinal skeleton from a photograph $\times 2$ of the holotype.

Middle Ordovicic (Trenton). Ottawa, Canada.

Collection of the Geological Survey of Canada (No. 1401a). 
Figs. 6-8.- Urasterella grandis (Meek) (also see plates 28 and 30).

6. Camera lucida drawing $\times 8$ of part of the abactinal area of a ray proxi. mally. Note how the ossicles are drawn out into nonarticulating blunt spines.

7. Camera lucida drawing $\times 4$ of the actinal side about the mouth. The complete oral armature is preserved.

8. Madreporite in outline, $\times 7$.

From specimens in the Harris collection of the United States National Museum (Cat. No. 40885).

\section{Plate 28.}

Figs. 1 and 2.- Urasterella grandis (Meek) (also see plates 27 and 30).

1. Retouched photograph, natural size, of a large and folded specimen. Both ventral and dorsal areas are shown.

2. Retouched photograph, natural size, of an average individual seen from the actinal side.

Upper Ordovicic (Richmondian). Near Waynesville, Ohio.

Harris collection of the United States National Museum (Cat. No. 40885).

Fras. 3 and 4.-Urasterella pulchella (Billings) (also see plate 30).

3. Photograph, natural size, of an electrotype, seen from the actinal side.

Middle Ordovicic (Trenton). Hull, Ottawa, Canada.

Original in collection of the Geological Survey of Canada; electrotype in United States National Museum (Cat. No. 60610).

4. Retouched photograph, natural size, of the abactinal area.

Middle Ordovicic (Trenton). Trenton Falls, New York.

Collection of the Museum of Comparative Zoölogy, Harvard University (No. 31).

Fig. 5.-Urasterella girvanensis, new species.

Reproduction $\times 2$ of the original figure by Nicholson and Etheridge, somewhat altered.

From a wax squeeze made by Bather, now in the United States National Museum (Cat. No. 60611).

Upper Ordovicic. Thraive, Girvan, Scotland.

Plate 29.

Fig. 1.- Urasterella ulrichi, new species (also see plate 30 ).

Retouched photograph, natural size, of the abactinal side of a cotype.

The three short blunt rays are interpreted as healed stumps.

Middle Ordovicic (Black River). Minneapolis, Minnesota.

Ulrich collection of the United States National Museum (Cat. No. 60612).

FIG. 2.-Urasterella huxleyi (Billings).

Photograph $\times 2$ of the holotype. Abactinal view.

Middle Ordovicic (about Chazy). Point Rịch, Newfoundland.

Collection of the Geological Survey of Canada (No. 554.)

Plate 30.

Fias. 1-4.-Urasterella grandis (Meek) (also see plates 27 and 28.)

1-2. Camera lucida drawing $\times 16$ of the adambulacrals with their articular spines and probable paxillæ.

3. Camera lucida drawing $\times 8$ of the two columns of ambulacral plates a little displaced. The pocial openings are situated laterally between the thinner ends of the ossicles.

4. Camera lucida drawing $\times 7$ of the adambulacrals with their spines. From specimens in the Harris collection of the United States National 
Frg. 5.-Urasterella pulchella (Billings) (also see plate 28).

Camera lucida drawing $\times 8$. The large plates to the left are the coinshaped adambulacrals (some have tipped over and show their articular faces), next are the small elongate inframarginals, and outside of these are the spinose ambitals.

Figs. 6 and 7.-Urasterella ulrichi, new species (also see plate 29).

6. Camera lucida drawing $\times 4$ of the abactinal side of a young individual. The medial ray plates should be more tumid than here represented. Note the primitive structure of the disk.

7. Camera lucida drawing $\times 6$ of the actinal side of a young individual. The outer dark margin is adhering rock, through which some of the abactinal ambital nonarticulating spines project. Note the phanerozonian interbrachial characters.

Middle Ordovicic (Black River). Minneapolis, Minnesota.

Ulrich collection of the United States National Museum (Cat. No. 60612).

Plate 31.

Figs. 1 and 2.-Compsaster formosus Worthen and Miller.

1. Actinal view, natural size, of the holotype. Reproduction of the original illustration.

2. Part of a ray, $\times 2$. After Worthen and Miller.

Upper Mississippic (Chester). Okaw Bluffs, Illinois.

"Illinois State collection of 1880, No. 2476.",

Fra. 3.-Calliasterella mira (Trautschold).

Reproduction, natural size, of Schöndorf's reconstruction.

Upper Carboniferous (Moscovian). Mjatschkowa, near Moscow, Russia.

Frg. 1.-Stenaster salteri Billings.

Plate 32.

Retouched photograph $\times 3$ of a cotype. Actinal view.

Middle Ordovicic (Trenton). Belleville, Ontario, Canada.

Collection of the Geological Survey of Canada.

Fig. 2.-Schuchertia stellata (Billings) (also see plate 33).

Photograph $\times 4$ of the actinal side of the holotype.

Middle Ordovicic (Trenton). Ottawa, Canada.

Collection of the Geological Survey of Canada (No. 1399).

Frg. 3.-Schuchertia laxata, new species (also see plate 33).

Retouched photograph $\times 2$ of the holotype from the abactinal side.

Upper Ordovicic (Richmondian). Waynesville, Ohio.

Harris collection of the United States National Museum (Cat. No. 60613).

Figs. 4 and 6.-Schonaster (?) legrandensis Miller and Gurley.

4-5. Actinal and abactinal views, natural size.

6. Part of actinal side $\times 6.5$. After Miller and Gurley.

Lower Mississippic (Kinderhookian). Le Grand, Iowa.

?Gurley collection of the University of Chicago.

Prate 33.

Fig. 1. -Schuchertia stellata (Billings) (also see plate 32).

Camera lucida drawing $\times 8$ of the abactinal surface. Somewhat restored.

Middle Ordovicic (Trenton). Near New Edinburgh, Canada.

Collection of the Geological Survey of Canada.

Figs. 2 and 3.-Schuchertia laxata, new species (also see plate 32).

2. Some of the outer ambital plates, all disjointed, $\times 8$.

3. An interbrachial area and ambulacrum, $\times 4$.

Upper Ordovicic (Richmondian). Waynesville, Ohio.

Harris collection of the United States National Museum (Cat. No. 
Fia. 4.-Tetraster wyville-thomsoni Nicholson and Etheridge.

Diagram $\times 4$ of the actinal skeleton. From a wax squeeze by Bather, in the United States National Museum (Cat. No. 60614).

Upper Ordovicic. Thraive, Girvan, Scotland.

Frg. 5.-Schoenaster (?) montanus Raymond.

Reproduction $\times 2$ of the original figure. Actinal side.

Mississippic (Madison). Spring Canyon, near Alder, Montana.

Collection of the Carnegie Museum.

Fig. 6.-Schoenaster (?) wachsmuthi Meek and Worthen.

Reproduction, natural size, of the original figure. Actinal view.

Lower Mississippic (Burlington). Burlington, Iowa.

Collection of the Museum of Comparative Zoölogy, Harvard University (No. 7).

\section{Plate 34.}

Fra. 1.-Palæosolaster (?) gyalum (Clarke).

Actinal view of one of the cotypes, natural size.

Upper Devonic (Portage). Ithaca, New York.

Collection of Cornell University.

\section{Plate 35.}

FIas. 1-4.-Schœenaster fimbriatus Meek and Worther.

1. View of the abactinal side, natural size, of one of the cotypes.

2. Enlarged view of one of the rays, showing the arrangement of the ossicles and the pores, as seen when the surface is ground down.

3. Actinal side of a ray, enlarged, showing only the adambulacrals.

4. Actinal side of another cotype, natural size.

The original figures of plate 19 , figs. $7 a$ to $7 d$.

Upper Mississippic (St. Louis). St. Clair County, Illinois.

Fias. 5 and 6-Encrinaster petaloides (Simonovitsch).

5. Abactinal view, about $\times 2$.

6. An arm from the actinal side, about $\times 2$.

After Schöndorf.

Lower Devonic (Upper Coblenzian). Niederlahnstein, Germany.

\section{Plate 36.}

Fia. 1.-Tæniaster spinosus (Billings).

Photograph $\times 2$ showing the actinal side of one of the cotypes.

Middle Ordovicic (Lower Trenton). Montmorency Falls, Quebec, Canada.

Collection of the Geological Survey of Canada (No. 1404).

Fias. 2 and 3.-Tæniaster cylindricus (Billings).

2. Abactinal view $\times 2$ of one of the cotypes.

3. Actinal view $\times 2$ of another cotype. Both specimens are on the same slab.

Middle Ordovicic (Trenton). Ottawa, Canada.

Collection of the Geological Survey of Canada (No. 1405a).

Fis. 4.-Alepidaster flexuosus (Miller and Dyer).

An unpublished photograph $\times 3.5$, made many years ago, of the holotype of Protasterina fimbriata Ulrich.

Upper Ordovicic (Lower Edenian). Covington, Kentucky.

Ulrich collection of the United States National Museum (Cat. No. 60615). 


\section{Plate 37.}

FIGs. 1 and 2.-Eucladia woodwardi Sollas.

Dorsal and ventral reconstructions $\times 5 / 3$ of this remarkable fossil. On it is based the order Ophiocistia Sollas. "One arm, the most proximal of the radius on the lower right-hand corner, is omitted, so as to show the aperture from which it proceeds." After Sollas.

Siluric (Lower Ludlow). Leintwardine, England.

\section{Plate 38.}

Fig. 1.-Eucladia (?) beecheri, new species.

Photograph $\times 2$ of the holotype from the actinal side. The specimen itself is difficult to make out, hence the indistinctness of the photograph.

Lower Devonic (Coeymans). Jerusalem Hill, Litchfield, Herkimer County, New York.

Collection of Peabody Museum, Yale University. 



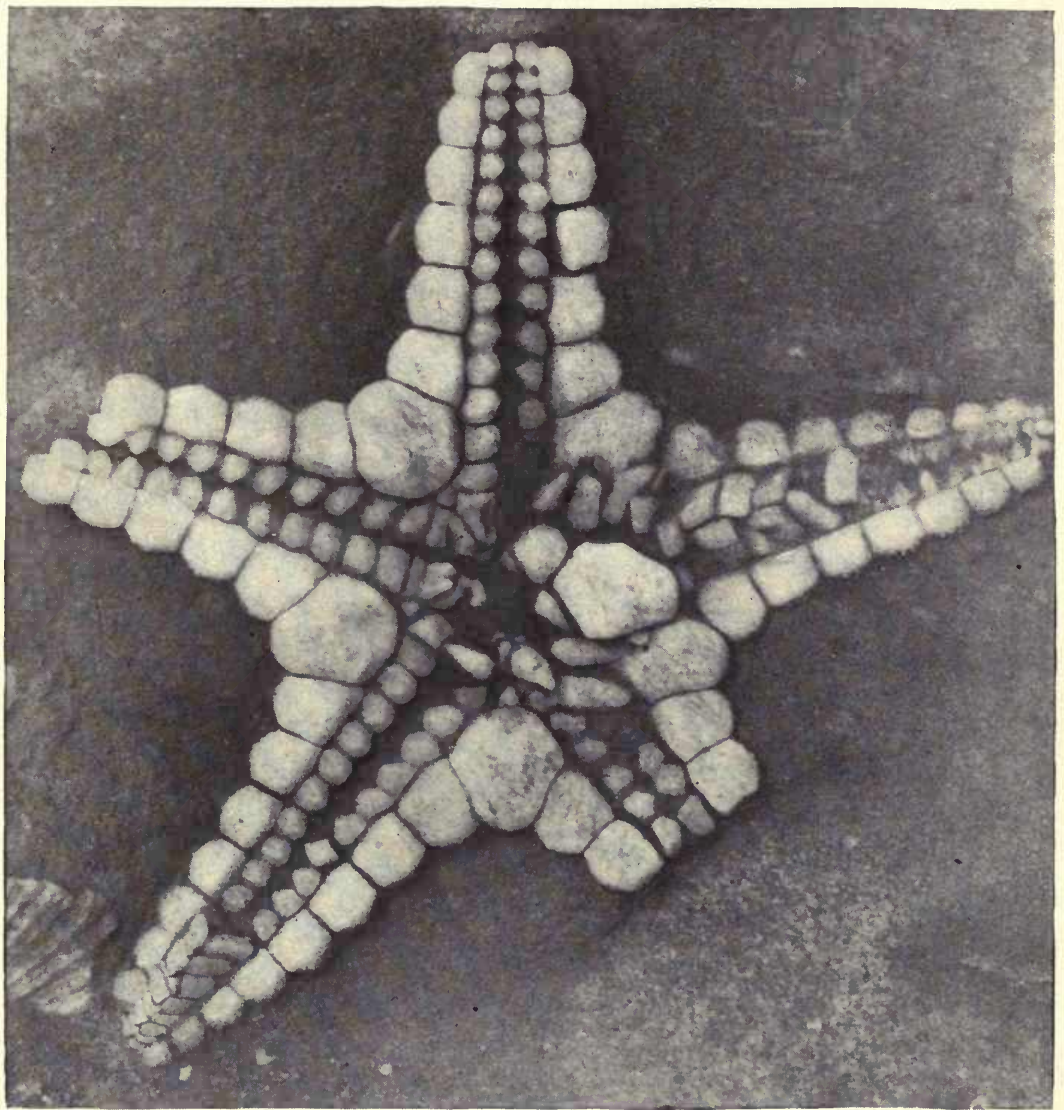

HUDSONASTER NARRAWAYI.

For EXPLANATION OF PLATE SEE PAGE 289. 



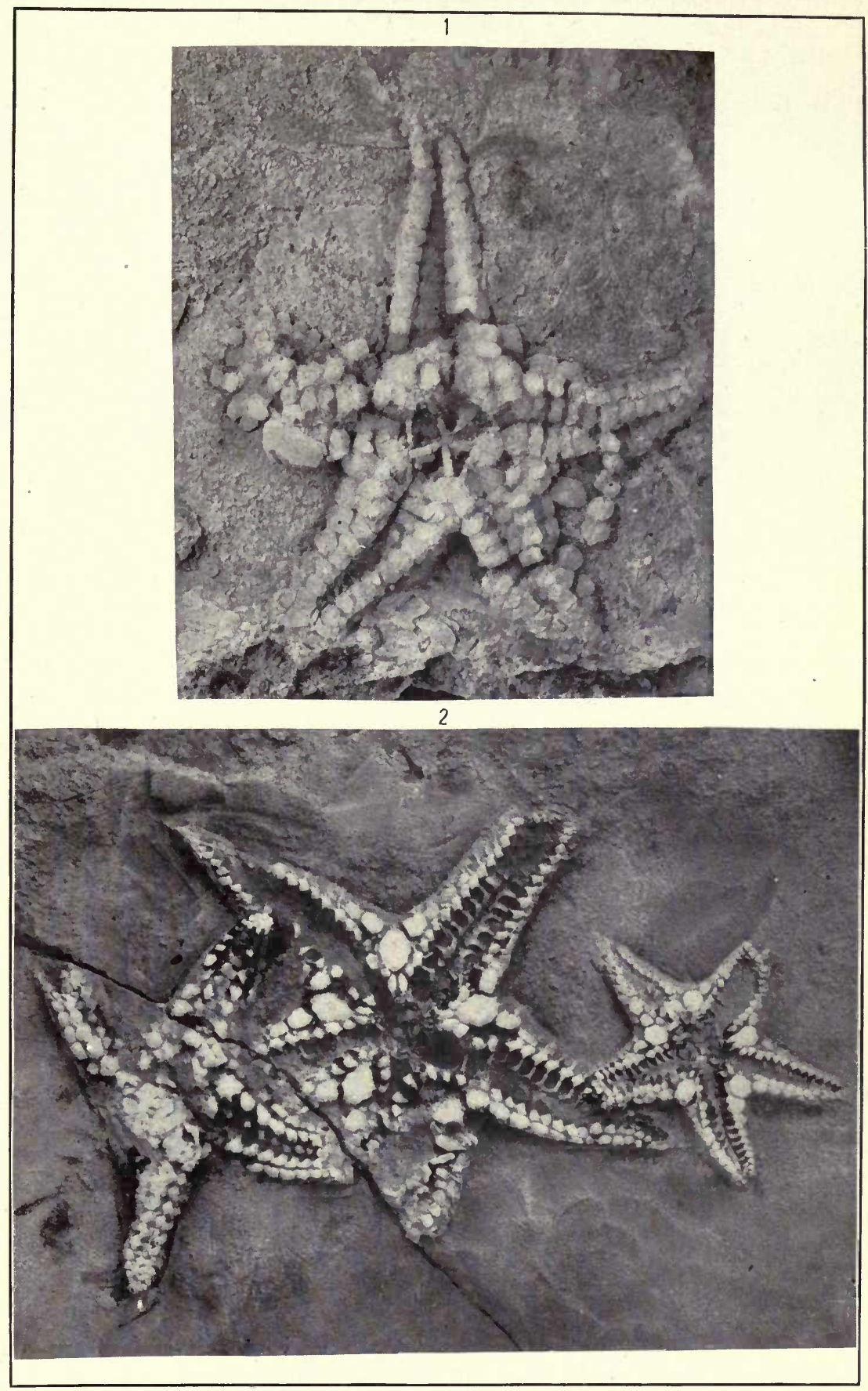

1, Hudsonaster narrawayi; 2, H. matutinus. 



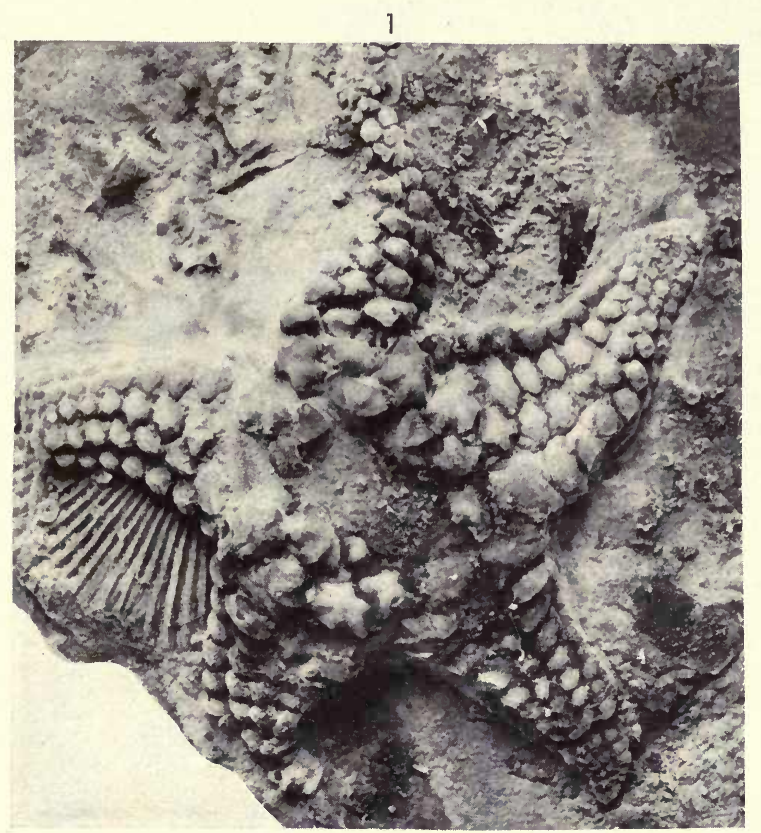

2
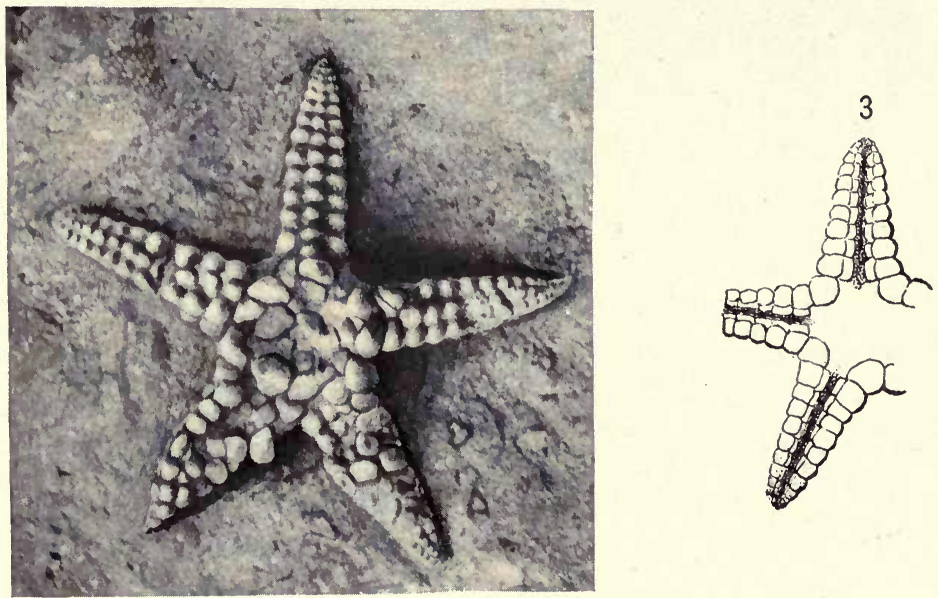

1, Hudsonaster rugosus; 2, H. matutinus; 3, H. Batheri.

For EXPLANATION OF PLATE SEE PAGE 289. 


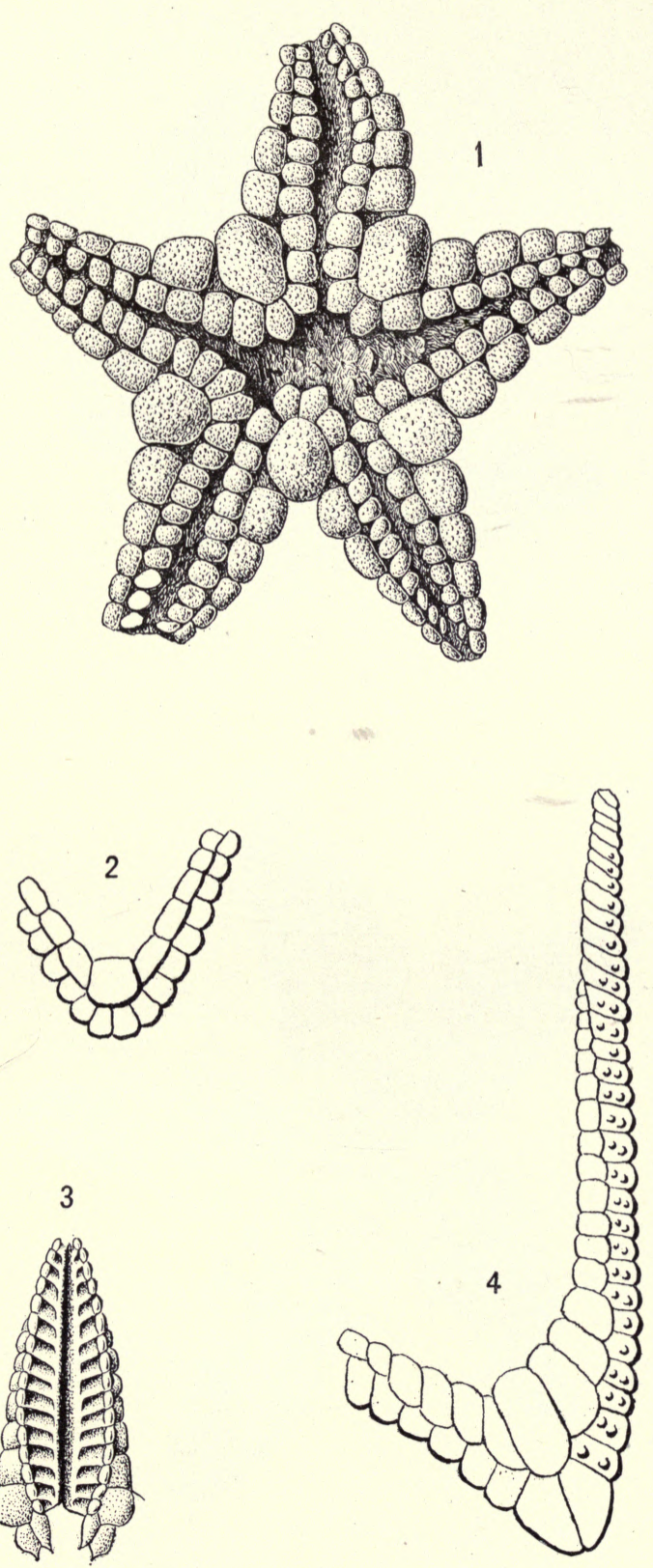

1, Hudsonaster narrawayi; 2, H. milleri; 3, Mesopalaeaster (?) Lanceolatus; 4, australaster giganteus. 


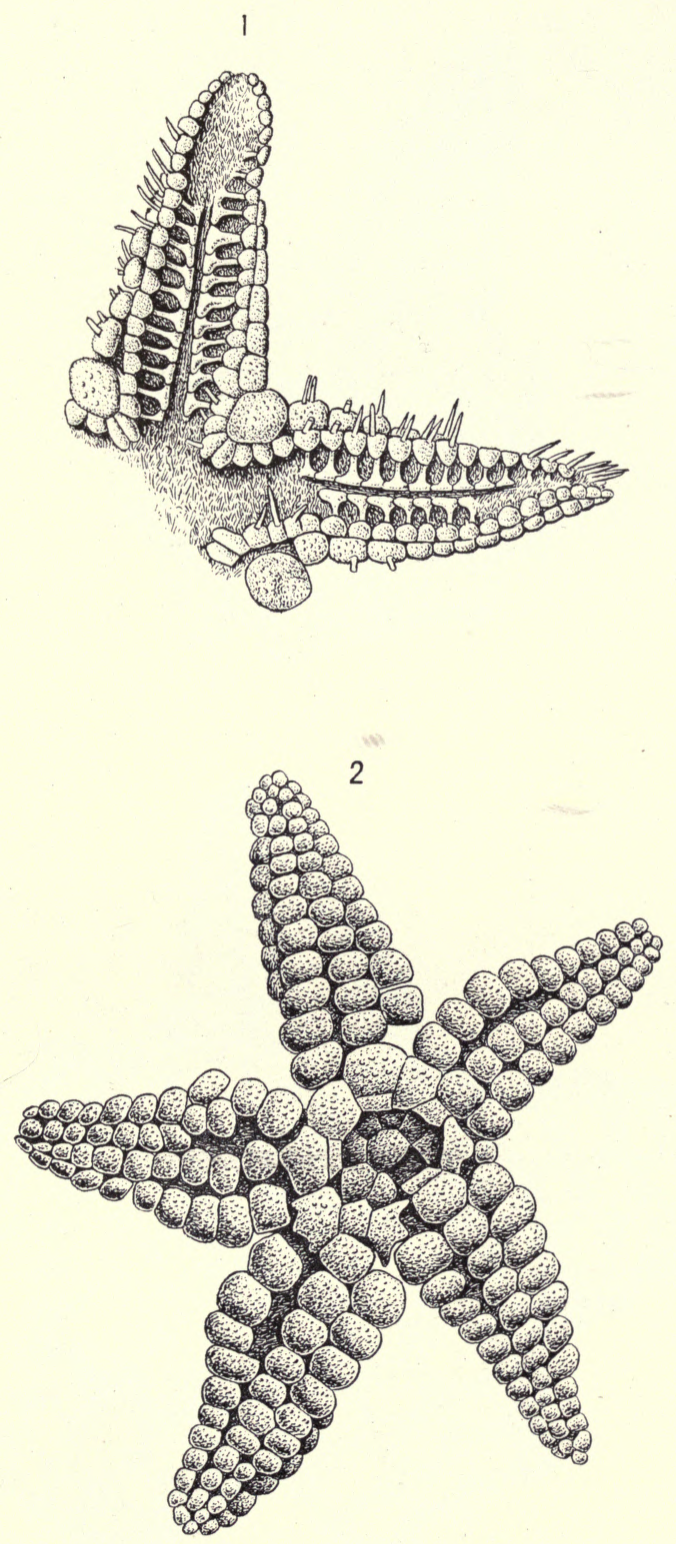

HUdSONASTER MATUTINUS.

For EXPLANATION OF PLATE SEE PAGE 290. 



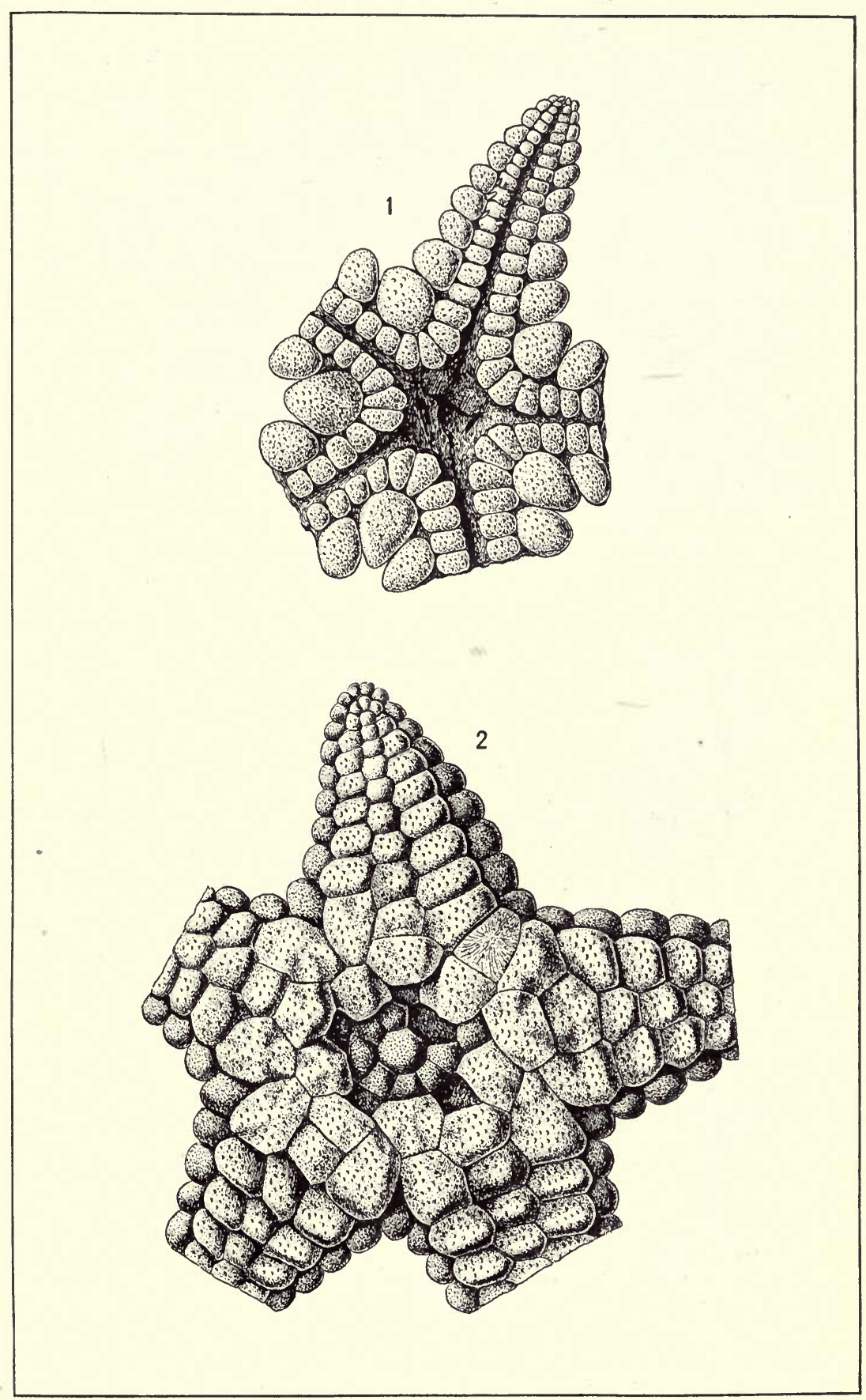

HUDSONASTER INCOMPTUS.

For EXPLANATION OF PLATE SEE PAGE 290. 


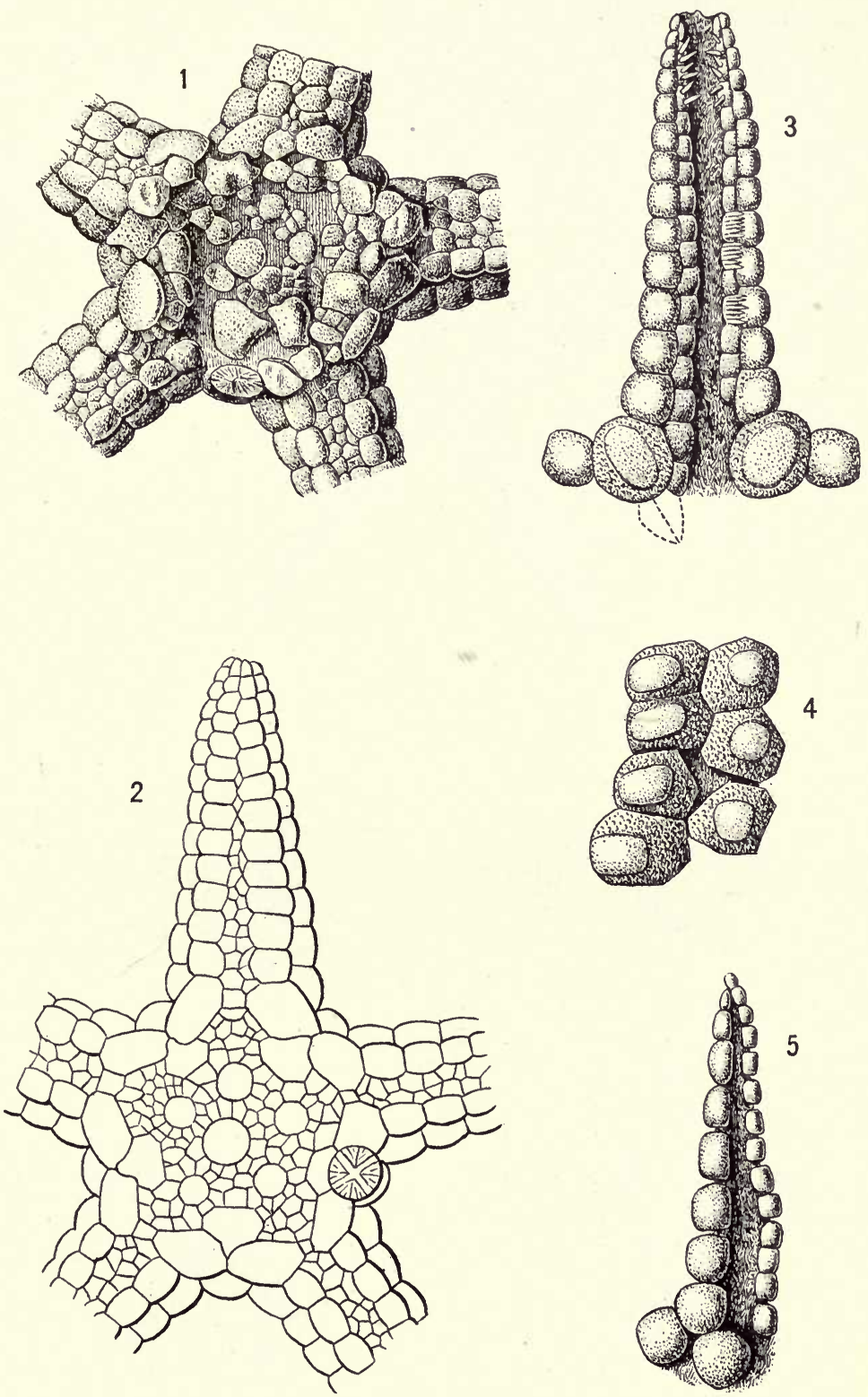


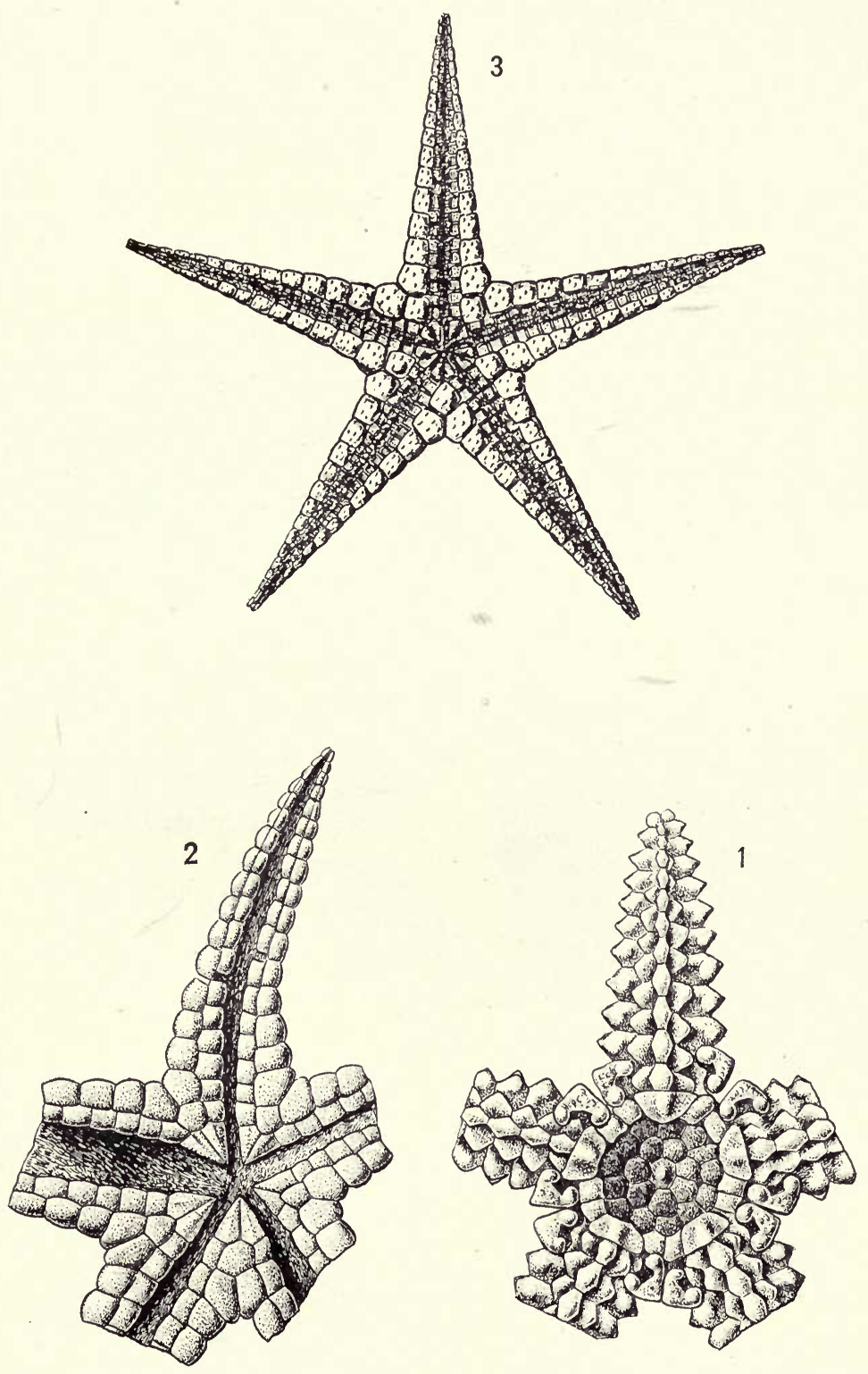

1, 2, Mesopaleaster shafferi; 3, Miomaster drevermanni. For explanation of plate see page 291. 



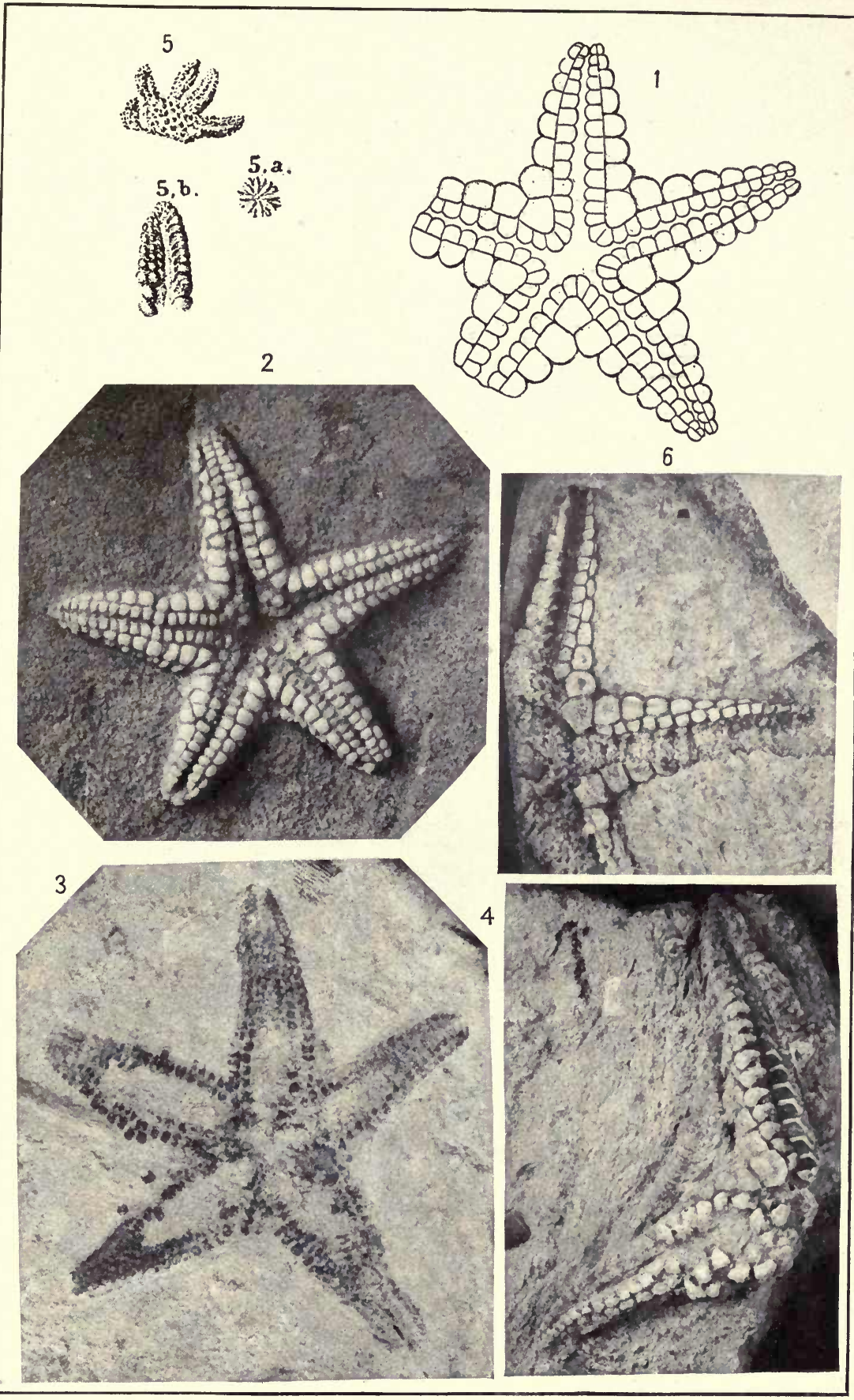

Six Species of Mesopalaeaster.

For EXPLANATION OF PLATE SEe PAgES 291 AND 292. 


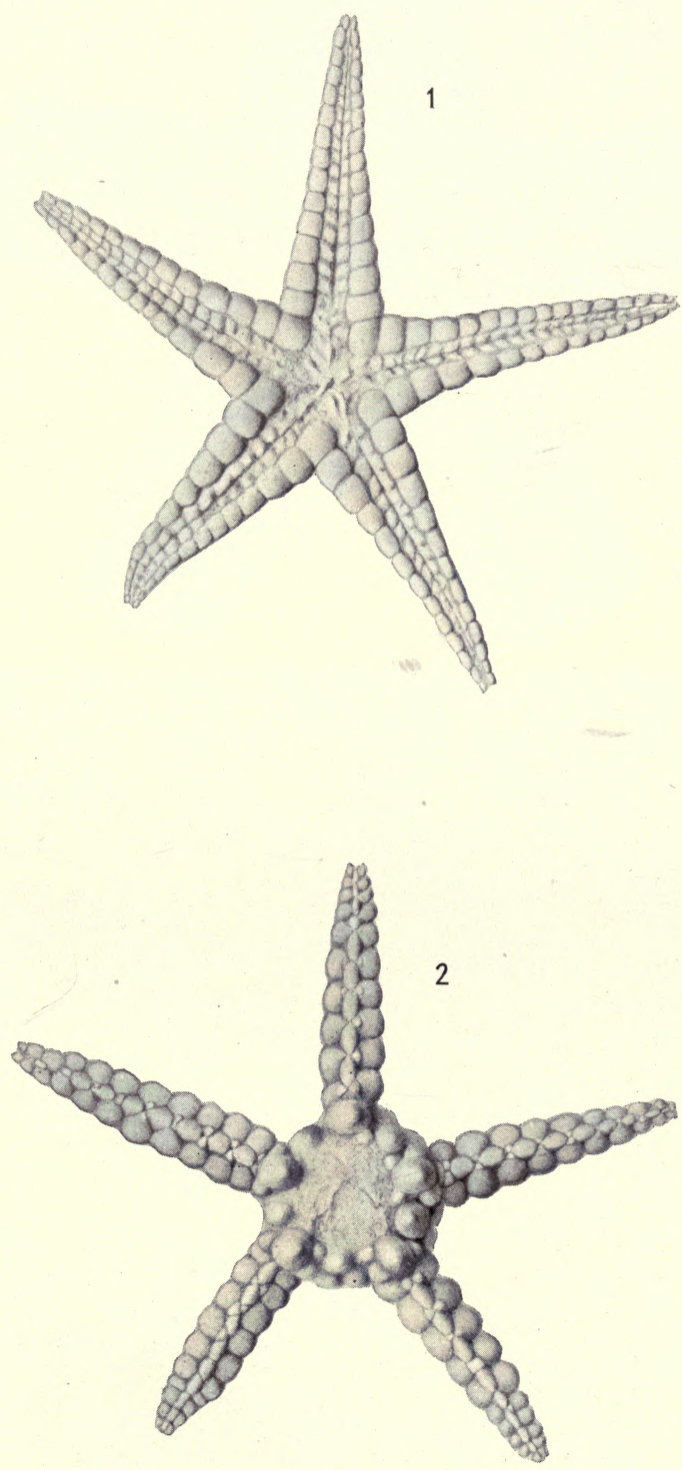

MESOPALAEASTER CLARKI.

For EXPLANATION OF PLATE SEE PAGE 292. 



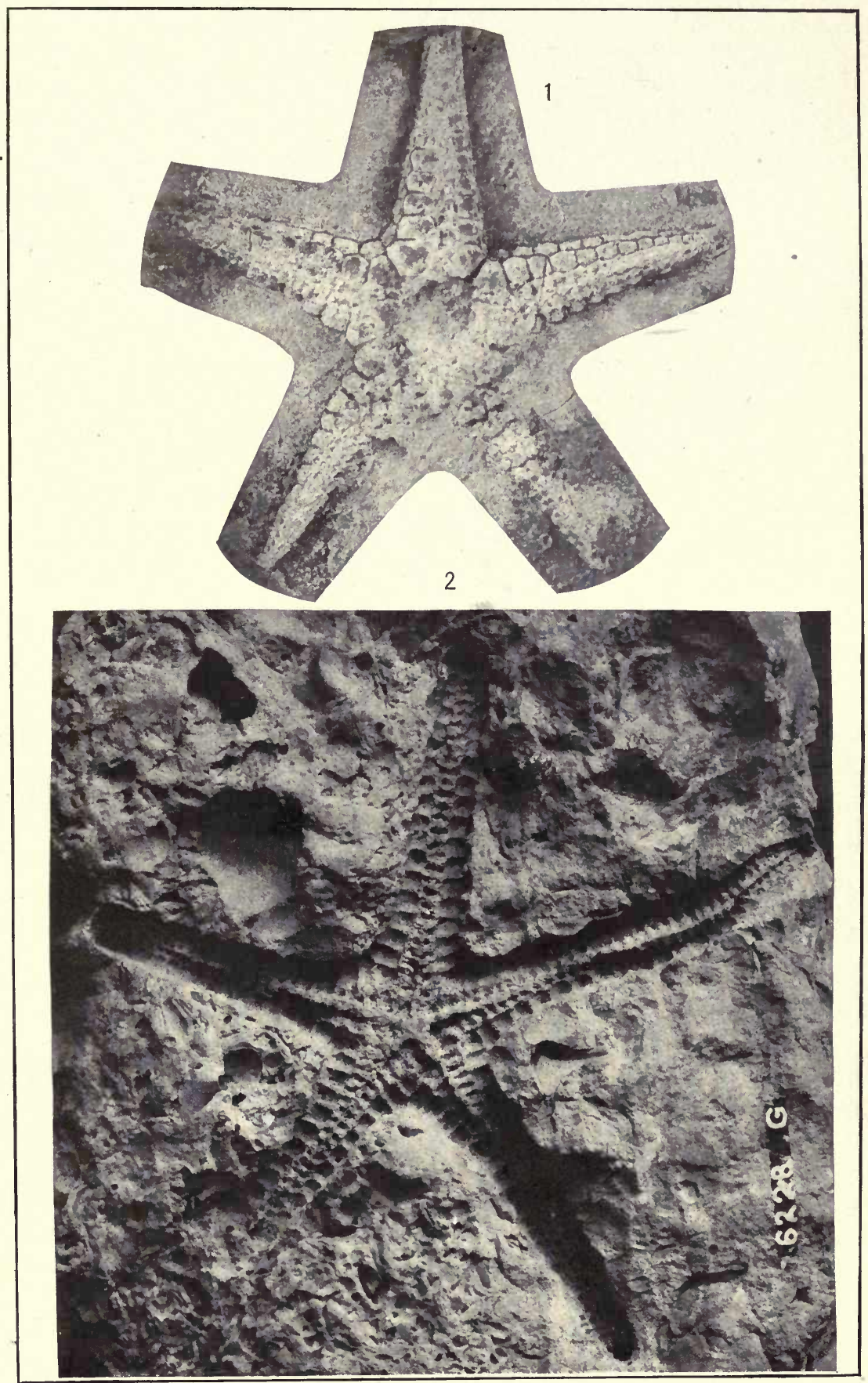

1, Mesopaleaster caractacl; 2, Devonaster chemungensis. 



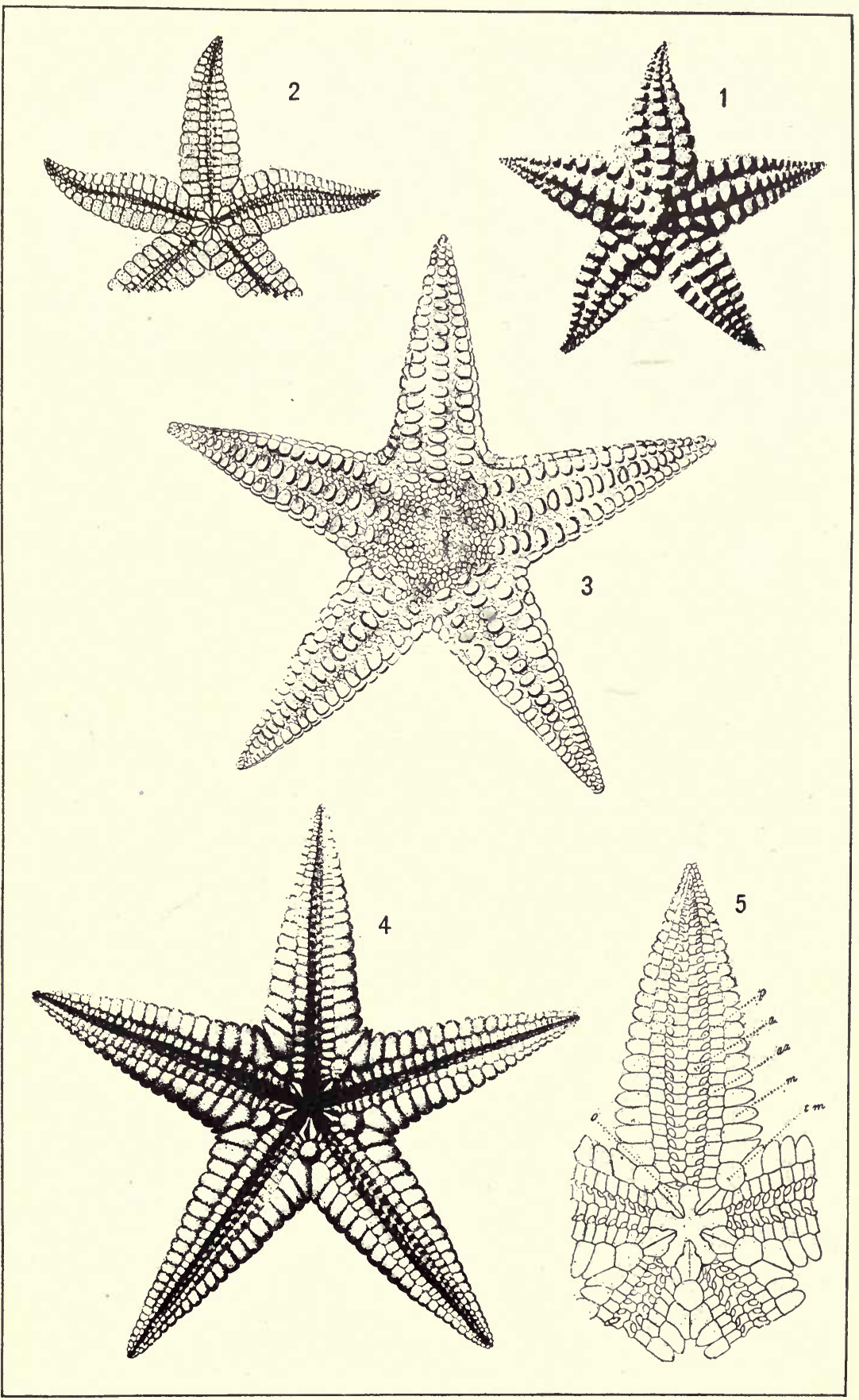

1, 2, Spaniaster latiscutatus; 3-5, DeVonaster eucharis. 



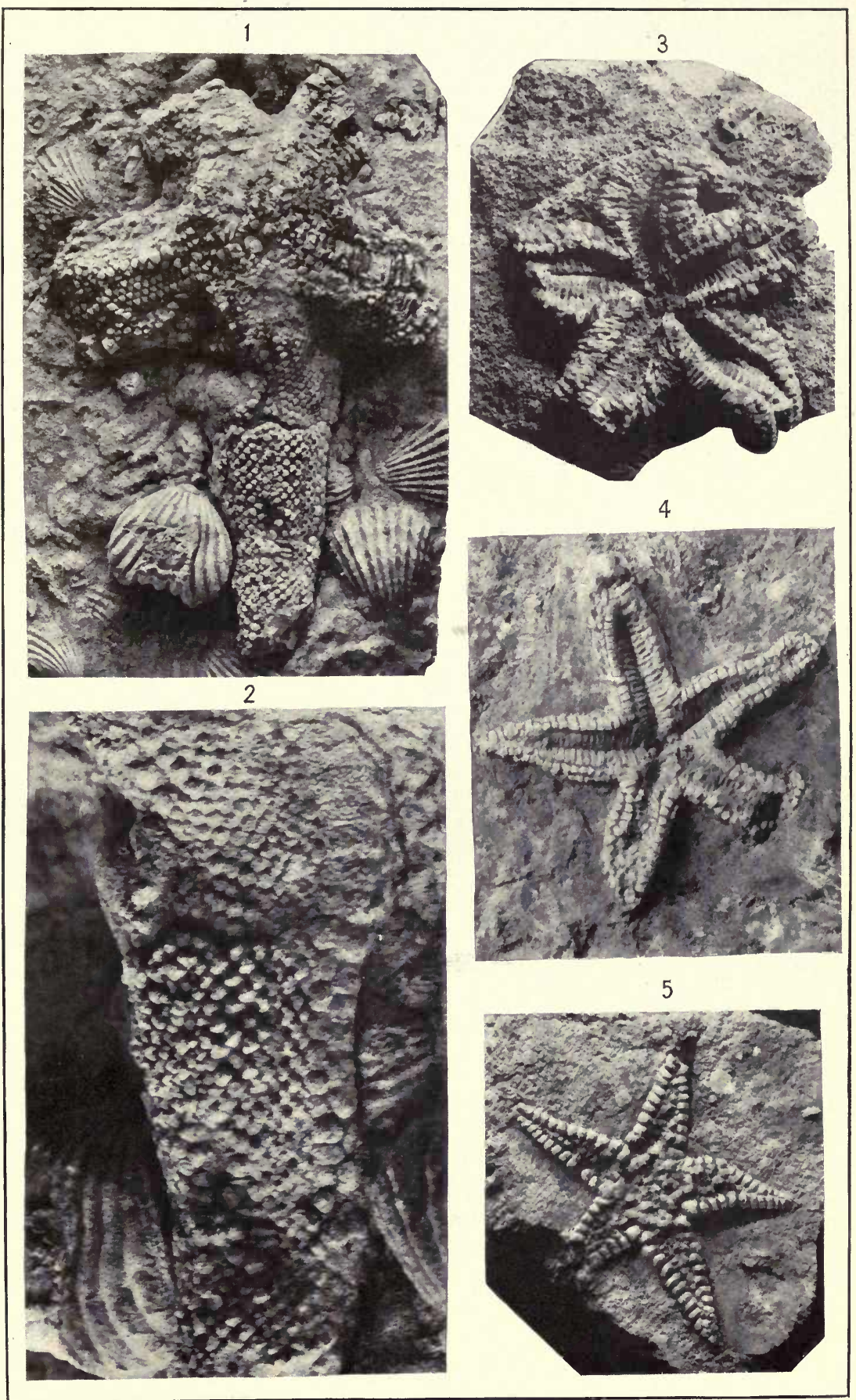

1-3, Promopaleaster; 4, Anorthaster; 5, Neopalfeaster. 



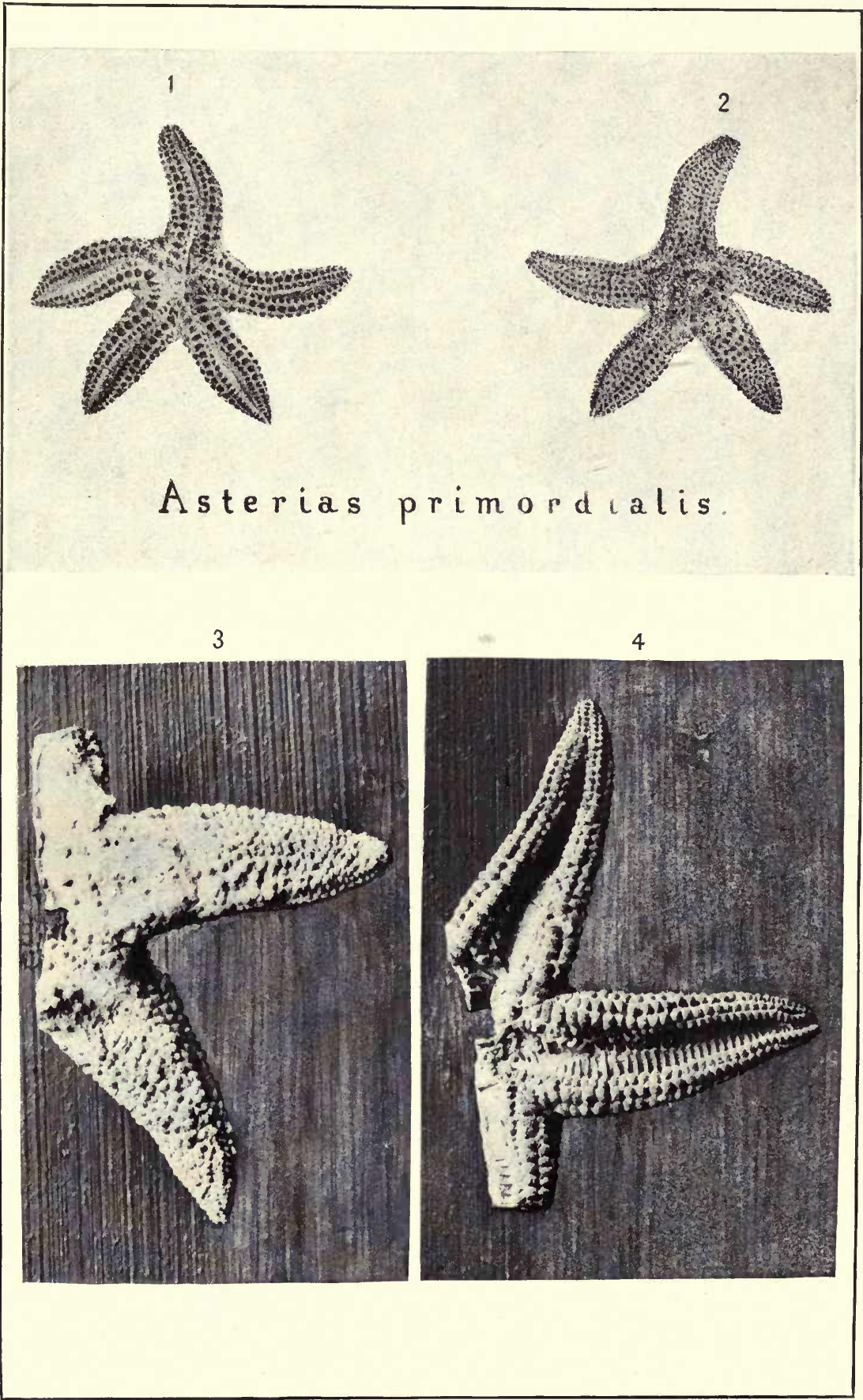

PROMOPALAEASTER SPECIOSUS.

For explanation of PLATE see PAge 293. 


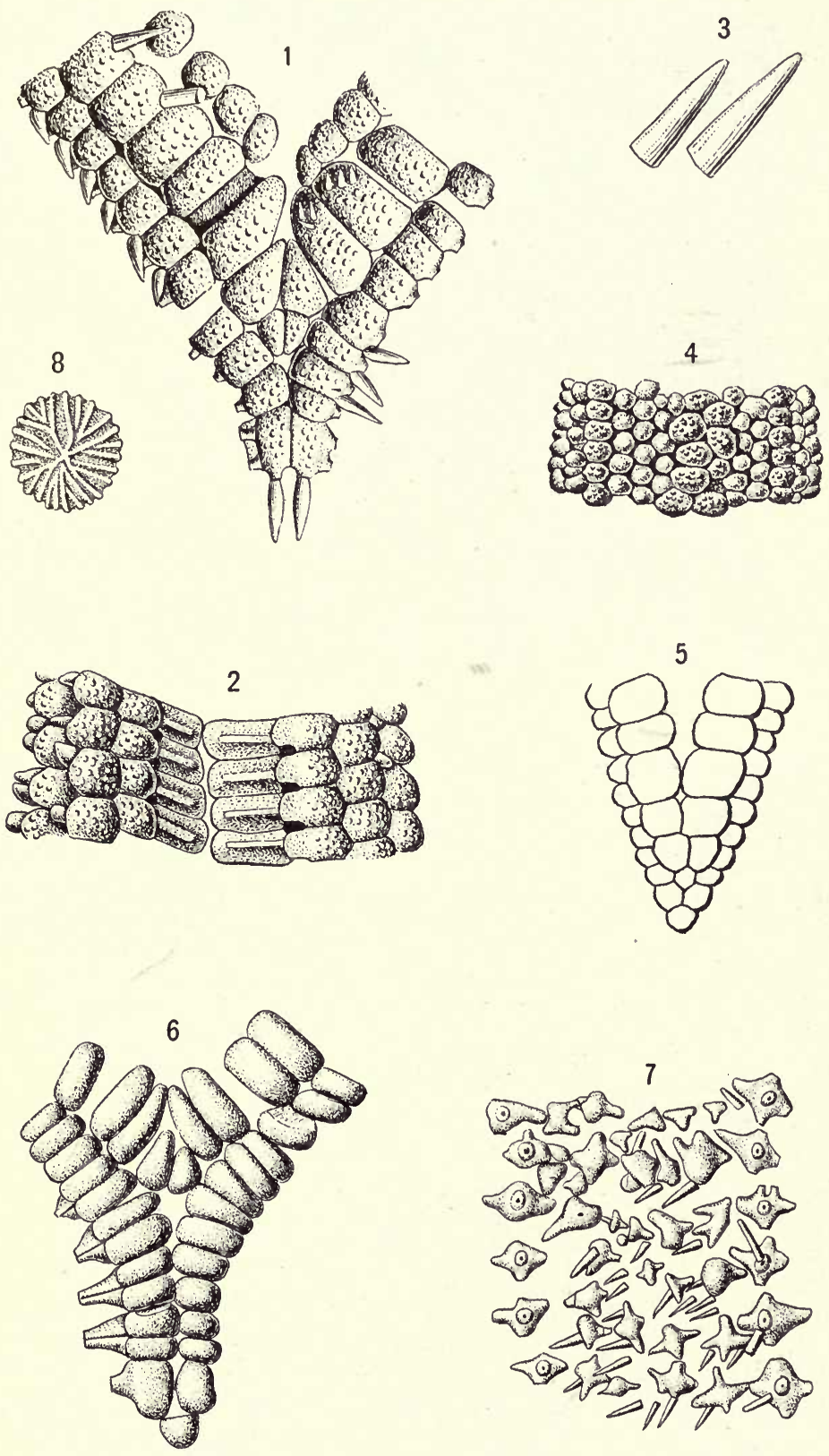

1-4, Promopalfeaster speciosus; 5, P. prenuntius; 6-8, P. Bellulus. 


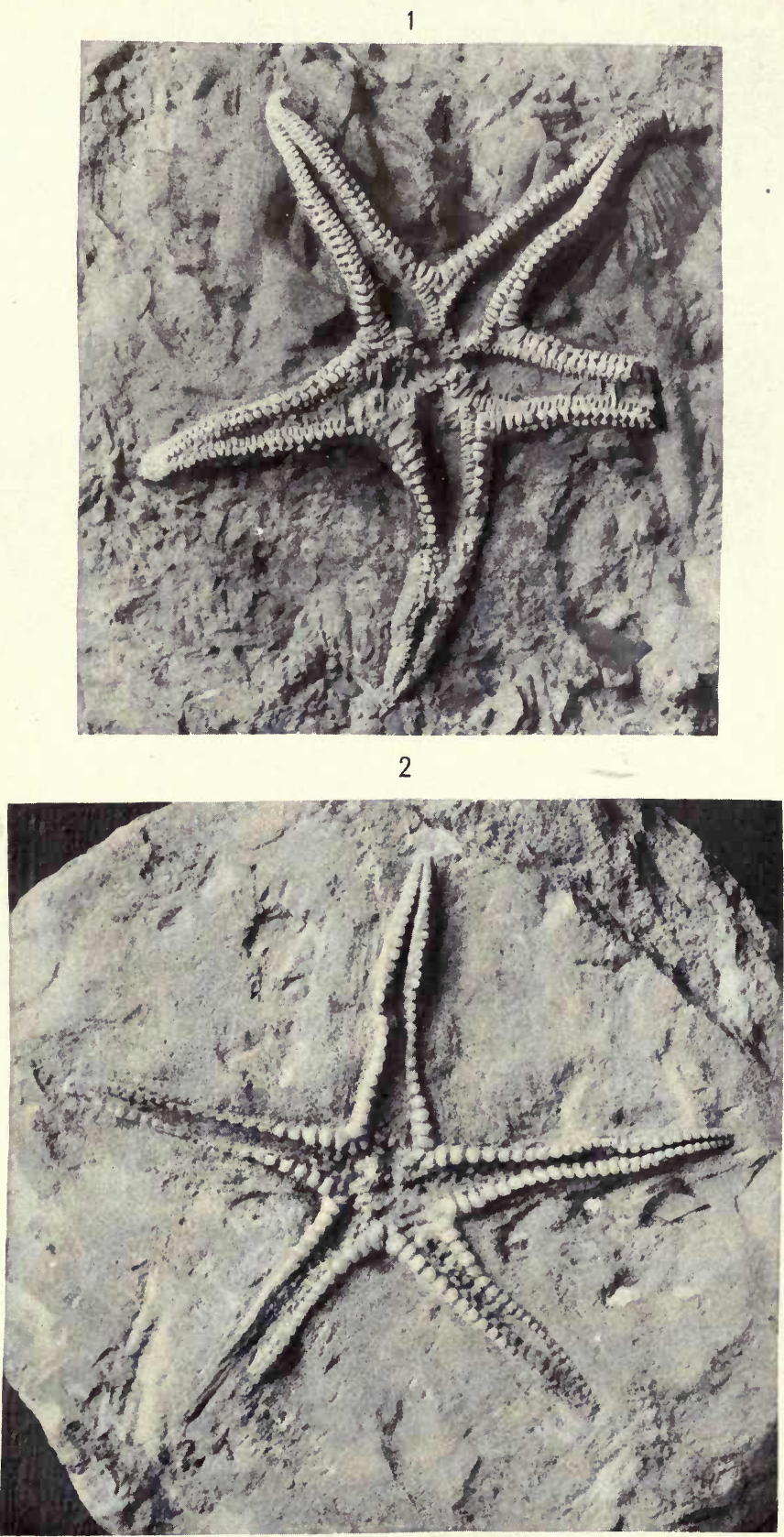

1, Promopalateaster bellulus; 2, P. spinulosus. 



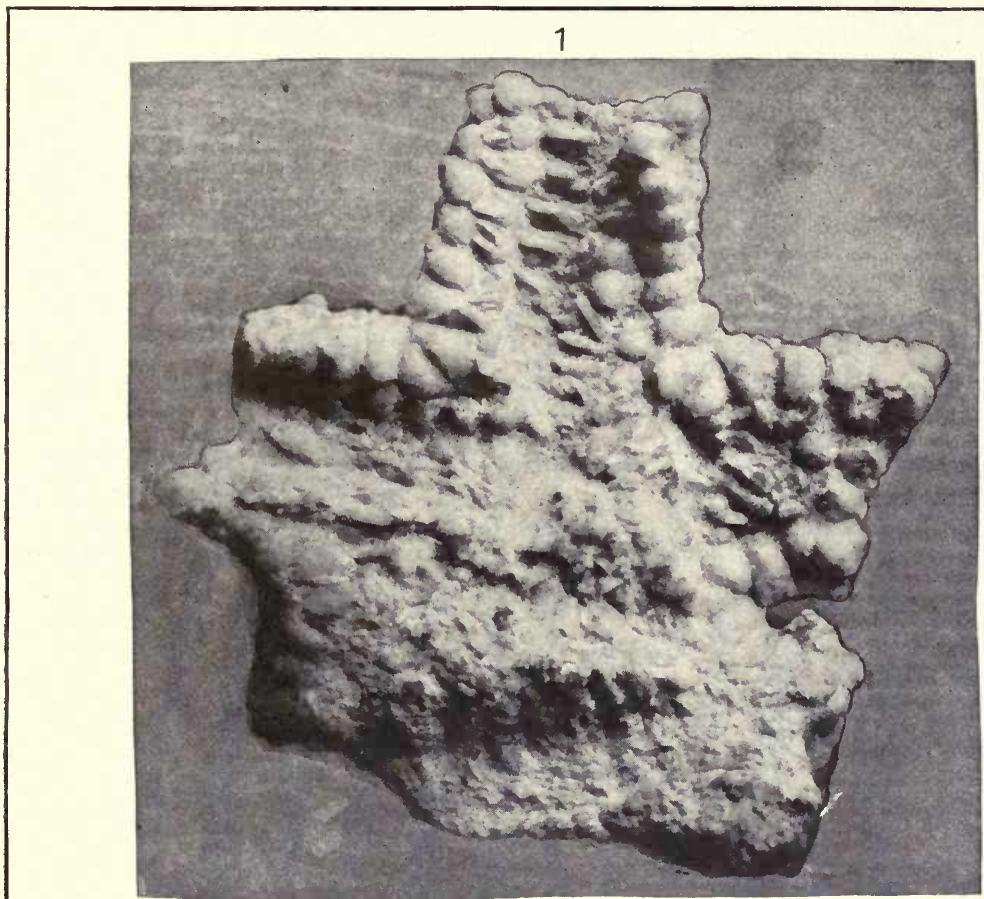

2

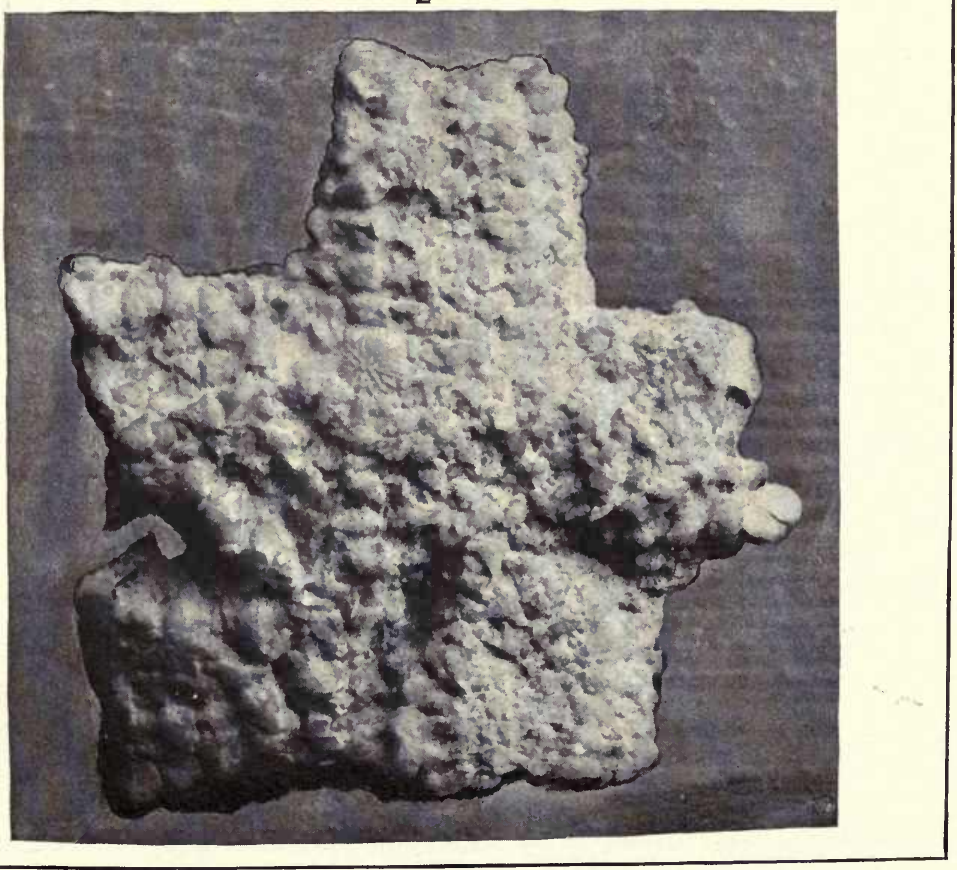

Promopaleaster spinUlosus. 


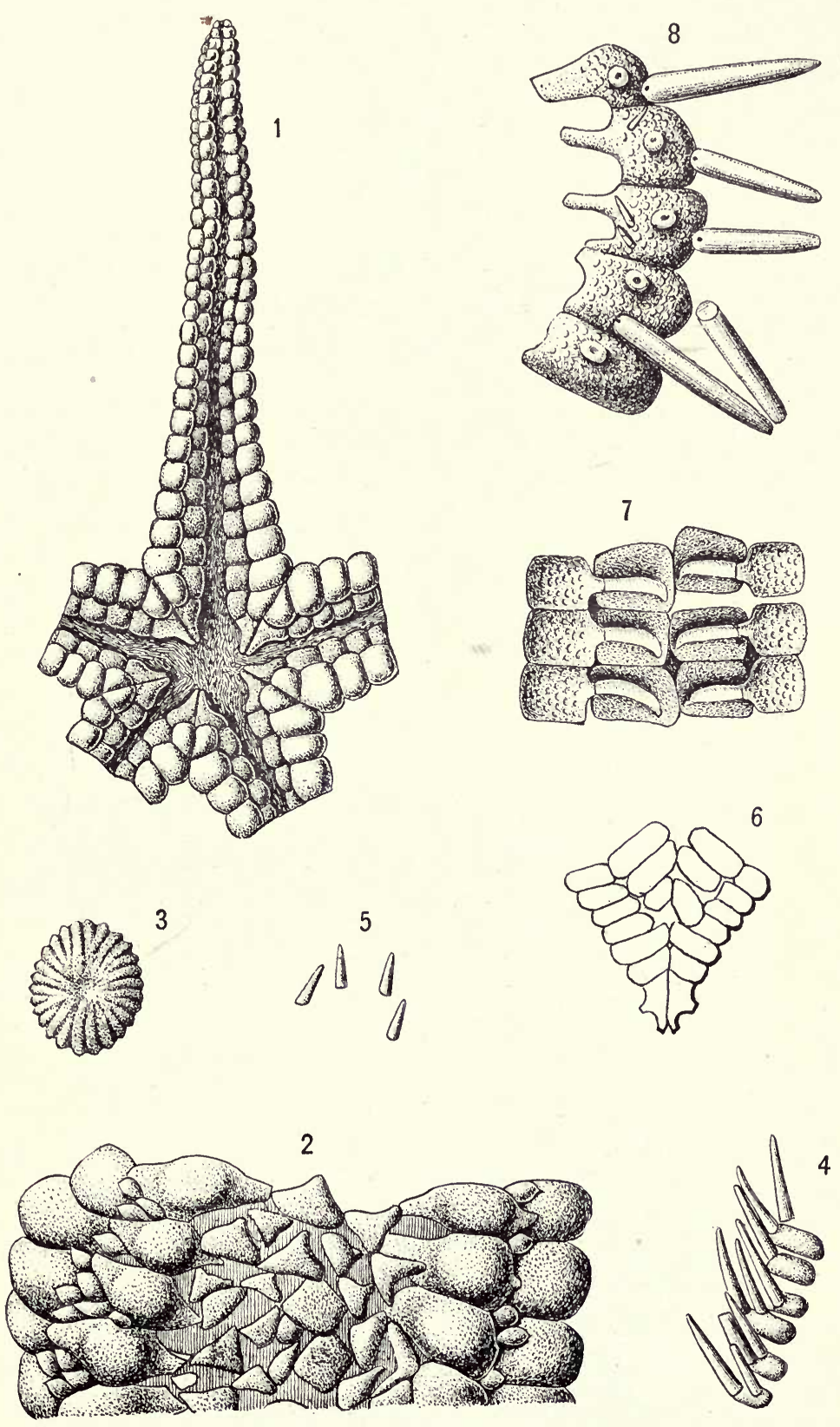

Detall of Five Species of Promopaleaster.

FOR EXPLANATION OF PLATE SEE PAGES 294 AND 295. 



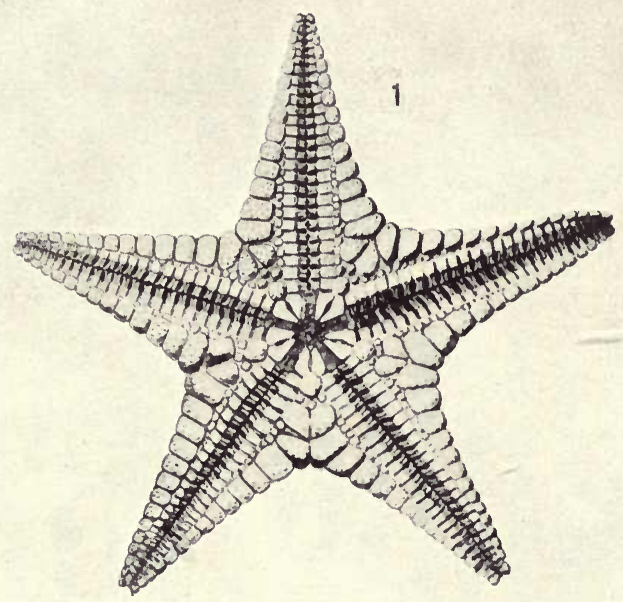

\section{2}

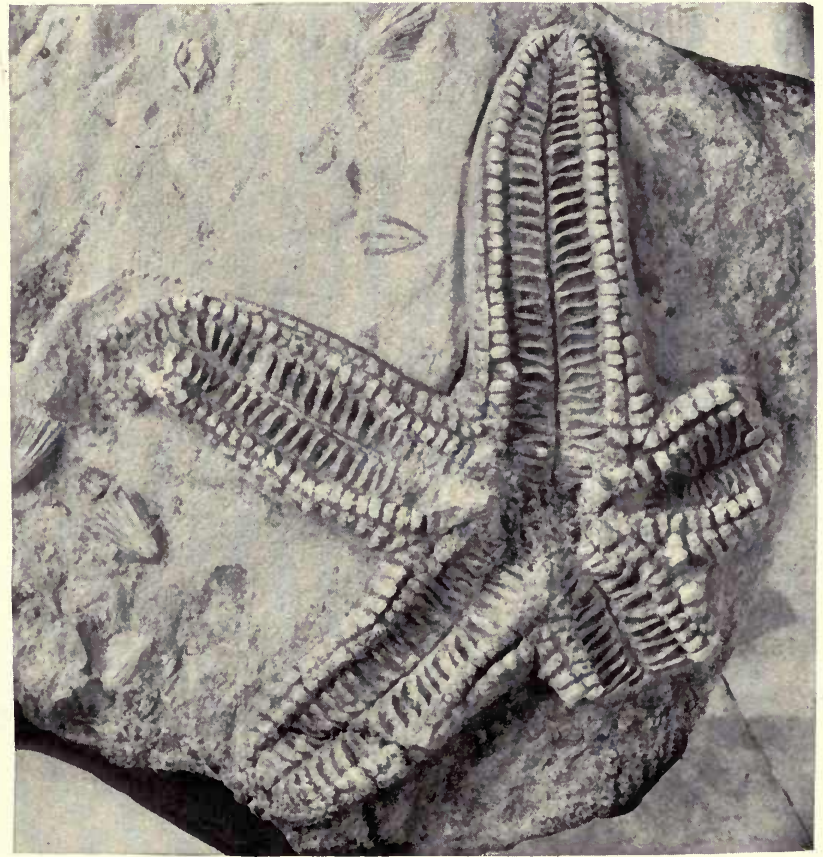

1, Trimeraster parvulus; 2, Promopaleaster Wykoffi.

FOR EXPLANATION OF PLATE SEE PAGE 295. 



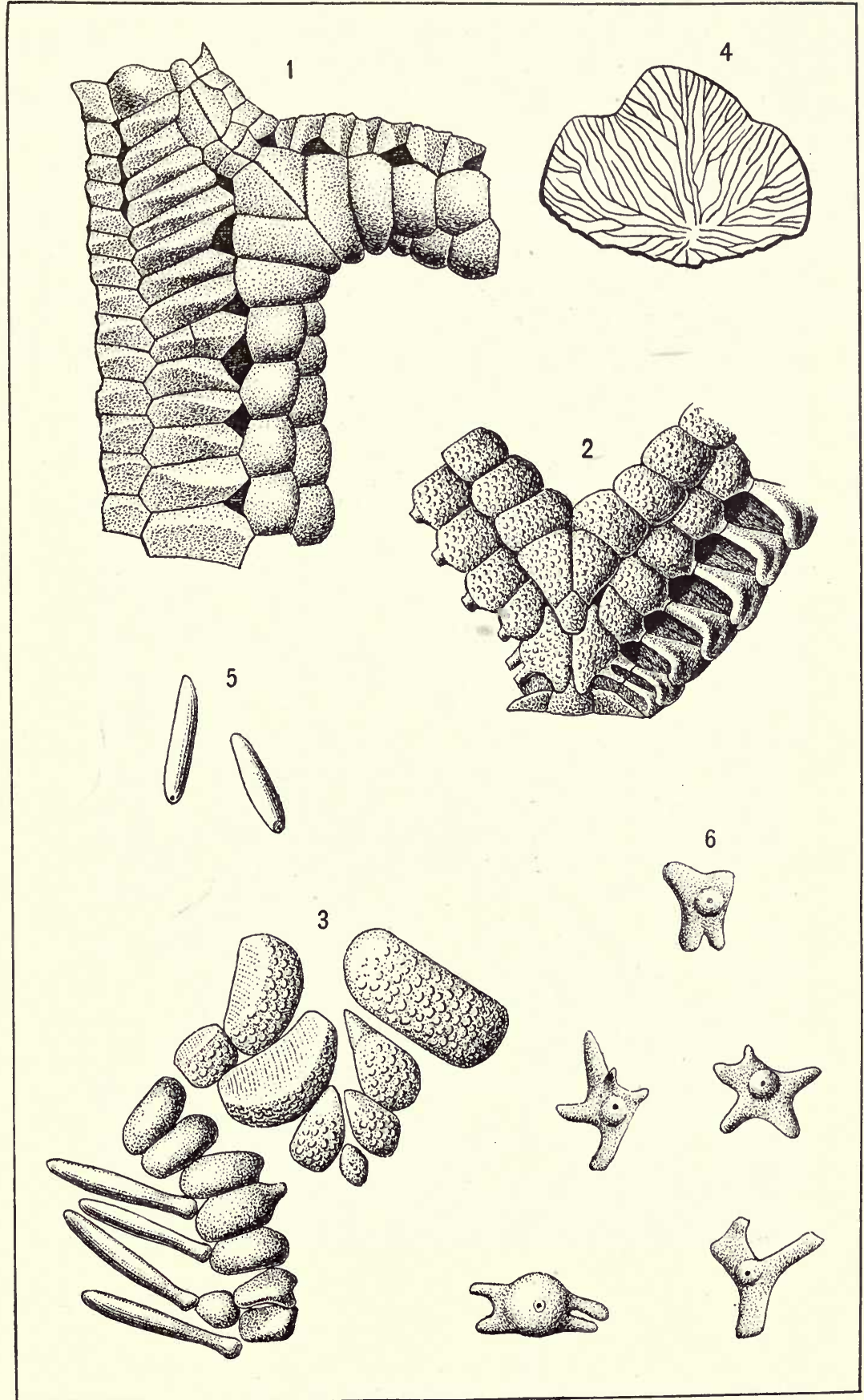

1, Detail of Anorthaster; 2-6, Promopalfeaster.

FOR EXPLANATION OF PLATE SEE PAGES 295 AND 296. 



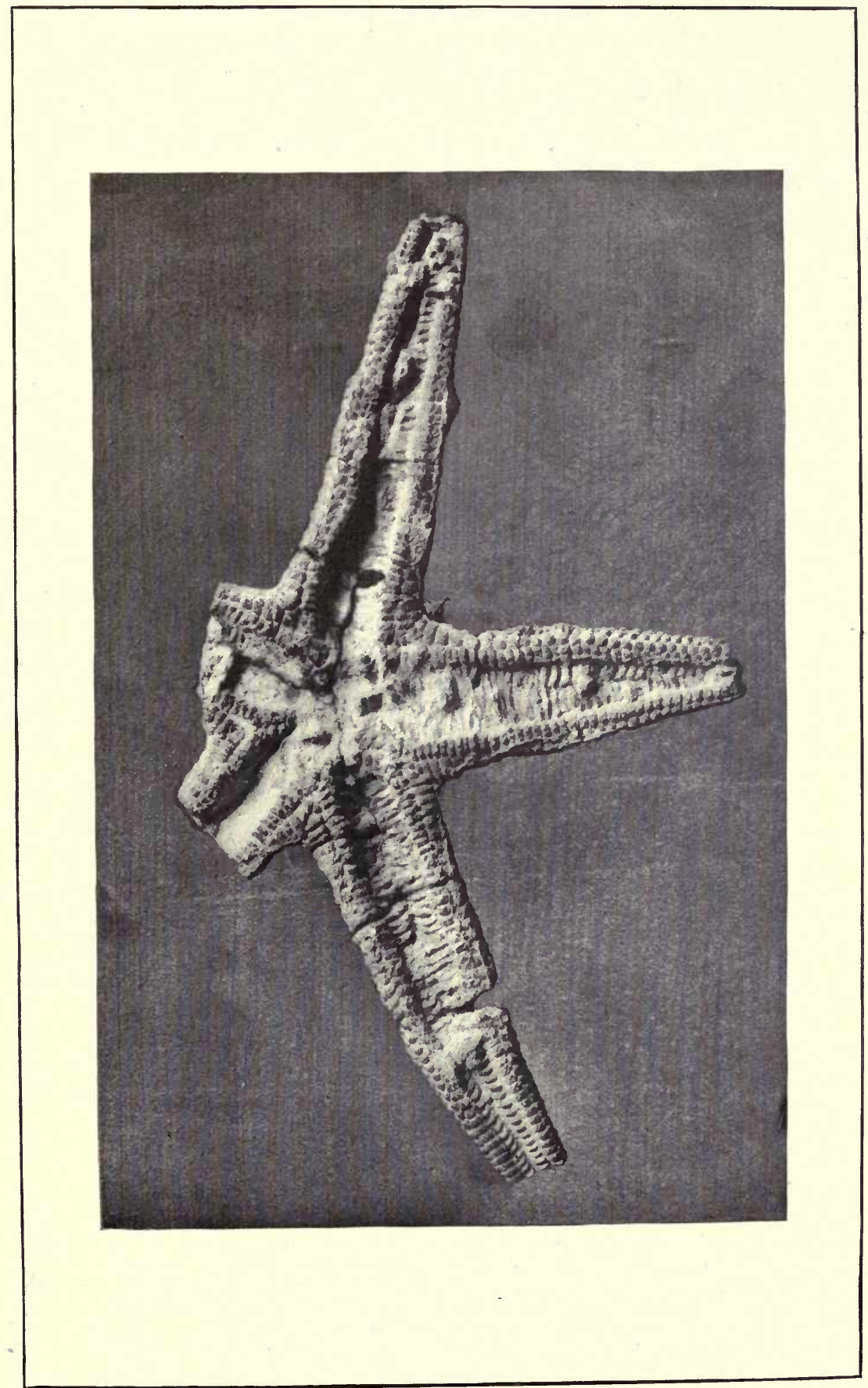

Promopaleaster MAgNificus.

For EXPLANATION OF PLATE SEE PAGE 296. 



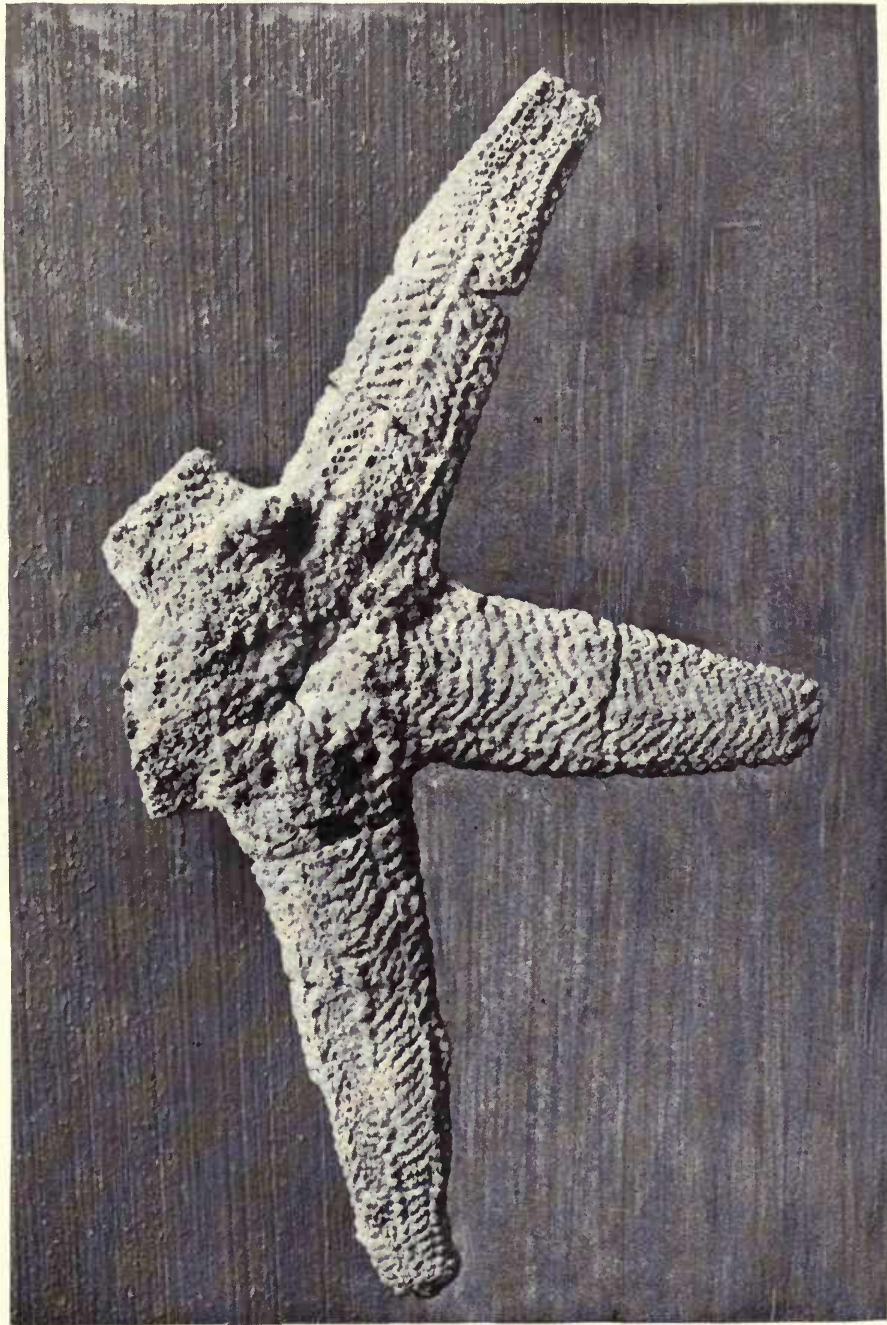

Promopalfeaster magnificus.

For explanation of PLATE see PAge 296. 


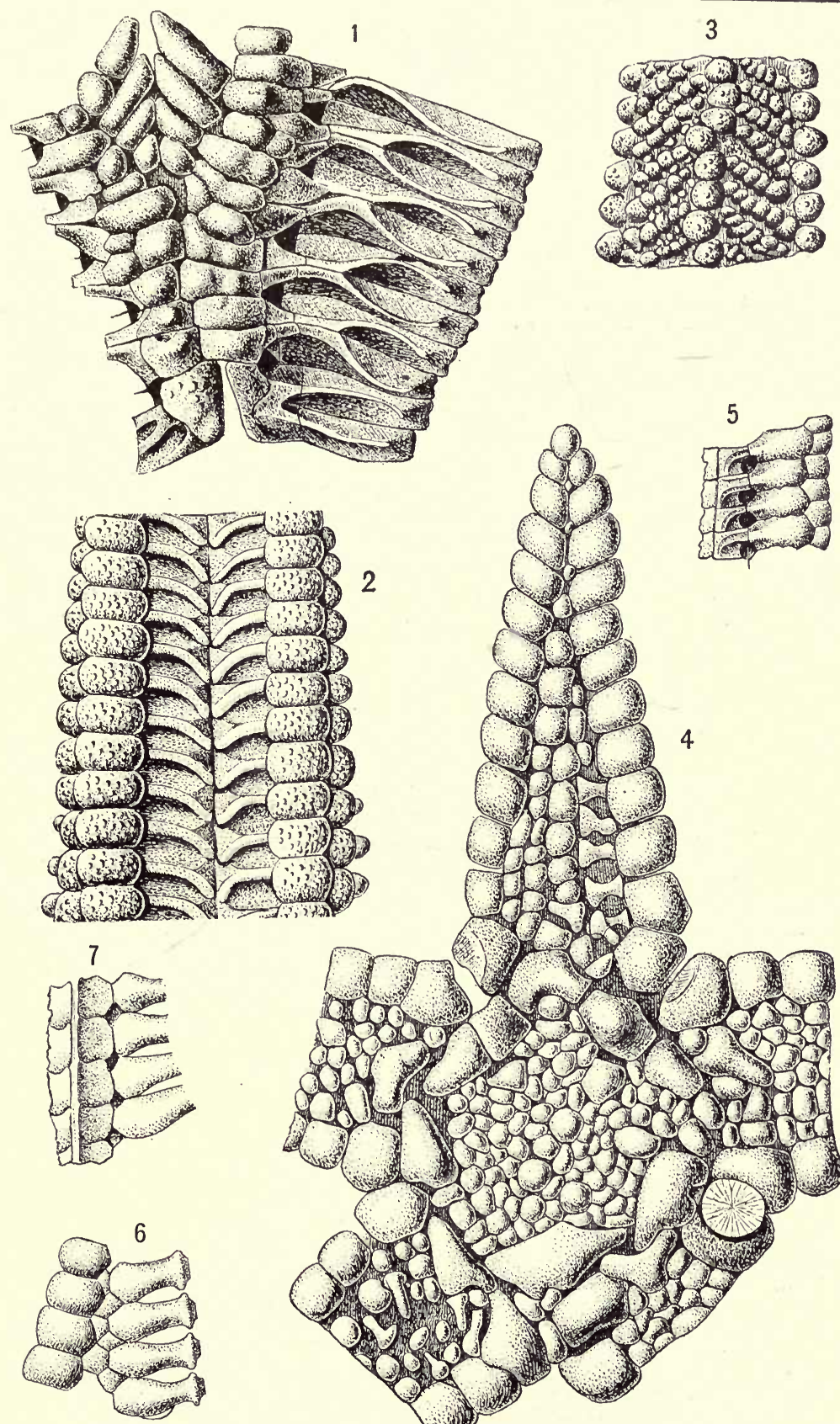

4
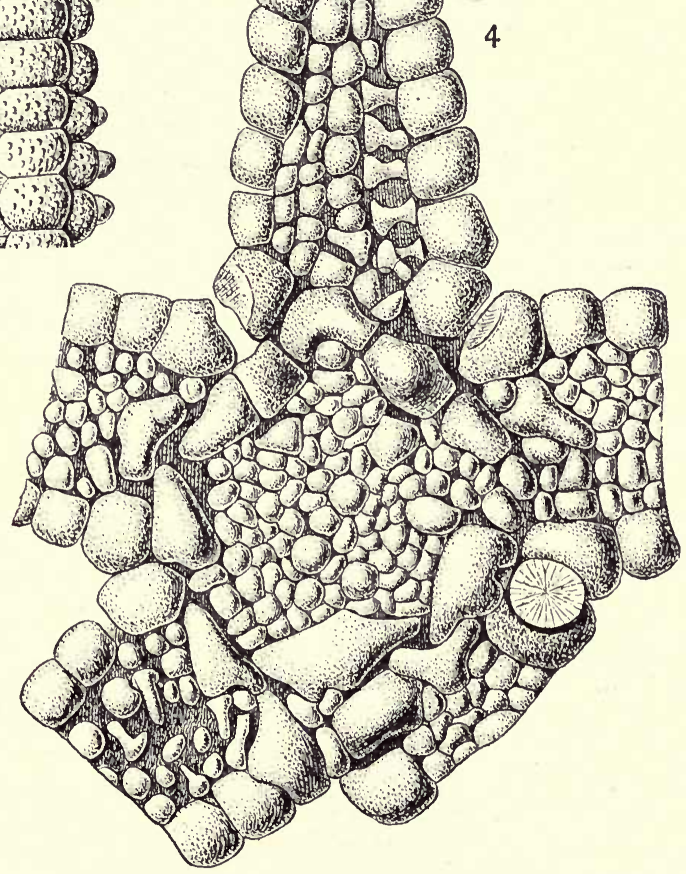

1-3, Detail of Promopalaeaster; 4, Neopalaeaster; 5-7, Petraster. 



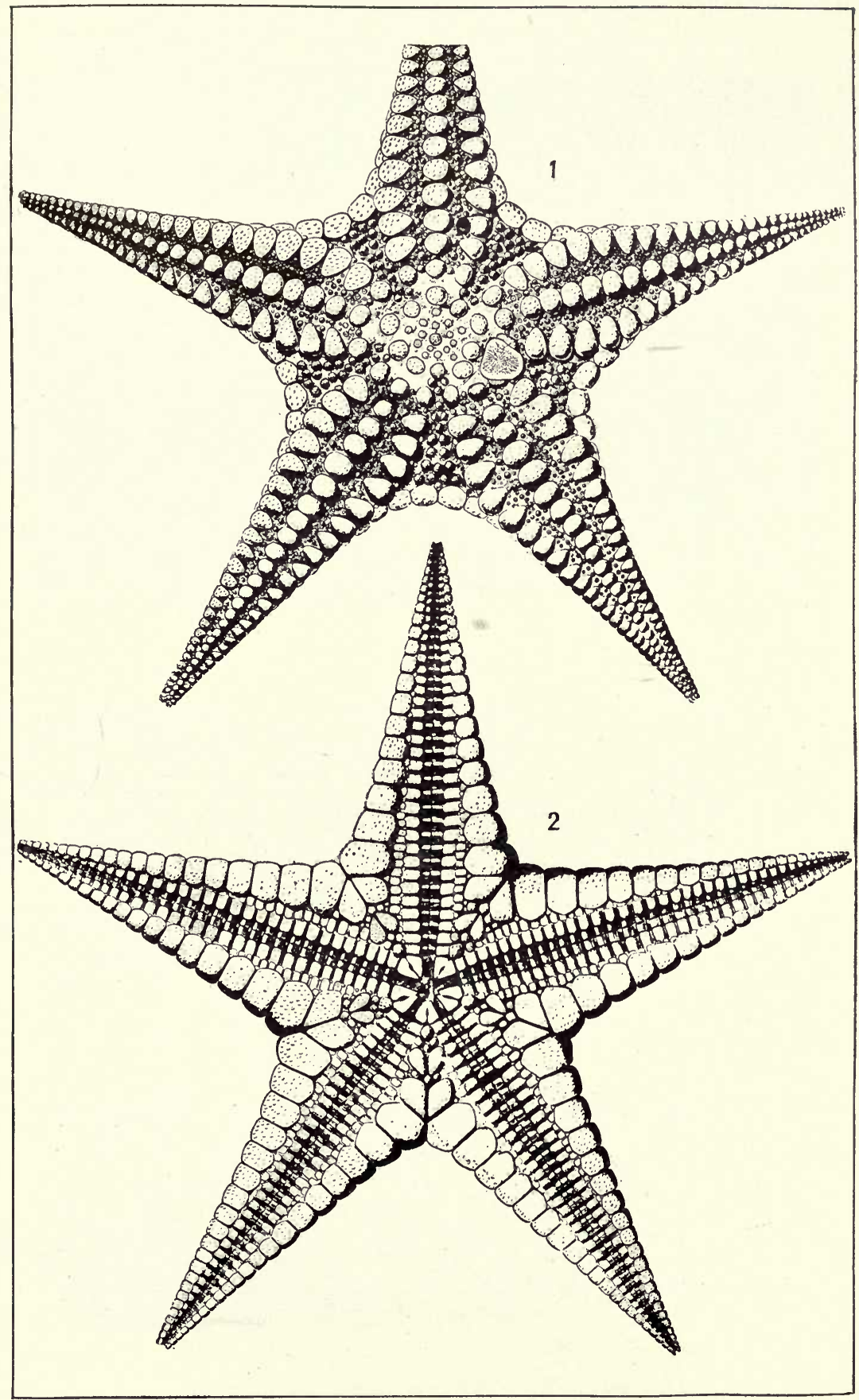

XenAster margaritatus.

For EXPLANATION OF PLATE SEe PAge 297. 


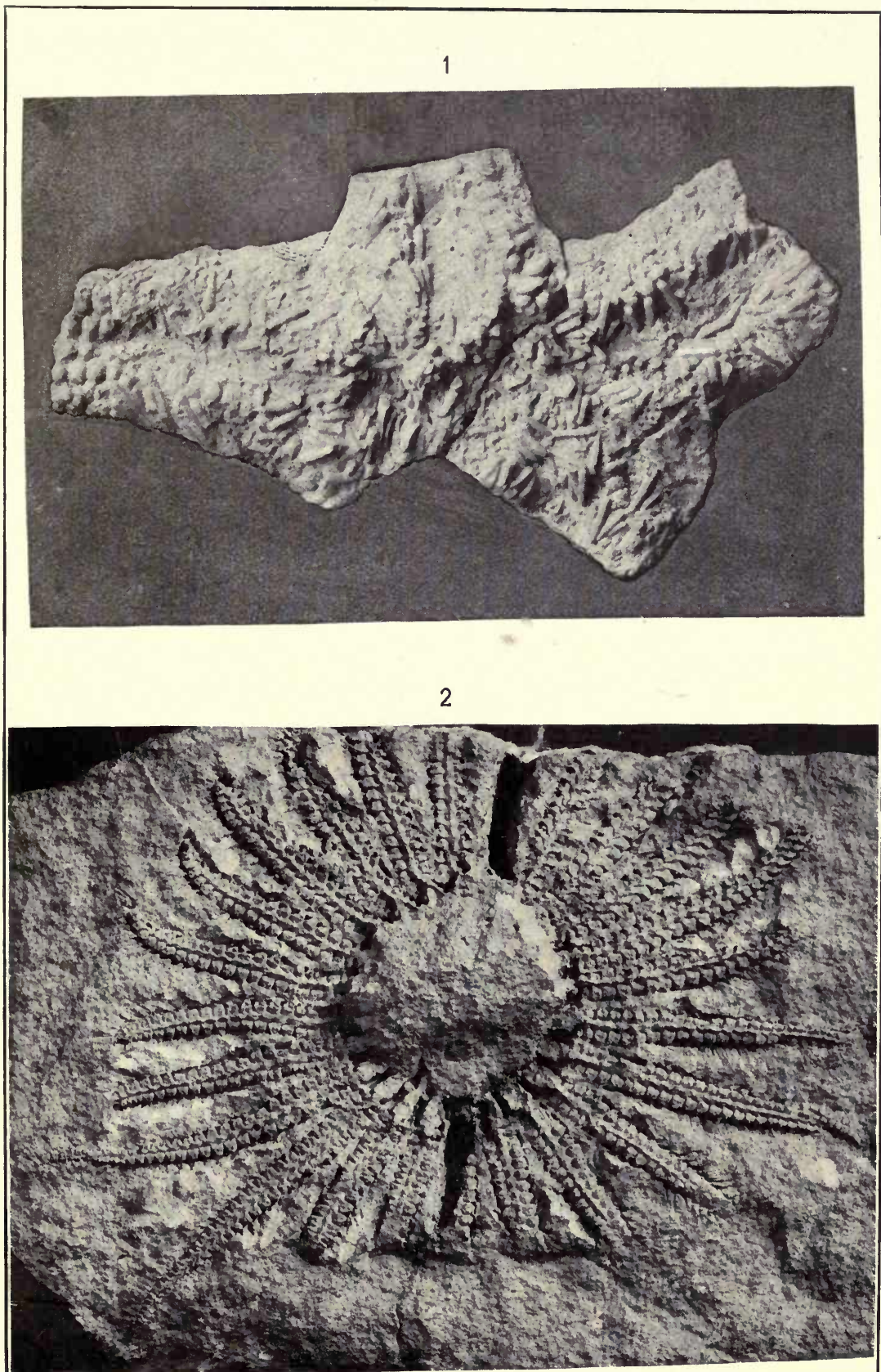

1, Promopaleaster dyeri; 2, Lepidasterella babcockI. 



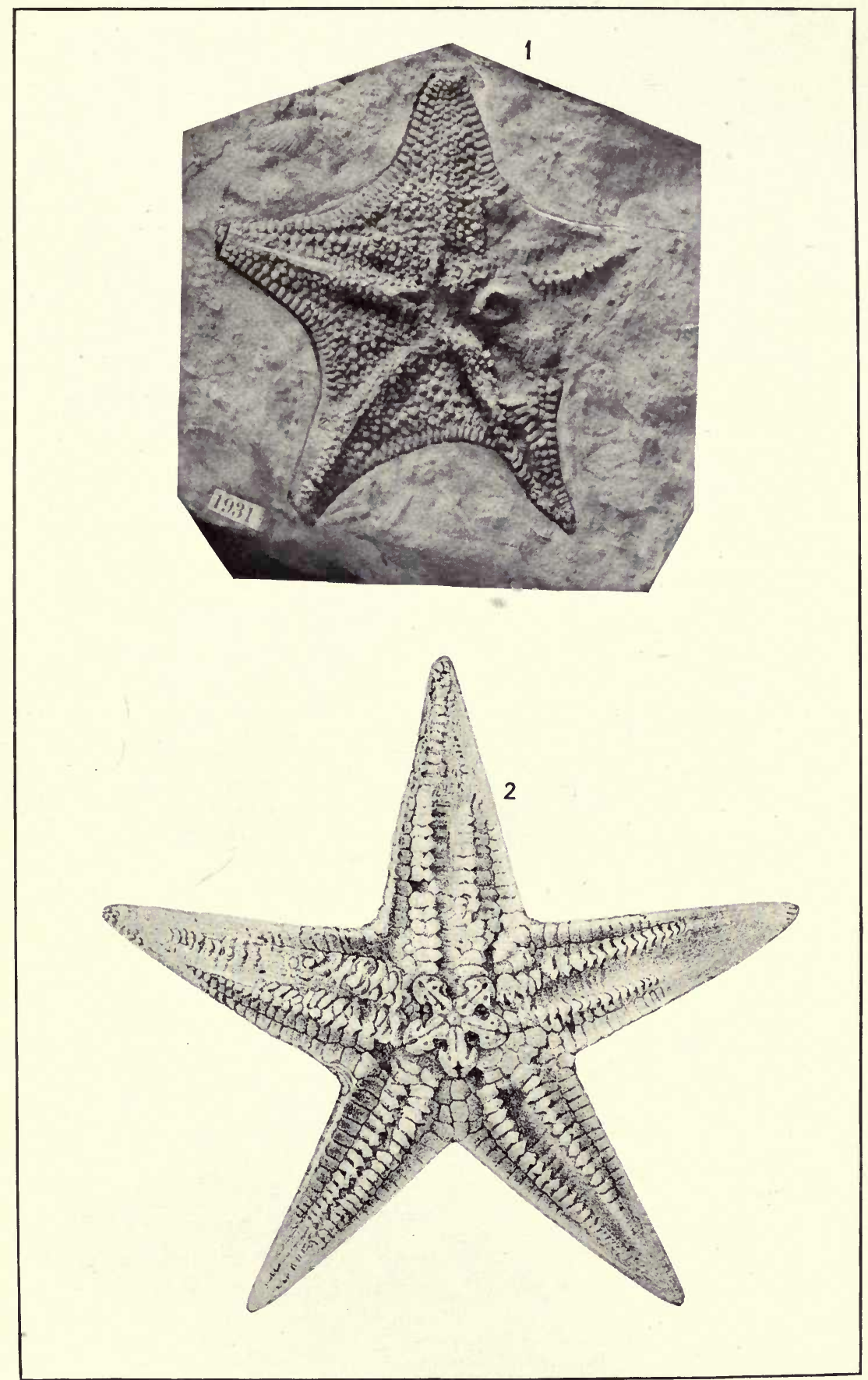

1, Petraster speciosus; 2, P. (2) americanus. 


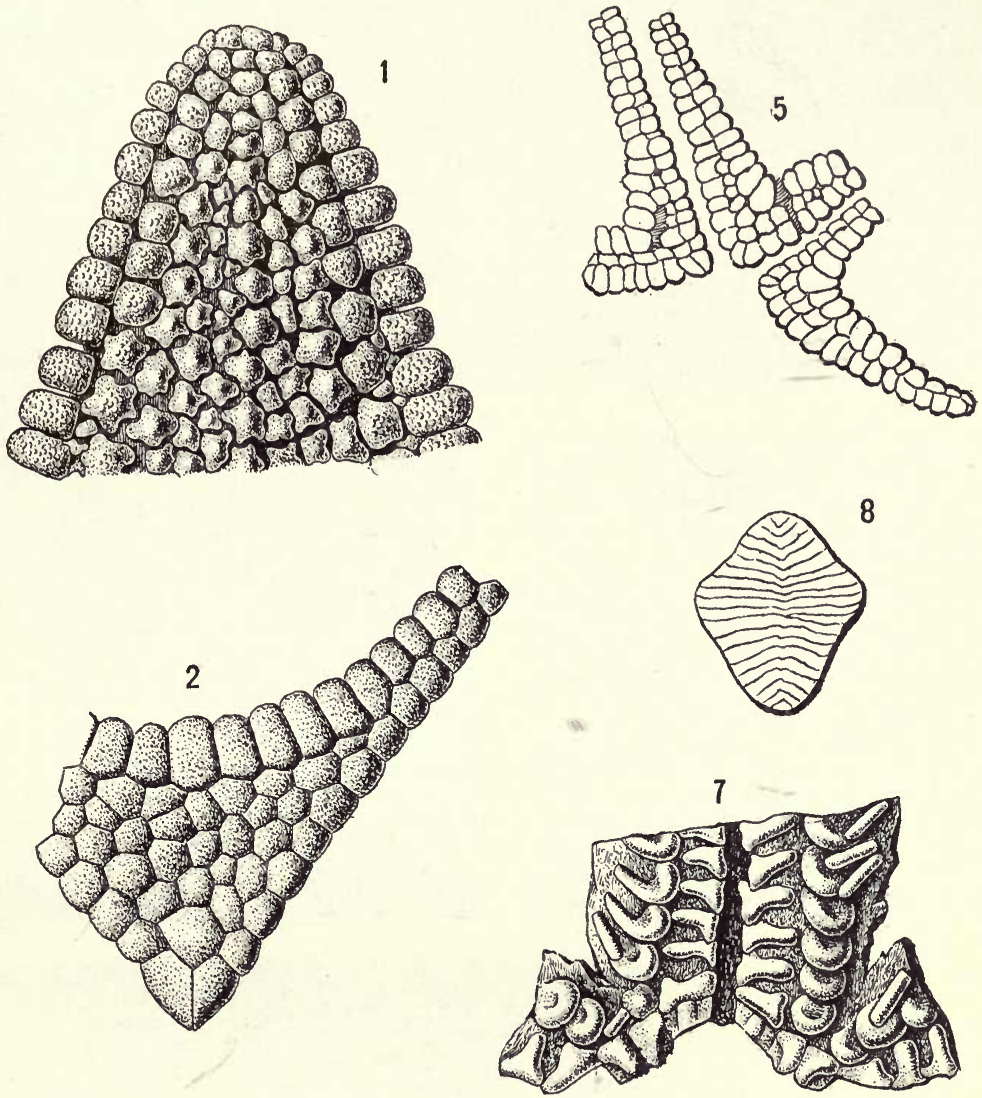

6
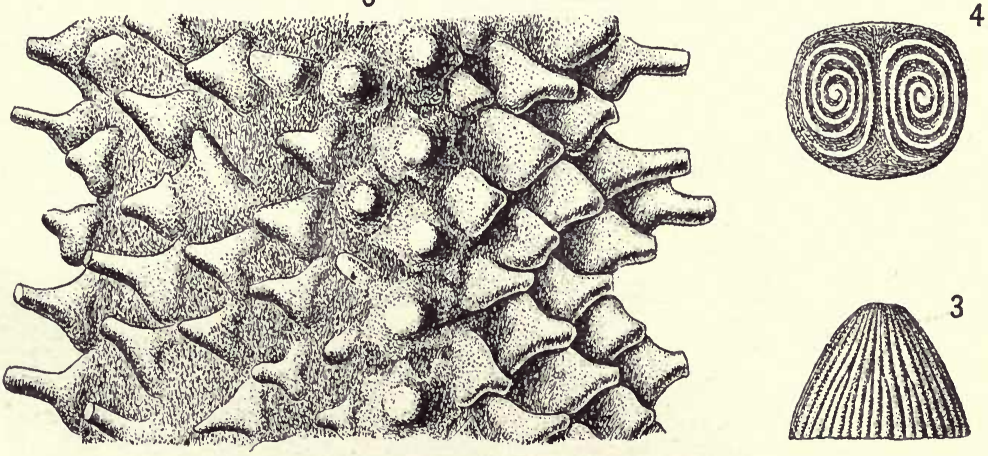

1-5, Detail of Petraster; 6-8, Urasterella. For EXPLANATION OF PLATE SEE PAGES 297 AND 298. 



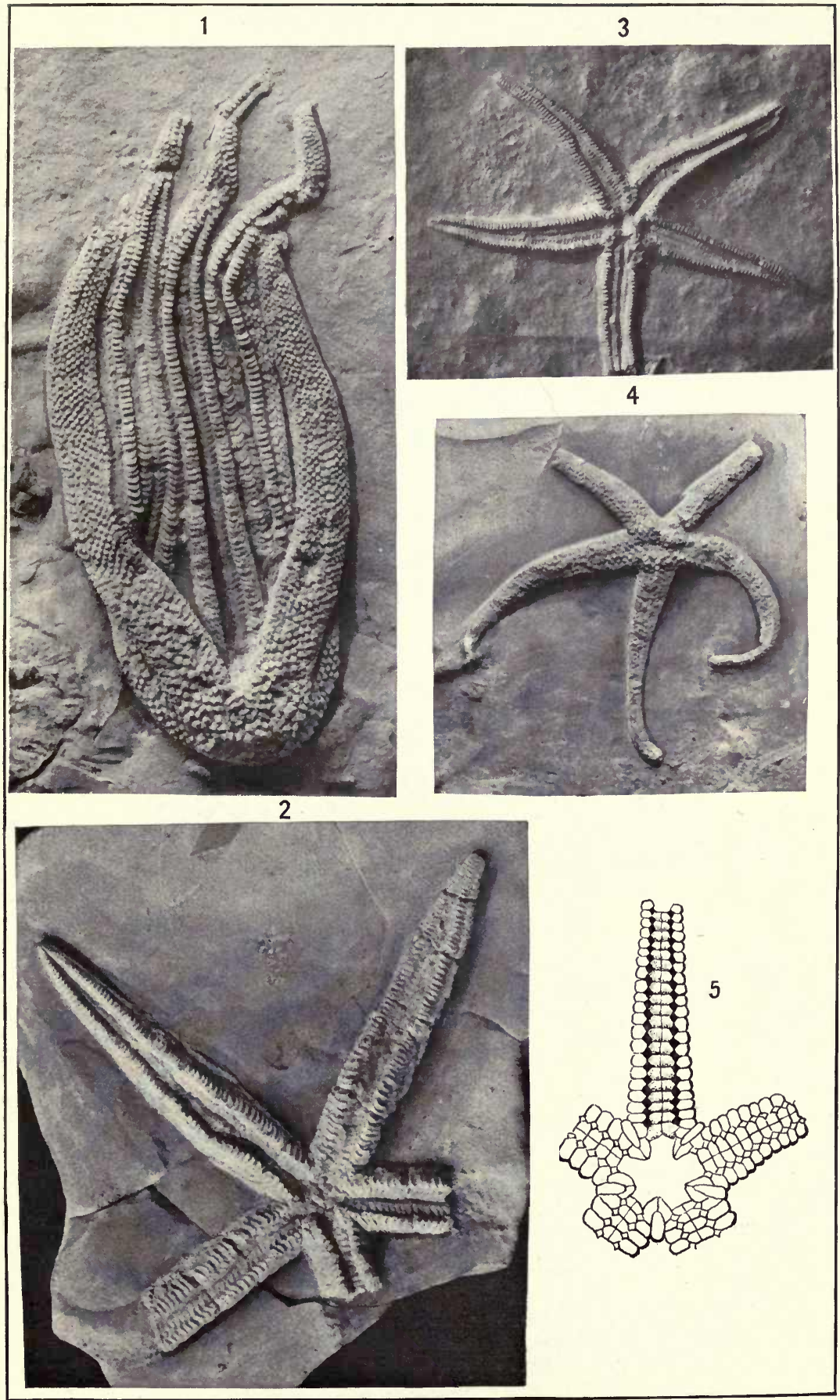

1, 2, Urasterella grandis; 3, 4, U. pulchella; 5, U. girVANensis. FOR EXPLANATION OF PLATE SEE PAGE 298. 


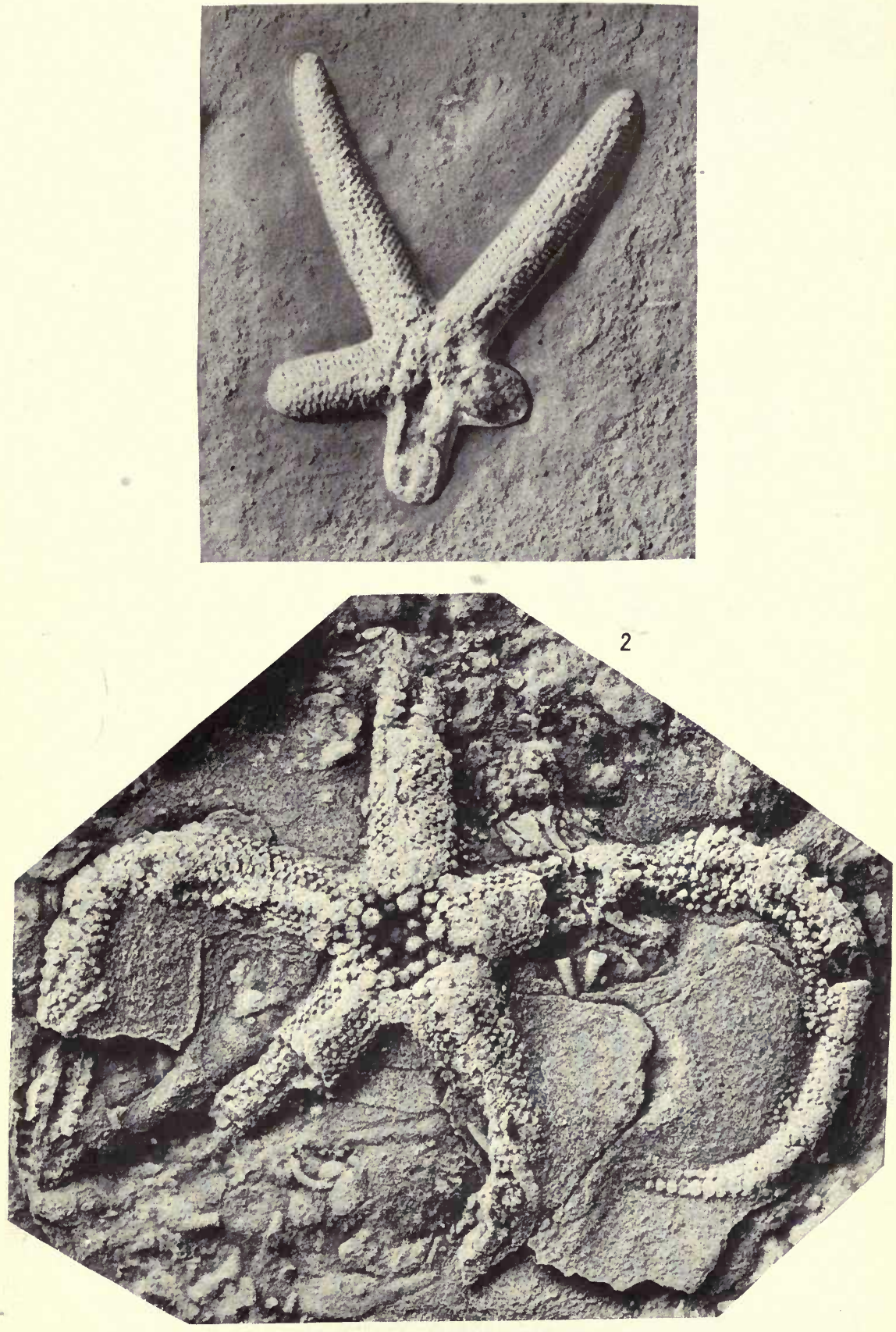

1, URAsterelLA ULRICHI; 2, U. HUXLEYI.

For EXPLANATION OF PLATE SEE PAGE 298. 


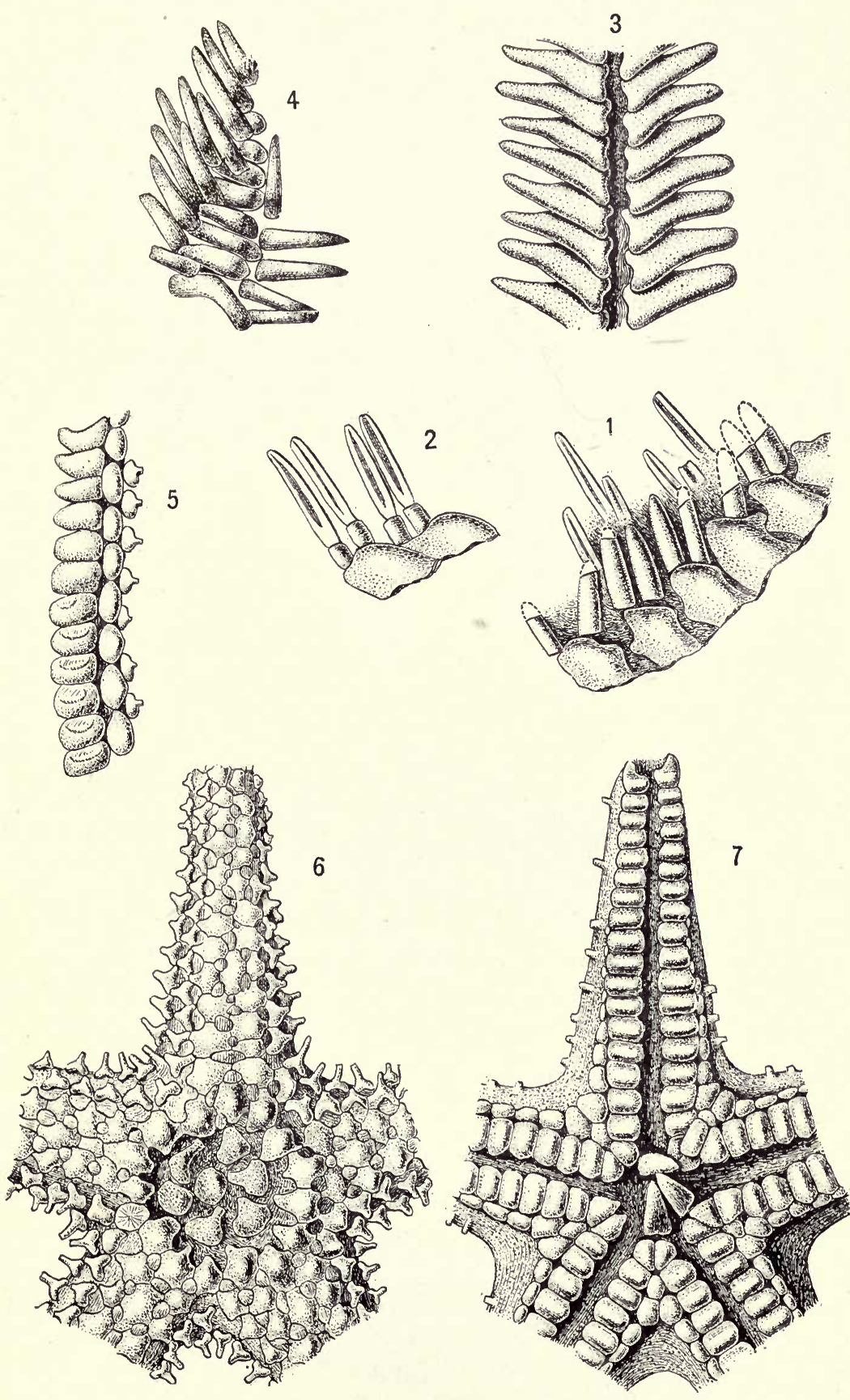

DetaIL of URASTERELLA.

For EXPLANATION OF PLATE SEE PAGES 298 AND 299. 


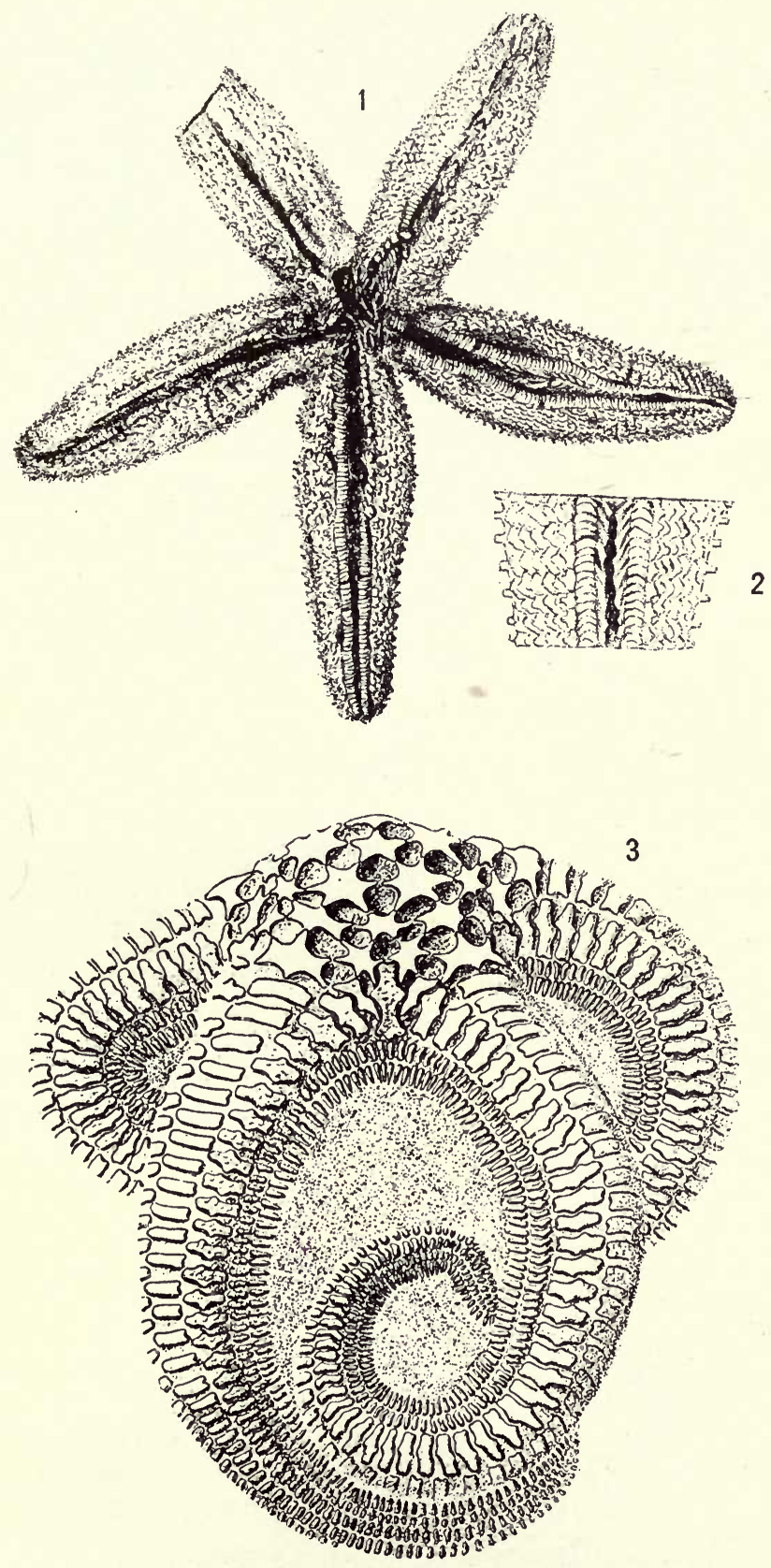

1, Compsaster formosus; 2, Calliasterella mira. 



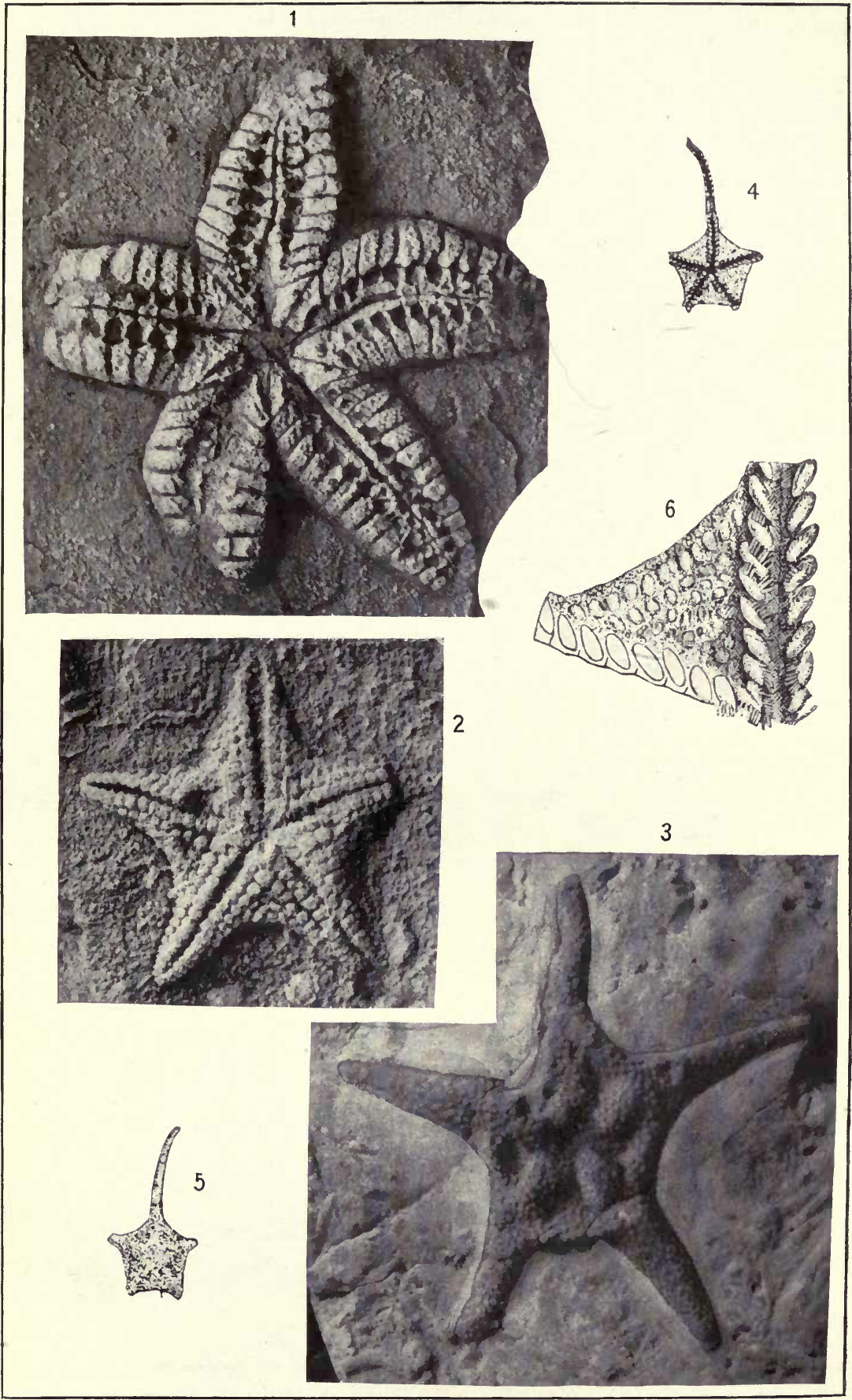

1, Stenaster; 2,3 , Schuchertia; 4-6, Schoenaster (?). 


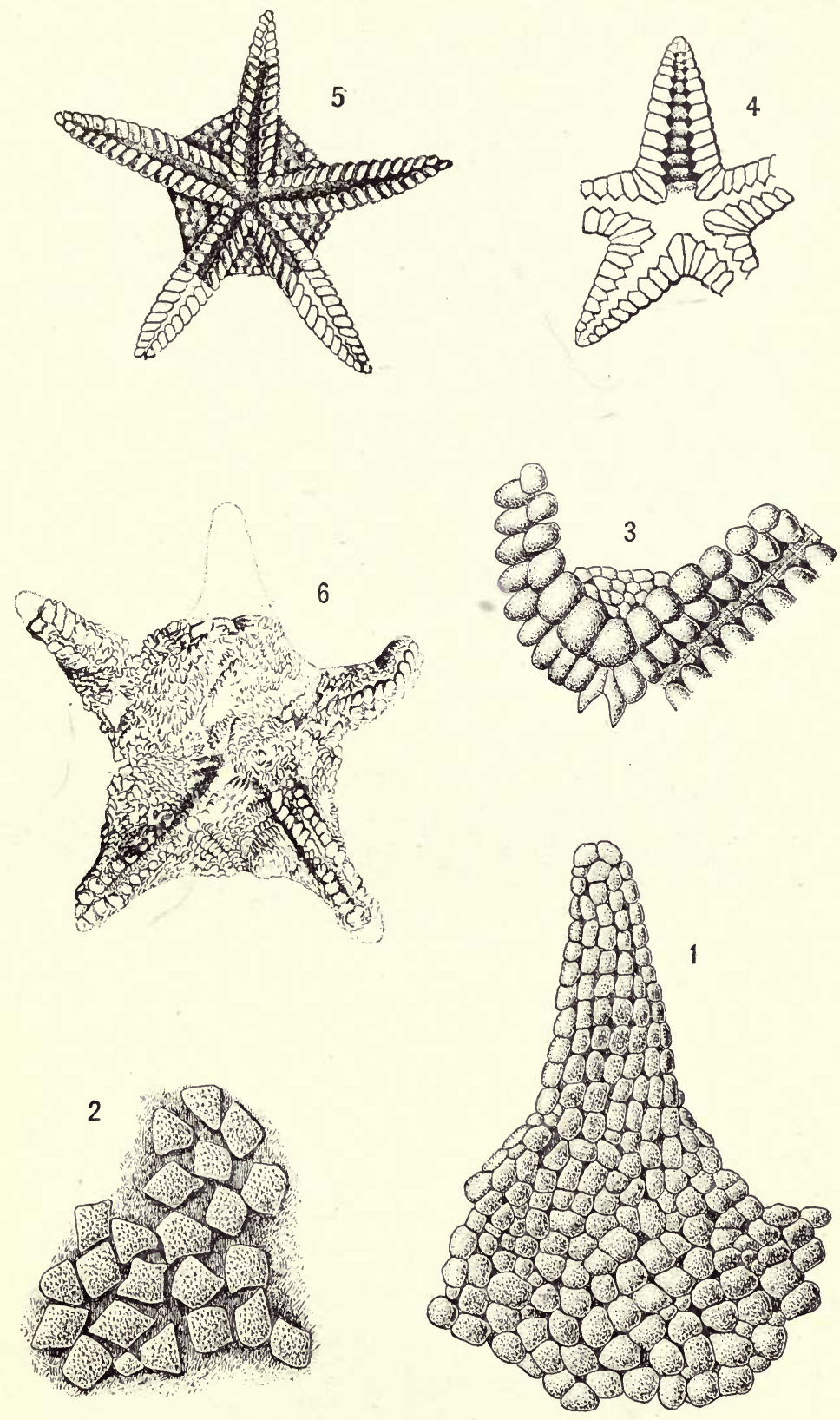



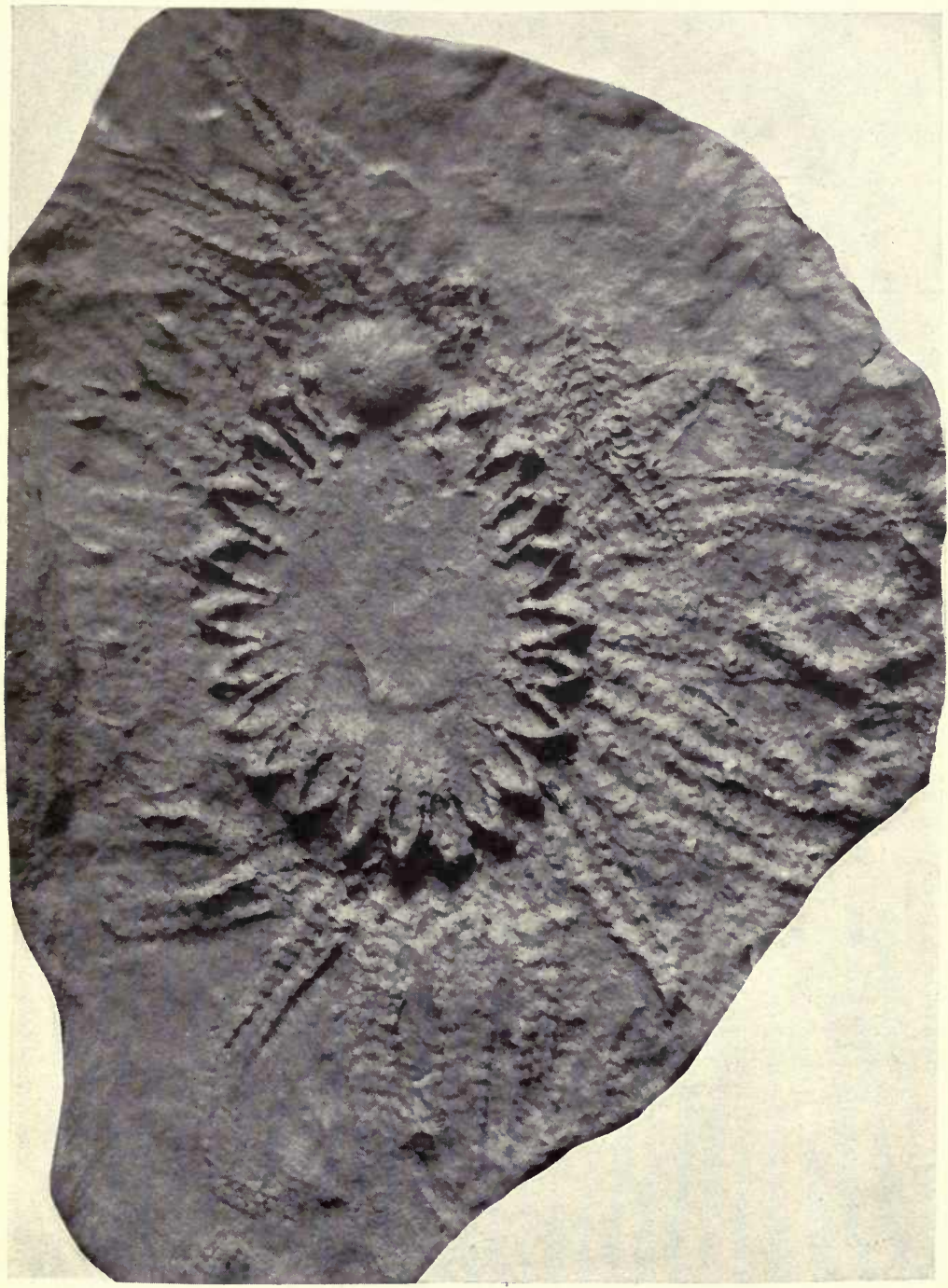

PALAeOsolaster (?) Gyalum.

FOR EXPLANATION OF PLATE SEE PAGE 300. 



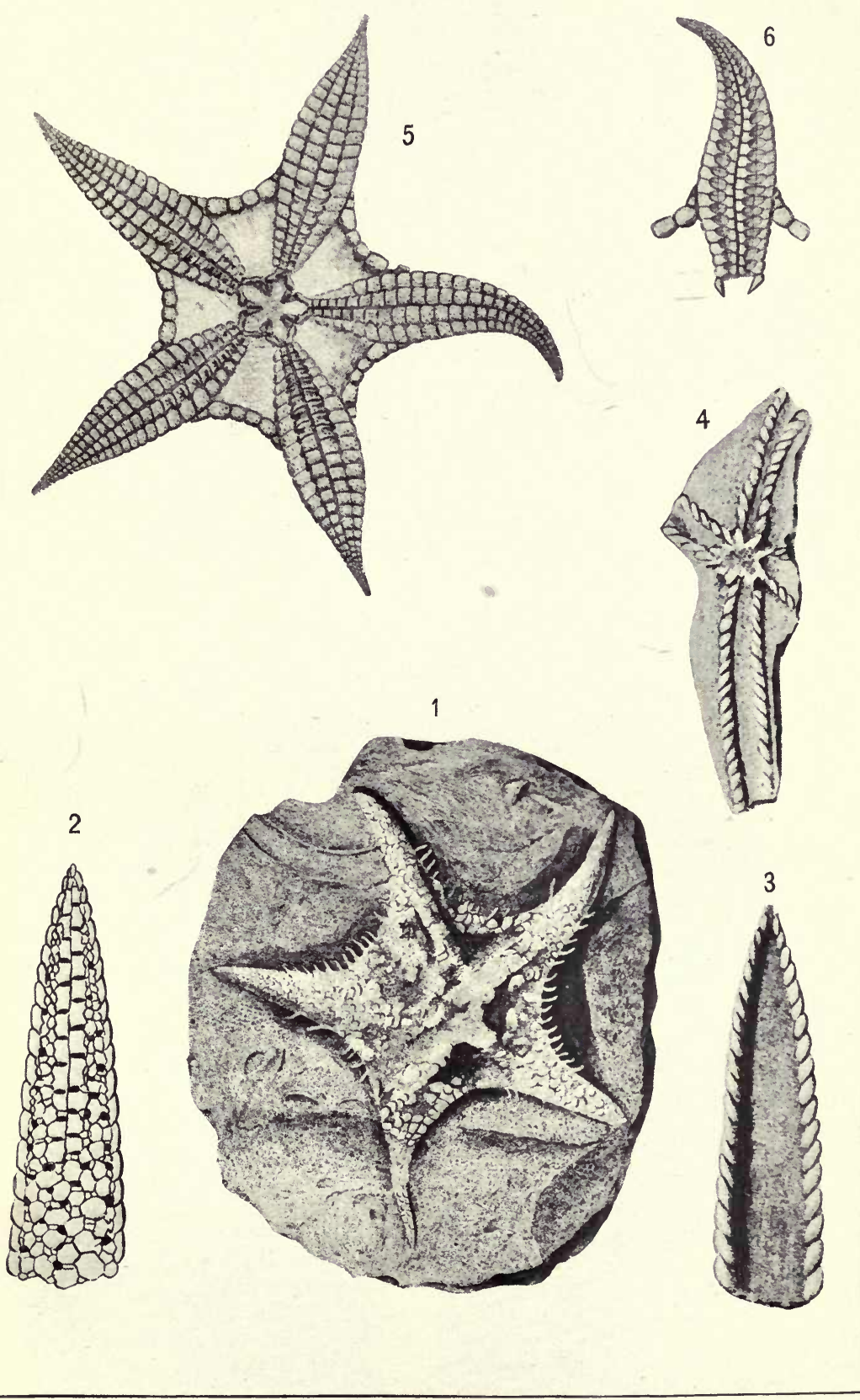

1-4, Schoenaster fimbriatus; 5, 6, ENCRINASTER PETALOIDES. 



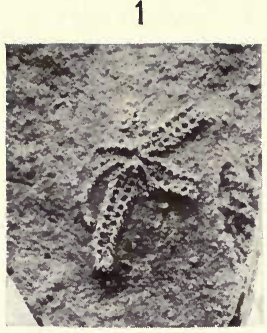

4

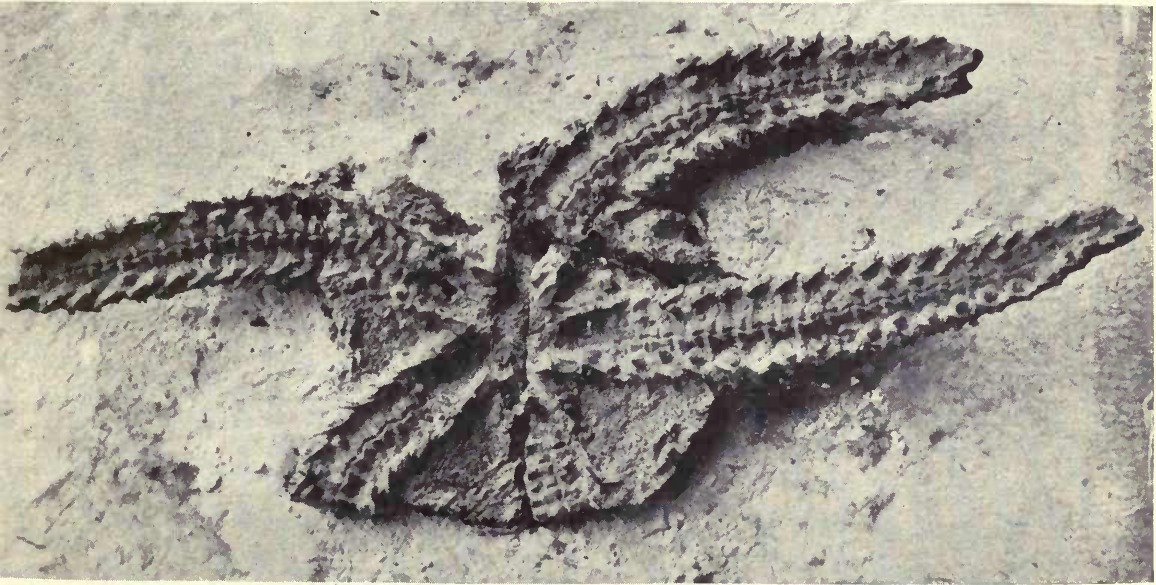

2

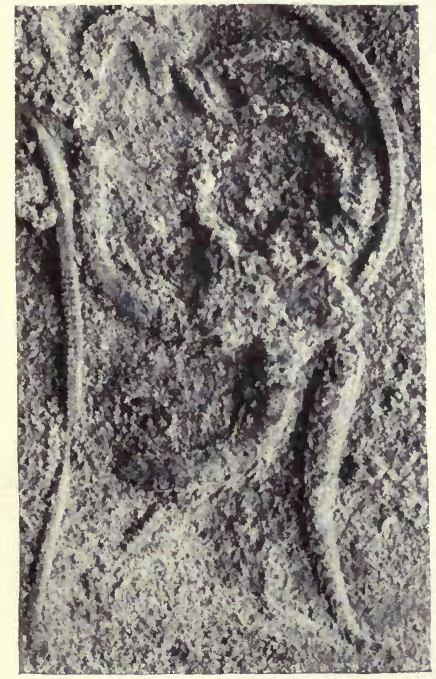

3

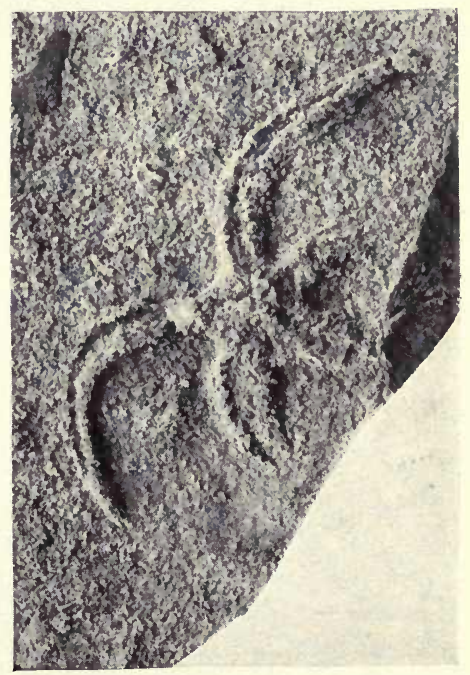

1, Theniaster spinosus; 2, 3, T. cylindRICUS; 4, Alepidaster fleXUOSUS. 


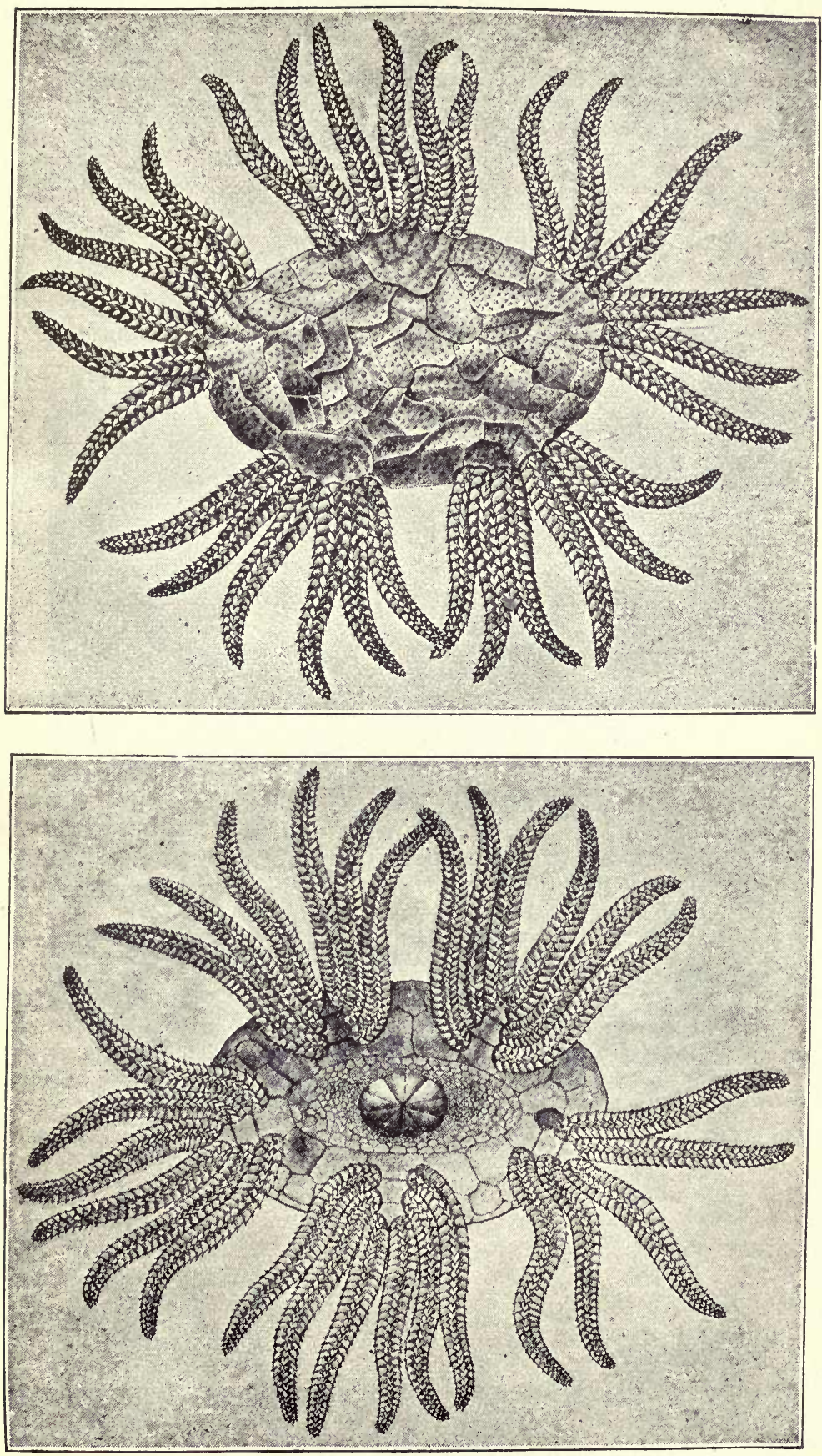

EUCLADIA WOODWARDI. 



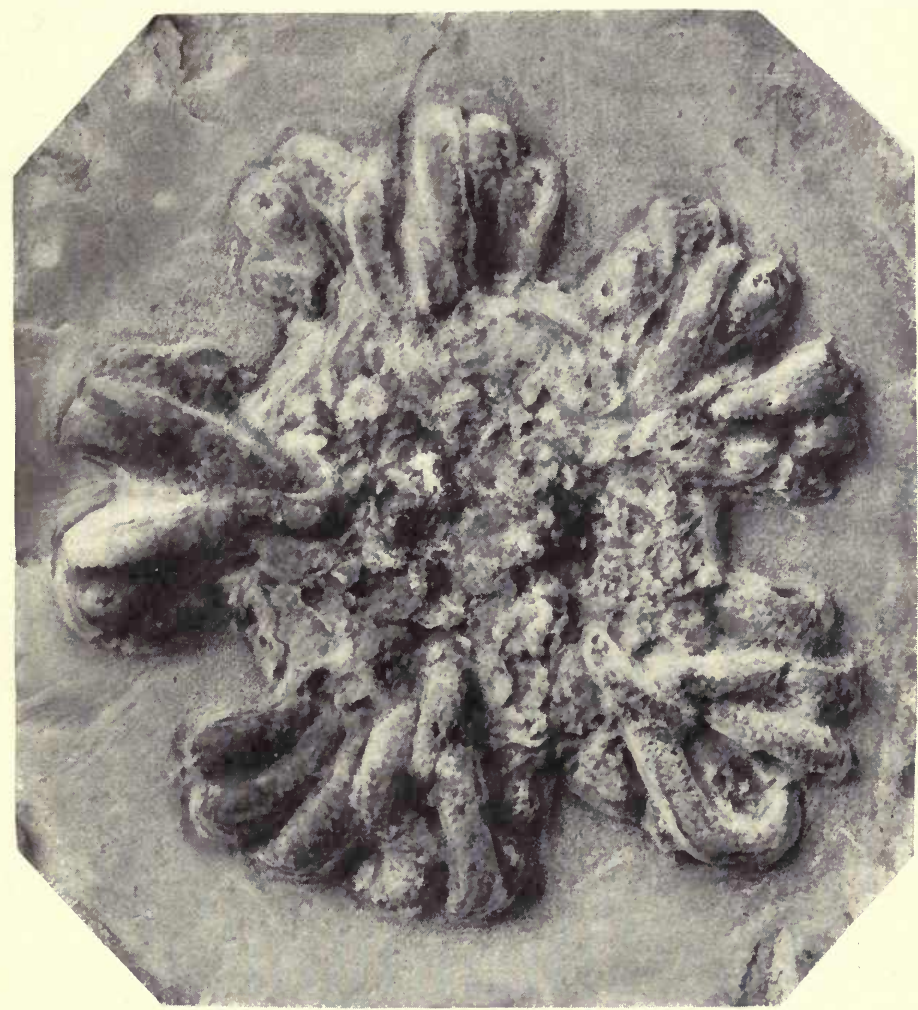

EUCLADIA (?) BEECHERI.

For EXPLANATION OF PLATE SEE PAGE 301. 



\section{N D E X.}

[The important references in each case are in heavy-faced typo. Synonyms are in italics.]

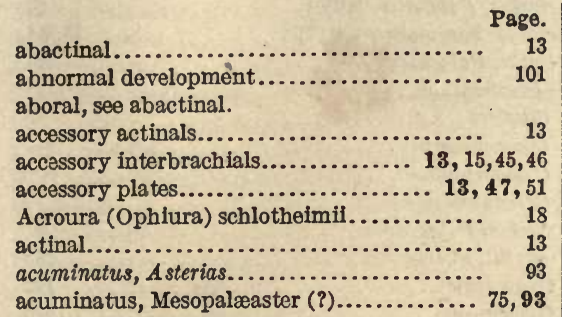

acuminatus, Mesopalæaster (?)............ 75,93
acuminatus, Roemeraster ( $) \ldots \ldots \ldots \ldots \ldots \ldots$.

adambulacralia, see adambulacrals.

adambulacral oral skelaton............. 16

adambulacral spines.................. 13,43

adambulacrals (see also lateral shields)..... 13,

$34,43,162,213,214,222$

Agalmaster..............40,49,128, 131, 133

A. grandis.......................... 132

A. Intermedius...................... 133

A. miellensis ......................... 132

Aganaster.......................... 263

A. gregarius........................ 264

A. (?) sp. Miller and Gurley ............ 251

Aganasteridæ...................... 246, 263

Alepldaster........................ 216, 228

A. flexuosus.................... 230, 231

A. granuliferus..................... 229, 230

A. gregarius........................... 264

A. miamiensis...................... 230, 238

A.n. $s p \ldots \ldots \ldots \ldots \ldots \ldots \ldots \ldots \ldots \ldots \ldots . \ldots \ldots, 230$

ambital and ambital plates........... 13, 46,174

ambulacralia, see ambulacrals.

ambulacral oral skeleton................ 16 ambulacrals.......... 13, 33,34, 41, 213,235, 258

alternate arrangement.............. 13, $33,41,152,172,174,213,214,215,222,226$

opposite arrangement............... 13, $41,163,213,214,224,246$

americanus, Colaster.

146

americanus, Petraster (?).............. 139, 146

ampullæ........................... 213

anal opening................... 18, 89, 54,61

Anorthaster................41,42,43,50,125

A. miamionsis....................... 127

Anorthasterinæ................. 52,74, 125

anthonii, Asterias........................ 146

antiqua, A rgaster......................... 86

antiqua, $\Lambda$ sterias, $\Pi$ isinger.............. $\quad 149$

antiqua, Asterias, Troost................. 86

antiqua, Hisingeraster................... 149

antiqua, Palzaster (A rgaster)............. 86

antiqua, Palzasterina.
Page.

antigua, Palmipes....................... 149

antiqua, Petraster (?)..................... 86

antiquata, Asterias....................... 109

antiquata, Palæaster.................... 109

antiquus, Asteriscus.................... 149

antiquus, Lindströmaster.............. 149, 153

antiquus, Mesopalæaster (?)........... 75, 86

antiquus, Palæaster...................... 86

anus, see anal opening.

approximata, Palæasterina................ 142

A rchæasterias....................... 129,130

arcs, see axil.

?Argaster......................... 74,77,87

A. antiqua.......................... 86

arnoldi, Aspidosoma.................... 243

arnoldi, Encrinaster................... 241, 248

asper, Onychaster.................... 270, 272

asperrima, Palæaster..................... 187

asperrima, Urasterella (?)............ 175, 187

asperrimus, Salteraster.................... 187

asperrimus, Tetraster.................... 187

asperula, Asterias...................... 188,262

asperula, Roemeraster.................. 188

asperula, Urasterella................. 175, 188

Aspidosoma......................... 241

A. arnoldi............................. 243

A. eifelense............................ 244

A. goldfussi.......................... 243

A. grayæ.......................... 245

A. petaloides......................... 243

A. petaloides goslariensis................ 243

A. ? pontis.......................... 244

A. roemeri.......................... 244

A. sehmidt1............................ 244

A. tischbeinianum................... 244

Aspidosomatidx...................... 241

Asterias.............................. 33

Asterias Graham, Anthony and James...... 146

A. acuminatus........................... 93

A. anthonit........................... 146

A. antiqua Hisinger..................... 149

A. antiqua Troost..................... 86

A. antiquata.......................... 109

A. asperula.......................... 188,262

A. constellata......................... 187

A. matutina........................... $\quad 57$

A. montanus............................ 189

A. primæva........................... 167

A. primordialis............................ 108

A. (A rchæasterias) rhenana............... 131

A. spinosissima ...................... 19

asterid radicle.......................... 34

vsterina............................ 33 
Asteriscus antiguus...................... 149 evolution of .............. 11, 30,48,52,106 number of, in Paleozoic............ 27, 28 terminology......................... 13

Astropecten ........................... 161

A. (?) schlüteri...................... 161

Ataxaster............................. 161

A. pygmæus......................... 161

Auluroidea........ 30, 38, 40,41, 42,43, 163, 212, 213 geological distribution of.............. 28 number of, in Paleozoic............ 27, 28

Australaster.............. 44, 45, 49,66, 72, 171

A. giganteus....................... 73, 171

A. (?) stutchburil.................... 73

australis, Tæniaster.................... 236

axil................................. 14

axillary inframarginal.................. 14

axillary interbrachial.................... 14

axillary marginal........................ 15

axillary ossicles......................... $\mathbf{3 4 , 4 9}$

babcocki, Lepidasterella................... 160

barrisi, Onychaster................. 270, 272

barrisi, Protaster (?)..................... 272

batheri, Hudsonaster............... 55, 65, 167

Bdellacoma ...................... 248,252, 254

B. vermiformis........................ 254

beecheri, Eucladis (?).................. 278

bellulus, Mesopalæaster............... 75,91

bellulus, Petraster...................... 91

bellulus, Promopalæaster.......... 104, 105, 113

beneckei, Bundenbachia................. 234

bibliography........................ 281-288

biforis, Protaster................. 226, 227

bivium.............................. 14

body-wall............................. 14

bohemica, Eophiura.................... 222

Bohemura....................... 216, 223

B. jahni............................. 223

bonneyi, Palæasterina.................... 153

bonneyi, Palasterina.............. 151,152, 158

brisingoides, Protaster................... 236

brisingoldes, Stürtzura................. 236

buccal processes......................... 225

Bundenbach......................... 29

Bundenbachia...................... 216, 284

B. beneckel.......................... 234

B. grandis.............................. 235

creal pores.......................... 14

Calliaster............................... 190

C. mirus.............................. 190

Calliasterella................. 39,47,49,50, 190

C. mira................................ 191

Calliasterellidæ................... 162, 163, 190

Calliasteridæ.......................... 190

caractacl, Mesopalæaster.............. 75,92

caractaci, Palæaster....................... 92

caractaci, Protopalæaster.................. 92

carbonarius, Cribellites................ 274

carinals, see radials.

catalogue of Paleozoic Stelleroidea.......... 51

cataractensis, Mesopalæaster (?).......... 75,89

central disk, sce disk.

central disk plate, see centrodorsal plate.

central plate, see centrodorsal plate.

centrodorsal plate.
Cheiropteraster.

Page.

C. giganteus.......................... 202

chemungensis, Devonaster............... 101

Cholaster............................ 265

C. peculiaris........................ 266

Cholasteridæ.................... 246, 265

ciliaris, Ophiura........................ 268

clarkana, Palzaster.................. 61,63

clarkei, Etheridgaster.................. 172

clarkei, Monaster.................. 171, 172

clarkei, Palzaster, De Koninck............. 172

clarkei, Palæaster, Miller................. 61

clarki, Mesopalæaster (?)............... 75, 94

clarki, Palæaster......................... 94

Classification.......................... 51

Coelaster............................. 95

C.americanus......................... 146

C.latiscutatus......................... 96

C. tenuiradiatus........................ 19

colvini, Palæocoma..................... 253

colvini, Stürtzaster.................... 253

Compsaster............................ 192

C. formosus............................. 193

C. n. sp............................ 194

Compsasterldæ.................. 162,163, 191

concinna, Eugasterella (?)............. 238, 239

concinnus, Eugaster................... 239

confluens, Stenaster (?).............. 165, 167

confragosus, Onychaster............. 270, 273

constellata, Asterias...................... 187

constellata, Urasterella (?)............ 175, 187

coronella, Palæaster.................... 167

coronella, Stenaster (?).............. 165, 167

crawfordsvillensis, Neopalæaster......... 135, 186

crawfordsvillensis, Palzaster.............. 136

Cribellites carbonarius................... 274

Crossaster.......................... 38

Cryptozonia.... 80,33,38,40,41, 43,44, 45, 46, 47, 162

cygnipes, Palæocoma..................... 253

cygnipes, Stürtzaster................... 253

cylindrica, Lapworthura................. 220

cylindrica, Palæocoma.................. 220

cylindrica, Tæniura.................... 220

cylindricus, Tæniaster........ 216,217, 218, 219, 220

daoulasensis, Furcaster (?)............... 261

daoulasensis, Protaster.................. 261

darwinl, Echinasterella (?).............. 200

decheni, Eoluidia........................ 262

decheni, Eophiurites................... 262

decheni, Protaster..................... 248

decheni, Tremataster (?).............. 247, 248

demissus, Onychaster.............. 270, 274

development, abnormal................ 101

geological, of Stelleroidea........... 27, 28

Devonaster......................... 40,44, $46,47,49,50,74,76,77,97,129,130,133$

D. chemungensis..................... 101

D. eucharis..................... 29,37,98

devonica, Palænectria................... 155

devonicus, Palasteriscus.................. 200

diffoilis, Tremataster................... 247

disk............................ 14,213,225

how enlarged..................... 32

disk accessory plates..................... 34,46

disk ambitals........................ 13

disk inframarginals.................. 15 


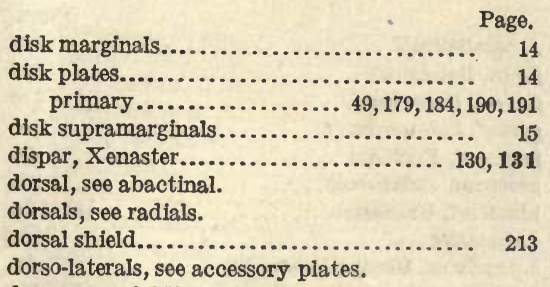

drevermanni, Miomaster...

dubius, Mesopalæaster (?) ................ 75, 85

dubius, Palæaster........................ 85

dyeri, Palzaster.......................... 120

dyeri, Petraster........................... 121

dyeri, Promopalæaster.............. 104, 105, 120

Echinaster............................. 45

Echinasterella........................ 199, 200

E. (?) darwini.......................... 200

E. sladeni.............................. 200

Echinasterias.................. 38,207,209, 211

E. spinosus............................ 211

echinatus, Squamaster.................... 249

Echini, radil of.......................... 35

Echinodiscaster............. 38, 40, 207, 209, 211

E. multidactylus......................... 211

Echinodiscites......................... 211

Echinodiscus........................... 211

E. multidactylus......................... 211

Echinostella.................... 38,207, 209, 212

E. traquairi........................... 212

Eifelaster....................... 128, 133

E. follmanni........................... 134

eifelense, Aspidosoma...................... 244

eifelensis, Encrinaster................... 244

elegans, Protaster....................... 221

elegans, Tæniaster..................... 219, 221

elegans, Xenaster..................... 130, 131

elizae, Uranaster........................ 155

Encrinaster (part) ....................... 224

Encrinaster..................... 43, 45, 226, 241

E. arnoldi........................... 241, 243

E. eifelensis............................ 244

E. goldfussi.............................. 243

E. (?) grayæ........................... 245

E. petaloides.......................... 243

E. petaloides goslariensis................ 243

E. pontis............................... 244

E. roemeri........................... 242, 244

E. schmidt1........................... 244

E. tischbeinianus.......................... 244

Encrinasteriæ (part)..................... 215

Encrinasteridæ....................... 215, 241

Eoactis........................... 173, 178

E. simplex.......................... 186

Eoluidia................................ 262

E. decheni............................. 262

Eoluidiidæ........................... 246, 262

Eophiura..................... 216, 222, 223, 259

E. bohemica........................... 222

Eophiuridæ.......................... 262

Eophiurites............................ 262

E. decheni........................... 262

Eospondylus........................ 262, 263

E. primigenius .

Etheridgaster......................... 170
Page.

E. clarkei............................ 172

eucharis, Devonaster................ 29,37, 98

eucharis, Palzaster........................ 98

eucharis, Xenaster........................ 98

Eucladia............................ 275, 276

E. (?) beecheri........................ 278

E. johnsoni........................... 276

E. woodwardi...................... 276, 277

Eucladiidæ.......................... 276

Eugaster.............................. 237

E. concinnus.......................... 239

E. logani............................. 238

Eugasterella.................... 235, 23 7, 259

E. (?) concinna..................... 238, 239

E. logani............................ 237, 288

Euophiuroidea......................... 213

Euryale annulatum.................... 20

Euthemon..................... 275,276, 279

E. igerna........................... 279

evolution of Asteroidea.................. $\quad 30$

exculptus, Palæaster...................... 117

exculptus, Promopalæaster.......... 104, 105, 117 eje-plate, see ocular plate.

ferox, Palæodiscus........................ 23

filiciformis, Helianthaster.............. 159, 160

fimbriata, Palæasterina................... 204

fimbrialu, Protaster...................... 231

fimbriata, Protasterina................... 231

fimbriatus, Schoenaster.................. 204

finel, Mesopalæaster..................... 75, 81

finei Palzaster........................... 81

flexilis, Onychaster................... 269, 270

flexuosus, Alepidaster................. 230, 231

flexuosus, Protaster..................... 231

flexuosa, Protasterina.................... 231

follmanni, Eifelaster...................... 134

follmanni, Palasterina................... 157

follmanni, Pseudopalasterina.......... 156, 157

forbesi, Hallaster................... 254, 255

forbesi, Protaster....................... 255

formosus, Compsaster................... 193

Furcaster...................... 248, 259, 261

F. (?) daoulasensis..................... 261

F. palæozoicus...................... 259, 261

Furcasteridæ......................... 248

genitals, see interradial plates.

genitals in Echini........................ 35

geological development of Stelleroidea...... 27, 28

geological distribution of Stelleroldea........ 28

giganteus, Australaster ................ 73, 171

giganteus, Cheiropteraster................ 202

giganteus, Monaster..................... 73

giganteus, Palæaster (Monaster)............ 73

girvanensis, Urasterella.............. 167, 175, 186

goldfussi, Aspidosoma................... 243

goldfussi, Encrinaster .................. 243

Goniaster............................. 61

grandis, Agalmaster ..................... 132

grandis, Bundenbachia................... 235

grandis, Palæophlomyxa.............. 234, 285

grandis, Stenaster...................... 180

grandis, Urasterella................ 174, 175, 180

grant1, Mesopalæaster ................. 75, 89

granti, Palæaster...................... 89

granuliferus, Alepidaster............. 229, 280 
granuliferus; Protaster (?)

granulosus, Palæaster, Hall............... 112

granulosus, Palæaster, Meek.............. 109

granulosus, Promopalæaster......... 104, 112,113

graspers............................. 33

grayæ, Aspidosoma.................... 245

grayæ, Encrinaster (?)................ 245

grayl, Lepidaster...................... 158

gregarius, Aganaster..................... 264

gregarius, Alepidaster.................... 264

gregarius, Protaster ( $($ ).................. 264

Gregoriura..........................216, 283

G. spry1.............................. 234

gregory1, Palæosolaster.................. 209

groomi, Protaster..................... 226, 227

gyalum, Helianthaster.................. 160,210

gyalum, Palæosolaster (?)................ 210

Hallaster.......................... 248, 254

H. forbesi . ........................ 254, 255

Harris, I. H., gift ofistarfishes by.......... 9

harrisi, Palæaster........................ 180

Helianthaster Clarke (part).............. 209

Helianthaster Roemer.................. 38,

$40,45,157,158,159,209,211$

H. fliciformis .................... 159, 160

H. gyalum (part)................... 160,210

H. rhenanus............................ 159

H. roemeri..........................209,211

H. n. sp. Clarke...................... 160

Helianthasteridæ.................... 157

Helianthasterinæ..................... 157

Heliaster............................ 38,208

hirudo, Palæaster........................ 188

hirudo, Uraster......................... 188

hirudo, Urasterella................... 175, 188

Hisingeraster...................... 148

H. antiqua........................ 149

Hudsonaster . ................... 31, 32, 34, 36,

$38,39,40,41,42,44,45,47,48,48,52,58$,

$69,75,105,135,140,158,165,179,194,196$

H. batheri...................... 55, 65, 167

H. incomptus............... 34, 36, 40,55, 61

H. matutinus. . ........ 34,55, 57, 139, 141, 166

H. milleri........................ 55,60

H. narrawayl................ 43,50,55, 59

H. rugosus........................ $36,55,64$

Hudsonasteridæ.'.................. 52, 53,162

huxleyi, Stenaster...................... 182

huxley1, Urasterella ................... 175, 182

Igerna, Euthemon...................... 279

imbricatus, Palæaster..................... 169

imbricatus, Tetraster (?)............. 168, 169

incomptus, Hudsonaster......... 34, $36,40,55,61$

incomptus, Palæaster.................... 61

inframarginalla............. 15, 34, 48, 152, 194

inframarginal plates......... 15, 33, 174, 179, 185

interactinals......................... 13

interbrachial adambulacrals............ 15, 128

interbrachial areas and arcs.... 14, 50, 138, 185, 194

interbrachial marginals.

intermarginal plates, see ambital plates.

intermarginals, see ambital.

intermedius, Agalmaster.

intermedius, Mesopalæaster.

interadial plates.

15,32

Jaekelaster
T. petaliformis

jahni, Bohemura ...................... 223

jamesi, Palæaster....................... 146

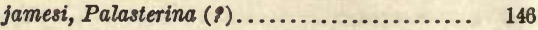

johnsoni, Eucladia....................... 276

kinahani, Palasterina.................... 155

kinahani, Uranaster................. 154,155

Labidaster............................. 208

lanceolatus, Mesopalaeaster (?)........... 75, 82

Lapworhtura................... 248, 250, 254

L. cylindrica......................... 220

L. miltoni....................... 250, 251, 253

L. sollasi............................... 251

L. (?) sp............................. 251

Lapworthuridæ..................... 246, 248

lateral shields........................... 214

latiscutatus, Coelaster..................... 96

latiscutatus, Spaniaster................... 96

laxata, Schuchertia.................. 196, 198

legrandensis, Schoenaster (?)............. 206

Lepidaster..................... 38, 40, 158, 160

L. grayl........................... 158

Lepidasteracea........................ 53

Lepidasterella....................... $38,40,160$

L. babcocki.......................... 160

Lepldasteridæ.................. 52,53, 157

leptosoma, Protaster.................... 237

leptosoma, Rhodostoma................... 237

leptosoma, Stürtzura............... 236, 237

leptosomoides, Stürtzura............ 236, 237

Lindströmaster.............. 138, 140, 148, 154, 156

L. antiquus....................... 149, 153

Lindstromasterinæ ................... 138

logani, Eugaster......................... 238

logani, Eugasterella.................... 237,238

longibrachiatus, Palæaster................ 115

Loriolaster............... 199,200, 201, 202,252

L. mirabilis........................... 201

lymani, Ophiurina...................... 247

Lysophiuræ........................ 215

madreporite..... 15,39,40,209,211, 214, 222, 223, 226

magnificus, Promopalæaster.............. 42,

$104,105,106,113,122$

margaritatus, Xenaster................ 131, 132

margaritatus, Xenaster............. 129, 130, 181

marginalia, see marginal plates.

marginal plates........... 15,33,43,135, 152, 213

marstoni, Palseocoma................... 253

marstoni, sturtzaster..................... 253

matutina, Asterias....................... 57

matutinus, Hudsonaster..... 34,55, $57,139,141,166$

matutinus, Palæaster.................... $\quad 57$

meafordensis, Tæniaster.................. 221

measurements......................... 15

median dorsals, see radials.

Medusaster.

$38,207,212$

M. rhenanus......................... 212

. Mesopalæaster...........28, 39, 41,44,45,46,47,49, $50,56,74,95,98,105,126,130,135,158$

M.(?) acuminatus..................... 75, 93

M.(?) antiquus........................ 75,86

M. bellulus........................ 75, 81

M. caractaci.......................... 75, 92

M.(?) cataractonsis..................... 75, 89

M.(?) clarkt..................... 75, 94

M.(?) dubius....................... 75,85 
Page.

M. finei.......................... 75, 81

M. granti....................... 75,89

M. intermedius...................... 75, 79

M.(?) lanceolatus.................... 75, 82

M.(?) parviusculus..................... 75,87

M. proavitus..................... 75, 83,85

M. shafferi.................... 44, 75, 7 7

M.(?) wilberanus..................... 75,84

Mesopalæasterinæ.................. 52, 74,162

miamiensis, Alepidaster.............. 230, 233

miamiensis, Anorthaster................. 127

miamiensis, Palæaster.................... 127

miamiensis, Protaster................... 233

miellensis, Agalmaster................... 132

milleri, Hudsonaster................. 55, 60

miltoni, Lapworthura . . . . . ......... 250, 251, 253

miltoni, Protaster...................... 251

minveri, Sympterura................... 256

Miomaster..................... 43, 50,74, 96

M. drevermanni...................... 96

Miospondylus...................... 262, 263

M. rhenanus......................... 263

mira, Calliasterella........................ 191

mirabilis, Loriolaster.................... 201

mirus, Calliaster....................... 190

mitchelli, Sturtzaster (?)................. 254

Monaster Gregory....................... 49,72

Monaster Etheridge...................40,170

M. Clarkei....................... 171, 172

M. giganteus.

$M$. stutchburii.

73

Monasteridx.

$162,163,170$

montana, Urasterella

175,189

montanus, Asterias.

189

montanus, Palæaster..................... 189

montanus, Schoenaster (?)............43, 207

mouth angle plate, see oral armature.

multidactylus, Echinodiscaster.

211

multidactylus, Echinodiscus.

multirayed starfishes.

211

narrawayi, Hudsonaster

$38,40,157,207$

narrawayi, Protopalæaster.

neglecta, Palæura.

Neopalæaster.

N.

N. crawfordsvillensis................. 135, 136

Neopalæasteridæ................. 52,53, 184

niagarensis, Palæaster...............6 68, 69

obtusus, Ophiura...................... $\quad 25$

obtusus, Palæaster.................... 167

obtusus, Protaster (Ophiura).............. 25

obtusus, Stenaster (?)............... 165, 167

obtusus, Uraster.......................... 167

occurrence of starfishes.................. 28

ocular plate................ 16, 34, 48, 134, 135

oculars in Echini..................... 35

ontogeny of Stelleroidea................ $\quad 36$

Onychaster.......................... 268

O. asper.......................... 270, 272

O. barrisi........................... 270, 272

0. confragosus..................... 270, 273

O. demissus........................ 270, 274

O. flexilis........................ 269, 270

Onychasteridø...................... 268

Ophiocistia............................. 275

Ophio-Encrinasterix................... 215

Ophiopege.............................. 263
Ophlura ciliaris Page.

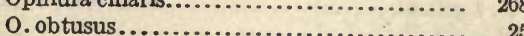

o. (?) ramosa.......................... 22

O. rhenana............................ 263

0. salteri............................. 227

O. schlotheimil......................... 18

Ophiurasteriæ....................... 215,246

Ophiurella........................... 263

0. primigenia......................... 263

Ophturina ....................... 246, 260

0.1 ymani............................. 247

Ophlurinidæ........................ 246

Ophluroidea ............41,42,43, 212, 258, 267

geological distribution of.............. 28

number of, in Paleozoic ............. 27, 28

oral, see actinal.

oral angles...

16

oral armature ...........16,43,162,172, 210,242 oral skeleton, see oral armature.

ordinaria, Schuchertia.

ossicles, see plates.

196,199

Palæaster

$40,41,44,49,56 \ldots \ldots . \ldots 10$

Palseaster (Monaster) Etheridge (part)..... 72, 170

$P$. (A rgaster) antiqua................... 86

$P$. antiquata........................... 109

P. anliquus............................ 86

$P$. asperrima.......................... 187

$P$. caractaci.......................... 92

$P$. clarkana........................... 61,63

$P$. clarkei Do Koninck................... 172

P. clarkei Miller......................... 61

P. clarki............................. 94

P. coronella.............................. 167

P. crawofordsvillensis.................... 136

P.dubius.......................... 85

P. dyeri............................ 120

P. eucharis............................ 98

P. exculptus......................... 117

$P$. finei.............................. 81

P. (Monaster) giganteus.................. 73

P. granti.............................. 89

P. granulosus Hall. ................... 112

P. granulosus Meek...................... 109

P. harrisi............................. 180

P. hirudo............................... 188

P.imbricatus......................... 169

P. incomptus........................... 61

P.jamesi............................... 146

P. longibrachiatus....................... 115

P. matutinus......................... 57

P. miamiensis......................... 127

P. montanus............................ 189

P. niagarensis......................68, 69

P.obtusus............................ 167

P. parviusculus........................ 87

P. pulchellus.......................... 178

P. pygmæa......................... 23

P. ruthveni............................ 187

P. shafferi........................... 77

P. simplex........................61,62

P. speciosus......................... 109

P. spinulosus........................... 115

P. squamatus......................... 23

$P$. (Monaster) stutchburii................ 73

P. wilberanus........................... 84 
Page.

P. ? wilsoni.

106

P. wykoffi.

Palæasteridæ.

Palæasterina

$52,53,66$

$P$. antiqua..

138,150

$P$. approximat

$P$. bonneyi.

P. fimbriata.

$P$. primæva.

P. speciosa.

Palæasterinæ..

Palæasterinidæ

Palæbrisingidæ.

Palæchinasteridæ

149

142

153

204

153

142

66

138

199

Palægoniasteridæ (part)

199

Palægoniasteridæ

66,241

Palænectria.

$P$. devonica.

Palæocoma Miller (part).

Palæocoma Salter.

Palæocoma (Bdellacoma).

Palæocoma (Rhopalocoma)

$P$. colvini.

$P$. cygnipes.

$P$. cylindrica.

$P$. marstoni.

$P$. princeps...

$P$. pyrotechnica

P. spinosa.

$P$. vermiformis.

Palæodiscus ferox.

Palæophiomyxa.

P. grandis .

Palæophiomyxidæ

Palæophlura.

P. simplex.

Palæophiuridæ.

Palæosolaster.

P. gregoryi.

P. (.) gyalum

P. rœmeri.

Palrospondylidx.................... 162,163, 207

Palæospondylus.......................... 261

Palæostella...................... 51,138, 155

P. solida................................ 156

palæozoicus, Furcaster................ 259, 261

Palæspondylus.......................... 261

P. zitteli............................... 262

Palæura........................... 216,223

P. neglecta.......................... 223

Palasteracanthion..................... 173

Palasterina Billings (part)................. 195

Palasterina Salter..................... 40 ,

$49,130,138,140,150,154,156,196$

P. bonneyi................... 151, 152, 153

P.follmanni........................... 157

P. (?) jamesi............................ 148

P. kinahani.......................... 155

P. primæva................. 149, 151, 152, 153

P. (?) ramseyensis................... 152, 154

$P$. rigidus............................ 141

P. rugosa............................ 64

P. stellata.............................. 196

Palasterinacea.
Palasterinidæ

Page.

$52,53,138,196$

.

Palasteriscus................. 40, 199, 200, 252

P. devonicus......................... 200

Palastropecten..................... 248, 261

P. zitteli............................... 262

Palmipes antiqua...................... 149

papulæ............................. 16

parviusculus, Mesopalæaster (?)........ 75,87

parviusculus, Palæaster................... 87

parvulus, Trimeraster................... 134

paxillæ........................... 116, 156

peculiaris, Cholaster..................... 266

pedicellariæ............................ 16

perfectus, Siluraster ..................... $\quad 66$

perradial............................ 17

petaliformis, Jaekelaster.................. 192

petaloides, A spidosoma................... 243

petaloides, Encrinaster................... 243

petaloides goslariensis, Aspidosoma......... 243

petaloides goslariensis, Encrinaster........ 243

Petraster........................... 39,

$44,45,46,47,51,138,149,154,156,196$

P. (?) americanus................... 139, 146

$P$. (g) antiqua........................ 86

P. bellulus............................ 91

P. dyeri........................... 121

$P$. rigidus (part) $\ldots \ldots \ldots \ldots \ldots \ldots \ldots \ldots \ldots . \quad 57$

P. rigidus........................ 139, 141

P. smythi......................... 139, 147

P. speciosus.................. 47, 139, 142

P. wilberianus.......................... 84

petri, Protaster......................... 25

Phanerozonia......................... 80 ,

$38,39,40,41,43,44,45,46,48,51$

phylembryo of Stelleroidea............... 34

Pisaster............................... 38

plates............................... 17

plumiformis, Trichotaster.............. 26, 38

podia and podial openings............... 13,

$17,33,38,39,209,213$

pontis, Aspidosoma?..................... 244

pontis, Encrinaster.................... 244

prenuntius, Promopalæaster............ 104, 107

preservation of starfishes................... 28

primæva, Asterias....................... 167

primæva, Palæasterina................... 153

primæva, Palasterina............. 149, 151, 152, 153

primzvus, Uraster ..................... 153

primary inframarginal.................. 15

primary radials ..................... 17, 32

primary skeleton........ 13,15, 17, 31,32,34,56, 191

primary supramarginal.................. 15

primigenia, Ophiurella................... 263

primigenius, Eospondylus................. 263

primitive starfish, most ............... 31, 33

primordialis, Asterias.................... 108

primus, Protasteracanthion................ 188

princeps, Palæocoma....................... 240

princeps, Ptilonaster............... 240, 259

proavitus, Mesopalæaster ........... 75, 83, 85

Promopalæaster........................ 28 ,

$39,41,42,44,46,46,47,50,56,76,98,102,126$

P. bellulus..................... 104, 105, 118

P. dyeri........................ 104, 105, 120

P. exculptus..................... 104, 105, 117 
Page.

P. granulosus

P. magnificus .

P. prenuntius.

P. speciosus

P. sp. undet

P. spinulosus.

P. wilsoni.

P. wykoff

Promopalæasteracea

Promopalæsteridæ.

Promopalæasterinæ.

Protaster Hall (part).

Protaster Forbes .

P. (?) barrisi.

P. biforis

$P$. brisingoides.

$P$. daoulasensis.

P. decheni.

$P$. elegans.

P. fimbriata.

$P$. flexuosus.

$P$. forbesi.

$P$. (P) granuliferus

$P$. (?) gregarius.

P. groomi.

P. leptosoma.

P. miamiensis.

P. miltoni.

P. (Ophiura) obtusus.

P. petri.

P. (?) salteri.

P. sedgwicki.

P. (?) stellifer .

P. (?) whiteavesianus.

Protasteracanthion.

$P$. primus.

Protasteridæ

Protasterina.

$P$. fimbriata.

P. flext 0 osa..

Protoeuryale.

Protopalzaster.

$P$. caractaci...

$P$. narrawayi

Protophiureæ.

Protophiuroidea.

proximal inframarginals.

proximal radials.

proximal supramarginal.

Pseudopalasterina.................. 138, 156

P. follmanni.

156,157

Ptilonaster.

235,239

P. princeps.

240, 259

pulchella, Urasterella.

175,178

pulchellus, Palæaster.

178

pulchellus, Stenaster.

Pycnopodia.

pygmæa, Palæaster.

178

pygmæus, Ataxaster

pyrotechnica, Palæocoma.

pyrotechnica, Rhopalocoma

radial accessory plates.

radialia

radicle of asterids.

ramosa, Ophiura (?)

ramseyensis, Palasterina (?) ray ambitals.................

rays.............. 17, 38,44,48, 207, 213,223

regeneration of..................... 185

regeneration..................... $\mathbf{8 7}, 185$

respiration, see papulæ and cæcal pores.

rhenana, Asterias (A rchæasterias)............ 131

rhenana, Ophiura...................... 263

rhenanus, Helianthaster................. 159

rhenanus, Medusaster................... 212

rhenanus, Miospondylus................. 263

rhenanus, Xenaster (?).............. 130, 181

Rhenaster...................... 43, 128, 138

R. schwerd1......................... 133

Rhodostoma......................... 236

R. leptosoma......................... 237

Rhopalocoma.................... 248,252, 254

R. pyrotechnica....................... 254

rigidus, Palasterina.................... 141

rigidus, Petraster........................ $\quad 57$

rigidus, Petraster..................... 139, 141

Romeraster....................... 173, 177

R. (?) acuminatus...................... 93

R. asperula........................... 188

Roemerasterinæ....................... 172

roemeri, Aspidosoma................... 244

roemeri, Encrinaster................ 242, 244

roemeri, Helianthaster.................. 209,211

roemeri, Palæosolaster.................. 211

rugosa, Palasterina..................... 64

rugosus, Hudsonaster. ............... 36, 55, $\mathbf{6 4}$

ruthveni, Palzaster...................... 187

ruthveni, Uraster...................... 187

ruthveni, Urasterella.............. 174, 175, 187

Salteraster............................ 173, 178

S. asperrimus........................... 187

salteri, Ophiura..................... 227

salteri, Protaster (?)................. 226, 227

salteri, Stenaster................... 164, 165

schlotheimii, Acroura (Ophiura)........... 18

schlotheimii, Ophlura.................. 18

schlüteri, Astropecten (?.)................ 161

schmidti, Aspidosoma.................... 244

schmidti, Encrinaster................ 244

Schœnaster............................ 202

S. fimbriatus.......................... 204

S. (?) legrandensis.................... 206

S. (?) montanus.................. 43,207

S. (?) n. sp .......................... 206

S. (?) wachsmuthi................... 205

Schœnasteridæ................. 162, 163, 202

schohariæ, Taeniaster................ 219, 220

Schöndorf, on revision of German starfishes.. 11

Schuchertia ............. 51, 140, 152, 194, 195, 252

S. laxata............................ 196, 198

S. ordinaria.......................... 196, 199

S. stellata.......................... 195, 196

Schuchertiacea....................... 163

Schuchertiidæ................... 162,163, 194

schwerdi, Rhenaster..................... 133

secondary skeleton, see secondary plates.

sedgwicki, Protaster.............. 225, 226, 243

selwyni, Urasterella.................. 175, 188

shafferi, Mesopalæaster.............. 44,75, 77

shafferi, Palwaster..................... 77

Siluraster........................ 49,53 65

S. perfectus........................... 66 


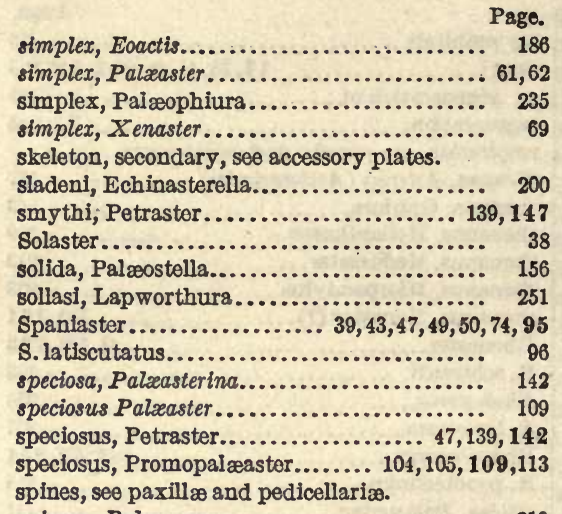
spinosa, Palæocoma..................... 219 spinosissima, Asterias..

spinosity............................ 37,41 spinosus, Echinasterias.................. 211 spinosus, Tæniaster............. 216, 217,218, 219 spinulosus, Palzaster. spinulosus, Promopalæaster...... 44, 104,105, 115 spryi, Gregoriura.

Squamaster.

S. echinatus 248,249

squamatus, Palæaster.

stalk of primitive starfishes.

23

starfish, most primitive

$\mathbf{8 3}, 34$

origin of graspers.

31, 33

origin of wriggiing type.

radicle.

stellata, Palasterina.

32

stellata, Schuchertia.

196

stellata, Trentonaster.

195,196

Stelleroidea............................. $\$ 1$

geological development............. 27,28

geological distribution............... 28

ontogeny......................... 36

phylembryo........................ 34

typembryo.....................85, 36

stollifer, Protaster (?)................ 226, 228

Stenaster (part)....................... 173

Stenaster......... 31, 41, 42, 43, 50,68, 163, 168, 212

S. (?) confluens................... 165, 167

S. (?) coronella .................... 165, 167

S. grandis............................. 180

S. huxleyi............................. 182

S. (?) obtusus..................... 165, 167

S. pulchellus........................... 178

S. salteri............................ 164, 165

Stenasteracea.......................... 163

Stenasteridæ......................162, 168

stone-canal, seo madreporito.

Streptophluræ.

215,249

Stürtzastor.

248,252

S. colvini.

253

S. cygnipes............................ 253

8. marstoni............................. 253

S. (?) mitchelli...................... 254

Stürtzura.......................... 235, 286

8. brisingoides...................... 236

8. leptosoma ..................... 236, 237

8. leptosomoides.

236,287
Page.

stutchburil, Australastor (?)............ 73

stutchburi, Monaster................... 73

stutchburil, Palzaster ( Monaster)............ 73

supramarginalia............... 15, 34,35,45

Symptorura....................... 248, 256

s. minveri............................. 256

syngnaths............... 218,222, 224, 242, 256, 267

Tæniaster........................... 216, 218

T.australis......................... 236

T. cylindricus............ 216,217, 218,219, 220

T. elegans........................ 219, 221

T. meafordensis................... 221

T. schohariæ...................... 219, 220

T. spinosus................. 216, 217,218, 219

Tæniasteridæ........................ 172

Tæniura.............................. 216

T.cylindrica......................... 220

tenuiradiatus, Coelaster................. 19

terminals, see ocular plates.

terminology of Asteroidea............... 13

Tetraster.........31,41,42,43,50,164,165, 167, 212

T.asperrimus........................ 187

T. (?) imbricatus..................... 168, 169

T. sp. Ind. Nicholson and Etheridge........ 186

T. wyville-thomsoni (part)................ 65

T. wyville-thomsoni.................... 168

tischbeinianum, Aspidosoma.............. 244

tischbeinianus, Encrinaster............... 244

torus......................... 16, 43,54,174

traquairi, Echinostella ................. 212

Tremataster..................... 246, 247

T. (?) decheni.................... 247, 248

T. difficilis.......................... 247

Trentonaster........................... 195

T. stellata.......................... 196

Trichotaster plumiformis............... 26, 38

Trimeraster..............44, 45, 50, 128, 184

T. parvuius ........................ 134

trivium............................. 14

Trochitaster, see Trichotaster.

typembryo of Stelleroidea............... 85, 36

ulrichi, Urasterella......... 37, 43, 45, 49, 175, 183

Uranaster........................ 51, 138, 154

U. elizæ............................... 155

U. kinahani....................... 154, 155

Uraster hirudo.......................... 188

V. obtusus........................... 167

U. primævus........................ 153

U. ruthveni....................... 187

Urasterella Stürtz..................... 163

Urasterella McCoy..................... 40 ,

$41,42,45,47,49,50,69,164,173,194,212$

U. (?) asperrima.................. 175, 187

U. asperula......................... 175, 188

U. (?) constellata.................... 175, 187

U. girvanensis. .................. 167, 175, 186

U. grandis.................... 174, 175, 180

U. hirudo........................... 175, 188

U. huxleyi........................ 175, 182

U. montana....................... 175, 189

U. n. sp.............................. 189

U. pulchella........................ 175, 178

U. ruthvenl................... 174, 175, 187

U. selwyni....................... 175, 188

U. ulrichi................ 37, 43, 45, 49, 175, 188 
Urasterellacea.

Urasterellidæ.

ventral, see actinal.

ventral shield.

vermiformis, Bdellacoma

vermiformis, Palæocoma.

vertebral ossicles.

wachsmuthi, Schoenaster (?)

whiteavesianus, Protaster (?)

wilberanus, Mesopalæaster (?)

wilberanus, Palæaster.

wilberianus, Petraster.

wilsoni, Palæaster (?)

wilsoni, Promopalæaster.

woodwardi, Eucladia.

wrigglers.
$162,163,172$

213

254

254

7,269

226, 227

75,84

84

84

106

104,106

276,277

$32,33,38$ wykoffi, Palæaster.

wykoffi, Promopalmaster................ 119 wyville-thomsoni, Tetraster................ 65

wyville-thomsoni, Tetraster.............. 168

Xenaster.......40,44, 45, 46,47,49,50,98, 128, 129

X. dispar........................ 130,181

X. elegans....................... 130, 181

X. eucharis.......................... 98

X. margaritatus Follmann.............. 131

X. margaritatus Simonovitsch (part)...... 131, 132

X. margaritatus Simonovitsch....... 129,130,131

X. (?) rhenanus.................... 130, 181

X. simplex.......................... 96

Xenasteridæ..................... 52,53, 128

zitteli, Palsospondylus .................. 262

zitteli, Palastropecten..................... 262 




\section{DAY USE}

\section{RETURN TO DESK FROM WHICH BORROWED}

\section{EARTH SCIENCES LIBRARY}

This book is due on the last date stamped below, or on the date to which renewed.

Renewed books are subject to immediate recall.

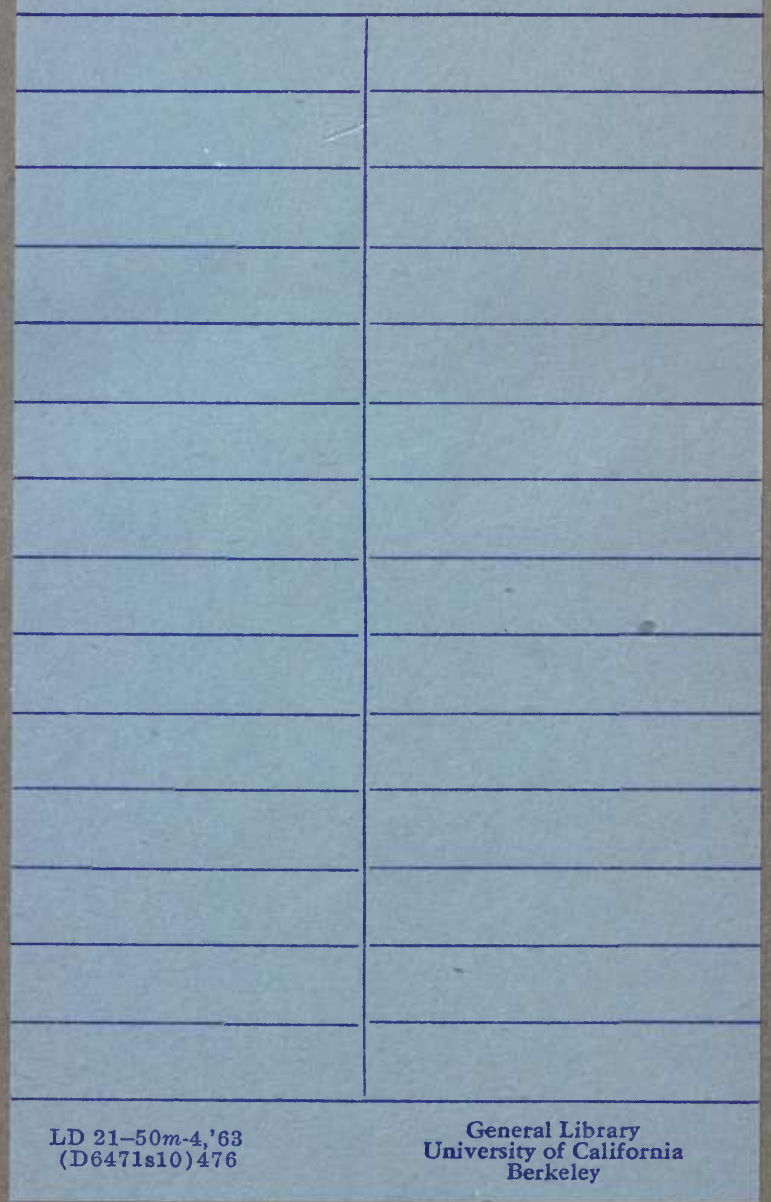


storage 
